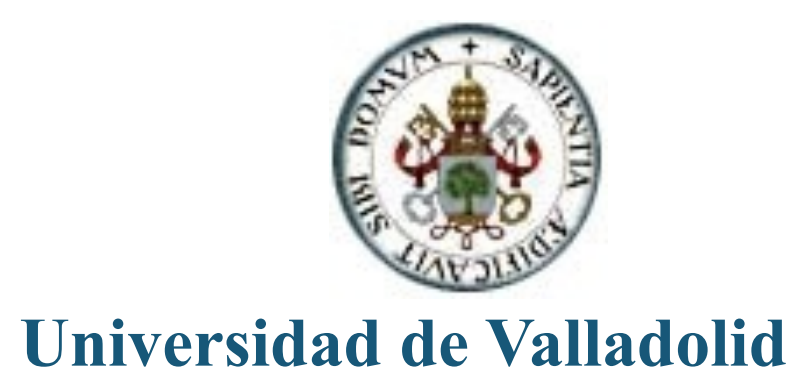

FACULTAD DE FILOSOFÍA Y LETRAS

DEPARTAMENTO DE FILOSOFÍA, LÓGICA Y FILOSOFÍA DE LA CIENCIA, TEORÍA E HISTORIA DE LA EDUCACIÓN, FILOSOFÍA MORAL, ESTÉTICA Y TEORÍA DE LAS ARTES

PROGRAMA DE DOCTORADO EN FILOSOFÍA TESIS DOCTORAL:

\title{
NIETZSCHE ANTE LA EXPERIENCIA DEL NIHILISMO: UN PROYECTO DE REAPROPIACIÓN ESTÉTICA DE LA EXISTENCIA
}

Presentada por Pablo Frontela Asensio para optar al grado de

Doctor por la Universidad de Valladolid

Dirigida por:

Dr. D. José Manuel Chillón Lorenzo 


\section{Tesis doctoral}

\section{Nietzsche ante la experiencia del nihilismo:}

un proyecto de reapropiación estética de la existencia

Pablo Frontela Asensio Bajo la dirección de: Dr. D. José Manuel Chillón Lorenzo Universidad de Valladolid Departamento de Filosofía 
A mis padres, por todo, que es tanto 


\section{ÍNDICE GENERAL}

INTRODUCCIÓN

PARTE I: La recuperación del cuerpo como fenómeno filosófico de existencia

Capítulo I: El cuerpo en Nietzsche: acontecimiento de pluralidad esencial

I.1. El cuerpo, síntoma de la voluntad de poder

I.2. El cuerpo como unidad de cuidado

I.3. El hombre encarnado como fondo de existencia

I.4. El cuerpo hermenéutico como ser de la dimensión de lo inconsciente

I.5. La creación artística del cuerpo por la voluntad de poder

I.6. Ética y estética: el hombre artista de la voluntad de poder

Capítulo II: El nuevo hombre

II.1. El fin del platonismo: el filósofo-artista

II.2. La transvaloración: el artista-filósofo

II.3. La tentadora amenaza nihilista de la compasión

PARTE II: La crítica de la modernidad desde Nietzsche

Capítulo I: A propósito de una crítica espiritual de Europa

I.1. El nihilismo como consecuencia de la esencialidad religiosa de la razón moderna

I.2. La redefinición de la ciencia como arte

I.3. Alba de nihilismo

Capítulo II: La epistemología como problema genético de la modernidad

II.1. El problema del lenguaje como concepción del mundo

II.2. El lenguaje como praxis vital en Nietzsche: la gramática de la voluntad de poder 
PARTE III: La respuesta nietzscheana ante el nihilismo: superación artísticofilosófica

Capítulo I: Nietzsche ante el nihilismo

I.1. La doble dimensión del nihilismo

I.2. La voluntad de poder

Capítulo II: La ventura del tiempo encarnado

II.1. El concepto del eterno retorno

II.2. El eterno retorno como imperativo trascendencia de lo humano

II.3. El tiempo del eterno retorno

II.4. El eterno retorno y Dioniso

Capítulo III: La reapropiación de la ocasión de vida

III.1. EI problemático concepto del superhombre

III.2. El superhombre ante el martillo

III.3. La apertura hacia el futuro como apertura perspectivista

III.4. Límites y condiciones del superhombre

III.5. La reapropiación mediante la redención

III.6. El superhombre tras Nietzsche: el «escándalo Sloterdijk» 


\section{ÍNDICE ESPECÍFICO}

INTRODUCCIÓN

PARTE I: La recuperación del cuerpo como fenómeno filosófico de existencia

Capítulo I: El cuerpo en Nietzsche: acontecimiento de pluralidad esencial

I.1. El cuerpo, síntoma de la voluntad de poder

I.2. El cuerpo como unidad de cuidado

I.3. El hombre encarnado como fondo de existencia

I.4. El cuerpo hermenéutico como ser de la dimensión de lo inconsciente

I.4.1. Voluntad de poder e instintos

I.4.2. Jerarquía, interpretación y responsabilidad

I.5. La creación artística del cuerpo por la voluntad de poder

I.6. Ética y estética: el hombre artista de la voluntad de poder

I.6.1. El pathos de la distancia

I.6.2. La alegría del creador

Capítulo II: El nuevo hombre:

$\begin{array}{ll}\text { II.1. El fin del platonismo: el filósofo-artista } & 65\end{array}$

$\begin{array}{ll}\text { II.2. La transvaloración: el artista-filósofo } & 67\end{array}$

$\begin{array}{ll}\text { II.2.1. Fisiología del arte } & 70\end{array}$

$\begin{array}{ll}\text { II.2.2. El gran estilo } & 71\end{array}$

$\begin{array}{ll}\text { II.3. La tentadora amenaza nihilista de la compasión } & 78\end{array}$

II.3.1. La compasión como despliegue de fuerzas reactivas de la voluntad de poder 79

II.3.2. La compasión como instrumento de nivelación $\quad 83$

II.3.3. El cristianismo como religión de la compasión y la filosofía del pesimismo 86

$\begin{array}{ll}\text { II.3.4. La alegría jovial del poderoso } & 94\end{array}$

$\begin{array}{ll}\text { II.3.4.1. «iAtrévete a ser alegre!» } & 97\end{array}$

$\begin{array}{ll}\text { II.3.4.1.1. El egoísmo solitario de la alegría } & 100\end{array}$ 
PARTE II: La crítica de la modernidad desde Nietzsche:

Capítulo I: A propósito de una crítica espiritual de Europa:

I.1. EI nihilismo como consecuencia de la esencialidad religiosa de la razón moderna

I.2. La redefinición de la ciencia como arte

I.2.1. La máscara como anhelo de verdad

I.3. Alba de nihilismo

Capítulo II: La epistemología como problema genético de la modernidad:

II.1. El problema del lenguaje como concepción del mundo

II.1.1. Olvido y voluntad de verdad

II.1.2. Descartes, gramático de la modernidad

II.2. EI lenguaje como praxis vital en Nietzsche: la gramática de la voluntad de poder

II.3. Nietzsche y el problema de la verdad

II.3.2. La metafísica de la cosa en sí y la verdad en la apariencia: un problema de trasfondo moral

PARTE III: La respuesta nietzscheana ante el nihilismo: superación artísticofilosófica

Capítulo I: Nietzsche ante el nihilismo 
II.2. EI eterno retorno como imperativo de trascendencia de lo humano

III.2. El superhombre ante el martillo

III.4. Límites y condiciones del superhombre 
Entonces calló Zaratustra de nuevo y se hundió en profunda reflexión. Por fin, como en sueños, dijo: «¿O se ha matado él mismo, y nosotros sólo hemos sido sus manos?».

(Nietzsche, otoño de 1881)

Nada es más peligroso que una deseabilidad que entra en conflicto con la esencia de la vida.

(Nietzsche, primavera de 1887)

Definición de la moral: moral - la idiosincrasia de décadents, con la intención oculta de vengarse de la vida - y con éxito.

(Nietzsche, Ecce homo)

Me he planteado la cuestión de si todos estos valores supremos de la filosofía, la moral y la religión que ha habido hasta ahora, no podrían compararse con los valores de los extenuados, los enfermos mentales y los neurasténicos: representan, en una forma atenuada, los mismos males...

(Nietzsche, primavera de 1888) 

Esta tesis se ha cobrado muchas horas de necesaria reclusión, momentos de oscuro encierro sin más compañía que la que brindaban los libros y un ordenador. Sin embargo, nunca me sentí solo gracias a ciertas personas sin cuya presencia el peso de este proyecto habría sido insoportable. Es justo reconocer su inestimable aportación, y al hacerlo hallo el momento más placentero en estos años protagonizados por el presente trabajo. Sirvan estas humildes líneas, aun incapaces de apresar mi gratitud, como gozoso y sentido homenaje.

Mamá y papá, por supuesto, sois los primeros en quienes pienso. Por encima de todo os agradezco haber hecho vuestra mi ilusión, compartir mis preocupaciones e iluminar mis avances. Tras toda una vida de cuidado sin vosotros no sería quien soy hoy.

Mi director de tesis, José Manuel Chillón, Jose, te agradezco la confianza que depositaste en mí. Sin siquiera conocernos, habiendo compartido tan sólo una conversación, aceptaste con gentileza la responsabilidad de conducir mis desvelos. La libertad que me concediste es comparable tan sólo con la calidez de tus sapientísimos consejos.

Iñi, mi hermano. Sabes que absolutamente nada que pueda decir te hará justicia. Una vida alimentada con tu amistad es el más dulce fruto de la felicidad. El eterno retorno torna grácil y deseable al contemplarnos juntos una y otra vez.

Mi tío Miguel, tan preocupado por mí. Siempre has sido un espejo en el que mirarme. No lograría expresar cuánto disfruto a tu lado, conversando de tantos temas, profesionales e íntimos. Además de ser mi tío, no puedo dejar de considerarte también un amigo.

Mis abuelos, Virgina y Manolo, quienes siempre cuidasteis de mí. Recuerdo con especial cariño cuando en mi niñez os esperaba en la estación de tren, aventurando toda una tarde juntos. Crecí y seguisteis protegiéndome. Y aunque el abuelo ya no está, aún me seguís acompañando los dos.

Caro, my sweetheart... you have totally changed my mind. Although I was broken and scared you fixed me by turning my disillusionment and fear into hope and joy. You gifted me your patience and your kindness. You made it easy what was supposed to be impossible and kept fighting for the sake of the two of us, even when I was depleted. Your warming hand over my shoulder, your intoxicating hugs in the middle of the deep night, the taste of your eyes and the colour of your lips froze time. Our paths crossed and now share the very way of love, and thanks to you I'm willing to keep forward this trip, our adventure. Beside you, the dream come true.

Mi queridísimo Vicente, haberte conocido ha justificado esta aventura filosófica. Paseos, animadas charlas y otros tantos momentos dichosos compartidos contigo. Las tardes se llenaban de chispas, vampiros, tritones o legiones de eldrazi; por las noches, campamos por Azeroth, sintiéndome totalmente seguro al saber que tú me cuidabas. Por encima de todo, gracias, amigo mío, por una amistad incólume y de la que jamás dudaré.

Kuz, my bosom pal. Who would've told us! I wasn't at my best and your support was crucial. We didn't know each other and yet you opened the gates of your world to me. Our friendship is built from scratch. Those shy first chats about trivialities which happily turned, I don't know how yet, into the living embrace of two friends who shall forevermore 
walk together. We've been through a lot and even though you know what you truly mean to me, I just needed to tell you I'm a better man than I was before meeting you.

Adrián Pradier, un maravilloso e inesperado regalo que la más feliz casualidad puso en mi vida. Pese a la juventud de nuestra amistad, la gozo sólida y fuertemente afianzada. Me has hecho experimentar la bella vivencia del tiempo kairológico de la amistad. Ternura, preocupación, cariño, diversión, confianza, seguridad, un largo etcétera que jamás habría esperado Eres, sin duda, una de las más altas conquistas de esta tesis.

Félix, mi maestro, ¡qué decirte! Un amigo, un hermano mayor, un protector impertérrito en quien siempre he podido confiar. No puedo imaginar mi vida sin tus consejos, tus ánimos, tu fuerza. Ignoro por qué decidiste que tu mundo y el mío convergiesen; sólo me cabe agradecértelo y disfrutar contigo.

Mis tíos Tere y Uti, soy incapaz de rememorar mi infancia sin vosotros. Tardes de cine, de juegos o de paseos que me siguen arrancando entrañables sonrisas. Hoy, ya adulto, pese a los naturales cambios del tiempo, seguís estando a la altura y puedo continuar construyendo mi presente y futuro con vosotros en él, manteniendo la distintiva sonrisa que os debo.

Iñi -otra vez-, Álex, Javi, Pedro, Juan compañeros de fatigas desde hace tantos años. Nos basta una mesa para zarpar juntos en busca de aventuras ignotas, en este mundo o en tantos otros de fantasía. Gracias a vosotros los Primigenios no han arrebatado aún toda mi cordura... Iä ï̈ Cthulhu fhtagn!

Mi amiga Ali, ejemplo de fortaleza, tenacidad y superación. Que nuestras sonrisas alcancen algún día a brillar como la tuya.

¡Moe! Te has convertido en un pilar fundamental de mi vida. Supimos vencer la distancia que nos separaba y afirmar nuestra amistad. Ahora, poder abrazarnos diariamente es un inestimable premio a nuestro esfuerzo.

No puedo olvidarme de Emilio Roger. Desde los primeros momentos de tu magisterio respondiste, con calidez y afecto, a mis jóvenes e infantiles cuitas. Guiaste mi formación trascendiendo el umbral estrictamente académico, brindándome las más sabias lecciones filosóficas. Cada página de este trabajo, elogiosa celebración de la vida, descansa sobre tu paciente y estimulante tutela.

Aquilino, aún sigo aprendiendo de ti. Eres una fuente de conocimiento y de sabiduría. Aunque tengo mucho que agradecerte, lo más preciado es que continuases creyendo en mí y nunca te rindieses conmigo.

Henar Zamora, por nuestros afables encuentros, que me han permitido conocer cuán maravillosa persona eres. Saber que disfruto de tu estima, así como tú de la mía, es un placentero oasis. Mi gratitud es extensible a tu encantadora familia. 



\section{INTRODUCCIÓN}

La presente tesis explotará la dolorosa experiencia del nihilismo finisecular decimonónico, partiendo tanto por su génesis como por sus consecuencias. La segunda mitad del mencionado siglo supuso la toma de conciencia de un profundo malestar cultural del cual adolecía el horizonte vital europeo. No tanto un simple pesar anímico como la sospecha de una mayúscula enfermedad largamente incubada.

La configuración de todo un universo, lo que en el lenguaje de Carl Schmitt vendría a tenerse por «teología política», Occidente, amenazaba con sucumbir ante las pústulas de una muerte anunciada. Los criterios que habían trazado el mundo hasta entonces conocido -epistemológicos, gnoseológicos, jurídicos, etc., que Nietzsche concierta conclusivamente en «moral»-, así como las instituciones nacidas de su intimidad-ciencia, sociedad, Derecho, etc., que Nietzsche encierra en la «cultura»- se resquebrajan.

Los códigos sagrados pierden su halo de impunidad y son profanados por los convulsos aires de una atmósfera cáustica que no puede mantenerse apacible en las viejas fronteras de las convenciones y los criterios de un pasado reciente. Una desorientación esencial que afectó el suelo sobre el cual había germinado a lo largo de más de dos milenios el mundo europeo. La crisis del nihilismo, como agudamente observó Nietzsche, no es un fenómeno surgido del natural acontecer moderno; se trataba, más bien, de una inevitable conclusión que la tradición occidental, por su génesis motriz, habría de enfrentar a su cierre.

Las promesas de las esforzadas ensoñaciones de la razón, los desvelos de los más colosales proyectos de futuro o el cálido y protector cobijo de la legitimación del sentido del mundo sucumben en las etapas finales de la modernidad. El esplendor del Barroco o el fervor de las décadas ilustradas son ahora simples evocaciones que traen al horizonte de la presencia la amargura de una promesa que ha fracasado.

Las expectativas depositadas desde las postrimerías del pensamiento en la razón parecen haber conducido hasta esta peculiar condición; tal es la sospecha de Nietzsche. Se trazó una difícil senda cuyas pretensiones acabaron por perder de vista las posibilidades reales de las facultades humanas, imprimiendo sobre el mundo una inmanencia racional inabordable e inaprensible para un sujeto que terminaría viéndose superado por las máximas de su propio programa cognoscitivo.

La inclusión de todo el orbe de la realidad dentro del atenazador horizonte de una razón fría y ajena a las dinámicas discursivas del mundo, no siempre éste prístino y accesible, acabó por mostrarse como una estrategia infructuosa e inexorablemente conducida a su propio fin. Así habría operado, de acuerdo con Nietzsche, el pensamiento metafísico, desde sus albores: habría ofrecido una serie de caracteres emanados de su más íntimo celo que a 
continuación habría vertido sobre el mundo humano exigiendo a éste la adecuación sistemática a sus eidéticos términos supramundanos.

La duplicación de mundos que tiene lugar en la metafísica, en el corpus platónico se encuentra la manifestación más descarada y elaborada, es la más esforzada estrategia de una razón embriagada de sí: genera todo un mundo ajeno al mundo, un cosmos de ideal inmanencia cuyas perspectivas pasan por una serie de avatares que se antojan ajenos e incompatibles respecto del universo humano, sometido en cambio a una dinámica de esencial indigencia que le impide mostrarse incólume en su eternidad.

El problema de la metafísica, observa Nietzsche, se juega en el difícil y arriesgado trazo del valor: para hacer del marco metafísico la fuente del mundo ha sido necesario estimarlo como tal; una valoración que, en último término, acontece y se afirma en detrimento de otra que no llegar a ser. La idealidad de la prole de la razón metafísica ha sido una tentativa del pensamiento cuya fuerza ontológica ha emanado de una apropiación -reactiva- valorativa de sentido.

Sin embargo, que la condición de posibilidad de la metafísica haya sido una determinación de sentido favorable no le resta un ápice de fuerza propositiva; al contrario, en la medida en que estamos sumidos en un mundo atravesado por la potencia hermenéutica, en dicho juego tiene su fuerza.

Como apuntábamos, sobre la tentativa platónica del pensamiento hunde sus raíces todo el decurso de la metafísica occidental. La condición ideal del mundo inteligible frente a la paupérrima cualidad mudable del espectro de apariencias es, como tal, una predisposición de valor, esto es, interpretativa: la concreción, como ontología, de la estimación de que la idea -el ser-prevalece sobre lo sensible -el devenir-.

Este posicionamiento radical del modus metafísico descansa, a su vez, en otra apropiación de sentido, a saber, que las condiciones elementales de la idea, la inmutabilidad e incorruptibilidad de una indisoluble unidad son preferibles frente a los entresijos de la materia, la cual deviene y sucumbe sustancialmente en el frenético movimiento del cambio.

Esta doble valoración presentada, que lo ideal prima sobre lo sensible toda vez que los rasgos de aquél se desean por encima de los de éste, se integra finalmente en una única disposición afectiva, paradigmática de la filosofía platónica: la distinción esencial entre el «mundo verdadero», que resiste la amenaza de la fugacidad, y el reino de la «apariencia», sometido, en cambio, a una caducidad fundamental que hace imposible toda tentativa sólida de creación. 
La metafísica, por tanto, presenta al filósofo desde sus primeros compases la difícil disyuntiva entre el ofrecimiento de eternidad que únicamente proporcionaría una aproximación teórica ajena al ocaso o bien la entrega irrestricta del ánimo a una dimensión sumida en el perpetuo agotamiento de sí misma, el cual no puede ser eludido en tanto que es estructural.

La conclusión nietzscheana es clara al respecto: la filosofía platónica, paradigma metafísico par excellence, resolvió esta tensión esquizofrénica en favor de la unicidad y la permanencia sustantiva de una realidad ajena al cambio. El «mundo verdadero» en detrimento del «mundo aparente». Una toma de valor, dirá el alemán, donde la voluntad de poder del pensador griego negó un prisma en beneficio del otro.

Sin embargo, prosigue, esta elección no será gratuita; es una onerosa determinación que endeudará y comprometerá el decurso de la posteridad. La valoración platónica del mundo verdadero como el ámbito verdaderamente real al que tender pondría de manifiesto la esencial constitución hermenéutica que, sospecha Nietzsche, constituye el fondo básico del mundo.

La ontología de la metafísica se cimenta sobre el fetichismo de la verdad, esto es, de la aprehensión de los subyacentes rasgos capitales de la existencia. Sin embargo, una vez más, el establecimiento del anhelo de verdad no es sino una valoración: que la verdad es deseable frente al error y el engaño, pues éste es malo mientras aquélla, «buena». De tal manera que la cognición metafísica de la verdad no se arma sobre un impulso netamente epistemológico, sino moral: la ecuación donde se desvela el íntimo trazo entre la verdad y el bien, que condensa paradigmáticamente el intelectualismo moral socrático.

Y así se lega desde la filosofía platónica el tratamiento de la realidad que caracterizará toda la tradición occidental, donde el germen moral colonizará todo el espectro de reflexión. El posicionamiento ante el mundo se plantea desde la metaposición de la verdad como bien, que dejará su rúbrica en todos los tratamientos brindados, distinguiéndose ésta únicamente según las exigencias propositivas epocales.

Se mantiene, por tanto, la impronta moral cuando se enfrenta el mundo como objeto central de estudio: éste es comprendido desde los caracteres de la verdad como bien. Las diferentes concreciones de dicho bien, como apuntábamos, variarán conforme las dinámicas concretas de cada momento histórico. Sin embargo, prosigue Nietzsche, tales matices son sutilezas que poco o nada afectan a la cuestión de fondo: cambios accidentales dentro del mismo cauce sustantivo.

Las observaciones de Nietzsche van más allá, al entender que se ha impregnado el mundo de una especie de optimismo racional que invita a considerarlo como si estuviese 
conducido por un feliz trazo moralizador: la estructura del mundo ha de ser racional, y como tal, debe responder a las exigencias que la razón impone, a saber, su plena conformidad con el universo propositivo de la verdad. Las consecuencias de esta imbricación de la razón en el mundo, que responde al horizonte metafísico pergeñado al inicio, lo privan de su originalidad, de su «inocencia», puesto que introduce una matriz conducente que perfila los meandros por los que ha de discurrir. Las tentativas escatológicas son diversas, concreciones distintas de un leitmotiv común contemplado desde los muchos prismas del tiempo histórico. De este modo encontramos la polis griega, la idea cristiana de la «salvación» o la «pax romana» como distintas manifestaciones de la valoración propositiva de una concurrencia de la razón en la genealogía del mundo que invitaba a la consideración de un fin dispuesto al término del proceso histórico y evolutivo del mundo: el bien en el que habríamos de concluir al cierre de la historia.

La suposición de una estructura racional para el decurso de los fenómenos debería haber soportado los cuestionamientos y las dudas decimonónicas; la disolución de la hipótesis de la conciencia subyacente en el discurso europeo refleja la desconfianza de los espíritus occidentales de la tardomodernidad a propósito de la concepción idealista de la razón. Las doctrinas escatológicas han nacido al abrigo de la tradición metafísica, sin embargo, es la ideología del «progreso» la concreción paradigmática del faro teleológico que condujo tanto la reflexión como la acción durante la modernidad. El «progreso» supone el despliegue del locus moderno en la compleja vastedad de sus distintas dimensiones -gnoseológica, moral, política, etc.- hasta sus episodios capitulares de desencantamiento y desengaño.

El «progreso» es la puerta de entrada a la especificidad del nihilismo en la modernidad, ya que además de haber germinado desde el sustrato de la metafísica, comprende la novedosa originalidad del nuevo período que se abre. Es una ideología superficialmente epistemológica: la acumulación «cuantitativamente» masiva de datos y conocimientos científicos habría de redundar en una mejor disposición de la vida humana, pues posibilitaría una óptima adecuación en una naturaleza «numérica» donde el proceso sumativo de conocimientos habría de hacer confluir todos los órdenes científico-técnicos en una mítica Arcadia de prosperidad eterna. Una pretensión ésta que llevará a advertir a Nietzsche que el fondo sustantivo del "progreso», en tanto que escatología, respondía al legado metafísico platónico de la duplicación de mundos, en particular, a su eco moderno de la doctrina de la adecuación.

La importancia de la ideología del progreso no la hemos de radicar, por tanto, en sus manifestaciones netamente empíricas, sino en su impronta sobre el pensamiento metafísico que fluye tras todos los atavismos del nuevo universo. En efecto, la premisa de que hay una entidad inteligible que conduce los días y las noches del tiempo, además de tener su sustrato en la metafísica dualista, condiciona otros dominios reflexivos, como la filoso- 
fía o la antropología. Así acontece en las máximas programáticas del progreso, donde la fe en los ídolos del pensamiento alumbró códigos filosóficos teleológicamente dispuestos: en último término, la creencia en una potencial mejora moral de la humanidad que vendría a darse una vez la vida de las hazañas humanas hubiese concluido en un plano de existencia eidético y, por tanto, ajeno al dominio empírico de la sensibilidad humana.

Las diferentes figuras del progreso moderno, a pesar de la peculiaridad específica de sus respectivas posiciones, concluyen en tentativas similares, a saber, en una promesa histórica de redención de la humanidad de acuerdo con los conceptos metafísicos de «libertad». Luego las expectativas de futuro pasan por una posición que prescinde del presente efectivo del sujeto para enajenarlo en premisas abstractas de las que mana una valoración peyorativa de la vida. Así, el futuro se brinda a costa del presente en un iluso compromiso de mejora progresiva, de acercamiento al bien en paralelo con una profundización cognoscitiva. En definitiva, el desarrollo filosófico - de raíz epistémica- y el progreso moral se coligarán en una estrategia análoga a la longeva ecuación socrática del intelectualismo moral que había hecho de la verdad una cuestión «moral», ignorando la faceta creativa de la valoración que hace de la verdad una diatriba hermenéutica.

Con todo, los ecos del progreso modernos no son sino la manifestación de la duplicación platónica de mundos, pasada esta vez por el tamiz de la secularización. No obstante, aún se corresponderían con la estrategia escatológica de un despliegue de la razón en el mundo que perfilaría los caracteres necesarios para la adecuación, para la participación, de lo sensible en el bien -moral-. Nietzsche se esforzará en mostrar la imposible asimilación de estas disposiciones metafísicas en la vida humana, encarnada y desprovista de un faro escatológicamente definido. Precisamente por su denuncia Nietzsche señalará, y ésta es nuestra tesis, que ha habido una enajenación de la conciencia de la experiencia de existencia a lo largo de todo el discurso de la tradición occidental como consecuencia de la distancia abismal que separaba la pretendida disposición metafísica del mundo con la efectiva cualidad sensible del hombre.

Por ello, en el primer capítulo mostraremos los rasgos de la vida encarnada tal como ésta es descrita en la filosofía nietzscheana. A lo largo de sus páginas señalaremos los distintos hitos del proceso de formación de la conciencia en Nietzsche, así como la radicalidad genuina del sujeto no epistémico. Nos valdremos de la propia hipótesis del autor de tomar el cuerpo «como hilo conductor». Ahondaremos en esta estrategia destacando cómo el fenómeno del cuerpo es para el filósofo alemán algo infinitamente más complejo que la mera caracterización somática como complejo estrictamente fisiológico.

La vindicación del cuerpo será inscrita, a su vez, dentro de las máximas de la transvaloración, resolviéndose de este modo en una propuesta filosófica novedosa contemplada fuera de los límites conceptuales de la metafísica de la duplicación y de la escisión 
del alma y el cuerpo. Con el fin de atrapar el esfuerzo nietzscheano por vindicar una imagen de la existencia emancipada de la metafísica, nos hemos valido del concepto de «corporalidad», en el cual hemos recogido la complejidad que el fenómeno existencial comporta para el autor, a saber, la íntima unidad «sintética» del espíritu y el cuerpo en una identidad de mayúscula complejidad radicada en la propia experiencia de existencia.

Hemos afirmado esta caracterización de la existencia como «corporalidad» como la clave del proyecto nietzscheano de la reapropiación de la existencia. Al tratarse de un contenido que extiende la vida más allá de las estrechas fronteras del biologicismo, la concepción de verdad manejada por Nietzsche en todo su corpus es netamente diferente de la modernidad en particular, y de la tradición occidental en general. La transvaloración ha transformado el suelo reflexivo y existencial, de tal forma que la noción de verdad no podrá ya ser idealista. Como alternativa, Nietzsche comulgará con una verdad de cariz «trágico» cuyo contenido no viene de antemano concretado en virtud de un plano supramundano ajeno a la contingencia sensible.

La vaciedad de sentido esencial de la verdad trágica exige también, y en consecuencia, una transmutación del sujeto de la verdad capaz de hacer propia la empresa de determinación del sentido perdido. Un sujeto a quien la conciencia de su condición hermenéutica lo abre a la creación perspectivista de significados: el «artista-filósofo» de nuestro trabajo, quien hace de sí el principio y el fin del contenido de sentido de su íntima existencia encarnada, tarea ésta intransferible del propio sujeto hermenéutico. En virtud de la condición hermenéutica del sujeto de la «corporalidad», el «artista-filósofo», y de la transvaloración de la noción de verdad, podremos presentar el proyecto de Nietzsche como uno de sustantiva cualidad «estética», como superación del maridaje de la «epistemología» y la «moral» que había conducido la tradición bimilenaria del platonismo.

Así, el primer capítulo cumple una doble función: nos permite presentar tanto el problema capital que hubo advertido Nietzsche en la totalidad de la filosofía occidental, la enajenación de la existencia, y su respuesta «estética» de la «corporalidad», como tomarlo de nexo con las dos partes restantes, donde se explorará la dimensión de la verdad como una cuestión relativa al valor y la crisis nihilista como tal. El primer capítulo, pues, asienta las bases para poder explicar a continuación el porqué de la angustia de la crisis finisecular del nihilismo, la desvaloración fundamental y la enajenación de la existencia encarnada.

El problema de la verdad como cuestión de valor nos obliga a efectuar un minucioso estudio de la epistemología moderna. Habremos de mostrar los isomorfismos estructurales de la metafísica platónica con la teoría del conocimiento de esta nueva época, concretamente con la acepción adecuacionista. Para ello, presentaremos las claves de dicha tesis, que remitiremos a Descartes. Un detallado estudio de la psicología cognoscitiva del francés que concluiremos en el psicologismo innatista de la mente autoconsciente. 
Una vez trazado tal recorrido, podremos adentrarnos en la propuesta nietzscheana de la verdad como una alternativa genuina del autor alemán, en sustantiva oposición respecto de la episteme metafísica imperante. Nietzsche no renunciará a la cuestión de la verdad, mas sí a su trazo legado en la tradición. Prescindirá del criterio de la adecuación en beneficio de una propuesta del valor: la verdad deja de ser un problema relativo a la epistemología para pasar a conformar el horizonte hermenéutico del sujeto creador de valores, o sea, la verdad como cuestión existencial.

Esta disposición actúa ontológicamente sobre la verdad, la transmuta en un cariz nuevo. La verdad no puede ser por más tiempo la adecuación entre el sujeto y el mundo, sino la irrefutable prueba de la vida que ha de enfrentarse desde la afirmación. La verdad será aquella de los griegos trágicos, dionisiaca, una pulsión de existencia que integra la muerte y un hálito de muerte que asimila la vida.

Por lo tanto, la aproximación a la verdad habrá de ser mediante otras premisas. Si se presenta desde una acepción de valor, su comprensión sólo podrá llegar desde este cauce, la voluntad de poder creadora. Luego la cuestión de la verdad nos abrirá al poderoso cosmos conceptual de Nietzsche, cuyo horizonte llega colonizado por nociones tales como «voluntad de poder», «eterno retorno», «amor fati» y otros, que enmascaran y desenmascaran el inaccesible fondo palpitante de la existencia.

La estrategia seguida por Nietzsche para el conocimiento nos desvelará una nueva perspectiva, donde la verdad no se corresponde con la certeza, un saber científico, sino con la sabiduría del artista-filósofo que se adueña «estéticamente» de la verdad, que la toma como propia y se identifica en ella a lo largo del juego de la vida.

Finalmente las últimas páginas vendrán dedicadas al problema radical de la filosofía del autor, el nihilismo y sus consecuencias más atronadoras. Presentaremos el nihilismo como resultado de cuanto ha acontecido en las centurias precedentes y nos apoyaremos, al tiempo, en los caracteres de Nietzsche que hemos presentado.

Abordaremos el nihilismo decimonónico desde la lectura nietzscheana del resentimiento metafísico que ha pauperizado esta vida, deponiéndola en instancias vacías. Explotaremos la cuestión de la desvaloración a través de las concreciones del nihilismo de la fuerza y su contraparte, el pasivo. Trazaremos un perfil psicológico del tipo nihilista y de su impacto corrosivo en las conciencias europeas.

A continuación, ofreceremos la respuesta propositiva de Nietzsche, desde sus peculiares códigos aforísticos en los cuales no parece haber una pista definida, tan sólo alusiones sutiles que, sin embargo, están cargadas de fuerzas. Por lo tanto, la voluntad de poder y el eterno retorno vertebrarán esta última parte como los límites peculiares de la apro- 
piación de una verdad que se sabe no epistémica, sino trágica. La reconsideración del tiempo del instante y su inclusión en la órbita de una voluntad que sólo puede querer hacia adelante son la hoja de ruta hacia el último gran concepto de la reapropiación, el superhombre.

El superhombre como sueño último y transmutador de Zaratustra; el anhelo de vida de Nietzsche proferido en un vocablo que es a la vez superior y mundano. Este célebre constructo nietzscheano se nos habrá de presentar como el valedor del mundo de una verdad no metafísica; el señor de un mundo no pauperizado y enajenado en las instancias fabulosas de una razón trasmundana, sino un mundo «santificado» por Zaratustra.

El superhombre nos obligará a mostrar cómo el escrúpulo escatológico de la razón rectora del orden del mundo no puede sostenerse en los nuevos aires del momento del nihilismo decimonónico. Este tipo humano de existencia habrá de desarrollarse en un mundo abierto e inocente. La superación del hombre por el superhombre será la reapropiación del propio sentido de existencia desde la óptica valoradora de la verdad: la aceptación de la verdad dionisiaca como pulsión de vida exigirá del superhombre la creación de valores tales que la integren plenamente en el instante eterno que es la vida encarnada que se afirma y se aprecia sin más referencia que sí misma.

Una vez más, insistimos, nuestra tesis buscará exponer el proyecto de reapropiación de la existencia del autor decimonónico. La metafísica será mostrada como la causa de la enajenación de la vida encarnada y, por ende, del sentido propio de la existencia de cada sujeto particular. Para la superación de la herida filosófico-existencial que el nihilismo como deslegitimación de los valores garantes de la tradición europea había supuesto se ofrecerá una alternativa en clave «estética», radicada en la identidad «sintética» del tipo humano del «artista-filósofo», quien guarda tanto la capacidad reflexiva como la fuerza creativa para afirmarse creador de su propia significación. La reapropiación, finalmente, habrá de consistir en la superación de la episteme metafísica occidental que dispuso dos mundos incompatibles en el que el sensible, dominio de la efectividad de la vida, pasó a ser despreciado en beneficio del segundo, de índole eidética. La reapropiación es el esfuerzo por redimir la vida de las vejaciones del desprecio reactivo del nihilismo; es la recuperación de la «inocencia» primigenia del mundo que al carecer de un rumbo preconcebido abre al hombre encarnado a la eterna ocasión de oportuna vida plena. Nietzsche nos ofrece las claves para poder consentir ante el tribunal del eterno retorno la afirmación de nuestra existencia encarnada como proyecto «estético» de cuidado. El abismo metafísico que separaba al sujeto del objeto es superado en Nietzsche -sin caer en el nihilismo, a pesar de las afirmaciones heideggerianas- al hacer de la «corporalidad» el proyecto de creación de la obra de arte del «artista-filósofo»: agente y objeto como unidad «sintética» abierta al horizonte perspectivista que se afirma en cada «instante» como acontecimiento de creación de sentido encarnado. 
PARTE I: LA RECUPERACIÓN DEL CUERPO COMO FENÓMENO FILOSÓFICO DE EXISTENCIA 
Corría la primera mitad del siglo XVII cuando Descartes creyó haber encontrado razones suficientes para afirmar «que la facultad de juzgar bien y de distinguir lo verdadero de lo falso, que es lo que propiamente se llama buen sentido o razón, es por naturaleza igual en todos los hombres» ${ }^{1}$. Esta sentencia goza de capital importancia en la historia del pensamiento, pues comporta el suelo nutricio del proyecto moderno. Una modernidad que, si bien ya incipiente y la cual había comenzado a dar sus pasos más primitivos años atrás ${ }^{2}$, carecía de una sistematización completa y explícita de sus máximas. Tal es la labor del ínclito autor francés. Un optimismo desmesurado anegó las conciencias europeas, legando a la posteridad algunos de los siglos más fecundos de la humanidad; los descubrimientos científicos en las más variadas disciplinas alimentaron el celo intelectual de sus protagonistas. Y la primera piedra de esta vorágine de éxitos y excelencia se debe remitir a la sincera y cismática caracterización igualitaria de la razón como elemento base del ser humano que hizo Descartes. En definitiva, supuso el Discurso del método -curiosamente la primera obra publicada en vida por el autor- el estímulo necesario para que las inmediatas generaciones venideras, en elogioso ejercicio de su razón, desarrollaran tan prodigiosamente las diferentes ramas del saber ${ }^{3}$.

En efecto, a lo largo de apenas dos siglos los triunfos epistemológicos se contaron por centenares. Sin embargo, más importante que el vasto número de éstos fue la gravedad de los mismos. Siguiendo el consejo cartesiano de rechazar las lecciones de los maestros del pasado, los autores modernos se percibieron legitimados para afirmar que su 'mundo' nada tenía de parecido con aquel barbárico que habían dejado atrás. No pueden negarse los avances sociales motivados por las innovaciones técnicas, éstas auspiciadas a su vez por el refinamiento gnoseológico. De modo que una lectura superficial de este período nos haría presagiar que esta dulce bonanza sería unánimemente celebrada, desde el más humilde campesino incapaz de distinguir la mecánica aristotélica de la newtoniana hasta la mayor autoridad dieciochesca en química, pasando por los estratos culturales intermedios.

Ante la descripción ofrecida de las décadas modernas resulta descorazonador que al comienzo del último decenio del siglo XIX un hastiado Wilde denuncie que «somos [...] una especie degradada y [que] hemos vendido nuestro derecho de primogenitura por un

${ }^{1}$ Descartes, R., Discurso del método, trad. de Eduardo Bello Reguera, Madrid, Tecnos, 2006, pág. 4.

2 Figuras como las de Michel de Montaigne o Pierre Charron son sin duda ejemplos estelares del original trazo que tomaría la filosofía durante los siguientes siglos. Autores de transición que actuaron como puente entre el mundo renacentista y el nuevo horizonte del pensamiento, allanando el camino mediante contribuciones que servirían para presentar temáticas y preocupaciones que dominarían el futuro espectro filosófico europeo.

${ }^{3}$ Sin embargo, no es el Discurso del método, sino las Meditaciones metafísicas la obra que marcará el decurso de la filosofía durante las centurias venideras. 
plato de hechos ${ }^{4}$. El desprecio con el que el genial escritor dublinés resume y denosta el desenlace de su época induce a pensar que durante el largo lapso de tiempo que separa al matemático francés del ácido literato y dramaturgo irlandés acontecieron diferentes avatares que anularon o pervirtieron las esperanzadoras promesas de la razón moderna. Quizá una traición a los axiomas programáticos que pudrió el fruto; tal vez un origen que encerraba los síntomas de su propia extenuación.

El demoledor dictamen de Wilde arroja una clave iluminadora: «un plato de hechos». El compendio por el cual cierra las gloriosas conquistas modernas es degradado conscientemente, con ánimo de destacar que los esfuerzos de este periodo fueron si no fútiles, al menos desorientados y carentes de un objetivo de sentido. No escatima descalificaciones, cada una más cruel que la anterior, contra la cualidad del tiempo que le ha tocado vivir: «vulgar», «grosera», «asfixiante», «soporífera», «insoportable». Describe, en suma, los patéticos esfuerzos de una época que se esforzaba por conservar hipócritamente sus ropajes dorados; pues pese a sus oropeles, no dejaba de ser «una época tan limitada y vulgar [...], una época groseramente carnal en sus placeres, y groseramente vulgar en sus objeti$\operatorname{vos} \ldots\rangle^{5}$.

Un retrato éste que no fue, sin embargo, único de Wilde. Su contemporáneo escocés Stevenson caracteriza el presente de un modo similarmente perverso y degenerado. $E l$ extraño caso del Dr. Jekyll y Mr. Hyde supone un descarnado reflejo de la dimensión más abyecta de los caracteres del siglo XIX; un portentoso tratado de psicología social en forma de novela que captó los instintos más viles de una humanidad ajena a los méritos progresistas modernos. Otra personalidad decimonónica, posiblemente la que más enérgicamente denunció las miserias modernas, Friedrich Nietzsche, se expresa entre el desdén y el más profundo pesar al observar que «todo es falso» ${ }^{6}$.

En algún momento se dio un desequilibrio entre la psicología moderna y la modernidad misma; un desplazamiento no sólo conceptual, sino también existencial que fue ahondando en la supurante llaga hasta que al término del siglo XIX el aroma que no mucho

${ }^{4}$ Wilde, O., La decadencia de la mentira, trad. de León Mirlas, Barcelona, Austral, 2016, pág. 127.

${ }^{5}$ Wilde, O., El cuadro de Dorian Gray, trad. de Manuel Francisco Míguez, Madrid, Cátedra, 1992, pág. 128.

${ }^{6}$ Nietzsche, F., Fragmentos póstumos IV, 2 [127], ed. de Diego Sánchez Meca, trad. de Juan Luis Vermal y Joan B. Llinares, Madrid, Tecnos, 2008, pág. 115 (KSA XII, 126) (las citas de Nietzsche en alemán corresponden a la siguiente edición: Sämtliche Werke. Kritische Studienausgabe in 15 Bänden. [KSA], herausgegeben von Giorgio Colli und Mazzino Montinari, München, Walter de Gruyter, 1988. Indicaremos a continuación el número del volumen en romanos y la página en numeración arábiga). 
antes había perfumado los más esplendorosos salones se tornó irrespirable ${ }^{7}$ Toda una retahíla de elementos que Nietzsche y Wilde concretan bajo las categorías de «nihilismo» y «decadencia». Palabras que, pese al sesgo peyorativo que comporta su significado connotativo, son, en realidad, definitorias. La palabra «decadente», estimará Nietzsche, no arrastra ya consigo ni la animadversión ni el rechazo; tan sólo sirve como definición ${ }^{8}$.

De modo que la frontera entre aquellos primeros modernos dichosos, imbuidos de un pueril optimismo y de una devoción desenfrenada, y estos últimos desencantados se antojaba abismal. Así, Nietzsche entiende que «el hombre es una cuerda tendida entre el animal y el superhombre, una cuerda sobre un abismo» ${ }^{9}$.

El desequilibrio mentado, que alude ineludiblemente a la crisis finisecular del nihilismo, hunde sus raíces precisamente en las aspiraciones gnoseológicas modernas; en sus mismas pretensiones racionalistas nacidas de una caracterización del ser humano radicalmente epistémica. Cuando Descartes advierte al comienzo del Discurso, cual axioma, que la razón se manifiesta «naturalmente igual» en todos los hombres, precisándola además como «facultad de juzgar», está afirmándola como una dimensión esencialmente especulativa, esto es, teorética y orientada en primer lugar al dominio del conocimiento. La búsqueda cartesiana, confiesa el propio autor, está consagrada en última instancia a «llegar al conocimiento de todas las cosas de las que mi ingenio fuera capaz» ${ }^{10}$. Los restantes órdenes del saber -ora la estética ora la moral, etc.- habrían de ser poco más que sendos corolarios de cariz secundario y cualitativamente dependientes. En esta frontera esencial se incubó el germen de las dolientes protestas posteriores; quejas amargas que se cristalizarían en distintas propuestas reactivas contra el propio canon racionalista que había configurado el universo occidental.

El marco conceptual de finales del siglo XIX debe ser entendido dentro de esta atmósfera desazonada. Se trata para Nietzsche de un cambio de paradigma que queda con-

${ }^{7}$ Cfr. ibid. (KSA XII, 126-127): «las consecuencias nihilistas de la actual ciencia de la naturaleza (junto con sus intentos de escaparse hacia el más allá). De su actividad se sigue finalmente una autodestrucción, un dirigirse en contra de sí, una anticientificidad. -Desde Copérnico, el hombre se desliza desde el centro hacia la X».

8 Cfr. Nietzsche, F., Correspondencia V. Enero 1885 - Octubre 1887, ed. de Luis Enrique de Santiago Guervós, trad. introd. notas y apéndices de Juan Luis Vermal, Madrid, Trotta, 2011, pág. 162 (KSB VII, 177) (las citas de la correspondencia de Nietzsche en alemán corresponden a la siguiente edición: Sämtliche Briefe. Kritische Studienausgabe in 8 Bänden. [KSB], herausgegeben von Giorgio Colli und Mazzino Montinari unter Mitarbeit von Helga Anania-HeB, München, Walter de Gruyter, 1986. Indicaremos a continuación el número del volumen en romanos y la página en numeración arábiga): «Pero esto es décadence, una palabra que, como se comprende de suyo entre nosotros, no pretende rechazar sino sólo designar». [Carta a Carl Fuchs. Mediados de abril de 1886].

${ }^{9}$ Nietzsche, F., Asi habló Zaratustra, trad. de Andrés Sánchez Pascual, Madrid, Alianza Editorial, 2009, pág. 38 (KSA IV, 16).

${ }^{10}$ Descartes, R., Discurso del método, op. cit., pág. 22. 
cretado en la despiadada fórmula de la «muerte de Dios»: la sospecha profunda de toda metafísica -sin importar si ésta es o no crítica - como una sistematización dogmática del mundo que lo restringe y cercena, al tiempo que condiciona las posibilidades intelectuales de sus agentes y su integración en el mundo ${ }^{11}$.

Se trata de un tiempo de despedida mientras se contempla la disolución de los valores de la modernidad. Un clima trágico frente al cual se posicionan algunas de sus más emblemáticas figuras, reconociéndose en un esforzado ejercicio redentor de la humanidad:

Yo soy un alegre mensajero como no ha habido ningún otro, conozco tareas tan elevadas que hasta ahora faltaba el concepto para comprenderlas; sólo a partir de mí existen de nuevo esperanzas. A pesar de todo esto, yo soy también, necesariamente, el hombre de la fatalidad. Pues cuando la verdad entable lucha con la mentira de milenios tendremos conmociones, un espasmo de terremotos, un desplazamiento de montañas y valles como nunca se había soñado ${ }^{12}$.

Las preguntas que se han de responder son varias: cuáles son los valores de la modernidad que, siguiendo a Nietzsche, equivale a inquirir por su genealogía; qué es la modernidad como tal, o sea, su desarrollo y recepción conforme los distintos momentos de su dinámica; el porqué de la crisis, esto es, su problemática, dificultades, inconsistencia y carencias. Se trata de atender a los rasgos cuyo desenvolvimiento hizo desembocar el sueño cartesiano no ya en una empresa fallida, sino en un mundo desangelado y nihilista. La confianza cartesiana de haber hallado una verdad «tan firme y tan segura que todas las más extravagantes suposiciones de los escépticos no eran capaces de socavarla» ${ }^{13}$, acabó cediendo su vigencia ante la violenta y corrosiva experiencia del nihilismo. Una realidad impensable que se afianzó en la experiencia filosófica del continente. En palabras de Heidegger, «nihilismo significa: los valores supremos se desvalorizan» ${ }^{14}$.

Dentro de toda su profunda exégesis del pensamiento moderno en particular, y de la historia de la filosofía en general, Nietzsche hará especial énfasis en los problemas emanados de la metafísica. En lo que respecta al horizonte del mundo moderno, comprenderá que los ecos clásicos han adquirido su peculiar idiosincrasia al abrigo de la obra cartesiana, cuyo trazo intelectual perseguirá durante las centurias posteriores. Así, el autor francés se le presentará como el heredero de la vieja tradición platónica de la duplicación de mundos -«verdadero»y «aparente»- y de la escisión de la persona -«alma» y «cuerpo»-: la fronte-

\footnotetext{
${ }^{11}$ Ya entonces el positivismo se había asentado como la visión normativa de la realidad.

12 Nietzsche, F., Ecce homo, trad. de Andrés Sánchez Pascual, Madrid, Alianza Editorial, 2008, pág. 136 (KSA VI, 366).

${ }^{13}$ Descartes, R., Discurso del método, op. cit., pág. 47.

${ }^{14}$ Heidegger, M., Nietzsche, trad. de Juan Luis Vermal, Barcelona, Ariel, 2013, pág. 36.
} 
ra abierta entre «res cogitans» $\mathrm{y}$ «res extensa» no es sino la nueva proposición del antiguo binomio irreconciliable de la metafísica griega.

Luego el estudio de Nietzsche pasará por los distintos avatares que la metafísica moderna ha afectado, desde la gnoseología en cuanto hasta la concepción moral, pasando por estimaciones políticas, estéticas e incluso científicas. Sin embargo, todas sus cuestiones atraviesan una preocupación radical común: el problema de la existencia subjetiva. La persona concreta se convierte para Nietzsche en el interrogante filosófica capital, al comprender que sobre ella brotan las demás cuestiones. Por tanto, el cosmos del hombre adquiere una importancia mayúscula, sin embargo, desde una posición ignorada durante la modernidad madura: la propia persona encarnada que desde su particular experiencia de existencia se ve azotada por dificultades, problemas y diatribas existenciales. Toda esta complejidad se concreta en la «corporalidad», estamento fundamental de vida desde la cual se despliegan las diferentes potencias y facultades que componen la «persona» presente y futura. 


\section{CAPÍTULO I: EL CUERPO EN NIETZSCHE: ACONTECIMIENTO DE PLURALIDAD ESENCIAL}

\section{I.1. El cuerpo, síntoma de la voluntad de poder}

Con la finura que caracteriza su aguda filosofía Martin Heidegger hizo ver que «Nietzsche concibe el nihilismo como un proceso histórico» ${ }^{15}$ que comienza con la progresiva «desvalorización de los valores hasta entonces supremos» ${ }^{16}$ y concluye en la definitiva «transvaloración de todos los valores anteriores» ${ }^{17}$. En este discurso histórico Nietzsche concibió el nihilismo como una etapa intermedia, de tránsito donde él mismo deviene el ideal de la vida más desbordante.

En la filosofía nietzscheana se persigue explotar la específica hybris de vida del nihilismo, la cual apunta hacia un hedonismo peculiar ejemplarmente cifrado en el Anticristo como reacción contra la ponzoña cristiana, que atraviesa no sólo la antropología católica de la culpa o el pietismo protestante, sino también la aparente secularización laica habida en la modernidad:

Podemos resumir el pensamiento de Nietzsche sobre el nihilismo incompleto de manera más clara y precisa diciendo: es verdad que el nihilismo incompleto sustituye los valores anteriores por otros, pero sigue poniéndolos en el antiguo lugar, que se mantiene libre a modo de ámbito ideal para lo suprasensible. Ahora bien, el nihilismo completo debe eliminar hasta el lugar de los valores, lo suprasensible en cuanto ámbito, y por lo tanto poner los valores de otra manera, transvalorarlos.

De aquí se deduce que para el nihilismo completo, consumado y, por tanto, clásico, se precisa ciertamente de la «transvaloración de todos los valores anteriores» [...]. La instauración de valores necesita un nuevo principio, esto es, renovar aquello de donde parte y donde se mantiene. La instauración de valores precisa de otro ámbito. Ese principio ya no puede ser el mundo de lo suprasensible, ahora sin vida. Por eso, el nihilismo que apunta a la inversión así entendida, buscará lo que tenga más vida. De este modo, el propio nihilismo se convierte en «ideal de la vida pletórica» $^{18}$.

La caracterización del nihilismo en este segundo momento, como disposición afectiva a través de la cual se pretende aprovechar su fuerza de vida, o sea, el nihilismo como puerta hacia la transvaloración, se encuentra en el elemento más revolucionario de la filosofía de Nietzsche, ya que bajo el mismo se pone fin al aspecto distintivo de la metafí-

${ }^{15}$ Heidegger, M., «La frase de Nietzsche 'Dios ha muerto'», trad. de Helena Cortés y Arturo Leyte, en Caminos de bosque, versión de Helena Cortés y Arturo Leyte, Madrid, Alianza Editorial, 2012, pág. 206.

16 Ibid.

${ }^{17}$ Ibid. pág. 169.

18 Ibid. pp. 168-169. 
sica europea tradicional: el dualismo de raigambre platónica. Tras una longeva disposición filosófica de más de dos milenios se desvanece en Nietzsche la frontera abismal entre el alma y el cuerpo y ambas dimensiones se integran solidariamente en una compleja unidad indisoluble bajo la difícil y oscura etiqueta de «corporalidad».

La noción de «corporalidad» en Nietzsche es un baúl de complejo significado. Es un concepto de cariz existencial que marca el devenir de una filosofía que, en sentido inverso que la filosofía de la existencia de Kierkegaard, parte de un estadio religioso -y atraviesa uno ético, que en Nietzsche será negado- para consumarse en plenitud en un universo estético que denuncia el duelo nihilista de la racionalidad moderna.

El fenómeno de la corporalidad había supuesto para Nietzsche un problema desde sus inicios, ya por importancia filosófica ya por mero posicionamiento contra la tradición. El legado platónico había denostado la materia en beneficio de una pretendida esencia espiritual, tanto para el mundo como para el hombre. La ortodoxia moderna, si bien se esforzó en postularse como una revolución del pensamiento cuyas aspiraciones pasaban por dejar atrás el pasado clásico, no fue menos censora de la carne que sus predecesores. De tal forma que la esencial distancia entre el «mundo ideal»y el «mundo aparente» de la Antigüedad tiene su homólogo moderno en las respectivas categorías de «mente» $\mathrm{y}$ «cuerpo».

Esta semejanza entre la Antigüedad y la Modernidad permite a Nietzsche trazar una línea intelectual continuista entre el pasado y el presente para concluir que la modernidad vigente no era sino la forma secularizada de la metafísica de la duplicación; un ateísmo que continúa afirmando la gramática del Dios muerto. Es dentro de esta órbita donde ha de ser explicado el concepto nietzscheano de «corporalidad», no tanto como la vacía vindicación del cuerpo como continente de procesos fisiológicos como la piedra angular desde la que ejecutar la crítica de la razón metafísica. La riqueza de esta noción, por tanto, rebasa las restrictivas concreciones dualistas, ya que no traza una frontera categórica esencial, sino que las imbrica en una unidad aparente de destino existencial. El problema de la reivindicación de la corporalidad en la filosofía de Nietzsche es, en última instancia, el problema de la reapropiación de la existencia tras la toma de conciencia de la crisis finisecular del nihilismo. Tópico éste, no obstante, recurrente en el horizonte intelectual de la segunda mitad de la centuria decimonónica:

Alma y cuerpo, cuerpo y alma -iqué misteriosos eran! Había algo de animal en el alma, y el cuerpo tenía momentos de espiritualidad. Los sentidos podrían refinar y el intelecto degradar. ¿Quién podía decir dónde cesaba el impulso carnal, o empezaba el mental? ¡Qué superficiales eran las arbitrarias definiciones de los psicólogos corrientes! Y sin embargo ¡qué difícil decidirse entra las pretensiones de las varias escuelas! ¿Era el alma una sombra sita en la casa del pecado? ¿O estaba el cuerpo en realidad en el alma, como pensaba Giordano Bruno? La separación entre 
el espíritu y la materia era un misterio, y la unión del espíritu con la materia también era un misterio ${ }^{19}$.

La muerte de Dios anunciada por Nietzsche, que arrastra consigo el deceso de la moral judeocristiana, tiene como consecuencia última la subsunción de todas las categorías humanas bajo la estética. La vindicación de la corporalidad es la consagración de un nuevo sujeto esteta en quien se conjugan arte, belleza y vida como la manifestación del más alto ideal de existencia: «te convertiste -le dice Basil a Dorian- para mí en la encarnación visible de ese ideal invisible cuyo recuerdo nos obsesiona como un sueño exquisito a los artistas $»^{20}$. La realización de la obra de arte que es la propia vida pasa, dice Nietzsche, por la arriesgada apuesta de vivir entre la infinitud del cielo y la limitación de la tierra, o sea, más allá del bien y del mal.

Los autores del siglo XIX, especialmente en su segunda mitad, sensibles a los efectos disruptivos del nihilismo hicieron coincidir el arte y la vida en un juego de valoraciones por el que los placeres más refinados de la vida se identificaron con la belleza artística: el valor supremo de la vida era, a su vez, su dignidad estética:

La gente corriente esperaba que la vida le revelase sus secretos, pero a unos pocos, a los elegidos, se les revelaban los misterios de la vida antes de descorrer el velo [...]. Pero de vez en cuando una personalidad compleja ocupaba el lugar y asumía la función del arte, era de hecho, a su manera, una verdadera obra de arte ${ }^{21}$.

Todo habrá de quedar concretado en caracteres estéticos tras la muerte de Dios, pues las instancias de la religión y la moral han quedado vacías de contenido: el dios ya no mora en dichos templos: «la Vida misma era la primera, la más grande de las artes, y todas las demás no parecía que fueran más que una preparación» ${ }^{22}$. El fenómeno decimonónico de la emergencia del cuerpo, el cual resulta especialmente relevante dentro de la crítica nietzscheana del dualismo platónico y de su legado racionalista cartesiano, hace de la «apariencia» un atributo tan legítimo como el «ser»: alma y cuerpo integradas en el complejo «corporalidad» tras la experiencia nihilista.

Es Nietzsche quien más ahonda en el devastador proceso de desvalorización del cuerpo sufrido en Occidente a lo largo de siglos de dualismo filosófico. Movimiento denigrante que condujo al hombre en general y al individuo en particular a una deplorable indigencia despreciadora:

\footnotetext{
${ }^{19}$ Wilde, O., El cuadro de Dorian Gray, op. cit., pág. 155.

${ }^{20}$ Ibid. pág. 218.

${ }^{21}$ Ibid. pág. 154.

${ }^{22}$ Ibid. pág. 236.
} 
¡Hundirse en su ocaso quiere vuestro sí-mismo, y por ello os convertisteis vosotros en despreciadores del cuerpo! Pues ya no sois capaces de crear por encima de vosotros.

Y por eso os enojáis ahora contra la vida y contra la tierra. Una inconsciente envidia hay en la oblicua mirada de vuestro desprecio.

¡Yo no voy por vuestro camino, despreciadores del cuerpo! ¡Vosotros no sois para mí puentes hacia el superhombre! ${ }^{23}$.

Este pasaje paradigmático encumbra el movimiento en virtud del cual Nietzsche iniciará la empresa de revalorización del cuerpo en una Europa que, entiende, no puede fingir como emancipatorios los aires tan tóxicos del nihilismo.

La corporalidad tiene un eco crucial en el corpus nietzscheano, pues sobre la misma se articula, proyecta y despliega la original y novedosa concepción del hombre y del mundo propuesta por el autor: «es esencial partir del cuerpo y utilizarlo como hilo conductor» ${ }^{24}$. En su reivindicación del cuerpo se hace explícita su cruzada contra los «despreciadores del cuerpo», frente a los cuales promueve el olvido de una tradición de siglos de «desnaturalización» del cuerpo. Desde los pilares fundamentales de Occidente -la dupla conformada por Sócrates y Platón- se estableció una actitud reactiva con respecto al cuerpo $^{25}$ : la moral bimilenaria occidental, ímpetu terrible que sería máximamente desarrollado por el cristianismo, propuso una praxis contraria a los estímulos de la vida. Una escuela que Nietzsche califica de degenerada y enferma ante la que propone una alternativa saludable que acoja los principios de vida en aras de su refinamiento:

la moral contranatural, es decir, casi toda moral hasta ahora enseñada, venerada y predicada, se dirige, por el contrario, precisamente contra los instintos de la vida, - es una condena, a veces encubierta, a veces ruidosa e insolente, de esos instintos $»^{26}$.

El desprecio del cuerpo, observa Nietzsche, va ligado a un profundo desconocimiento de dicho acontecimiento: no se antoja suficiente aceptar con Platón que tenemos cuerpo, sino que hemos de afirmarnos en él: «somos cuerpo». Nuestro ser en el mundo tiene lugar desde la corporalidad, que supera la apreciación platónica de «cárcel»; cuanto somos es expresión del cuerpo: sentimientos y afectos, pasiones y tensiones, mas también el

\footnotetext{
${ }^{23}$ Nietzsche, F., Así habló Zaratustra, op. cit., pág. 66 (KSA IV, 40-41).

${ }^{24}$ Nietzsche, F., Fragmentos póstumos III, 40 [15], ed. de Diego Sánchez Meca, trad. de Diego Sánchez Meca y Jesús Conill, Madrid, Tecnos, 2010, pág. 848 (KSA XI, 635).

${ }^{25}$ Cfr. Nietzsche, F., Fragmentos póstumos IV, 2 [102], op. cit., pág. 107 (KSA XII, 112): «La creencia en el cuerpo es más fundamental que la creencia en el alma: la última ha surgido de las aporías de una consideración acientífica del cuerpo (algo que lo abandona. Creencia en la verdad del sueño —)».

26 Nietzsche, F., Crepúsculo de los ídolos, trad. de Andrés Sánchez Pascual, Madrid, Alianza Editorial, 2010, pág. 63 (KSA VI, 85).
} 
intelecto y la razón. Así termina Nietzsche sentenciando que «el cuerpo humano es una creación mucho más perfecta que cualquier sistema de pensamiento y de sentimientos, incluso muy superior a una obra de arte» ${ }^{27}$.

Su peculiar condición hace imposible concretar el cuerpo en términos de unidad. Al contrario, en él se aglutina una pluralidad irreductible que desvela tanto la fuerza insostenible de las infinitas posibilidades de existencia como la terrible decrepitud de un organismo perecedero que revela la voracidad temible y dolorosa de la muerte insalvable. De este modo el cuerpo aniquila las pretéritas imágenes del hombre idealizado: la corrupción es el destino de todo hombre, que se eleva sobre un fondo esencial orgánico. Con todo, el cuerpo es tanto límite como infinitud: en él conviven realidades múltiples donde unas fueron; algunas pueden ser; otras jamás serán dentro del umbral definitivo de la muerte. El hombre, en tanto que es cuerpo, alberga un universo dentro de sí. El ser humano concreto no ha de olvidar este insondable fondo de indeterminación y posibilidades, pues suya es la responsabilidad de decidir cuáles explotar en beneficio o en detrimento de la vida. Una puesta en escena que acontece mediante la voluntad de poder.

Son muchos los pasajes en los que Nietzsche describe el cuerpo como «hilo conductor» ${ }^{28}$. La cuestión es, no obstante, doble: ¿destino y telos? El cuerpo es el hilo conductor de la sabiduría de la vida, la hebra capaz de guiarnos en la realización de la obra de arte que es la vida propia: el cuerpo es el hilo conductor del qué hacer, en detrimento del deber del imperativo kantiano. Desde el cuerpo profundizamos en el conocimiento de nosotros mismos, aunque desde principios y estamentos distintos de los cartesianos, pues no nos guía a la autoconciencia, sino a la conciencia de los instintos. El énfasis depuesto en unos u otros determina el tipo de hombre que somos, el decadente «cristiano» despreciador de sí mismo o un espíritu libre que se vindica en su finitud infinita. Es decir, desde nuestra apreciación y apropiación del cuerpo, la voluntad de poder se despliega en la fecundidad de la aurora o en la depravación de la cultura nihilista.

En respuesta de toda la tradición moderna de la subjetividad, Nietzsche persigue un nuevo conocimiento del individuo; una recuperación de la vieja máxima de Delfos rendida, sin embargo, a las exigencias determinantes del fondo insondable de indeterminación del cuerpo: el conocimiento de sí debe integrar el umbral de oscurantismo que subrepticia-

${ }^{27}$ Nietzsche, F., Fragmentos póstumos III, 25 [408], op. cit., pág. 523 (KSA XI, 119).

${ }^{28}$ Entre otros, cfr. ibid. 36 [35], pág. 804 (KSA XI, 565): «Siguiendo el hilo conductor del cuerpo.

Suponiendo que 'el alma' fuera un pensamiento atractivo y misterioso del que los filósofos, con razón, se han separado sólo de mala gana - quizá lo que aprenden hoy a aceptar a cambio es todavía más atractivo, todavía más misterioso. El cuerpo humano, en el que revive y se encarna el entero pasado más lejano y más próximo del devenir orgánico, por el cual, a través del cual y más del cual parece fluir una enorme corriente imperceptible: el cuerpo es un pensamiento más maravilloso que la vieja 'alma'». 
mente opera en nosotros y perfila nuestra identidad ${ }^{29}$, en tanto que «la mayor parte de nuestras vivencias es inconsciente y es efectiva ${ }^{30}{ }^{3}$. La importancia concedida por Nietzsche a los procesos ocultos acentúa la necesidad de la dimensión del «cuidado», que tanto cultivará el autor: la curación de una herencia enferma que ha impedido afrontar desde una dimensión artística la tarea de la propia vida, pues «iel buen gusto de una comida es la consecuencia de su buen provecho!»» ${ }^{31}$.

La disposición del cuidado a la que aboca la corporalidad es crucial para la jerarquización de los hombres, hito imprescindible en la filosofía de Nietzsche. Elementos aparentemente tan distintos como la riqueza de su pluralidad o su resistencia al sufrimiento se entremezclan en la complejidad de la voluntad de poder, en último término, su disposición afirmativa o reactiva ante la vida: la fortaleza y la debilidad del cuerpo son las condiciones del «sí» y del «no» respectivamente. Entendida la corporalidad como nuestro ser las diferencias cualitativas entre los hombres son entonces innegables: al débil le corresponde un cuerpo de semejantes rasgos, al tiempo que el vigoroso invoca la fortaleza hercúlea de unos miembros infatigables. Ahora bien, el propio Nietzsche reconocía la precariedad de su salud en paralelo con la inquebrantable tenacidad de su fisionomía. Bajo esta aparente contradicción se comprende que sus conceptos de «fortaleza» y «vigor» aluden menos a la pueril fuerza de unos músculos embrutecidos que a la capacidad para convertirse a uno mismo en fuente de fuerza creadora.

Habiendo hecho del cuerpo el hilo conductor de la sabiduría de la vida puede Nietzsche evaluar el sustrato de la cultura, sobre la cual se constituye un tipo humano $u$ otro de acuerdo con los rasgos que ésta haya asentado. Luego las «tablas morales» son respuestas valorativas de la realidad fisiológica de los dominantes, de suerte que un pueblo de hombres débiles y frágiles, extraños a la fuerza torrencial de una vida robusta, pregonará principios de subordinación y sometimiento, esto es, una contranaturaleza; por el contrario, los pueblos históricamente vigorosos se educaron en la fortuna del poderoso que se contempla a sí mismo como creador. Sólo desde esta órbita de la corporalidad se comprende el

${ }^{29}$ Cfr. Nietzsche, F., Aurora, trad. de Jaime Aspiunza, en Obras completas. Volumen III. Obras de madurez I, ed. de Diego Sánchez Meca, Madrid, Tecnos, 2014, pág. 660 (KSA III, 278): «Curas lentas. Las enfermedades crónicas del alma se originan como las del cuerpo, rara vez por haber contravenido en una sola ocasión la razón del cuerpo y del alma, sino generalmente por un número incontable de pequeños descuidos inadvertidos. [...] Todas estas curas son lentas y minuciosas; también quien desee curar su alma ha de meditar acerca de la transformación de los hábitos más nimios».

${ }^{30}$ Nietzsche, F., Fragmentos póstumos III, 25 [359], op. cit., pág. 516 (KSA XI, 106).

${ }^{31}$ Ibid. 25 [373], pág. 517 (KSA XI, 106). 
«deseo» con que cierra el Tratado I de La genealogía de la moral, a saber, una historia fisiológica de la moral ${ }^{32}$.

El cuerpo es, con todo, el camino por el que transita la voluntad de poder. En su vasta complejidad se suceden fuerzas que se enfrentan entre sí y de cuya colisión emerge el constructo que llamamos «vida», confeccionada en función de aquellos instintos que hayan sido establecidos jerárquicamente dominantes: somos el resultado de la conflictiva colaboración de muchas voluntades de poder que luchan por imponerse. La relación entre el cuerpo y la voluntad de poder se cifra en un círculo íntimo donde los instintos son aprehendidos por ella que, a su vez, nos hace retornar al cuerpo configurado. Un cuerpo en el que convergen la unidad sintiente del hombre con la pluralidad subyacente de las voluntades de poder y que cifra la concepción ontológica de Nietzsche: el modo de ser es la pluralidad, que, sin embargo, se concreta en una unidad tan real como coyuntural y precaria que ha renunciado a la pretensión de alcanzar un Ser inmutable. Somos cuerpo, es decir, voluntad de poder.

\section{I.2. EI cuerpo como unidad de cuidado}

La unidad en Nietzsche es precaria, mas ello no supone una deficiencia que haya de ser superada. Es una condición que responde al devenir estructural de la dinámica de la voluntad de poder: el constante juego de voluntades en conflicto convierte en imposible la empresa de una unidad esencial e incorruptible. Mas, como se apunta, no es una dificultad que remediar, sino la peculiaridad de la existencia humana que sobre el cuerpo no flaquea ni fragmenta. Por ello, pese a su inestabilidad Nietzsche no cuestiona su integridad; todo queda dispuesto en el arco de posibilidades que facultad el cuerpo.

La sólida defensa de la unidad corporal como ser del hombre se comprende desde su revisión de la historia moral de Occidente. El énfasis por la unidad somática es una punta de lanza contra el dualismo, la dupla alma-cuerpo de la Antigüedad que se corresponde con la donidad mente-cuerpo de la subjetividad moderna. El hombre de conocimiento, aquel que se ha adentrado en el fondo de la vida ha comprendido imposible el mantenimiento del dualismo: «el sapiente, dice: cuerpo soy yo íntegramente, y ninguna otra cosa; y

${ }^{32}$ Cfr. Nietzsche, F., La genealogía de la moral, trad. de Andrés Sánchez Pascual, Madrid, Alianza Editorial, 2011, pp. 79-80 (KSA V, 288-289): «Aprovecho la ocasión que me proporciona este tratado para expresar pública y formalmente un deseo que hasta ahora he manifestado tan sólo en conversaciones ocasionales con personas doctas; a saber, que alguna Facultad de Filosofía se haga benemérita del fomento de los estudios de historia de la moral

[...], también resulta necesario, desde luego, ganar el interés de los fisiólogos y médicos para estos problemas (acerca del valor de las apreciaciones valorativas habidas hasta ahora): aquí se les puede dejar a los filósofos de oficio el representar, también en este caso singular, el papel de abogados y mediadores, una vez que hayan logrado que la relación originariamente tan áspera, tan desconfiada, entre filosofía, fisiología y medicina se transforme en el más amistoso y fecundo de los intercambios». 
alma es sólo una palabra para designar algo en el cuerpo» ${ }^{33}$. La expectativa metafísica de un mundo suprasensible, el paroxismo onírico de pueblos rudimentarios e ingenuos es hoy insostenible para el nuevo hombre de Delfos.

Asegura que por sí mismo «el cuerpo es una gran razón, una pluralidad dotada de un único sentido» ${ }^{34}$, y que, el «cuerpo y su gran razón: ésa no dice yo, pero hace yo» ${ }^{35}$. Nietzsche, no obstante, no parece tener denodado interés en sacrificar el viejo léxico del dualismo, por lo que mantiene todavía la palabra «espíritu», al que sin embargo, ha privado de sus rasgos clásicos para hacerlo dependiente de la unidad plural del cuerpo.

El desprecio del cuerpo hunde sus raíces en un paralizador pavor ante la vida que responde a una inserción en el mundo desde la amargura y el dolor. Actitudes éstas que devienen hábito dentro de la cultura y que terminan por hacer de la vida un dolor insoportable. En respuesta a tamaña amargura surgen las religiones y morales piadosas, que tratan de remediar la angustia existencial mediante la radical y virulenta censura del cuerpo.

La dimensión corporal nos había introducido en el umbral moral desde la metáfora del hilo conductor: un cuerpo débil evocaba principios de valoración débiles ${ }^{36}$. Por lo mismo, la actitud del cuidado como exigencia de una existencia artística trae consigo la denuncia de la tiranía del idealismo moral ascético que convirtió al hombre débil, enfermo, degenerado y hostil contra su cuerpo en adalid de rectitud y virtud; un individuo que labró su ejemplar fama en la lucha contra sí mismo, contra sus pulsiones y apetencias en beneficio del espíritu puro de su ser. Luego una actitud consistente en el enfrentamiento contra sí mismo como resulta ser el ascetismo, una reacción contraria a la naturaleza del viviente se identifica con una moral de desprecio de la corporalidad. De tal manera que al asumir que somos cuerpo Nietzsche hace una proclama de la transvaloración. La concepción nietzscheana del cuidado recupera el cuerpo como fuente de existencia y de valoración moral: la existencia se identifica con el cuerpo en su totalidad, rompiendo con la imagen platónica de la alegoría del carro alado, donde cada parte del alma residía, según sus rasgos, en una u otra parte del cuerpo.

La tradición de los despreciadores del cuerpo y su odioso ascetismo había terminado por identificar en el cuerpo la fuente de todo mal moral. Nietzsche, en su transvaloración, percibe en estos rasgos la decadencia del nihilismo de los tiempo: «la condena del

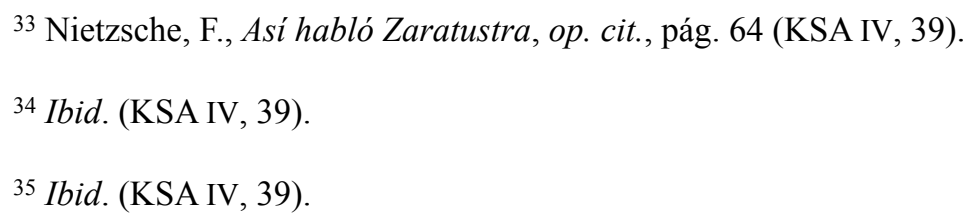

${ }^{36}$ Cfr. Nietzsche, F., Fragmentos póstumos III, 26 [45], op. cit., pág. 548 (KSA XI, 159): «nuestras estimaciones de valor están en relación con las condiciones de vida en que creemos: si éstas cambian, cambian también nuestras estimaciones de valor». 
cuerpo como señal característica de la mezcla malograda, igual que la condena de la vida: un signo de los vencidos» ${ }^{37}$.

\section{I.3. EI hombre encarnado como fondo de existencia}

Por elemental contraposición el rechazo del dualismo lleva a Nietzsche a una feroz defensa del monismo. Sin embargo, también éste goza de caracteres específicos en la obra nietzscheana, pues supera las tentativas coetáneas. Nietzsche no persigue un reduccionismo pueril y burdo a estamentos estrictamente materiales -marxismo- o fisiológicos biologicismo-; los diferentes elementos del cuerpo se integran en una oscura unidad desde la que se proyecta la vida: «iqué fríos y extraños nos han resultado los mundos que la ciencia iba descubriendo! ¡Qué distintos son, p. ej., el cuerpo tal como lo percibimos, vemos, sentimos tenemos o admiramos, y el 'cuerpo' tal como nos lo enseña la anatomía!» ${ }^{38}$.

El monismo nietzscheano no ofrece tan sólo una explicación mecánica de la vida, pues sería parcial e insuficiente. La dicotomía entre materia y espíritu se antoja perezosa y estéril, pues mantiene las tensiones de las formas del nihilismo europeo. El ser humano no es para Nietzsche una personalidad escindida que se mueve entre la carne o el alma, sino una nueva concreción de unidad motivada desde la multiplicidad. Una unidad fugaz y perecedera toda vez que se despliega sobre una jerarquización de valores sujeta a la constante confrontación contra otros tantos nuevos. Por ello puede Nietzsche hablar de una unidad plural, pues existe efectivamente al tiempo que tras ella palpita la multiplicidad de polaridades. Esta presentación ontológica del mundo apunta a la tradicional división filosófica de la apariencia y la realidad, que se diluye en el flujo de jerarquías de valores y apariencias. La ontología nietzscheana debilita la unidad de la realidad en detrimento de las pretéritas pretensiones de la esencialización del ser; el fondo de la existencia aduce a la corporalidad como integración tan sólida como voluble de infinitas personalidades: «el individuo contiene muchas más personas de las que él cree. 'Persona' es sólo una acentuación, un resumen de rasgos y cualidades ${ }^{39}$. El hombre encarnado es el resultado fisiológico del engarce de pasiones y afectos que flotan en un océano psicológico cuyo oscuro e inescrutable fondo hace imposible pretenderlo definitivo.

La imposibilidad de un fondo último, afecta a la corporalidad, a la voluntad de poder que si bien se reconoce como nuestro ser, no se le otorgan las atribuciones de fundamento. La apariencia no existe, por tanto, a expensas de una realidad ulterior. El cuerpo no

${ }^{37}$ Ibid. 25 [385], pág. 519 (KSA XI, 112-113).

38 Nietzsche, F., Fragmentos póstumos II, 14 [2], ed. de Diego Sánchez Meca, trad. de Manuel Barrios y Jaime Aspiunza, Madrid, Tecnos, 2010, pág. 869 (KSA IX, 623).

${ }^{39}$ Nietzsche, F., Fragmentos póstumos III, 25 [363], op. cit., pág. 516 (KSA XI, 108). 
es de este modo el fundamento ontológico, sino un estamento radical que atraviesa otras estancias. La unidad del cuerpo como complejo juego de jerarquías antecede al individuo, que es síntesis coyuntural resultante de la pluralidad somática. Así puede sentenciar Nietzsche que el concepto de individuo es falso, «y el inventor de sí mismo será considerado durante mucho tiempo un extraviado» ${ }^{40}$. La jerarquización de las pulsiones y tensiones que palpitan tras el cuerpo hace de la ficción del yo algo tan precario como necesario: desde el yo se vive y desde el cuerpo vive el yo.

Nietzsche lleva a cabo una revisión profunda de la subjetividad moderna y de su respectivo sujeto metafísico. La unidad del hombre encarnado a través de la voluntad de poder sacude los cimientos mismos de la modernidad filosófica. El legado mecanicista europeo se le presenta burdo e inapropiado; la metáfora de el hombre máquina de La Mettrie no es deseable, pues es una reducción infantil e ineficaz que no recoge la riqueza de la pluralidad del cuerpo. El mecanicismo construyó sobre la hipertrofia de una razón ideal dualista -mente y cuerpo- una unidad inerte ajena a las pulsiones de la vida y de la jerarquización de la voluntad de poder.

La hipertrofia de la razón es un fenómeno duramente rechazado por Nietzsche al contemplarlo como reflejo de la caracterización moderna del dualismo antiguo. En su denuncia Nietzsche sostiene que el pensamiento no es la única instancia determinante. La mente y el espíritu de la epistemología moderna son por el cuerpo, pues en él se manifiestan. Así Nietzsche transforma irremediablemente la concepción de cuerpo y espíritu habida hasta entonces. En su filosofía no son dos entidades movidas en la tensión agónica de una incómoda e indeseable relación simbiótica, sino la fusión hermenéutica de uno y otro en el otro: el cuerpo es tan espiritual como corporal el espíritu, constituyendo una unidad no amalgamada de las fuerzas conscientes e inconscientes que confluyen en la persona encarnada que se afirma como «yo». Puede entonces Nietzsche sentenciar que el cuerpo piensa en la medida en que el espíritu se corporaliza.

La relación entre fisiología y psicología en Nietzsche es recíprocamente retrospectiva, en tanto que asume una interpretación psicológica de los fenómenos fisiológicos del mismo modo que rastrea una causa fisiológica para la dimensión psicológica, concretándose una imbricación absoluta de ambos dominios. Síntesis ésta no exenta de dificultades y peligrosos problemas al concedérsele fuerza ontológica a la disposición psicológica del sujeto. Así explica Nietzsche la desazón orgánica y cultural del pesimismo decimonónico: a un malestar fisiológico como es el agotamiento de la vida se le identifica una correspondiente (des)motivación psicológica que tacha toda tentativa vitalista de infructuosa e ineficaz. En estas claves se comprende que exista una psicologización de lo fisiológico y una fi-

40 Ibid. 12 [12], pág. 281 (KSA X, 402). 
siología de lo psicológico. Este descubrimiento del que se jacta Nietzsche es fundamental para su teoría del cuidado, ya que lo abre a la comprensión del exponente vital de la psicología y su elemental papel dentro de la función artística de la vida.

La apreciación de una implicación ontológica en la psicología ofrece a Nietzsche claves para acometer su gran empresa de transvaloración. Recogiendo su propia invitación de La genealogía de la moral de llevar a cabo una historia fisiológica de la moral ${ }^{41}$, termina comprendiendo que la ignorancia de la «cuestión fisiológica» ha sido responsable de las penosas y maledicentes morales contranaturales que han colonizado el espectro occidental en un horizonte común: el desprecio del cuerpo y de la voluntad de poder, esto es, de la vida. Al malestar fisiológico de un momento concreto y su correspondiente hermenéutica psicológica se les atribuyó una interpretación moral. El salto es ilegítimo y, sin embargo, trazó el marco europeo: el agotamiento de fuerzas -fisiología- se percibe en caracteres psicológicos como una hermenéutica reactiva contra los instintos vitales, siguiendo inmediatamente una responsabilidad moral sobre dicho estado, a saber, la culpabilidad de tal flaqueza. Parafraseando la ecuación socrática del intelectualismo moral que ligaba el conocimiento, la felicidad y la virtud Nietzsche identifica el desconocimiento de la fisiología, la psicología y la moral de la contranaturaleza. Una tríada que halla su máxima manifestación en el cristianismo, el cual propugna un idealismo moral que deshumaniza al hombre al alejarlo de su corporalidad. El hombre cristiano, entendido cual tipo ideal weberiano, ha sido constituido de espaldas a su ser y contra sus instintos e inclinaciones; se le ha inculcado el odio y el resentimiento contra la vida. Una consideración moral que, en último término, hunde sus raíces tanto en la enfermedad -el tipo cristiano es un enfermo cuyas exiguas fuerzas han claudicado de la empresa de la existencia- como en el desconocimiento fisiológico de su propio ser encarnado.

Hacer una hermenéutica moral de los procesos fisiológicos arranca una específica significación del sufrimiento y del malestar, ya personal ya cultural. En vista de que lo fisiológico y lo psicológico se han entrelazado en una estrategia para derribar tanto el bruto biologicismo decimonónico como la antropología dualista de la cosa pensante propia del mecanicismo, la reflexión filosófica debe proyectar un nuevo tipo de hombre emancipado de los prejuicios morales. La filosofía debe penetrar el ser del hombre, la corporalidad para contemplar en plenitud la complejidad fisiológica y psicológica que se sacudan en un suelo de indeterminación que la voluntad de poder terminará especificando mediante su labor de jerarquización de los instintos afirmadores de la vida, es decir, del cuerpo y sus procesos de existencia en el hombre encarnado.

${ }^{41}$ Nietzsche, F., Fragmentos póstumos IV, 9 [173], op. cit., pág. 289 (KSA XII, 437): «[...] los afectos y los impulsos básicos expresan en cada raza y en cada estamento algo de sus condiciones de existencia». 
El simbolismo fisiológico abunda en la obra madura de Nietzsche como cauce de conocimiento, proyección y fortaleza. El Zaratustra puede ser leído como un peculiar tratado sobre el cuerpo, ya que se suceden en él las figuras relativas a las funciones orgánicas: nutrición, sueño, enfermedad, agotamiento son algunas de las imágenes de las que se sirve el autor para ilustrar el proceso de la vida. El hombre que vive puede quedar saciado de la existencia, mas también abotargado o sediento.

En ocasiones la vida puede resultar un mal de estómago, dice Zaratustra, que termina por rechazar cuanto ha ingerido y vomita -desprecia- sobre la mesa en torno a la cual se hubo sentado; un organismo cuyas funciones biológicas han sido malogradas tras ponzoñosos alimentos que lejos de nutrir las fuerzas del cuerpo las han desmantelado y entumecido.

Como un caprichoso comensal el hombre elige los manjares de los que disfrutar. Y así como el débil recurre a dulces frutos con los que aliviar la pesada carga de la existencia -narcóticos varios, como la creencia en las realidades en sí de los grandes conceptos de la historia de la moral: «bien», «Dios», «sacrificio», «castigo», «justicia», etc.-, el poderoso acepta las agrias semillas del sufrimiento y el conocimiento de la corporalidad que consigue transmutar en fuerza y deseo de vivir: «El veneno ante el que sucumbe la naturaleza más débil es para el fuerte un fortalecimiento - y tampoco lo llama veneno» ${ }^{42}$. Desde esta red de metáforas Nietzsche esgrime una dura crítica del hombre moderno y de su hambrienta cultura cuya alimentación sólo ha atrofiado por saciedad el espíritu contemporáneo: «Mi filosofía está dirigida a la jerarquía» ${ }^{43}$.

El hombre moderno ha perdido en su voracidad la capacidad de discriminación; no es un estómago selecto y refinado. En términos morales, la «nivelación» ${ }^{44}$. Su espíritu desconoce la fuerza que yace en el «no» creador y, como el asno, dice «sí» («I-A»). De tal modo que es incapaz de dejar atrás cuanto lo daña, maltrata y lastra. Es el camello que carga con las deudas y los errores del pasado al tiempo que cercena la posibilidad de la obra creativa de su vida. Es más, «el supremo objetivo del arte no debería ser representado por los débiles» ${ }^{45}$.

Frente a esta antropología Nietzsche propone el hombre rebelde que se sostiene sobre la corporalidad. Un conocimiento profundo de la fisiología del cuerpo lo descubre

${ }^{42}$ Nietzsche, F., La gaya ciencia, trad. de Juan Luis Vermal, en Obras completas. Volumen III, op. cit., pág. 751 (KSA III, 390).

${ }^{43}$ Nietzsche, F., Fragmentos póstumos IV, 7 [6], op. cit., pág. 203 (KSA XII, 280).

${ }^{44}$ Cfr. Nietzsche, F., Fragmentos póstumos II, 41 [42], op. cit., pág. 463 (KSA VIII, 590): «la comunidad surge para poner fin a la lucha por la existencia. El equilibrio, su punto de vista».

45 Ibid. 41 [61], pág. 465 (KSA VIII, 593). 
como una compleja red de interpretaciones de inaprensible sentido ${ }^{46}$ : el cuerpo en su vivir -encarnado- interpreta; interpretaciones que cristalizan en posteriores valoraciones. De modo que en el hombre nietzscheano vida y cuerpo conforman una unidad sintética que transita sobre la interpretación de perspectivas; el sujeto nietzscheano es hermenéutico, pues la fisiología le ha mostrado que no existe la parmenídea instancia del ser en $\mathrm{si}^{47}$. Es más, la sospecha de nuestro autor pasa por apostar que la relación tradicionalmente solidaria entre el hombre y el ser es incompatible con una vida encarnada: «todo lo que entra en la conciencia como una 'unidad' es ya enormemente complejo: nunca tenemos más que una apariencia de unidad» ${ }^{48}$. Ser sujeto es ser interpretativo; el acontecimiento de la interpretación es un fenómeno ilimitado toda vez que se nutre no de un suelo provisto de fundamento, sino de un juego de fuerzas que en su interacción violenta se transforman y dan lugar a valoraciones. Este fondo hermenéutico es inaccesible desde los caracteres de la razón especulativa moderna enraizada en la consciencia del yo. La imagen que arroja Nietzsche de la vida hermenéutica, sin embargo, no reposa en la ignorancia y la indigencia del desarraigo de sí mismo, sino en el compromiso filosófico de quien pretende la paulatina apropiación de sí dentro de un horizonte que axiomáticamente niega la plena realización de dicha empresa.

\section{I.4. El cuerpo hermenéutico como ser de la dimensión de lo inconsciente}

La impenetrable oscuridad de los procesos subrepticios de la vida es un estamento más de la vida hermenéutica. Es decir, no colisiona con la pretensión de un sujeto que trate de ahondar en el abismo de su ser. Es más, prosigue Nietzsche, el esfuerzo por la progresiva conquista de la autocomprensión es algo a lo que no podemos renunciar, es condición necesaria de nuestra especie, al tiempo que insuficiente por sí misma. La conciencia de la conciencia es un hito diferenciador del ser humano que lo ha situado de un modo específico en el mundo, a saber, el de la representación, la subjetividad. La autoconciencia es tanto límite como condición de posibilidad, pues al tiempo que nos presenta como seres vulnerables y frágiles ${ }^{49}$, alberga dentro de sí el espejo del mundo merced al cual caracterizamos

${ }^{46}$ Nietzsche, F., Fragmentos póstumos IV, 5 [55], op. cit., pág. 161 (KSA XII, 205): «Error capital de los psicólogos: consideran a la representación indistinta como una especie inferior de representación respecto de la clara: pero lo que se aleja de nuestra conciencia y por ello se vuelve oscuro, puede por ello ser en sí perfectamente claro. El volverse oscuro es cuestión de la perspectiva de la conciencia. a lo 'oscuro'».

La 'oscuridad' es una consecuencia de la óptica de la conciencia, no necesariamente algo inherente

${ }^{47}$ Cfr. ibid. 7 [6], pág. 205 (KSA XII, 283): «el 'hay necesidad de una sola cosa' y el 'aspira al reino de Dios: y todo lo demás te será dado por añadidura' ('lo demás' incluye también p. ej. el amor al prójimo, la moran en el sentido actual)».

48 Ibid. 5 [56], pág. 161 (KSA XII, 205).

49 Podemos conservar la vida orgánica si prescindimos de la autoconciencia, ya que las funciones biológicas perduran, mas no la vida genuinamente humana. 
ambos, nuestra propia existencia y la de la realidad exterior, como apreció Descartes en sus investigaciones sobre el cogito. La dimensión autoconsciente es una barrera infranqueable e inaccesible en su plenitud para el sujeto, al tiempo que sin ella no existe posibilidad alguna de representación ${ }^{50}$. De modo que la inconsciencia es algo imposible para el hombre, puesto que sería lo mismo que negar la capacidad de representación; de modo que aun contemplando su fragilidad y la imposibilidad de profundizar y escudriñar sus más íntimos secretos, el «yo» es condición de vida: «¿qué son, por último las verdades del hombre? Son los errores irrefutables del hombre ${ }^{51}$. El yo, sentencia Nietzsche, es un «error irrefutable».

Sin embargo, del mismo modo que defiende enérgicamente la autoconciencia rechazará tan furibundamente la cartesiana $f e$ de la plena autoconciencia. No es admisible que la tradición filosófica, y la modernidad particularmente, hayan tomado como única fuente de ejercicio y contenido mental efectivo el pensamiento consciente: la autoconciencia no es condición suficiente de la existencia. Nietzsche antes que Freud contempla que el grueso de nuestro psiquismo es inconsciente. El hombre decimonónico no puede eludir por más tiempo el abismo de infinitud del inconsciente que se ha abierto ante él. Un abismo terrorífico, puesto que nosotros somos ese inconsciente y somos por ese inconsciente: el caparazón que de nuestra imagen se percibe desde el exterior hunde sus raíces en un suelo oscuro que atenta contra el soberbio antropocentrismo que legara la Revolución copernicana, pues nada indubitable podemos decir de él:

El desconocido mundo del «sujeto». — Lo que, desde los tiempos más remotos hasta ahora mismo, tan difícil se les hace de entender a los hombres es jel desconocimiento que tienen de sí mismos! No sólo en lo que toca al bien y al mal, sino también a ¡un asunto que es mucho más esencial! Sigue aún viva la arcaica ilusión de que se sabe, con absoluta precisión y en todos los casos, cómo se lleva a cabo la acción humana. Y no sólo Dios, «que ve en el corazón de los hombres», no sólo el autor que reflexiona lo que hace, — no, ningún otro duda tampoco que entienda lo esencial del proceso de actuación de cualquiera. «iSé lo que quiero, lo que he hecho, soy libre y responsable de ello, hago al otro responsable; a las posibilidades morales y a las emociones íntimas que anteceden a una acción sé llamarlas por su nombre; a vosotros os gustaría actuar como quisierais, - en eso me conozco bien y os conozco a todos vosotros!» — así pensaba antes todo el mundo, así piensa aún casi todo el mundo. [...] ¿No es justo ésa la «terrible» verdad: que todo lo que se pueda saber de un acto nunca es suficiente para llevarlo a cabo, que hasta ahora jamás se ha tendido el puente que va del conocimiento al acto, ni una sola vez? ¡Las acciones nunca son lo que parecen ser! Hemos puesto tanto empeño en aprender que las cosas de fuera no son tal como se nos presentan, - ipues bien, con el mundo interior sucede exactamente lo mismo! Las acciones morales son realmente «al-

${ }^{50}$ La propia muerte, condición existencial elemental en Nietzsche, es ella misma también una representación pensada desde el sujeto consciente que contempla la posibilidad de la muerte desde el artificio de imágenes e interpretaciones que trae consigo la subjetividad.

${ }^{51}$ Nietzsche, F., La gaya ciencia, op. cit., pág. 827 (KSA III, 518). 
go distinto», — más no podemos decir: y todas las acciones son en esencia desconocidas. La creencia general ha sido y sigue siendo la contraria: contra nosotros está el realismo más ancestral; hasta ahora la humanidad pensaba: «una acción es tal como se nos presenta» ${ }^{52}$.

El descubrimiento de lo inconsciente no puede ser un anecdótico momento de la trayectoria filosófica del autor. Preocupado radicalmente por la existencia, Nietzsche se pregunta por los efectos de esto en la vida, concluyendo que habrá de afectar necesariamente a las aspiraciones existenciales mismas: la «vieja ilusión» de creernos conspicuos sabedores de las motivaciones de la acción humana se vino abajo.

El descubrimiento de lo inconsciente enfrenta la exigencia de inmediatez de la cultura moderna con la filosofía en ocasiones lenta y meditada de Nietzsche. Lo consciente es la plasmación inmediata de la realidad humana, pero precisamente por ello no puede ignorarse que el sustrato sobre el que germina es un trasfondo de pluralidad de fuerzas enfrentadas que tratan de ganar un lugar privilegiado en la determinación jerárquica de las muchas perspectivas posibles. De tal modo que lo inconsciente, que es un aspecto nuclear de la existencia, conlleva que el conocimiento que podemos llegar a alcanzar de nosotros mismos sea irremediablemente parcial. Así, nuestra vida queda por tanto caracterizada dentro de la limitación cifrada por los procesos inconscientes, tanto restricción como condición de vida encarnada. La unidad subjetiva deviene aparente. Mas ello no ha de tomarse como un deplorable estado terminal de un sujeto vencido por las fuerzas que lo dominan, sino como el triunfo de la vida que ha sobrevivido al desprecio: una vez ha desaparecido la creencia en el ser en sí -incólumemente unitario e incorruptible- parmenídeo la apariencia pasa de ser un estamento peyorativo a una dulce perspectiva vital, dado que lo aparente no es de suyo irreal, ni fábula ni imitación. La consciencia de la metafísica, el sujeto pensante cartesiano, es una instancia soberbia que prescribe una dramática autonomía respecto del cuerpo, del cual se ha escindido. En su lugar, Nietzsche alcanza a contemplar que la consciencia emerge del cuerpo y es estrictamente correlativa a él. Y en la medida en que somos sobre una pluralidad inabarcable e inaccesible de perspectivas, el sueño dogmático que aspiraba a la autoconciencia resulta no sólo imposible, sino también indeseable: tamaña multiplicidad aplacaría la conciencia del sujeto mediante su insostenible peso. Por ello, cabe imaginar que ante la dimensión de lo inconsciente el cuerpo, el ser, sea hermenéutico.

El cuerpo es contenedor de una multitud de fuerzas -impulsos, deseos-instintivas en su mayoría inconscientes que han impulsado la vida. La aproximación a tales dominios resulta pavorosa, pues supone el enfrentamiento de una dimensión cuyo sentido ulterior nos está vedado. Las herramientas cognitivas de las que tanto se enorgulleció la civilización moderna son insuficientes, ya que tan sólo abarcan la superficie de la existencia, esto

${ }^{52}$ Nietzsche, F., Aurora, op. cit., pág. 552 (KSA III, 108-109). 
es, la manifestación a través del cuerpo de aquellas fuerzas que han prevalecido sobre las demás. Por ello afirma Nietzsche que tomada la corporalidad como ser del hombre ésta abisma al propio sujeto al hacerle notar cuán fútil es la conciencia sobre la que creyó construir la «vida». El conocimiento de sí mismo desde los estrictos caracteres del oráculo de Delfos, así como su isomorfismo moderno, el cogito cartesiano perfectamente autoconsciente termina por resultar imposible, amén de una empresa insoportable para un individuo que ha descubierto cuán estéril es la expectativa de autonomía respecto de la historia evolutiva de la civilización moral. Las fuerzas impuestas a lo largo de la tradición han afectado el imaginario colectivo y por ende individual, haciendo imposible identificar cuáles de nuestros rasgos específicos son como tal genuinos y cuántos, en cambio, heredados. Nietzsche concluye que la comprensión de esta condición lleva al hombre a sentirse «extraño de sí mismo», a cuestionarse quién y qué es ser yo: «nosotros los que conocemos somos desconocidos para nosotros, nosotros mismos somos desconocidos para nosotros mismos $[\ldots]$... Necesariamente permanecemos extraños a nosotros mismos $\rangle^{53}$.

La cultura fue el triunfo de ciertos instintos sobre otros, condicionando fatalmente el desarrollo psicológico de los individuos. El resultado a lo largo de la historia ha sido el horizonte hermenéutico de valor que solidificó en el sistema moral imperante: los múltiples procesos que tuvieron lugar dentro de la maduración inconsciente de la persona y la civilización, un complejo despliegue del cosmos interior de la humanidad, se revelan en la superficie del mundo que es la cultura.

\section{I.4.1. Voluntad de poder e instintos}

A pesar de sostener que el grueso de la herencia cultural que ha conformado tanto la personalidad colectiva como individual remite a lo inconsciente, tampoco es posible, juzga Nietzsche, emancipar irresponsablemente los instintos de la voluntad subjetiva, lo cual haría del hombre un títere del fondo del mundo, como acontecía en el sistema schopenhaueriano. Queda dentro del dominio humano la determinación de qué instintos conscientes han de prevalecer y afirmarse en él; mantenerse dentro de la mentalidad de rebaño distintiva de la Europa moderna o rebelarse contra el indolente hombre moral, bueno.

Los instintos son la traslación fisiológica de un entramado de fuerzas, de tal modo que encuentran su origen en la voluntad de poder. La voluntad de poder, dice al respecto Deleuze, es «el elemento genealógico de la fuerza, diferencial y genético a la vez. La voluntad de poder es el elemento del que se desprenden a un tiempo la diferencia de cantidad de las fuerzas en relación, y la cualidad que, en esta relación, corresponde a cada

${ }^{53}$ Nietzsche, F., La genealogía de la moral, op. cit., pp. 25-26 (KSA V, 247). 
fuerza» ${ }^{54}$. Ahora bien, como hemos apuntado ya líneas atrás, que la voluntad de poder sea un elemento estructural que armoniza y canaliza la relación de fuerzas no la convierte en un fundamento ulterior del ser del hombre. Acorde con su caracterización hermenéutica del hombre, la voluntad de poder conserva también los rasgos de apariencia $-\mathrm{y}$, por ende, de precariedad y contingencia- y pluralidad que determinan el imaginario antropológico de Nietzsche: la voluntad de poder es real en tanto que es perspectiva de la realidad; una realidad de cuyo fondo insondable emerge tras el juego conflictivo un dominio coyuntural de fuerzas imperantes motivadas y traducidas por el constante flujo de la voluntad de poder, que torna imposible la posibilidad de una realidad en sí, inmutable e incólume.

El exterior de nuestro ser, el precario y débil sujeto consciente que queda tras la jerarquización interna de fuerzas, conserva la apariencia de unidad sobre el vasto océano de pluralidad que como corporalidad nos conforma. Luego en virtud de la peculiaridad del ser del hombre, éste es voluntad de poder. Más aún, especifica Nietzsche, dado el carácter aparente y múltiple de ella, el hombre es una pluralidad de voluntades de poder entretejidas en una unidad aparente que, sin embargo, es real. Aquello que llamamos autoconciencia, que en Nietzsche es el limitado conocimiento posible de los aspectos inconscientes que han sobrevenido y alcanzado la superficie, es entonces ficticio, o sea, una perspectiva sometida a la condición de transitoriedad.

Los instintos, en tanto que fuerzas, son condiciones de vida. Remiten estrictamente a la cuestión fisiológica. Sin embargo, una vez integrados en el movimiento de la vida, el ser hermenéutico del hombre interpreta moralmente dichos instintos. Los «buenos» empujan y propician la vida, aun cuando pueden resultar terribles y mortales; por el contrario, los «malos» encubren las enfermas dinámicas reactivas que desprecian el cuerpo: «¿qué es malo? [...]: todo lo que procede de la debilidad, de la envidia, de la venganza» ${ }^{55}$. La valoración es un acontecimiento inseparable del hombre; los estamentos desde los que acometerla, en cambio, dependen de las facultades fisiológicas del hombre. Aquellos que son vigorosos podrán acometer una hermenéutica poderosa y pareja al ritmo incesante de la vida, mientras que de los espíritus enfermos cabe tan sólo esperar una valoración moral igualmente degenerada. Así se explica el triunfo de la moral como contranaturaleza, aquella escandalizada por el cuerpo y que contra él bramaba ${ }^{56}$. La moral contranatural nace del agotamiento del hombre y de su rencor contra la vida que se sabe estéril. Nietzsche insta a una transvaloración, a una consideración favorable de las pasiones y los instintos que los con-

\footnotetext{
54 Deleuze, G., La filosofía de Nietzsche, trad. de Carmen Artal, Barcelona, Anagrama, 2013, pp. 73-74.

55 Nietzsche, F., El Anticristo, trad. de Andrés Sánchez Pascual, Madrid, Alianza Editorial, 2007, pág. 112 (KSA VI, 244).

${ }^{56}$ Cfr. Mt 5:29: «Y si tu ojo derecho es para ti ocasión de pecar, sácalo y arrójalo fuera de ti».
} 
vierta en puentes hacia la superación de uno mismo en el ejercicio de creación de una vida bella.

\section{I.4.2. Jerarquía, interpretación y responsabilidad}

Los instintos se relacionan unos con otros, ora en términos favorables, ora en oposición. Su situación no es armoniosa, sino que exige la discriminación, puesto que muchos son contrarios e incompatibles. Por eso los instintos son condición de vida, dice Nietzsche, pues la determinación de unos en detrimento de otros afecta a las posibilidades de vida efectiva. El conflicto es connatural a los instintos; lo contrario indicaría una unidad esencial cuya simpleza resultaría incompatible con la vida.

El hombre nietzscheano es el resultado sintético de un cúmulo de instintos y pasiones que albergan posibilidades virtualmente infinitas y entre ellas incompatibles. La realidad sintética refleja la contradicción en la que vive y se afirma el sujeto hermenéutico: reconoce la estructura opositora sobre la que es y se integra dentro de ella como mecanismo de resolución. Vivir en la contradicción es la estrategia de existencia propuesta por Nietzsche, dado que implica vivir contemplando el pozo de pluralidad al que estamos abiertos y que nos sostiene en la unidad aparente que se nutre de la posibilidad constante del cambio.

Este hombre surgido al abrigo de la síntesis pulsional e instintiva encarna el sentido del gusto y el estilo nietzscheano. Ha renunciado a la pretensión de unidad estructural de lo humano; al mismo tiempo no admite que la pluralidad signifique una integración caótica de distintos avatares existenciales emanados del libre arbitrio de los instintos. El hombre sintético nietzscheano es el artista, el verdadero filósofo dominado por la voluntad de creación y conducido por las expectativas del genuino conocimiento, el que sirve para vi$v^{5}{ }^{57}$. El «verdadero filósofo» ha discriminado entre la pluralidad de pasiones y ha escogido las vigorosas, ha sometido su conciencia moral ${ }^{58}$ bajo el instinto dominante.

La filosofía hermenéutica nietzscheana es una oda a la salud. Asentada sobre el cuerpo busca canalizar los instintos más poderosos como incombustible motor de una vida de generación y crecimiento. Para ello el cuerpo es pensado en términos no estrictamente biologicistas, sino hermenéuticos: el cuerpo es un texto que interpretar. La lectura literalista únicamente arroja concreciones fisiológicas brutas, o sea, la reducción simplista del or-

\footnotetext{
${ }^{57}$ Nietzsche imprime una inversión radical de las formas filosóficas aristotélicas. Para el Estagirita la vida es aquella entregada al conocimiento como tal; la filosofía carece de utilidad en el corpus aristotélico, pues no tiene sentido ulterior, ella misma es su propio sentido. Nietzsche la contempla contrariamente al pensar la filosofía como la más beneficiosa ayuda para la vida; una ayuda intelectual al arte de vivir.

${ }^{58}$ La conciencia moral es la manifestación última de las pasiones, instintos y perspectivas tras la jerarquización de todos los procesos, conscientes e inconscientes, que azotan al sujeto.
} 
ganismo a hormonas y procesos bioquímicos varios; los caracteres del libro han de ser interpretados, ya que del estrato fisiológico emanan los juicios morales y las valoraciones que definen la vida encarnada.

La interpretación multiplica el libro de la vida humana. El texto fundamental deviene tantos otros de acuerdo con la perspectiva: la interpretación se hace texto que habrá a su vez de ser interpretado. Esta dinámica ilimitada de interpretaciones ilustra que el hombre sintético al que se refiere Nietzsche es la interpretación última ${ }^{59}$ de todas las fuerzas que nos conforman. Esta interpretación última, que es la vida encarnada actual, es necesariamente transitoria, pues sigue inserta en el horizonte del conflicto interpretativo del cual no tenemos un acceso claro y distinto: tras la unidad aparente del sujeto palpita un fondo salvaje de lucha. No nos es posible especificar el sentido de la concreción de nuestras determinaciones hermenéuticas, ya que el conflicto interpretativo nos es sólo parcialmente cognoscible:

En el momento, sin embargo, en que por fin actuemos, nos veremos determinados por un género de motivos distinto del que aquí se tenía en consideración, el de la «imagen de las consecuencias». [...]; obra algo corporal que aparece de manera por completo inesperada, obra el humor, obra, irrumpiendo, un afecto cualquiera que estaba a punto de saltar: en una palabra, obran motivos que en parte no conocemos en absoluto, en parte conocemos muy mal, y que de ningún modo hemos podido tener en cuenta y comparar de antemano. Es probable que también entre ellos tenga lugar una pugna, un tira y afloja, que se compensen o se hundan las partes [en litigio] - y esa sería la verdadera «pugna de los motivos»: - algo que para nosotros resulta totalmente invisible e inconsciente. He evaluado las consecuencias y el buen éxito, introduciendo así un motivo muy importante en el frente de batalla de los motivos, - mas ese frente de batalla ni lo establezco yo ni tampoco lo veo: la pugna misma es algo que se me oculta, y lo mismo hay que decir de la victoria en cuanto tal victoria; de lo que sí me entero es de lo que a la postre hago, - pero de cuál sea el motivo verdadero que con ello resulta vencedor, de eso no me entero. Estamos, sin embargo, acostumbrados a no incluir en la evaluación todos esos procesos inconscientes y a pensar antes de hacer algo sólo en aquello de lo que somos conscientes: y así confundimos la pugna de los motivos con el comparar las consecuencias de diversas acciones posibles, - ¡ iconfusión esta de las más graves, de las de más funestas consecuencias para el desarrollo de la moral! ${ }^{60}$.

¿Cómo sostener entonces con Kant que la máxima de nuestras acciones sea correspondiente con un principio de ley general si ni siquiera podemos concretar los motivos últimos de nuestras máximas?.

La voluntad de poder atraviesa la corporalidad. En virtud de ella las pulsiones e instintos se enfrentan por el dominio sobre el sujeto a lo largo de un juego, no obstante, va.

59 Última en términos cronológicos, o sea, la más reciente; nunca puede ser «última» como definiti-

${ }^{60}$ Nietzsche, F., Aurora, op. cit., pág. 559 (KSA III, 119-120). 
eminentemente humano. A Nietzsche «le gusta -dice Deleuze- oponer la voluntad de poder al querer-vivir schopenhaueriano, aunque sólo sea en función de la extrema generalidad de éste. Si, al contrario, la voluntad de poder es un buen principio, si reconcilia al empirismo con los principios, si constituye un empirismo superior, es porque es un principio esencialmente plástico que no es más amplio que lo que condiciona, que se metamorfosea con lo condicionado, que se determina en cada caso con lo que determina ${ }^{61}$. El carácter plástico de la voluntad advertido por Deleuze es fundamental para comprender su riqueza, ya que la convierte en un proceso vivo que nos introduce en la cuestión de la responsabilidad.

El problema de la responsabilidad es inscrito en nuevos márgenes dentro de la filosofía nietzscheana, la cual no pretende huir de la reciente revelación de los fenómenos inconscientes: no existe la responsabilidad absoluta de las acciones. La cantidad de procesos y elementos que interfieren veladamente en nuestras decisiones y comportamientos impiden contemplar la voluntad como fruto de una libertad incondicionada. La voluntad libre kantiana $^{62}$ es una ficción que conduce a un idealismo incompatible con la realidad de la vida humana; la libertad incondicionada de la voluntad es deshumanizadora, ya que se sostiene sobre la imagen metafísica del hombre, aquella que lo contemplaba como sujeto esencialmente espiritual -mental, para los modernos- y que había de trazar una frontera insalvable con la corporalidad.

La responsabilidad no puede discurrir en independiente oposición respecto del cuerpo si queremos liberarnos de la tiranía de una moral como contranaturaleza. La voluntad no descansa en un inmaculado reino eidético separado de los afectos; cuerpo y voluntad, voluntad y cuerpo se integran en la ficticia unidad humana, obligando con ello a matizar nociones como las de «responsabilidad», «culpa», «transgresión». Esto no debe inducirnos, no obstante, a imaginar la filosofía de Nietzsche como una barbárica loa a la irresponsabilidad de un individuo sometido a la pulsión del presente inmediato. Esta forma de actuación, carente de meditación, de sosiego, de reflexión es otro síntoma de los tiempos que Nietzsche desprecia ${ }^{63}$ con la misma furia que al piadoso kantiano, pues enajena al hombre de su vida, lo torna indiferente de la creación valorativa de una u otra ficción. La ineludible contemplación de lo instintivo y lo pulsional afecta a la noción de responsabilidad, mas no la agota y anula en una orgiástica sucesión de acciones volitivas sujetas a la apetencia irrestricta de una voluntad pueril que nada ha de decir de sí.

${ }^{61}$ Deleuze, G., La filosofia de Nietzsche, op. cit., pág. 74.

${ }^{62}$ Kant es tomado como el paradigma de esta posición.

${ }^{63}$ Cfr. Nietzsche, F., Humano, demasiado humano II, trad. de Alfredo Brotons Muñoz, Madrid, Akal, 2013, pág. 71 (KSA II, 470): «Motivo de la esterilidad. Hay espíritus sumamente dotados que nunca son sino estériles más que porque, debido a una debilidad de temperamento, son demasiado impacientes para esperar a la culminación de su preñez». 
La voluntad es una ficción más de las muchas sobre las que nos instituimos, pero su condición fabulada no anula, en cambio, las expectativas de superación y creación que dominan el corpus nietzscheano. La voluntad es un capítulo más del infinito índice del libro que somos. La vida filosófica es la vida responsable, la propia de quienes aceptan el reto de una realidad polifacética que les exige escoger entre «bueno»y «malo», entre lo que faculta y estimula la vida o bien lo que la degrada y anula. En la elección jerárquica de las fuerzas reside el marco de la voluntad y el respectivo umbral de responsabilidad. Nietzsche niega la libertad abstracta propia de los sistemas idealistas que contemplan la dimensión mental del hombre abstraída de sus determinaciones somáticas, al tiempo que estima que en su propia acción de vida el ser humano se percibe como libre. La aparente contradicción queda resuelta desde su crítica de la subjetividad: la afección de lo inconsciente no niega la conciencia, sino que obliga a repensarla. La filosofía parte del cuerpo, en el cual se concretan los distintos impulsos y fuerzas, entre los que la razón es uno más con sus específicas peculiaridades. Así, donde el hombre sintético nietzscheano se antoja un individuo irresponsable desde los caracteres de la ontología metafísica al autor se le presenta la ocasión de emancipación de la moral del resentimiento y la culpa que sumió a Occidente en una ciénaga de enfermedad y tinieblas. La concreción aquí propuesta de la libertad y la responsabilidad le permite al hombre sentirse exonerado de elementos nocivos y perniciosos como la culpa, el remordimiento o el pecado; tampoco es una caída en la piedad ciega o la complacencia. Es una reordenación de los éxtasis vitales: la vida es un juego de azar ${ }^{64}$ que nos fuerza a participar con las cartas que nos han tocado en la mesa del mundo; hemos de ser capaces de conseguir el mejor resultado teniendo en consideración nuestra mano, así como las ajenas que, por supuesto, nos son desconocidas. No disponemos de todas las variables en liza, pero hemos de jugar con honestidad, pues somos responsables de cada jugada: «madurez del hombre adulto: significa haber reencontrado la seriedad que de niño tenía al jugar» ${ }^{65}$. Y así nos insta Zaratustra a que dejemos a las cosas «bailar sobre los pies del azar» ${ }^{66}$.

Es necesario matizar que pese a su insistencia en la dimensión de lo inconsciente, Nietzsche está lejos de las posiciones del psicoanálisis: que haya fuerzas inconscientes no implica que su revelación sea algo beneficioso; al contrario, puede ser algo catastrófico.

\footnotetext{
${ }^{64}$ El azar es una categoría decisiva en la filosofía de Nietzsche, pensada contra la proyección de una razón en la evolución histórica. Frente a las muchas tentativas escatológicas de la modernidad, para Nietzsche la valoración y el azar concurren: «qué poca razón, cuánto azar domina entre los seres humanos» (Nietzsche, F., Fragmentos póstumos II, 3 [19], op. cit., pág. 49 [KSA VIII, 19]). Así, finalidad y azar se terminan identificando entre sí: «cuando pensé el fin, pensé también el azar» (Nietzsche, F., Fragmentos póstumos III, 4 [172], op. cit., pág. 123 [KSA X, 162]).
}

${ }^{65}$ Nietzsche, F., Más allá del bien y del mal, trad. de Andrés Sánchez Pascual, Madrid, Alianza Editorial, 2009, pág. 104 (KSA V, 90).

${ }^{66}$ Nietzsche, F., Asi habló Zaratustra, op. cit., pág. 240 (KSA IV, 209). 
Nietzsche no es entonces, aunque lo pretendieron muchos de sus críticos, un apologeta de lo instintivo. La defensa de lo instintivo es menos una excusa de libertinaje moral que uno de los hitos de la transvaloración de la moral de siglos. La presencia de rasgos ajenos a la conciencia ha reunificado al hombre, que ya no tiene motivos para avergonzarse de su cuerpo, de $s u$ sí mismo. El hombre artista ha comprendido que cuanto ha proyectado de su vida no es sino una bella ficción que ha bebido de multitud de fuentes indeterminadas y renunciado a otras tantas en favor de su instinto de vida; el proyecto de vida bella es el ejercicio constante del hombre que se ha afirmado en su corporalidad y ha aceptado el peso de la ficción y la apariencia de una realidad polifacética y de rasgos difusos.

\section{I.5. La creación artística del cuerpo por la voluntad de poder}

El hombre descansa radicalmente sobre un suelo fisiológico que antecede a las demarcaciones de la cultura. Esta arcilla primigenia ha de moldearse a lo largo de un complejo proceso durante el cual lo biológico se entremezcla con las ficciones históricas y culturales. Del producto de esta síntesis emerge el hombre en su plenitud, es decir, como un agregado armónico de contradicciones donde lo simbólico y lo natural comparten rasgos ontológicos. La vida, por tanto, es el conjunto de valoraciones posibles que parten, confluyen y concluyen en el cuerpo, donde se difuminan las respectivas fronteras de la evolución biológica y de la evolución cultural.

De tal suerte que el proyecto nietzscheano de superación del hombre, el superhombre, no es la esperanzada expectativa de una original especie, sino la de una reformulación del tipo humano, que asentado sobre su corporalidad -su condición natural, biológicala cual condiciona irremediablemente las lindes de la transformación, en aras de la creación de su correspondiente nuevo tipo de mundo.

Cuando Nietzsche reclama la corporalidad como ser del hombre está rechazando con ello las tentativas metafísicas que aportaron un origen divino. El ser humano queda irremediablemente inserto en la naturaleza, que es $s u$ naturaleza: no hay una naturaleza humana divinizada, sino los trazos específicos que el desarrollo biológico le ha concedido. Y ahí reside, sin embargo, en los rasgos típicamente humanos, su maravillosa cualidad: la condición ficticia y fabuladora, la cual es el mecanismo evolutivo de nuestra especie, obliga a reinventar el mundo de la vida, que no se limita a la mera supervivencia físiológica. Nietzsche lo sentencia al señalar que sólo el hombre tiene fines y metas, fines y metas que en su realización se identifican con sus propios medios para concretarse en la salud de las nuevas auroras, que devienen virtud última ${ }^{67}$ :

${ }^{67}$ Cfr. Nietzsche, F., La gaya ciencia, op. cit., pág. 893 (KSA V, 635-636): «La gran salud. Nosotros, nuevos, sin nombre, difíciles de comprender, nosotros, hijos prematuros de un futuro aún no probado - nosotros necesitamos para un nuevo fin también un nuevo medio, a saber, una nueva salud, más fuerte, más perspicaz, más resistente, más temeraria, más alegre que lo que ha sido cualquier salud hasta ahora». 
Salud del alma. - La popular fórmula moral médica (cuyo autor es Aristón de Quíos): «la virtud es la salud del alma» — debería por lo menos, para ser utilizable, transformarse en: «tu virtud es la salud de tu alma». Porque no hay una salud en sí, y todos los intentos de definir algo así han fracasado estrepitosamente. De tu finalidad, de tu horizonte, de tus fuerzas, de tu impulso, de tus errores y especialmente de los ideales y fantasmas de tu alma depende la determinación de qué habrá de significar salud, incluso para tu cuerpo. Hay por lo tanto innumerables saludes del cuerpo; y cuanto más se permita levantar de nuevo la cabeza a lo singular e incomparable, cuanto más se olvide el dogma de la «igualdad de los hombres», tanto más tendrá que desaparecer para nuestros médicos el concepto de una salud normal, junto con el de una dieta normal o el del proceso normal de una enfermedad ${ }^{68}$.

La vindicación del hombre como ser natural -como cuerpo- es una denuncia más rica que la mera reducción de éste a las funciones tróficas: es la consideración del sustrato inconsciente que nos abre a la pluralidad de sentidos y que exige la constante tarea de la asignación de valores y la finura del gusto refinado capaz de discriminar entre «bueno» $\mathrm{y}$ «malo». El hombre como ser natural se revela como un enigma irresoluble que, sin embargo, nos instiga a ofrecer tentativas resolutivas estructuralmente precarias y sujetas a valoración perenne que juzga y jerarquiza.

La historia de la moral arroja pistas del rumbo de la humanidad una vez ésta se alejó de su condición natural en favor de un presunto origen divino. El temple de todas las épocas desnaturalizadas, indistintamente de su concreción histórica, coincidía en un desprecio de la vida que pasaba por la nostalgia del anhelado génesis supramundano. Un rechazo que se tradujo en términos morales como contranaturaleza: la jerarquización de los instintos agotados, el rechazo de la vida y el desprecio del cuerpo tomados como «bueno» ${ }^{69}$. La desnaturalización ha sido una enfermedad demasiado usual de la humanidad que terminó por hacer del hombre un producto extraño de sí mismo.

La condición del hombre como ser natural es hermenéutico, pues su rasgo distintivo es la valoración. Ser hombre, dice Nietzsche, consiste, en último término, en crear una cultura, esto es, un horizonte de valores desde los que comprender, juzgar, censurar, afirmar o rechazar los fenómenos del mundo. Un marco cognitivo, lo que Foucault bautizó co-

${ }^{68} \mathrm{Ibid}$. pág. 800 (KSA III, 477).

${ }^{69}$ Cfr. Nietzsche, F., Así habló Zaratustra, op. cit., pág. 68 (KSA IV, 43): «[...]; y más de uno se fue al desierto y se mató porque estaba cansado de ser batalla y campo de batalla de virtudes». 
mo «episteme» ${ }^{70}$, que emana de la determinación de la voluntad de poder, juez último que sentencia la gradación valorativa de los instintos. La voluntad de poder es, por tanto, el dominio de una fuerza rebosante capaz de integrar a todas las demás bajo una misma cúpula. Sin embargo, no se hace justicia con la filosofía de Nietzsche si convertimos la voluntad de poder en un desatado torrente de dominación cruel y despótica. Estos cauces, también transitables por la voluntad de poder, pertenecen a los espíritus más pueriles que contemplan la dominación como la imposición de uno sobre otro; la voluntad de poder no es fuerza embrutecida, sino el refinado instinto que triunfa sobre la fuerza misma: «ser señor».

La oscura fórmula «ser señor» entabla una relación biyectiva: hay un dominador y un dominado. Las interpretaciones más burdas de la obra de nuestro autor han visto en ella una invitación a la coerción de unos por otros, siendo los primeros poseedores de fuerza bruta que en nada se asemeja a la imagen nietzscheana de la dominación. La llamada del «señorío» es el momento decisivo hacia la transvaloración, proyecto estrictamente privado, pues concierne a la voluntad concreta y particular del hombre encarnado. La relación que se entabla en el señorío es circular, el principio es también la meta; y su dominio, la escrupulosa frontera de la propia existencia: «ser señor» es «ser señor de sí mismo». El señorío de sí es, comprendido de este modo, la conquista de la fuerza, el más poderoso ejercicio de dominación, ya que en virtud de la voluntad de poder, la fuerza deviene medio en manos del hombre ${ }^{71}$. Un medio para la dominación de uno mismo, esto es, el criterio específico del peculiar ascetismo nietzscheano que permite la discriminación de los instintos y fuerzas que elogian y potencian la vida dentro de la expectativa del artista. En el «señorío de sí» hombre y voluntad de poder se encuentran en el solidario proyecto de creación de la vida bella, aquella que partiendo del cuerpo se ha abierto a la pluralidad de un mundo con el cual ha adquirido el compromiso libre y responsable de exigirle lo mejor y más refinado para sí.

La responsabilidad y la libertad son componentes incuestionables en la filosofía de Nietzsche; la puesta en duda de su condición cualitativa no significa, sin embargo, la de su posibilidad efectiva. Hay un margen de maniobra sobre los instintos el cual, a su vez, no

70 Cfr. Foucault, M., Las palabras y las cosas, trad. Elsa Cecilia Frost, Madrid, Siglo XXI de España, 2006, pág. 7: «[...] un estudio que se esfuerza por reencontrar aquello que a partir de lo cual han sido posibles conocimientos y teorías; según cuál espacio de orden se ha constituido el saber; sobre el fondo de qué a priori histórico y en qué elemento de positividad han podido aparecer las ideas, constituirse las ciencias, reflexionarse las experiencias en las filosofías, formarse las racionalidades para anularse y desvanecerse quizá pronto. No se tratará de conocimientos descritos en su progreso hacia una objetividad en la que, al fin, puede reconocerse nuestra ciencia actual; lo que se intentará sacar a luz es el campo epistemológico, la episteme en la que los conocimientos, considerados fuera de cualquier criterio que se refiera a su valor racional o a sus formas objetivas, hunden su positividad y manifiestan así una historia que no es la de su perfección creciente, sino la de sus condiciones de posibilidad».

${ }^{71}$ La fuerza bruta de la que se vale el insaciable conquistador de reinos es fin en sí misma: la dominación es un basto ejercicio de exaltación de la fuerza por la fuerza misma. No existe un proyecto de valoración ulterior, sino la pueril acumulación que acrecienta la burda ensoñación de poder. 
debe ser contemplado como la diligencia del auriga del Fedro, donde lo racional terminaba por domeñar lo irracional. La comparación no se sostiene en tanto que tal escisión dramática de la personalidad es anulada en Nietzsche en virtud de su vindicación de su renovada imagen del cuerpo. La dimensión de lo inconsciente, que es condicionante del sujeto, aflora sobre la superficie del cuerpo encarnado, la cual sí es susceptible de ser objeto de la responsabilidad del sujeto libre. Nietzsche no insta a una conducción de los instintos cual auriga, sino a su cultivo y embellecimiento.

Lo inconsciente no es terreno donde more lo espontáneo y el libertinaje; al contrario, comprende Nietzsche, requiere de la responsable mesura de quien situándose frente al abismo de la infinita pluralidad se exige «ser señor». La faceta del cuidado se recupera una vez más como medida de refinamiento de la vida salvaje a la cual nos abocaría el libertinaje de la irresponsable espontaneidad absoluta. Con prístina agudeza supo ver Hobbes que no existía la libertad política como tal allí donde no hubiese imperativo de legalidad ${ }^{72}$, y del mismo modo Nietzsche entiende que no puede hablarse de la libertad de la acción cuando el agente se entrega de manera irrestricta a los impulsos y pasiones. El azar y el oscuro fondo de pluralidad que caracterizan la concreción del hombre en el mundo no pueden ser, sin embargo, sino condiciones de posibilidad del cuerpo encarnado, nunca los principios regentes de la conducta; no son fines, sino medios en el proceso de creación de la propia vida: el hombre no es un ser inmutable y perfectamente trazado y dispuesto desde el origen, sino un campo que cultivar para, como apunta en el subtítulo de Ecce homo, «llegar a ser lo que se es», un proceso a lo largo del cual, se siente en casa:

Siempre en casa. - Un día alcanzamos nuestra meta - y entonces señalamos con orgullo los largos viajes que hemos hecho para llegar a ella. En verdad, no nos dábamos cuenta de que viajábamos. Pero llegamos tan lejos porque en cada sitio nos imaginábamos estar en casa $^{73}$.

La fórmula «llegar a ser lo que se es» resulta sumamente compleja, pues alberga tanto la inmunda corrupción del hombre nihilista que deambula patéticamente por el creciente desierto como el hombre movido por el cuidado de sí en aras de la creación artística de su vida bella. Las imágenes del gusto y el estilo entran en escena en el proyecto estético de la vida; dado que no existe un modelo único y privado de proyección de vida las alternativas de construcción son tantas como sujetos: el individuo al que aspira Nietzsche no se yergue sobre elementos extraños a sí mismo; todo empieza y acaba en él. Por eso mismo combate enérgicamente la nivelación, la cual instituye cánones universales: moral de rebaño. La esencial igualdad que ha caracterizado Occidente es un síntoma de mal gusto que

${ }^{72}$ Cfr. Hobbes, T., Leviatán, trad. de Carlos Mellizo, Madrid, Alianza Editorial, 2009, pág. 194: «En cuanto a otras libertades, dependerán del silencio de la ley».

${ }^{73}$ Nietzsche, F., La gaya ciencia, op. cit., pág. 825 (KSA III, 516). 
atribuye a todos los modos humanos el mismo valor, haciendo imposible distinguir, más que como una formal cuestión de grado, al que se sitúa ante el abismo de la existencia y lo reta en aras de la afirmación del despreciador del cuerpo.

Para Nietzsche la vida es la más peculiar y refinada de las tareas. En ella coinciden en una unidad de destino el artista y la obra. Sobre el material dado que es la tradición cultural y la situación evolutiva de la especie debe el hombre alcanzar sus máximas posibilidades. Vale para Nietzsche la metafórica afirmación de Miguel Ángel según la cual su trabajo no consistía sino en sacar a la superficie la obra que yacía, oculta, dentro del bloque de mármol, para lo cual había de extirpar el material sobrante que recubría y oscurecía la dormitante belleza posible. Nuestra vida es nuestra tarea -unsere Aufgabe-, difícil, peligrosa, atravesada por el dolor y el sufrimiento, y, sin embargo, dichosa: es el bello y fecundo esfuerzo por identificar el sentido de la vida con el vivir mismo, aceptando con fortaleza, serenidad, alegría y lucidez la envergadura de un proyecto virtualmente infinito y de profundidad abismal. Hacer de la vida la tarea propia par excellence es aceptar el desafío propuesto por la libertad. Una libertad no ingenua que consciente de lo inconsciente nos impele a actuar en favor de la vida, o sea, enseñorearnos y poder entonces en virtud de ello discriminar las propuestas reactivas en favor de aquellas tales que nos mueven al despliegue de la vida mejor.

Así puede entenderse que Nietzsche rechace la subordinación pasiva y resignada del sujeto a sus pasiones, una forma más de esclavitud bajo una apariencia emancipatoria. Desde los principios del cuidado es fácil para el autor exigir el empoderamiento respecto de los instintos como medida imprescindible de la apropiación de uno mismo, como regla de cultivo personal para «llegar a ser lo que se es», para que hagamos de nuestra vida unsere Aufgabe. En la realización de la tarea de la vida, esto es, en el propio vivir, el hombre nietzscheano muestra su constitución sintética; en él espiritualiza el cuerpo y corporaliza el espíritu como dimensión de plenitud de lo que significa ser «ser humano». De tal modo que «ser señor de sí mismo» consiste en maximizar las posibilidades de vida, como cuerpo encarnado, desde las condiciones de partida, biológicas y culturales, heredadas. La caracterización de Nietzsche del cuidado pasa por tomarlo como una virtud de excelencia: «llegar a ser lo que se es» conmina a alcanzar nuestra situación de existencia óptima. Una especie de telos que obliga a reimaginar la vieja noción clásica, pues no ha lugar en la filosofía de Nietzsche a un trazo escatológico; la finalidad es propiamente «llegar a ser lo que se es», meta alcanzable únicamente viviendo dentro de un despliegue ilimitado de posibilidades que sólo concluye con la muerte. El hombre es, con todo, un proyecto incesante y eterno cuyo fin viene abocado por la necesidad insalvable de la muerte: «que el carácter 
sea inmutable no es verdad en sentido estricto [...]. La brevedad de la vida humana induce a muchas afirmaciones erróneas sobre el carácter del hombre» ${ }^{74}$.

El señor de sí no rechaza las pasiones, tampoco se entrega a ellas, sino que las transforma en fuerza motriz del proceso de creación de su vida, en la vindicación de su existencia encarnada. El señor de sí se ha convertido en su propia meta como sustrato desde el que explotar sus fuerzas. Su buen gusto ha orientado aquéllas hacia las metas más grandes, dejando atrás la indigencia existencial de los instintos brutos; el señor de sí se apropia de su miedo, de su ira, de su lujuria, de su desprecio, de su venganza ${ }^{75}$ : «venganza se asienta en tu alma: allí donde tú muerdes, se forma una costra negra; ;con la venganza produce tu veneno vértigos al alma!» ${ }^{76}$. Y por ello «que el hombre sea redimido de la venganza: ése es para mí el puente hacia la suprema esperanza y un arco iris después de prolongadas tempestadas ${ }^{77}$. Es decir, el enseñoreamiento de sí es un momento elemental de la superación de sí mismo, que en última instancia no consiste más que en la reapropiación de nuestro ser a través de la dirección creativa de unas pasiones que ni son rechazadas ni integradas neuróticamente en nuestro cuerpo, sino orientadas hacia logros selectos y ambiciosos.

El cultivo del cuerpo en beneficio de una vida elevada y señorial requiere de un fortísimo compromiso ascético. Nietzsche, una vez más, se presenta como una ejemplar figura de mesura y templanza. Sin embargo, en su moderación hay desborde y exultante derroche. El ascetismo de cuño nietzscheano rompe con la tradición ascética dado que no opera en caracteres contrarios a la naturaleza; no nace del desprecio del cuerpo y de la debilidad. Hunde sus raíces en el poder, es un signo de fuerza que se orienta hacia la acumulación de poder: «¿qué es felicidad? - El sentimiento de que el poder crece» $^{78}$. El signo de la fuerza se refleja en la jerarquía y la distinción, en aquellos que se diferencian por encima de la multitud homogénea. Nietzsche refuta el imperio de la apetencia inmediata, que es síntoma de una vida débil y degenerada. El ascetismo no es la restricción contranatura del

\footnotetext{
74 Nietzsche, F., Humano, demasiado humano I, trad. de Alfredo Brotons Muñoz, Madrid, Akal, 2013, pág. 69 (KSA II, 65).

${ }^{75}$ Cfr. Nietzsche, F., Así habló Zaratustra, op. cit., pág. 148 (KSA IV, 121): «pues ésta es vuestra verdad: sois demasiado limpios para la suciedad de estas palabras: venganza, castigo, recompensa, retribución».

Cfr. ibid. pág. 150 (KSA IV, 123): «sino para vosotros, amigos míos, os canséis de las viejas palabras que habéis aprendido de los necios y mentirosos:

Os canséis de las palabras 'recompensa', 'retribución', 'castigo', 'venganza en la justicia'».

${ }^{76}$ Ibid. pág. 155 (KSA IV, 128).

${ }^{77}$ Ibid. (KSA IV, 128).

${ }^{78}$ Nietzsche, F., El Anticristo, op. cit., pág. 32 (KSA VI, 170).
} 
cuerpo, sino la disciplina como exigencia de uno hacia sí mismo sin más juez que su propio estilo y gusto: el tipo de hombre nietzscheano ha de ser $d u r o$.

La dureza no apunta a una terrible crueldad déspota y despiadada contra el otro, cual sanguinario conquistador de tierras, sino al refinado ascetismo para con uno mismo, el dominio de sí que logra cristalizar las pasiones y los instintos en virtuosa fuerza motriz para la vida. Quien alcanza el señorío de sí, este hombre endurecido, ha sabido zafarse de las debilidades que llevan al rebaño a entregarse ciegamente a sus instintos, sabiendo reconocer que el caducifolio goce de lo inmediato ofrece una satisfacción estéril y vana más propia de una bestia iracunda y privada de razón que de un hombre libre y selectivo que elevándose sobre la homogénea multitud habrá de contribuir a la aparición de un nuevo tipo humano, esplendoroso y genial, que piense y viva desde los valores más elevados que su corporalidad hermenéutica haya sido capaz de priorizar:

[...]; se ha vuelto posible que surjan asociaciones de linaje internacionales que se impongan la tarea de criar una raza de señores, los futuros «señores de la tierra»; - una nueva, prodigiosa aristocracia, edificada sobre la más dura autolegislación, en la que se dará una duración más que milenaria a la voluntad de hombres filosóficos violentos y artistas tiranos: - un género superior de hombres que, gracias a su supremacía en el querer, en el saber, en riqueza y en influencia, se servirían de la Europa democrática como el más flexible y dúctil de sus instrumentos para tomar en sus manos los destinos de la tierra, para dar forma como artistas que trabajen sobre el «hombre» mismo $^{79}$.

El fin de la dureza del espíritu no es, por tanto, la eliminación de los instintos ni la indolente sumisión ante los mismos, pues esto se correspondería con una actitud despreciativa respecto del cuerpo y con un temple nivelador y ordinario que tanto mastica la piedad como la crueldad sin criterio diferenciador, respectivamente. Su pretensión se imbrica en el gusto de aquel que, cual esforzado alquimista, consigue la ansiada transmutación de la basta piedra en fino oro: la transvaloración de la moral tradicional de Occidente en la belleza de una aurora esperanzadora: «iquebrad a los buenos y los justos!» ${ }^{80}$.

Persigue Nietzsche, en último término, la transvaloración del socratismo; del universo moral que hizo de la lucha encarnizada contra el cuerpo virtud y abanderó la hipertrofia de la razón. Sócrates ejemplificó -el tipo Sócrates- la degeneración del espíritu griego: temía la palpitante pulsión de vida que reverberaba desde el fondo del cuerpo. El mito del carro alado no es sino el reflejo de tal pavor, el miedo a que las pasiones domeñaran sobre la lógica y $s u$-correspondiente imagen de-razón. La antropología socrática se antoja débil e incapaz de arrojar una imagen bella del cuerpo; su suerte depende de una neurótica

\footnotetext{
${ }^{79}$ Nietzsche, F., Fragmentos póstumos IV, 2 [57], op. cit., pág. 92 (KSA XII, 87-88).

${ }^{80}$ Ibid. 2 [71], pág. 95 (KSA XII, 93).
} 
negación de la corporalidad mediante la falaz oposición con el alma. El caballo blanco, rector racional del hombre, esconde en verdad los rasgos de un tirano escuálido que actúa movido por el miedo de poder «llegar a ser lo que se es» ${ }^{81}$.

La mencionada ecuación socrática del intelectualismo moral es la estrategia del filósofo ateniense. Propone en ella la cura mediante la razón de la enfermedad que son los instintos. $\mathrm{Y}$ en tanto que las pulsiones, sustrato de la corporalidad, se contemplaron como patología del hombre, la propia antropología socrática estima la existencia ruinosamente, bajo la imperiosa necesidad de una purga balsámica. La vida tomada como la más perniciosa enfermedad de la existencia; un mal que resolver, un daño del que redimirnos. Nietzsche pretende una transvaloración de esta imagen del cuerpo en favor de otra en la que el valor del hombre sea restaurado y donde la elevación consista no en el abandono del mundo, sino en el embellecimiento de sí mismo, como sujeto encarnado: transmutar la experiencia de la moral para imbricarla en la naturaleza. La virtud moral pasará a ser el esfuerzo por dignificar la existencia desde la experiencia misma de vida en toda su magnitud, consciente e inconsciente. Recuerda Nietzsche, con todo y pese a todo hijo de la modernidad, que se trata del combate por la libertad; bien podríamos hacer suya una de las Sentencias Vaticanas epicúreas: «el fruto más delicioso del propio contento es la libertad» ${ }^{82}$.

El hombre como su más bella obra artística no puede sostenerse desde los inquebrantables estamentos de la imperturbable lógica; la pluralidad de caras a la que estamos abiertos exige la tarea hermenéutica de constituirnos sobre una neblina que oscurece nuestro ser y que lo torna inaccesible. La demanda socrática de razón a cualquier precio es una petición asfixiante e inhumana, pues obliga precisamente a prescindir de nuestros rasgos más humanos. Nietzsche nos procura una nueva estrategia de virtud al vindicar el juego oscuro y secreto de la voluntad de poder: «Concepto de 'perfección': no sólo mayor complicidad, sino mayor poder (—necesita ser no sólo una mayor masa)»» ${ }^{83}$.

\section{I.6. Ética y estética: el hombre artista de la voluntad de poder}

El gusto ha sido presentado como un aspecto elemental en la configuración del hombre nietzscheano. Es una noción que sirve de puente entre las categorías estéticas y éticas de su filosofía. En la tarea que es la vida la simple conservación no es ni objetivo último ni condición suficiente de la existencia; no es el mantenimiento orgánico el fin al que

\footnotetext{
${ }^{81}$ La transvaloración persigue la transformación de tal apreciación del cuerpo, y por ende, de la vida. Mas, veremos más adelante, ésta no consiste simplemente en una mera inversión de formas y categorías: el hombre disoluto que claudica de la razón en estricto beneficio de sus apetencias somáticas es igualmente degenerado, y su vida tanto o más ruinosa y fea, ya que carece de la fortaleza y del vigor requeridos para sobreponerse a la inmediata demanda del instinto
}

${ }^{82}$ Epicuro, Obras completas, ed. y. trad. de José Vara, Madrid, Cátedra, 2012, pág. 105.

${ }^{83}$ Nietzsche, F., Fragmentos póstumos IV, 2 [76], op. cit., pág. 98 (KSA XII, 96). 
apunta su pensamiento. La historia de Occidente atestigua sucesivas generaciones que reflejan la contradicción generada entre el esfuerzo biológico de mantenimiento de la especie y la pauperización cualitativa de su condición humana. La cuestión antropológica en el autor pivota sobre el tipo de vida: se legitima la vida en una intrincada estrategia a lo largo de la cual medios y fines se integran, de forma que el ser de la vida bebe de la elección que el hombre encarnado haga de su proyecto encarnado. El hombre que vive es su propio proyecto y fin, luego el modo de vida desde el que se despliega atribuye el valor y el sentido: «¿vosotros decís que la buena causa es la que santifica incluso la guerra? Yo os digo: la buena guerra es la que santifica toda causa» ${ }^{84}$.

La determinación de un tipo u otro de vida depende esencialmente del gusto, que permite a Nietzsche marcar una frontera esencial entre su filosofía, de carácter cualitativo, y el paradigma moderno, de cuño cuantitativo. La clave moral del autor no descansa en un hipotético progreso histórico de la civilización y la humanidad, sino en un criterio estético: el gusto. Desde esta matriz justificará toda su filosofía de la diferencia y la jerarquía, de la discriminación y la desigualdad contra la nivelación de la decadente moral europea. Los márgenes de la ética y la estética tornan difusos en Nietzsche precisamente por la legitimación artística de la particularidad moral: «la decisión cristiana de encontrar el mundo feo y malo ha hecho al mundo feo y malo» ${ }^{85}$.

Efectivamente Nietzsche tiende isomorfismos esenciales entre una y otra -ética y estética- al punto de remontarse a un hipotético lejano pasado donde hubieron de ser una y la misma: «tuvo que haber algún momento en el que la concepción religiosa, estética y moral fueron una sola» ${ }^{86}$. Ahora bien, como ocurre frecuentemente con sus textos es imprescindible matizarlos, dado que una lectura literalista induciría inevitablemente a errores y confusiones que distorsionan profundamente el sentido de su trabajo. Cuando Nietzsche se refiere a la «estética» lo hace desde una definición particular que no se agota en la rigurosa conceptualización de ésta como teoría de la sensación. En Nietzsche es imposible desligar la estética de implicaciones morales: la moral es artística toda vez que su fuerza motriz es la acción artística de la voluntad de poder. Al tiempo no es posible pretender hacer que el autor suscriba tesis «esteticistas», en las cuales los criterios remiten tan sólo al placer estético del individuo particular, como tampoco restringir su actitud con el mundo a una respuesta contemplativa propia del nihilismo pasivo, al modo schopenhaueriano ${ }^{87}$.

${ }^{84}$ Nietzsche, F., Asi habló Zaratustra, op. cit., pág. 84 (KSA IV, 59).

${ }^{85}$ Nietzsche, F., La gaya ciencia, op. cit., pág. 805 (KSA III, 485).

${ }^{86}$ Nietzsche, F., Fragmentos póstumos III, 9 [42], op. cit., pág. 249 (KSA X, 358).

87 Cfr. Nietzsche, F., Fragmentos póstumos IV, 2 [106], op. cit., pág. 107 (KSA XII, 113): «Schopenhauer aparece, por el contrario, como el obstinado hombre moral que, para conservar la razón con su apreciación moral, se convierte finalmente en negador del mundo. Finalmente en 'místico'». 
Cuando Nietzsche afirma el carácter estético de la moral no hace sino sostener su condición afirmativa y creativa, por un lado; y, por otro, reconocer, otra vez, el fuerte y doloroso compromiso ascético del hombre encarnado que apunta a las más altas cumbres. Por lo tanto, el maridaje de la ética y la estética arroja el compromiso del sujeto a consumar esforzadamente su acción creadora en un mundo que reconoce fuente de dolor y sufrimiento.

Igualmente la propuesta de una moral reducida a estética se muestra como la respuesta coherente de una filosofía que ha abdicado, tras la muerte de Dios, del ser sustancial del mundo, ya que la apelación a lo absoluto se ha desvanecido. La alternativa pasa a promover la creación de ésta misma desde la radical orfandad de la pérdida de la verdad objetiva. La verdad deviene apariencia y queda inscrita en el juego autofundante de los valores, de cuya determinación emanará la significación de los distintos modos de vida. Esto, y no el banal goce hedonista, significa la reducción de la ética a la estética:

La cuestión de los valores es más fundamental que la cuestión de la certeza: la última sólo adquiere seriedad en el supuesto de que la cuestión del valor haya tenido respuesta.

Ser y apariencia, revisados psicológicamente, no dan por resultado ningún «ser en sí», ningún criterio de «realidad», sino sólo de grados de apariencia, medidos según la fuerza de la parte que le otorguemos a una apariencia ${ }^{88}$.

Y así Nietzsche nos conmina a «dar a la existencia una significación estética» ${ }^{89}$. La moral tradicional, concluye finalmente el Nietzsche genealogista, es «inmoral», dado que su raíz es otra.

De acuerdo con la fenomenología del hecho moral, ésta es el conjunto de normas más o menos articulado que prescriben directamente qué conductas, qué prácticas son buenas o malas, correctas o incorrectas. Desde esta caracterización no resulta disparatado contemplar la íntima relación entre ésta y la vida. Ahora bien, aquello cifrado como «bueno» no podrá remitirse más que a la propia experiencia de la vida como ejercicio de valoración. La raíz de la moral es inmoral si pensamos dicha acepción a partir de los modos tradicionales de verdad y ser; es moral en un sentido eminentemente estético, esto es, como expresión de jerarquías de valor. El hombre es un ser moral, dice Nietzsche, en tanto que no es posible vivir sin valorar; vivir es valorar, y por tanto, la raíz de la vida es estético-artística. El hombre es un ser fabulador, creador de sus propias condiciones de existencia:

Que el valor del mundo reside en nuestra interpretación (— que quizá en alguna parte sean posible otras interpretaciones, diferentes de las meramente humanas - ), que las interpretaciones habidas hasta ahora son estimaciones perspectivistas en

\footnotetext{
${ }^{88}$ Ibid. 7 [49], pág. 220 (KSA XII, 311).

${ }^{89}$ Nietzsche, F., Fragmentos póstumos II, 11 [162], op. cit., pág. 794 (KSA IX, 504).
} 
virtud de las cuales nos mantenemos en vida, es decir, en la voluntad de poder, de crecimiento del poder, que toda elevación del hombre lleva consigo la superación de interpretaciones más estrechas, que toda fortificación y ampliación de poder que se alcance abre nuevas perspectivas y hace creer en nuevos horizontes - esto recorre mis escritos. El mundo que en algo nos concierne es falso, es decir, no es un hecho, sino una invención y un redondeo a partir de una magra suma de observaciones; está siempre «fluyendo», como algo que deviene, como una falsedad que continuamente vuelve a trasladarse, que no se acerca nunca a la verdad: porque — no hay «verdad» ${ }^{90}$.

De este modo el fondo de la moral revela su condición poiética, artística que no descansa sobre un suelo de objetividad, sino sobre la propia actividad del sujeto que juzga y valora, o sea, que vive. El recurso a un sustrato objetivo colisiona frontalmente con las estimaciones de valor; observación ésta todavía imperceptible para el hombre moderno, en quien se aprecia una «falta de educación estética» ${ }^{91}$.

Todo modo de vida es resultado de una jerarquía de valores, de la preeminencia de unos en detrimento de otros. Y en tal elección interviene el «gusto», eco de la voluntad de poder y, en cuanto tal, la determinación de las condiciones de vida. En el juego de la valoración están implícitos conceptos tales como discriminación y distinción. El buen gusto es radicalmente opuesto a la nivelación masiva que rigió el horizonte moral del Occidente «cristiano». La elección emanada del buen gusto es una de tantas valoraciones, al tiempo que se distingue sobre las demás en virtud de su forma. «Ahora decide en contra del cristianismo nuestro gusto, ya no nuestras razones ${ }^{92}$.

La valoración que nace del buen gusto, del gusto, en último término, es la piedra angular de la nueva moral pergeñada por Nietzsche. Un original posicionamiento en el mundo que reconoce su carácter estético y que renuncia a la ensoñación de una normatividad universal y necesaria ${ }^{93}$. El gusto hace imposible la universalidad de la moral, ya que se sostiene sobre el propio sujeto encarnado, luego el hombre concreto y particular es la única medida de sí mismo; una reconversión de la sentencia de Protágoras del hombre como medida por la que el gusto queda ceñido en los márgenes de la persona singular y se hace depender de la dimensión ascética del cuidado.

${ }^{90}$ Nietzsche, F., Fragmentos póstumos IV, 2 [108], op. cit., pág. 108 (KSA XII, 114).

91 Nietzsche, F., Fragmentos póstumos I, 19 [313], ed. de Diego Sánchez Meca, trad. de Luis Enrique de Santiago Guervós, Madrid, Tecnos, 2010, pág. 411 (KSA VII, 515).

92 Nietzsche, F., La gaya ciencia, op. cit., pág. 805 (KSA III, 485).

${ }^{93}$ Cfr. Nietzsche, F., Fragmentos póstumos IV, 2 [67], op. cit., pág. 94 (KSA XII, 91): “'Yo' 'sujeto' como línea del horizonte. Inversión de la mirada perspectivista». 
Dado que el gusto procede de la voluntad de poder exige el esforzado compromiso de la superación de la situación efectiva de vida. La valoración dada por un hombre ilustra el tipo de vida en que se halla y aquel al que aspira. De manera que el gusto es el elemento distintivo que separa a unos hombres de otros en virtud de sus respectivos proyectos de existencia. Como piedra angular de la superación de sí mismo, el gusto es estrictamente privado, es decir, las pesquisas valoradoras son íntimas, intransferibles. Ello permite al autor trazar la diferencia mayúscula entre su ética estética y las tentativas morales colectivistas. Las últimas encuentran su razón de ser fuera del sujeto, pues no son sino la reproducción mecánica y neurótica de los miedos, amarguras y dolores que han recorrido durante generaciones a la civilización occidental: «el 'ser' como invención de quienes padecen con el devenir» ${ }^{94}$. Los programas morales tradicionales han emergido de un paladar vulgar incapaz de apreciar los más refinados sabores: débiles y fuertes, enfermos y sanos, enclenques y vigorosos son homogeneizados por la mentira de la igualdad de las almas. El hombre nietzscheano, por el contrario, tiene un gusto duro, propio de un espíritu que huye del crédito acomodaticio de los grandes sistemas metafísicos que truecan seguridad por vida libre e independiente; acepta vivir en el peligro que significa la muerte de Dios en aras del cultivo de su ser, la superación de sí mismo.

Por todo ello el gusto es íntimo e inconmensurable, es el reducto más propio de la individualidad, pues en sus más recónditos parajes mora la persona como tirano y soberano de su propia existencia ${ }^{95}$. El gusto determina lo bueno mediante la valoración, por eso la moral es reducida a estética en la obra nietzscheana. El gusto es el criterio diferenciador, mas no gravita en torno a lo placentero, sino a lo oneroso y duro; es la reivindicación de la vida encarnada que conducida por la acción creadora de la voluntad de poder se ha sumergido en el abismo de la existencia y ha destacado, entre la infinita pluralidad posible, como la propuesta de vida más hermosa y cultivada: la propia vida alberga en su seno la fuerza de la superación, resultando con todo una tarea que se justifica por sí misma y a la que cabe entregarse por entero:

Si nuestro «yo» es para nosotros el único ser de acuerdo con el cual hacemos y comprendemos todo ser: ¡muy bien! entonces resulta muy justificada la duda de si no hay aquí una ilusión perspectivista - la unidad aparente en la que todo se une como en una línea del horizonte. Siguiendo el hilo conductor del cuerpo se muestra una enorme multiplicidad; está permitido metodológicamente emplear el fenómeno más rico, que puede ser estudiado mejor, como hilo conductor para la comprensión del más pobre ${ }^{96}$.

${ }^{94}$ Ibid. 2 [110], pág. 108 (KSA XII, 115).

${ }^{95}$ Cfr. Ibid. 2 [84], pág. 101 (KSA XII, 103): «Juzgar es nuestra creencia más antigua, nuestro más habitual tener por-verdadero o por-no-verdadero».

${ }^{96}$ Ibid. 2 [91], pág. 103 (KSA XII, 106). 
El mensaje estético de Nietzsche no puede radicarse más lejos del hedonismo esteticista de sus contemporáneos: ¿por qué -podría objetársele a Nietzsche- un modus vivendi tan exigente y sacrificado? Es decir, ¿por qué no habría de ser lícito abandonarse en la placidez de una vida desenfadada y relajada, licenciosa, fácil e inmediatamente placentera? Tras todo lo expuesto no es difícil comprender que tales interrogantes nacen del más profundo y denigrante nihilismo, pues «nada es más peligroso que una deseabilidad que entra en conflicto con la esencia de la vida» ${ }^{97}$.

El gusto como aspecto cualitativo de la valoración está enraizado en la corporalidad, lo que significa que alude a la totalidad del ser humano, desde el espectro consciente hasta la negrura inaccesible del fondo inconsciente. El gusto, pues, destapa el conflicto de la voluntad de poder como despliegue de fuerzas que anhelan llegar a ser en un determinado modo de acción, o sea, de vida encarnada: «es sólo una cuestión de fuerza: tener todos los rasgos enfermizos del siglo, pero compensarlos en una fuerza extremadamente rica, plástica, reconstituyente. El hombre fuerte» ${ }^{98}$.

\section{I.6.1. El pathos de la distancia}

Las reflexiones a propósito del gusto han servido a Nietzsche para caracterizar los rasgos del sujeto moderno: mal gusto, hedonismo inmediato y acomodaticio, adocenado y vulgar. El gusto blando y ordinario responde a la sensibilidad soez y basta de un hombre semejante. En contraposición, Nietzsche reclama la presencia endurecida y esforzada de un individuo selecto que rechaza la facilidad del sensualismo burdo; el gusto es volición que discrimina, acoge unas condiciones de vida al tiempo que descarta tantas otras.

Este querer capaz de distinguir, que rechaza la igualdad y la aquiescencia indolente, es escaso. Exige de sus hombres una altura sublime que termine por alejarlo de sus contemporáneos, lo que Nietzsche concibió como «pathos de la distancia». El hombre elevado y soberbio se halla en la tensión sangrante entre el gusto rústico y servil de los tiempos modernos y el refinado, delicado y sutil del creador que se afirma; por eso éste último, para no ver lastrada su nobilísima tarea ha de despertar en sí el sentimiento de distancia que lo mueva a alejarse del grueso ${ }^{99}$ : el hombre que ha de crear un tiempo nuevo, ese hombre intempestivo, se encuentra en necesaria oposición contra el sino de sus días.

${ }^{97}$ Ibid. 7 [8], pág. 210 (KSA XII, 292).

${ }^{98}$ Ibid. 2 [81], pág. 100 (KSA XII, 100).

${ }^{99}$ Cfr. Nietzsche, F., Más allá del bien y del mal, op. cit., pág. 71 (KSA V, 60): «hay que apartar de nosotros el mal gusto de querer coincidir con muchos». 
El pathos de la distancia es una de las claves del aristocratismo del espíritu: aquellos capaces de distanciarse de los hombres son los individuos más sublimes y especiales. El hombre que se distancia ha sido capaz de quebrar el gusto de los hombres, es una amenaza difícil e incómoda para el gusto dominante del pueblo. Y es que éste último, el sabor de la plebe, es la ejemplificación de la debilidad de la voluntad de poder en las almas más lúgubres y raquíticas, mas también en las resentidas que anhelan una plenitud que jamás podrán alcanzar. Aquí se encuentra otro síntoma de la enfermedad del hombre moderno, pues en su aspiración de poder, tan ambiciosa como irrealizable, hipoteca su propia existencia ya que subordina su gusto a cualquier avatar que prometa fuerza y robustez; y así, el gusto moderno, capaz de deglutirlo todo indiscriminadamente, se ha postrado a las más terribles aberraciones contra el carácter humano, como la subordinación de los señores ante los esclavos.

Con el fin de evitar caer en las tentaciones del gusto imperante de la plebe, el pathos de la distancia y la dureza se integran solidariamente: el gusto duro del hombre que busca su superación y que, por tanto, no teme el titánico esfuerzo que su empresa exige. Querer y poder, distancia y dureza son elementos distintivos del nuevo tipo humano pretendido por Nietzsche, quien responsable y libremente distingue entre los factores motrices de la vida y renuncia a aquellos que no contribuyen a la consecución del más esplendoroso estilo: «esta enseñanza te doy a ti, necio, como despedida: donde no se puede continuar amando se debe - ipasar de largo! $-\gg{ }^{100}$. Con todo, el nuevo hombre está inseparablemente ligado a un nuevo gusto distanciado de la mediocridad de los muchos. Desde las cimas de su soledad habrá de crear su propia escala de valores que nutrirán la llama de la superación de sí mismo. Y en su caso, su dureza convierte en posible tal tarea. Comprendemos de este modo la necesidad del autor de una «educación estética del género humano» ${ }^{101}$.

\section{I.6.2. La alegría del creador}

Tras todo cuanto hemos expuesto al respecto de la cuestión de la corporalidad en Nietzsche y sus corolarios, cabe sentenciar que la apuesta última del pensador de la superación consiste en el dulce empeño por recuperar la alegría, perdida en la frialdad del mundo moderno. La alegría tiene, además, valor filosófico como argumento contra el rencor y el desprecio hacia la vida que trazó el decurso de la tradición occidental.

La alegría es el momento del arte de vivir en el cual se conjugan el conocimiento, la actividad creadora y el proyecto humano de llegar a «ser lo que se es». Un conocimiento que, sin embargo, no mana de las fuentes de la lógica y la adecuación del pensamiento en

${ }^{100}$ Nietzsche, F., Asi habló Zaratustra, op. cit., pág. 255 (KSA IV, 225).

${ }^{101}$ Nietzsche, F., Fragmentos póstumos I, 8 [88], op. cit., pág. 233 (KSA VII, 255). 
sí, sino de la estética. Un saber froh-Die fröhliche Wissenschaft-, esto es, alegre, jovial. Se trata de una ciencia alegre porque ha reconocido el fondo abismal de la existencia y ha aceptado la tarea de la superación transmutando el riesgo y la amenaza que éstos comportan en canales de poder y vida.

La alegría, como el resto de conceptos nietzscheanos, ha sufrido una matización significativa que resulta imprescindible explicar para eludir las aparentes contradicciones. La alegría no conduce necesariamente a una imagen plácida y dichosa, no es la ensoñación de una mítica Arcadia feliz, sino el potente estímulo de vida de un hombre que sumido en el drama y el dolor de la existencia halla, no obstante, motivo de baile y celebración: alegría trágica. Esta pulsión de poder que palpita tras la alegría se debe a que su faro de sentido ha cambiado, dejando atrás la reflexión abstracta en beneficio de una que se pliega a los posibles modos de vida efectivos. La alegría es la cima más alta que ha de conquistar el hombre, pues es el pensamiento más esforzado y serio que perseguir, la única promesa realmente merecedora de nuestro sudor:

Hay un malentendido de la jovialidad que no es posible disipar: pero quien lo comparte puede finalmente sentirse satisfecho con él. - Nosotros, que nos refugiamos en la felicidad - : nosotros, que necesitamos todo tipo de sures y una indómita plenitud de sol y que nos ponemos en camino hacia donde la vida pasa como un ebrio desfile de máscaras - como algo que saca de juicio - nosotros, que precisamente le pedimos a la felicidad que saque «de juicio»: ¿no parece que tenemos un saber al que tememos? ¿Con el que no queremos estar solos? ¿Un saber cuya presión nos hace temblar, cuyo susurro nos hace palidecer? Ese empecinado sustraerse a los espectáculos tristes, esos oídos tapados y duros ante todo lo que sufre, esa audaz y burlona superficialidad, ese arbitrario epicureísmo del corazón que no quiere tener nada cálido y completo, y que adora la máscara como su divinidad última y su redentora: ese desdén frente a los melancólicos del gusto, en los que siempre adivinamos una falta de profundidad - ¿no es todo eso una pasión? Parece que nos sabemos a nosotros mismos demasiado frágiles, quizás ya rotos e irreparables; parece que temiéramos esa mano de la vida que nos tiene que romper y que huyéramos hacia su apariencia, hacia su falsedad, hacia su superficie y su variopinto engaño; parece que somos joviales porque somos enormemente tristes. Somos serios, conocemos el abismo: por eso nos defendemos de todo lo serio ${ }^{102}$.

La alegría, decíamos, es una conquista; una conquista consistente en la asimilación de la profundidad insondable de la existencia. Y semejante aceptación, esta nueva alegría de vivir es el carácter propio del espíritu de superación del nihilismo. En la medida en que la alegría es el resultado de una conquista se concreta como el duro esfuerzo del hombre que ha conseguido reapropiarse de su existencia. La alegría que experimenta el que vive no es ya la del ingenuo optimismo rousseauniano, sino la de quien ha sabido transmutar el valor del abismo y ha hecho virtud de la experiencia dolorosa del sacrificio y el ascetismo que exige el cultivo artístico de uno mismo.

102 Nietzsche, F., Fragmentos póstumos IV, 2 [33], op. cit., pág. 86 (KSA XII, 79). 
En un fragmento póstumo tardío liga Nietzsche la jovialidad con la próxima aurora de un Occidente que apunta a la superación del nihilismo en un tiempo futuro inminente: «pero quizás mañana, quizás pasado mañana. - Veo surgir nuevos $\mathrm{f}<$ ilósofos $>$, etc.» ${ }^{103}$. Los filósofos del futuro disfrutarán de una alegría dura y trabajada que se burlará del gusto mediocre de los tristes hombres del presente que cual bestias porcinas se revuelcan sobre el barro que es su débil placer. El filósofo del futuro gusta de la vida, pero, sin embargo, su alegría no es todavía plena. Aun siendo dura y habiendo superado el fantasma de la ingenuidad, no es una alegría completa. Esta alegría seria y dura sería la propia del «león»rugiente, y como tal, un etapa de transición hacia aquella característica del «niño», a saber inocente. Como oda a la vida, la alegría del creador debe ser radicalmente nueva, despojada de todos los elementos que lastraron las potencias afirmadoras de la voluntad de poder en Occidente. El «niño» es un nuevo comienzo, un camino que se inicia allí donde el nihilismo y el hombre tradicional concluyeron. Motivo éste por el cual el tipo filósofo del futuro no es suficiente para Nietzsche; ni siquiera los hombres superiores son lo bastante grandes para Zaratustra, quien renuncia a perseguirlos cuando huyen despavoridos tras el rugido de su león. El hombre superior aún está contaminado de la ponzoña «cristiana».

El nuevo tipo de hombre que vislumbra Nietzsche en el horizonte nunca ha poblado el mundo. Ha habido tiempos mejores para la especie, como el mundo griego si se compara con el universo cristiano; en aquéllos se libró una incesante lucha en aras de la superación, mientras que en éstos, por el contrario, ha acontecido un terrible hundimiento del espíritu, que ha claudicado de la nobilísima tarea de la vida. Aunque Nietzsche toma a los helenos como tipo de gran hombre, acaso el mejor de cuantos han existido, tampoco dejaron de ser demasiado humanos. Hasta el momento únicamente ha habido hombres reactivos, o sea, preocupados finalmente de protegerse para sobrellevar las fatigas que comporta vivir.

Nietzsche concluye que a la luz de su desarrollo evolutivo -biológico y culturalel hombre se ha constituido reactivamente. Es un sueño romántico pretender erigir desde él un fin último de superación. Motivo éste por el cual el autor postula la necesidad del «superhombre»-«Übermensch»-, un nuevo modo de existencia que ha trascendido los límites reactivos del tipo humano, en general. El superhombre es una meta irrealizable de la que sí cabe, en cambio, arrojar un esquema aproximado de sus caracteres formales, destacando entre todos que supone un nuevo comienzo, un abandono de la pretérita imagen de la existencia. El superhombre empieza sobre un terreno virgen, de ahí su alegría inocente, pues no hay avatares que distorsionen su cosmos estético-moral.

${ }^{103}$ Ibid. 2 [32], pág. 86 (KSA XII, 79). 


\section{CAPÍTULO II: EL NUEVO HOMBRE}

\section{II.1. EI fin del platonismo: el filósofo-artista}

Del acontecimiento de la muerte de Dios narrado en los aforismos de la Gaya ciencia no destaca únicamente el deceso de la divinidad; en el motivo mismo de su fin descansa el rasgo crucial que no puede ser ignorado: Dios no sólo muere, sino que cae «desangrado bajo nuestros cuchillos» ${ }^{104}$, pues «nosotros lo hemos matado» ${ }^{105}$. No se trata de un asesinato más en la historia de los hombres. Con él nos hemos convertido en los «asesinos entre todos los asesinos» ${ }^{106}$, pues hemos puesto fin al longevo discurso de la metafísica tradicional, las veneradas reglas del juego del dualismo de Platón. La duplicación de mundos y la distinción del alma y el cuerpo del pensador griego no distaba esencialmente de la cartesiana escisión de la res cogitans respecto de la res extensa. Una vez más Heidegger arroja luz:

En la frase «Dios ha muerto», la palabra Dios, pensada esencialmente, representa el mundo suprasensible de los ideales, que contienen la meta de esta vida existente por encima de la vida terrestre y así la determinan desde arriba y en cierto modo desde fuera. [...].

En el lugar de la desaparecida autoridad de Dios y de la doctrina de la Iglesia, aparece la autoridad de la conciencia, asoma la autoridad de la razón ${ }^{107}$.

Y semejante nueva autoridad quiere que

si Dios y los dioses han muerto en el sentido de la experiencia metafísica explicada, y si la voluntad de poder es querida, con conocimiento de causa, como principio de toda posición de las condiciones de lo ente, esto es, como principio de toda instauración de valores, entonces el dominio sobre lo ente como tal pasa, bajo la figura del dominio sobre la tierra, al nuevo querer del hombre, determinado por la voluntad de poder. Nietzsche cierra la primera parte de "Así habló Zaratustra», que apareció un año después de la «La gaya ciencia», en 1883, con la frase: «Muertos están todos los dioses, ahora queremos que viva el transhombre» ${ }^{108}$.

Así como Gadamer - afirma Vattimo- hubo de venir para urbanizar la provincia de Heidegger, lo mismo podemos decir de éste respecto de Nietzsche. Resulta oscuro el salto hacia el árido terreno de la fórmula «ecce homo». Las pistas que brinda el maestro de Friburgo acerca de la «muerte de Dios» ilustran el esfuerzo de Nietzsche por dejar atrás las

\footnotetext{
${ }^{104}$ Nietzsche, F., La gaya ciencia, op. cit., pág. 802 (KSA III, 481).

${ }^{105}$ Ibid. (KSA III, 481).

106 Ibid. (KSA III, 481).

${ }^{107}$ Heidegger, M., La frase de Nietzsche 'Dios ha muerto'», op. cit., pp.164-165.

108 Ibid. pág. 189.
} 
categorías teológico-éticas en beneficio de las únicas capaces de respetar -y a él ajustarseel carácter plástico de la voluntad de poder: el hombre estético. La consagración existencial de «ecce homo» es la de un individuo que sabedor del vacío consecuente de la pérdida del Dios metafísico imprime a la ética un cariz fundamentalmente estetizante que aspira a la perfección de una vida encarnada, no enajenada en bellas ilusiones divinas, y que soporta en sí los rasgos y caracteres de la existencia: convergen en «ecce homo», solapándose significativamente, el poeta y el poema del «superhombre» como resultado plástico de la fuerza artística de la voluntad de poder que convierte al hombre en el artista de la bella obra de su vida concreta.

La muerte de Dios bajo nuestras manos encierra la clave de vida de Nietzsche, pues Él ha de perecer para que nosotros alcancemos a vivir. El filósofo-artista, la extraña figura en que se concreta su pensamiento esteticista, ha renunciado a la pretensión de un saber prístino y último, ha superado la decadencia inherente de la sabiduría y la santidad: «concibe la realidad tal como ella es: [...] no es una especie de hombre extrañada, alejada de la realidad, es la realidad misma, encierra todavía en sí todo lo terrible y problemático de ésta, sólo así puede el hombre tener grandeza» ${ }^{109}$. Zaratustra es quien a través de su acción creadora puede tanto escalar las cimas de Apolo como sumergirse en los profundos abismos de Dioniso ${ }^{110}$.

El filósofo-artista es una obra estética donde lo místico -que no el misticismo- y lo ético se han transmutado para una realización efectiva de la métrica zaratustriana del superhombre. Es a la vez la culminación filosófica y biológica de Nietzsche, el momento definitivo en que el influjo pesimista de Schopenhauer y Wagner, radicales en El nacimiento de la tragedia y en las Consideraciones intempestivas, es conquistado tras las primeras tentativas de superación en Humano, demasiado humano y la Gaya ciencia. Las consideraciones acerca de la falta de sentido intrínseco del mundo así como las relativas a la pérdida del fundamento último -muerte de Dios- de la realidad y de la escatología histórica no arrojan a Nietzsche a un pozo de indefectible amargura, sino que lo entregan al vasto horizonte de indeterminada creación que emana del fundamental conflicto de la voluntad de poder. La muerte de Dios no es para el filósofo-artista sino ocasión de recuperación del propio ser, durante largo tiempo enajenado, al comprender el cariz ficticio de la realidad, abierto ahora a la fuerza creadora de su interés de vida que canaliza y cristaliza la plasticidad de la voluntad de poder. Nietzsche supera de este modo el pesimismo filosófico que entrañaban la metafísica-estética de Schopenhauer y la estética-metafísica de Wagner al

${ }^{109}$ Nietzsche, F., Ecce homo, op. cit. pp. 140-141 (KSA VI, 370).

${ }^{110}$ No debemos, no obstante, indicar, y lo desarrollaremos posteriormente en el presente trabajo, que la figura de Apolo sufrirá un progresivo desdoro en beneficio de su contraparte Olímpica, hasta su completa desaparición del cosmos nietzscheano. Sin embargo, no es menos cierto tampoco que el propio Dioniso habrá de sucumbir en la imagen definitiva de la filosofía del autor, terminando también por diluirse. 
comprender que la radical dimensión de lucha y confrontación sobre la que se asienta la vida no ha de eludirse al extrañar la existencia en la peregrina búsqueda de una remota unidad primordial, sino enfrentarse desde la potencia creadora de la voluntad de poder que da forma a lo indeterminado: lo que Nietzsche llamó «corporalidad», la vida encarnada. Precisamente por la eminencia del cuerpo en su filosofía y el empeño por romper con una tradición en la cual el pensamiento había cercenado toda atisbo somático, al cierre de su obra Nietzsche permutará los términos de su fórmula consumando con ello la transvaloración: de filósofo-artista a artista-filósofo.

\section{II.2. La transvaloración: el artista-filósofo}

Como veremos más adelante, la transvaloración no consiste en una inversión de los valores «bueno» y «malo», sino en una transformación cuasialquímica del criterio mismo de la valoración, tornando al cuerpo en el criterio primero y último de determinación. Así conceptos del pensamiento nietzscheano como el «amor fati» o el «eterno retorno» son algo más que fragmentos dispersos de una doctrina acerca de la afirmación de la vida. Se trata de las claves desde las que ejecutar la transmutación del modo filosófico que colonizó el espectro occidental. La precedencia del «artista» respecto del «filósofo» consigna el rechazo de la perspectiva bimilenaria que entendió pertinente la escisión del alma y del cuerpo pauperizando éste en beneficio de aquélla.

El artista antecede al filósofo en la obra de Nietzsche en lo que consiste la más sólida manifestación de su posicionamiento intelectual. No se trata de un empeño por defenestrar la filosofía como tal, sino la imagen que de ella cultivaron el racionalismo y el idealismo en la fragua del platonismo. El tránsito de filósofo-artista a artista-filósofo debe ser visto como el consecuente desarrollo del proyecto filosófico nietzscheano: la deconstrucción de la metafísica tradicional -desde Platón hasta Hegel, pasando por figuras tales como Plotino, Descartes, Leibniz o Kant-, perpetrada a «martillazos» ${ }^{111}$, como reza el subtítulo de Crepúsculo de los ídolos, se correspondería con el momento del filósofo-artista, que abonaría el alumbramiento del posterior artista-filósofo, quien en irrestricto ejercicio de su voluntad de poder lleva a término la «transvaloración de todos los valores». Siguiendo la metáfora de las transformaciones del Zaratustra, el león correspondería al filósofo-artista, cuyo rugido negador aludiría al sólido martillazo de quien busca romper los vacíos ídolos del pasado; en el niño, no ha lugar a duda, se encarnaría la fuerza de la transvaloración que crea un nuevo punto cardinal para la valoración.

Nietzsche se estima como un hito profanador del pensamiento reconociendo que marca «un antes y un después» en la historia del hombre occidental. Se sabe destructor de

${ }^{111}$ Cfr. Nietzsche, F., Fragmentos póstumos IV, 2 [100], op. cit., pág. 106 (KSA XII, 110): «El martillo: una doctrina que, al desencadenar el pesimismo más ávido de muerte, provoca una selección de los más capaces de vivir»». 
una añeja tradición que en el momento de recibirla ya ha alcanzado su más alta cima. Sobre esta percepción de sí mismo se construye Crepúsculo de los ídolos, como la radicalización del criticismo kantiano que, al ejecutar máximamente la crítica de la razón pura, termina deviniendo antikantiano, toda vez que el proyecto filosófico del prusiano concluye en una serie de postulados - como la «cosa en sí»- que abrirán las puertas del idealismo alemán.

Nietzsche es un corruptor de la filosofía occidental, así confiesa explícitamente en Ecce homo lo que filosóficamente ha atestiguado en Crepúsculo. En esta obra ha consumado el olvido de la «cosa en sí», la ha apartado del horizonte del conocimiento para recuperar lo que para la metafísica fue el fantasma del cuerpo. Una corporalidad desarropada de abrigos éticos y religiosos que a lo largo de un discurso trazado escatológicamente habían aupado lo racional sobre lo irracional en un juego de desdoro y desprecio de la vida encarnada.

En su vindicación del cuerpo Nietzsche pretende concretar el fracaso de la metafísica occidental, la cual había acentuado una dolorosa fractura entre el sujeto y el mundo que se tradujo finalmente en una desafección estructural entre el pensamiento y la vida encarnada, en perjuicio de la última. A partir del diagnóstico de que no había vínculo real entre el pensamiento metafísico y la vida, esto es, la destrucción de los vetustos ídolos, Nietzsche propone la potencia irrestricta del «arte» como alternativa salvífica frente a las manifestaciones legadas por el idealismo.

Sin embargo, dado que la transvaloración no consiste en una mera inversión de los valores, la nueva construcción del artista-filosófo no pasa por ser tan sólo un cambio en el orden de los términos; la transvaloración es la irrupción de un nuevo prisma de valoración, a saber, el «cuerpo»: «ino buscar el sentido en las cosas: sino introducirlo!» ${ }^{112}$. Un cuerpo distinto del de la paupérrima imagen platónica como receptáculo del alma, como res extensa; en él se afirma la superación del dualismo como enfoque filosófico que sostenía la esencial fractura entre la dimensión espiritual y la somática: Nietzsche reintegra cuerpo y alma en una nueva síntesis de cuerpo que se cimenta sobre un equilibrio entre la conciencia y las pulsiones vitales. El filósofo-artista todavía tiene demasiado de Apolo; el artista-filósofo es la instancia última donde se vence a la tiránica razón platónica y sus ecos racionalistas.

La renuncia de Apolo no significa, no obstante, el rechazo del orden, del equilibrio o de la conciencia. Esto supondría no la transvaloración, sino una inversión de valores que nos arrojaría a una corporalidad bruta, estrictamente biologicista. En este caso, al tratarse de una inversión se otorgaría la primacía que hasta entonces ostentaba el espíritu al

112 Ibid. 6 [15], pág. 182 (KSA XII, 238). 
cuerpo, una estrategia decadente toda vez que continúa la lógica de la metafísica de la duplicación. Dejar atrás a la deidad olímpica implica, precisamente, la ruptura con el último bastión de razón idealista que moralizaba desde estamentos ajenos a la propia vida.

La corporalidad anunciada en la filosofía nietzscheana es una síntesis de ambas facetas, alma y cuerpo, donde ambas han sido reconciliadas, de tal forma que la tensión dialéctica entre ellas ha cedido en favor de una equilibrada unidad que celebra la fuerza plástica de un cuerpo que piensa y de un alma que siente. La corporalidad y la estética se imbrican de este modo bajo la forma de «fisiología del arte»: no es sólo poética, sino poiesis, ejercicio de fuerza y creación. Motivo que explica que la espiritualidad del cuerpo alumbre la vida en su totalidad, instintos y pulsiones, pensamiento y reflexión:

El engaño de Apolo: la eternidad de la forma bella; la legislación aristocrática «jasi debe ser siempre!».

Dioniso: sensibilidad y crueldad. La caducidad podría interpretarse como el gozo de la fuerza generadora y destructora, como continua creación ${ }^{113}$.

No contempla Nietzsche al artista-filósofo como una de tantas imágenes filosóficas habidas en los voluminosos manuales de la historia de la filosofía. Si bien acertó Heidegger al entender que el pensamiento nietzscheano sigue dentro de la atmósfera moderna en la medida en que se despliega en conceptos, no es menos cierto que esta conceptualización procura una proyección efectiva sobre la vida. El artista-filósofo es el intento último de Nietzsche por salvar al hombre que tras la experiencia de la muerte de Dios y su correspondiente pérdida de sentido -«Occidente ha perdido su brújula», rubricará inmortalmente- deambula desamparado por un creciente desierto de miseria e indigencia existencial.

Ahora bien, Nietzsche nos recuerda, insistentemente, que no es un profeta ni un guía al que seguir; suyo no es el rol de caudillo. El artista-filósofo es una clave de existencia que, sin embargo, tampoco se ajusta a un «tipo ideal» weberiano: su contenido está abierto al horizonte de vida específico de cada sujeto. De manera que no podemos esperar un listado de cualidades genéricas de este avatar que extrapolar a una pretendida humanidad abstracta. El artista-filósofo es quizá otra nomenclatura del «superhombre», esencialmente plural y, por ende, distinto de los demás y de sí mismo. Tan sólo una condición acaso para la concreción de esta figura: la conciencia de finitud de una refinada corporalidad, tan espiritual como biológica, que escapa de la soga escatológica que trenzó la metafísica de la duplicación.

${ }^{113}$ Ibid. 2 [106], pp. 107-108 (KSA XII, 113). 


\section{II.2.1. Fisiología del arte}

La fisiología del arte presupone la solidaria comunión del alma y el cuerpo en una nueva imagen de corporalidad construida sobre la unión armónica de una y otra dimensión: el proceso vital que se despliega desde la voluntad de poder como máxima creación artística del hombre parte de la existencia de un componente fisiológico en su seno.

La fisiología del arte es, otra más, una crítica de la filosofía kantiana. Concretamente alude a los pasajes de la Crítica del juicio del «desinterés». Las categorías de lo «bello» y lo «feo» son pensadas por Nietzsche desde un juicio radicado en la vida, de tal modo que sus consideraciones comienzan desde la experiencia de nuestros instintos. Lo bello y lo feo son extensiones de lo que hace aumentar o decrecer el sentimiento de poder, respectivamente. Por tanto, tales sentimientos no pueden ser explicados desde el «desinterés», el cual es un fenómeno específico de una vida enajenada en instancias eidéticas.

La preeminencia de los instintos sobre la razón pura en la filosofía nietzscheana no es una loa de irracionalidad, sino una reordenación de los rasgos de la vida. Es el encomiable empeño de un pensador que inserto en la ola nihilista europea ha comprendido la imperiosa necesidad de reunir nuevamente las dimensiones humanas escindidas desde hace dos mil años. La recuperación de la fuerza de la esfera instintiva es menos la vindicación del irracionalismo que la caracterización del cuerpo como principio filosófico fundamental ${ }^{114}$. Lo bello y lo feo se juega en el escenario de las potencias de la vida, fuerzas de creación para una tarea estética que es tanto fisiológica como intelectual: el cuerpo como manifestación de la vida más elevada. He aquí el único imperativo moral de todo el corpus filosófico nietzscheano: la obligación de sí y sobre sí, «para sí», de comprometerse con el cuidado de la propia existencia, encarnada y radicada en un mundo tan anímico como somático.

La fisiología del arte es, finalmente, una estética del alma y del cuerpo que ha prescindido del apriorismo en beneficio de un nuevo rumbo de corte hermenéutico. El artista-filósofo opera en la «vida», desde sus posibilidades y limitaciones, desde su contingencia e ilimitada finitud. Nietzsche enarbola la bandera de una filosofía biográfica, de un pensamiento al que no es extraña la vida, a la cual juzga como bella y fea en virtud de sus posibilidades generadoras: el gusto de la estética nietzscheana apunta al «gran estilo» que anhela la consecución de la vida efectiva más fecunda.

114 Cfr. Nietzsche, F., Crepúsculo de los ídolos, op. cit., pág. 60 (KSA VI, 83): «[...] atacar las pasiones en su raíz significa atacar la vida en su raíz». 


\section{II.2.2. El gran estilo}

El gran estilo es el que le corresponde al artista-filósofo, al superhombre, como tipo de arte superior en el que se conjuga la síntesis de las voluntades de poder espirituales y somáticas. Es el ideal último de la estética nietzscheana en el cual se recupera el aristocratismo de los sentimientos socavado por el «cristianismo» ${ }^{115}$. El gran estilo supone el refinamiento definitivo del gusto, la exquisitez de lo bello, entendiéndolo como criterio potenciador de una vida que se afirma en su plena corporalidad. Se trata de una norma que emanada de la estética desemboca en la vida, consumando la exigencia -que explicaremos posteriormente- nietzscheana de que todo sea reducido a estética, pues ésta no consistirá más en la concepción moderna como teoría de la sensibilidad, sino en disposición de vida: las funciones fisiológicas y las directrices morales se solapan en un proyecto esteticista a lo largo del cual, en ejercicio de la voluntad de poder, el hombre encarnado hace de sí la más bella obra artística como manifestación de su afirmación de la vida. «Lo primero que hace falta -dice Nietzsche- es vida: el estilo debe vivir. El estilo debe adaptarse en cada momento a ti»>116.

El gran estilo es el árbol frutal germinado sobre el nutricio suelo del mundo aparente una vez ha sido recuperado; supone la potencia generadora de un mundo que falto de sentido fundamental y telos al que tender encuentra en sí mismo las semillas de una existencia fecunda que no necesita más que de sí para justificar y responder a los porqués hum$\operatorname{anos}^{117}$. Es el esforzado ejercicio activo y constante de una existencia reapropiada que se afirma en todo momento en su voluntad de poder. El ideal del gran estilo no aspira al rigor de un conocimiento científico ${ }^{118}$; en su lugar, persigue la sabiduría jovial y gozosa de una vida construida sobre sus propias exigencias y criterios de valoración, pues «¿qué puede ser únicamente el conocimiento? — ‘interpretación', no 'explicación’»119. Unas «tablas nuevas» que acentúan la condición hermenéutica de toda empresa estética; una finitud ilimitada que anuncia el fin de la escisión platónica: si bien no se hablará más de la distancia entre el alma y el cuerpo, no es menos cierto que se cerrará también el abismo moderno entre el sujeto y el mundo.

115 Nietzsche, F., Fragmentos póstumos IV, 11 [122], op. cit., pág. 402 (KSA XIII, 59): «Siendo nuestra vida humana tal como es, toda 'verdad', toda 'bondad', toda 'santidad', toda 'divinidad' al estilo cristiano, se han manifestado hasta ahora como un gran peligro - e incluso hoy día la humanidad está en peligro de perecer por una idealidad contraria a la vida».

${ }^{116}$ Nietzsche, F., Fragmentos póstumos III, 1 [45], op. cit., pág. 35 (KSA X, 22).

117 Nietzsche, F., Fragmentos póstumos IV, 9 [73], op. cit., pág. 255 (KSA XII, 374): «La necesidad de un mundo metafísico es la consecuencia de que no se ha sabido extraer un sentido, un ¿para qué? del mundo existente. 'Por consiguiente, se concluyó, este mundo sólo puede ser aparente'».

118 Ibid. 15 [118], pág. 669 (KSA XIII, 480): «el gusto aristocrático marca límites incluso al conocimiento. Quiere, de una vez por todas, no saber muchas cosas».

119 Ibid. 2 [86], pág. 102 (KSA XII, 104). 
Nietzsche no pierde, sin embargo, el horizonte de lo que convino en llamar «voluntad de verdad». El esfuerzo dogmático de la adecuación que obligaba a bascular toda doctrina en los límites de la «verdad»y la «falsedad». Nociones epistemológicas éstas que pierden su significado en la obra del pensador alemán toda vez que las integra en un océano hermenéutico de contingencia radical. Desde el momento en que el «mundo ideal» ha sido despojado de su hegemonía sobre el «aparente» mediante la transvaloración, la cual, recordemos, no ha pauperizado el primero para investir de rédito al último, sino que ha acabado como tal con la distinción metafísica de uno y otro, la concepción moral del mundo ha desaparecido, cediendo su espacio a un sentido «extramoral» ${ }^{120}$ : la falsedad y la verdad se han identificado, pues se antoja falsa la verdad de una objetividad supramundana y antitética respecto de las potencias vitales de la voluntad de poder. Una trascendencia más allá del tiempo y el espacio, capaz de atravesar la naturaleza y la historia y cuya validez se estima universal resulta grosera y zafia para el artista-filósofo. El ideal del gran estilo responde al perspectivismo, que es la verdad de la estética: la «máscara» y el calco. La verdad hermenéutica se construye en la vida, de tal forma que se arma como una manifestación de la misma y nunca cual ruptura o escisión:

Un gran hombre, un hombre al que la naturaleza ha construido e inventado con gran estilo, ¿qué es? Primero: él tiene en todo su hacer una lógica amplia, que debido a su extensión es difícilmente abarcable, por consiguiente induce a error, una capacidad de extender su voluntad sobre grandes superficies de su vida y de despreciar y eliminar cualquier pequeña cosa, aunque sean las cosas más bellas, «más divinas», del mundo. Segundo: él es más frío, más duro, más irreflexivo y sin miedo a la «opinión»; le faltan las virtudes que están unidas al «respeto»y al ser respetado, en general todo lo que forma parte de la «virtud del rebaño». Si no puede guiar, entonces va solo; entonces sucede que gruñe a muchas cosas que se encuentra en el camino. 3) no quiere un corazón «compasivo», sino servidores, instrumentos, él busca siempre, en el trato con los hombres, hacer algo por ellos. Él se sabe incomunicable: considera carente de gusto hacerse «familiar»; y él no lo es habitualmente, cuando se lo tiene por tal. Cuando no habla consigo mismo, lleva su máscara. Prefiere mentir que decir la verdad: cuesta más espíritu y voluntad. Hay soledad en él, como algo inalcanzable para el elogio y la censura, como una jurisdicción propia, que no tiene ninguna instancia sobre sí1 ${ }^{121}$.

El arte es verdadero porque se ha zafado de la voluntad de verdad «a cualquier precio»; no aspira a la verdad inmutable y eterna, sino a la integración solidaria en el mundo, el cual se nutre de un incesante devenir.

La voluntad de verdad de la razón del platonismo perece a los pies del gran estilo de la voluntad de poder, que impone una voluntad de apariencia e ilusión, un mandamiento

${ }^{120}$ Ibid. 5 [80], pág. 169 (KSA XII, 220): «hay problemas aún más fundamentales que los problemas morales: éstos sólo llegan a verse cuando uno ha dejado detrás de sí el prejuicio moral».

${ }^{121}$ Nietzsche, F., Fragmentos póstumos III, 34 [96], op. cit., pág. 736 (KSA XI, 451-452). 
de mentira y falsedad en detrimento de la pretensión de realidad del ser de la metafísica. El arte posee más valor que la verdad, pues aquél procede del cuerpo que vive mientras ésta halla su origen en un plano metamundano. El arte, en tanto que expresión de la voluntad de poder, es el canal de manifestación de la vida: «el gran estilo, expresión de la 'voluntad de poder' misma ${ }^{122}$.

La expulsión de aquellos poetas que no actuaran conforme las exigencias de verdad de la República es la confirmación de que el gran arte es, esencialmente, antiplatónico. De manera que la teoría nietzschena del arte, que encuentra su cima en el gran estilo, es una teoría de la verdad estetizante al haber acuñado el compromiso contradictorio de la verdad de la falsedad. En una jocosa y ácida nota Nietzsche inscribe el esfuerzo de las tentativas intelectualistas dentro de las patologías mentales: "Inscripciones en la fachada de un manicomio moderno. Las necesidades intelectuales son necesidades morales ${ }^{123}$.

El gran estilo es menos conocimiento científico que sabiduría. Es el saber por el cual se logra la espiritualización de las pulsiones, de lo instintivo y la encarnación de lo espiritual en la nueva imagen de cuerpo; un cuerpo recobrado que no se percibe desde caracteres netamente biológicos ni tampoco genuinamente artísticos, sino desde los parámetros sintéticos de la «fisiología del arte». Luego no es erróneo admitir el gran estilo como el colofón de la sabiduría de vida que es la fisiología del arte, a saber, la reapropiación de una existencia que no responde ya a códigos metafísicos de escisión de la identidad individual. Se trata de una concepción no dualista de la imagen del hombre y del mundo, los cuales a su vez no son por más tiempo recíprocamente extraños, que al haber prescindido de la proyección significativa de una verdad trascendental los retrata ahora desde los rasgos hermenéuticos de un artista y su respectiva obra. Consiste por ende en una caracterización estetizante del ser que impregnará tanto las claves antropológicas como las máximas morales: una esencial contingencia que, sin embargo, no nos arroja a un yermo paraje de indigencia, sino de infinitas posibilidades ${ }^{124}$. Nos sitúa el gran estilo -acaso baste tan sólo la tendencia hacia el mismo- en un sendero de recuperación del propio cuerpo, esto es, la vida reapropiada para una época despojada del garante del Dios metafísico, al tiempo que implica una advertencia de rigor y honestidad:

No hay duda de que el arte $\mathrm{w}<$ agneriano $>$ obra hoy sobra las masas; el que sea capaz de hacerlo - ¿no nos dice algo sobre ese arte mismo? - Hay tres cosas buenas en el arte para las cuales las «masas» nunca han tenido sentido, la aristocracia, la lógica y la belleza - pulchrum est paucorum hominum [lo bello es cosa de

${ }^{122}$ Nietzsche, F., Fragmentos póstumos IV, 11 [138], op. cit., pág. 405 (KSA XIII, 63).

${ }^{123}$ Ibid. 14 [48], pp. 522-523 (KSA XIII, 242).

${ }^{124}$ Cfr. ibid. 14 [47], pág. 522 (KSA XIII, 241): «el arte es esencialmente afirmación, bendición, divinización de la existencia». 
pocos] - : por no hablar de otra cosa aún mejor, del gran estilo, al que hasta ahora ni siquiera los mejores artistas del tiempo moderno han podido decir ni sí ni no: no han tenido todavía derecho a él, se sentían lejos de él y avergonzados, y esta vergüenza ha sido su máxima elevación. Wagner está pero que muy lejos del gran estilo: lo desbordante y lo heroico-soberbio de sus medios artísticos entra en contradicción directa con el gran estilo; y asimismo lo que tiene de tierno-seductor, de variado e incitante, de inquieto, incierto, palpitante, momentáneo, de secretamente exaltado, toda la mascarada «suprasensible» de los sentidos enfermos y todo lo que sólo en sentido típico puede llamarse «wagneriano». Y, no obstante, a pesar de la más profunda incapacidad para ello: Wagner mira de reojo hacia el buen estilo, él, que ni siquiera es capaz de la lógica ordinaria, correcta, auténtica. Lo sabe muy bien, lo reconoció a tiempo: pero en seguida pasó, con esa habilidad de histrión sin escrúpulos en la que es maestro, a interpretar su defecto como ventaja. Hay en lo ilógico, en lo a medias lógico mucho de tentador - esto lo vio Wagner con claridad - : en especial para los alemanes, quienes la oscuridad la perciben como «profundidad» ${ }^{125}$.

La visión nietzscheana del arte, apuntada ya en su primer trabajo, el joven El nacimiento de la tragedia, no apunta al placer sensorial que puedan evocar sus obras. No es únicamente una teoría de la contemplación, sino un ideal de existencia. La magnificencia del arte se juzga no desde la forma, sino desde su aproximación al gran estilo ${ }^{126}$, desde su fuerza generadora de vida. El verdadero arte, aquel por medio del cual habla la voluntad de poder, conquista la propia vida, se adueña de los márgenes plásticos de creación, pues en su facultad el artista y la obra se unen: «dominar el caos que uno es; obligar al caos propio a que se convierta en forma [...]: que se convierta en algo lógico, simple, inequívoco [...]; que se convierta en ley - : en eso consiste aquí la gran ambición» ${ }^{127}$. La grandeza del gran estilo, descrita como la conquista del propio ser, se fundirá con el genuino ascetismo que profesará Nietzsche, donde la dominación de los instintos no es tanto su aniquilación como su reordenación al servicio de las condiciones efectivas de vida:

Todas las pasiones tienen una época en la que son meramente nefastas, en la que, con el peso de la estupidez, tiran de sus víctimas hacia abajo - y una época tardía mucho más posterior, en la que se desposan con el espíritu, en la que se «espiritualizan ${ }^{128}$.

El camino hasta el gran estilo ha hecho a Nietzsche transitar entre las esferas ética y estética en una dinámica oscilación que ha encontrado su acomodo definitivo en la «grandeza», donde se reconcilian las fuerzas vitales tras un complejo ejercicio de jerarqui-

${ }^{125}$ Nietzsche, F., Fragmentos póstumos III, 41 [2], pp. 871-872 (KSA XI, 673-674).

126 Cfr. Nietzsche, F., Fragmentos póstumos IV, 14 [61], op. cit., pág. 526 (KSA XIII, 246): «la grandeza de un artista no se mide por los 'bellos sentimientos' que suscita [...]. Sino por el grado en que se aproxima al gran estilo, en que es capaz de gran estilo».

${ }^{127}$ Ibid. 14 [61], pág. 526 (KSA XIII, 247).

${ }^{128}$ Nietzsche, F., Crepúsculo de los ídolos, op. cit., pág. 59 (KSA VI, 82). 
zación $^{129}$. Por su «grandeza» el artista ha alcanzado a armonizar en un mismo impulso la razón y las pasiones sin lastrar a una u otras; su cometido, la vigorización de la vida más selecta y elevada. Ha comprendido «el problema de la jerarquía entre tipos humanos que siempre $<$ han $>$ existido y que siempre existirán ${ }^{130}$ y refinado su estilo hasta la consecución de una vida propia que no se ha visto forzada a extirpar una parte de sí. Por todo ello, sentencia el autor, la «cima de la evolución: el gran estilo» ${ }^{131}$.

La sabiduría del gran estilo entraña la salvación de la humanidad. Sin embargo, es absolutamente necesario matizar esta última idea, toda vez que es proferida por un autor radicalmente ateo, alguien que ha tornado imposible para sí las creencias de una postrera bienaventuranza que redima la existencia de las calamidades a ella misma inherentes y de abstracciones, al modo nouménico, en las que se concrete colectivamente el espíritu del ser. La grandeza del estilo ha descubierto momentos antes el «eterno retorno» ${ }^{132}$, bajo cuyas premisas se lleva a cabo la obra del artista-filósofo: no es una narrativa del curso del tiempo ni una vuelta a un pasado mítico, sino un principio de jerarquización de los instantes de la existencia. La perspectiva metafórica de la repetición hace que el artista seleccione los momentos más bellos y plásticos de su experiencia vital, aquellos que se viven desde el ejercicio creativo de la voluntad de poder, como modelo de manifestación de su ser en el mundo.

Es gracias a la revelación del pensamiento del eterno retorno que la salvación y la afirmación de la vida se condensan en un instante de presente absoluto ${ }^{133}$. Este presente se ha desembarazado de ilusiones y fantasmas que orientaban la mirada al porvenir en detrimento del momento efectivo. El eterno retorno hace del presente experiencia concreta del hombre singular, pues concierne a las manifestaciones particulares de la existencia de cada cual. Y de este modo el presente se exonera de toda culpa y responsabilidad-«inocencia del devenir»- y torna la propia acción de vida encarnada en fuente de sentido. La vida de mayor jerarquización, la más estilosa que ha forjado la voluntad de poder es un goce que

${ }^{129}$ Insiste furibundamente Nietzsche en la necesidad de una jerarquía de los valores, pues «el primer problema es el de la jerarquía de los tipos de vida» (Nietzsche, F., Fragmentos póstumos IV, 7 [42], op. cit., pág. 219 [(KSA XII, 309)]).

${ }^{130}$ Ibid. 15 [120], pág. 670 (KSA XIII, 481).

${ }^{131}$ Ibid. 14 [117], pág. 555 (KSA XIII, 294).

${ }^{132}$ Cfr. Nietzsche, F., Asi habló Zaratustra, op. cit., pág. 304 (KSA IV, 272): «¿es que ha venido a ti un nuevo conocimiento, un conocimiento ácido, pesado?».

133 Cfr. Nietzsche, F., Fragmentos póstumos III, 5 [1], op. cit., pág. 155 (KSA X, 210): «inmortal es el instante en el que engendré el retorno. Por amor de este instante soporto el retorno».

${ }^{134}$ Nietzsche, F., Así habló Zaratustra, op. cit., pág. 436 (KSA IV, 403). 
anhela la repetición eterna, ya que «todo placer se quiere a sí mismo» ${ }^{134} \mathrm{y}$, como tal, «el placer quiere eternidad» ${ }^{135}$. Es aquella vida que puede soportar el peso más grave:

El peso más grave. - Qué pasaría si un día o una noche un demonio se deslizara furtivo en tu más solitaria soledad y te dijera: «Esta vida, tal como la vives ahora y tal como la has vivido, la tendrás que vivir una vez más e incontables veces más; y no habrá nada nuevo en ella, sino que cada dolor y cada placer y cada pensamiento y suspiro y todo lo indeciblemente pequeño y grande de tu vida tendrá que retornar a ti, y todo en la misma serie y la misma sucesión - e igualmente esta araña y este claro de luna entre los árboles, e igualmente este instante y yo mismo. El eterno reloj de arena de la existencia será girado siempre de nuevo - y tú con él, mota de polvo del polvo!» — ¿No te echarías al suelo y castañetearías los dientes y maldecirías al demonio que así hablaba? ¿O has vivido alguna vez un instante formidable en el que le hubieras respondido: «ieres un dios y nunca escuché algo más divino!»? Si ese pensamiento adquiriera poder sobre ti, te transformaría, tal como eres, y quizás te destruiría; ¡la pregunta, a propósito de todo y de cada cosa, «¿quieres esto otra vez e innumerables veces más?» estaría en tus manos como el peso más grave! O bien, ¿cómo tendrías que quererte a ti y a la vida para no pretender nada más que esta confirmación última, que este último sello? ${ }^{136}$.

El artista-filósofo, maestro del eterno retorno, «abogado del círculo», título con el que se enviste a sí mismo Zaratustra, no teme las palabras de dicho demonio nocturno. Sus rodillas no se hunden bajo el peso del «eterno reloj de arena de la existencia»; su vida es dichosamente placentera $\mathrm{y}$, por tanto, la afirma infinitamente: «ipues yo te amo, oh eternidad!» ${ }^{137}$.

Con todo, la sabiduría suprema que es el «gran estilo» del artista-filósofo, ejemplo encarnado de su ideal aristocrático, se ciñe a la crítica del platonismo que tejió una conciencia moral en el mundo que conllevó el desprecio de la materia en beneficio de la espiritual idea. Ha llevado a Nietzsche a sumergirse en los mares de la estética y la ética para advertir sus confines y reunificar tales universos, el alma y el cuerpo, en una novedosa corporalidad que se asiente sobre la gozosa afirmación de la vida concreta que es cada uno: «el gran estilo se manifiesta a consecuencia de la gran pasión. Desdeña complacer, se olvida de convencer. Da órdenes. Quiere» ${ }^{138}$.

En el fondo, el mensaje del gran estilo es una enseñanza que contempla el mundo desde una perspectiva esteticista: conocimiento, ética, mundo, etc., son pensados y caracte-

\footnotetext{
${ }^{135}$ Ibid. (KSA IV, 403).

${ }^{136}$ Nietzsche, F., La gaya ciencia, op. cit., pág. 857 (KSA III, 570).

${ }^{137}$ Nietzsche, F., Así habló Zaratustra, op. cit., pág. 319 (KSA IV, 287).

${ }^{138}$ Nietzsche, F., Fragmentos póstumos IV, 15 [118], op. cit., pág. 669 (KSA XIII, 479).
} 
rizados desde la estética como nueva concreción hermenéutica de la verdad que se despliega desde la intensidad del instante presente de vida. La existencia se arma sobre la síntesis vital del hedonista ascético que es el artista-filósofo.

El hedonismo y la estética se sintetizan creativamente en la imagen nietzscheana de la corporalidad, convirtiéndola en un complejo donde no pueden definirse los estrictos límites de la ética, la moral y la antropología. El ascetismo que sustenta la filosofía de Nietzsche radica en su peculiar pesimismo, el cual, no obstante, dista de manera esencial del schopenhaueriano. Mientras el maestro renuncia a toda expectativa de superación al concebir al hombre como un mal inmanente del mundo, el joven discípulo hace de la decadencia de la especie la clave para su superación: el objeto ideal de la filosofía nietzscheana, a saber, la superación del hombre en cuanto tal, sólo es posible una vez sea alcanzada la máxima degeneración ${ }^{139}$. El ascetismo exige al hombre máximamente, lo despoja de aquellos rasgos demasiado humanos llevándolo al monstruoso extremo del desprecio de sí, de la renuncia de su personalidad para apacentar en esta estrategia la simiente del superhombre. Sólo una vez el hombre haya sido depuesto en una forma tosca y cruel, podrá Zaratustra exigir su superación: la crueldad del ascetismo nietzscheano termina por revelar la condición inmunda que la existencia humana se ha procurado bajo el sino de la metafísica de la duplicación, motivando la náusea que moverá finalmente al hombre superior hacia el abandono - la aniquilación- de tan indigente cualidad de vida: «iquebrad a los buenos y los justos!» ${ }^{140}$. El ascetismo del gran estilo debe tomarse como un gran ascetismo, un ascetismo sobrehumano que en virtud de su distancia esencial con el «humano» occidental pondrá fin a dicha tradición.

El propio Nietzsche es consciente de que su exigencia ascética apenas puede ser exigida, dado que se antoja insostenible para los distintos tipos humanos que pueblan la superficie de la tierra; una crueldad olímpica, tal vez inaccesible para los mortales. Aquí se encuentra la última amenaza, la última tentación de Zaratustra, su «último pecado»: la compasión:

Oh, vosotros hombres superiores, vuestra necesidad fue la que aquel viejo adivino me vaticinó ayer por la mañana, -

- a acudir a vuestra necesidad quería seducirme y tentarme: oh Zaratustra, me dijo, yo vengo para seducirte a tu último pecado.

¿A mi último pecado?, exclamó Zaratustra y furioso se rió de sus últimas palabras: «¿qué se me había reservado como mi último pecado?»

- Y una vez más Zaratustra se abismó dentro de sí y volvió a sentarse sobre la gran piedra y reflexionó. De repente se levantó de un salto, -

139 No deja de resultar fascinante la lectura paulina de la superación nietzscheana: «cuanto más abundó el pecado, tanto más sobreabundó la gracia» $(R m$ 5:20).

${ }^{140}$ Nietzsche, F., Fragmentos póstumos IV, 2 [71], op. cit., pág. 95 (KSA XII, 93). 
« ‘Compasión! ¡La compasión por el hombre superior! [... $]^{141}$.

La compasión es el último vestigio de la «moral cristiana» que aún podría afectar el proyecto nietzscheano de reapropiación de la existencia; sólo la vieja moral que protege al «débil» en detrimento del fuerte, esa voluntad de poder emanada de canales reactivos tendría todavía capacidad para hacerle renunciar de su programa esteticista de creación de la propia experiencia efectiva de vida. La compasión como triunfo definitivo de los débiles conlleva el abandono de la ascesis que sublimaría la decadencia en un nuevo tipo humano, el «superhombre».

\section{II.3. La tentadora amenaza nihilista de la compasión}

La compasión es uno de los aspectos más polémicos y difíciles de la filosofía de Nietzsche, a la cual enfrenta cruel y ásperamente, sin contemplaciones ni tibiezas. Su crítica no debe abordarse superficialmente ${ }^{142}$, ya que nos abocaría a una pobre lectura donde éste parece repudiar la ayuda del prójimo o incluso ser esgrimida como justificación de atrocidades. Su juicio de la compasión atenta contra el último bastión de la barbarie de una voluntad de poder reactiva que se apoya en la fuerza bruta; luego ha de comprenderse en su profundidad filosófica, como elemento crucial de la transmutación de los aspectos más oscuros y terroríficos de la existencia en una loa de afirmación de la vida.

La compasión se presenta a Zaratustra como su última y pecaminosa tentación. Detrás de las formas piadosas de ésta Nietzsche ha advertido que se oculta un sentido nihilista que todavía aspira a una redención metafísica del dolor del mundo. Los ojos de Zaratustra han superado la ingenuidad del longevo mirar metafísico, atravesando la superficialidad de los avatares del mundo; sus pies, han ascendido las más altas cumbres, contemplando en su desnudez el fondo del mundo: no hay exoneración metafísica, sino alivio humano de nuestra propia existencia.

El rechazo de la compasión hunde sus raíces en las aspiraciones de excelencia que inundan la filosofía nietzscheana. El amor por la vida conlleva indefectiblemente el desprecio de una compasión que tras su máscara de inocencia e ingenuidad alberga la condena de aquélla. El escrutinio que hace Nietzsche de la compasión revela que la voluntad de poder que la rige es vitalmente destructiva, por lo cual no es valiosa en cuanto tal. Zaratustra se opone a las apreciaciones tradicionales de la compasión, y en su negación se apunta hacia una nueva forma de valoración: el elogio dichoso de la vida culmina en una estrategia que se posiciona finalmente contra la tendencia moral de la compasión, esto es, compartir el su-

\footnotetext{
${ }^{141}$ Nietzsche, F., Así habló Zaratustra, op. cit., pág. 441 (KSA IV, 408).

${ }^{142}$ Cfr. Nietzsche, F., La gaya ciencia, op. cit., pág. 803 (KSA III, 482): «Explicaciones místicas. Las explicaciones místicas son consideradas profundas; la verdad es que no son ni siquiera superficiales».
} 
frimiento - propio y ajeno- como mecanismo frente al dolor esencial del mundo ${ }^{143}$. Allí donde la moral propugnó la participación unitaria en el pesar universal, Nietzsche exige el respeto hacia la singularidad y riqueza del hombre concreto, para lo cual se posiciona en las antípodas de una compasión como pasión deshumanizadora: «¿Qué es para ti lo más humano? - Ahorrar a alguien la vergüenza» ${ }^{144}$.

\section{II.3.1. La compasión como despliegue de fuerzas reactivas de la voluntad de} poder

La compasión, como cualquier otro instinto o pasión, es un despliegue de fuerzas emanado de la voluntad de poder. En su peculiar concreción de la moral occidental, dichas motivaciones entrañan un empeño de perversa dominación que somete tanto al compasivo como al que la demanda. La compasión del horizonte filosófico metafísico, dice Nietzsche, nace del resentimiento, de la envidia y de la venganza del rebaño, el cual, al no permitir la diferencia ni la emancipación, convierte al hombre superior en un ser arrepentido de su propia victoria. La compasión no es sino la victoria del resentimiento de los débiles sobre el hombre superior, quien abdica de su dichosa vida para ajustarse a los esquemas de pequeñez de la plebe y hacer propia su miseria. La compasión, termina sentenciando Nietzsche, es menos un sentimiento de piedad que el resentimiento y la envidia de los enfermos.

La compasión como juego reactivo de fuerzas comprende un doble sentido a lo largo del cual el apiadador y el apiadado se sumergen en una misma identidad nihilista en la cual tras la pretendida benevolencia se esconde un sentimiento de perversa sumisión donde o bien los débiles consiguen auparse sobre los poderosos al llevarlos a la vergonzante condición de culpa por su situación pletórica o bien los pequeños se sienten grandes al participar de un común sentimiento de dolor. Este macabro despliegue de la compasión durante la historia moral de Europa ha procurado un enfermizo placer en los siglos de regencia de la metafísica idealista sobre el cuerpo: como catarsis; como santificación de la inferioridad; y como «narcótico».

La primera manifestación placentera de la compasión nihilista apunta hacia una catarsis ante el dolor mediante la descarga pulsional que facilita el arte. Contra la apreciación schopenhaueriana del arte como vehículo filosófico para escapar definitivamente del dolor existencial de la voluntad, Nietzsche renuncia a la vulgarización romántica del arte como mero vehículo de derroche pasional. Esta caracterización, ejemplarizada en Wagner,

143 Una dinámica de valoración moral que desde el cristianismo se ha perpetuado en distintas formas, tanto filosóficas como religiosas, hasta el momento nietzscheano, con Schopenhauer como último gran momento de tal discurso.

${ }^{144}$ Ibid. pág. 828 (KSA III, 519). 
es «decadente», ya que su fin es la condonación de la deuda que supone en sí misma la existencia a través de un piadoso sentimiento de conmiseración que da forma a un sujeto sui generis que identifica a la humanidad entera en su miseria vital ${ }^{145}$. Así sucede con Senta ${ }^{146}$, quien sacrifica su ser para exonerar al terrible monstruo del Holandés, que hasta entonces no era objeto de piedad. El amor incondicional de Senta se alimenta de una compasión piadosa universal en cuyo seno incluye también a la criatura; y por tal pasión la protagonista se sacrifica en un ejercicio de «pena» que priva de su ser al monstruo y lo salva de sí mismo liberándolo de su existencia irredenta, al tiempo que el público sucumbe, partícipe, de la catarsis emotiva de dicha escena. Wagner pone en el escenario la filosofía de Schopenhauer, quien a su vez intelectualiza el cristianismo privándolo de Dios pero manteniendo sus contenidos piadosos:

¿Qué suelen si no adoptar de su maestro los seguidores de Schopenhauer en Alemania? [...] sus confusiones y escapatorias místicas, en aquellos puntos en los que el pensador de los hechos se deja seducir y corromper por el vanidoso impulso de convertirse en descifrador del mundo: la indemostrable doctrina de una voluntad única [...], la negación del individuo [...], el sinsentido de la compasión y del quebrantamiento del principii individuationis que ella posibilita como fuente de toda moralidad [...]: estas y otras similares extravagancias y vicios del filósofo son siempre adoptadas en primer lugar y convertidas en artículos de fe [...]. Pero hablemos del más famoso de los schopenhauerianos vivos, de Richard Wagner [...], la fascinación en la que cayó con este pensador no sólo lo volvió ciego respecto de todos los otros filósofos, sino incluso respecto de la ciencia misma; cada vez más todo su arte quiere presentarse como un paralelo y un complemento de la filosofía de Schopenhauer y renuncia de modo cada vez más explícito a la ambición mayor de volverse un paralelo y un complemento del conocimiento humano y la ciencia. [...] Schopenhaueriano es el intento de Wagner de comprender el cristianismo como una semilla del budismo traída por el viento y de preparar para Europa una época budista, acercándose de vez en cuando a fórmulas católico-cristianas ${ }^{147}$.

Con todo, la tragedia romántica, Wagner par excellence, es la puesta en escena del cristianismo.

Nietzsche se opone virulentamente a esta capacidad catárquica de la tragedia, de cuño aristotélico, al insistir en que el dolor no ha de ser purgado, sino transmutado en fuerza de vida. La contemplación de la tragedia desde las categorías schopenhauerianas y wagnerianas -acaso las mismas-, esto es, como acto catártico por medio de la compasión,

145 Cfr. Nietzsche, F., Fragmentos póstumos IV, 2 [60], op. cit., pág. 92 (KSA XII, 88): «¿Qué? ¿El drama es el fin, la música sólo el medio? Puede que ésa fuese la teoría de $\mathrm{W}<$ agner $>$ : su práctica, por el contrario, era: la pose (dramática) es el fin, la música sólo un medio para una pose (para aclararla, reforzarla, interiorizarla - )».

146 Ibid. 16 [48], pág. 684 (KSA XIII, 502): «En cuanto a la mujer histérico-heroica que Richard Wagner ha inventado $<\mathrm{y}>$ puesto en música, una criatura andrógina de muy ambiguo gusto».

${ }^{147}$ Nietzsche, F., La gaya ciencia, op. cit., pp. 787-788 (KSA III, 453-456). 
hunde sus raíces en una visión metafísico-moral del mundo que al término lo ha ya condenado. El pensamiento pesimista, no importa su forma -Schopenhauer, cristianismo- es en su raíz nihilista, preciso motivo por el cual arrastra hacia una filosofía de la compasión:

que la historia de la tot $<$ alidad $>$ de los $\mathrm{f}<$ enómenos $>$ de la moralidad se deje simplificar tanto como lo creía Schopenhauer - es decir, de modo tal que se podría encontrar la compasión como raíz de toda tendencia moral habida hasta el momento - a ese grado de absurdidad e ingenuidad sólo podía llegar un pensador que estaba desprovisto de todo instinto histórico y que se había escapado de la manera más sorprendente incluso de esa fuerte educación en la historia que han hecho los alemanes de Herder a Hegel ${ }^{148}$.

El autor de El nacimiento de la tragedia, trazando una distancia insalvable con su primera obra, ofrece una forma alternativa para enfrentar la aflicción tomándola como elemento constitutivo de la vida, una vida que no necesita perdón ajeno a sí misma: «¿Qué es — se pregunta Nietzsche- lo que vuelve heroico? Ir al mismo tiempo al encuentro del propio sufrimiento supremo y de la propia esperanza suprema» ${ }^{149}$.

Una segunda muestra del morboso y cruel éxtasis de la compasión ha de hallarse en la perversión que hace del valor de la jerarquía. El sujeto receptor de compasión es pauperizado en una jerarquía perversa que descansa al abrigo de la buena conciencia: el piadoso hace valer una impostada superioridad que induce en el apiadado una imagen de inferioridad que lo mueve a avergonzarse de su propia existencia, que torna lastimosa, indigente, menesterosa anhelando ser otro:

Benevolencia. - [...] en la benevolencia hay que distinguir: el impulso de apropiación y el impulso de sometimiento, según sea el más fuerte o el más débil el que siente benevolencia. La alegría y el deseo van juntos en el más fuerte que quiere transformar algo en función suya: la alegría y el querer ser deseado, en el más débil, que quisiera convertirse en función. - La compasión es esencialmente lo primero, una agradable excitación del sentimiento de apropiación ante la vista del más débil: en lo que hay que tener en cuanta además que «fuerte» y «débil» son conceptos relativos ${ }^{150}$.

Esta gradación de los seres en virtud de su relación con la piedad se antoja inhumana toda vez ambos polos enajenan su propia cualidad de existencia, pues los dos tienen necesidad de la aflicción: el apiadador la persigue para poder sentirse más; el apiadado, para contar con un ejemplo de vida superior al que apuntar. Y así uno y otro conforman una unidad que gravita alrededor de una corrupta concepción de «felicidad» que pasa por la participa-

\footnotetext{
148 Nietzsche, F., Fragmentos póstumos IV, 2 [188], op. cit., pág. 134 (KSA XII, 160).

${ }^{149}$ Nietzsche, F., La gaya ciencia, op. cit., pág. 827 (KSA III, 519).

${ }^{150}$ Ibid. pág. 799 (KSA III, 476).
} 
ción en el dolor esencial del mundo. En un meritorio momento de Humano, demasiado humano Nietzsche, evocando la figura de La Rochefoucauld, señala el mecanismo de poder que subyace a la compasión:

Querer inspirar compasión - [...] Quizá pueda prevenirse todavía más categóricamente contra esta muestra de compasión si esa necesidad de los desdichados no se concibe precisamente como estupidez y deficiencia intelectual, como una especie de perturbación espiritual que la desgracia conlleva (y así parece concebirla La Rochefoucauld), sino que se la entiende como algo enteramente distinto y que da más que pensar. Obsérvese más bien a los niños que lloran y gritan para que se les compadezca y que por eso esperan el momento más propicio; vívase en trato con enfermos y espiritualmente deprimidos, y pregúntese si su elocuente lamentación y gimoteo, la exhibición de la desgracia, no persiguen en el fondo la meta de causar dolor a los presentes; la compasión que éstos entonces manifiestan es un consuelo para los débiles y sufrientes en la medida en que con ello reconocen tener todavía, sin embargo, pese a toda su debilidad, al menos un poder, el poder de causar dolor. Extrae el desdichado una especie de placer de este sentimiento de superioridad de que le hace consciente el testimonio de la compasión; su vanidad se exalta: todavía sigue siendo lo suficientemente importante para infligirle dolor al mundo. Es por tanto la sed de compasión una sed de goce de sí mismo, y ciertamente a costa del prójimo; muestra al hombre en toda la brutalidad de su querido yo más propio $^{151}$.

La compasión emana de los lugares más oscuros de la interioridad del hombre, de su envidia y rencor hacia la vida. Por eso confesará Zaratustra haberse «avergonzado de haber visto sufrir al que sufre, a causa de la vergüenza de él; y cuando le ayudé, ofendí duramente su orgullo» ${ }^{152}$, ya que al cierre del Libro Tercero de La gaya ciencia, responderá que la libertad pasa por no avergonzarse más ante sí mismo ${ }^{153}$.

Finalmente Nietzsche se detiene en la estrategia europea que tomó la compasión como un «narcótico» frente a la visión insoportable del mal del mundo. La compasión es un acto propio de naturalezas «epileptoides» que sufren de una sensibilidad neurótica que les impide comprender que tanto la amargura como la alegría son gotas derramadas del mismo cáliz que es la vida. Así se entregan ciegamente en la pasión comunal de la conmiseración donde todos son uno y uno es todos para compartir la lesiva carga de la vida:

Los remedios que los hombres emplean contra los dolores no son muchas veces más que narcóticos. Pero todos esos remedios responden a un nivel bajo del arte médico. En las religiones y las artes, que en tal medida entran a formar parte de la historia del arte médico, se encuentran ideas que hacen las veces de narcóticos. Particularmente las religiones saben hacer perder de vista mediante hipótesis la causa

${ }^{151}$ Nietzsche, F., Humano, demasiado humano I, op. cit., pp. 72-73 (KSA II, 70-71).

152 Nietzsche, F., Así habló Zaratustra, op. cit., pág. 140 (KSA IV, 114).

${ }^{153}$ Cfr. Nietzsche, F., La gaya ciencia, op. cit., pág. 828 (KSA III, 519): «¿Cuál es el sello de la libertad conseguida? — No avergonzarse más ante sí mismo». 
del sufrimiento, diciéndoles por ejemplo a los padres a los que se les ha muerto un hijo que éste no ha muerto y añadiendo, a la vista del cadáver, que su hijo sigue viviendo aun más hermoso ${ }^{154}$.

Luego la compasión sostiene una ecuación impura donde el compasivo es arrastrado por el compadecido a su misma situación penumbrosa; los débiles hacen gala de su último cúmulo de fuerzas las cuales, manando del resentimiento hacia la vida y el deseo de venganza, inoculan vergüenza y culpa en los fuertes por su propia bonanza y plenitud. También interviene en el proceso de conmiseración la voluntad de poder, mas lastrada por el influjo de los enfermos que han renunciado a toda forma de vida elevada: exhiben su amargura con ánimo de contagiarla, su hastío vital contagia los estratos nobles de la existencia corrompiendo mediante su propio dolor el mundo.

\section{II.3.2. La compasión como instrumento de nivelación}

La compasión se ha presentado como una estrategia que avergüenza al poderoso y lo lleva a cohibir su propia plenitud, cercena sus canales de fuerza y los constriñe entre la masa, es decir, nivela. Su ejercicio desprecia la vida particular encarnada en cada sujeto, pues iguala las diferentes manifestaciones vitales ignorando sus distancias cualitativas: el compadecido es rebajado a un tipo existencial inferior, necesitado del auxilio vital del otro al saberse incapaz de soportar el amargo fondo del mundo; quien se compadece, por su parte, se siente impelido por su contraparte y participa de su respectivo dolor al tiempo que se responsabiliza de su penuria y culpa por su propia plenitud: se siente llamado a acompañar a sus semejantes en la universal aflicción mundanal. La compasión, pues, iguala; la vileza de sus mecanismos antropológicos «envilece», invierte los significados de «pobreza» $\mathrm{y}$ «riqueza» y convierte la menesterosidad en virtud y la abundancia en lamento y desestimación.

El intercambio de fuerzas que se despliega en este proceso anula la concreción de la vida que se resuelve en la persona particular. En el momento en que la experiencia vital radical del sujeto -en el espectro de la compasión, el dolor- se abstrae en un imaginario colectivo el hombre se desvanece en la humanidad. La privación efectiva del dolor a través de la piedad que comparte las amarguras hace soportable las inclemencias de un mundo moralmente malo, mas cobra el oneroso precio de agotar la intimidad de la existencia humana. Hay un componente privado en el sufrimiento que al ser comunicado enajena la subjetividad en el todo unitario y genérico que conforma el «rebaño» como conciencia única y sui generis de la realidad.

El principio moral de la compasión sitúa todos los dolores en un punto equidistante al hombre, por lo que éstos tornan superficiales. La existencia del hombre afligido devie-

${ }^{154}$ Nietzsche, F., Fragmentos póstumos II, 18 [33], op. cit., pág. 263 (KSA VIII, 322). 
ne en consecuencia superficial y es despojada de su singularidad. La nivelación en la que insiste la filosofía de la compasión anula las jerarquías: no aprecia los rasgos «buenos»y «malos» del carácter; tampoco concede ocasión de distinción entre unos y otros, postulando la irrevocable conclusión de lo que es el tipo humano piadoso último:

La voluntad de sufrir y los compasivos. - [...] Aquello por lo que sufrimos de manera más profunda y personal es incomprensible e inaccesible a casi todos los demás: en esto estamos ocultos al más próximo, aunque coma de nuestro plano. Pero dondequiera que se perciba que sufrimos, nuestro sufrimiento es interpretado de modo superficial; forma parte de la esencia de la afección compasiva despojar al sufrimiento ajeno de lo propiamente personal: — nuestros «benefactores», más que nuestros enemigos, son los que empequeñecen nuestro valor y nuestra voluntad. En la mayor parte de las acciones benéficas que se dispensan a personas desdichadas hay algo indignante en la ligereza con la que el compasivo trata de dirigir el destino: ¡no sabe nada de todas las secuencias y entrelazamientos internos que significan la desdicha para mí o para $t i$ ! Toda la economía de mi alma y el equilibrio que consigue con la «desdicha», la apertura de nuevas fuentes y necesidades, la cicatrización de viejas heridas, el rechazo de pasados enteros - todo eso, que puede estar ligado con la desdicha, no le preocupa al buen compasivo: él quiere ayudar y no piensa en que hay una necesidad personal de la desdicha, que el terror, las privaciones, los empobrecimientos, las medianoches, las aventuras, las osadías, los desaciertos son para ti y para mí tan necesarios como sus opuestos, que incluso, para expresarme de modo místico, el camino que conduce al propio cielo pasa siempre por la voluptuosidad del propio infierno. No, de esto no sabe nada: «la jreligión del compasivo (o «el corazón») ordena ayuda, y cree haber ayudado mejor cuando más rápido ha ayudado! Si vosotros, adeptos de esta religión, tenéis realmente con vosotros mismos la misma disposición que con vuestros semejantes, si no queréis que vuestro propio sufrimiento esté ni una hora con vosotros y prevenís siempre desde lejos toda posible desdicha, si sentís vuestro sufrimiento y vuestro displacer en general como algo malo, odioso, digno de ser aniquilado, como una tacha de la existencia, entonces, además de vuestra religión de la compasión, tenéis en el corazón otra religión, y ésta quizá la madre de aquella: — la religión de la comodidad. ¡Ay vosotros, cómodos y bonachones, qué poco sabéis de la felicidad de los hombres! - iporque la felicidad y la desdicha son dos hermanos y gemelos, que crecen juntos o, como en vuestro caso, se quedan pequeños juntos! ${ }^{155}$.

La nivelación compasiva ha arrebatado al hombre su misma cualidad de humanidad, dado que uno y otro, apiadador y apiadado, acaban por avergonzarse de su propia existencia por culpabilizarse a causa de su bonanza y por lamentar patéticamente su menesterosidad, respectivamente.

Motivos éstos que mueven a Zaratustra a avergonzarse de sí mismo: Zaratustra todavía arrastra en su seno el bacilo de la compasión y como tal lamenta el deplorable estado en que se encuentra la humanidad, arrojado a un yermo de amargura y terror. No es hasta la Cuarta -y última- parte del Zaratustra cuando el protagonista cobra conciencia, tras topar-

${ }^{155}$ Nietzsche, F., La gaya ciencia, op. cit., pp. 854-855 (KSA III, 566-567). 
se con el asesino de Dios, del fondo del enigma de la compasión, cómo ésta desdibuja los rasgos del hombre y hace insoportable su propio reflejo, que deviene indigno e innoble ${ }^{156}$.

El asesino de Dios es el más feo de los hombres, en cuyo semblante ha logrado vislumbrar Zaratustra el sufrimiento y la miseria. Sin embargo, tras caer al suelo por su descubrimiento, se alza de nuevo y con él una nueva «compasión». No es ya la piadosa compasión de los compasivos que arrojan su vergonzante limosna ${ }^{157}$; Zaratustra enseña que «la compasión es importuna», ya que humilla y somete al apiadado a lo largo del acto de venganza del piadoso. No hay generosidad y abundancia, sino rencor y venganza en la caridad moral.

Al término de su encuentro con el más feo de los hombres Zaratustra ha dado un paso más hacia la «transvaloración». Ha transmutado el concepto de compasión mediante un nuevo orden de vergüenza: al contemplar su reflejo no se avergüenza ya de sí mismo, de su propia existencia, sino del avergonzado. La nueva imagen de la vergüenza que ofrece Nietzsche en este capítulo, una donde lo vergonzoso es aquel sujeto que siente vergüenza por su propia concreción vital, es, en último término, su esfuerzo por devolver a los hombres la dignidad de su vida. El pródigo regalo de Zaratustra trata de acomodar de nuevo al individuo en su corporalidad; en su desprecio e impiedad hay más calidez, amor y respeto que el contenido en la «discreción» de una ayuda propia de una diestra desconocida por su izquierda ${ }^{158}$ :

Cualquier otro -le dice el más feo de los hombres- me habría arrojado su limosna, su compasión, con miradas y palabras. Mas para esto - no soy yo bastante mendigo, eso tú lo has adivinado -

- para esto soy yo demasiado rico, jrico en cosas grandes, terribles, en las cosas más feas, más inexpresables! ¡Tu vergüenza, oh Zaratustra, me ha honrado!

A duras penas logré escapar de la muchedumbre de los compasivos, - para encontrar al único que hoy enseña "la compasión es importuna" - ¡a ti, oh Zaratustra!

- ya sea compasión de un Dios, ya sea compasión de los hombres: la compasión va contra el pudor. Y no querer-ayudar puede ser más noble que aquella virtud que se apresura solícita.

[...] Tú pusiste en guardia contra la compasión - no a todos, no a nadie, sino a ti y a los de tu especie.

Tú te avergüenzas de la vergüenza del que sufre mucho; y en verdad, cuando dices "de la compasión procede una gran nube, ¡atención, hombres!"159.

\footnotetext{
${ }^{156}$ Cfr. Nietzsche, F., Así habló Zaratustra, op. cit., pág. 360 (KSA IV, 328): «La compasión lo acometió; y se desplomó de golpe».

${ }^{157}$ Cfr. ibid. pág. 35: «No, respondió Zaratustra, yo no doy limosnas» (KSA IV, 13).

${ }^{158}$ Cfr. Mt 6:3: «Mas tú, cuando das limosna, haz que tu mano izquierda no perciba lo que hace tu
} derecha».

${ }^{159}$ Nietzsche, F., Asi habló Zaratustra, op. cit., pp. 362-363 (KSA IV, 329-330). 
II.3.3. El cristianismo como religión de la compasión y la filosofía del pesimismo

La salvación del dolor que ofrece la conmiseración se consuma desde la unidad fundamental del ser. La necesaria aflicción metafísica que implica la radicación de la vida humana en el mundo halla su porqué en la compasión nacida del Ser unitario y trascendente, «Dios». El cristianismo es el hito definitivo y más perfecto de la filosofía de la compasión, la cual ha tornado en este momento religión. En el cristianismo el acto más abominable es el que garantiza la redención ${ }^{160}$. Con su último hálito Dios hecho hombre se integra en el suplicio que arrastra la humanidad y garantiza su postrera expiación. La figura del Dios-Hijo, núcleo de toda piedad, se entrega al dolor del mundo, por él perece con el consuelo de asumir Él toda su amargura radical y liberar a la humanidad de tan pesada carga. En el corazón de su piedad Dios despoja a sus hijos mortales de su dignidad al considerarlos incapaces de soportar por sí mismos el pesar de su vida concreta; los iguala en su miseria y los condena a vagar errantes por un valle de lágrimas hasta el momento de la consecución de la definitiva bienaventuranza ${ }^{161}$. La perversión antropológica del cristianismo hace de la muerte carnal la purga de los males que agitan el espíritu humano; se trata de la pauperización de la intelectualidad socrática, pues el griego aún aspiraba a la búsqueda de la verdad con su muerte, mientras que el cristiano actúa movido únicamente por el hastío de su extenuante vagabundeo por la superficie de la tierra.

La disposición moral cristiana, sin embargo, no se acaba en el momento en que Longino clava su lanza en el costado de Cristo. La salvación es una recompensa tardía accesible únicamente para quienes participan de la conmiseración divina ${ }^{162}$. De este modo la moral de rebaño que traslucen los Evangelios mantiene el dominio del espíritu bajo la aterradora premisa del pecado y el Infierno:

Sin odio. - ¿Quieres decir adiós a una pasión? Hazlo, pero ¡sin odiarla! Si no, lo que tendrás será otra pasión. - El alma de los cristianos que se han liberado del pecado suele quedar arruinada por el odio al pecado. ¡Mira el rostro de los cristianos más importantes! ¡Son rostros de gente que odia mucho! ${ }^{163}$.

El sufrimiento injustificable del cual no puede desligarse la experiencia de vida es enajenado en la redención concedida por una divinidad compasivamente sacrificada con el ánimo de someter la pluralidad del mundo en una salvífica unidad inmanente. La Encarnación, el misterio genuinamente cristiano, se ha apropiado bajo la figura del Hijo -Dios en-

\footnotetext{
${ }^{160}$ Cfr. Lc 23:34: «Padre mío, perdónales porque no saben lo que hacen».

${ }^{161}$ Cfr. Lc 23:43: «Y Jesús le dijo: En verdad te digo que hoy estarás conmigo en el paraíso».

${ }^{162}$ Cfr. Mt 5:7: «Bienaventurados los misericordiosos, porque ellos alcanzarán la misericordia».

163 Nietzsche, F., Aurora, op. cit., pág. 645 (KSA III, 254-255).
} 
carnado- de la culpa y del mal moral de la realidad; Cristo ofrece su vida en pago de una amargura que no debería existir a tenor de la benevolente Creación divina: la Encarnación es la factura que ha de pagar Dios por el néctar derramado de la manzana mordida. Es tan horrenda la concreción misericordiosa de la culpa cristiana, necesariamente inseparable de la amargura de la esencia del mundo, que sólo puede alcanzarse la redención mediante el sacrificio último del Hijo ${ }^{164}$ : Dios muere en la cruz por nuestros pecados.

No es entonces extraño que Nietzsche haya contemplado la muerte de Dios dentro de los esquemas de su crítica de la compasión. En la Gaya ciencia se narra la peculiar forma en que la divinidad sucumbe: Dios es asesinado. El «más feo de los hombres» ha acabado con Él. Tal crimen, execrable a ojos de la chusma, ha sido perpetrado en aras de la liberación del propio hombre. Y para acometerlo, se valió de su fealdad, bajo cuya horripilante silueta se percibe el insoportable mal radical del mundo, insoportable incluso para el mismo Dios creador. Tan colosal dolor sólo podría ser redimido por el acto último de piedad: «'Dios ha muerto; a causa de su compasión por los hombres ha muerto Dios’» ${ }^{165}$. Dios muere para exonerarnos de la aflicción de su propia obra que es la vida; mas en su sacrificio se encuentra también la fuente de dominación de los débiles: la venganza y el rencor hacia la vida que se concretan en la noción de «pecado». Dios deviene víctima de su amor y lo impone como medida de salvación universal. Y así se lo pregunta Zaratustra al último papa, para corroborar las noticias que le llegaron a propósito de tal deceso:

Yo soy Zaratustra el ateo, que dice: ¿quién es más ateo que yo, para gozarme con sus enseñanzas? -

Así habló Zaratustra, y con sus miradas perforaba los pensamientos y las más recónditas intenciones del viejo papa. Por fin éste comenzó a decir:

«Quien lo amó y lo poseyó más que ningún otro, ése lo ha perdido también más que ningún otro -:

- mira, ¿no soy yo ahora, de nosotros dos, el más ateo? ¡Mas quién podría alegrarse de eso!»-

- «Tú le has servido hasta el final, preguntó Zaratustra pensativo, después de un profundo silencio, ¿sabes cómo murió? ¿Es verdad, como se dice, que fue la compasión la que lo estranguló,

- que vio cómo el hombre pendía de la cruz, y no soportó que el amor al hombre se convirtiese en su infierno y finalmente en su muerte?» ${ }^{166}$.

El miedo al dolor y la salvación por medio de la conmiseración es sublimada en el cristianismo en la forma de una religión del amor ${ }^{167}$, estrategia en la cual se extrema la ac-

${ }^{164}$ Cfr. $M r$ 15:34: «Dios mío, Dios mío, ¿por qué me has desamparado?».

165 Nietzsche, F., Así habló Zaratustra, op. cit., pág. 142 (KSA IV, 115).

166 Ibid. pág. 355 (KSA IV, 323).

167 Cfr. Nietzsche, F., El Anticristo, op. cit., pág. 66 (KSA VI, 201): «El miedo al dolor, incluso a lo infinitamente pequeño en el dolor - no puede acabar de otro modo que en una religión del amor...». 
titud nihilista de la compasión. En el momento de la fe de Cristo ha triunfado el agotamiento y el hastío hacia la vida; la nada es enarbolada como la reactiva bandera de un tiempo privado de toda clase de valor, pues la nivelación ha impregnado finalmente la totalidad de cuanto hay. El cristianismo como doctrina religiosa de la compasión descansa sobre el sufrimiento y el bondadoso sacrificio de Dios como acto de redención universal. Una vez muerto, esta religión se intelectualiza y convierte en términos modernos en la filosofía del pesimismo, un cristianismo sin Cristo que, sin embargo, comparte sus rasgos íntimos y esenciales: la contemplación, la conmiseración y la renuncia al mundo como estrategias de salvaguarda ante el dolor ${ }^{168}$.

La última tentación de Zaratustra, el signo del cual advierte el viejo mago, la «compasión», toca aquí su profundidad: no es tan sólo la mera piedad que sufre por los demás, sino la filosofía pesimista que arrastra consigo el nihilismo reactivo de la claudicación de la vida ${ }^{169}$ :

Lo que hay que temer, lo que produce efectos más fatales que ninguna otra fatalidad, no sería el gran miedo, sino la gran náusea frente al hombre; y también la gran compasión por el hombre. Suponiendo que un día ambas se maridasen, entraría inmediatamente en el mundo, de modo inevitable, algo del todo siniestro, la «última voluntad» del hombre, su voluntad de la nada, el nihilismo ${ }^{170}$.

No entraña en sí misma la náusea por el hombre un peligro, al contrario, es bien recibida, pues denota el hastío hacia aquello que el hombre moderno es; la imagen fisiológica de la «náusea» ha de tomarse como fuerza motriz hacia la consumación de aquello que el hombre puede llegar a ser, la superación de su imagen pretérita, decadente y reactiva, débil y enferma. Es, no obstante, la imbricación de la compasión en la náusea -en el desprecio respecto de las concreciones efectivas del hombre presente- donde se encuentran las puertas del nihilismo. La aflicción por cuanto hay puede ser el motor hacia la superación de tamaña quejumbrosa realidad únicamente en aquellos espíritus más vigorosos, capaces de transmutar la experiencia del dolor en saludable fuerza creativa; por otro lado, en aquellos individuos débiles, despojadas hace tiempo sus voluntades de poder de toda tendencia activa, puede inducir la tentación de un impulso supresor de dicho mal y, con ello, de un esforzado

\footnotetext{
${ }^{168}$ Cfr. Nietzsche, F., Crepúsculo de los ídolos, op. cit., pág. 55 (KSA VI, 78): «temo que no vamos a desembarazarnos de Dios porque continuamos creyendo en la gramática».

${ }^{169}$ Cfr. Schopenhauer, A., El mundo como voluntad y representación I, trad. introd. y notas de Pilar López de Santa María, Madrid, Trotta, 2004, pp. 435-436: «Como punto final de mi exposición mostraré cómo el amor, cuyo origen y esencia sabemos que consiste en traspasar el principium individuationis, conduce a la salvación, en concreto a la renuncia total de la voluntad de vivir, es decir, de todo querer [...]; pero antes de seguir adelante y proceder a ello tengo que expresar y explicar aquí un principio paradójico, no por ser tal sino porque es verdadero y completa el pensamiento que aquí he presentado. Es este: 'Todo amor es compasión'».
}

${ }^{170}$ Nietzsche, F., La genealogía de la moral, op. cit., pp. 178-179 (KSA V, 368). 
empeño por negar a la existencia su valor al sumirla en un decurso donde los fallos y errores, de antemano trazados, son la dinámica genuina.

Schopenhauer es el gran adalid de esta posición existencial. Hace del objeto de la filosofía la conceptualización ${ }^{171}$ de «lo que todos los hombres, por el hecho de ser hombres, ya conocen previamente» ${ }^{172}$, a saber, que la vida carece de valor alguno y está sometida al brutal yugo del sufrimiento. Una sospecha, una intuición oscura que se hace nítida en el ejercicio filosófico y torna precisamente en esta claridad ocasión de salvación y liberación del tormento del mundo:

[...] Entonces vemos que el hombre, tras haber sido llevado al borde de la desesperación pasando por todos los grados crecientes del tormento en medio de la más violenta adversidad, de repente vuelve sobre sí, se conoce a sí mismo y el mundo, cambia todo su ser, se eleva sobre sí y sobre todo sufrimiento; y, como purificado y santificado por él, en una tranquilidad, felicidad y sublimidad inquebrantables, renuncia voluntariamente a todo lo que antes quería con la mayor violencia, recibiendo la muerte con alegría. Es el destello de la negación de la voluntad de vivir, es decir, de la salvación, nacido de la llama purificadora del sufrimiento ${ }^{173}$.

Esta verdad del mundo es, entiende Schopenhauer, la esencia del cristianismo, que postula una «ética de renuncia» del mundo y de la vida ${ }^{174}$; esta verdad religiosa es a su vez la verdad filosófica del budismo y el hinduismo ${ }^{175}$. Esta doctrina es lo que intelectualiza Schopenhauer en su filosofía de la voluntad, y en su ética de la compasión universal en particular, reflexión filosófica ésta de la renuncia y la resignación:

Pero si ese traspasar el principium individuationis, ese conocimiento inmediato de la identidad de la voluntad en todos sus fenómenos, se da en un alto grado de claridad, mostrará enseguida una influencia de mucho mayor alcance sobre la voluntad. En efecto, si ante los ojos de un hombre aquel velo de Maya, el principium individuationis, se ha levantado tanto que ese hombre no hace ya una diferencia egoísta entre su persona y la ajena sino que participa del sufrimiento de los demás individuos tanto como del suyo propio, y así no solamente es compasivo en grado sumo sino que incluso está dispuesto a sacrificar su propia individualidad tan pron-

${ }^{171}$ Cfr. Schopenhauer, A., El mundo como voluntad y representación I, op. cit., pág. 445: «Reproducir de forma abstracta, general y clara toda la esencia del mundo, y depositarla como imagen reflejada en conceptos de la razón permanentes y siempre dispuestos: eso y no otra cosa es la filosofía». no abstracto».

172 Cfr. ibid. pág. 445: «[...] el conocimiento del que nace la negación de la voluntad es intuitivo y

${ }^{173}$ Ibid. pp. 454-455.

${ }^{174}$ Cfr. ibid. pág. 448: «[...] el cristianismo, cuya ética se ubica plenamente en el espíritu indicado y no solamente conduce al más alto grado de la caridad, sino también a la renuncia».

175 Cfr. ibid. pág. 449: «Pero aquello que hemos denominado negación de la voluntad de vivir lo encontramos aún más desarrollado, expresado con mayor variedad y presentado con mayor viveza de lo que pudiera estar en la Iglesia cristiana y en el mundo occidental, en los escritos antiguos de la literatura sánscrita». 
to como hay que salvar con ello a varios individuos ajenos, de ahí se deduce por sí mismo que es hombre, que se reconoce en todos los seres a sí mismo, su más íntimo y verdadero yo, también considera como suyos infinitos sufrimientos de todo lo viviente y se apropia así del dolor del mundo entero. Ningún sufrimiento le resulta ya ajeno. Todos los tormentos ajenos [...], todas las penas de las que él tiene noticia [...], actúan sobre su espíritu igual que las suyas propias. Lo que él tiene a la vista no es ya el cambiante placer y dolor de su persona tal y como ocurre en el hombre aún sumido en el egoísmo, sino que todo le resulta igualmente cercano porque ha traspasado el principium individuationis. Él conoce el todo, comprende su ser y lo encuentra condenado a un constante perecer, una vana aspiración, un conflicto interno y un sufrimiento permanente [...], aquel conocimiento que se ha descrito de la totalidad, del ser de las cosas en sí, se convierte en aquietador de todo querer. Ahora la voluntad se aparta de la vida y siente escalofríos ante sus placeres, en los que reconoce su afirmación. El hombre llega al estado de la renuncia voluntaria, de la resignación, de la verdadera serenidad y la plena ausencia de querer ${ }^{176}$.

Hinduismo, budismo, cristianismo, filosofía pesimista son tradiciones todas ellas coincidentes en su raíz nihilista, observa Nietzsche; distintas escuelas que, sin embargo, son sólo manifestaciones distintas del nihilismo pasivo que rechaza la vida y renuncia a la creación de la propia existencia:

La locura de un orden moral mundial. - No existe necesidad eterna alguna que exija que se expíe y pague toda culpa, — el pensar que exista ha sido una tremenda locura, con una utilidad mínima - : del mismo modo que es una locura el creer que sea culpa todo lo que se percibe como tal. Lo que ha trastornado tanto a los hombres no son las cosas, sino ¡lo que piensan de cosas que no existen! ${ }^{177}$.

El cristianismo irguió su doctrina sobre dos grandes dogmas: el «pecado original», que asume consigo cual castigo nociones tales como caída, culpa, muerte, trabajo o dolor, entre otras; la doctrina de la «redención», en segundo lugar, la cual dentro de la filosofía pesimista de Schopenhauer halla su homólogo en la negación de la voluntad de vivir:

[...] la negación de la voluntad de vivir, que es aquello que se denomina resignación total o santidad, nace siempre del aquietador de la voluntad que supone el conocimiento de su contradicción interna y de su nihilidad esencial, tal y como se expresa en el sufrimiento de todo ser viviente. La diferencia que nosotros hemos presentado [...] radica en si es el sufrimiento meramente conocido el que suscita aquel conocimiento mediante la libre apropiación del mismo al traspasar el principium individuationis, o bien es el sufrimiento inmediatamente sentido el que lo causa. La verdadera salvación, la liberación de la vida y el sufrimiento, no son penables sin una negación total de la voluntad. Hasta entonces cada cual no es más que esa voluntad misma cuyo fenómeno es una existencia evanescente, una aspiración siempre vana y siempre fracasada, y ese mundo lleno de sufrimientos aquí presentado, al que todos pertenecen irremediablemente del mismo modo. Pues antes descubrimos que a la voluntad de vivir la vida le es siempre cierta y su única

176 Ibid. pp. 440-441.

${ }^{177}$ Nietzsche, F., Aurora, op. cit., pág. 692 (KSA III, 328). 
forma real es el presente, del que ninguno de aquellos fenómenos escapa por mucho que en ellos imperen el nacimiento y la muerte ${ }^{178}$.

La negación de la voluntad de vivir se encuentra ejemplarmente plasmada, entiende el pensador de la voluntad, en la persona de Cristo. Nietzsche continúa esta línea abierta por el viejo maestro y en su escrutinio fisiológico de la figura de Jesús lo revela como el hombre más compasivo: ha anulado toda la distancia entre los tipos humanos por medio de una íntima unión entre todos ellos. En Él la nivelación es absoluta, es el nihilista más puro. El cristianismo «fue la incredulidad con respecto a los 'hombres superiores'» ${ }^{179}$, y Cristo, la antítesis fisiológica de la «genialidad» y de la «heroicidad»:

Lo que a mí me interesa es el tipo psicológico del redentor [...]: la incapacidad de oponer resistencia se convierte aquí en una moral («no resistas al mal», la frase más honda de los evangelios, su clave, en cierto sentido), la bienaventuranza en la paz, en el no-poder-ser-enemigo. ¿Qué significa la «buena nueva»? La vida verdadera, la vida eterna está encontrada - no se la promete, está ahí, está dentro de vosotros: como vida en el amor, en el amor sin sustracción ni exclusión, sin distancia. Todo hombre es hijo de Dios - Jesús no reclama nada para sí solo - en cuanto hijo de Dios todo hombre es idéntico al otro... ¡Hacer de Jesús un héroe! - ¡Y qué malentendido es sobre todo la palabra «genio»! [...] Dicho con el rigor del fisiólogo, aquí estaría en su lugar más bien, una palabra completamente distinta: la palabra idiota. [...] odio instintivo a toda realidad, como huida a lo «inaprensible», a lo «inconcebible», como aversión a toda fórmula, a todo concepto de tiempo y de espacio, a todo lo que es sólido [...], como un habitar en un mundo no tocado por ninguna especie de realidad, en un mundo meramente «interior», en un mundo «verdadero», en un mundo «eterno»... «El reino de Dios está dentro de vosotros $\rangle^{180}$.

El concepto de Dios del cristianismo, a su vez núcleo secularizado de la filosofía pesimista, se ha nutrido del odio hacia la realidad; es la divinidad más corrupta de cuantas han existido, es el nihilismo más claro y desbocado: «un dios del amor podría decir un día, aburrido por su virtud: 'probemos una vez con lo diabólico' — ¡y he ahí un nuevo origen del mal! ¡Por aburrimiento y virtud! $\rightarrow \gg 181$.

Allí donde Schopenhauer veía motivos de admiración en Jesús, Nietzsche, por el contrario, sólo puede despreciarlo y temer el peligro que entraña, pues es la «última tentación»: la compasión universal por un mundo colmado de dolor y desprovisto de inocencia que debe purgar la culpa de su propia existencia mancillada. Un mundo tal por el que úni-

\footnotetext{
${ }^{178}$ Schopenhauer, A., El mundo como voluntad y representación I, op. cit., pp. 459-460.

${ }^{179}$ Nietzsche, F., El Anticristo, op. cit., pág. 63 (KSA VI, 198).

${ }^{180}$ Ibid. pp. 64-65 (KSA VI, 199-200).

${ }^{181}$ Nietzsche, F., Fragmentos póstumos IV, 2 [18], op. cit., pág. 83 (KSA XII, 75).
} 
camente podemos aspirar a su negación misma en beneficio de la promesa de un reino cuyo dominio está fuera de este mundo ${ }^{182}$ :

Con la interpretación moral, el mundo es insoportable. El cristianismo fue el intento de superar con ella el mundo: es decir, de negarlo. In praxi, este atentado demencial - de una demencial presunción del hombre frente al mundo - condujo $<\mathrm{al}>$ ensombrecimiento, empequeñecimiento, empobrecimiento del hombre: sólo el tipo más mediocre e inofensivo, el tipo gregario de hombre encontró allí su satisfacción, su estímulo, si se quiere ${ }^{183}$.

En esta tentación sucumbe Schopenhauer, señalando que el mejor ejercicio de claridad filosófica pasaría por descorrer el velo de Maya y contemplar tras él el esencial e inevitable dolor del mundo. Su contemplación nos llevaría a identificarnos en las agonías ajenas haciendo propio el tormento del mundo. Consecuentemente, renunciaríamos a la vida y a la perpetuación de la misma, pues ella y su continuidad no es sino la continuidad del tormento de la realidad. Tras el velo de Maya se esconde la Unidad radical de la realidad: $m a-$ ligna para Schopenhauer, la Voluntad ciega y hambrienta; bondadosa para el cristianismo que, no obstante, es aplastada por el yugo del dolor y asfixiada por su propia lástima compasiva. Nietzsche reacciona virulentamente contra esta doble conclusión piadosa, proponiendo la afirmación de la fuerza de la existencia, pese al dolor que pudiera -y que de hecho así sucede- llegar a salpicarla. No existe tal velo de Maya y, en consecuencia, tampoco la Unidad. El cristianismo, como paradigma de religión piadosa, y Schopenhauer, como máximo representante de la filosofía pesimista, han buscado respuestas en un Absoluto que no existe, cayendo entonces en el nihilismo y en la «ética de la renuncia» en la cual confluyen todas las almas gracias al juego estratégico de la compasión en su renuncia universal de la vida:

Porque todo sufrimiento, al ser una mortificación y una llamada a la resignación, es potencialmente una fuerza salvadora, se explica que una gran desgracia y un profundo dolor inspiren ya en sí mismos un cierto respeto. Pero el que sufre sólo nos parece totalmente respetable cuando, contemplando el curso de su vida como una cadena de sufrimientos o lamentándose de un dolor grande e incurable, en realidad no mira hacia la concatenación de circunstancias que arrojaron su vida a la tristeza ni se queda parado en aquella gran desgracia individual que le afectó [...]. Antes bien, él no es realmente respetable hasta que su mirada se haya elevado desde lo individual a lo universal, hasta que considere su propio sufrimiento como un simple ejemplo del todo $y$, haciéndose genial en sentido ético, para él un caso valga por mil y entonces la totalidad de la vida, concebida en esencia como sufrimiento, le conduzca a la resignación. [...].

Un carácter sumamente noble nos lo imaginamos siempre con un cierto toque de callada tristeza, que para nada es el continuo malhumor por las contrariedades cotidianas $[\ldots]$ sino la conciencia de la nihilidad de todos los bienes y el sufrimien-

182 Cfr. Jn 18:36: «Respondió Jesús: Mi reino no es de este mundo».

${ }^{183}$ Nietzsche, F., Fragmentos póstumos IV, 2 [114], op. cit., pág. 111 (KSA XII, 119). 
to de toda vida, no solo de la propia; una conciencia esta que ha nacido del conocimiento ${ }^{184}$.

Nietzsche apura las consecuencias nihilistas de estas tradiciones para aceptar la no existencia de la mítica Unidad metafísica; lo Uno es disuelto en la multiplicidad. A la realidad, entonces, le corresponde como elementos constitutivos precisamente la pluralidad de apariencias que se presentan ante nosotros en perspectivas susceptibles de determinación subjetiva. Luego en la filosofía nietzscheana el sufrimiento adquiere nuevos tintes, ya que pese a seguir siendo inevitable, no es ya el fruto de la corrupción de la obra de una divinidad como tampoco las heridas abiertas de una Unidad rota en pedazos, sino una condición propia de la individualidad.

Un mundo distinguido por la pluralidad no significa ser un mundo azotado por el sufrimiento. La existencia humana no es ni un error ni una agonía sin razón. La contemplación, no obstante, de la misma desde tales prismas sí supone en cambio una amenazadora fuente de peligro voraz: el nihilismo es el riesgo en que incurre el hombre que vive aspirando ingenuamente a la separación esencial del dolor y su propia experiencia vital. Pretender concluir esta imposible frontera lleva finalmente al descrédito de la vida encarnada, vista como un sustrato de amargura de la que todos participamos, y a la posterior renuncia de la misma. La compasión es el mecanismo que interviene en la identidad universal -y unitaria- del mal del mundo, la «última tentación», el «último pecado» que termina por negar el valor de la vida, pues aniquila la conciencia individual para fundirla en la imagen de un sujeto universal víctima culpable de un duelo radical de lágrimas. La compasión así contemplada, aquella que eleva a máxima moral la miseria de la vida, continúa Nietzsche, es de todo punto perniciosa, luego ha de ser apartada del imaginario humano. El último pecado del hombre debe superarse en una apuesta de afirmación creativa que haga de la vida el espacio jovial de la existencia: el superhombre.

La crítica de la compasión en Nietzsche no es el discurso de un hombre incólume ante el llanto de sus congéneres. Muy al contrario, nace precisamente del amor a la vida encarnada, propia y ajena, que necesita después de milenios de debilidad, renuncia e igualación de una «aristocratización del sentimiento». La renuncia a la piedad es la denuncia del instinto de rebaño que ha motivado durante siglos el anhelo de venganza hacia todo lo superior: ascetas, mártires, profetas, todos ellos paladines del bien son desenmascarados cuando se desnuda el contenido de la conmiseración. Hay, como se apuntaba, amor en esta crítica, pues Nietzsche contempla desde su peculiar óptica del «desprecio» ${ }^{185}$ a los piado-

${ }^{184}$ Schopenhauer, A., El mundo como voluntad y representación I, op. cit., pág. 458.

$185 \mathrm{El}$ «desprecio» que profesa Nietzsche a los hombres mana precisamente de su amor por los caracteres más elevados de éstos. Desprecia lo que son porque ama aquello que pueden llegar a ser. 
sos, comprende su dolor y decide no abandonarlos en su miseria: «mi sufrimiento y mi compasión - ¡qué importan! ¿Aspiro yo acaso a la felicidad? ¡Yo aspiro a mi obra!»186. Para ello Nietzsche nos muestra algunos ejemplo de los grandes hombres de la humanidad, como Goethe o Napoleón, no sin advertirnos del riesgo de semejantes figuras: ellos han de servir de estímulo, pues dan muestra de que la anhelada grandeza es real y efectiva; suponen también una ocasión de peligro, ya que al acercarnos a ellos, incluso en su enorme altura siguen siendo pequeños, demasiado humanos, sufrientes de una existencia dolorosa y fugaz.

\section{II.3.4. La alegría jovial del poderoso}

La compasión es un tema de gran complejidad en la filosofía de Nietzsche. A lo largo de las anteriores páginas hemos mostrado cómo bajo ella subyace una de las últimas manifestaciones del nihilismo pasivo así como su incapacidad para crear: la compasión muere en sí misma al integrarse, en virtud de su distintiva idiosincrasia, en el sufrimiento ajeno. En esta síntesis de amarguras, propias y externas, se desarrolla una corrosiva debilidad del carácter humano que convierte al hombre en el rostro del dolor del mundo. Esta actitud de máxima claridad cognoscitiva - se conoce la totalidad del sufrimiento- desvanece las fronteras entre el «yo» y el «ellos» y convierte el principio compasivo en un imperativo moral demasiado pesado, demasiado insoportable y, con ello, incompatible con la vida. Una experiencia de vida de este tipo convertiría la existencia en un continente de dolor y subyugado por la compasión; el tipo humano del hombre del sufrimiento universal: Cristo, el Dios cristiano hecho hombre que muere en la cruz ahogado por su compasión.

El sujeto compasivo comprende la vida como una condena que ha de expiarse; el primero de sus infiernos es la propia experiencia encarnada de su existencia. Este tipo psicológico necesita como condición de perpetuación el sufrimiento: tan sólo encuentra consuelo y balsámico placer al revolcarse en la compasión. Su compasión es una enfermedad de decrepitud y miseria, de pobreza e indigencia dado que la miel que liban procede únicamente del pesar y el hastío de voluntades de poder degeneradas y que sólo miran hacia abajo.

Sin embargo, al cierre del anterior epígrafe habíamos señalado que la crítica de la compasión de Nietzsche estaba motivada, precisamente, por el «amor». El acto de mayor amor hacia los hombres, entiende nuestro autor, descansa en la invitación a la recuperación de su propia existencia como un pozo de valor inestimable. El rechazo de la piedad es menos la indiferencia ante los padecimientos externos que la preocupación profunda ante los mismos. La conmiseración es una pasión débil y enferma, únicamente capaz de sumergirse en los tormentos. Como tal, ahonda en la pena; la pasión opuesta, la alegría nace en cambio

${ }^{186}$ Nietzsche, F., Así habló Zaratustra, op. cit., pág. 441 (KSA IV, 408). 
del derroche extático de una vida que desborda fuerza. Aunque la alegría no es simplemente el paroxismo de la vida; su importancia yace en su empeño por llegar más allá de sí. Mientras la compasión se agota en sí misma, la alegría es de una condición tal que sobresale de sus propios confines e inunda el mundo de plenitud. La compasión es estéril, emanando de ella sólo padecimientos; la alegría, es una virtud afirmativa y creadora: «en verdad, yo he hecho sin duda esto y aquello en favor de los que sufren: pero siempre me parecía que yo obraba mejor cuando aprendía a alegrarme mejor» ${ }^{187}$. El pasaje citado continúa inmediatamente con lo que Zaratustra estima ha sido el «pecado original» del mundo: «desde que hay hombres el hombre se ha alegrado demasiado poco: ¡tan sólo esto, hermanos míos, es nuestro pecado original!» ${ }^{188}$. Adán y Eva pecaron a causa de su soberbia ante Dios; el hombre de la tierra ha pecado por su tristeza y compasión, esto es, por ausencia de alegría.

El carácter del compasivo viene marcado por la pasividad de aquellos hombres cuya fuerza se agota en su conmiseración, careciendo de la fuerza necesaria para evitar el dolor. El tipo humano «alegre» irradia una acción salvífica que ofrece auténtico auxilio. Al contrario que Cristo, en los espíritus joviales hay «genialidad» $\mathrm{y}$ «heroicidad»: «la guerra y el valor han hecho más cosas grandes que el amor al prójimo. No vuestra compasión, sino vuestra valentía es la que ha salvado hasta ahora a quienes se hallaban en peligro» ${ }^{189}$. La alegría por la vida no nace del nihilismo -no se arma sobre el rencor y la venganza del pesimismo, pero tampoco sobre la ceguera pueril del optimismo-, sino de la «tragedia». Es la alegría trágica distintiva de aquel hombre que sabe del pesar del mundo y a pesar de ello está alegre. No es el llanto inconsolable ni la grotesca risotada necia del histrión. Es un síntoma de nobleza, pues, dice Nietzsche, le es más fácil al alma compadecerse que alegrarse del éxito del otro: «recordad también esta frase: todo gran amor está por encima incluso de toda su compasión: pues él quiere además - ¡crear lo amado!» ${ }^{190}$.

El hombre que persigue Nietzsche no se compadece, es decir, no se identifica y personifica en los dolores de sus congéneres, al igual que no se complace en la crueldad de quien se deleita atentando contra su prójimo. Es un hombre «bueno», concepto que alcanza novedosos caracteres en Zaratustra:

Muchos países ha visto Zaratustra, y muchos pueblos: así ha descubierto el bien y el mal de muchos pueblos. Ningún poder mayor ha encontrado Zaratustra en la tierra que las palabras bueno y malvado. [...]

\footnotetext{
${ }^{187}$ Ibid. pág. 140 (KSA IV, 114).

188 Ibid. (KSA IV, 114).

189 Ibid. pág. 84 (KSA IV, 59).

${ }^{190}$ Ibid. pág. 142 (KSA IV, 116).
} 
Muchas cosas que este pueblo llamó buenas son para aquel otro afrenta y vergüenza: esto es lo que yo he encontrado. Muchas cosas que eran llamadas aquí malvadas las encontré allí adornadas con honores de púrpura. [...]

Una tabla de valores está suspendida sobre cada pueblo. Mira, es la tabla de sus superaciones; mira, es la voz de su voluntad de poder ${ }^{191}$.

El hombre bueno no es el clemente superficial, ya que quizá lo sea debido a su debilidad: su falta de fuerza y por consiguiente su incapacidad creadora han teñido por bondad su miedo, su envidia y su deseo de venganza. Quien es «bueno», sigue Zaratustra, es aquel cuyas fuerzas son completamente suyas, quien siendo capaz de dañar elige no hacerlo; y en tamaña muestra de bondad encuentra su superación.

Debe superarse el impulso que hace al hombre deleitarse con la desgracia, el cual denota la vileza y mezquindad de una humanidad que como hasta ahora se ha contemplado débil e insegura de su fuerza creativa se ha arrojado a los malabares reactivos del nihilismo, renunciando con ello a la vida.

En su crítica de la compasión Nietzsche no ha renunciado al hombre, sino a los elementos inherentes a ella que han generado una ignominiosa animadversión contra la vida. La tristeza y la angustia, la debilidad, la necesidad del dolor, el rencor y el deseo de venganza, los valores reactivos en suma han nutrido durante demasiado tiempo la experiencia de existencia del hombre; es momento de reapropiarse de ella: «Mas decidme, hermanos: si a la humanidad le falta todavía la meta, ¿no falta todavía también - ella misma?» ${ }^{192}$. La alegría y la jovialidad creativas aparecen como contrapunto de la conmiseración. Se trata de un conocimiento que afirma la vida en su total plenitud, también con sus sufrimientos. Es un saber «alegre», porque rebasa las estrictas directrices del conocimiento teórico, frío y desinteresado de la razón pura. Sus maestros expresan los valores de una voluntad de poder enseñoreada y dueña de sí inserta en la dinámica de la constante superación.

La «gaya ciencia» es el saber de Dioniso. En él se recogen las fórmulas para hacer alquimia de los valores y transmutar en fuerza afirmadora el miedo y el dolor. Este saber es el propio del «superhombre», del cambiapieles ${ }^{193}$, cuya alegría es síntesis de fecundidad y sagacidad al reconocer el valor ilimitado de una realidad múltiple que necesita de ilusiones que, precisamente por su cualidad ilusa, construyen la pluralidad de un mundo en devenir envuelto en el ciclo de su propia superación. Es una alegría trágica, ya que ha comprendido

${ }^{191}$ Ibid. pág. 99 (KSA IV, 74).

192 Ibid. pág. 101 (KSA IV, 76).

193 Cfr. Nietzsche, F., Aurora, op. cit., pág. 694 (KSA III, 330): «Cambiar de piel. — La serpiente que no logra cambiar de piel perece. Lo mismo le pasa al espíritu al que se le impide cambiar de opiniones; deja de ser espíritu». 
la existencia en su totalidad y como tal la acepta tomando la vida, pese al dolor y el horror de los que no puede zafarse, como aquello más meritorio y valedor del último esfuerzo existencial.

\section{II.3.4.1. «iAtrévete a ser alegre!»}

Nietzsche describe tres modos de alegría: la propia del optimista, ingenua y superficial; la alegría seria de quien ha conquistado el abismo de la existencia; y la alegría inocente del superhombre, quien transita por nuevos caminos. Nietzsche aspira al último tipo, aunque no es menos cierto que reconoce el valor de las restantes sobre la tristeza existencial del pesimista, preñada de desprecio y aspiraciones de rencorosa venganza contra la vida y los que viven. En la alegría seria, además, se concreta una portentosa ocasión para el despliegue antropológico del hombre presente y la reconquista de su presencia largo tiempo enajenada.

La alegría del conquistador es una alta cumbre, pues en ella el hombre moderno, tras siglos de vida extramundana, recupera la fuerza del instante. Cambia profundamente la valoración del tiempo, el cual transcurre y a la vez se detiene como momento de plenitud. La frialdad emanada de los precisos mecanismos del reloj, que miden y cifran cada momento de la vida humana, es atravesada por el calor de una pulsión kairológica que procura la oportunidad de integrar al hombre en el mundo que puebla. Esta novedosa apreciación del discurrir del tiempo emancipa de la tiranía del cálculo al viviente y lo libera de la férrea cadena de la sucesión ciega de los acontecimientos. Y esta reapropiación del tiempo vivido llega únicamente después de la conquista de la alegría, tras la transvaloración de los canales ciegos y fecundos de la existencia en fondo afirmativo de creación. La alegría es el goce por vivir, y la vida acontece en el presente ${ }^{194}$.

Una vida alegre es únicamente posible desde una voluntad de poder cuyas fuerzas se afirman en el presente, único horizonte temporal desde el cual la vida es explotada en plenitud: el pasado es un nostálgico lamento de lo ocurrido y el futuro, la aspiración por algo que aún no es, y que quizá nunca sea. Una apropiación alegre del instante, sin embargo,

194 La cuestión del presente es harto compleja en Nietzsche. Es necesario arrojar ahora algunas apreciaciones, todavía demasiado vagas, no obstante suficientes. «La alegría es el goce por vivir, y la vida acontece en el presente», pues ni el «ya fue» ni el «todavía no» son síntomas de alegría. El que se aferra nostálgicamente al pasado disfruta de una alegría fantasmagórica, una que ya fue; por otro lado, quien hace descansar sus esperanzas en el porvenir no es capaz de degustar la propicia ocasión del fecundo hoy, pues su alegría todavía no ha de llegar.

Sin embargo, estas consideraciones han de ser escrupulosamente matizadas si no queremos poner en riesgo la condición hermenéutica del pensamiento nietzscheano. Esta tradición, y Gadamer da cuenta de ello mejor que nadie, funde los horizontes de pasado, presente y futuro en una compleja perspectiva donde la sucesión cronológica de los acontecimientos deviene polifacético sustrato kairológico: en la filosofía de Nietzsche la apreciación kairológica del tiempo es un hito crucial toda vez que en virtud de ella tiene lugar una reordenación de los éxtasis temporales para pasar a entender la prioridad del futuro como generador del pasado que vive el presente. . 
contempla el pasado como fuente de conocimiento para la vida y mira al futuro como canal de infinita apertura.

La alegría por la vida es un elemento de la peculiar concepción estético-ética de Nietzsche. Una conquista asentada sobre la solidez del conocimiento jovial que la afirma como una alternativa de vida mejor respecto de las modalidades melancólicas que existieron hasta entonces. A diferencia de la exhortación kantiana del sapere aude que enfatizaba el valor del pensamiento lógico, Nietzsche promueve una oda a la alegría que no es sino la reivindicación de la corporalidad como suelo radical de la existencia. Si bien no hay condición de posibilidad de la alegría al margen de la vida, el sentido de la flecha en esta relación es doble: la alegría no es independiente de la vida, la cual, a su vez, toma la fuerza para su perfecto despliegue del poder corporal de la alegría. Este maridaje imprime sobre el hombre la tarea de vivir de un modo alegre, posición situada en las antípodas de la indiferencia del atemperado hombre moderno, cuya indolencia ante su propia existencia lo hace ajeno de tal experiencia.

De manera que la loa a la alegría nietzscheana comporta el deber de explotación de la fuerza de la voluntad de poder, que la volición y la fuerza se integren en la promesa efectiva de una vida radicada en la corporalidad. Un deber, no obstante, que no ha de ser identificado con la formalización kantiana de la razón pura; brota del propio ser artístico del sintético hombre hermeneuta, unidad de destino de la dureza, la voluntad y el ascetismo: hacer y querer se funden mediante la voluntad de poder en la empresa de «llegar a ser lo que se es»».

El conocimiento jovial de la superación de sí mismo que nutre al artista creador es uno de sus rasgos inherentes, quizá el más distintivo, y lo reconcilia con la obra dichosa que es la empresa de su vida encarnada. La alegría conquistada entraña la plenitud del compromiso de la superación para una mejor y más bella disposición de vida. La superación adquiere un fin y la alegría un contenido: la superación sin alegría conduce al ascetismo reactivo de los despreciadores del cuerpo; la alegría sin superación, es el reflejo de la mentalidad de rebaño que se conforma con la vacuidad de la conservación. La seriedad carece de la genialidad de la inocencia, pero constituye la primera piedra de la laboriosa expectativa de «llegar a ser lo que es».

La alegría es parte del gusto sublime que se niega los bocados nihilistas de la nivelación y la resignación. La tristeza y la decadencia que acompañan al resentimiento y al miedo son superadas mediante el entusiasmo jovial del carácter que identifica como su deber el principio volitivo de realización de ser en plenitud. Deber y querer son una y la misma cosa para el individuo nietzscheano que ha aceptado como propio el imperativo estético-moral de cultivo y embellecimiento de la existencia implícito en la voluntad de 
poder. La fuerza de la alegría marca una segunda diferencia crítica con Kant en la frontera de apropiación de la vida encarnada: el deber de la razón pura kantiana, en tanto que carente de contenido, se presume externo al propio sujeto, mientras que la apreciación nietzscheana lo colma de significado en la medida en que se orienta hacia la superación de sí mismo. Además, al hacerlo radicar en lo más profundo del hombre, que es la voluntad de poder, el deber y el querer convergen en el proyecto jovial de la realización vital. Allí donde en Kant se persigue el sentimiento de sentirse digno de la felicidad, en la filosofía de Nietzsche la felicidad como tal se despliega encarnada en la vida concreta.

Luego la tarea de superación nietzscheana no es la imagen de un hombre ajeno, al contrario que el inhumano imperativo categórico kantiano. El imperativo de alegría es una vindicación de la corporalidad que emprende el laborioso y duro compromiso ascético de una vida libre y responsable. La alegría sólo puede ser tenida en cuenta dentro de la empresa de la superación, ya que son elementos complementarios: el esfuerzo de la superación falto de alegría es el rasgo distintivo del ascetismo que ha despreciado la vida; la alegría sin el compromiso de la superación es el eco de la vida del rebaño que, refocilándose en la comodidad de una vida mediocre y sin exigencias, ha dado la espalda a las demandas de dureza de la voluntad de poder. Y precisamente por este desapego respecto del rebaño la alegría no es un fin escatológicamente trazado: no hay una guía de acción encaminada hacia la jovialidad. A causa de la simbiosis de la estética y la ética el ser de la vida alegre acentúa el «modo» para llegar a «ser lo que se es» en detrimento de una hipotética definición.

El modo de vida de la alegría, que no puede estar definido conceptualmente si la superación aspira a dejar atrás el nihilismo reactivo, sí puede, sin embargo, concretarse en caracteres formales: todo aquello que sea fuente de pasión por existir. Por lo tanto, aunque en términos de contraposición, el modus vivendi propugnado por Nietzsche es aquel que rechaza los canales tradicionales de tristeza y odio, de agotamiento y hastío. Se trata de un entusiasmo jovial por el hombre encarnado que sufre y disfruta, que llora y ríe, que padece y goza mirando siempre hacia un futuro mejor que se vive, sin embargo, en la plenitud del presente dichoso.

En uno de sus más famosos poemas diagnosticaba cómo «el desierto crece» ${ }^{195}$. Esta vida desértica es la que corresponde al espíritu del «camello», incapaz de experimentar la alegría de la existencia. Despreciador de la buenaventura de la superación carga consigo mismo como si del más doloroso y oneroso peso se tratase. La alegría explota la fuerza transmutadora de la voluntad de poder; es un gran hito del proyecto vital del hombre

195 Nietzsche, F., Poesía completa, ed. y trad. de Laureano Pérez Latorre, Madrid, Trotta, 2011, pág. 61 (KSA VI, 382). 
que busca dejar atrás el nihilismo y que se inicia con el rugido del león que rechaza las viejas tablas de valoración.

\section{II.3.4.1.1. El egoísmo solitario de la alegría}

La alegría tiene un componente eminentemente egoísta que obliga al hombre a caminar en soledad. Sin embargo, esto no debe inducirnos al error de tomar a Nietzsche como el teórico de una vida ermitaña y austera incapaz de entablar compromisos tangibles con el otro. La alegría es la manifestación más prístina del vigor de la voluntad de poder. Es exceso y sobreabundancia de fuerzas, ya que impele al sujeto mismo a adueñarse del fecundo sustrato de su vida. En este aspecto es egoísta y solitaria; es una vocación intransferible que brota y muere en el cuerpo encarnado. Se puede comprender entonces que una voluntad de poder que busca procurar la alegría sobre los congéneres es burda y soez, reactiva y débil. Es la alegría de la pequeñez de quien ofrece un consuelo, un analgésico, un narcótico: «"no, respondió Zaratustra, yo no doy limosnas. No soy bastante pobre para eso'» ${ }^{196}$. La alegría es un llamado a la soledad antropológica, a la conciencia de que la labor artística es íntima y privada. La alegría de Zaratustra aspira a la grandeza de quien pretende hacerse mejor como mandato estético y moral. Es el motivo por el cual se despierta en el hombre el deseo de superación, el anhelo de «llegar a ser lo que se es».

196 Nietzsche, F., Así habló Zaratustra, op. cit., pág. 35 (KSA IV, 13). 
PARTE II: LA CRÍTICA DE LA MODERNIDAD DESDE NIETZSCHE 
La cuestionabilidad de una disposición sistemática de la filosofía se hizo especialmente patente en la segunda mitad del siglo XIX, destinando su mirada crítica al fundamento, validez y vigencia de estas construcciones omniabarcadoras que habían colonizado el horizonte del pensamiento moderno. La caída de estos colosales proyectos estaba necesariamente ligada al fin de las pretensiones epocales; las nuevas generaciones de intelectuales, hijos del dolor de la escisión filosófica, no pudieron más que renunciar a las ambiciosas ínfulas que condujeron el nuevo paradigma.

En definitiva, consistía en un momento caracterizado por un sentir de desconfianza respecto de la certeza metafísica que había motivado las novedosas incursiones filosóficas. Se trataba del tiempo dedicado a sacar a la luz aquellos mecanismos que subrepticiamente habían operado sobre la conciencia de Occidente con el fin de mostrar, no sin esfuerzo, la esterilidad que subyacía esencialmente a una filosofía abonada durante siglos: el «nihilismo».

La alusión de la crisis finisecular desde Nietzsche significa la explicitación radical del advenimiento del nihilismo en Occidente. Ahora bien, las claves conceptuales de dicha denuncia no son las propias de un pensador reactivo y antimoderno que mediante la corrosión de su presente pretende la recuperación de un pasado anhelado. Al contrario, el prisma nietzscheano es el característico de quien decidió discurrir la totalidad del itinerario de la filosofía moderna, sin detenerse temerosamente ante sus sinuosos meandros, ocasionalmente tan incómodos como crueles. De tal suerte que su cáustico análisis no busca tanto la conclusión del discurso inaugurado por Descartes como su completa realización, esto es, la subordinación del mismo a sus propias máximas escépticas. El escrutinio que hiciera Nietzsche de la razón, celoso e incondicional, consiste menos en el esforzado empeño por socavar los sueños de la luz que en el encomio por alumbrar allí cuanto aún estuviera preso del oscurantismo que denunciase la razón moderna. Ahora bien, unas tinieblas que no podrían ser negadas arreglo al desbocado «progreso», ya éste entendido como desarrollo científico-técnico ya tomado cual proceso de moralización en la historia.

Con la irrupción de la filosofía de Nietzsche se abre una grieta que lo distingue de la tradición intelectual precedente. Sin embargo, tal veta no constituye una fractura en realidad dramática si se lo comprende más como la crítica y juiciosa voz de la modernidad que como un pirómano sin más anhelos que los de deponer los sueños del nuevo paradigma. Su denuncia de la razón nunca debe ser caracterizada como un despiadado ataque contra ésta. Consiste más bien en la actitud de rebeldía frente a aquellos juicios dogmáticos que acabaron por convertirla en una institución ajena a los cuestionamientos que ella misma exigía como criterio regulador. Fue precisamente haberla investido de un carácter sacrosanto lo que incapacitó la disposición crítica de los sujetos modernos, insiste Nietzsche, arrojándolos a una realidad que había mecanizado la existencia. 
La preocupación fundamental de la filosofía nietzscheana -al igual que la de la filosofía moderna- queda ceñida en el dominio de la libertad. Es la suya, sin embargo, una aproximación a ésta abismalmente alejada de la de sus contemporáneos modernos. A lo largo de las décadas que habían armado los siglos de la fecunda modernidad, el problema de la libertad había sido tratado, entiende Nietzsche, desde categorías y concreciones inadecuadas. En último término, la libertad fue contemplada dentro de las lindes de la filosofía política, también las tentativas más espirituales, como la kantiana ${ }^{197}$. Esta reducción de la libertad a meras tentativas políticas revela el fetichismo moderno del concepto, un abrumador empeño por definir y acotar precisamente todos los aspectos del mundo que, sin embargo, se probó incapaz de llegar a los estamentos más profundos y oscuros de la realidad más íntima de la existencia humana.

El radical fondo de la existencia humana, que a Nietzsche se le ha presentado inaccesible en su plenitud, es un acontecimiento demasiado determinante como para ignorarlo. El esfuerzo moderno por caracterizar positivamente la libertad presupone veladamente un escrupuloso conocimiento de todas las instancias subjetivas, rechazando la dimensión inconsciente cuya dinámica juega un rol crucial para Nietzsche. Así puede sentenciar nuestro autor que la caracterización moderna de esta noción -la libertad- está abocada desde su raíz a conclusiones nihilistas, por un doble motivo: en primer lugar, no descansa sobre la radicalidad de la experiencia de vida del sujeto en la medida en que ignora aspectos elementales de la identidad subjetiva; además, su sustrato sigue siendo la vieja metafísica de la duplicación, ahora secularizada por la filosofía cartesiana de la «cosa pensante» y la «cosa extensa». La antigua distinción del «mundo verdadero» y del «mundo aparente»

${ }^{197}$ La empresa de la crítica de la razón práctica, que buscaba responder al oscuro y problemático interrogante del «¿qué debo hacer?» se termina concretando en un proyecto de espectro político, como es la «Sociedad de naciones»: «los pueblos pueden considerarse, en cuanto Estados, como individuos que en su estado de naturaleza (es decir, independientes de leyes externas) se perjudican unos a otros por su mera coexistencia y cada uno, en aras de su seguridad, puede y debe exigir del otro que entre con él en una Constitución semejante a la Constitución civil, en la que se pueda garantizar a cada uno su derecho. Esto sería una federación de pueblos que, sin embargo, no debería ser un Estado de pueblos. Habría en ello, no obstante, una contradicción porque todo Estado implica la relación de un superior (legislador) con un inferior (el que obedece, es decir, el pueblo) y muchos pueblos en un Estado vendrían a convertirse en un solo pueblo, lo cual contradice la hipótesis (nosotros hemos de considerar aquí el derecho de los pueblos en sus relaciones mutuas en cuanto formando Estados diferentes, que no deben fundirse en uno solo)» (Kant, I., Sobre la paz perpetua, trad. de Joaquín Abellán, Madrid, Alianza Editorial, 2009, pág. 58). Los fundamentos de la celebérrima «Sociedad de naciones», si bien descansan en motivaciones morales, sólo pueden concretarse en un marco jurídico: «este homenaje que los Estados tributan al concepto de derecho (al menos de palabra) demuestra que se puede encontrar en el hombre una disposición moral más profunda, latente por el momento, a dominar el principio malo que mora en él (que no puede negar) y a esperar esto mismo de los otros, pues, de lo contrario, nunca pronunciarían la palabra derecho» (ibid. pág. 60). La tradición contractualista que hereda Kant es repensada en la filosofía del prusiano bajo la fórmula de un contrato cuyo fin es el contrato mismo. Un fondo moral que, no obstante, se despliega en ley positiva, pues «la razón, desde el trono del máximo poder legislativo moral condena la guerra como una vía jurídica y convierte, en cambio, en un deber inmediato el estado de paz, que no puede establecerse o garantizarse, ciertamente, sin un pacto entre los pueblos: tiene que existir, por tanto, una federación de tipo especial a la que se puede llamar la federación de la paz [...], asegurando de esta manera el estado de libertad de los Estados conforme a la idea del derecho de gentes» (ibid. pp. 60-61). 
seguía, no obstante, dominando el horizonte del pensamiento occidental bajo las categorías de «mente» y «cuerpo», que impusieron la dogmática doctrina de la adecuación, donde lo sensible había de estar de algún modo en idéntica correlación con la realidad del pensamiento, la nueva instancia eidética tras la secularización moderna.

La longeva escisión platónica no se había cerrado y en consecuencia toda la producción filosófica adolecía de los mismos defectos estructurales que la del antecesor griego. Una cuestión tan reservada como la libertad, sigue Nietzsche, debe contemplar la dimensión humana en profundidad, incluso aquello que no puede alcanzar a ser contemplado. Por lo tanto, pretender definirla desde la claridad y distinción de un supuesto «yo» metafísico, el cual cumple las funciones del «mundo ideal», significa olvidar una parte estructural e inevitable de la persona, su fondo inconsciente que a pesar de su impenetrabilidad, actúa y determina el ser específico de cada cual.

La estrategia por la que los autores modernos se aproximaron a la libertad perpetúa la antigua duplicación platónica, incidiendo en la fractura del alma y el cuerpo, al tiempo que continúa con su respectiva consideración peyorativa de la materia. La reflexión moderna de la libertad, sin duda fecunda, le muestra a Nietzsche un problemático trasfondo de mayor envergadura, a saber, que la existencia apunta hacia su enajenación en la medida en que sigue siendo contemplada desde la abismal frontera esencial de lo eidético respecto de lo sensible. La genuina concepción moderna de la libertad, radicalmente política, halla su sentido en el celo conceptual de estos pensadores; en su lugar, Nietzsche la contempla desde su peculiar imagen de la «corporalidad». Con ello pretende cerrar la brecha que durante tanto tiempo extrañó al hombre de su propia existencia: la libertad se despliega desde la inmensidad intangible de la vida encarnada.

En la primera parte del trabajo expusimos cómo toda la filosofía de Nietzsche es dispuesta desde el «cuerpo», entendiendo por tal algo más complejo que la simple descripción biologicista que conduce los distintos procesos fisiológicos de la vida orgánica. Las páginas pasadas han servido para presentar el problema de la existencia desde la corporalidad, una dificultad que apunta a la reintegración de todos los órdenes de la vida en la unidad experiencial del sujeto encarnado en quien ánima y sómata se funden armoniosamente como partes indisolubles e inseparables de la pulsión de existencia. Para alcanzar dicha empresa, Nietzsche ha debido poner fin a la impronta metafísica que invitaba a caracterizar la vida en términos puramente eidéticos: la supresión de la duplicación de mundos platónica, mas también su equivalente moderno del sujeto autoconsciente. De aquí se sigue la importancia fundamental que atribuye a la libertad, pensada sin embargo, desde rasgos que descansan en el fondo radical del sujeto de la corporalidad: el compromiso político de un orden social determinado es una consecuencia tardía de la evocación de la libertad, cuyo desafío primordial, sigue Nietzsche, impele al hombre concreto y particular a actuar en fa- 
vor de la vida, a «ser señor» de su propia realidad y discriminar las propuestas reactivas en beneficio de las alternativas de la mejor vida posible. La libertad, por tanto, se erige sobre el oscuro e inescrutable yermo existencial que sustenta la personalidad, contemplando de este modo el insalvable rango inconsciente que impide apresar con absoluta claridad el resultado de la construcción personal.

Esto hace de la libertad nietzscheana, como hemos destacado, un desafío. Una arriesgada apuesta de ser-en-el-mundo, dicho con Heidegger, que nos fuerza a radicarnos en un horizonte de indeterminación del cual nos apropiamos mediante la creación de valores. El individuo libre es aquel que se integra en el ejercicio creativo de la voluntad de poder sabedor de que sólo mediante su inserción en dicho juego plástico puede dar a su vida un contenido propio, en sí y para sí, en correspondencia con su fundamental rasgo hermenéutico: el compromiso de la libertad vincula al hombre con la tarea artística de su vida.

Por su profundización en la libertad, que lo ha llevado a comprender su núcleo vital, Nietzsche concluye que la libertad moderna arrastra consigo paradójicamente la esclavitud del hombre. Durante los siglos modernos la libertad se hizo radicar sobre un sustrato ciego respecto de la condición hermenéutica humana, privando al sujeto de su inserción en la tarea de dominación de la voluntad de poder. Al haberse extrañado de la dinámica artística de la existencia, la vida concreta es enajenada de la propia experiencia encarnada, abocando con ello al nihilismo que colonizó el horizonte epocal nietzscheano. El elogio de la libertad en Nietzsche, consistente en la recuperación de la vida encarnada del sujeto, es, con todo, una etapa más de su empeño por superar el devastador fenómeno del nihilismo que ha encerrado el espíritu en falsas deidades que, no obstante, se pretendieron en virtud de su inalterabilidad reales, evidentes, claras y distintas, situándose en virulenta oposición contra la mutabilidad de la apariencia deveniente.

Sin embargo, este tratamiento de la libertad se muestra difuso en la obra del autor. Apenas dedica pasajes explícitos; alusiones metafóricas, aforismos, fragmentos aislados y sentencias difíciles y crueles componen el grueso de su meditación sobre la libertad. Ésta se despliega con fina sutileza en su deconstrucción de la noción de «verdad». Se presenta la verdad como la piedra angular de toda la filosofía nietzscheana, desde la cual abre distintos meandros de crítica -metafísica, paradigma lingüístico, ideal de la teoría del conocimiento, moral- que confluyen en un prolijo estudio de la especificidad moderna y de la tradición occidental en general cuya terrible conclusión apunta a la alienación de la existencia en los mentados ídolos vacíos.

A lo largo de su estudio, Nietzsche traza una línea de continuidad entre la imagen clásica de la verdad y la moderna. Los ecos eidéticos de los griegos resuenan en el intelectualismo continental del nuevo paradigma europeo: las exigencias y pretensiones que en la Antigüedad comportaba la verdad, desde exactitud gnoseológica hasta virtuosismo moral, 
perviven en la episteme inaugurada por la Revolución científica desde las claves de «certeza» y «deber». La tarea de Nietzsche consiste en una fehaciente labor genealógica para rescatar los diferentes elementos que vinculan íntimamente el viejo modus metafísico con las pretendidas originales disposiciones modernas. La verdad como eje desde el cual comprender su crítica de la tradición occidental acabará por desvelala como la instancia de enajenación última de las conciencias, pues reproduce los fantasmas e ídolos de la escisión platónica del alma respecto del cuerpo en favor de la primera.

La crítica de Nietzsche de la razón moderna apunta al método científico, a una metodología que acabaría por devorar a la modernidad como tal. No obstante, cuando alude a la metodología moderna no se refiere tan sólo a una organización programática desde la que operar en aras del avance cognoscitivo, sino a la configuración de las conciencias europeas resultante de tal estructura; es decir, la crítica de la metodología cientificista se extiende al mundo que ésta ha construido. Nietzsche vincula íntimamente a través de su crítica la actitud cientificista epocal -la cual preconizaba encarecidamente el método científico- y la situación psicológica de los europeos de entonces, subordinados a unas expectativas de moralización trazadas desde la dimensión de estos oscurantismos de progreso, como en el paradigmático caso kantiano que, a la postre, termina por enajenar en instancias externas la propia vida del sujeto encarnado.

La relación fundamental que traza Nietzsche entre los paradigmas antiguo y moderno se concreta en la vieja fórmula socrática del intelectualismo moral, cuyo legado permite a Nietzsche distinguir el sustrato elemental sobre el cual hundirá sus raíces el mundo moderno: la epistemología. Del mismo modo que Sócrates creyó que el conocimiento intelectual del Bien implicaría indefectiblemente la acción virtuosa por la ajustada adecuación del intelecto en el mundo, los hijos del cartesianismo entendieron que la escrupulosa y pulquérrima apreciación intelectual, la certeza, significaría la consecuente apropiación del mundo del sujeto; allí donde la regente Idea imprimía desde su cúspide sus formas en el dominio de la apariencia, la «mente» del subjetivismo materializa el exterior, tanto fenoménico como moral. De tal manera que la dialéctica ascendente del platonismo palpita veladamente bajo el cientificismo europeo, pues una y otro se nutren del mismo ideal de racionalidad, el distintivo del intelectualismo metafísico de la duplicación -«alma-cuerpo»y «mente-mundo»- que extiende desde el rigorismo inefable del saber cognoscitivo su aspiración de escrupulosa normatividad a los demás estamentos de la realidad.

La verdad, por tanto, acaba mostrándose como el ídolo desde el cual se ha configurado el cosmos filosófico occidental. De ella emanan los múltiples caracteres que han conformado al sujeto moderno: conocimiento, moral, libertad o vida son algunos de los avatares del ideal de verdad que en virtud de su condición eidética prescribe dogmáticamente, arrojando ulteriormente una imagen del sujeto que no se ajusta a sus elementales 
rasgos hermenéuticos. Por todo ello, continúa Nietzsche, la verdad pergeñada por la tradición filosófica de la adecuación está trazada en radical oposición respecto de la vida, en cuyo fondo de verdad la oscuridad y la claridad se salpican constantemente y la determinación artificial de la verdad se presenta como elemento insalvable de la existencia subjetiva.

Por eso el espectro crítico de Nietzsche no queda ceñido únicamente a la neta epistemología; la crítica del conocimiento abre el paso a consideraciones de carácter no científico pero insertas en la atmósfera de racionalidad cientificista, como la filosofía moral. El haber ampliado tanto el dominio de su análisis deconstructivo de la modernidad le permite a Nietzsche asegurar que esta etapa del pensamiento se procuró un enfoque erróneo de la razón, insuficiente por su parcialidad, ya que la ciencia no es su actividad constitutiva, sino uno de sus tantos modos de despliegue.

La gran puerta moderna al nihilismo pasa por su reflexión científica, mejor dicho, por la apropiación de la disposición científica por la filosofía. La reflexión filosófica moderna se radicó en el celo positivista de una imagen del mundo naturalista, contemplando todos los aspectos de la realidad desde este prisma. La problematización de las cuestiones gravitó sobre el «número» en detrimento de la persona. Así se comprende la importancia de la reflexión nietzscheana del conocimiento en cuanto tal: es la crítica de los pilares que llevaron a la racionalidad moderna al olvido de la cuestión de la existencia desde su dimensión humana fundamental. Las máximas cientificistas de la razón moderna no son sino el correlato epocal del anhelo clásico del mundo eidético: una subordinación de todas las instancias del mundo ante el inalterable resultado del cálculo y la medida; es la secularización de las pretensiones de la metafísica de la duplicación.

La verdad había abierto una brecha cismática, especialmente sensible en la modernidad, entre el sujeto y el mundo, contemplados como realidades ontológicamente diferentes: del sujeto emerge mediante la actividad intelectual de su mente el exterior. Un «exterior» que no comprende tan sólo la naturaleza, sino la materia en la que se encarna el propio individuo -res extensa-. Precisamente por esta estrategia, heredera de la duplicación, el nihilismo fue un elemento estructural de los siglos modernos, puesto que el hombre estaba desposeído de su ser-en-el-mundo. La pretensión nietzscheana de reapropiación de la existencia pasó por reintegrar al hombre en el mundo como un avatar más de éste, haciéndolo partícipe del suelo que pisaba. No obstante, esta estrategia de reinserción habría de perpetrarse desde un paradigma distinto del metafísico, una transvaloración del fondo de valor de la verdad por la cual ésta gravitase en torno al capital problema de la existencia en detrimento del conocimiento intelectual. La libertad del sujeto exige la crítica de la verdad.

La consecuencia de la emancipación de la razón de las formas y corsés de la ciencia moderna supone la liberación del pensamiento de las categorías metafísicas que lo han determinado en términos objetivos. Agotadas las posibilidades de las justificaciones esen- 
cialistas, se deberá buscar una nueva legitimación para los juicios; una tal que no apueste por una estrategia como la duplicación platónica, que acababa escindiendo al individuo del mismo mundo que habitaba. Nietzsche descubre el objetivismo metafísico de la racionalidad cientificista moderna: denunciadas las ilusiones y las falsedades sobre las que descansaba este sistema, el fenómeno del nihilismo se habrá de presentar como una consecuencia inevitable de la modernidad.

Si bien Nietzsche denuncia el corrosivo efecto del nihilismo, alertando de sus dramáticos efectos sobre las conciencias de los hombres, sabe extraer de tan peyorativa situación una enseñanza balsámica: la consumación del fin de las categorías metafísicas occidentales, esto es, la aceptación de su imposibilidad alberga las condiciones de un nuevo modo de pensamiento donde lo concreto y lo aparente, lo transitorio y lo caducifolio -el devenir- no sean por más tiempo despreciados en beneficio de la imperturbable inmutabilidad del ser, sino acogidos como los estamentos radicales de la existencia. Una existencia que en su precariedad tiene precisamente su riqueza, pues está abierta al ilimitado horizonte de posibilidades de ser-en del que habrá de apropiarse mediante el ejercicio de su voluntad de poder.

A lo largo de los siguientes epígrafes ahondaremos en el mencionado fetichismo moderno de la conceptualización y en su respectivo ideal de certeza y adecuación para mostrar tanto su problemática génesis -que la modernidad sea radicalmente una diatriba más epistemológica que existencial- como sus consecuencias -el fantasma del nihilismo-. Procederemos inversamente: primero ilustraremos la perentoria situación en que se encontraba la modernidad como la recibe Nietzsche en su momento filosófico; para proceder a continuación a tratar de explicar los porqués de dicha circunstancia mediante la exposición del detallado análisis del ideal de verdad que llevó a cabo el autor. 


\section{CAPÍTULO I: A PROPÓSITO DE UNA CRÍTICA ESPIRITUAL DE EUROPA}

\section{I.1. El nihilismo como consecuencia de la esencialidad religiosa de la razón moderna}

El imperativo de autonomía se hacía valer por las máximas dogmáticas de la razón científica y sus corolarios -la lógica que la articulaba y la epistemología de raigambre empirista-. Desde la lógica y la percepción sensorial como fuente única de datos informativos el valor de la autonomía de la razón apuntó a las ataduras místicas que durante la Edad Media y buena parte del Renacimiento habían emponzoñado las facultades del juicio con nebulosas de superstición. La Ilustración tomó los mitos como el relato de los pueblos precientíficos para dar explicación y cuenta de los fenómenos cosmológicos y naturales que escapaban de sus capacidades de comprensión. Por supuesto estas narraciones, quizá de belleza literaria pero de nulo rigor científico, no soportaban el tamiz de la disolvente racionalidad lógico-experimental. El significado de tales fórmulas, si es que lo hubiese, sólo podía materializarse por la razón, de suerte que su valor fue excluido de la gnoseología. La función de los mitos quedó resignada a la cuestión didáctica, sometidos al instrumentalismo de una razón que se sirvió de ellos como mera comparsa paisajística para facilitar las labores pedagógicas y de aprendizaje.

Los principios místicos se oponían a las mecánicas lógicas de la razón científica, que veía amenazada su capacidad y dominio ante las restricciones resultantes de las contradicciones entre ella y la mitología. Se trataba de acabar con la inercia heredada de una tradición que ponderaba por igual los productos de la imaginación y los de la epistemología metódica y racional: la Ilustración como lucha contra el prejuicio. Resulta evidente que el objeto místico por excelencia contra el que hubo de combatir la Ilustración fue el de Dios cristiano. Y es que resonancias de disposiciones como la del Aquinate, quien buscó la conciliación entre ambos orbes, aún defendían su espacio en la episteme moderna. Las respuestas fueron muchas, y las que aún trataron de mantener el pensamiento cristiano abogaron por una lectura depurada de las Escrituras que prescindiera de los elementos irracionales, esto es, de los que no fueran susceptibles de una reducción lógico-experimental. En definitiva, estas aproximaciones, verbi gratia Kant o Wolff, confiaban en que el dogma cristiano no era mitología - como sí, en cambio, las fábulas de la religión grecorromana- en virtud de su rango de revelación. Cualidad ésta que facilitaba una intelección racional.

Sin embargo, la Ilustración no tardó en aseverar que todo el mundo precedente que se trataba de abandonar se había construido sobre el cristianismo; la totalidad interpretativa del Antiguo Régimen -sentimientos, valores, organización social, etc.- se remitía al cristianismo. La razón analítica lo vio como un elemento amenazante, no tardando en descomponer la unidad hermenéutica en que consistía el paradigma cristiano. La Revolución 
Francesa no fue sólo un proceso político, tampoco únicamente religioso, sino la disolución de una doble conciencia moral y antropológica que habían convergido en una unidad de destino conformando un mundo, el mundo cristiano, con sus respectivos sistemas y códigos. La Ilustración, con su crítica de la razón teológica cristiana pretendió la constitución de una nueva unidad totalizadora emancipada, sin embargo, de los condicionantes irracionales de aquélla. El proyecto teleológico kantiano de la razón práctica que se propone la constitución de un orden universal cosmopolita responde a esta necesidad de integrar nuevamente al individuo en la unidad primigenia de la comunidad política cristiana. La razón práctica podría ser capaz de elucidar principios legitimados por sí mismos, sin apelación a coyunturas históricas determinadas. Es decir, la razón práctica habría de recomponer desde cometidos lógicos el marco epistémico que otrora proporcionó el mito ${ }^{198}$.

Las pretensiones de autonomía de la razón, que motivaron la secularización genuina de la modernidad, pusieron en cuestión la necesidad de una fe revelada. Dado que la razón, en su faceta práctica, podía llegar a inteligir valores fundamentados en sí mismos, no había ya motivo para mantener las enseñanzas morales de la religión. Sin embargo, la lectura en este punto es doble: en efecto, las lecciones religiosas se pierden en beneficio de un posicionamiento moral racional; pero, en tanto que la razón práctica se postulaba como una alternativa secularizada de la razón revelada, su condición fue puesta en duda. Como nueva manifestación de la razón mitológica, ésta y la razón práctica compartían su génesis, ambas eran resultado de la acción humana subjetivada y adscrita a condicionantes históricos y sociales. La razón práctica no pudo soportar la reflexión de su propio juicio, desvelándose en una nueva modalidad de teología ${ }^{199}$. La razón científica acabó con el sustrato de la objetiva razón metafísica donde las diferentes creencias humanas habían hundido sus raíces en una unión esencial, la ontología cristiana. De modo que la crítica ilustrada del cristianismo no apuntaba tanto a la divinidad como a la razón teológica que abonó la idea de absoluto de la

198 Así, Karl Löwith afirmará que la modernidad no es sino el proyecto de secularización de la idea cristiana de «salvación». Cfr. Löwith, K., Historia del mundo y salvación, trad. de Norberto Espinosa, Buenos Aires, Katz Editores, 2007, pág. 141: «la confianza cristiana ha desaparecido del pensamiento histórico moderno, pero sigue dominando la visión dirigida hacia el futuro como tal. Impregna todo el pensamiento europeo y toda la preocupación por nuestra historia, por su 'para-qué' y su 'hacia dónde'. Así como se ha mantenido el horizonte del futuro, ha quedado también la pregunta por el sentido en cuanto 'para qué'». Pues «queda claro [...] en las teorías históricas de la ilustración, que este concepto de una historia que se rige por el progreso hacia un objetivo no sólo es 'nuestro' por ser occidental, sino también por ser cristiano. Proviene en última instancia de la esperanza de un reino de Dios» (ibid. pág. 152). Este reino de Dios, idea de una providencia que guiaba la historia universal, se presentó en la modernidad «en oposición a la reflexión de la sentimentalidad religiosa y de la mera experiencia desprovista de conceptos, la tarea de la filosofía de la historia consiste en desarrollar el principio que impregna todas las transformaciones históricas. La filosofía, al aportar los 'ojos de la razón' y mirar el mundo de manera racional, reconoce el contenido racional de la historia universal [...]. La razón de la historia reside en que es un progreso continuo en la conciencia de la libertad, por el cual la libertad se produce a sí misma para hacer de sí un mundo [...]. La filosofía de la historia justifica la fe en la providencia que los teólogos no comprendían» (ibid. pág. 153). Termina Löwith destacando que «con la disolución de la fe moderna en el progreso racional, la secularización de la escatología cristiana ha llegado a su fin» (ibid. pág. 155).

${ }^{199}$ Cfr. Nietzsche, F., Crepúsculo de los ídolos, op. cit., pág. 56 (KSA VI, 79): «[...] ya sea del modo cristiano, ya sea al modo de Kant (en última instancia, un cristiano alevoso)». 
religión revelada. Así fue superado el concepto objetivo de razón, el cual se había postulado como elemento comprensivo de la naturaleza profunda de la realidad y dador de los principios comportamentales rectores para nuestra vida:

Los filósofos de la Ilustración atacaron a la religión en nombre de la razón; en última instancia, a lo que dieron la estocada definitiva no fue a la iglesia, sino a la metafísica y al mismo concepto objetivo de razón, la fuente de poder de sus propios esfuerzos. Finalmente la razón pasó a ser considerada, en cuanto órgano de la aprehensión de la verdadera naturaleza de las cosas y de la determinación de los principios rectores, como anticuada. La especulación es sinónimo de metafísica y la metafísica lo es de mitología y superstición. Cabría decir que la historia de la razón o de la Ilustración desde sus comienzos en Grecia hasta la actualidad ha llevado a una situación en la que hace a la propia razón sospechosa de designar algún tipo de esencia mitológica. La razón se ha autoliquidado en cuanto medio de intelección ética, moral y religiosa ${ }^{200}$.

Las conquistas de la época moderna como ejercicio crítico de la disolvente razón analítica de la razón metafísica se concretaron en una emancipación de la ciencia de los dominios de la teología y el mito; la autonomía del sujeto de conocimiento se gana en tanto que el mundo natural pierde el oscurantismo mágico con el que hasta entonces había sido explicado, convirtiéndose en consecuencia en un sistema mecánico de leyes cognoscibles y caracterizables mediante formulaciones matemáticas. Una vez quedó afirmada y garantizada la autonomía epistemológica del sistema mecanicista, la moral fue el siguiente plano que se vio afectado: la autonomía gnoseológica comportaba consigo también el compromiso de emancipación e independencia de la libertad de los móviles de acción. Es decir, el nivel epistemológico tendría su idéntico correlato en el horizonte moral ${ }^{201}$, donde la autonomía se desplegaría en términos de la libertad subjetiva de un individuo capaz de distinguir por sí mismo la legitimidad de las hazañas que pudiera emprender en aras de su bienestar concreto y privado.

La modernidad como el espacio de colonización de la libertad subjetiva fue sólo posible mediante el celo de la razón analítica, cuya crítica fue capaz de disolver el trasfondo de la razón metafísica que había logrado por medio de la religión el establecimiento de una unidad discursiva en la que quedaban engarzadas las diferentes dimensiones y momentos de la vida. A pesar de los numerosos éxitos de la racionalidad científica, al término de la modernidad no fueron pocas las voces que clamaron contra esta disolución al comprender la trascendencia de la pérdida sufrida. Hegel dedicó a este problema numerosas páginas

${ }^{200}$ Horkheimer, M., Crítica de la razón instrumental, trad. de Jacobo Muñoz, Madrid, Trotta, 2010, pág. 56.

201 Cfr. Chillón Lorenzo, J. M, El pensar y la distancia, Salamanca, Sígueme, 2016, pág. 174: «La razón infalible es sin más la razón que hace del dominio el ídolo al que todo se sacrifica, constata Horkheimer en su Crítica de la razón instrumental. Un dominio que empieza siendo del hombre hacia la naturaleza y que termina deformando la relación entre los hombres. Y todo ello derivado de una concepción de ser humano entendido como individuo y sujeto de derechos a partir de la noción de autonomía». 
de su obra, concretándolo en la Fenomenología del espíritu como la escisión entre fe y saber que daba lugar al espíritu extrañado de sí. Observa Hegel que una sociedad no religiosa carece del estrecho vínculo necesario para instituir una comunidad humana; situado en el seno de un ordenamiento secular, el individuo concreto habría quedado despojado de los lazos de fraternidad y solidaridad que conmovían la presencia de los demás en el interior de su conciencia. Esto significaba la muerte de Dios en la filosofía hegeliana:

Ésta sabe qué es lo que de verdad pasa con la vigencia real de la persona abstracta, y también con la vigencia de ella en el pensamiento puro [es decir, sabe qué es lo que de verdad hay en ello]. Ella sabe tal vigencia [o tal valer, o tal tener valor, o tal validez] de la persona abstracta más bien como la completa pérdida. Ella misma es tal pérdida consciente de sí y el extrañamiento de su saber de sí misma [o el extrañamiento de su saber respecto de ese mismo saber]. -Y vemos que esta conciencia desgraciada es el lado opuesto [la contrapartida] y el complemento de la conciencia en sí perfectamente feliz, de la conciencia cómica, es decir, de la conciencia tal como la conciencia se nos presenta en la comedia. A esta última es adonde se retrae, o retrocede, o se reduce en definitiva todo ser divino, o lo que es lo mismo: esa conciencia [la conciencia cómica] es el perfecto o completo extrañamiento de la sustancia. Y al revés, la conciencia desgraciada es, en cambio, el destino trágico de la certeza de sí misma, en su haber de ser esa certeza en y para sí. Es la conciencia de la pérdida de toda esencialidad en esta certeza de sí y de la pérdida precisamente de ese saber de sí [o de la pérdida que representa ese saber de sí], [de la pérdida] tanto de la sustancia como del self, es el dolor que se expresa en la dura frase: Dios ha muerto ${ }^{202}$.

Precisamente Hegel es tomado por Adorno y Horkheimer como el momento decisivo de la tradición que se remite a los tiempos platónicos. En la filosofía del sabio alemán se condensa ejemplarmente el esfuerzo vacuo de un legado centrado en las ideas absolutas, absolutamente vacías, carentes de correlato empírico. La denuncia del positivismo de la «teoría crítica» apunta hacia la concreción de facticidad en que ha devenido el mundo, categorizándolo objetivamente desde la subjetividad del sujeto. Así se comprende la especial relevancia que concedieron a Hegel: tras la proclamación de la realización de la razón en la historia en la filosofía del espíritu, el único ámbito posible para la filosofía sería el positivismo, el cual quedaría limitado a la afirmación y categorización del presente. Por su afirmación del dominio de los hechos la razón ha perdido su distintiva actitud crítica. «Sin consideración para consigo misma -señalaron Adorno y Horkheimer-, la Ilustración ha consumido hasta el último resto de su propia autoconciencia. Sólo el pensamiento que se hace violencia a sí mismo es lo suficientemente duro para quebrar los mitos» ${ }^{203}$. La filosofía hegeliana resume paradigmáticamente la actitud progresista de la razón moderna a instancias de la escatología del espíritu. Sin embargo, al tratarse de un progreso guiado desde

202 Hegel, G. W. F., Fenomenología del espíritu, trad. de Manuel Jiménez Redondo, Valencia, PreTextos, 2015, pág. 849 .

${ }^{203}$ Horkheimer, M. y Adorno, T., Dialéctica de la Ilustración, trad. de Juan José Sánchez, Madrid, Trotta, 2009, pág. 60. 
caracteres dominados por los hechos, en su decurso la «libertad» es enajenada, al caracterizarla positivamente, objetivamente como libertad negativa. De tal forma que la pretensión de autonomía de la racionalidad moderna acabaría concluyendo, desafortunadamente, en la inhumanidad de un pensamiento que procuró únicamente autenticidad a lo factual. Dicho en términos frankfurtianos, la «razón subjetiva» fagocitó el suelo nutricio de la «razón objetiva», distinguida por su esencia moral.

La Ilustración, apuntan, nació «enferma» ${ }^{204}$. Las premisas de la lucha contra el prejuicio y la emancipación de las conciencias surgieron «bajo el signo de una triunfal calamidad [...] el desencantamiento del mundo» ${ }^{205}$, vehículo para someter la naturaleza, ahora nada más que «pura materia» ${ }^{206}$. El programa de máximas que hizo de la ciencia objeto de devoción emprendió una tarea desmitificadora. Sin embargo, con finísima agudeza los frankfurtianos creyeron ver que el ímpetu dominador de la razón científica se remontaba precisamente a su génesis mítica: «los mitos que caen víctimas de la Ilustración eran ya producto de ésta» ${ }^{207}$. Y es que «el mito quería narrar, nombrar, contar el origen: y con ello, por tanto, representar, fijar, explicar» ${ }^{208}$. A pesar de sus fastuosas conquistas, la Ilustración sacrificó la razón objetiva, privando al mundo de un elemental suelo moral.

Siguiendo entonces la tesis de la Dialéctica, el proceso de racionalización durante la Ilustración no fue tanto una desmitificación como la legitimación de determinados mitos en detrimento de otros, censurados, y más aún, la consagración de la esencia dominadora de éstos: «el mito se disuelve en Ilustración y la naturaleza en mera objetividad» ${ }^{209}$.

${ }^{204}$ Cfr. Horkheimer, M, Crítica de la razón instrumental, op. cit., pág. 179: «de hablarse de una enfermedad que afecta a la razón, ésta no debería ser entendida en el sentido de haber afectado a la razón en un momento histórico determinado, sino como inseparable de la esencia de la razón en la civilización, tal como la hemos conocido hasta la fecha. La enfermedad de la razón tiene sus raíces en su origen, el afán del hombre de dominar la naturaleza».

Ahora bien, sobre una hipotética enfermedad prenatal de la Ilustración ya encontramos en Nietzsche cuantiosas afirmaciones: «[...], toda ética sin una comprensión negativa del concepto de felicidad, toda metafísica y física que conoce un finale, un estadio último de algún tipo, todo anhelo preponderantemente estético o religioso hacia un aparte, un más allá, un fuera de, un por encima de, permite preguntar si no ha sido la enfermedad lo que ha inspirado al filósofo. El disfraz inconsciente de necesidades fisiológicas bajo el manto de lo objetivo, lo ideal, lo puramente espiritual va terriblemente lejos, $-\mathrm{y}$ con mucha frecuencia me he preguntado si, tomada en general, la filosofía no ha sido hasta ahora sólo una interpretación del cuerpo, un malentendido del cuerpo. [...]. Sigo estando a la espera de que un médico filosófico en el sentido excepcional de la palabra -alguien que tiene que perseguir el problema de la salud global de un pueblo, de una época, de una raza, de la humanidad - tenga alguna vez el coraje de llevar a su culminación mi sospecha y osar esta frase: en todo filosofar no ha sido hasta ahora de ningún modo cuestión de la 'verdad' sino de otra cosa, digamos de salud, futuro, crecimiento, poder, vida...» (Nietzsche, F., La gaya ciencia, op. cit., pág. 719 [KSA III, 348-349]).

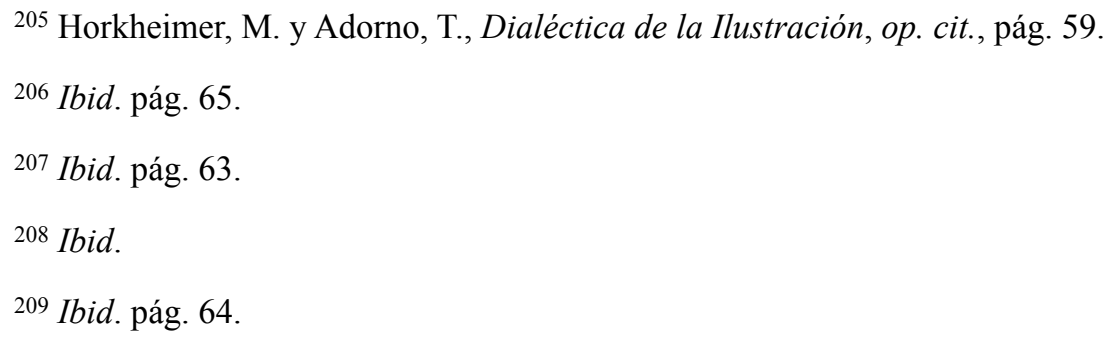


El mito ilustrado de la autonomía, contemplado, sin embargo, desde una episteme positivista, no hizo sino pauperizar la razón, acabando ésta en un movimiento reactivo que la manchó con el sello de la irracionalidad: al perder su inmanencia crítica, la razón se traiciona a sí misma y cae en su oposición, a saber, la aceptación y legitimación de un presente de hecho que ha enajenado en la brutalidad de los hechos la conciencia moral.

En los tiempos del mundo del espíritu extrañado de sí mismo las antiguas afinidades habían dejado paso a una condición de orfandad. Con la madurez de la Ilustración llega la comprensión de los efectos disruptivos de la razón analítica. La etapa de racionalización de los siglos XVII-XVIII había reducido la integridad del sujeto a una estructura de dominio epistémico; paradójicamente el sueño de la liberación se construyó sobre el potencial de soberanía. Una contradicción que se terminaría resolviendo en una ulterior alineación en la cual la soez reducción de la razón a una eficiente maquinaria de sometimiento conlleva el olvido del hombre, cosificándolo 210 :

${ }^{210}$ En esta situación, Horkheimer destaca, no obstante, la importancia de Hegel, de cuya filosofía resalta el vasto esfuerzo por superar la cosificación en su proyecto objetivista. Cfr. Horkheimer, M, Crítica de la razón instrumental, op. cit., pág. 177: «la relación entre el concepto subjetivo y el objetivo de razón, ha de ser tratado a la luz de las anteriores reflexiones sobre espíritu y naturaleza, sobre sujeto y objeto. Lo que en la primera parte fue caracterizado como razón subjetiva es esa actitud de la consciencia que por temor a caer en la irresponsabilidad y en la arbitrariedad y a convertirse en un mero juego mental, opta, contrariamente, por adaptarse sin reservas a la alienación de sujeto y objeto, al proceso social de cosificación. Los sistemas actuales de la razón objetiva representan, por otra parte, intentos de evitar la entrega de la existencia al azar y a una contingencia ciega. Pero los abogados de la razón objetiva corren el peligro de quedar a la zaga de las evoluciones industriales y científicas, de afirmar un sentido que se revela como ilusorio, de elaborar ideologías reaccionarias. Al igual que la razón subjetiva tiende al materialismo vulgar, la razón objetiva desarrolla una inclinación al romanticismo, y el intento filosófico más grande de construir una razón objetiva, el de Hegel, debe su potencia incomparable a su lucidez crítica en lo que afecta a este peligro».

Recogen, sin embargo, con mayor rigor y justicia el colosal esfuerzo del filósofo idealista las páginas que le dedica en el capítulo monográfico «Hegel y el problema de la metafísica» en Historia, metafísica y escepticismo (cfr. Horkheimer, M., Historia, metafísica y escepticismo, trad. de María del Rosario Zurro, Madrid, Alianza Editorial, 1982, pp. 121-136). En un esclarecedor pasaje, el pensador de la Escuela de Frankfurt destaca lo siguiente a propósito de la tentativa hegeliana por superar la cosificación propia de las improntas naturalista y positivista del legado cientificista moderno-ilustrado: «Las categorías deducidas del principio de identidad constituyen el criterio según el cual se opera la distinción entre realidad verdadera y mera existencia 'casual'. Estas categorías definen la Razón, que en última instancia subyace a la realidad y a la cual remite Hegel ante la comprobación del sinsentido de lo parcial y del sufrimiento de las criaturas; y esas mismas categorías hacen posible que Hegel se refiera a tales comprobaciones tildándolas de 'apariencias'. Con la varita mágica del concepto idealista de conocimiento, Hegel convierte el saber mundano en conocimiento divino, se exime de equiparar el Conocimiento a la ciencia positiva, distingue entre acontecer casual y necesario, y procede a una criba de los hechos, oponiendo algunos de ellos, en tanto que esenciales y verdaderos, a la mera existencia 'huera'. Merced a este artilugio considera teleológicamente acontecimientos históricos posteriores como subyacentes a estados de cosas anteriores y justifica las causas reales, poco sublimes, de los acontecimientos - causas a cuyo conocimiento no se cierra - por medio de la imagen, igualmente poco sublime, de la astucia de la razón, que se sirve de ellas como instrumentos. La doctrina de la Identidad le coloca en una situación que le permite futilizar 'las existencias bajas y no verdaderas' dentro del ámbito de la filosofía, sin que ésta tenga que renunciar a la pretensión de abarcar lo 'real'. La certeza de no admitir como válido más que aquello que se presente objetivamente confiere a este doctrina un sentido ilustrado; pero este sentido ilustrado sufre una reconversión metafisica al llevarse a cabo entre lo dado una selección según la cual 'la existencia es, en parte, fenómeno y, sólo en parte, realidad'. El saber de lo transitorio como transitorio hace creer al filósofo que con eso supera su objeto; el progreso dentro del sistema consiste fundamentalmente en que todas las alegrías y penalidades de los hombres individuales, la pobreza y la riqueza y, en general, todas las contradicciones reales del mundo terrenal, reciben la marca reconciliadora de lo 'meramente' finito» (ibid. pp. 124-125). (La cursiva es nuestra). 
[...] no hay ninguna diferencia entre el destino económico y el hombre mismo. Nadie es otra cosa que su patrimonio, que su sueldo, que su posición, que sus oportunidades. La máscara económica y lo que hay bajo ella se superponen en la conciencia de los hombres, incluidos los interesados, hasta en los pliegues más sutiles. Cada cual vale lo que gana, cada cual gana lo que vale. Experimenta lo que es en las alternativas de su vida económica. No se conoce como otra cosa [...]. Los individuos valoran su propio sí mismo de acuerdo con su valor de mercado y aprenden lo que son a través de lo que les acontece en la economía capitalista. Su destino, incluso el más triste, no es exterior a ellos, y ellos lo reconocen ${ }^{211}$.

La alienación es una consecuencia inconcebible para los ilustrados, aunque lógica dentro de la dinámica de la Ilustración. La violencia metódica del Occidente mecanicista, movida por la mentalidad de dominio y la supuesta desmitificación, encumbraron la ciencia experimental, aquella de un empirismo hosco que sólo se ceñía a los hechos brutos. Y, desgraciadamente, «en el camino hacia la ciencia moderna los hombres renuncian al sentido» ${ }^{212}$. Un sentido que ha sido enajenado a lo largo de una estrategia en virtud de la cual los modernos «sustituyen el concepto por la fórmula, la causa por la regla y la probabilidad $»^{213}$. Una estratagema propia, ciertamente, del «animal totémico» si aceptamos la definición del mito moderno como ímpetu dominador ${ }^{214}$. Así, Adorno y Horkheimer describen cómo la razón analítica acabó por inscribir la Ilustración dentro de las fronteras de la mitología al hacer de la dominación un rasgo necesario: «el precio de la supervivencia es la colaboración en la práctica, la transformación de la idea en dominio» ${ }^{215}$. Por su violencia, «la Ilustración es totalitaria» ${ }^{216}$, inmortalizaron Adorno y Horkheimer.

Según la tesis pesimista de Adorno y Horkheimer, la Ilustración se trataba de una empresa condenada desde su génesis a su propia destrucción debido a su orientación domi-

\footnotetext{
${ }^{211}$ Horkheimer, M. y Adorno, T., Dialéctica de la Ilustración, op. cit., pág. 253.

212 Ibid. pág. 61.

213 Ibid
}

214 Blumenberg ha estudiado en profundidad el significado del mito, su valor, sus condiciones, sus efectos. Se ha sumergido en su poder sintetizador y creador, así como ha analizado el papel que han jugado en la constitución de los diferentes mundos humanos y sociales. Ha vinculado el mito con poderes dogmáticos y normativos y ha terminado por destacar una especie de estructura mitológica de la realidad. Sobre el mito como fuente que cristaliza y verbaliza la voluntad de una comunidad (cfr. Blumenberg, H., Trabajo sobre el mito, trad. de Pedro Madrigal, Barcelona, Paidós, 2003). Resultan sugerentes unas breves líneas de este libro donde Blumenberg acude a la estructura del «mito social» definida por Sorel, en las cuales se aprecia el carácter normativo del mito, con capacidad definitoria del dominio canónico: «con el concepto 'mito social', inventado por Sorel en 1906, se ha llegado al mínimo de lo que aún podría denominarse mito. Ya no se narra una historia; únicamente, se toca un trasfondo de deseos, de repulsas, de voluntades de poder. Tal como habla Sorel de la 'huelga general', no es sino una forma de titular un acontecimiento avasallador, una manifestación contundente de voluntad dirigida hacia un je ne-sais-quoi [no sé qué]. El vigor de este mito final reside en su fuerza de exclusión: es un canon de un saber siempre -y un querer- lo que no debe ser. Pero, de este modo, se llega a una sorprendente convergencia con el dogma, el cual, por su origen, es el canon para la exclusión de herejías» (ibid. pág. 246).

${ }^{215}$ Horkheimer, M. y Adorno, T., Dialéctica de la Ilustración, op. cit., pág. 256.

216 Ibid. pág. 62. 
nadora de la naturaleza. La violencia contra el medio se refleja contra el sujeto epistémico, que ha devenido estrictamente materia de dominio. La lógica de la dominación se impone de forma tan extrema que la naturaleza humana queda presa de su mismo cometido. Desde la libertad granjeada por la ciencia moderna, que ha desnudado el mundo, el individuo torna esclavo de una mitología pretendidamente secular según la cual ha de acontecer proceso, eterno y sin descanso, de apropiación de los hechos brutos de la realidad: «el derecho de las figuras míticas, en cuanto derecho del más fuerte, vive sólo de la irrealizabilidad de sus preceptos» ${ }^{217}$.

En el aparentemente inevitable movimiento ilustrado hacia su autodestrucción, la ideología de dominio de la naturaleza por el hombre, puesta frente al espejo de la racionalidad moderna, ha ofrecido el reflejo del dominio del hombre por la naturaleza -alienación y cosificación-. Una contradicción aparentemente aporética que introduce el conflicto esencial que recorre las páginas del análisis frankfurtiano: la dialéctica hombre-naturaleza. Sin embargo, no se trata de un antagonismo sustantivo; no es el despliegue necesario de la Ilustración. La crítica de estos autores se orienta al rescate de la dimensión «positiva»-esto es, propositiva- de la Ilustración, de suerte que su denuncia no es tanto hacia el momento histórico referido como a la perversión que ha hecho de la racionalidad una razón instrumental, calculadora y cosificadora. La cuestión entonces pasa por identificar el momento en que la razón se convierte en una instancia como la aquí descrita. Entienden que se debe a un «olvido» en el inicio mismo de la razón occidental, la cual perdió de vista su unidad con la naturaleza para configurarse estrictamente desde el prisma del dominio:

Podría surgir la sospecha de que nos comportamos con los otros hombres y con la criatura en general no de distinta forma a como lo hacemos con nosotros mismos una vez superada la operación: ciegos frente al dolor. El espacio que nos separa de los otros tendría el mismo significado, para el conocimiento, que el tiempo que se interpone entre nosotros y el dolor de nuestro propio pasado: el de un límite infranqueable. Pero el dominio permanente sobre la naturaleza, la técnica médica y la no médica, recibe su fuerza de esta ceguera; más aún, ella se ha hecho posible sólo merced al olvido. Pérdida del recuerdo como condición transcendental de la ciencia. Toda reificación es un olvido ${ }^{218}$.

Haber acentuado este olvido de su unidad con la naturaleza no es, en cambio, una estrategia romántica que pretende el retorno a un espacio nostálgico. Al contrario, se trata de una enfática reivindicación de la Ilustración como garante crítico y emancipador: la superación de la perversión de la razón instrumental no puede llegar más que desde las máximas ilus-

217 Ibid. pág. 111.

218 Ibid. pág. 275. 
$\operatorname{tradas}^{219}$ : sólo desde la razón se puede dejar atrás la irracional escisión entre el hombre racional y la naturaleza: «mediante este recuerdo de la naturaleza en el sujeto, en cuya realización se encierra la verdad desconocida de toda cultura, la Ilustración se opone al dominio en cuanto tal» ${ }^{220}$. Tesis ésta, sin embargo, de la cual es Jürgen Habermas el gran defensor. No son pocos los pasajes donde el autor de la segunda generación frankfurtiana pugna por recuperar el cariz crítico de la «razón» moderna desde unas premisas que, a la vez, procuren salvaguardas contra las consecuencias cosificadoras del momento ilustrado. La propuesta habermasiana resulta más prolija que el infeliz análisis de Adorno y Horkheimer sobre el momento ilustrado: no ha de llevar indefectiblemente la razón moderna a catástrofes propias de premisas netamente calculadoras e instrumentales. Precisamente desde las posibilidades críticas de la razón como «razón comunicativa» se superaría, entiende Habermas, el abismo cismático del hombre y la naturaleza:

A la crítica radical de la razón sólo se le pueden echar en cara su carácter nivelador y las desdiferenciaciones que practica en la imagen de la modernidad, recurriendo a descripciones alternativas que por su parte estén guiadas por intuiciones de carácter normativo. Y si no ha de permanecer arbitrario, este contenido normativo ha de poder obtenerse y justificarse a partir del potencial de razón que la propia práctica cotidiana lleva en su seno. El concepto de razón comunicativa que de forma muy provisional he introducido en otra parte y que apunta más allá de la razón centrada en el sujeto tiene como fin sacarnos de las paradojas y las nivelaciones en las que, por su carácter autorreferencial, se ve envuelta la crítica radical de la razón; pero por otra parte tiene también que poder afirmarse contra el enfoque rival que representa esa teoría de sistemas que deja de lado la problemática de la racionalidad en general, se despoja de todo concepto de razón como de una camisa de fuerza viejo-europea y, con no poca ligereza, hace suya la herencia de la filosofía del sujeto (y también la "teoría del poder" del más rotundo adversario de esa filosofía). Este doble frente convierte la rehabilitación del concepto de razón en una empresa doblemente arriesgada. Esa rehabilitación ha de cuidarse muy bien por ambos lados: ha de guardarse de volver a caer en las trampas del pensamiento centrado en el sujeto, que no consiguió mantener libre la peculiar coacción sin coacciones que caracteriza a la razón, y ha de huir tanto de los rasgos totalitarios de una razón instrumental que convierte en objeto todo cuanto la rodea e incluso a sí misma, como de los rasgos totalizantes de una razón inclusiva que todo se lo incorpora y al final acaba triunfando como unidad sobre toda diferencia. La filosofía de la praxis quiso extraer los contenidos normativos de la modernidad de una razón encarnada en el acontecer mediador que es la praxis social. ¿Cambia la perspectiva de totalidad que el concepto de praxis social lleva inscrita cuando la categoría de trabajo social se sustituye por la categoría de acción comunicativa? ${ }^{221}$.

${ }^{219}$ Horkheimer, M, Crítica de la razón instrumental, op. cit., pág. 179: «la ‘curación’ [de la enfermedad de la que adolece la razón] depende del conocimiento de la esencia de la enfermedad originaria, no de un tratamiento limitado a los síntomas más tardíos. La verdadera crítica de la razón descubrirá necesariamente y sacará a la luz las capas más profundas de la civilización».

${ }^{220}$ Horkheimer, M. y Adorno, T., Dialéctica de la Ilustración, op. cit., pág. 93.

221 Habermas, J., El discurso filosófico de la modernidad, trad. de Manuel Jiménez Redondo, Madrid, Katz Editores, 2013, pp. 367-368. 
El tránsito de la razón emancipadora hacia la calculadora, instrumento de dominio y violencia, se representa como «naturaleza olvidada de sí», es decir, como ese hegeliano espíritu hoy extrañado de sí mismo. Las claves de recuperación de la íntima unidad entre el hombre y la naturaleza ponen de manifiesto que el terreno sobre el que se están moviendo Adorno y Horkheimer no es tan sólo el de la crítica de la faceta ideológica de la razón capitalista; el mercado no crea la violencia, sólo la multiplica. Más aún, es una crítica ontológica de la razón occidental en toda su amplitud. Pareja al esfuerzo nietzscheano:

[...] la praxis verdaderamente subversiva depende de la intransigencia de la teoría frente a la inconsciencia con la que la sociedad permite reificarse al pensamiento. No son las condiciones materiales de la realización, la técnica desencadenada en cuanto tal, lo que cuestiona dicha realización [...]. La culpa la tiene un conjunto social de ofuscación y ceguera. El mítico respeto científico de los pueblos ante lo dado, que sin embargo ellos mismos continuamente producen, termina por convertirse a su vez en el hecho positivo [...], como pura construcción de medios, la Ilustración es tan destructiva como le reprochan sus enemigos románticos ${ }^{222}$.

Por lo tanto, a pesar del profundo pesimismo que reverbera en cada página de la Dialéctica de la Ilustración, Adorno y Horkheimer aún atisbaban la hipótesis de una dimensión no esencialmente dominadora de la razón. Si bien habían censurado la identificación del saber con el poder, porque significaba renunciar a la «felicidad del conocimiento» ${ }^{223}$, que era la «verdad», en favor del método y la explotación de la naturaleza, entendieron percibir la «utopía oculta en el concepto de razón» ${ }^{224}$, o sea, la posibilidad de una recuperación de la verdad desde la que «preparar un concepto positivo de ésta, que la libere de su cautividad en el ciego dominio» ${ }^{225}$. Qué sea la verdad quedó, sin embargo, pendiente de precisión. Ahora bien, la importancia de este concepto radica en que mediante el mismo

${ }^{222}$ Horkheimer, M. y Adorno, T., Dialéctica de la Ilustración, op. cit., pág. 94.

${ }^{223} \mathrm{Ibid}$. pág. 60.

También, cfr. ibid. pp. 60-61: «la estéril felicidad del conocimiento es lasciva para Bacon. Lo que importa no es aquella satisfacción que los hombres llaman verdad, sino la operación, el procedimiento eficaz [...]. No debe existir ningún misterio, pero tampoco el deseo de su revelación».

${ }^{224}$ Ibid. pág. 132.

${ }^{225} \mathrm{Ibid}$. pág. 56. 
encontraron la veta a través de la cual salvar el proyecto «positivo» ${ }^{226}$ de la Ilustración superando las contradicciones inherentes en el programa de dominación de la naturaleza:

Ella [la Ilustración] se encuentra a sí misma sólo si rechaza el último compromiso con estos enemigos y se atreve a abolir el falso absoluto, el principio del ciego dominio. El espíritu de esta teoría intransigente podría reorientar al del inexorable progreso mismo hacia su fin [...]. La Ilustración se realiza plenamente y se supera cuando los fines prácticos más próximos se revelan como lo más lejano logrado, y las tierras 'de las que sus espías y delatores no recaban ninguna noticia', es decir, la naturaleza desconocida por la ciencia dominadora, son recordadas como las tierras del origen ${ }^{227}$.

La disolución de la razón metafísica hizo imposible el establecimiento de vínculos estrechos como aquellos que unían las sociedades antiguas en una identidad de significación $^{228}$; en la nueva máquina estatal tan sólo quedó la conciencia nostálgica de un pasado mítico. Una añoranza por un contenido con el cual llenar el vacío del presente que apresó Rousseau, captando el espíritu epocal de la modernidad como tiempo escindido:

No corresponde a mi tema mostrar cómo de semejante disposición nace tanta indiferencia para el bien y para el mal, pese a discursos tan hermosos de moral; cómo al reducirse todo a las apariencias, todo se convierte en ficticio y fingido: honor, amistad, virtud, y con frecuencia hasta los vicios mismos, de los que finalmente se encuentra el secreto de glorificarse; cómo, en una palabra, al pedir siempre a los demás lo que nosotros somos y no atreviéndonos a preguntarnos sobre ello a nosotros mismos, en medio de tanta filosofía, humanidad, educación y máximas subli-

226 Nuevamente Blumenberg, el pensador contemporáneo destaca de la experiencia moderna una conclusión "positiva» próxima a la frankfurtiana, sosteniendo también la posibilidad de una emancipación de las restricciones instrumentales de la razón ilustrada dentro de la propia conciencia de la Ilustración. Las expectativas de superación de la escisión se deben esperar, no obstante, tras una pertinente asimilación de las efectivas capacidades del conocimiento científico. Cfr. Blumenberg, H., Trabajo sobre el mito, op. cit., pág. 254: «si nos atenemos a lo experimentado en los tiempos modernos, lo que resulta es una enseñanza incomparable, pero tomada muy poco a pecho, que hubiera podido ser extraída de la condición de las ciencias y de su forma histórica: ver la no-posesión de la verdad -al contrario de la promesa de que la verdad nos hará libres- como lo que más cerca está de hacernos libres. Puede ser que la historia de la ciencia sea todavía demasiado corta como para que a la conciencia de la época se le haga patente ese resultado del trato con ella. Pero hay razones para temer que el hartazgo producido por la misma ciencia se fundamente precisamente en ese procedimiento suyo peculiar de retractarse continuamente, o en su modo de obtener conocimientos mediante revisiones o gradaciones. Y, entonces, antes de haber podido sacar de la época de la ciencia su mayor provecho, consistente en su forma peculiar de conocer, habría fracasado la recogida de esa cosecha por el disgusto ante la ingente cantidad de esfuerzo que eso supone.

Si es cierto que la presunta posesión de demasiadas verdades estropea la verdad, la sensibilidad para la verdad y, sobre todo, la sensibilidad respecto a la verdad de otros, entonces la Ilustración tenía razón en ver el criterio más grande de diferenciación entre el mito y el dogma en la tolerancia».

Por supuesto se aprecia también en Blumenberg el influjo de la crítica nietzscheana de la ciencia y su revaloración de la no-verdad.

${ }^{227}$ Horkheimer, M. y Adorno, T., Dialéctica de la Ilustración, op. cit., pp. 94-95.

228 Cfr. Nietzsche, F., El nacimiento de la tragedia, trad. de Andrés Sánchez Pascual, Madrid, Alianza Editorial, 2009, pág. 190 (KSA I, 145): «Las imágenes del mito tienen que ser los guardianes demónicos, presentes en todas partes sin ser notados, bajo cuya custodia crece el alma joven, y con cuyos signos se da el varón a sí mismo una interpretación de su vida y de sus luchas: y ni siquiera el Estado conoce leyes no escritas más poderosas que el fundamento mítico, el cual garantiza su conexión con la religión, su crecer a partir de representaciones míticas». 
mes, no tenemos más que un exterior engañoso y frívolo, honor sin virtud, razón sin sabiduría, y placer sin dicha. Me basta con haber probado que no radica ahí el estado original del hombre y que es únicamente el espíritu de la sociedad y de la desigualdad que ella engendra los que sí cambian y alteran todas nuestras inclinaciones naturales 229 .

El agotamiento que conllevó la modernidad para las conciencias europeas se debió, en gran medida, a lo recogido en la denuncia de Rousseau. Una época frívola y contraria al latir humano que no logró satisfacer las ilusionantes expectativas de virtud, sabiduría y dicha que prometió la razón científica. Tras haberse constatado que la modernidad no iba a procurar tales recompensas, como Rousseau, se extrañó un tiempo mítico que apelara a un «estado original del hombre».

El diagnóstico de Rousseau al final del Segundo Discurso ilustra con claridad la amargura vivida al término del siglo ilustrado. Sin embargo, sus conclusiones no satisfarán en modo alguno a Nietzsche, que no duda en tildar al ginebrino de ingenuo y nihilista. El propósito del pensador suizo apuntaba a la constitución de un orden social que tomara como principios esenciales las relaciones humanas en el estado de naturaleza; sabedor de que dada la evolución de la humanidad no podrían dejarse ya atrás las construcciones estatales modernas, se trataba de lograr que éstas emulasen máximamente el estado de inocencia previo a la aparición de la sociedad política para conseguir un régimen de libertad cuasinatural. Ya que el derecho no se basa en la naturaleza, sino en las convenciones, Rousseau comprende que se ha de intentar armonizar las convenciones del estado civil con las consecuencias de libertad del estado de naturaleza. De tal forma que el gobierno tendrá que afanarse en reconstruir desde el artificial derecho unas leyes que procuren unas condiciones de libertad parejas a la asociación que pudo encontrar el hombre natural en aquel momento primero. Ahora bien, al respecto objetará Nietzsche desde sus momentos más jóvenes, cuando ya barrunta la posibilidad ontológica de la realidad dionisiaca, que la ensoñación romántica de una vuelta a la naturaleza como concreción de una profecía escatológica por la que se recupera la armonía de una vida integrada en aquella unidad primigenia es «ingenua»:

Aquí hay que manifestar que esta armonía, más aún, unidad del ser humano con la naturaleza, contemplada con tanta nostalgia por los hombres modernos, para designar la cual Schiller puso en circulación el término técnico «ingenuo», no es de ninguna manera un estado tan sencillo, evidente de suyo, inevitable, por así decirlo, con el que tuviéramos que tropezarnos en la puerta de toda cultura, cual si fuera un paraíso de la humanidad: esto sólo pudo creerlo una época que intentó imaginar que el Emilio de Rousseau era también un artista, y que se hacía la ilusión de haber encontrado en Homero ese Emilio artista, educado junto al corazón de la naturaleza. Allí donde tropezamos en el arte con lo «ingenuo», hemos de reconocer el efec-

${ }^{229}$ Rousseau, J.-J., Sobre el origen y los fundamentos de la desigualdad entre los hombres, en Del Contrato social. Discursos., trad. de Mauro Armiño, Madrid, Alianza Editorial, 2005, pp. 315-316. (La cursiva es nuestra). 
to supremo de la cultura apolínea: la cual siempre ha de derrocar primero un reino de Titanes y matar monstruos, y haber obtenido la victoria, por medio de enérgicas ficciones engañosas y de ilusiones placenteras, sobre la horrorosa profundidad de su consideración del mundo y sobre una capacidad de sufrimiento sumamente excitable ${ }^{230}$.

La desaparición de la unidad motivada por la identidad religiosa, si bien puso fin a la aceptación inercial de dogmas absolutistas, también desterró las medidas comunales de solidaridad entre los individuos. La Ilustración como estadio de entrada en la mayoría de edad de la humanidad, sobre el armazón de la autonomía, compuso un sujeto plenamente libre, recipiente de una independencia inconmensurable que lo llevó a desprenderse radicalmente de los otros. La divinidad secularizada se había encarnado en el sujeto moderno. Cada uno era su propia deidad ${ }^{231}$. Así, la «muerte de Dios» no es -o al menos no sólo- el fin del concepto teológico que legitimaba lo objetivo, sino el derrumbe de la imagen que de sí había labrado el actor moderno, a quien gustaba sentirse hecho a imagen y semejanza de Dios. La muerte de Dios se refiere, por tanto, a la claudicación, al deceso de los ideales del hombre moderno:

Pues ésta es la manera como las religiones suelen fallecer: a saber, cuando, bajo los ojos severos y racionales de un dogmatismo ortodoxo, los presupuestos míticos de una religión son sistematizados como una suma acabada de acontecimientos históricos, y se comienza a defender con ansiedad la credibilidad de los mitos, pero resistiéndose a que éstos sigan viviendo y proliferando con naturalidad, es decir, cuando se extingue la sensibilidad para el mito y en su lugar aparece la pretensión de la religión de tener unas bases históricas ${ }^{232}$.

La conciencia de la muerte de Dios por los ilustrados maduros no ofreció tampoco una solución a tal dificultad. Lejos de acotarla, abonó el sustrato nihilista del tardío Occidente dieciochesco. La posición del hombre como receptáculo de la cualidad divina, y por ende, preñado de potencial creador apuntó a la historia como el espacio de despliegue de la razón en aras de la recuperación de un sentido unitario. La escisión que produjo la razón analítica vendría a ser resuelta en un ámbito que comprendiese bajo su manto todas las contradicciones - la pérdida del sentido individual, la ruptura de los lazos sociales, la frontera abierta entre el sujeto y la naturaleza, que Hegel sintetiza bajo la formulación del espíritu extrañado de sí- y las superase en aras de una existencia armónica. Los ilustrados concibieron su tiempo desde la esquizofrénica complementariedad de una realidad que tanto incuba el extrañamiento como da los frutos resolutivos de su alienación. Esencial agonía resuelta en la historia, horizonte donde la acción humana se reviste nuevamente de significado.

${ }^{230}$ Nietzsche, El nacimiento de la tragedia, op. cit., pág. 56 (KSA I, 37).

${ }^{231}$ Cfr. Nietzsche, F., Crepúsculo de los ídolos, op. cit., pág. 33 (KSA VI, 59): «Para vivir sólo hay que ser un animal o un dios -dice Aristóteles. Falta el tercer caso: hay que ser ambas cosas -un filósofo...».

${ }^{232}$ Nietzsche, F., El nacimiento de la tragedia, op. cit., pág. 102 (KSA I, 74). 
Las estrategias filosóficas de Kant y Hegel, en último término esforzadas propuestas escatológicas sobre un desarrollo evolutivo de la razón en la historia orientado hacia su óptima concreción ulterior-la moralización en la historia para Kant; la plena autoconciencia del espíritu, en Hegel-, apuntaban a una positivación de la razón teleológica que recuperara la primigenia unidad entre el sujeto y el mundo. En su obra ya madura, Hegel resume la síntesis de las contradicciones mediante la razón, entendiendo que la enajenación de la naturaleza era una etapa ineludible del desarrollo de la razón mecanicista y que quedaría favorablemente resuelta en una etapa dialéctica posterior. No consiste para Hegel la modernidad tan sólo en el despliegue de la razón analítica; también es el momento de la conquista histórica de la subjetividad por parte del sujeto autónomo. Así la superación de las contradicciones de la analiticidad y de la modernidad acontecería en la historia, contenedor de la razón libre. En su proceso teleológico la razón acabaría asumiendo la reunificación de la vida y la naturaleza dentro de un sistema filosófico pensado e incubado por ella ${ }^{233}$. La empresa teleológica histórica es, no obstante, genéticamente un fraude, sigue Nietzsche, que atenta contra los principios de la «inocencia del devenir»:

Schopenhauer nos ha recordado algo que olvidamos inmediatamente y que, en cualquier caso, quisimos olvidar: que la vida del individuo no puede tener su sentido en ser histórica, en desaparecer en cualquier especie y en las configuraciones grandes y cambiantes de la nación, el Estado y la sociedad, y tampoco en las pequeñas de la comunidad y la familia. Quien sólo es histórico no ha comprendido la lección de la vida, y tendrá que estudiarla de nuevo ${ }^{234}$.

El extrañamiento de la razón analítica es también reflexivo. Ha afectado a la relación del hombre con la naturaleza, pero también se implica a sí misma, ya que no es capaz de legitimar el porqué de su existencia, ni sus cualidades ni, por supuesto, sus fines. En el ámbito de la razón analítica, que Horkheimer también llama «razón subjetiva», se da una «neutralización de la razón, que sustrae a la misma toda relación con un contenido objetivo y la fuerza de juzgarlos, degradándola así a la condición de mera capacidad ejecutiva más volcada al cómo que al qué, la transforma de modo creciente en un mero aparato obtuso para el registro de hechos» ${ }^{235}$. La razón analítica moderna no logra dar explicaciones concernientes al sentido. Éstas están fuera de su espectro, que se ocupa estrictamente del cál-

${ }^{233}$ Horkheimer observa que la estrategia de Hegel es, en verdad, una farsa, una estrategia errónea en el mejor de los casos. La reunificación de las contradicciones en una síntesis resolutiva no puede esperarse acontezca espontáneamente en la historia. Más aún, el desarrollo inercial de las contradicciones termina por legitimarlas. De hecho, apunta el frankfurtiano, esta aquiescencia con respecto a las contradicciones de la razón analítica por la Ilustración es lo que ha llevado a la desembocadura de la crisis de la razón al final del siglo. Cfr. Horkheimer, M., Crítica de la razón instrumental, op. cit., pág. 77: «la probabilidad, o, mejor aún, la calculabilidad sustituye a la verdad, y al reducirla a una frase huera, la propia filosofía asiente al proceso histórico que tiende a convertir dentro de la sociedad la verdad en una frase vacía, legitimándolo».

234 Nietzsche, F., Fragmentos póstumos sobre política, trad. de José Emilio Esteban Enguita, Madrid, Trotta, 2004, pág. 128 (KSA VII 34 [32], 802).

${ }^{235}$ Horkheimer, M., Crítica de la razón instrumental, op. cit., pág. 85. 
culo, las inferencias y las generalizaciones numéricas. Precisamente por su insuficiencia en cuanto al problema del sentido la modernidad se verá abocada al nihilismo, puesto que se ha asentado sobre una razón incapaz de legitimar su obra.

Si bien hay cuestiones y aspectos paralelos entre las críticas de Nietzsche y las de la Escuela de Frankfurt, son esencialmente lejanas, distintas e irreconciliables. Aunque ambas denuncias captaron el carácter positivista de la Ilustración, sus enfoques impiden trazar una relación feliz entre ellos. Un primer elemento distintivo debe buscarse en sus respectivos fundamentos. Las tesis frankfurtianas se sostienen al amparo del materialismo marxista, en el cual todo queda nuclearmente concretado en relaciones materiales de producción. No son pocos los pasajes en los que Nietzsche se opone al pensamiento de Marx, al percibir que la concepción marxista de la «materia» la ha reducido groseramente a meras magnitudes. En Nietzsche hay una expectativa de espiritualidad que no va desligada y en oposición de lo factual, sino en escrupulosa e íntima identidad como «corporalidad». Al mismo tiempo, los frankfurtianos partieron de una experiencia desoladora, a saber, que el proyecto de la razón ilustrada, que habría de haber supuesto una emancipación de las conciencias al término de su programa escatológicamente trazado, había fracasado. Una amargura que da muestra última de la sólida confianza en el sustrato de la razón moderna de los pensadores frankfurtianos: las expectativas de una legitimación del orden moral del mundo gracias a la esencia de la razón objetiva. Por lo tanto, el problema de la Ilustración no estaba en la afección progresista, sino en el rumbo irracional que ésta tomó al enajenar en la «razón subjetiva» la fuerza crítica de la «razón objetiva». Del mismo modo, tampoco puede esperarse en Nietzsche, como sí ocurriría después en la «teoría crítica», un procedimiento teleológico de la razón, toda vez que postulará en su lucha contra los ídolos vacíos de la metafísica una premisa de existencia inocente: la «inocencia del devenir».

Nietzsche y la Escuela de Frankfurt toman el nihilismo como consecuencia postrera de la modernidad. Sin embargo, como hemos expuesto, desde premisas fundamentalmente distintas. Es más, desde el estudio nietzscheano del nihilismo, no habría dudado en cifrar la «teoría crítica» como una manifestación más de la decadente la tradición filosófica occidental. No es posible la confianza en la existencia de valores últimos y trascendentales, tampoco la apelación a los mismos como medida legitimadora del mundo, ora epistemológico ora moral. Aunque el análisis de Adorno y Horkheimer desnuda perfectamente las maquinaciones de la razón moderna, desvelando sus pretensiones de objetivación como manifestación definitiva del subjetivismo epocal, no deja de resultar, por su confianza devota en las posibilidades morales de la «razón objetiva», otra manifestación tardía del legado de la metafísica platónica de la duplicación de mundos y de la escisión del alma y del cuerpo que durante milenios enajenó al hombre de su propia experiencia de vida. 


\section{I.2. La redefinición de la ciencia como arte}

La secularización, dice Nietzsche, no ha sido sólo la conquista de la libertad por los ilustrados. También ha significado consecuentemente el hundimiento del mundo ${ }^{236}$ en el cual se ha vivido hasta entonces: «muerte de Dios». El nihilismo como pérdida del sentido se inscribe en la deslegitimación de la totalidad de la realidad una vez que el marco de comprensión vigente deja de percibirse válido: el dios garante no mora por más tiempo en el templo del cristianismo, que era el horizonte epistemológico occidental en general, ahora vacío. De manera que sobre la necesidad de hallar un sustituto que continúe arrojando justificación gravitará la investigación ilustrada: la búsqueda, en definitiva, de una nueva deidad portadora del significado con el que construir un nuevo horizonte de precomprensión. El Dios ilustrado -mejor aún, la diosa- fue la razón. Así los proyectos progresistas mate-

${ }^{236}$ La tesis del colapso del mundo es extraordinariamente sugerente. Con ella, Heidegger señala el momento en que la esencia de un ente dentro de un determinado contexto humano pierde su finalidad originaria, abriendo entonces paso a la infinitud de la potencia hermenéutica.

Esta idea tiene un correlato muy estricto en el ámbito de la estética, como el mismo autor señala. Nos pone el ejemplo de un templo griego: a él acudían los helenos a las prácticas ritualistas y de purificación cotidianas. $Y$ es en el momento en que esa finalidad primera, de carácter sacro, cae en el olvido del tiempo cuando la hermenéutica se abre paso. Una multitud de personas peregrinan hasta ese mismo templo, mas con una nueva pretensión: la contemplación estética del templo, en tanto que obra de arte. Esta situación refleja el colapso de un mundo, el griego: ya no ha lugar para los ritos cotidianos, sustituidos por una nueva manera de concebir esa manifestación de la realidad. Así, el pretérito mundo griego deviene fenómeno hermenéutico, siendo percibido de acuerdo con los modos y actitudes del tiempo presente. Cfr. Heidegger, M., «El origen de la obra de arte», trad. de Helena Cortés y Arturo Leyte, en Caminos de bosque, op. cit., pág. 48: «Cuanto más solitaria se mantiene la obra dentro de sí, fijada en la figura, cuanto más puramente parece cortar todos los vínculos con los hombres, tanto más fácilmente sale a lo abierto ese impulso - que hace destacar a la obra- de que dicha obra sea, tanto más esencialmente emerge lo inseguro y desaparece lo que hasta ahora parecía seguro. Pero este proceso no entraña ninguna violencia, porque cuanto más puramente se queda retirada la obra dentro de la apertura de lo ente abierta por ella misma, tanto más fácilmente nos adentra a nosotros en esa apertura y, por consiguiente, nos empuja al mismo tiempo fuera de lo habitual. Seguir estos desplazamientos significa transformar las relaciones habituales con el mundo y la tierra y a partir de ese momento contener el hacer y apreciar, el conocer y contemplar corrientes a fin de demorarnos en la verdad que acontece en la obra. Detenerse en esta demora es lo que permite que lo creado sea la obra que es». Y sigue «La verdad como claro y encubrimiento de lo ente acontece desde el momento en que se poetiza. Todo arte es en su esencia poema en tanto que un dejar acontecer la llegada de la verdad de lo ente como tal. La esencia del arte, en la que residen al tiempo la obra de arte y el artista, es el ponerse a la obra de la verdad. Es desde la esencia poética del arte, desde donde éste procura un lugar abierto en medio de lo ente en cuya apertura todo es diferente a lo acostumbrado. Gracias al proyecto puesto en obra de ese desocultamíento de lo ente que recae sobre nosotros, todo lo habitual y normal hasta ahora es convertido por la obra en un no ente, perdiendo de este modo la capacidad de imponer y mantener el ser como medida [...]. El efecto de la obra no proviene de un efectuar. Consiste en una transformación, que ocurre a partir de la obra, del desocultamiento de lo ente, o lo que es lo mismo, del ser» (ibid. pág. 52). Y es que «el proyecto poético de la verdad, que se establece en la obra como figura, tampoco se ve nunca consumado en el vacío y lo indeterminado. Lo que ocurre es que la verdad se ve arrojada en la obra a los futuros cuidadores, esto es, a una humanidad histórica. Ahora bien, lo arrojado no es nunca una desmesurada exigencia arbitraria. El proyecto verdaderamente poético es la apertura de aquello en lo que el Dasein ya ha sido arrojado como ser histórico. Aquello es la tierra y, para un pueblo histórico, su tierra, el fundamento que se cierra a sí mismo, sobre el que reposa con todo lo que ya es, pero que permanece oculto a sus propios ojos. Pero es su mundo, el que reina a partir de la relación del Dasein con el desocultamiento del ser. Por eso, todo lo que le ha sido dado al ser humano debe ser extraído en el proyecto fuera del fundamento cerrado y establecido expresamente sobre él. Sólo así será fundado como fundamento que soporta» (ibid. pág. 54). Con todo, «siempre que acontece el arte, es decir, cuando hay un inicio, la historia experimenta un impulso, de tal modo que empieza por vez primera o vuelve a comenzar. Historia no significa aquí la sucesión de determinados sucesos dentro del tiempo, por importantes que éstos sean. La historia es la retirada de un pueblo hacia lo que le ha sido dado hacer, introduciéndose en lo que le ha sido dado en herencia» (ibid. pp. 55-56). 
rialistas, como el liberalismo, el socialismo o el positivismo, pero también aquellos de corte intelectual, como el kantiano o el hegeliano, eran esfuerzos por extrapolar la salvación cristiana del Paraíso en la Tierra a lo largo del discurso histórico humano:

Incluso cuando los fenómenos correspondientes no resisten a los criterios de identificabilidad, autenticidad y expropiación y, con ello, su secularización hubiera de ser considerada una pura apariencia, esa apariencia tendría, con todo, un fundamento en la cosa misma: su pertenencia, demostrable, a una lógica histórica. Como forma de explicación de acontecimientos históricos, la «secularización» sólo aparecería como algo plausible cuando una serie de representaciones presuntamente secularizadas pueden ser remitidas, en gran parte, a una identidad subyacente en el proceso histórico. Tal identidad no es, ciertamente, según la tesis aquí defendida, una identidad de contenidos, sino de funciones. En efecto, contenidos completamente heterogéneos pueden asumir, en determinados puntos del sistema de interpretación del mundo y del hombre, funciones idénticas. Este sistema ha sido decisivamente determinado, en nuestra historia por la teología cristiana [...]. Su propia fuerza no podía ser otra cosa que la debilidad de sus herederos. Quienquiera llamar a esto un reproche que lo compare con el reproche que Leibniz le hiciera a Descartes: con su radicalidad en la duda del conocimiento y su cuestionable superficialidad en la superación de la misma, Descartes habría puesto en circulación en el mundo una exigencia de certeza que, por el rigor de sus pretensiones, no podría ser satisfecha no por él mismo ni por ningún otro, sin que, no obstante, haya forma ya de retirarla o anularla a causa de esa imposibilidad ${ }^{237}$.

Heidegger, por el contrario, se muestra disconforme con la propia expectativa de progreso en la filosofía, entendiendo que dicha contemplación impide profundizar en el auténtico compromiso filosófico de la verdad. La mera idea de un desarrollo acumulativo del pensar significa, entiende Heidegger, la cosificación misma de la filosofía, un discurso que se atiene a lo ente y culmina el olvido del ser. La búsqueda ilustrada de un nuevo dios garante del sumativo conocimiento natural y de la especulación filosófica irrumpe irremisiblemente en el nihilismo por un doble motivo: continúa subordinando la reflexión del pensamiento ante los estándares de «enticidad»-die Seindheit-de una razón que atiende a «lo existente»-das Seiende-, esto es, a lo efectivamente manifiesto de las apariencias vacías; al tiempo que perpetúa la tradición platónica de una mirada desplazada, enajenada de su esencia, pues «'verdad' significa desde hace largo tiempo para el pensamiento occidental la coincidencia de la representación pensante con la cosa: adaequatio intellectus et rei» ${ }^{238}$.

Si atiende a su esencia, en realidad la filosofía no progresa nada. Se pone en su lugar para pensar siempre lo mismo. Progresar, es decir, marchar más allá de ese lugar, es un error que sigue al pensar como esa sombra que él mismo arroja. Es precisamente porque el ser sigue impensado todavía por lo que también en Ser y tiempo se dice del ser que: «se da». [...] Este «se da» reina como destino del ser. Su historia llega al lenguaje a través de la palabra de los pensadores esenciales. Por

${ }^{237}$ Blumenberg, H., La legitimación de la edad moderna, trad. de Pedro Madrigal, Valencia, pág. 70.

${ }^{238}$ Heidegger, M., «La doctrina platónica de la verdad», trad. de Helena Cortés y Arturo Leyte, en Hitos, versión de Helena Cortés y Arturo Leyte, Madrid, Alianza Editorial, 2007, pp. 183-184. 
eso, el pensar que piensa en la verdad del ser es histórico en cuanto tal pensar. No existe un pensar «sistemático»y, a su lado, a modo de ilustración, una historia de las opiniones pretéritas. Pero tampoco existe, como piensa Hegel, una sistemática que pueda convertir a la ley de su pensamiento en ley de la historia y que pueda asumir simultáneamente tal historia en el sistema. Pensado de modo más inicial, lo que hay es la historia del ser, de la que forma parte el pensar como memoria de esa historia, un pensar acontecido por ella misma. [...] El ser llega a ser destino en la medida en que él mismo, el ser, se da. Sin embargo, la definición de Hegel de la historia como desarrollo del «espíritu» no carece de verdad. [...] La metafísica absoluta, junto con las inversiones que llevaron a cabo Marx y Nietzsche, pertenece a la historia de la verdad del ser. Lo que de ella sale no se puede atacar ni mucho menos eliminar por medio de refutaciones. Sólo se puede asumir, siempre que su verdad se vuelva a albergar de manera más inicial en el propio ser y se sustraiga al ámbito de la mera opinión humana. Toda refutación en el campo del pensar esencial es absurda ${ }^{239}$.

De la experiencia del nihilismo, si bien catastrófica para las conciencias europeas, también extrae Heidegger posibles consecuencias beneficiosas para el espíritu humano, pues «suponiendo que el hombre pueda pensar en el futuro la verdad del ser, pensará desde la exsistencia. Ex-sistiendo, el hombre se encuentra ya en el destino del ser». La filosofía, como el genuino modus contemplativo del destino del ser, no puede consistir, por tanto, en la sistemática acumulación de conocimientos positivos; si Nietzsche hizo remitir el germen nihilista de la tradición occidental hasta la filosofía platónica a causa de la duplicación de mundos, Heidegger hará la propio, aunque por estimaciones distintas: «lo que allí [en la filosofía platónica] permanece no dicho es un giro en la determinación de la esencia de la verdad» 240 :

Las cosas nombradas en el «símil», que se tornan visibles fuera de la caverna, son, por contra, la imagen de aquello en lo que verdaderamente consiste lo ente de lo ente. Esto es, según Platón, aquello a través de lo cual lo ente se muestra en su «aspecto». Platón no toma este «aspecto» como mera «aparición». El «aspecto» también tiene para él algo de un salir afuera por medio del que todo se «presenta». Encontrándose en su «aspecto» se muestra el propio ente. «Aspecto» significa en

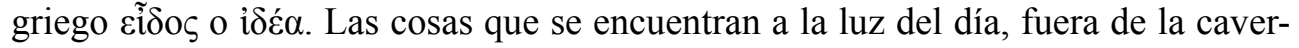
na, en donde existe una libre visión de todo, representan en el «símil» las «ideas». Según Platón, si el hombre no las tuviese, es decir, si no tuviese en su mirada el correspondiente «aspecto» de las cosas, los seres vivos, los hombres, los números, los dioses, nunca podría percibir esto y aquello como casa, árbol o dios. Por lo general, el hombre cree estar viendo directamente esta casa y aquel árbol y, del mismo modo, todos y cada uno de los entes. De entrada, el hombre no sospecha nada de que todo aquello que corrientemente le parece «lo efectivamente real» sólo lo ve a la luz de las «ideas». Eso que aparentemente es lo único verdaderamente real, que es inmediatamente visible, audible, tangible y calculable, según Platón, no es más que el ensombrecimiento de la idea y por ende una sombra. Esto próximo y

${ }^{239}$ Heidegger, M., Carta sobre el humanismo, trad. de Helena Cortés y Arturo Leyte, Madrid, Alianza Editorial, 2009, pp. 45-47.

${ }^{240}$ Heidegger, M., «La doctrina platónica de la verdad», op. cit., pág. 173. 
que sin embargo es como una sombra mantiene cotidianamente preso al hombre. Vive en una prisión y deja a su espalda todas las «ideas». Y precisamente porque no reconoce su cárcel como tal, toma a ese ámbito cotidiano que se halla bajo la bóveda celeste como el espacio donde se mueven la experiencia y el juicio, que son los únicos que otorgan la medida para todas las cosas y relaciones, los únicos que proporcionan las reglas para su disposición y organización ${ }^{241}$.

De este modo, en la verdad de las «ideas» platónicas, entiende Heidegger, se ha perpetrado un giro esencial en el cual es precisamente la esencia aquello que es ignorado en beneficio de lo accidental; el ser ha sido relegado por el ente. Sin embargo, continúa Heidegger, esta inversión es radicalmente significativa -esencial, como apuntábamos-dado que no es únicamente una inversión, sino, dicho nietzscheanamente, una «transvaloración»: la respuesta de la pregunta por el ser del ente no conduce a una respuesta errónea, sino a una instancia enajenada, pues se entiende por tal, en su lugar, el «ente de lo ente». La «transvaloración» platónica ha afectado fundamentalmente el discurso occidental, llevando a la filosofía en su totalidad a centrar sus esfuerzos en la pretensión de una racionalización objetivista del ser en el ente:

En la descripción del «símil» y en la propia interpretación de Platón se da casi por sobreentendido que la caverna subterránea y su exterior son el ámbito en cuya esfera se desarrollan los sucesos descritos. Sin embargo, lo esencial son los tránsitos allí narrados, la subida al exterior, fuera del ámbito del resplandor artificial del fuego para entrar en la claridad de la luz del sol, así como el retorno descendente, desde la fuente de toda luz hacia la oscuridad de la caverna. En el «símil de la caverna» la fuerza de la ilustración plástica no proviene de la imagen de clausura de la bóveda subterránea y de la prisión, así como tampoco de la visión del espacio abierto fuera de la caverna. Antes bien, para Platón, la fuerza significativa y metafórica del «símil» se concentra en el papel del fuego, el reflejo del fuego y las sombras, la claridad del día, la luz del sol y el propio sol. La clave de todo reside en el resplandor de lo que aparece y en el proceso por el que se torna posible su visión. Es verdad que se nombra al desocultamiento en sus distintos grados, pero en realidad sólo es pensado en relación con el modo en que vuelve accesible a eso que aparece en su aspecto ( $\varepsilon \tilde{i} \delta \circ \varsigma$ ) y hace que sea visible eso que se muestra a sí mismo

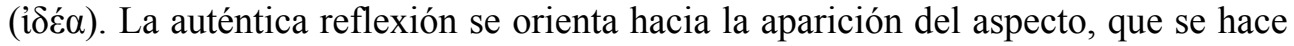
posible gracias a la claridad del resplandor. Dicho aspecto permite tener la visión de aquello bajo lo que se hace presente cada ente. La auténtica reflexión concierne a la i $\delta \varepsilon ́ \alpha$. La «idea» es el aspecto prestado por la visión a todo lo que se presenta. La i $\delta \varepsilon ́ \alpha$ es el puro resplandor en el sentido de la expresión: «luce el sol». La «idea» no deja «aparecer» a ninguna otra cosa (tras ella), sino que ella misma es lo que resplandece, al cual sólo le importa y el cual sólo consiste en su propio resplandor. La i $\delta \varepsilon ́ \alpha$ es aquello que puede resplandecer. La esencia de la idea reside en la posibilidad de resplandecer y de hacer que algo sea visible. Ella consuma la venida a la presencia, concretamente la venida a la presencia de aquello que sea en cada caso un ente. En el qué-es de lo ente aquello viene en cada ocasión a la presencia. Pero la venida a la presencia es en general la esencia del ser. Por eso, para Platón, el ser tiene su auténtica esencia en el qué-es. [...] Lo que trae a la vista la idea, y por lo

${ }^{241}$ Ibid. pág. 180. 
tanto ofrece a la vista, es, para la mirada dirigida hacia ella, lo no oculto de aquello bajo lo que ella aparece. Y así, lo no oculto es concebido de antemano y únicamente como lo aprehendido en la aprehensión de la íśa, como lo conocido

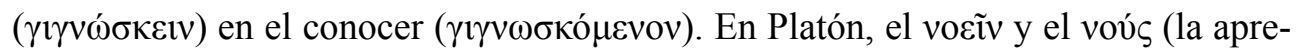
hensión) sólo alcanzan la relación esencial con la «idea» en esta fórmula concreta. En el sentido de este orientarse hacia las ideas, es la disposición la que determina la esencia de la aprehensión y, a partir de allí, la esencia de la «razón» ${ }^{242}$.

Con todo, contrario a la lectura ortodoxa habida hasta entonces de Platón, Heidegger puede afirmar cómodamente que es en este célebre «símil» donde se inocula en la razón la distintiva impronta objetivista que caracterizó las centurias del decurso del pensamiento occidental. De tal manera que la búsqueda de la verdad en el horizonte de posibilidad antiguo no distaba esencialmente del propio de los modernos toda vez que uno y otro apuntaban ulteriormente al mismo objeto, precisamente el objeto, como consecuencia de una nueva forma de mirar. Una orientación que se concreta, tanto para Platón -tipo filosófico antiguocomo para Descartes -tipo filosófico moderno- en las doctrinas de la corrección y de la adecuación:

$\mathrm{Si}$, en general, en cada relación con lo ente lo que importa es la i $\delta \varepsilon \tilde{i} v$ de la i $\delta \varepsilon \dot{\varepsilon} \alpha$, la contemplación del «aspecto», entonces todo esfuerzo debe concentrarse en primer lugar en hacer posible semejante modo de ver. Para eso es necesario el correcto mirar. Una vez que abandona las sombras y se dirige hacia las cosas, incluso el que ha sido liberado dentro de la caverna orienta su mirada hacia aquello que «es más ente» que las meras sombras: [...] «y al estar de cara hacia eso que es más ente, debería ver de modo mucho más correcto» ${ }^{243}$. El tránsito de una situación a otra consiste en ese tornarse cada vez más correcta la mirada. Todo depende del ỏ $\theta$ ótๆs, de la rectitud o corrección de la mirada. Por medio de dicha rectitud, el ver y el conocer se vuelven correctos, de tal modo que al final se dirigen directamente hacia la idea suprema y quedan fijados en esa «orientación» En este orientarse la aprehensión se adecua a aquello que debe ser visto. Ésa es la «apariencia» de

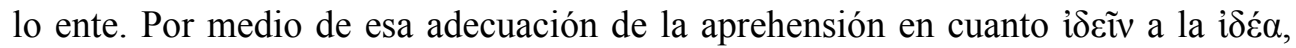

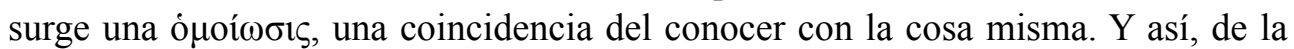

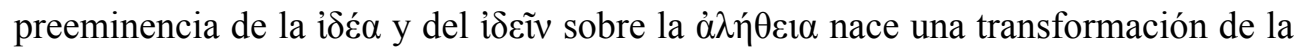

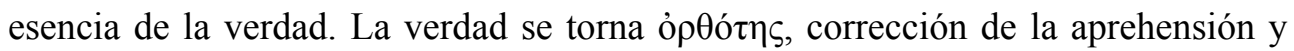
del enunciado ${ }^{244}$.

Aunque fundamentalmente distintas -y distantes- parecen las sospechas de Nietzsche y de Heidegger coincidir en la importancia del momento platónico. Ambos entienden que en el

242 Ibid. pp. 188-189.

${ }^{243}$ La traducción de Heidegger, si bien un extraordinario conocedor del griego antiguo, no deja de antojarse demasiado viciada por las exigencias de sus propios conceptos filosóficos y de sus sospechas. Ofrecemos la traducción de Eggers, ya clásica en nuestro idioma, como contraste. Platón, Diálogos IV. República, 515d, introd. trad. y notas de Conrado Eggers Lan, Madrid, Gredos, 1988, pp. 339-340: «y que ahora, en cambio, está más próximo a lo real, vuelto hacia cosas más reales y que mira correctamente».

Es en la traducción de «lo real» por «lo ente»-«más real»; «más ente»- donde Heidegger hace descansar su tesis de que en Platón acontece el cambio en el mirar occidental, pues acaba reduciendo el fondo de lo que hay, «lo real», al efectivo aparecerse, «lo ente»: el qué de lo real es el qué de lo ente.

${ }^{244}$ Heidegger, M., «La doctrina platónica de la verdad», op. cit., pág. 192. 
corpus del pensador griego se da el punto de inflexión que determinará el sentido del pensar de los siguientes dos milenios: la estrategia de la duplicación de mundos que depreció lo aparente, lo múltiple que deviene en favor de lo inteligible, de la unicidad del ser, por un lado; y, por otro, el cambio de la mirada que trasladó la pregunta por la verdad hacia lo ente de lo ente como real confluyen en sus conclusiones: la enajenación de la existencia en avatares irreales que atentan contra la «corporalidad», en Nietzsche; la reflexión sobre el ser en caracteres de apariencia. Con todo, uno y otro denuncian el modus de la razón filosófica de Occidente, afanada en la determinación conceptualista del objeto. Puede sentenciar por tanto Heidegger al respecto que la filosofía ha devenido instrumento, «ocupación» al perder su sustrato fundamental, lo cual ha supuesto, en consecuencia, la derrota existencial del hombre:

Cuando el pensar se encamina a su fin por haberse alejado de su elemento, reemplaza esa pérdida procurándose una validez en calidad de $\tau \dot{\varepsilon} \chi v \eta$, esto es, en cuanto instrumento de formación y por ende como asunto de escuela y posteriormente empresa cultural. Paulatinamente, la filosofía se convierte en una técnica de explicación a partir de las causas supremas. Ya no se piensa, sino que uno se ocupa con la «filosofía». [...] Especialmente en la Edad Moderna [...], la que se suele llamar «existencia privada» no es absoluto el ser-hombre esencial o, lo que es lo mismo, el hombre libre ${ }^{245}$.

La secularización moderna por el progreso hizo propios elementos fundamentales del cristianismo a la vez que trataba de renunciar al aparataje teológico de éstos. Los frutos de la racionalización del orden religioso se extendieron rápidamente por toda la geografía moderna: ciencia, Estado, ética, en definitiva, los distintos estamentos de la razón que confluyeron en la nueva disposición de la historia como el optimista desarrollo evolutivo de un logos analítico. Los ilustrados creyeron haber extirpado la condición mitológica de los distintos totems citados; la empresa consistía en alcanzar desde la desmitologización del mundo un nuevo ordenamiento tal que no admitiese ídolos incapaces de resistir el crítico tamiz de la ácida analiticidad. La peculiaridad de la «desdivinización» moderna fue agudamente estudiada por Heidegger, quien, no obstante, señala con asombrosa agudeza que la racionalización del horizonte religioso trajo consigo una reconfiguración de la relación entre los hombres y la divinidad:

Un quinto fenómeno de la era moderna es la desdivinización o pérdida de dioses. Esta expresión no se refiere sólo a un mero dejar de lado a los dioses, es decir, al ateísmo más burdo. Por pérdida de dioses se entiende el doble proceso en virtud del que, por un lado, y desde el momento en que se pone el fundamento del mundo en lo infinito, en lo incondicionado, lo absoluto, la imagen del mundo se cristiani$\mathrm{za}, \mathrm{y}$, por otro lado, el cristianismo transforma su cristiandad en una visión del mundo (la concepción cristiana del mundo), adaptándose de esta suerte a los tiempos modernos. La pérdida de dioses es el estado de indecisión respecto a dios y los dioses. Es precisamente el cristianismo el que más parte ha tenido en este aconteci-

${ }^{245}$ Heidegger, M., Carta sobre el Humanismo, op. cit., pp. 17-18. 
miento. Pero, lejos de excluir la religiosidad, la pérdida de dioses es la responsable de que la relación con los dioses se transforme en una vivencia religiosa. Cuando esto ocurre es que los dioses han huido. El vacío resultante se colma por medio del análisis histórico y psicológico del mito ${ }^{246}$.

Una relación ésta del individuo y del Dios que estaba todavía muy lejos del «ateísmo» tal y como concibe Nietzsche este fenómeno, como celebrada exaltación de la amorfa pluralidad valorativa que necesita de la ejecución de la actividad de la voluntad de poder como mecanismo catalizador para imprimir forma y jerarquía.

Como a Heidegger después, a Nietzsche no le satisfizo esta posición de exaltado elogio de la razón de cariz científico. Su oposición radical del cientificismo debe ser pensada como una denuncia contra la filosofía de la ciencia, y la filosofía en general, acusándolas de haber promovido a lo largo de su longeva tradición un planteamiento reflexivo sobre la ciencia erróneo, que pasó por subordinarse frente a aquélla. Algo que se hizo dramáticamente patente en la modernidad. El esfuerzo por distinguir la verdadera cuestión de la ciencia pasaba por diferenciar su dominio del filosófico para que esta disciplina se independizara de la ciencia, y no a la inversa. El conflicto de la identidad de la filosofía enajenada en la ciencia tal y como lo planteó Nietzsche fue un legado continuado por Heidegger, quien lo llevó a las reflexiones más prolijas. Advirtió cuán perniciosa había sido la relación que durante la modernidad la filosofía había entablado con la ciencia, observando que su subordinación al dominio tecno-científico incubaba el fin de la filosofía como tal, el final de la filosofía en la ciencia:

Uno de los fenómenos esenciales de la Edad Moderna es su ciencia. La técnica mecanizada es otro fenómeno de idéntica importancia y rango. Pero no se debe caer en el error de considerar que esta última es una mera aplicación, en la práctica, de la moderna ciencia matemática de la naturaleza. La técnica mecanizada es, por sí misma, una transformación autónoma de la práctica, hasta el punto de que es ésta la que exige el uso de la ciencia matemática de la naturaleza. La técnica mecanizada sigue siendo hasta ahora el resultado más visible de la esencia de la técnica moderna, la cual es idéntica a la esencia de la metafísica moderna ${ }^{247}$.

\footnotetext{
${ }^{246}$ Heidegger, M., «La época de la imagen del mundo», trad. de Helena Cortés y Arturo Leyte, en Caminos de bosque, op. cit., pág. 64.

247 Ibid. pág. 63.
} 
Nietzsche, cual prístino augur, entendió que la secularizadora modernidad estaba haciendo de la ciencia una nueva teología; pensamiento que concluirá Heidegger lamentando que la ciencia se había convertido en la nueva religión de nuestros días ${ }^{248}$.

Sin embargo, esta sospecha nietzscheana no se haría explícita hasta sus últimos momentos de lucidez, cuando en la madurez de La genealogía de la moral presenta el paralelismo entre ciencia y religión. La tercera sección de esta obra está dedicada precisamente a la crítica de los ídolos -ora teológicos ora científicos-, presentando aquellos elementos gemelos de una y otra. Así se explica, prosigue Nietzsche, que igual que todo crítico de la religión se veía acusado de antirreligioso, a los osados cuestionamientos de la ciencia les iba asociada la acusación de anticiencia. Como supo ver Heiddeger, se trataba de una valoración nihilista surgida al abrigo del extrañamiento del ser en lo ente de lo ente:

[...] ¿qué más «lógico» que quien niega en todo lugar lo verdaderamente ente se sitúe del lado de lo no-ente y con ello predique la mera nada como sentido de la realidad?

¿Qué es lo que pasa aquí? Oímos hablar de «humanismo», de «lógica», de «valores», de «mundo», de «dios». Además, oímos hablar de una oposición. Conocemos y asumimos todo lo nombrado como lo positivo. Por contra, todo lo que se ha dicho contra lo nombrado, aún antes de haber reflexionado a fondo sobre lo que se ha oído, lo asumimos en el acto como su negación y tal negación como lo «negativo», en el sentido de destructivo. Efectivamente, en Ser y tiempo se habla expresamente de la «destrucción fenomenológica». Con la ayuda de la tan invocada lógica y ratio consideramos que lo que no es positivo es negativo, que por lo tanto rechaza la razón y en consecuencia merece llevar el sello del desprecio. Estamos tan imbuidos de «lógica» que todo lo que va en contra de la habitual somnolencia del opinar pasa a ser considerado en el acto como una oposición que debe ser rechazada. Se desecha todo lo que se sale fuera del conocido y querido elemento positivo arrojándolo a la fosa previamente preparada de la mera negación, que lo niega todo, acabando en la nada y consumando de ese modo el nihilismo. Siguiendo esta vía lógica se deja que todo acabe hundiéndose en un nihilismo inventado con ayuda de la lógica $^{249}$.

En la racionalización ilustrada de los contenidos religiosos cristianos se mantuvo, no obstante, su condición teológica; la secularización moderna, entiende Nietzsche, no fue tal toda vez que mantuvo en la Razón y el Progreso, al abrigo de los desarrollos en el conocimiento científico, las cualidades salvíficas del mensaje de las Escrituras. La misma voluntad de poder que condujo los primeros movimientos cristianos coloniza ahora la menta-

248 Cfr. Heidegger, M., Seminarios de Zollikon, trad. de Ángel Xolocotzi Yáñez, México D. F., Herder, 2013, pág. 197: «lo exacto de las ciencias exactas no puede ser determinado exactamente, es decir, mediante cálculo, sino sólo ontológicamente, y así también el tipo de verdad que se aplica a la 'ciencia' en el sentido de la ciencia natural exacta. Su verdad se verifica por la eficiencia de sus resultados. Cuando este modo de pensar científico determina el concepto de ser humano y éste es 'investigado' de acuerdo con el modelo de círculo de leyes, como ahora sucede en la cibernética, entonces la destrucción del ser humano es perfecta. Por eso combato la ciencia, pero no la ciencia en cuanto ciencia, sino sólo la absolutización de la ciencia natural».

${ }^{249}$ Heidegger, M., Carta sobre el Humanismo, op. cit., pp. 64-65. 
lidad cientificista moderna, esto es, sus propios contenidos científicos, así como las máximas morales y los preceptos políticos:

[...] aquello sobre lo que se basa nuestra creencia en la ciencia sigue siendo una creencia metafísica, - que incluso nosotros, hombres del conocimiento de hoy, nosotros, sin dios y antimetafísicos, también recogemos nuestro fuego del incendio que ha provocado una creencia milenaria, esa creencia cristiana que era también la creencia de Platón, de que dios es la verdad, de que la verdad es divina... ${ }^{250}$.

Algo que repite en La genealogía de la moral, con una importancia ahora capital. En esta tardía obra desarrolla la tesis última de la secularización, apuntando que la racionalización del cristianismo no comporta simplemente el final del cristianismo como religión, sino de la cristiandad, entendiendo por ella el universo teológicopolítico que dio unidad conceptual y moral a Occidente:

Nuestra fe en la ciencia reposa siempre sobre una fe metafísica -también nosotros los actuales hombres del conocimiento, nosotros los ateos y antimetafísicos, también nosotros extraemos nuestro fuego de aquella hoguera encendida por una fe milenaria, por aquella fe cristiana que fue también la fe de Platón, la creencia de que Dios es la verdad, de que la verdad es divina ${ }^{251}$.

Ante esto, Nietzsche pone en seria cuestión si la sustitución de la fe en Dios por la ciencia y su correspondiente racionalidad es, en realidad, una auténtica conquista, ya que ésta también reposa sobre una fe metafísica de ascendencia común.

A causa de esta duda sobre la oscura y difusa identidad de la concepción de la ciencia moderna Nietzsche recoge la batuta de la Ilustración y continúa la inacabada tarea de secularización: el esfuerzo secularizador de los hombres del siglo XVIII, que había llevado a un imperial triunfo de la razón, se hace reflexivo en Nietzsche ${ }^{252}$. La crisis de la razón de la centuria decimonónica consistió en esto, en una desmitologización de la divinidad ilustrada. El pensador de Röcken observa isomorfismos estructurales entre la acepción cientificista de la razón y el Dios metafísico. De manera que la crítica llevada a cabo sobre los parámetros de la teología «cristiana» debía desplegarse seguidamente sobre la teodicea científico-metafísica del mundo copernicano. La conclusión de Nietzsche apunta a un nuevo derrumbe de los pilares del pensamiento: si la primera oleada secularizadora terminó con la refundación de la metafísica en clave crítica en torno al sujeto epistémico, la si-

${ }^{250}$ Nietzsche, F., La gaya ciencia, op. cit., pág. 860 (KSA III, 577).

${ }^{251}$ Nietzsche, F., La genealogía de la moral, op. cit., pág. 219 (KSA V, 400-401).

252 Procedimiento compartido posteriormente por Horkheimer, al entenderlo como el único posible para enjuiciar pertinentemente el momento patológico al que ha abocado la racionalidad instrumental: «la razón sólo puede realizar su racionalidad mediante la reflexión sobre la enfermedad del mundo tal como ésta es producida y reproducida por el hombre; en tal autocrítica la razón permanecerá, a la vez, fiel a sí misma toda vez que se atiene al principio de la verdad, que debemos únicamente a ella misma, lejos de dejarse guiar por cualquier otro móvil» (Horkheimer, M., Crítica de la razón instrumental, op. cit., pág. 180). 
guiente etapa había de consistir en el deceso mismo del sujeto metafísico moderno. La crisis de la ideología del progreso o el incipiente escepticismo en cuanto a las mieles de la razón que empiezan a configurarse al término del Siglo de las Luces se deben pensar en esta atmósfera de continuismo crítico de los ídolos ${ }^{253}$ : «temo que no vamos a desembarazarnos de Dios porque continuamos creyendo en la gramática....» ${ }^{254}$. La gramática de ese «Dios», ora platónico ora cristiano, que ha impreso un régimen censor de la materia y de la pluralidad; una sintaxis inflexible que ha hecho del fondo inconsciente sobre el que se construye el individuo mediante el ejercicio de la voluntad de poder un mero complemento sin función significativa. El ateísmo del horizonte nihilista tan sólo es nominativo, pues sigue venerando las pretéritas prescripciones dictadas por el estamento metafísico último a pesar de jactarse del cariz «crítico» de su racionalidad. Dada la vacuidad de los ídolos del «mundo verdadero» no es necesario, podemos continuar desde Crepúsculo, su mantenimiento, ya que la adoración ciega ha impregnado las aquiescentes conciencias de los crédulos trazando determinantemente las condiciones de posibilidad de su horizonte hermenéutico. La duplicación de mundos, la escisión del cuerpo y del espíritu que hizo de la existencia encarnada algo ajeno al propio sujeto viviente sigue abierta. Ha señalado agudamente Heidegger que «el pensar $[\ldots]$ busca la palabra adecuada en el seno del lenguaje de la metafísica y de su gramática, transmitido durante largo tiempo» ${ }^{255}$. A pesar de la muerte de Dios Nietzsche teme que Europa siga rigiéndose bajo su respectiva gramática metafísica como problema típico tras la conciencia de la crisis nihilista: el nihilismo reactivo de la compasión y del rechazo propio de individuos blandos incapaces de soportar la carga de su propia gravedad. La conservación efectiva de la gramática metafísico-divina es tan sólo una inversión y, por tanto, insuficiente: allí donde antes se hablaba de «bueno» ahora se trata de «malo» y viceversa; una inversión valorativa que no afecta al sustrato categorial, puesto que mantiene los contenidos de significado moral acuñados a lo largo de la tradición. La muerte de Dios debe ser la simiente de un acontecimiento estético -artístico-filosófico- que transmute la experiencia del nihilismo en fuente de vida: una veta de fuerza activa que impulse la creación de un nuevo horizonte de precomprensión capaz de generar una nueva posición de valoración sustantiva. Con todo, tras la muerte de Dios no basta con permutar el significado de los términos tradicionales; se ha de procurar a los nuevos hombres ateos las reglas de una gramática original distinguida por categorías genuinas. Es decir, a la muerte de Dios debe seguirle la transvaloración, un paisaje donde no se extrañe la deidad perdida ni pervivan sus ecos, sino que se celebre la inocencia esencial de un fondo de existencia del cual no

${ }^{253}$ Así al comienzo de Crepúsculo, cuando insiste en la necesidad de «preguntar» con el martillo, de filosofar a martillazos: «hacer aquí alguna vez preguntas con el martillo y oír acaso, como respuesta, aquel famoso sonido a hueco que habla de entrañas llenas de aire» (Nietzsche, F., Crepúsculo de los ídolos, op. cit., pág. 32 [KSA VI, 57-58]).

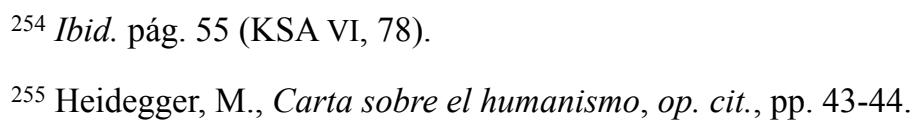


podemos pretender una claridad absolutamente escrupulosa. Nietzsche teme, pues, insistimos, que a causa de su ceguera los hombres modernos no alcancen a explotar las fecundas posibilidades abiertas tras el fin del garante metafísico; que de su inexistencia no se siga su deslegitimación, o sea, que se perpetre una mera inversión de valores cuando, por el contrario, habría de acometerse la transvaloración de todos los valores, la cual supone no sólo poner fin al dominio de Dios, sino también al de su «gramática».

Nietzsche no piensa en términos de una nueva secularización emanada del fracaso de la primera. Se trata de la continuación de un proyecto que no ha tocado su etapa definitiva. De ahí su insistencia en una radicalización de la secularización que abarque la totalidad del mundo, conllevando un enfrentamiento crítico con los resultados mismos de la propia secularización toda vez que ésta no ha logrado depurar los elementos teológicos del antiguo mundo «cristiano»:

¡Pero un mundo esencialmente mecánico sería un mundo esencialmente carente de sentido! Suponiendo que se apreciara el valor de una música ateniéndose a la cantidad de ella que pudiera ser contada, calculada, llevada a fórmulas -iqué absurda sería una apreciación «científica» tal de la música! ¿Qué se habría concebido, comprendido, conocido de ella? ¡Nada, absolutamente nada de lo que en ella es propiamente «música»! 256 .

Escasas líneas atrás insistimos en el problema de la «gramática» y las dificultades que supondría la continuidad del esquema categorial de la metafísica tradicional. Como respuesta activa ante el nihilismo, Nietzsche exige el endurecimiento del hombre moderno para hacer frente de un modo creativo a la onerosa disrupción de los valores que habían legitimado la larga historia de la filosofía occidental. La dureza del hombre inserto en el desangelado presente de la Europa decimonónica había, entre otras cosas, de rechazar la gramática del pensamiento del ser como mecanismo existencial de reapropiación de la «corporalidad». Sin embargo, tal acontecimiento, el fin de la gramática de Dios, se antoja profundamente complejo para Nietzsche en la medida en que comporta la transvaloración. Nietzsche se topa con una dificultad: ¿cómo armonizar la continuación del proyecto moderno de secularización con la transvaloración del paradigma filosófico continental que, a la postre, parece suponer el fin de la propia modernidad? La solución de semejante diatriba la ofrece el propio espíritu intelectual del autor, duramente moderno: el fin de la gramática de Dios debería significar en realidad la consumación del verdadero programa moderno, esto es, la extensión a todos los orbes de dicho horizonte de precomprensión de las máximas capitales de crítica de la razón genuinamente moderna. Luego la crítica nietzscheana de la muerte de Dios -y de su respectiva gramática- no es sino la ejecución ulterior del leitmotiv moderno, a saber, el cuestionamiento de todos los estamentos que habían sido sostenidos mediante procedimientos ilegítimos de una razón tramposa y desviada de la realidad efectiva. Ahora

${ }^{256}$ Nietzsche, F., La gaya ciencia, op. cit., pág. 888 (KSA III, 626). 
bien, ¿por qué no ocurrió tal cosa?, ¿por qué el ateísmo moderno sigue siendo creyente?, ¿por qué es un «ateísmo cristiano»? A este respecto concluye Nietzsche que la propia raíz de la modernidad se sostuvo sobre la duplicación platónica y, por ende, arrastraba en sí el germen del nihilismo. La coherencia con las máximas modernas, de acuerdo con cómo sus autores las presentaron, exigiría la concreción de este momento del pensamiento en la muerte de Dios y en la figura del artista-filósofo, esto es, en la desaparición de la gramática de la metafísica de la escisión. Sin embargo, que Nietzsche nos advierta de los riesgos en los caracteres esgrimidos en Crepúsculo de los ídolos no refleja sino una distancia fundamental entre los planteamientos conceptuales y su fondo sustantivo: subrepticiamente la racionalidad moderna no era sino la de Platón, aquella misma que otrora hubo enajenado la existencia al rechazar su condición aparente, polimórfica, polifacética, plural, deviniente en favor de la imperturbable unicidad inmanente del ser. Por lo que la deconstrucción de la razón moderna llevada a cabo por nuestro autor puede tomarse como la plena realización de ésta misma: la crítica de los ídolos termina desvelando la propia idolatría que comportaba la -diosa- razón como tal. Sólo así puede responderse el dilema presentado al respecto de la secularización y la transvaloración: el momento final de la secularización tendría que ser la transvaloración de todos los valores de la razón cientificista, que era la del intelectualismo platónico, cuyos cuestionamientos apuntaban a «lo ente de lo ente». Sobre el pertinente despliegue de las pesquisas críticas de la razón moderna, tal y como Nietzsche exige, una crítica de la crítica de la razón pura que agote las expectativas ilusas, ha señalado Barthes que «ser moderno es saber qué es lo que ya no es posible» ${ }^{257}$.

Con todo, Nietzsche afirma ser el primero en haber «problematizado» la ciencia, o sea, en haberla planteado como una cuestión filosófica crítica, objeto por tanto del más exhaustivo escrutinio. La secularización, prosigue nuestro autor, consiste precisamente en tomar por cuestionable el carácter cientifico de la ciencia. La secularización es entendida por Nietzsche como un proceso por el cual todas las instancias que se inmiscuyen en la vida humana carecen de carácter sacro. La realidad se convierte en la suma de las distintas dimensiones que en su devenir contribuyen en la configuración de los rasgos de la identidad del sujeto, inaprensible e incognoscible en su totalidad y, sin embargo, encarnada en el proyecto subjetiva de una vida concreta.

Ha de extenderse, por tanto, la secularización que plantea Nietzsche al acontecimiento filosófico último, a saber, el sujeto encarnado que vive y que se ha alzado sobre un fondo oscuro plenamente inaccesible. La secularización debe destacar tanto en el dominio de claridad de la existencia como en la dimensión inconsciente sobre la que pivota la conciencia humana y renunciar consecuentemente a la fábula del sujeto autocognoscente. La secularización pone entonces de manifiesto la necesidad de legitimar desde instancias pro-

257 Barthes, R., Lo obvio y lo obtuso. Imágenes, gestos, voces, trad. de C. Fernández Medrano, Barcelona, Paidós, 1986, pág. 236. 
fanas la polisemia de sentidos que configuran el mundo. Como ha dicho Vattimo, un nosotros a posteriori:

Por supuesto, decir que "queremos" (o debemos, o no podemos menos que, etcétera) mantenernos fuera del juego y del mecanismo de la metafísica, implica hablar en nombre de un sujeto, de un "nosotros" que, en sí mismo, parece ya de por sí enteramente integrado dentro de esa lógica metafísica de la que se desea huir. Nietzsche es plenamente consciente de ello; es posible, inclusive, que a causa precisamente de ello insista tanto, en sus escritos del último período, en la oposición entre "superhombre" y "esclavos", o que configure su doctrina [...] bajo la forma del "complot"; todos los citados son distintos modos de excluirse explícitamente del horizonte de las afirmaciones "universales", características de la filosofía metafísica de la tradición. Además, y por sobre todo, la proposición más abarcadora y escandalosa de sus textos, la sentencia "Dios ha muerto", no constituye una tesis metafísica argumentada y "demostrada" al nosotros ideal de la razón humana; es el relato de una experiencia, la apelación a otros a fin de que la descubran en sí mismos, estableciendo, sobre esa base, un nosotros al cual, y en nombre del cual, pueda Nietzsche hablar ${ }^{258}$.

Así pues, en una línea diametralmente opuesta a la de una modernidad acríticamente guiada por la ciencia -que, recordemos, es la novedosa manifestación del encomio platónico-, Nietzsche le procuró a la filosofía su respectiva autonomía de la ciencia, subordinando ésta ante aquélla, esto es, haciendo de la ciencia una cuestión esencialmente filosófica, toda vez que «el problema de la ciencia no puede ser conocido en el terreno de la ciencia ${ }^{259}$. Frente a la ortodoxia racionalista, la estrategia nietzscheana pasará por «ver la ciencia con la óptica del artista» ${ }^{260}$. En un impensable juego para la Ilustración, equiparó la ciencia y el arte, haciendo de la honestidad ${ }^{261}$ el único criterio diferenciador. Una honestidad que convierte el arte en una ilusión no hostil contra la vida, a diferencia del ideal de

258 Vattimo, G., «Metafísica, violencia, secularización», trad. de Carlos Cattroppi y Margarita N. Mizraji, en La secularización de la filosofía, comp. por Vattimo, G., Barcelona, Gedisa, 2001, pág. 64.

${ }^{259}$ Nietzsche, F., El nacimiento de la tragedia, op. cit., pág. 27 (KSA I, 13).

${ }^{260}$ Ibid. pág. 28 (KSA I, 14).

${ }^{261}$ Cfr. Ibid. pp. 133-134 (KSA I, 99): «Por ello Lessing, el más honesto de los hombres teóricos, se atrevió a declarar que a él le importa más la búsqueda de la verdad que esta misma: con lo que ha quedado al descubierto el secreto fundamental de la verdad, para estupor, más aún, para fastidio de los científicos. Ciertamente, junto a este conocimiento aislado está, como un exceso de honestidad, si no de altanería, una profunda representación ilusoria, que por vez primera vino al mundo en la persona de Sócrates, - aquella inconcusa creencia de que, siguiendo el hilo de la causalidad, el pensar llega hasta los abismos más profundos del ser, y que el pensar es capaz no sólo de conocer, sino incluso de corregir el ser. Esta sublime ilusión metafísica le ha sido añadida como instinto a la ciencia, y una y otra vez la conduce hacia aquellos límites en los que tiene que transmutarse en arte: en el cual es en el que tiene puesta propiamente la mirada este mecanismo».

Para la declaración a la que se alude de Lessing, cfr. Lessing, G. E., Acerca de la verdad, trad. de Agapito Maestre y José Romagosa, en ¿Qué es Ilustración?, Agapito Maestre (ed.), Madrid, Tecnos, 2009, pp. 67-68: «Un hombre que, tan inteligente como humildemente, intenta imponer la no verdad con buena intención entre creencias encontradas es infinitamente más valioso que cualquier otro hombre, que defienda la mejor y más noble verdad con prejuicios, desacreditando a sus enemigos de forma vulgar.

[...] Si Dios tuviera encerrada en su mano derecha toda la verdad y en su izquierda el único impulso que mueve a ella, y me dijera: ‘¿Elige!', yo caería, aun en el supuesto de que me equivocase siempre y eternamente, en su mano izquierda, y le diría: ‘¡Dámela, Padre! ¡La verdad pura es únicamente para ti!’». 
verdad de la religión o de la ciencia ${ }^{262}$. La equiparación del arte y la ciencia se deberá, en última instancia, a que «la vida tiene necesidad de ilusiones, es decir, de tomar por verdades las no-verdades» ${ }^{263}$. Más aún, no se trata exactamente de una equiparación ontológica de horizontes, sino de ver la ciencia desde el arte.

A lo largo de las páginas que dedicamos a la «corporalidad» destacamos la importante exigencia nietzscheana según la cual había que subordinarlo todo a la «estética», contemplar todo cuanto acontece bajo caracteres que devolvieran al sujeto su condición creadora desde las facultades de su voluntad de poder. Dentro de esta expectativa de reapropiación de la existencia debe ser tomada la fórmula del «Ensayo de autocrítica» de contemplar la ciencia -piedra angular del paradigma de pensamiento moderno- bajo la óptica del artista. No se trata de un alegato primitivista ni reaccionario que rechace los logros del saber científico, sino de la revaloración de la episteme que había impuesto la frialdad de la ciencia sobre la vida encarnada: el discurso tecno-científico no es sino otro de los tantos más que conforman el libro de la naturaleza, el cual constituye, a su vez, únicamente un capitulo del índice del «mundo», como horizonte hermenéutico de vida. El saber objeto de la filosofía natural es repensado por Nietzsche, especialmente tras el éxtasis ilustrado, para imbricarlo dentro del devenir humano: la vida no puede ser orientada desde el preciso dictamen de la inflexible exactitud de la lógica del «número» y del «cálculo», pues dichos estándares no apresan la agilidad y plasticidad del horizonte de indeterminación al cual está abierto en su contante encarnación el sujeto hermenéutico. La racionalidad cientificista es un meandro de la «gramática» del Dios muerto, por lo que el abandono de aquélla se sigue de la superación de ésta. Dejar de ver mecánicamente el mundo, esto desde el «optimismo» de la lógica, para contemplar la vastedad de un universo de arcilla que ha de ser moldeado en el constante juego de la valoración y de la jerarquización que demanda una vida encarnada; es, pues, la transvaloración del horizonte de precomprensión dogmático que había ceñido la existencia en la idealidad de lo eidético, en otro asentado en una apariencia que no está denostada en lo inteligible, mas tampoco priorizada sobre aquello que es objeto de la cognoscencia intelectual: bajo la regencia de la óptica del arte la apariencia -cuerpo-y lo inteligible - alma - se unen solidariamente en una «identidad sintética», que Nietzsche esboza en su peculiar imagen de la «corporalidad», reintegrando la existencia en toda su inmensidad -lo cognoscible y lo incognoscible- en los márgenes de la vida efectiva y concreta de cada sujeto particular. Un individuo encarnado que ha de ser duro para integrarse en el sustrato «trágico» de una vida que no responde a las condiciones benevolentes del intelectualismo moral, sino que en su inocencia, hace al sujeto absolutamente libre y responsable del cuidado de su propia actividad estética.

\footnotetext{
${ }^{262}$ Cfr. Nietzsche, F., Fragmentos póstumos I, 19 [43], op. cit., pág. 355 (KSA VII, 433): «toda aspiración efectiva de la verdad llega al mundo por la lucha en torno a una convicción sagrada».

263 Ibid. (KSA VII, 433).
} 
El mundo de la modernidad, cuyo horizonte está colonizado por la lógica epistémica de la doctrina de la corrección y de la adecuación, es la más tardía manifestación de los mundos «aparente» y «verdadero» platónicos, el legado postrero de la metafísica clásica que ha de derrocarse «a martillazos». Para lo cual ha invocado Nietzsche el carácter de los griegos trágicos, cuyo signo le sirve para pergeñar la figura del artista-filósofo, a través de quien la voluntad de poder más fuerte logra arrojar una nueva imagen de la existencia, donde el espíritu se ha corporalizado y el cuerpo espiritualizado: la transvaloración, en suma, es la reapropiación de la existencia como «corporalidad» creada y en creación. Frente a la intangible verdad platónica del ser, que únicamente puede ser contemplada en la esforzada intelección del alma, Nietzsche postula la verdad de la ilusión, sometida ésta a la exigente dinámica del movimiento perenne que dinamiza la pulsión de vida.

Las ilusiones son un elemento constitutivo de la vida, a diferencia de la verdad, que no resulta siempre ventajosa para la existencia; es más, ya en Sobre verdad y mentira en sentido extramoral, una jovencísima obra, destacaba que algunas verdades podían resultar hostiles e incluso destructivas ${ }^{264}$. Es necesario entonces admitir «que no es posible vivir con la verdad; que la 'voluntad de verdad' es ya un síntoma de degeneración» ${ }^{265}$. Y dado que no se puede vivir con la verdad, la alternativa existencial es el arte; someterlo todo al espectro del arte. Con lo que tomar la ciencia como arte es la estrategia nietzscheana para no sucumbir por la verdad; el imperativo estético del artista-filósofo para armonizar pertinemente su vida con el devenir del sustrato indeterminado sobre el que hunde las raíces de su existencia encarnada. Entonces, ¿por qué el arte? El imperativo del arte no es tanto una consigna estética como existencial: «tenemos el arte para no perecer a causa de la verdad» ${ }^{266}$. En la medida en que buscamos garantizar nuestra propia supervivencia, la ciencia ha de devenir arte; debe hacerse de ella «una defensa sutil obligada contra la verdad» ${ }^{267}$. Así pues se ha de llevar a término el exponente conceptual del «Ensayo de autocrítica» de tomar la ciencia desde el horizonte del artista. Sólo mediante el recurso del arte se puede eludir la definición teológica de la ciencia, que es «la forma más reciente y más noble» del ideal ascético:

[...] testimonio de ello sería toda nuestra ciencia moderna, - esa ciencia moderna que, por ser una auténtica filosofía de la realidad, evidentemente no cree más que en sí misma, evidentemente tiene el coraje de ser ella misma, la voluntad de ser

${ }^{264}$ Cfr. Nietzsche, F., Sobre verdad y mentira en sentido extramoral, trad. de Luis M. Valdés y Teresa Orduña, Madrid, Tecnos, 2007, pág. 21 (KSA I, 878): «El hombre nada más que desea la verdad en un sentido análogamente limitado: ansía las consecuencias agradables de la verdad, aquellas que mantienen la vida; es indiferente al conocimiento puro y sin consecuencias e incluso hostil frente a las verdades susceptibles de efectos perjudiciales o destructivos»».

${ }^{265}$ Nietzsche, F., Fragmentos póstumos IV, 16 [40], op. cit., pág. 682 (KSA XIII, 500).

266 Ibid. (KSA XIII, 500).

${ }^{267}$ Nietzsche, F., El nacimiento de la tragedia, op. cit., pág. 27 (KSA I, 13). 
ella misma, y hasta ahora se las ha arreglado bastante bien sin Dios, sin el más allá, sin virtudes negadores. Ahora bien, ese ruido y esa locuacidad de agitadores no me producen ninguna impresión: esos trompeteros de la realidad son malos músicos [...], en los hocicos de tales trompeteros el vocablo «ciencia» es sencillamente una impudicia, un abuso, una desvergüenza. La verdad es cabalmente lo contrario de lo que aquí se afirma: la ciencia no tiene hoy sencillamente ninguna fe en sí misma, y mucho menos un ideal por encima de sí, - y allí donde aún es pasión, amor, fervor, sufrimiento, no representa lo contrario de aquel ideal ascético, sino más bien la forma más reciente y más noble del mismo. [...] el hecho de que ahora se trabaje con rigor en la ciencia y de que existan trabajadores satisfechos no demuestra en modo alguno que la ciencia en su conjunto posea hoy una meta, una voluntad, un ideal, una pasión propia de la gran fe [...], la ciencia es hoy un escondrijo para toda especie de mal humor, incredulidad, gusano roedor, despectio sui [desprecio de sí], mala conciencia, - es el desasosiego propio de la ausencia de un ideal, el sufrimiento por la falta del gran amor, la insuficiencia de una sobriedad involuntaria. [...] La ciencia como medio de aturdirse a sí mismo 268 .

Recordemos que el imperativo estético nietzscheano remite a la transvaloración, una loa de la condición eminentemente artística del hombre, en tanto que su fondo de existencia descansa sobre la deviniente multiplicidad de posibilidades de ser-en-el-mundo, la cual exige una actitud activa que imprima forma efectiva al sustrato desnudo que es el sujeto trágico; una transvaloración, ya que se ha de prescindir de las pretéritas caracterizaciones que del hombre dibujó la metafísica del ser. La filosofía moderna, de cariz genuinamente epistemológico, es el desvelo nostálgico de la esforzada estrategia de la duplicación, y como tal ha mantenido el régimen de enajenación de las formas clásicas: del mismo modo que Platón hizo del mundo supramundano el «verdadero» lugar de cobijo del ser de la existencia al tiempo que privaba de todo sentido el dominio de la existencia efectiva -«mundo aparente»-, bajo la ciencia moderna palpita el esfuerzo por radicar la vida en un dominio ajeno al del mundo, pues la lógica de la adecuación y de la corrección no es sino la forma más reciente y más noble de la verdad inteligible. El empeño por superar el ideal ascético sólo puede concluirse erradicando los modismo del mismo, dejando finalmente atrás la relación dicotómica bueno-verdad y malo-mentira; no una inversión significativa, sino una transvaloración, esto es, la supresión del marco mismo de la valoración dicotómica.

\section{I.2.1. La máscara como anhelo de verdad}

Como vimos al comienzo de nuestro trabajo, el cruce de la pluralidad de sentidos compone la base esencial de la estructura del ser humano. La secularización había de ser, por tanto, el último esfuerzo de la racionalización occidental por recuperar la original plurivocidad identitaria, silenciada por el empeño «cristiano» de univocidad. La construcción moral del mundo por el cristianismo ha silenciado la polifonía en favor de un único grito

${ }^{268}$ Nietzsche, F., La genealogía de la moral, op. cit., pp. 214-216 (KSA V, 396-397). 
de sentido; ha impuesto una máscara «simple, áspera, fea, repugnante» ${ }^{269}$ que ha reducido la condición humana, restringiéndola en categorías unívocas de validez: «sin duda hay una veracidad más laudable en cada uno de los pequeños signos de interrogación que colocáis detrás de vuestras palabras favoritas y de vuestras doctrinas preferidas» ${ }^{270}$.

La muerte de Dios pasa por ser la denuncia del enmascaramiento de la esencial ausencia de sentido del ser humano y el mundo. En primer lugar, con la tarea masiva de racionalización de todos los órdenes a la que se consagró la modernidad los mundos inteligibles y metafísicos sucumbieron, y con ellos, las fuentes de sentido. La radical experiencia de orfandad significativa que atraviesa el sujeto decimonónico responde a la conciencia de fragilidad y caducidad de las interpretaciones ulteriores de espectro universal que habían dado razones y justificaciones del mundo. Nietzsche explicó este fenómeno con unas palabras cuyo rigor -tan sólo semejable a su belleza- hizo que el propio Heidegger, como él mismo reconociera, las grabara con fuego en su memoria:

Y por lo que hace a nuestro futuro, difícilmente se nos volverá a encontrar en la senda de aquellos jóvenes egipcios que por la noche vuelven inseguros los templos, abrazan las estatuas y quieren desvelar, descubrir, llevar a la luz clara absolutamente todo lo que con buenas razones se mantiene cubierto. No, ese mal gusto, esa voluntad de verdad, de «verdad a cualquier precio», ese delirio de adolescente en el amor a la verdad -nos provoca rechazo: somos demasiado experimentados, demasiados serios, demasiado divertidos, demasiado profundos, estamos demasiado quemados para ello... Ya no creemos que la verdad siga siendo verdad si se le quita el velo; hemos vivido demasiado para creerlo. Hoy es para nosotros una cuestión de decencia no querer ver todo en su desnudez ${ }^{271}$, no querer estar presente en todo, no querer comprender y «saber» todo ${ }^{272}$.

Con el ocaso del concepto de «Dios», sucumben tanto la caracterización de la vida como la pretensión de verdad única y última. Sin embargo, esto supone para Nietzsche un momento de celebración al arrojarnos a un plano de infinitas interpretaciones. Descubre la fuerza de una nueva forma de filosofía según la cual la realidad, en cuantas formas sea conceptualizada, se reduce a un juego de interpretaciones superpuestas, anulando la posibilidad de un sustrato gnoseológico fundamental indubitable, claro y distinto. Una aproximación hacia la verdad remotamente hermenéutica; y es que Nietzsche, como hombre moderno, comparte la motivación del anhelo de verdad. No obstante, su búsqueda lo hará transitar por una senda específica, inédita hasta entonces, donde la verdad se acaba desvelando como una máscara. De este descubrimiento extrae Nietzsche una verdad conceptual para la filosofía, una nueva estrategia sostenida sobre la condición plástica de la voluntad de poder, quizá la últi-

${ }^{269}$ Ibid. pág. 40 (KSA V, 258).

${ }^{270}$ Nietzsche, F., Más allá del bien y del mal, op. cit., pág. 52 (KSA V, 42).

${ }^{271}$ Nos topamos aquí con una nueva reivindicación de lo inconsciente, tópico capital de este trabajo.

272 Nietzsche, F., La gaya ciencia, op. cit,, pág. 721 (KSA III, 351-352). 
ma, para llevar el iluminismo a los rincones más tenebrosos: la reducción de todo el espectro de realidad a interpretaciones, toda vez que se comprende que «todo lo que es profundo ama la máscara; las cosas más profundas de todas sienten incluso odio por la imagen y el símil» ${ }^{273}$. Por eso, en su esfuerzo por recuperar la existencia subjetiva, el artista ha de anteceder al filósofo, pues sólo el primero es capaz de integrarse en el juego voluble de la voluntad de poder, a diferencia del segundo, que se ha limitado a contemplarla como objeto cognoscitivo. Es este último caso el de Descartes, quien se adueña de la realidad al crearla desde el pensamiento -argumento ontológico-.

La imagen filosófica que presenta Nietzsche como un continuo sucederse interpretativo comporta su propia ontología, donde la lógica de la mascarada hace del ocultamiento de las causas y principios la esencia de la realidad. El anhelo moderno de verdad como suposición última, causa primera, garante ulterior se consume en su propia ilusión:

[Goethe] Vivió así en el arte como en el recuerdo del verdadero arte: su poetizar se había convertido en recurso del recuerdo, de la comprensión de épocas artísticas antiguas, ha mucho desvanecidas. Sus postulados eran ciertamente irrealizables en relación con la fuerza de la nueva época; pero el dolor por ello fue ampliamente compensado por el gozo de que en un tiempo fueron realizados y de que también nosotros podemos todavía participar de esa realización. Nada de individuos, sino máscaras más o menos idealizadas; nada de realidad, sino una generalidad alegórica; caracteres de época, colores locales evaporados hasta lo casi invisible y convertidos en míticos; el sentir actual y los problemas de la sociedad actual comprimidos en las formas más simples, despojados de sus cualidades atractivas, excitantes, patológicas, dejadas sin efecto en cualquier otro sentido menos artístico ${ }^{274}$.

Tan sólo podemos esperar hallar una máscara que esconde otra distinta que, a su vez, encubre una siguiente. Si el sustrato de la realidad ha sido abonado por el juego de máscaras, no es menos cierto que la esencia de la máscara es su vacuidad: lo propio de la máscara es estar vacía. En la ontología hermenéutica hay una reordenación categorial donde el concepto cede su trono a la forma: el contenido pierde la hegemonía que ostentó durante el statu quo moderno en favor del fenómeno mismo de la máscara, por cuyo vaciamiento recoge el sentido trágico de la vida. La condición trágica hace que sea el propio individuo, artista de su existencia, quien determine por medio de la jerarquización de valores el contingente rostro cubierto por la máscara; rostro sujeto al constante juego abierto del devenir marcado por lo consciente y lo inconsciente, que se superponen y jerarquizan en virtud de la fuerza de sus respectivas voluntades de poder.

El paradigma abierto por Nietzsche, por supuesto, parte de una concepción de la existencia contraria al posicionamiento trascendental que había dominado el último siglo. El rechazo de una verdad trascendental sobre la que construir todo el sistema filosófico, o

${ }^{273}$ Nietzsche, F., Más allá del bien y del mal, op. cit., pág. 69 (KSA V, 57).

274 Nietzsche, F., Humano, demasiado humano I, op. cit., pág. 148 (KSA II, 184). 
sea, la muerte de Dios, proviene de una actitud no ingenua para con la verdad; si aceptamos con Ricoueur que Nietzsche es una de los maestros de la 'escuela de la sospecha' ${ }^{275}$ se debe a que apreció que la verdad, así como su uso, no había sido emancipada de intereses espurios que la manipulaban. La muerte de Dios hace valer la tesis de que no cabe una máscara original, una máscara trascendental; en lo que puede ser una disposición circular, la muerte de Dios señala que el criterio normativo de la máscara es el calco. Así pues, no cabe pensar más en hipotéticos sentidos últimos ni en relaciones ontológicas entre las palabras y el mundo; tan sólo, la figuración de una máscara. De este modo se explica que «haya podido construirse sobre las metáforas mismas el edificio de los conceptos» ${ }^{276}$. Mediante la conceptualización el ser humano se apropió del mundo, que le resultaba tan hostil y ajeno. Con todo, el origen de la existencia, dice el Nietzsche genealogista, no puede ser trascendental, sino discursivo y por ende receptivo ante el horizonte inabarcable e ilimitado de lo posible que ha de ser apropiado y reapropiado infinitamente en la tarea de valoración del mundo subjetivo que deviene.

\section{I.3. Alba de nihilismo}

Nietzsche nos empuja a un abrupto paraje donde se ha prescindido de la verdad. Una realidad salvaje e inocente que ya no disfruta del apacible descanso de un suelo inquebrantable. Consciente de que por su novedad esta perspectiva habrá de espantar a sus futuros lectores, acepta no obstante ser teñido con el sello de la infamia:

Conozco mi suerte. Alguna vez irá unido a mi nombre el recuerdo de algo monstruoso, - de una crisis como jamás la hubo antes en la Tierra, de la más profunda colisión de conciencias, de una decisión tomada, mediante un conjuro, contra todo lo que hasta este momento se ha creído, exigido, santificado. Yo no soy un hombre, soy dinamita ${ }^{277}$.

«Algo monstruoso». Una inconmensurable crisis sin parangón en la historia que socavaría las conciencias: el nihilismo. Eruditamente Volpi ha señalado que el nihilismo hunde sus raíces bastante antes del siglo XIX, en la transición del XVII al XVIII ${ }^{278}$. Es más, si aceptamos que la fórmula de la muerte de Dios apresa paradigmática esta experiencia, no es posible ignorar al premonitorio Jean Paul, quien ya antes que Hegel, y en una atmósfera de teoría - por valernos de la sugerente metáfora de Danto- próxima a la de Nietzsche,

275 Cfr. Ricoeur, P., Freud: una interpretación de la cultura, trad. de Armando Suárez, México, Siglo XXI, 1970, pág. 32: «[aquella que] dominan tres maestros que aparentemente se excluyen entre sí: Marx, Nietzsche y Freud».

276 Nietzsche, F., Sobre verdad y mentira en sentido extramoral, op. cit., pág. 33 (KSA I, 886).

277 Nietzsche, F., Ecce homo, op. cit., pág. 135 (KSA VI, 365).

${ }^{278}$ Cfr. Volpi, F., El nihilismo, trad. Cristina I. del Rosso y Alejandro G. Vigo, Madrid, Siruela, 2007, pp. 13-16. 
había anunciado el fallecimiento de Cristo ${ }^{279}$. Ahora bien, tampoco deja de apuntar que se generaliza como tópico de discusión en la segunda mitad del XIX, conviniendo en aceptar «que los dos padres fundadores y grandes teóricos del nihilismo han sido Dostoievski y Nietzsche» ${ }^{280}$.

Otro brillante estudio del nihilismo es el de Vattimo, cuya advertencia de que «la esencia de lo moderno se hace realmente visible sólo a partir del momento en que el mecanismo de la modernidad se distancia de nosotros» ${ }^{281}$ debe ser tomada junto con el diagnóstico nietzscheano de que el hombre se aleja deslizándose desde el centro hacia la $\langle\mathrm{X}\rangle^{282}$. Un alejamiento respecto de un garantista espacio de seguridad hacia otro de incertidumbre. Parafraseando a Vattimo, la pérdida del centro es la dura metáfora por la que se expresa la incapacidad de sostener por más tiempo el pensamiento fuerte dentro del nuevo universo que es la mascarada.

El fin del marco trascendental exige acabar con la pretendida solidaridad entre el pensador y lo pensado, que, por otro lado, había llevado a la escisión epistémica del sujeto y el mundo. Escisión que ha abierto ante nosotros un abismo en cuyo límite nos ha situado Nietzsche. El vértigo fruto de la contemplación del fondo dramático de este precipicio nos impide retroceder; sólo cabe vivir en dicho extremo, «vivir sin valores», vivir bajo el para-

279 Cfr. Paul, J., Alba del nihilismo, ed. de Adriano Fabris, trad. de Jorge Pérez de Tudela, Madrid, Istmo, 2005, pp. 49-51: «una vez, una tarde de verano, cuando yacía frente al sol en la cima de un monte, me quedé dormido. En esto empecé a soñar que me habían despertado en un cementerio las ruedas del reloj de la torre, que daba las once. En el yermo cielo nocturno busqué el sol, creyéndolo eclipsado por la luna. [...]. Por encima de mí oía un rumor lejano de aludes, debajo de mí la primera sacudida de un inmenso temblor de tierra. La iglesia oscilaba por obra de la inaudita discordancia de dos notas que chocaban en su interior queriendo en vano armonizarse. A veces, un lívido resplandor fulguraba en sus vidrieras, y bajo ese fuego el plomo y el hierro de los ventanales se licuaban, fundiéndose. La red de la niebla y la trémula tierra me empujaron hacia el templo; ante su portada dos centelleantes basiliscos incubaban en sendos nidos venenosos. Me abrí camino entre sombras desconocidas, acuñadas por siglos antiguos. Las sombras se erguían en torno al altar, temblorosas, palpitante su pecho, y no su corazón. Sólo un muerto, enterrado otrora en la iglesia, reposaba aún su cabeza en la almohada sin que el pecho le palpitase, y en su rostro sonriente aleteaba un sueño feliz. Pero apenas entró alguien vivo, se despertó y dejó de sonreír: alzó trabajosamente los pesados párpados, pero bajo ellos no había ojos, y en el pecho palpitante, en lugar de corazón, se abría una herida. Levantó las manos y las unió para rezar: pero los brazos se alargaron y se desprendieron, y las manos enlazadas fueron a caer más allá. En lo alto de la bóveda de la iglesia estaba el cuadrante de la eternidad, en el que no había números y que era su propia manecilla; sólo un dedo negro lo señalaba, y los muertos se esforzaban por leer en él el tiempo.

En esto bajó sobre el altar, desde lo alto, una excelsa y noble figura, sumida en un dolor inextinguible, y todos los muertos gritaron: ‘¡Cristo!, ¿no hay un Dios?'.

Él contestó: 'no hay ninguno'.

La sombra de cada difunto tembló por entero, y no sólo en su pecho; una tras otra quedaron aplastadas por ese temblor».

280 Volpi, F., El nihilismo, op. cit., pág. 17.

281 Vattimo, G., El fin de la modernidad, trad. de Alberto Luis Bixio, Barcelona, Gedisa, 2007, pág. 95.

282 Nietzsche, F., Fragmentos póstumos IV, 2 [127], op. cit., pág. 115 (KSA XII, 126): «las consecuencias nihilistas de la actual ciencia de la naturaleza (junto con sus intentos de escaparse hacia el más allá). De su actividad se sigue finalmente una autodestrucción, un dirigirse en contra de sí, una anti-cientificidad. Desde Copérnico, el hombre se desliza desde el centro hacia la X». 
digma de la máscara, o precipitarnos en la negrura insondable de una caída eterna que es la de una vida extrañada e impersonal. Por lo que continuando con la tesis de Vattimo, la esencia de lo moderno se hizo visible cuando acabamos apostados ante el abismo de la dinámica interpretativa, tras el agotamiento del paradigma objetivista. El propio discurrir de la modernidad apuntaba hacia este colapso de la metafísica, de manera que en el momento de su cierre ya no es concebible siquiera el retorno a la vieja maquinaria trascendental, dado que «el nihilismo no es una causa, sino sólo la lógica de la décadence» ${ }^{283}$.

La celebración de Nietzsche consiste en su afirmación de la faceta activa del nihilismo. El nihilismo, la confirmación irrevocable de que el mundo carece de un sentido primigenio al cual retroceder, nos ha introducido en este universo de polifonía y máscaras que afecta de manera esencial a la razón. La unidad del mundo, trazada discursivamente por la universalidad de la razón por la que pugnó Descartes, ha sido fragmentada. Ya no es posible apelar a la instancia ilustrada divina de «la razón». En singular adquirió rasgos absolutistas y totalitarios por sus ínfulas omniabarcadoras. Qué sea lo verdadero se reparte en idéntica proporción entre las interpretaciones perspectivistas -máscaras- de la realidad. La pluralidad hermenéutica no es, empero, consecuencia de la crisis de la razón. Más bien al contrario, la crisis de la razón ha tenido lugar, entre otros motivos, al haber sido ésta privada de su esencial polifonía. La muerte de Dios ha servido para deslegitimar las irrealizables pretensiones de universalidad de una razón que se fingió deidad. La secularización habrá de continuarse, entiende Nietzsche, hasta consumar la emancipación de la razón de su fundamento divino y del cariz «subjetivista» del que se ha revestido en la modernidad: «si como ilustración y progreso espiritual entendemos la liberación del hombre de creencias supersticiosas en poderes malignos, en demonios y hadas, en el destino ciego -en una palabra, la emancipación del miedo-, entonces la denuncia de lo que hoy se llama razón es el mayor servicio que puede rendir la razón» ${ }^{284}$. Nuevamente Horkheimer parece haber hecho suyas las tesis de Nietzsche.

La conciencia del nihilismo como experiencia de la muerte de Dios es también una emancipación del mundo mismo. El mundo ya no está dispuesto arreglo a la categoría de verdad de una razón metafísica, sino que queda abierto al abismo de las interpretaciones, del cambio y de la esencial contingencia de un tiempo ahora efímero. Abismo perfectamente recogido por Löwith:

${ }^{283}$ Ibid. 14 [86], op. cit., pág. 537 (KSA XIII, 265).

${ }^{284}$ Horkheimer, M., Crítica de la razón instrumental, op. cit., pág. 187.

Se antoja fascinante la trayectoria intelectual de Horkheimer y Adorno. Si bien el sustrato capital de ambos es la filosofía de Karl Marx, hay poderosos indicios que sugieren una deriva en su pensamiento de madurez, coincidiendo con el asalto de la crítica como «crítica total». A pesar de que el enfrentamiento con la ideología fue una constante, parece que su abordaje no es exactamente marxista. En la medida en que sus argumentaciones apuntan a su causa ascendente, la estrategia es más próxima a la del genealogista que a la del filósofo marxista. ¿Hay quizá un viraje nietzscheano en el rumbo de estos pensadores, interrumpido por unas muertes demasiado precoces? 
El abismo que separaba para siempre la filosofia anticristiana de Nietzsche de la teología filosófica de Hegel, y el "martillo" de Nietzsche de la "especulación" hegeliana, fue traspasado por los discípulos de Hegel mediante el puente de una serie coherente de rebeliones contra la tradición cristiana y la cultura burguesa. Hegel y Nietzsche están respectivamente en el comienzo y en el fin de dicho puente, y la cuestión consiste en saber si, más allá de Nietzsche, queda todavía algún camino transitable ${ }^{285}$.

En el nihilismo nietzscheano se da la difícil paradoja de toparnos con un mundo que, despojado de valores, sirve a su vez de laboratorio de creación. Nos insta Nietzsche a hacer del mundo el fundamento de nuestros nuevos valores; a tomar las dinámicas estructurales de la nueva realidad, el cambio, la contingencia, la pluralidad, el sustrato hermenéutico de la máscara en última instancia como principio creador. Recuperar el sentido de la tierra:

Que camine pues toda esta mascarada en las melodías y cadencias, en los saltos y regocijos de esas óperas. ¡Es la vida del mundo antiguo! ¡Qué se entiende de ella si no se entiende el placer por la máscara, la buena conciencia de toda mascarada! Allí está el baño y el descanso del espíritu antiguo: -y puede ser que las naturalezas raras y elevadas del mundo antiguo tuvieran más necesidad de este baño que las vulgares $^{286}$.

Recuperar el sentido de la tierra, será posteriormente el mandamiento de Zaratustra.

La racionalización del mundo llevada a cabo durante la modernidad, y en la cual los ilustrados quisieron ver la salida de la minoría de edad de la humanidad, ha supuesto en realidad un proceso de desencantamiento que ha extirpado del mundo la fuerza mágica de las religiones ${ }^{287}$. La racionalización supuso el yugo de la ciencia, cuyos tentáculos se extendieron por todo el espectro de la realidad. La primacía de la ciencia llevó a imprimir sobre el mundo un aura cientificista que estableció criterios de verdad y falsedad según el examen de la razón analítica. Esto situó a la ciencia en una posición privilegiada, en el nuevo altar olímpico, haciendo de ella también una institución mítica bajo cuya mirada contemplar el mundo. Sin embargo, no logró satisfacer las exigencias de sentido de los individuos, como sí hubo logrado hasta su disolución la religión. Los grandes interrogantes que motivaron dos de las Críticas kantianas, «¿qué debo hacer?»y «¿qué me cabe esperar?»,

285 Löwith, K., De Hegel a Nietzsche. La quiebra revolucionaria del pensamiento en el siglo XIX, trad. de Emilio Estiú, Madrid, Katz Editores, 2008, pág. 233. (La cursiva es nuestra).

286 Nietzsche, F., La gaya ciencia, op. cit., pág. 775 (KSA III, 433).

287 Cfr. Weber, M., «La ciencia como vocación», en El político y el científico, trad. de Francisco Rubio Llorente, Madrid, Alianza Editorial, 2005, pp. 231-232: «el destino de nuestro tiempo, racionalizado e intelectualizado y, sobre todo, desmitificador del mundo, es el de que precisamente los valores últimos y más sublimes han desaparecido de la vida pública y se han retirado, o bien al reino ultraterreno de la vida mística, o bien a la fraternidad de las relaciones inmediatas de los individuos entre sí [...]. A quienes no puedan soportar virilmente este destino de nuestro tiempo hay que decirles que vuelvan en silencio, llana y sencillamente, y sin la triste publicidad habitual de los renegados, al ancho y piadoso seno de las viejas Iglesias, que no habrán de ponerles dificultades. Es inevitable que de uno u otro modo tengan que hacer allí el 'sacrificio del intelecto'». 
así como la pregunta sintética «¿qué es el hombre?», quedaban huérfanos de respuesta desde el umbral científico. Únicamente era posible la concreción de las condiciones de posibilidad del conocimiento y explicar los mecanismos para ejecutar el dominio técnico de la naturaleza que presidía el horizonte utilitarista y calculador de la racionalidad epocal. Tampoco se podía, sin embargo, dar razones de dicho carácter, esto es, era imposible aventurar el sentido de la dominación técnica del mundo ${ }^{288}$. La secularización como proceso de racionalización significó la deslegitimación de una racionalidad universal de sentido en beneficio de una racionalidad cientificista instrumental, calculadora, objetiva. La característica distintiva de esta razón es su asepsia. Se trata de una esterilidad axiológica esencial: no provee de sentido a sus fines. En la primera parte del presente trabajo destacamos que en la «corporalidad» nietzscheana el hombre se distingue por su capacidad de tener -de darsemetas y fines, es decir, por su capacidad para proveerse de sentido interior sus motivaciones existenciales. Contemplar entonces el mundo y todos sus avatares -el hombre como uno de ellos- desde una razón aséptica y estéril hace imposible la conquista de la propia existencia, encarnada. Una vez presentado un fin, tan sólo prescribe, tras un cálculo previo, las disposiciones más eficaces para alcanzarlo. La dificultad estriba en determinar cuáles serán los fines. La difícil situación existencial del siglo XIX había puesto de manifiesto que resultaba imposible apelar a una instancia única que arrojara significado al mundo. El desencanto del mundo había aniquilado la cosmovisión holística de la realidad, y junto a ello, abocado a los sujetos a configurar el sentido según sus propias convicciones e intereses. Una pluralidad axiológica que Nietzsche recogió bajo el concepto y el rótulo de «politeísmo»:

La mayor utilidad del politeísmo.- Que el hombre erija su propio ideal y deduzca de él su ley, sus alegrías y sus derechos -ha sido considerado hasta ahora como el más monstruoso de los extravíos humanos y como la idolatría en sí; de hecho, los pocos que lo han osado han tenido siempre una necesidad de una apología ante sí mismos, y ésta era por lo común: «¡no yo!, ¡no yo!, ¡sino un dios a través mío!». Fue en la fuerza y el arte maravilloso de crear dioses -el politeísmo- donde este impulso pudo descargarse, donde se purificó, perfeccionó, ennobleció: porque originariamente era un impulso vulgar y poco apreciable, emparentado con la obstinación, la desobediencia y la envidia. Ser hostil a este impulso de un ideal propio: ésa era entonces la ley de toda moralidad. Había sólo una única norma: «el hombre» -y cada pueblo creía tener esa norma única y última. Pero por encima y fuera de sí, en un lejano mundo superior, era lícito ver una pluralidad de normas: ¡un dios no era la negación o la blasfemia de otro dios! Aquí se permitió por primera vez a los individuos, aquí se honró por primera vez el derecho de los individuos [...]. El monoteísmo, por el contrario, la rígida consecuencia de la doctrina de un único hombre normal -o sea la creencia en un dios normal, al lado del cual sólo hay falsos dioses mentirosos- ha sido quizás el mayor peligro de la humanidad hasta el momento

288 Cfr. Ibid. pág. 211: «todas las ciencias de la naturaleza responden a la pregunta de qué debemos hacer si queremos dominar técnicamente la vida. Las cuestiones previas de si debemos y, en el fondo, queremos conseguir este dominio y si tal dominio tiene verdaderamente sentido son dejadas de lado o, simplemente, son respondidas afirmativamente de antemano»». 
[...]. En el politeísmo estaba prefigurada la libertad de espíritu y la pluralidad de espíritu del hombre: la fuerza de crearse ojos nuevos y propios, y de seguir siempre creando otros nuevos y aún más propios: de manera tal que, entre todos los animales, sólo para el hombre no hay horizontes y perspectivas eternas ${ }^{289}$.

La defensa del politeísmo es la defensa de la plasticidad de la voluntad de poder en manos del artista-filósofo.

Pese al aparente desasosiego por el nihilismo, ya hemos destacado que Nietzsche lo celebra. El mundo desencantado ha sido abierto a la multiplicidad; ha roto el yugo unitario de la razón en favor de un politeísmo de fuentes valorativas. La secularización radical, que no es otra cosa que aceptarla hasta sus últimas consecuencias, ha conllevado la muerte de Dios, esto es, el fin del sentido monoteísta que había legado la metafísica platónica.

${ }^{289}$ Nietzsche, F., La gaya ciencia, pág. 808 (KSA III, 490-491). 


\section{CAPÍTULO II: LA EPISTEMOLOGÍA COMO PROBLEMA GENÉTICO DE LA MODERNIDAD}

\section{II.1. El problema del lenguaje como concepción del mundo}

Al comienzo del Tractatus, en la proposición inaugural -desarrollada después en sus respectivos apéndices-, Wittgenstein señala que «el mundo es todo lo que es el caso $»^{290}$, apostillando que «el mundo es la totalidad de los hechos, no de las cosas ${ }^{291}$. Inmediatamente, en la proposición segunda, advierte que «lo que es el caso, el hecho, es el darse efectivo de estados de $\operatorname{cosas} »^{292}$, que se concreta en la «figura ${ }^{293}$. La figura consta de sus propios elementos, que se comportan entre sí de un determinado modo el cual determina el comportamiento de las cosas. «Esta interrelación -sigue Wittgenstein- de los elementos de la figura se llama estructura y la posibilidad de la misma, su forma de figuración» ${ }^{294}$. En la forma de figuración estaría entonces «la posibilidad de que las cosas se interrelacionen al igual que los elementos de la figura» ${ }^{295}$. Posibilidad que enlaza la figura con la realidad ${ }^{296}$, resultando en que «a la figura pertenece también la relación figurativa que la convierte en figura» ${ }^{297}$. En consecuencia, «en la figura y en lo figurado tiene que haber algo idéntico en orden a que aquélla pueda siquiera ser figura de esto» ${ }^{298}$. Y este rasgo «en común con la realidad para poder figurarla a su modo y manera - correcta o falsamente- es su forma de figuración ${ }^{299}$. El razonamiento de Wittgenstein adquiere cada vez caracteres más abstractos, como forma para apresar la totalidad del mundo. Así, «lo que cualquier figura, sea cual fuere su forma, ha de tener en común con la realidad para poder siquiera - correcta o falsamente- figurarla, es la forma lógica, esto es, la forma de la realidad» ${ }^{300}$. De suerte que «si la forma de la figuración es la forma lógica, la figura se llama la figura lógica» ${ }^{301}$. Este po-

\footnotetext{
290 Wittgenstein, L., Tractatus Logico-Philosophicus, § 1, trad. de Jacobo Muñoz e Isidoro Reguera, Madrid, Alianza Editorial, 1995, pág. 15.

${ }^{291}$ Ibid. $\S 1.1$.

292 Ibid. $\S 2$.

${ }^{293}$ Cfr. ibid. $\$ 2.11$ : «la figura representa el estado de cosas en el espacio lógico, el darse y no darse efectivos de estados de cosas».

294 Ibid. $\$ 2.15$, pág. 25.

295 Ibid. $\S 2.151$.

${ }^{296}$ Cfr. ibid. $\S 2.1511$ : «la figura está enlazada así con la realidad; llega hasta ella».

${ }^{297}$ Ibid. $\S 2.1513$.

298 Ibid. $\S 2.161$.

299 Ibid. $\S 2.17$, pp. 25-27.

${ }^{300}$ Ibid. § 2.18, pág. 27.

301 Ibid. § 2.181.
} 
sicionamiento ostenta una fuerza ontológica portentosa, como atestigua que «la figura lógica de los hechos es el pensamiento» ${ }^{302}$ y que, por tanto, «el pensamiento contiene la posibilidad del estado de cosas que piensa. Lo que es pensable es también posible» ${ }^{303}$ en la medida en que «no podemos pensar nada ilógico» ${ }^{304}$, ya que «de un mundo 'ilógico' no podríamos, en rigor, decir qué aspecto tendría» ${ }^{305}$. Y es que «en la lógica nada es casual: si la cosa puede ocurrir en el estado de cosas, la posibilidad del estado de cosas tiene que venir ya prejuzgada en la cosa» ${ }^{306}$. Así se entiende que en el Prólogo afirme resumir el sentido entero del libro en que «lo que siquiera puede ser dicho, puede ser dicho claramente; y de lo que no se puede hablar hay que callar» ${ }^{307}$.

La presentación del lenguaje en el Tractatus ha sido estudiada por numerosos teóricos, comenzando por Russell. Sin embargo, resulta especialmente sugerente la aproximación de Kenny, quien termina destacando que los planteamientos de dicha obra comportan, en última instancia, un psicologismo estricto que acaba desbordando las capacidades del Tractatus mismo: en el Tractatus se nos dicen pocas cosas acerca de los pensamientos. Es posible extraer algunas conclusiones a partir de la definición de un pensamiento como una pintura lógica de los hechos, como propone Kenny ${ }^{308}$. «Toda pintura, desde luego, es una pintura lógica; pero los pensamientos son pinturas lógicas par excellence, puesto que la estructura lógica es el todo de su forma pictórica. Si eliminamos la lógica, las pinturas lógicas son imposibles, de modo que el pensamiento no puede representar algo que contradiga las leyes de la lógica [...]. Pero el pensamiento no puede representar la lógica como tampoco puede representar la ilogicidad, porque ninguna pintura puede pintar su forma pictórica, y la lógica es la forma pictórica del pensamiento» ${ }^{309}$. Aunque la lógica es la forma pictórica del pensamiento, su forma representacional no se precisa. Recuerda Kenny que no puede pensarse sobre ello dado que la figura no puede colocarse fuera de su forma representacional. Con todo, Kenny incide en las implicaciones del psicologismo fuerte wittgensteiniano, donde hay una vinculación esencial entre lo pensado y lo proferido siendo, en último término, uno y lo mismo.

302 Ibid. § 3, pág. 29.

303 Ibid. $\S 3.02$.

${ }^{304}$ Ibid. $\S 3.03$.

305 Ibid. $\S 3.031$.

306 Ibid. $§ 2.012$, pág. 17.

307 Ibid. pág. 11.

Con la segunda parte de esta fórmula, por supuesto, cierra el tratado en una única y última proposición: «de lo que no se puede hablar hay que callar» (ibid. § 7, pág. 183).

${ }^{308}$ Cfr. Kenny, A., Wittgenstein, trad. de Alfredo Deaño, Madrid, Alianza Editorial, 1982, pp. 59-72.

${ }^{309}$ Ibid. pp. 62-63. 
Desde la posición del Tractatus, la dupla lenguaje-mundo es sustantiva ${ }^{310}$ : el uno crea al otro. Y aunque es una de las tesis capitales del Primer Wittgenstein y sobre la que se vertebra una de las grandes obras de la filosofía del lenguaje, no es original suya. La actividad reflexiva sobre el lenguaje y su intimidad con el mundo se remonta a los tiempos de la filosofía griega: la importancia que concedieron los sofistas a la retórica, los estudios aristotélicos sobre ésta o algunos diálogos platónicos, como el Crátilo lo atestiguan. La modernidad mantuvo y continuó la cuestión del lenguaje, con tentativas sugerentes sobre su posible génesis; así Rousseau, Diderot o Kant. Nietzsche no es, por tanto, una excepción cuando trate este fenómeno.

Del mismo modo que Wittgenstein después Nietzsche afirmará la fuerza constitutiva del lenguaje y su rol determinante en la ontología del mundo. Sin embargo, el planteamiento de Nietzsche difiere notablemente del que sostendrá el pensador austriaco, toda vez que dentro del imaginario del filólogo decimonónico el mundo no es tan sólo todo lo que es el caso, sino además todo lo que no acaece y cuanto puede llegar a acaecer. La capacidad ontológica que adquiere el lenguaje en Nietzsche va más allá del psicologismo cartesiano que heredará el autor del Tractatus.

Para Nietzsche el lenguaje es un hito insalvable del proceso de creación de la pretensión de verdad, en virtud de su carácter artístico; en un primer momento de esta ambiciosa pretensión se «fija» lo que debe ser tenido por «verdad», «es decir, se ha inventado una designación de las cosas uniformemente válida y obligatoria, y el poder legislativo del lenguaje proporciona también las primeras leyes de verdad» ${ }^{311}$. Leyes éstas que se arman sobre la dicotomía verdad-mentira y que ilustran el cariz ilusorio del lenguaje ${ }^{312}$. Una verdad que no es una mera tautología, «conchas vacías», y por la cual se habrán de trocar «continuamente ilusiones por verdades» ${ }^{313}$. Afirma Nietzsche, contrariamente a la posterior posición wittgensteiniana, que «la 'cosa en sí' (esto sería justamente la verdad pura, sin consecuencias) es totalmente inalcanzable y no es deseable en absoluto para el creador del lenguaje» ${ }^{314}$. El lenguaje no es en sí el vehículo que imbrica el pensamiento en el mundo y

\footnotetext{
310 Cfr. Wittgenstein, L., Tractatus Logico-Philosophicus, § 5.6, op. cit., pág. 143: «los límites de mi lenguaje significan los límites de mi mundo».

${ }^{311}$ Nietzsche, F., Sobre verdad y mentira en sentido extramoral, op. cit., pág. 20 (KSA I, 878).

312 Cfr. ibid., pág. 25 (KSA I, 880-881): «¿Qué es entonces la verdad? Una hueste en movimiento de metáforas, metonimias, antropomorfismos, en resumidas cuentas, una suma de relaciones humanas que han sido realzadas, extrapoladas y adornadas poética y retóricamente y que, después de un prolongado uso, un pueblo considera firmes, canónicas y vinculantes; las verdades son ilusiones de las que se ha olvidado que lo son; metáforas que se han vuelto gastadas y sin fuerza sensible, monedas que han perdido su troquelado y no son ahora ya consideradas como monedas, sino como metal». (La cursiva es nuestra).
}

313 Ibid. pág. 21. (KSA I, 878)

${ }^{314}$ Ibid. pág. 22. (KSA I, 879) 
viceversa, sino la profesión metafórica de la imagen humana de las relaciones de las cosas con respecto a los hombres. Con todo,

en cualquier caso, el origen del lenguaje no sigue un proceso lógico, y todo el material sobre el que, y a partir del cual, trabaja y construye el hombre de la verdad, el investigador, el filósofo, procede, si no de las nubes, en ningún caso de la esencia de las cosas ${ }^{315}$.

Las diferencias entre el paradigma de Nietzsche y el logicista de un Wittgenstein heredero de un cierto cartesianismo y el de Nietzsche son fehacientes. Mientras para el segundo «no podemos pensar nada ilógico» ${ }^{316}$, el otro entiende que el origen del lenguaje no es reductible a un proceso lógico; la imagen de un mundo ilógico, que para Wittgenstein no es sino un dislate, es en cambio preferible para Nietzsche, quien en su defensa de lo inconsciente se adhiere antes a la hipótesis de un origen del mundo en «las nubes» que a la del hallazgo de la pretendida esencia. No obstante, que la matriz nietzscheana no persiga la esencia de las cosas no disminuye un ápice la fuerza ontológica de su planteamiento; nos introduce en un prisma distinto - de rango marcadamente hermenéutico- donde el abanico de condiciones de posibilidad no viene determinado por las directrices de la estructura lógica, sino que se hace remitir a las capacidades figurativas y metafóricas del propio sujeto. Algo que ha advertido con insistencia Jesús Conill, «por lo que se refiere al origen, sobresale la concepción del hombre como 'sujeto creador artístico', al que es esencial un 'impulso a la formación de metáforas'»»317.

La capacidad metafórica obedece más a la dimensión estética que a la gnoseológica, al menos que a una gnoseología al modo moderno. Mediante este elemento lingüístico fundamental acaece la relación entre el sujeto y el objeto en los términos y caracteres del artista-filósofo. La vieja dupla entre el actor epistémico y el mundo que había desembocado en la doliente escisión es reescrita en una nueva clave por Nietzsche: las capacidades lingüísticas se ven desbordadas cuando éste trata de expresar la realidad tal cual. El horizonte de lenguaje al que nos arroja Nietzsche es, por su intento por eludir la escisión epistemológica moderna, trágico: la asume e integra no como una experiencia incapacitante, sino como la desgarradora dimensión constitutiva de la relación no armónica del sujeto y el mundo de la cual no podemos escapar.

315 Ibid. pág. 23. (KSA I, 879)

316 Wittgenstein, L., Tractatus Logico-Philosophicus, § 3.03, op. cit., pág. 29.

317 Conill, J., El poder de la mentira, Madrid, Tecnos, 2007, pág. 36. 


\section{II.1.1. Olvido y voluntad de verdad}

Dado el carácter trágico del lenguaje, que comporta una experiencia de vida análoga, la pregunta que enfrenta Nietzsche es el porqué de la voluntad de verdad como aspiración de una descripción isomórfica que enlace estructuralmente las palabras con la esencialidad del mundo ${ }^{318}$, algo así como la concreción lingüística de los hechos elementales del mundo que condujo el Tractatus. La investigación sobre las condiciones de posibilidad de un lenguaje con sentido, esto es, de una descripción lingüística de los hechos del mundo llevaría a Wittgenstein a afirmar que tal correspondencia esencial en el nivel lógicamente simple de los últimos constituyentes del lenguaje y del mundo estaba previamente dada. Correlación esencial de una forma lógica cuyo sujeto lógico identificó en el Tractatus como «el yo del solipsismo» ${ }^{319}$, el cual establece los límites del lenguaje y del mundo.

La teoría figurativa de Wittgenstein descansaba sobre la convicción filosófica de la posibilidad de acceder a un gran modelo de la realidad, dado éste por medio de una descripción exhaustiva y verdadera de todos los hechos del mundo a través de la descripción respectiva de los hechos elementales que los componen. Esta clase de fe comportaba el corolario de la necesaria estructura esencial en el lenguaje, correlativa con la estructura ontológica de los hechos del mundo, que, si bien permanece oculta bajo la gramática externa, un análisis lógico ${ }^{320}$ podría aproximar, al remitirnos finalmente hasta el nivel lógicamente simple de las proposiciones y los hechos elementales. Nietzsche insistirá en que al lenguaje no le subyace una estructura esencial «oculta», como tampoco contemplará la reducción única del análisis lingüístico al análisis lógico. Y sin embargo, sobre ello cifra su crítica de la gramática moderna, la cual es otra de las formas de su crítica de la tradición filosófica del ser parmenídeo.

Al igual que el resto de tentativas semióticas ilustradas, Nietzsche plantea su propia hipótesis no ya tanto sobre el origen del lenguaje como de las pretensiones del mismo que observa en el presente: el anhelo de verdad. Nietzsche remite todo a un olvido:

Sólo mediante el olvido de este mundo primitivo de metáforas, sólo mediante el endurecimiento y petrificación de un fogoso torrente primordial compuesto por una masa de imágenes que surgen de la capacidad originaria de la fantasía humana, sólo mediante la invencible creencia en que este sol, esta ventana, esta mesa son una verdad en sí, en resumen: gracias solamente al hecho de que el hombre se olvi-

318 Cfr. Wittgenstein, L., Tractatus Logico-Philosophicus, § 4.021, op. cit., pág. 55: «la proposición es una figura de la realidad: pues conozco el estado de cosas representado por ella si comprendo la proposición. Y comprendo la proposición sin que me haya sido explicado su sentido».

${ }^{319}$ Cfr. ibid. $§ 5.64$, pág. 145: «se ve aquí cómo, llevado a sus últimas consecuencias, el solipsismo coincide con el puro realismo. El yo del solipsismo se contrae hasta convertirse en un punto inextenso y queda la realidad con él coordinada».

320 Por otro lado, el análisis lógico es el único análisis pertinente, pues «hay un análisis completo, y sólo uno, de la proposición» (ibid, $§ 3.25$, pág. 35), y éste es el análisis lógico. 
da de sí mismo como sujeto y, por cierto, como sujeto artísticamente creador, vive con cierta calma, seguridad y consecuencia; si pudiera salir, aunque sólo fuese un instante, fuera de los muros de esa creencia que lo tiene prisionero, se terminaría en el acto su «conciencia de sí mismo». Le cuesta trabajo reconocer ante sí mismo que el insecto o el pájaro perciben otro mundo completamente diferente al del hombre y que la cuestión de cuál de las dos percepciones del mundo es la correcta carece totalmente de sentido, ya que para decidir sobre ello tendríamos que medir con la medida de la percepción correcta, es decir, con una medida de la que no se dispo$n e^{321}$.

$\mathrm{Y}$ es que «el concepto hoja se ha formado al abandonar de manera arbitraria esas diferencias individuales, al olvidar las notas distintivas, con lo cual se suscita [...] una especie de arquetipo primigenio» ${ }^{322}$. Pues, en definitiva, «solamente mediante el olvido puede el hombre alguna vez llegar a imaginarse que está en posesión de una 'verdad'» ${ }^{323}$. Es, en último término, el olvido del fondo insondable e inconsciente de la existencia que nos introduce en un espectro de indeterminación dentro del cual el hombre se abre paso por medio de la jerarquización de valores mediante el ejercicio de apropiación de la voluntad de poder.

El primer hito que conduce al hombre por el sendero del anhelo de verdad es el olvido de la especificidad metafórica del lenguaje y su inmediata consecuencia: que no es posible llegar a conocer las cosas en sí. Luego la crítica de la verdad como crítica de la metafísica se despliega en Nietzsche como crítica del lenguaje. En tanto que genéticamente metafórico, el lenguaje exuda actividad artística; mediante la construcción de metáforas nos apropiamos del mundo y lo cargamos de un sentido artificial, es decir, «nos procuramos metas y fines». Aceptándose el carácter manufacturado del lenguaje se abraza su cariz artístico, haciendo válida con ello la máxima que años después motivaría el retrospectivo «Ensayo de autocrítica» de El nacimiento de la tragedia: subordinarlo todo a la óptica del artista. Si el mundo adquiere su sentido a través del lenguaje, por cuyo sustrato metafórico podemos afirmar su condición artística, el hombre como portador de un logos vocálico creativo es necesariamente «artista». La sentencia de asumirlo todo bajo la atenta mirada del artista no es más que el alegato de reapropiación del mundo para un sujeto que no es ya epistémico al haber recuperado su memoria metafórica. Una rememoración que vuelve incompatible los trazos parmenídeos en la existencia: el devenir antes que el ser. Y por ello mismo la pretensión de verdad, o sea, la búsqueda del isomorfismo entre las palabras y la esencia del mundo se desvanece en beneficio de una dimensión ilusoria. Así se explica que «la vida tiene necesidad de ilusiones» ${ }^{324}$, o sea, necesidad de afirmar su condición ficticia, alegórica que se produce y reproduce artesanalmente.

${ }^{321}$ Nietzsche, F., Sobre verdad y mentira en sentido extramoral, op. cit., pág. 29 (KSA I, 883-884).

322 Ibid. pág. 24 (KSA I, 880).

323 Ibid. pág. 21 (KSA I, 878).

${ }^{324}$ Nietzsche, F., Fragmentos póstumos I, 19 [43], op. cit., pág. 355 (KSA VII, 433). 
Hay también en Nietzsche una relación entre la dupla pensamiento-lenguaje y el mundo, aunque no sustantiva, sino relativa: si la imagen del mundo es configurada por el lenguaje -a través del cual se explicita el pensamiento-, habrá tantas concepciones de mundo como lenguajes, esto es, como formas de significación. El lenguaje en Nietzsche está inscrito dentro de su imagen del mundo como realidad ilimitada y esencialmente inescrutable. La capacidad creadora del lenguaje mediante metáforas revela que tras tal fenómeno se halla el juego efectivo de la voluntad de poder, que en virtud de su plasticidad no arroja sino significaciones precarias y contingentes que mantienen al sujeto abierto al incognoscible espectro de posibilidades forzándolo a acometer un ejercicio constante de valoración y jerarquización de sentidos, esto es, de reapropiación del mundo, el cual empieza en la vida concreta, en el «cuerpo». Esta aproximación relativista al fenómeno lingüístico es una manifestación taimada del nihilismo europeo: ¿acaso es posible la pregunta por la verdad o dicha cuestión es ya inadmisible una vez se ha admitido la producción de tantas concepciones de verdad como mundos, lenguajes, «gramáticas» haya?

A este respecto, Heidegger ha destacado el elemental sustrato metafísico de la posición adoptada por Nietzsche con respecto al lenguaje: una metafísica del devenir a través del lenguaje. Validando la afirmación presente en Sobre verdad y mentira de que la verdad es una ilusión, Heidegger trata de enlazarla con el esencial devenir del mundo: «la verdad sería entonces incorrección, error, una 'ilusión', aunque quizás una ilusión necesaria» ${ }^{325}$. Ante lo que concluye que «la verdad, en el sentido de lo verdadero, entendido como lo presuntamente ente en el sentido de lo consistente, fijo e inmutable sólo es una ilusión si el mundo 'es'no un mundo ente sino un mundo 'deviniente' $\gg{ }^{326}$. Entonces, si el mundo es para Nietzsche, como sostiene Heidegger, «deviniente», ¿cómo se salva el salto cualitativo entre la realidad y la vocación de permanencia del lenguaje? Dado que lo esencial del mundo es el devenir, esta verdad es inaprensible para la tradicional gramática del ser, la cual imprime fijeza y estatismo. El lenguaje había quedado articulado arreglo los conceptos, y ocurre que «el gran edificio de los conceptos ostenta la rígida regularidad de un columbarium romano e insufla en la lógica el rigor y la frialdad peculiares de la matemática» ${ }^{327}$. En la confección del edificio de los conceptos, «trabaja originariamente el lenguaje;

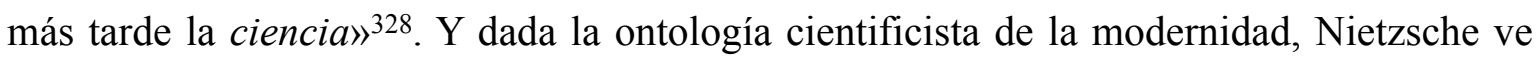
un vínculo irrompible entre el lenguaje moderno y $s u$ ciencia: «la ciencia trabaja inconteniblemente en ese gran columbarium de los conceptos [...], se esfuerza en llenar ese colosal andamiaje que desmesuradamente ha apilado y en ordenar dentro de él todo el mundo em-

${ }^{325}$ Heidegger, M., Nietzsche, op. cit., pág. 438.

${ }^{326}$ Ibid.

${ }^{327}$ Nietzsche, F., Sobre verdad y mentira en sentido extramoral, op. cit., pp. 26-27 (KSA I, 882).

328 Ibid. pág. 33 (KSA I, 886). 
pírico, es decir, el mundo antropomórfico» ${ }^{329}$. Por eso mismo del actor epistemológico moderno, el «hombre del conocimiento», como lo llama Nietzsche, dirá que es una suerte de sublimación de todos los ideales epocales, pues

si ya el hombre de acción ata su vida a la razón y a los conceptos para no verse arrastrado y no perderse a sí mismo, el investigador construye su choza junto a la torre de la ciencia para que pueda servirle de ayuda y encontrar él mismo protección bajo ese baluarte ya existente. De hecho necesita protección, puesto que existen fuerzas terribles que constantemente le amenazan y que oponen a la verdad científica «verdades» de un tipo completamente diferente con las más diversas etiquetas $^{330}$.

Con todo, en la medida en que Nietzsche procura una crítica radical de la ontología cientificista moderna y de sus corolarios, la esencialidad lenguaje-mundo que se concretaba en la verdad, queda rota. El lenguaje ya no expresa la pureza del pensamiento, puesto que «las verdades son ilusiones de las que se ha olvidado que lo son» ${ }^{331}$.

Ahora bien, la identificación de la verdad como ilusión no es una sentencia gratuita. Como ha sabido ver Heidegger, tal interpretación - del mundo, en última instancia- asume un posicionamiento ontológico fundamental en la filosofía de Nietzsche: se trata de una posición de valor ${ }^{332}$. Nietzsche estima la verdad como ilusión, y como tal la afirma. Sin embargo, continúa Heidegger, en este rasgo apreciativo de la verdad se encuentra el resquicio que aún pervive en Nietzsche de la metafísica moderna: la valoración a través de la subjetividad que ha olvidado el ser en beneficio del ente:

la verdad como estimación de valor, es decir como tener-por, es decir como tener por algo que es y es así, está en una conexión esencial con el ente en cuanto tal. Lo verdadero es lo tenido por algo que es, por algo que es de tal o cual modo, lo que se toma por ente. Lo verdadero es el ente 333 .

La presunción heideggeriana apunta a que en Nietzsche perdura la solidaria equidad entre la verdad y el «tener por verdadero» propia de la epistemología de la representación. «Tener algo por lo que es, re-presentarlo como lo que es de tal o cual manera, adecuarse en el representar a lo que surge y sale al encuentro [...] ésta es la esencia de la verdad como corrección ${ }^{334}$. Observación ante la cual Heidegger no puede más que concluir que en tanto

${ }^{329}$ Ibid. (KSA I, 886).

${ }^{330}$ Ibid. (KSA I, 886).

${ }^{331}$ Ibid. pág. 25 (KSA I, 880-881).

332 Cfr. Heidegger, M., Nietzsche, op. cit., pág. 411: «estimación de valor quiere decir: apreciar algo como valor y ponerlo como tal».

333 Ibid. pág. 412.

334 Ibid. 
«que dice que la verdad es una estimación de valor, Nietzsche no piensa en el fondo otra cosa que: la verdad es corrección» ${ }^{335}$ :

La ciencia moderna se basa y al mismo tiempo se especializa en proyectar determinados sectores de objetos. Estos proyectos se despliegan en los correspondientes métodos asegurados gracias al rigor. El método correspondiente en cada caso se organiza en la empresa. El proyecto y el rigor, el método y la empresa, al plantearse constantes exigencias recíprocas, conforman la esencia de la ciencia moderna y la convierten en investigación.

Estamos reflexionando sobre la esencia de la ciencia moderna con la intención de reconocer su fundamento metafísico. ¿Qué concepción de lo ente y qué concepto de la verdad hacen posible que la ciencia se torne investigación?

El conocimiento, en tanto que investigación, le pide cuentas a lo ente acerca de cómo y hasta qué punto está a disposición de la representación. La investigación dispone de lo ente cuando consigue calcularlo por adelantado en su futuro transcurso o calcularlo a posteriori como pasado. En el cálculo anticipatorio casi se instaura la naturaleza, en el cálculo histórico a posteriori casi la historia. Naturaleza e historia se convierten en objeto de la representación explicativa. Dicha representación cuenta con la naturaleza y ajusta cuentas con la historia. Sólo aquello que se convierte de esta manera en objeto es, vale como algo que es. La ciencia sólo llega a ser investigación desde el momento en que se busca al ser de lo ente en dicha objetividad.

Esta objetivación de lo ente tiene lugar en una re-presentación cuya meta es colocar a todo lo ente ante sí de tal modo que el hombre que calcula pueda estar seguro de lo ente o, lo que es lo mismo, pueda tener certeza de él. La ciencia se convierte en investigación única y exclusivamente cuando la verdad se ha transformado en certeza de la representación. Lo ente se determina por vez primera como objetividad de la representación y la verdad como certeza de la misma en la metafísica de Descartes. El título de su obra principal reza: «Meditationes de prima philosophia»,

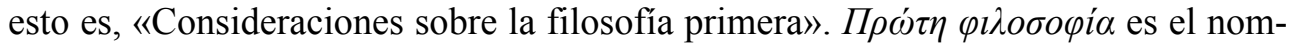
bre aristotélico para aquello que más tarde se llamará metafísica. Toda la metafísica moderna, incluido Nietzsche, se mantendrá dentro de la interpretación de lo ente y la verdad iniciada por Descartes ${ }^{336}$.

Hasta el punto de atreverse a apuntar, al abrigo de la continuidad de la escuela racionalista en el continente, una coincidencia entre el pensador de Röcken y el de Königsberg, concluyendo, con la figura de Hegel en el horizonte, que al cierre de la modernidad, «cuando se ha consumado la presentación de la manifestación de la certeza sensible de aquello que ella toma por lo ente y lo verdadero, ha surgido su ser en tanto que nuevo objeto, la verdad de la certeza, certeza que es la autoconciencia que se sabe a sí misma» ${ }^{337}$.

La lectura de Heidegger nos parece errónea, toda vez que parece inscribir dentro de la historia de la epistemología del subjetivismo trascendental a Nietzsche, quizá como

335 Ibid

${ }^{336}$ Heidegger, M., «La época de la imagen del mundo», op. cit., pp. 71-72.

${ }^{337}$ Heidegger, M., «El concepto de experiencia de Hegel», trad. de Helena Cortés y Arturo Leyte, en Caminos de bosque, op. cit., pp. 155-156. 
su último hito. La tentativa se nos antoja imposible ya que la caracterización manejada por Nietzsche del concepto de verdad no es genuinamente epistemológica. Mientras los pensadores de la modernidad, joven y madura, habían hecho de la verdad criterio de corrección gnoseológico, desde la cual luego extrapolar las consideraciones oportunas hacia los demás grandes ámbitos filosóficos -moral, estética y antropología-, en Nietzsche las fronteras son otras. La verdad se inscribe dentro del dominio de la voluntad de poder. Como ha afirmado Sánchez Meca, «Nietzsche no se propone disolver ningún error ni alcanzar una verdad más fundamental. Lo único que trata es de colaborar activamente a la consumación del nihilismo» ${ }^{338}$. La verdad, en suma, no tiene un trasfondo epistemológico, sino, en realidad, moral: «el hombre exige la verdad» ${ }^{339}$, comprende Nietzsche. Sin embargo, «la produce en las relaciones morales con los hombres $»^{340}$. Es decir, la filosofía nietzscheana es enfrentada por Heidegger desde su propia distinción esencial entre lo que es verdadero y lo que, por oposición, no es, cuando en realidad Nietzsche parte de la empresa genealógica del significado y del valor de la voluntad de verdad. De manera que mientras Heidegger parte de la afirmación de la existencia de la verdad dentro de su particular investigación de la historia del ser, Nietzsche pretende reivindicar la intervención protagónica de la voluntad de poder como fuerza motriz del proceso creativo de dicha voluntad de verdad. Lo que sucede, sin embargo, es que para Heidegger la voluntad de poder es voluntad, esto es, «valor», objeto de una valoración estimada del hombre, y, en cuanto tal, subjetividad:

La «lógica» entiende el pensar como el representar de lo ente en su ser, un ser que el representar se atribuye en la generalidad del concepto. Pero qué ocurre con la reflexión sobre el propio ser, esto es, con el pensar que piensa la verdad del ser? Este pensar es el primero que toca la esencia inicial del $\lambda$ ó $\gamma$ oc, que en Platón e incluso Aristóteles, el fundador de la «lógica», ya está alterada e incluso perdida. Pensar contra «la lógica» no significa romper una lanza a favor de lo ilógico, sino simplemente repensar el $\lambda$ ó o $\varsigma$ y su esencia, manifestada en el alba del pensar, esto es: esforzarse por una vez en preparar semejante repensar. ¿Para qué nos valen todos los sistemas de la lógica, por muy amplios de miras que sean, si ya previamente e incluso sin saber lo que hacen rehuyen la tarea de preguntar aunque sólo sea por la esencia del $\lambda$ ó $\varsigma_{o}$ ? Si quisiéramos hacer objeciones, lo que desde luego sería completamente infructuoso, podríamos decir con toda la razón que es precisamente el irracionalismo, en cuanto negación de la ratio, el que reina desconocido e indiscutido en la defensa de la «lógica», que cree poder esquivar una reflexión sobre el $\lambda$ ó $\gamma$ s y sobre la esencia de la ratio que en él se funda.

El pensar contra «los valores» no pretende que todo lo que se declara como «valor»-esto es, la «cultura», el «arte», la «ciencia», la «dignidad humana», el «mundo» $\mathrm{y}$ «dios»- sea carente de valor. De lo que se trata es de admitir de una vez que al designar a algo como «valor» se está privando precisamente a lo así valorado de su importancia. Esto significa que, mediante la estimación de algo como valor, lo valorado sólo es admitido como mero objeto de la estima del hombre. Pero aquello

338 Sánchez Meca, D., En torno al superhombre, Barcelona, Anthropos, 1989, pág. 129.

${ }^{339}$ Nietzsche, F., Fragmentos póstumos I, 19 [97], op. cit., pág. 367 (KSA VII, 452).

${ }^{340}$ Ibid. (KSA VII, 452). 
que es algo en su ser no se agota en su carácter de objeto y mucho menos cuando esa objetividad tiene carácter de valor. Todo valorar es una subjetivización, incluso cuando valora positivamente. No deja ser a lo ente, sino que lo hace valer única y exclusivamente como objeto de su propio quehacer. El peregrino esfuerzo de querer demostrar la objetividad de los valores no sabe lo que hace. Cuando se declara a «dios» el «valor supremo», lo que se está haciendo es devaluar la esencia de dios. El pensar en valores es aquí y en todas partes la mayor blasfemia que se pueda pensar contra el ser. Y, por eso, pensar contra los valores no significa proclamar a son de trompeta la falta de valor y la nulidad de lo ente, sino traer el claro de la verdad del ser ante el pensar, en contra de la subjetivización de lo ente convertido en mero objeto $^{341}$.

De acuerdo con Heidegger, toda vez que Nietzsche hace de la voluntad de poder el elemento capital se está apropiando objetivamente de ella; enviste de valor lo objetivado desde la propia acción valoradora del sujeto, esto es, desde la subjetividad. Continúa Heidegger advirtiendo que en la filosofía de Nietzsche acaece el momento definitivo de la metafísica occidental, puesto que todo es comprendido desde una subjetividad absoluta que objetualiza el acontecer del mundo en una «enticidad» radical que ciega la mirada respecto del claro del ser; en Nietzsche, concreta Heidegger, se cierra el abismo gnoseológico del sujeto y el objeto al ser integrados el uno y el otro:

Todo ente es ahora o lo efectivamente real, en cuanto objeto, o lo eficiente en cuanto objetivación en la que se forma la objetividad del objeto. Representando, la objetivación dispone el objeto sobre el ego cogito. En este disponer se evidencia el ego como aquello que subyace a su propio hacer (el dis-poner poniendo-delante o re-presentado), esto es, se evidencia como subjectum. El sujeto es sujeto para sí mismo. La esencia de la conciencia es la autoconciencia. Por eso, todo ente es o bien objeto del sujeto, o bien sujeto del sujeto. En todas partes, el ser de lo ente reside en el poner-se-ante-sí-mismo y, de esta manera, im-poner-se. En el horizonte de la subjetidad de lo ente el hombre se alza a la subjetividad de su esencia. El hombre accede a la subversión. El mundo se convierte en objeto. En esta objetivación subvertidora de todo ente, aquello que en principio debe pasar a disposición del representar el producir, esto es, la tierra es desplazado al centro de toda posición y controversia humana. La propia tierra ya sólo puede mostrarse como objeto del ataque que, en cuanto objetivación incondicionada, se instaura en el querer del hombre. Por haber sido querida a partir de la esencia del ser, la naturaleza aparece en todas partes como objeto de la técnica ${ }^{342}$.

Se explica así la razón de la peculiar hermenéutica heideggeriana de Nietzsche, la cual lo incluye en el decurso histórico de la metafísica como cénit de la misma y manifestación masiva y más asfixiante del nihilismo:

Para la interpretación moderna de lo ente, la noción de valor es tan esencial como el sistema. Únicamente donde lo ente se ha convertido en objeto del representar se puede decir de algún modo que lo ente pierde su ser. Esta pérdida se

\footnotetext{
${ }^{341}$ Heidegger, M., Carta sobre el humanismo, op. cit., pp. 66-67.

${ }^{342}$ Heidegger, M., «La frase de Nietzsche 'Dios ha muerto’», op. cit., pág. 190.
} 
percibe de una manera tan poco clara y vaga que rápidamente se ve colmada de nuevo y de tal modo que al objeto y a lo ente interpretado como tal se les asigna un valor y, en general, se mide lo ente por valores y los propios valores se convierten en la meta de toda actividad. Dado que la actividad se comprende como cultura, los valores se convierten en valores culturales y, a su vez, éstos se convierten en la expresión de las supremas metas del crear al servicio de un asegurarse el hombre como subjectum. De ahí ya sólo falta un paso para convertir a los propios valores en objetos. El valor es la objetivación de las metas de las necesidades del instalarse representador en el mundo como imagen. El valor parece expresar que es precisamente en la posición de relación con él donde se lleva a cabo lo más valioso y, sin embargo, el valor es justamente el impotente y deshilachado disfraz de una objetividad de lo ente que ha perdido toda relevancia y trasfondo. Nadie muere por meros valores [...]. Como el pensamiento de Nietzsche permanece preso de la idea de valor, no le queda más remedio que explicar lo más esencial del mismo de una manera regresiva en tanto que inversión de todos los valores. Sólo cuando se consigue comprender el pensamiento de Nietzsche con independencia de la noción de valor, llegamos al punto desde el que la obra del último pensador de la metafísica se convierte en una tarea del preguntar y la hostilidad de Nietzsche contra Wagner se comprende como una necesidad de nuestra historia ${ }^{343}$.

El pensamiento de Nietzsche únicamente adquiere sentido para Heidegger cuando lo comprende dentro de la historia de la metafísica, dentro del despliegue de las distintas épocas a lo largo del cual el ente ha predominado sobre el ser en sus diferentes manifestaciones -la moral, el arte, la ciencia o, como sucede eminentemente en la modernidad, la técnica ${ }^{344}$-: «la verdad sobre el ente en su totalidad lleva desde antiguo el nombre de 'metafísica'. Cada época, cada humanidad, está sustentada por una metafísica y puesta por ella en una determinada relación con el ente en su totalidad y por lo tanto también consigo misma» ${ }^{345}$. La historia de la metafísica es la historia del olvido del ser en el ente, y Nietzsche es la figura donde llegaría su acabamiento y se abonaría el suelo nutricio de una nueva época que abriría nuevas puertas hacia la comprensión de la fundamental relación entre el ser y el ente. Por eso caracteriza la modernidad como la era del fin de la metafísica: durante los momentos históricos precedentes ha ido aconteciendo un olvido del ser al tiempo que se iluminaba el ente; Nietzsche significaría el punto de inflexión donde la metafísica occidental acabaría por desvelar su esencia ocultada durante milenios, conformando con ello las puertas hacia su superación desde el nihilismo:

343 Heidegger, M., «La época de la imagen del mundo», op. cit., pp. 82-83.

${ }^{344}$ Heidegger, M., «La frase de Nietzsche 'Dios ha muerto'», op. cit., pp. 158-159: «De acuerdo con la implicación esencial de la metafísica con las ciencias - exigida y perseguida una y otra vez por la propia metafísica - y teniendo en cuenta que dichas ciencias forman parte de la propia descendencia de la metafísica, el pensar preparatorio también tendrá que moverse durante un tiempo en el círculo de las ciencias, porque éstas siguen pretendiendo ser, bajo diversas figuras, la forma fundamental del saber y lo susceptible de ser sabido, ya sea con conocimiento de causa, ya sea por el modo en que se hacen valer y actúan. Cuanto más claramente se aproximen las ciencias hacia la esencia técnica que las predetermina y señala, tanto más decisivamente se explica la pregunta por esa posibilidad del saber a la que aspira la técnica, así como por su naturaleza, sus límites y sus derechos» (La cursiva es nuestra).

${ }^{345}$ Heidegger, M., Nietzsche, op. cit., pág. 551. 
El nihilismo es, por el contrario, ese acaecimiento que dura desde hace tiempo en el que la verdad sobre el ente en su totalidad se transforma esencialmente y se encamina hacia un final determinado por ella..

[...] El propio Nietzsche comprende su filosofía como la introducción al comienzo de una nueva época [...] Los escenarios del teatro del mundo podrán seguir siendo los mismos durante un cierto tiempo, la obra que se está representando ya es otra [...] se lo saluda como una liberación, se lo impulsa como una conquista definitiva y se lo reconoce como un acabamiento.

El «nihilismo» es la verdad que se torna dominante, según la cual todas las metas que tenía el ente hasta el momento se han vuelto caducas ${ }^{346}$.

La esencia que se desvela en el pensamiento de Nietzsche es la enticidad de la voluntad de poder, «el venir a la luz» del ente como voluntad de poder y su consecuente máximo alejamiento del ser. El nihilismo, como gran acontecimiento de Occidente, sería la historia finalmente triunfante del ente que acaba desvelándose como voluntad de poder.

El nihilismo significaba para Nietzsche, sigue Heidegger, la desvalorización de los valores supremos que hasta entonces habían regido el horizonte de pensamiento occidental; la muerte de Dios, por su parte, incide además en la pérdida de la necesidad de tales valores, así como de su rol legitimador: la desaparición radical del «mundo verdadero». La hermenéutica heideggeriana a propósito de la deconstrucción de la historia del nihilismo efectuada por Nietzsche lleva al exégeta a contemplar que durante las distintas épocas metafísicas y filosóficas se ha mantenido la pulsión de la esencia del ente. Luego la superación del nihilismo vendría desde la «transvaloración», que si bien para Nietzsche remite a la disolución de la mentalidad duplicadora y de la escisión, para Heidegger supone algo más: un nuevo modo de la relación entre el ser y el valor que habrá de partir de un origen distinto que colme de valor tales valores, a saber, la vida como voluntad de poder.

Para Nietzsche, la vida es voluntad de poder, la cual va más allá de la simple conservación fisiológica o de la darwiniana lucha por la vida; dos visiones de la existencia netamente positivistas inaceptables para el autor del Zaratustra, quien entiende que una vida encaminada únicamente a la mera conservación orgánica es «decadente», pues ha abandonado la «responsabilidad» que exige la dimensión del cuidado como condición de la «libertad» que opera en una existencia reapropiada. La voluntad de poder como esencia de la vida destaca la condición hermenéutica humana: vivir es crear valores. Ante lo cual señalará Heidegger que los valores cumplen la función de condiciones de posibilidad de la voluntad de poder como tal; algo así como un círculo donde la voluntad de poder como esencia de la vida es constituida por los valores que ella misma imprime. La voluntad de poder, en tanto que condición fundamente valoradora del hombre, cuenta en sí misma con los valores que la conforman, de tal forma que «voluntad de poder» es tanto como decir «voluntad», pues el «poder» no es sino valorar:

$$
346 \text { Ibid. }
$$


La voluntad no es un mero desear o un aspirar a algo, sino que querer es, en sí, dar órdenes, ordenar. [...] La voluntad no aspira en primer lugar a lo que quiere como a algo que no tenga todavía. Lo que quiere la voluntad, ya lo tiene. Porque la voluntad quiere su querer. Su voluntad es eso querido por ella. La voluntad se quiere a sí misma. Se supera a sí misma. Así pues, en cuanto querer, la voluntad quiere ir más allá de sí misma y, por lo tanto, tiene que llevarse detrás y debajo de sí misma. La superación de sí mismo en el poder forma parte de la esencia del poder. Esta superación del poder forma parte y surge del propio poder, en la medida en que es una orden y como orden se otorga el poder de superarse a sí misma en cada nivel de poder alcanzado. Es verdad que de esta manera el poder está siempre en camino hacia sí mismo, pero no como una voluntad que se encuentra disponible para sí misma en algún lugar y que intenta alcanzar el poder en el sentido de una aspiración. El poder tampoco se otorga poder sólo para superarse a sí mismo en cada grado de poder alcanzado, sino únicamente con la intención de apoderarse de sí mismo en lo incondicionado de su esencia. Según esta determinación esencial, querer es en tan escasa medida una aspiración, que más bien se puede decir que toda aspiración es y permanece una forma posterior o previa del querer.

En la fórmula «voluntad de poder» la palabra poder sólo nombra la esencia del modo en que la voluntad se quiere a sí misma, en la medida en que es el ordenar. En cuanto tal ordenar, la voluntad se reúne consigo misma, esto es, con lo querido por ella. Este autorrecogimiento es la facultad de poder del poder. Existe tan poco una voluntad por sí misma, como un poder por sí mismo. Así pues, voluntad y poder tampoco se limitan a estar agrupados en la voluntad de poder, sino que la voluntad es, en cuanto voluntad de voluntad, la voluntad de poder en el sentido del otorgamiento de poder. Pues bien, el poder tiene su esencia en el hecho de que, en cuanto voluntad dentro de la voluntad, está al servicio de la voluntad. La voluntad de poder es la esencia del poder. Muestra la esencia incondicionada de la voluntad que, en cuanto pura voluntad, se quiere a sí misma ${ }^{347}$.

Con todo, concluye Heidegger, dado que la voluntad de poder es voluntad de voluntad, su ser-en consiste en una vuelta eterna sobre sí misma. Y ahí radica precisamente su condición nihilista, en que no es capaz de darse metas, sino que se despliega en ella misma como tal en un juego absolutamente idealista. La voluntad de poder, por tanto, no se diferenciaría de la voluntad schopenhaueriana si aceptamos la apreciación de Heidegger: si la voluntad de poder es voluntad de voluntad, se definirá a lo largo de un círculo donde la voluntad quiere lo que ella es, a saber, el querer mismo.

Tras todo puede finalmente explicar Heidegger que el «salir a la luz» del ente como voluntad de poder en la filosofía de Nietzsche es el último advenimiento a la presencia del ente en el discurso del pensamiento europeo. Nietzsche es la conclusión del subjetivismo moderno que iniciase Descartes: ya en el francés el pensar está subordinado al querer, pues la verdad del ego cogito es el yo quiero [existir] ${ }^{348}$. Bajo la disposición intelectual car-

${ }^{347}$ Heidegger, M., «La frase de Nietzsche 'Dios ha muerto'», op. cit., pp. 174-175.

348 Cfr. Nietzsche, F., Fragmentos póstumos III, 40 [24], op. cit., pág. 852 (KSA XI, 641): «no hay certezas inmediatas: cogito, ergo sum presupone que se sabe qué es 'pensar' y, en segundo lugar, qué es 'ser'», pues «la fe en la certeza inmediata del pensamiento es una fe más, iy no una certeza!» (ibid. 40 [25] [KSA XI, 641]). 
tesiana se revela una voluntad que pretende adueñarse del ente, a saber, un método que capaz de procurar certeza; trayectoria que continúa Kant al perseguir un criterio de objetiva validez universal; y que al cierre culmina en la voluntad de poder nietzscheana, en la cual la voluntad se zafa de toda condición material: ella es su propio querer. Descartes inaugura el subjetivismo moderno con una filosofía donde el pensar está subordinado al querer, ímpetu que se despliega en los siglos posteriores hasta que finalmente, en Nietzsche, se integran -el pensar y el querer- plenamente: la verdad es el querer. La metafísica de la subjetividad se consuma en Nietzsche al sacar definitivamente a la luz que el ser de la razón es el querer, la volición, la «voluntad».

No es extraño entonces que Heidegger afirme que tras Nietzsche sea imposible la metafísica. Sin embargo, no nos parece adecuado ni su análisis ni su justificación. La metafísica, de acuerdo con Heidegger, surge al abrigo de la diferencia entre el ser y el ente, y su historia es la del progresivo olvido de tal distancia. El relato de las épocas del pensamiento occidental ha ido, en su decurso, alumbrando lo que yacía oculto, a saber el olvido del ser y el predominio del ente en esta dupla, hasta consumar su ulterior olvido, cerrando la brecha entre uno y otro integrándolos en un concepto último: la voluntad de poder. La revisión que hace Heidegger del corpus nietzscheano en general y de la voluntad de poder, en particular, no es pertinente, pues desplaza el eje en torno al cual gravita tan importancia concepto. La cáustica deconstrucción llevada a término por Nietzsche de la racionalidad occidental concluye en la imposibilidad de los esencialismos para legitimar la vida desde su más radical intimidad, la corporalidad. Si se quiere, podría tomarse la vida como la esencia de la vida; y en ese fundamental sustrato en el cuerpo y espíritu se reintegran interviene la voluntad de poder. Es gracias a los valores, en la medida en que desde ellos se despliega la condición perspectivista del hombre, que la vida puede postular a algo más que la simple conservación biológica; la expectativa de la mejor vida posible, el «llegar a ser lo que se es» es sólo accesible una vez la vida se desvela esencialmente como creadora de valores. Y los valores son, cierra Nietzsche, la condición de posibilidad de la voluntad de poder que, en un juego circular, ella mismo dispone. La vida es, en cuanto tal, voluntad de poder ${ }^{349}$. Mas no sólo hay tantas voluntades de poder como individuos, sino que por su concepción trágica de la existencia, Nietzsche contempla la presencia de diversas voluntades de poder dentro de cada sujeto. De este modo, a la luz de la madura sentencia del Zaratustra de que «en todos los lugares donde encontré seres vivos, encontré voluntad de poder» ${ }^{350}$, puede Nietzsche sostener que no habrá una verdad ontológica ni, por extensión, una verdad como adecuación pensamiento-mundo, sino tantas como voluntades de poder afirmándose activamen-

\footnotetext{
${ }^{349}$ Cfr. Nietzsche, F., Fragmentos póstumos IV, 2 [84], op. cit., pág. 101 (KSA XII, 103): «Juzgar es nuestra creencia más antigua, nuestro más habitual tener por-verdadero o por-no-verdadero».

350 Nietzsche, F., Así habló Zaratustra, op. cit., pág. 176 (KSA IV, 147).
} 
te ${ }^{351}$ : «el fenómeno del cuerpo es el fenómeno más rico, más claro, más aprehensible: anteponerlo metódicamente, sin decidir nada sobre su significado único» ${ }^{352}$. La «corporalidad» puso de manifiesto la elemental dimensión inconsciente de la personalidad, lo que impide a todas luces la identificación en la filosofía nietzscheana, como pretendió Heidegger, del pensar y el querer: si bien es cierto que la verdad es el querer, también lo es que aquello que contenga nuestra volición no está absolutamente claro ${ }^{353}$. El ser de la razón es el querer, mas tal «voluntad» no es la de un sujeto plenamente autoconsciente. Esto significa la recomendación de Nietzsche, que expusimos en la primera parte, de «tomar el cuerpo como hilo conductor»: el yo no coloniza el dominio de interrelación de las fuerzas que impulsan la existencia, conscientes algunas; inconscientes, otras -instintos-. De modo que nuestra conciencia del querer no significa la clara y distinta determinación de la voluntad, sino la constante valoración y posterior jerarquización de la deviniente voluntad de poder, cuyas implicaciones ulteriores no somos capaces de cifrar indubitablemente. Luego el querer como ser de la razón habrá de contemplar tanto lo consciente como lo inconsciente, esto es, renunciar a la pretensión unívoca y unitaria del ser para, en su lugar, concretarse en la disposición metodológica de «tomar el cuerpo como hilo conductor»:

Si nuestro «yo» es para nosotros el único ser de acuerdo con el cual hacemos y comprendemos todo ser: ¡muy bien! entonces resulta muy justificada la duda de si no hay aquí una ilusión perspectivista - la unidad aparente en la que todo se une como en una línea del horizonte. Siguiendo el hilo conductor del cuerpo se muestra una enorme multiplicidad; está permitido metodológicamente emplear el fenómeno más rico, que puede ser estudiado mejor, como hilo conductor para la comprensión del más pobre. Por último: suponiendo que todo es devenir, el conocimiento sólo es posible sobre la base de la creencia en el ser ${ }^{354}$.

Heidegger acusa a Nietzsche de no haber comprendido correctamente el fenómeno del nihilismo, radicando en semejante desconocimiento la definitiva deriva nihilista del pensamiento nietzscheano, metafísico. Parece, no obstante, que o bien fue Heidegger el que no comprendió satisfactoriamente la dimensión del nihilismo o no supo ver el núcleo problemático que enfrenta Nietzsche: para Heidegger la esencia del nihilismo no remite al hombre y, por ende, no lo afecta, sino que es cosa del ser; Nietzsche, por el contrario, lo ciñe al indescifrable misterio por el que la existencia y la capacidad de crear valores -la voluntad de poder- quedan sustantivamente ligados. Y en la medida en que la vida es voluntad de poder, el nihilismo habrá de ser un problema genuino de la existencia humana. Por

${ }^{351}$ Cfr. Sánchez Meca, D., En torno al superhombre, op. cit., pp. 259-282.

${ }^{352}$ Nietzsche, F., Fragmentos póstumos IV, 5 [56], op. cit., pág. 161 (KSA XII, 205-206).

353 Cfr. ibid. 5 [69], pág. 164 (KSA XII, 210): «Nuestras pasiones e inclinaciones quieren $s u$ satisfacción y para ello también el dominio sobre el intelecto».

${ }^{354}$ Ibid. 2 [91], pág. 103 (KSA XII, 106). 
lo tanto, el nihilismo, tal y como lo contempla Nietzsche, apunta más bien hacia la cualidad relativa y ficticia de los valores: la validez objetiva del deber ser pierde su legitimidad. El nihilista consecuente, este hombre duro, como el contemplado por Nietzsche, aprovecha la experiencia del nihilismo para erradicar las expectativas de un nuevo deber ser que sustituya al pretérito. No lleva razón Heidegger cuando dice que el nihilismo saca a la luz el deber ser -la aspiración cartesiana de certeza, de «enticidad»-como la verdad esencial de los valores; el nihilismo, dice Nietzsche, nos devela la lucha en la historia por la conquista de la epistemología moral, el enfrentamiento de fuerzas por el cual hacer de un valor específico la verdad única e indubitable:

Para poder decir no a todo lo que representa en la tierra el movimiento ascendente de la vida, la buena constitución, el poder, la belleza, la afirmación de sí mismo, para poder hacer eso, el instinto, convertido en genio, del resentimiento tuvo que inventarse aquí otro mundo, desde el cual aquella afirmación de la vida aparecía como el mal, como lo reprobable en síis5.

El nihilismo europeo como historia de Occidente descansa en una valoración, jerárquicamente alzada por la voluntad de poder, que ha puesto el sustrato germinal de la vida en un punto externo a la vida. El nihilismo es, pues, la enajenación de la existencia como consecuencia de radicarla fuera de sí misma. Así pues, el nihilismo tiene menos que ver con la certeza, como sugiere Heidegger, que con el problema de la valoración, puesto que el concepto de sujeto en cuanto tal es difuso y confuso a causa del fondo inconsciente: «la cuestión de los valores es más fundamental que la cuestión de la certeza: la última sólo adquiere seriedad en el supuesto de que la cuestión del valor haya tenido respuesta» ${ }^{356}$. En la filosofía de Nietzsche el sujeto epistémico no preexiste en la génesis del sujeto.

El nihilismo culmina, entonces, en la experiencia de desvalorización de los valores supremos que habían coordinado el paradigma occidental: la conciencia de la muerte de Dios, de que los fines y el sentido que guiaron escatológicamente el universo europeo, que radicaban en la idealidad metafísica - «mundo verdadero» o «mundo suprasensible» platónico- ya no aportaban por más tiempo significado; «entrañas llenas de aire».

No le faltaba razón a Heidegger al señalar que tras Nietzsche empezaba una nueva época para la filosofía. Sin embargo, este incipiente mundo nunca sería el del advenimiento del ser sobre el ente, como intuía el pensador de Friburgo, sino un espacio contemplado por

355 Cfr. Heidegger, M., Nietzsche, op. cit., pág. 821: «Si la metafísica de Nietzsche no sólo interpreta el ser como un valor desde el ente en el sentido de la voluntad de poder, si piensa además a la voluntad de poder como el principio de una nueva posición de valores y comprende a ésta como una superación del nihilismo, entonces en ese querer superar se expresa el más extremo quedar enredada de la metafísica en lo impropio del nihilismo, de manera tal que con ese quedar enredada se cierra el paso a su propia esencia y así, en la forma de una superación del nihilismo, le da a éste, sólo entonces, la eficiencia de su inesencia desencadenada».

356 Nietzsche, F., Fragmentos póstumos IV, 7 [49], op. cit., pág. 220 (KSA XII, 311). 
el hombre para y desde el hombre. El ser es ciego al hombre, por lo que la preocupación heideggeriana no apunta ulteriormente a la existencia. Nietzsche, por el contrario, anhela la imagen trágica del mundo, cuya dimensión no sólo no resultaba ajena a los caracteres elementales del hombre, sino que se armaba sobre éstos en un espacio que, si bien se antojaba difícil, peligroso, arriesgado proporcionaba acogida y las condiciones necesarias para hacer de la vida encarnada una existencia de cuidado. El nuevo tiempo abierto por Nietzsche es pensado como la redención de una existencia que durante todo el trazo de la tradición sufrió su propia condición:

El «ser» como invención de quienes padecen con el devenir.

[...]: con el nombre «apolíneo» se designa el permanecer arrobado ante un mundo inventado y soñado, ante el mundo de la bella apariencia, como una redención del devenir: con el nombre de Dioniso se bautiza, por otra parte, el devenir, activamente aprehendido, sentido subjetivamente, como la furiosa voluptuosidad del creador que al mismo tiempo conoce la ira del destructor. Antagonismo de estas dos experiencias y de los apetitos que están a su base: el primero quiere que el fenómeno sea eterno, ante él el hombre se vuelve sosegado, sin deseos, como un mar en calma, se restablece, se pone de acuerdo consigo y con toda la existencia: el segundo apetito empuja al devenir, a la voluptuosidad de hacer-devenir, es decir, de crear y aniquilar. El devenir, sentido e interpretado desde el interior, sería el continuo crear de alguien insatisfecho, extremadamente rico, infinitamente tenso y apremiado, de un Dios que sólo supera la tortura de ser con la transformación y el cambio permanentes: - la apariencia como su redención temporal, alcanzada en cada instante; el mundo como la sucesión de visiones divinas y redenciones en la aparien$\operatorname{cia}^{357}$.

La tarea de superación del nihilismo, o sea, la superación de la metafísica, habría de perseguir el fin de la episteme que ésta dispuso; el fin de la escisión del alma y el cuerpo, así como la disolución de la distancia cualitativa de los dos mundos. Con Heidegger podemos decir que Nietzsche cierra el abismo que separaba al sujeto del objeto, aunque no a causa de que éste llevara finalmente a término las máximas de la subjetividad integrando a uno en el otro, sino por desahuciar semejante abismo al reubicar el eje de gravedad de la reflexión sobre la propia vida. La nueva época a la que nos abre Nietzsche es aquella donde la gramática del Dios ha muerto ha sido superada; el ser es desprovisto de legitimidad en favor del devenir caótico de una existencia que ha de ser constantemente creada. Es, en suma, la transvaloración de un horizonte estático concebido epistemológicamente en otro hermenéutico cuyo acceso es estético:

Sólo estéticamente hay una justificación del mundo. Honda sospecha frente a la moral (pertenece también al mundo fenoménico).

La felicidad por la existencia sólo es posible como felicidad por la apariencia.

La felicidad por el devenir sólo es posible en la aniquilación de lo real de la «existencia», de la apariencia bella, en la destrucción pesimista de la ilusión.

357 Ibid. 2 [110], pp. 108-109 (KSA XII, 115). 
en la destrucción incluso de la apariencia más bella llega a su cima la felicidad dionisíaca ${ }^{358}$.

La transvaloración desnuda la existencia y el fondo del mundo, descubriendo su peculiaridad trágica. No rechaza el pesar y el dolor que entraña la vida ni las onerosas exigencias que implica el difícil escenario de un vida privada de sentido ulterior. Nietzsche destruye la ilusión benévola de la moral de los justos que había justificado los padecimientos abogando por la prometida recompensa de una vida trasmundana dichosa; en su lugar, recupera la «inocencia del devenir», que acentúa la cualidad plástica del hombre concreto y encarnado, haciéndolo «responsable», en tanto que «libre», de la creación de sus propias metas y fines de sentido.

Así pues, dado que la superación de la metafísica consiste para Heidegger en la recuperación del horizonte del ser, mas éste no pertenece al dominio del hombre, el proyecto del maestro de Friburgo no persigue la recuperación de la existencia encarnada. Por lo que podríamos invertir la hermenéutica heideggeriana para sentenciar, desde la contemplación de Nietzsche del nihilismo, que es en realidad Heidegger el pensador metafísico.

Al respecto de la muerte de Dios en Nietzsche Heidegger ha dicho lo siguiente:

La frase «Dios ha muerto» significa que el mundo suprasensible ha perdido su fuerza efectiva. No procura vida. La metafísica, esto es, para Nietzsche, la filosofía occidental comprendida como platonismo, ha llegado al final. Nietzsche comprende su propia filosofía como una reacción contra la metafísica, lo que para él quiere decir, contra el platonismo.

Sin embargo, como mera reacción, permanece necesariamente implicada en la esencia de aquello contra lo que lucha, como le sucede a todos los movimientos contra algo. El movimiento de reacción de Nietzsche contra la metafísica es, como mero desbancamiento de ésta, una implicación sin salida dentro de la metafísica, de tal modo que ésta se disocia de su esencia y, en tanto que metafísica, no consigue pensar nunca su propia esencia. Y así, para la metafísica y por causa de ella, permanece oculto eso que ocurre precisamente dentro de ella y en tanto que ella mis$\mathrm{ma}^{359}$.

Sin embargo, esta reducción del posicionamiento de Nietzsche a «mera reacción» contra el platonismo obedece más bien a las exigencias de los compromisos filosóficos del propio Heidegger que a una hermenéutica honesta. No debemos olvidar el relato de Crepúsculo de los ídolos en el cual Nietzsche narra la conversión del «mundo verdadero» en fábula: estas líneas apuntalan el derrumbamiento del ser de la metafísica como dador de significado. En su lugar, una nueva óptica, la de la voluntad de poder, que se enfrenta al «egipticismo» de

358 Ibid. 2 [110], pág. 109 (KSA XII, 116).

162.

${ }^{359}$ Heidegger, M., «La frase de Nietzsche 'Dios ha muerto'», en Caminos de bosque, op. cit., pág. 
la tradición filosófica, para la cual «lo que es no deviene; lo que deviene no es...» ${ }^{360}$. Una veneración absoluta del estatismo conceptual que se ha concretado tras el discurso de los siglos en el culto del «monótono-teísmo», particularmente en el de «ese deplorable Dios del monótono-teísmo cristiano» ${ }^{361}$ bajo cuyo seno queda «divinizada la nada, santificada la voluntad de nada» ${ }^{362}$. Como decíamos, la momificación a la que han sido sometidos los conceptos filosóficos es atravesada perpendicularmente por Nietzsche cuando introduce, gracias a la voluntad de poder, el perspectivismo. Y es que «luchar por una verdad y luchar por LA verdad son cosas completamente distintas ${ }^{363}$. El ser no es, con todo, como lo piensa Heidegger, no se oculta. El ser acontece por acción de la voluntad de poder. El ser como valor no se hace eco de la metafísica de la subjetividad; es tan sólo una interpretación: «¿Qué puede ser únicamente el conocimiento? - ‘interpretación', no ‘explicación’» ${ }^{364}$.

Así pues, que la verdad no sea pensada en caracteres epistémicos, sino morales, apunta a la preocupación íntima de Nietzsche: la vida y la garantía de sus condiciones. La estrategia nietzscheana no se trata de una vulgar reacción contra la metafísica, tampoco una inversión de sus formas, esto es, la permutación del mundo inteligible por el sensible y viceversa. Consiste en la eliminación radical de tal disposición del pensamiento. El eje de su filosofía descansa en la capacidad humana de valorar y juzgar, la cual atribuye significado a las metas y valores subjetivos; la metafísica es, precisamente, aquella cosmovisión cuya valoración pasa por una desvaloración de la vida y del mundo. Al poner fin al paradigma metafísico, se extirpa de la conciencia la dualidad contrapuesta de mundos; no es tampoco uno en detrimento de otro: «jal eliminar el mundo verdadero hemos eliminado también el aparente!» 365 .

La incursión de Nietzsche en la difícil cuestión de la verdad reformula la gramática logicista vertida en la modernidad. El lenguaje adquiere una tónica novedosa, extrayéndose de la bivalencia de los criterios «verdadero» y «falso»; ni siquiera son ya contrarios, antónimos, opuestos. El valor «1» no es deseable en detrimento del «0». Más aún, el primero no se contempla ya desde la nostalgia utópica de la corrección, sino que ha mutado en indeseable y odioso. A la verdad se le atribuye la fijeza inmutable del ser que niega el devenir subyacente a la vida; la falsedad es ahora, en cambio, motor de vida y de creación artístico-filosófica. La mentira, como ejercicio de la falsedad hace de la voluntad de ilu-

\footnotetext{
${ }^{360}$ Cfr. Nietzsche, F., Crepúsculo de los ídolos, op. cit., pág. 51 (KSA VI, 74).

${ }^{361}$ Nietzsche, F., El Anticristo, op. cit., pág. 49 (KSA VI, 185).

362 Ibid. (KSA VI, 186).

363 Nietzsche, F., Fragmentos póstumos I, 19 [106], op. cit., pág. 369 (KSA VII, 454).

${ }^{364}$ Nietzsche, F., Fragmentos póstumos IV, 2 [86], op. cit., pág. 102 (KSA XII, 104).

365 Nietzsche, F., Crepúsculo de los ídolos, op. cit., pág. 58 (KSA VI, 81).
} 
sión, de la máscara condición de posibilidad de la vida. Conforma la táctica intelectual desde la que poder introducirnos en un mundo que puesto que es, deviene. La transvaloración filosófica que ejecuta Nietzsche en el lenguaje, ese «poder de la mentira» busca ser «una filosofía de la vida del lenguaje en su uso tradicional, a través de la cual se abre una nueva forma filosófica de pensar» ${ }^{366}$.

En el marco del nuevo tiempo que los protagonistas decimonónicos sufren en primera persona, cuando los criterios y normas clásicos - tanto antiguos como modernos- han perdido su carácter sagrado, no puede mantenerse el cadáver de la lógica argumentativa de los viejos momentos. Los nihilistas que aceptan su inexorable situación definitoria han de abjurar ${ }^{367}$ del pretérito anhelo de verdad, pues su empresa no es ya epistemológica, sino esencialmente humana. Quizá demasiado humana, pues atendiendo a su finitud, que tanto restringe como capacita al hombre, se mueve en un clima de indeterminación que hace imposible su completa concreción conceptual: si aceptamos que no podemos definir la «verdad», no es menos cierto que la caracterización de la mentira se nos antoja igualmente incapaz, más allá del recurso poético de la máscara metafórica. Ahora bien,

la falsedad de un concepto no es para mí todavía ninguna objeción contra él. En eso nuestro lenguaje suena quizá de un modo muy extraño: la cuestión es hasta qué punto es favorecedor de la vida, conservador de la vida, conservador de la especie. Yo creo fundamentalmente incluso que las suposiciones más falsas son para nosotros las más imprescindibles, que sin aceptar la ficción lógica, sin medir la realidad con el mundo inventado de lo incondicionado, de lo igual a sí mismo, el hombre no puede vivir y que negar esta ficción, una renuncia práctica a ella, significaría tanto como una negación de la vida ${ }^{368}$.

Que no haya una verdad lingüística ontológica no implica que por medio del lenguaje no se prescriba una suerte de ontología. Como ha visto Conill, una ontología donde el lenguaje y la vida se funden en una afirmación sacrosanta para Nietzsche: la dimensión «deveniente» del «animal fantástico» ${ }^{369}$ que es el hombre.

Por lo que podemos concretar que la posición nietzscheana respecto del valor comporta, efectivamente, una peculiar y heterodoxa afirmación ontológica. La máscara, la mentira pese a su condición ficticia es a la vez traslúcida y opaca: en tanto que vacía de contenido, es prístina y transparente, nada oculta, mas en cuanto sometida por una voluntad de poder, que la asume e integra en su vida, se oscurece al adquirir el contenido que una

366 Conill, J., El poder de la mentira, op. cit., pág. 16.

367 Cfr. Nietzsche, F., Fragmentos póstumos III, 35 [35], op. cit., pág. 781 (KSA XI, 526): «la fe en la gramática, en el sujeto y objeto lingüísticos, en los verbos, ha subyugado hasta ahora a los metafísicos: yo enseño a abjurar de esta fe. [...]: algo puede ser condición de vida y a pesar de ello falso».

${ }^{368}$ Ibid. 35 [37] (KSA XI, 526-527).

${ }^{369}$ Cfr. Conill, J., El enigma del animal fantástico, Madrid, Tecnos, 1991. 
mentira hermenéutica concreta le ha atribuido. Por eso mismo puede afirmar Nietzsche, frente a una posible acusación de extremo e inoperante relativismo, que

liberado de la tiranía de los conceptos «eternos», estoy lejos, por otra parte, de precipitarme por eso en el abismo de una arbitrariedad escéptica: más bien, invito a considerar los conceptos como ensayos, con cuya ayuda determinadas especies de hombre se crían ${ }^{370}$.

Frente a Heidegger nos sentimos cómodos en la imagen de un Nietzsche emancipado de connotaciones metafísicas. Más aún, desde las observaciones últimas de La genealogía de la moral, la crítica se puede volver contra el propio Heidegger, a raíz de su enroque en la «nada». Y es que, como un nihilista más, ¿cabría la posibilidad de que Heidegger «prefiere querer la nada a no querer...» $»^{371}$ ?

\section{II.1.2. Descartes, gramático de la modernidad}

No sería extraño asegurar que la influencia cartesiana sobre la modernidad probablemente haya sobrepasado las expectativas del propio autor. Lo que empezara siendo la tentativa de un método demostrativo que garantizara para la ardua empresa de la investigación cognoscitiva una cierta seguridad acabaría en la configuración de un mundo nuevo, sin parangón con lo habido hasta entonces e irrepetible.

De igual modo que la colosal dupla griega que compusieron Platón y Aristóteles se repartió el horizonte intelectual antiguo y medieval, la presencia del francés se impondría durante las centurias modernas. Parafraseando a Whitehead, toda la modernidad son notas a pie de página de las obras de Descartes. No en vano, Nietzsche acaba haciendo retroceder su crítica del lenguaje a una crítica de la racionalidad logicista cartesiana: «la determinación y transparencia lógica como criterio de la verdad ('omne illud verum est, quod clare et distincte percipitur' [es verdadero todo lo que es percibido de modo claro y distinto] Descartes): de este modo resulta plausible y creíble la hipótesis mecánica del mundo» ${ }^{372}$.

El innatismo cartesiano se desvela en Nietzsche más como una de tantas fábulas gnoseológicas que el ser humano necesita esgrimir para apropiarse de un fragmento de la realidad que como un infalible precepto epistemológico; una más de las concreciones de la voluntad de poder, en este caso, reactiva. Tras el armazón conceptual arreglo al cual el pensador francés erigió una esforzada metafísica que afirmaba la existencia indubitable del ser pensante -la manifestación moderna del ser de la metafísica clásica, como ya hemos indicado-, Nietzsche objeta que tal empresa se hizo descansar no sobre una revelación invulne-

${ }^{370}$ Nietzsche, F., Fragmentos póstumos III, 35 [36], op. cit., pág. 781 (KSA XI, 526).

${ }^{371}$ Nietzsche, F., La genealogía de la moral, op. cit., pág. 144 (KSA V, 339).

372 Nietzsche, F., Fragmentos póstumos IV, 9 [91], op. cit., pág. 261 (KSA XII, 386), 
rable y sólidamente deducida, sino sobre una fe en la gramática, en la lógica del ergo $^{373}$. Descartes quedó atrapado en la trampa de las palabras, creyendo haber llegado, por medio de la gramática y la lógica, a una certeza inmediata: la fe en la gramática pone las cosas; nosotros, mientras tanto, seguimos lejos de la certeza.

La revelación indubitable del ser pensante cartesiano se acaba presentando a ojos de Nietzsche como una «contradictio in adjecto», al entender que las preguntas que condujeron todo su programa teórico -«¿pienso?», «¿existo?», «¿tengo certeza de?»- venían ya garantizadas cual autos de fe. Dado que todo quedó al abrigo de la confianza en la gramática, «antes de la pregunta por el 'ser' tendría que estar decidida la cuestión del valor de la lógica» ${ }^{374}$. La afirmación, por tanto, de la existencia subjetiva no puede aceptarse como una verdad primera desde la que haya de partir el conocimiento, sino como supuesto axiomático que responde a las exigencias lógicas de su propio planteamiento:

«Se piensa: por consiguiente hay un ser pensante»: en esto desemboca la argumentatio de Descartes. Pero esto significa poner ya como «verdad a priori» nuestra creencia en el concepto de substancia: -que si se piensa tiene que haber algo «que piensa» es sin embargo simplemente una formulación de nuestro hábito gramatical que para una acción pone un agente. En suma, aquí se está haciendo ya un postulado lógico-metafísico -y no simplemente constatando... Por la vía de Descartes no se llega a algo absolutamente cierto sino sólo al hecho de una creencia muy fuerte 375 .

El posicionamiento innatista cartesiano, en último término de carácter lógico-gramatical, es desnudado por Nietzsche, sacando a la luz su vacuidad; en el mejor de los casos, como la realidad del pensamiento no es cuestionada a lo largo de todo el proceso del cogito, arroja Descartes a la posteridad una tautología. Y en tanto que su ontología reviste de existencia el contenido estrictamente mental, entiende Nietzsche que «lo que Descartes quería es que el pensamiento no tenga sólo una realidad aparente sino una realidad en sí» ${ }^{376}$. Es, nuevamente, la estrategia de la duplicación, donde la Idea -el contenido de lo mental-rige sobre lo aparente -el mundo, el cuerpo-. El pensamiento no es, dice Nietzsche, un baluarte de claridad y distinción, sino una instancia más de la «corporalidad» que está en contacto con la potencial pluralidad existencial del hombre. En tanto que se ve afectado también por el dominio inconsciente, del pensamiento, tal y como lo presenta Descartes, no puede emanar un sujeto autoconsciente, o sea, un sujeto enteramente «cierto de sí».

${ }^{373}$ Cfr. Nietzsche, F., Fragmentos póstumos III, 40 [23], op. cit., pág. 851 (KSA XI, 640): «[...] habría que saber de antemano qué sea 'ser', para extraer del cogito un sum, así como habría que saber también qué sea saber: se parte de la fe en la lógica — ¡ante todo, en el ergo!».

${ }^{374}$ Ibid. (KSA XI, 640).

${ }^{375}$ Nietzsche, F., Fragmentos póstumos IV, 10 [158], op. cit., pág. 350 (KSA XII, 549).

376 Ibid. pág. 351 (KSA XII, 549). 
La ontología cartesiana descansa alevosamente sobre una reflexión lingüística que nunca llegó a explicitar. Una correlación de identidad entre el lenguaje y la realidad que se cristaliza en la noción de verdad. Así se puede entender el porqué de la crítica nietzscheana del lenguaje como crítica de la verdad. Por medio del lenguaje no se accede a la verdad, ya que en su intimidad el lenguaje precisamente distorsiona, desfigura, engaña, enmascara. De tal forma que adquiere inusitada fuerza la hipótesis de una mentira como motor significativo del lenguaje: el rasgo compartido del animal humano, creador de metáforas, es su capacidad figurativa, su apropiación simbólica de los contenidos del lenguaje en detrimento de una gramática lógicamente rígida. Es decir, el hombre, en virtud de su capacidad lingüística, tiene la capacidad de dar valor. Parafraseando a Heidegger, podría decirse que el lenguaje es la casa de la voluntad de poder.

\section{II.2. El lenguaje como praxis vital en Nietzsche: la gramática de la voluntad} de poder

La crítica del lenguaje se ha presentado en Nietzsche como una etapa fundamental de su crítica de la noción moderna de verdad. Sin embargo, no hemos de caer en el error de tomarla desde una perspectiva gnoseológica; no al menos si nos atenemos a la concepción moderna de la misma. La deconstrucción de la verdad alude, en realidad, más al propósito existencial que barrunta el pensador alemán que a una empresa científica. La inclusión del hombre en el mundo tiene lugar mediante el lenguaje; dicho heideggerianamente, sería algo próximo a un existenciario.

Ni el lenguaje es un fenómeno precursor al ser ni el ser determina el lenguaje; se establece para Nietzsche una unidad indisoluble según la cual no es posible concebir al hombre sin capacidad lingüística ni ésta siendo atribuible a otro organismo. En el ejercicio de esta interacción acontece el mundo humano: en la capacidad fabuladora del lenguaje se acopla perfectamente el carácter ficticio de las creaciones del hombre, empezando por sí mismo. Cuando Nietzsche afirma que somos lenguaje hace de nuestra especie, en último término, un ser fantástico; una fantasía que lo abre a una existencia potencialmente creativa: «ilas series y sucesiones de sentimientos, pensamientos, etc. que aparecen son síntomas del auténtico acontecer! Por debajo de cada pensamiento se esconde un afecto» ${ }^{377}$. Afirma al respecto Sánchez Meca que «Nietzsche define la vida como una forma duradera de múltiples procesos de tomas de posición de fuerzas en la que lo esencial es el poder de crear formas, es decir, de interpretar, de estimar, de evaluar sin más finalidad ni meta que la de conservar y acrecentar de ese modo su fuerza» ${ }^{378}$.

377 Ibid. 1 [61], pág. 53 (KSA XII, 26).

378 Sánchez Meca, D., Nietzsche. La experiencia dionisíaca del mundo, Madrid, Tecnos, 2009, pág. 150. 
Por lo que el lenguaje adquiere un cariz más vinculado a la filosofía práctica que a la teórica y conceptual; es el sustrato primero sobre el que se ha de nutrir la semilla de la propia vida. Es más, el lenguaje en Nietzsche acaba perdiendo el rigorismo lógico en beneficio de su dimensión estética, esto es, de su cualidad creativa emancipada de precaracteres conceptuales. De tal forma que el lenguaje no es un vehículo para expresar cuanto acontece; el sentido de la flecha es inverso en Nietzsche: no del mundo al lenguaje, sino del lenguaje al mundo. Emancipado de una creencia metafísica en el origen, las palabras están vacías, no tienen un fondo categorial desde el que tomar su significado. Son, entonces, invenciones que deben su procedencia a la fuerza vital del hombre y a su necesidad de supervivencia. La fecunda tensión moderna entre la construcción metafísica del mundo y el imperio de la necesidad observada por los primeros autores realistas es reescrita por Nietzsche en caracteres nihilistas: en el último tercio del siglo XIX la agonía queda establecida entre la fabulación hermenéutica $\sin$ fin $^{379}$ y las insalvables oposiciones naturales del medio. En el lenguaje queda cristalizada esta infinita oposición que Nietzsche llama «vida», pues vivir no es sino afirmar el esfuerzo humano por adueñarse creativamente de un mundo salvaje, en tanto que ficticio, y limitado y condicionado, en la medida en que se encuentra subordinado a la inexorable necesidad: «el 'ser' -no tenemos de él otra representación más que 'vivir'-. ¿Cómo puede entonces 'ser' algo muerto?»3 ${ }^{380}$.

El lenguaje se comprende entonces desde dos dimensiones, estética y utilitarista, que sin embargo no rompe la unidad constituyente por medio de la cual el hombre crea y se procura las condiciones de su supervivencia. En la convergencia de tales dos dominios tiene lugar la formación de la verdad, cuya genealogía no puede ya hacerse remitir a un relato metafísico, sino a una suerte de raíz social que responde a las expectativas pragmáticas ya mencionadas. No existe, pues, la correspondencia mítica entre la palabra y lo nombrado, tan sólo la necesidad de comunicación. Necesidad ésta que resalta la cualidad ficcional del mundo, ahogando con ello la contemplación de un horizonte de objetividad subyacente. Ahora bien, tampoco conlleva que la significación lingüística acontezca «por convención», al modo aristotélico. Decía el Estagirita que «nombre, pues, es un sonido significativo por convención» ${ }^{381}$. Esta definición no se ajusta exactamente a la caracterización nietzscheana. La aproximación del filósofo clásico invita a pensar en un quorum tácito por cuya conveniencia se concretan los conceptos; la respuesta de Nietzsche pasa por considerar la convención desde sus esquemas de ficción: la convención no es más que una mentira, una fabulación emanada de la proyección estética del hombre dentro del horizonte de la necesi-

379 Cfr. Nietzsche, F., Fragmentos póstumos IV, 2 [151], op. cit., pág. 123 (KSA XII, 140): «No se debe preguntar: ‘¿entonces quién interpreta?', sino que el interpretar mismo, en cuanto una forma de la voluntad de poder, tiene existencia (pero no como un 'ser', sino como un proceso, un devenir) como un afecto»,

380 Ibid. 2 [172], pág. 130 (KSA XII, 153).

381 Aristóteles, Sobre la interpretación, 16a 19, en Tratados de lógica II, introd. trad. y notas de Miguel Candel Sanmartin, Madrid, Gredos, 1988, pág. 37. 
dad comunicativa para garantizar la supervivencia. Precisamente por su origen convencional, por su condición mentirosa puede Nietzsche aseverar que «las verdades son ilusiones de las que se ha olvidado que lo son» ${ }^{382}$. Ilusiones, además, que han sido olvidadas debido al impacto colonizador del ser de la metafísica platónica en el imaginario occidental durante tantos siglos. Vattimo ha sabido concretar en pocas palabras el propósito de la reflexión lingüística de Nietzsche: «Nietzsche trata de encontrar, ni más ni menos, una alternativa a la metafísica, que en todas sus formas [...] produce así esa depresión de la vida en que consiste la decadencia vinculada con el racionalismo socrático (platónico)-cristiano» ${ }^{383}$.

El esfuerzo del autor por hacer del lenguaje una praxis vital dificulta la contraposición escolástica verdad-mentira. En realidad no es posible concluirla en Nietzsche, al menos en sus significados ortodoxamente legados ${ }^{384}$, pues la verdad es mentira y la mentira, verdad: todo cuanto acontece tiene lugar por la condición estética del hombre, es una fabulación y, por ende, mentira. Luego no es factible atribuirle un sustrato último, esto es, metafísicamente verdadero al mundo. Del mismo modo, esa mentira adquiere tintes de verdad toda vez que dicha ficción contribuye satisfactoriamente al fin de la comunicación, que es la supervivencia:

El intelecto, como medio de conservación del individuo, desarrolla sus fuerzas principales fingiendo, puesto que éste es el medio merced al cual sobreviven los individuos débiles y poco robustos, como aquellos a quienes les ha sido negado servirse, en la lucha por la existencia, de cuernos, o de la afilada dentadura del animal de rapiña. En los hombres alcanza su punto culminante este arte de fingir; aquí el engaño, la adulación, la mentira y el fraude, la murmuración, la farsa, el vivir del brillo ajeno, el enmascaramiento, el convencionalismo encubridor, la escenificación ante los demás y ante uno mismo, en una palabra, el revoloteo incesante alrededor de la llama de la vanidad es hasta tal punto regla y ley, que apenas hay nada tan inconcebible como el hecho de que haya podido surgir entre los hombres una inclinación sincera y pura hacia la verdad ${ }^{385}$.

Con todo, Nietzsche ha proyectado una pasarela que facilita el tránsito del lenguaje a la verdad. Ha hecho remitir el contenido de la verdad a las necesidades lingüísticas, y con ello perpetra una inversión radical del modo filosófico occidental, o sea, una transvaloración: el hombre antecede a la verdad, la cual nace con el objeto de resolver las carencias naturales con las que nuestra especie ha de lidiar. Nietzsche prosigue en su deconstrucción

\footnotetext{
382 Nietzsche, F., Sobre verdad y mentira en sentido extramoral, op. cit., pág. 25 (KSA I, 880-881).

${ }^{383}$ Vattimo, G., Introducción a Nietzsche, trad. de Jorge Binaghi, Barcelona, RBA Libros, 2012, pág. 37.

${ }^{384}$ En Sobre verdad y mentira Nietzsche hace interesantes referencias a esta definición ortodoxa de la mentira. Una peculiarmente precisa dice que «el mentiroso utiliza las designaciones válidas, las palabras, para hacer aparecer lo irreal como real; dice, por ejemplo, 'soy rico' cuando la designación correcta para su estado sería justamente 'pobre'» (Nietzsche, F., Sobre verdad y mentira en sentido extramoral, op. cit., pág. 20 [KSA I, 877]).
}

385 Ibid. pp. 18-19 (KSA I, 876). 
de la racionalidad metafísica de Occidente y conjetura que si en efecto la verdad conforma el universo de posibilidades, como así ha tenido por cierto la herencia platónica, desde esta nueva estrategia por él planteada este universo emergido de la verdad es sustancialmente humano: la verdad como horizonte regulador y fuente de condiciones de posibilidad proporciona su marco ontológico dentro de las cualidades estéticas del hombre, orientadas a la satisfacción de sus carencias y faltas. Nietzsche afirma una ontología del mundo enteramente humana, pues

no cabe duda de que con ello se ha traído a la luz una nueva verdad, pero es de valor limitado; quiero decir; es antropomórfica de cabo a rabo y no contiene un solo punto que sea 'verdadero en sí', real y universal, prescindiendo de los hombres. El que busca tales verdades en el fondo solamente busca la metamorfosis del mundo en los hombres; aspira a una comprensión del mundo en tanto que cosa humanizada $^{386}$.

Carlo Gentini ha apuntado en su fantástica monografía sobre nuestro autor que «la célebre máxima de Protágoras [...] se convierte en el fundamento de esta primera formulación del prospectivismo nietzscheano» ${ }^{387}$.

La íntima vinculación entre la verdad y su capacidad de producir efectos humanos $^{388}$-acciones, sí, pero también, y más importante, significados, valores y sentidos, metas y fines-conviene, por tanto, en la conclusión de que no existe la correspondencia isomórfica entre la verdad como mundo exterior al individuo y la comprensión subjetiva de dicho mundo. Es cierto que «la vida necesita creer en la verdad, pero es suficiente luego la ilusión» ${ }^{389}$, es decir, no existe diferencia esencial entre hablar de la mentira y de la verdad, ya que ésta no descansa sobre el orden lógico, sino en su fuerza ${ }^{390}$. La verdad es una cuestión pragmática emanada de las propias necesidades de la existencia. En palabras de Eugen Fink,

la consideración teórica del mundo se encuentra basada en un cultivo del arte que se ha tornado débil e impotente. El concepto lógico es, por así decirlo, la hoja

386 Ibid. pág. 28 (KSA I, 883).

387 Gentili, C., Nietzsche, trad. de Beatriz Rabadán, y José Luis Serrano, Madrid, Biblioteca Nueva, 2004, pág. 214.

388 Cfr. Nietzsche, F., Fragmentos póstumos I, 19 [43], op. cit., pág. 355 (KSA VII, 433): «las 'verdades' se demuestran mediante sus efectos, no mediante demostraciones lógicas».

389 Ibid. (KSA VII, 433).

390 Cfr. ibid. (KSA VII, 433): «las 'verdades' se demuestran mediante sus efectos, no mediante demostraciones lógicas sino con demostraciones de la fuerza. Aquello que es verdadero y lo que ejerce una acción son considerados como si fuesen lo mismo, y también en este caso nos plegamos ante la fuerza. ¿Cómo es entonces posible que se dé en general una demostración lógica de la verdad? En la lucha entre 'verdad' $y$ 'verdad' buscan éstas la alianza de la reflexión. Toda aspiración efectiva de la verdad al mundo por la lu-

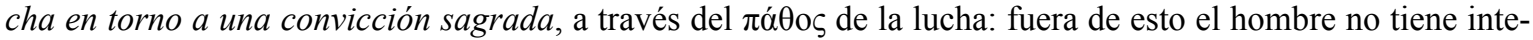
rés por el origen lógico»». 
seca y marchita que antes, como imagen, todavía florecía en el "árbol áureo" de la vida $^{391}$.

De modo que vida y verdad son, en el fondo, una y la misma cosa, en tanto que toda verdad lo es de acuerdo con la existencia y sus vericuetos respectivos. Así puede comprenderse una advertencia del propio Nietzsche, según la cual «luchar por una verdad y luchar por LA verdad son cosas completamente distintas ${ }^{392}$. El artículo determinado remite a la construcción lógica de dicho concepto, típica de la tradición metafísica, y la somete al imperio de la unicidad: la verdad, como reflejo exacto del exterior, es única; mientras que el artículo indeterminado, por el contrario, reduce las soberbias pretensiones de ésta al concebirla dentro de una pluralidad que fluye conforme el propio discurrir indeterminado de la vida. La lucha por «la verdad», con todo, recogería para Nietzsche la estrategia seguida a lo largo de la historia entera de la filosofía occidental. La defensa de «una verdad», en cambio, plasma las nuevas declamaciones que tienen lugar al ocaso de la modernidad, los aires de tinte nihilista que han impregnado los últimos momentos de esta época negando y negándose la posibilidad de una verdad trascendente. Decía Max Weber que una característica elemental de estos nuevos tiempos era el desencantamiento, la pérdida de la magia. Sin duda alguna este proceso se inicia con los jóvenes estudios de Nietzsche sobre el lenguaje. «En algún apartado rincón del universo centelleante, desparramado en innumerables sistemas solares, hubo una vez un astro en el que animales inteligentes inventaron el conocimiento. Fue el minuto más altanero y falaz de la 'Historia Universal'» ${ }^{393}$. Por todo lo dicho se explica que el momento de invención del conocimiento fuera altanero y falaz, el más altanero y falaz, pues emerge como resultado de una jerarquización de valores por la voluntad de poder desde el fondo insondable que es el hombre.

Dado que no existe una verdad última que trascienda y conceda una significación definitiva, su contenido dependerá de las fuerzas creadoras de los hombres. Mas tampoco es exacto sentenciar que el contenido depende de la humanidad. Alejado de los modismos metafísicos, no puede esperarse que Nietzsche deponga en una idea abstracta las dotaciones de sentido. Siguiendo la estela nietzscheana, Jesús Conill ha convenido en concretar al ser humano como aquel animal «que vive el enigma de la experiencia»" ${ }^{394}$, habiendo de ordenar el mundo en una serie de perspectivas ficticias para inocular un cierto orden significativo en tal vasto océano de complejidades. Y prosigue al respecto Conill destacando que

${ }^{391}$ Fink, E., La filosofia de Nietzsche, trad. de Andrés Sánchez Pascual, Madrid, Alianza Editorial, 1969, pág. 39.

\footnotetext{
${ }^{392}$ Nietzsche, F., Fragmentos póstumos I, 19 [106], op. cit., pág. 369 (KSA VII, 454).

${ }^{393}$ Nietzsche, F., Sobre verdad y mentira en sentido extramoral, op. cit., pág. 17 (KSA I, 875).

${ }^{394}$ Conill, J., El enigma del animal fantástico, op. cit., pág. 210.
} 
«la proyección perspectivista del mundo tiene su origen en la imaginación poética» ${ }^{395}$, la cual no expresa la dominación por la desnuda fuerza bruta, sino que canaliza la misma potencia de la vida, pues es «fruto de la voluntad de poder creadora» ${ }^{396}$.

La dificultad en este punto pasa por la afirmación de Zaratustra que contempla la voluntad de poder en todo ser natural: la voluntad de poder subyace en todos los hombres, pero las esperanzas de esta nobilísima tarea poética, de aspiraciones redentoras para la posteridad, no pueden depositarse en cualquier voluntad, pues «dentro de la especie humana se dan perspectivas e interpretaciones antagónicas, tales como las del esclavo y del señor, las del dionisismo y las del cristianismo, etc. Tales perspectivas diferentes son modos de percepción distintos que determinan diferentes formas de vida, lo cual demuestra que en el ámbito de los seres vivos se da una jerarquía de perspectivas que se diferencian unas de otras según el grado de poder y de dominio» ${ }^{397}$. Así que la constitución del horizonte hermenéutico de perspectivas y de significado debe quedar reservada únicamente para aquellas individualidades excepcionales que «no renuncian a su propia voluntad para someterse a la mediocridad de la mayoría» ${ }^{398}$. Lo que Nietzsche llamó «artistas» y que hemos concretado en este trabajo como «artista-filósofo».

El relato del mundo es desprovisto ya desde el joven trabajo El nacimiento de la tragedia de toda neutralidad; no es un hecho emancipado de fuerzas externas, sino que se trata de un discurso que proyectan distintas teorías que confeccionan todo un círculo hermenéutico que se aproximan a una objetividad inalcanzable. El mundo y su historia son un relato humano; no escapan de las restricciones de la interpretación y de la creación de sus propios agentes. Los actores que escriben y protagonizan el guión del mundo confiriéndole sentidos y significados son los artistas, quienes en virtud de su ejecución simbólica conforman los límites definitorios de cada época. Mediante el despliegue de su voluntad de poder el artista confecciona los trazos del concepto de «vida» de su correspondiente momento temporal y, con éste, sus respectivas necesidades y quebrantos. De este modo, la existencia y la voluntad de poder se integran en una unidad de destino ${ }^{399}$ la cual queda formalmente consagrada una vez es verbalizada, o sea, lingüísticamente proferida.

Por la condición contingente del contenido de los conceptos lingüísticos capitales de la tradición filosófica -vida, mundo, historia, etc.- es imposible atribuirles un significa-

395 Ibid

${ }^{396}$ Ibid. pág. 324.

397 Santiago Guervós, L. E. de, Arte y poder, Madrid, Trotta, 2004, pág. 437.

${ }^{398}$ Conill, J., El enigma del animal fantástico, op. cit., 324.

399 Cfr. Nietzsche, F., Fragmentos póstumos III, 5 [1], op. cit., pág. 139 (KSA X, 187): «¿Voluntad de vida? En su lugar encontré tan sólo Voluntad de poder». 
do ulterior; la verdad metafísica que durante siglos los había sustentado se desvanece en un archipiélago representacional de ilusiones, ficciones e interpretaciones. No es posible entonces acceder al 'en sí' de ellos -quizá inexistente, atribula Nietzsche- dado que su fondo, en tanto que salpicado de avatares inconscientes, es incognoscible. Cabe únicamente esperar aproximarnos a aquellas figuraciones hermenéuticas que hayamos sido capaces de conjugar. El lenguaje no metafísico no tiene potestad para apresar la verdad, ya que se ha deshecho de ella. No se pretende, tampoco es ya siquiera deseable, penetrar en la intimidad sustantiva del mundo: importa menos la objetivación de la vida que la labor orfebre de la voluntad de poder.

En última instancia, mediante el poder del lenguaje tan sólo evocamos el primitivo mundo de metáforas, olvidado hace tanto tiempo en las ensoñaciones objetivistas de la verdad metafísica. La crítica del lenguaje nietzscheana es una remisión a los orígenes de la fabulación humana, donde la potencia existencial de la voluntad de poder del artista regía en detrimento de las plebeyas aspiraciones de verdad, propias de espíritus incapaces de dar lugar mediante su propia fuerza, capacidad e ingenio a un círculo simbólico de delimitaciones vitalistas. Es el reconocimiento del inescrutable fondo humano y su esforzada recuperación; es el rechazo de la clarividencia del subjetivismo moderno y de las trascendentales ideas griegas. En su lugar se presenta la existencia inserta en un marco de fragilidad sometido al cambio y a la corrupción que comporta de propio el devenir; al tiempo que arrojada a la infinidad del horizonte de posibilidades de ser, dependientes éstas de la determinación artístico-filosófica de la voluntad de poder de cada individuo. Es, con todo, la renuncia de una configuración abstracta y formalmente uniforme de la existencia para ofrecer en su lugar la alternativa de una distinción peculiar que devuelva al sujeto concreto el rol significante de su propia existencia encarnada.

La coyuntura simbólica del lenguaje es homóloga a la de la verdad. Esto permite a Nietzsche $-y$ a la hermenéutica posterior- argüir efectivamente a favor de la existencia de la verdad, mas humanamente condicionada: la verdad existe no como realidad objetiva y extraña al hombre, sino que en él halla sus condiciones. La confirmación lingüística del mundo no es otra cosa que la afirmación de la vida, al convenir en el trasfondo puramente humano que motiva las conceptualizaciones de sus pilares gramaticales -verdad, voluntad, ser, existencia entre otros-. Se configura un cosmos de significación, «cultura», que validará unos u otros criterios, y dentro del cual los individuos se identifican en su esencial pluralidad.

La constitutiva faceta simbólica determina en un primer momento las categorías cognoscitivas epocales. A continuación, y desde ella, se entabla el entramado posible de relaciones e interacciones humanas: el cumplimiento de los códigos conductuales establecidos propicia la integración del sujeto en la comunidad, del mismo modo que el rechazo de 
los mismos comporta la censura de los semejantes, confirmándose con ello el carácter enteramente pragmático del lenguaje, siendo imposible superar las propias limitaciones germinales. No existen los en sí, sino que la adquisición simbólica de significado se corresponde con su inclusión en una situación histórica concreta. Así sucede que «un hecho, una obra tiene algo nuevo que decir a cada época y a cada especie nueva de hombre. La historia dice siempre verdades nuevas» ${ }^{400}$.

La dependencia histórica del lenguaje se comprende desde la lucha nietzscheana contra la hermenéutica cristiana. El Dios que hoy yace muerto correspondía la promesa de inmortalidad con el «egipticismo» de los conceptos; las momias conceptuales que esencializaban la gramática del ser ${ }^{401}$. La voz metafísica tiene por reflejo un espectro del hombre y del conocimiento necesariamente metafísico, esto es, eterno e inalterable, incólume ante el devenir de los tiempos. Abrazar la gramática desde el umbral del simbolismo significa dar la espalda definitivamente a los embalsamadores de conceptos, quienes constriñen la realidad mediante férreos vendajes de esterilidad que esquilman la fecundidad propia de la vida. El rechazo del egipsticismo es la negación de la consagración de lo inmóvil, del ser en cuanto tal ha sido concebido tradicionalmente, es la aceptación incondicional del devenir y el cambio como constantes típicas de la casuística de la vida. Y es que «vosotros no debéis -sentencia Nietzsche- refugiaros en una metafísica, sino que ¡debéis sacrificaros activamente a la cultura en devenir!» ${ }^{402}$. Ocurre que lejos de toda aparente contradicción, la aceptación de la vida acoge en su seno también la muerte: a diferencia de la inmutabilidad metafísica, en el frenesí del devenir percuten tanto la generación como la destrucción, «por eso soy severo frente al idealismo soñador» ${ }^{403}$, cierra Nietzsche.

En síntesis, el devenir al que nos arroja el lenguaje no metafísico, que extiende el eterno ciclo de la generación y la corrupción sobre los grilletes del inmovilismo conceptual de una tradición milenaria, es uno de los hitos sobre los que pretende Nietzsche devolver al hombre las claves de su propia existencia, enajenada desde tanto tiempo en ídolos extraños y cualitativamente contrarios a la inconceptualizable inmanencia de la vida encarnada. Las deidades intemporales han sido preguntadas a martillazos y no han soportado el interroga-

${ }^{400}$ Ibid. 16 [78], pág. 360 (KSA X, 525).

${ }^{401}$ Cfr. Nietzsche, F., Crepúsculo de los ídolos, op. cit., pág. 51 (KSA VI, 74): «¿Me pregunta usted qué cosas son idiosincrasia en los filósofos?... Por ejemplo, su falta de sentido histórico, su odio a la noción misma de devenir, su egipticismo. Los filósofos creen otorgar un honor a una cosa cuando la deshistorizan, sub specie aeterni [desde la perspectiva de lo eterno], - cuando hacen de ella una momia. Todo lo que los filósofos han venido manejando desde hace milenios fueron momias conceptuales; de sus manos no salió vivo nada real. Matan, rellenan de paja, esos señores idólatras de los conceptos, cuando adoran, -se vuelven mortalmente peligrosos para todo, cuando adoran. La muerte, el cambio, la vejez, así como la procreación y el crecimiento son para ellos objeciones, - incluso refutaciones. Lo que es no deviene; lo que deviene no es... Ahora bien, todos ellos creen, incluso con desesperación, en lo que es».

$$
\begin{aligned}
& 402 \text { Nietzsche, F., Fragmentos Póstumos I, } 19 \text { [154], op. cit., pág. } 378 \text { (KSA VII, 467). } \\
& { }^{403} \text { Ibid. (KSA VII, 467). }
\end{aligned}
$$


torio; tras el sonido hueco de sus entrañas, se desvela la engañosa fábula sobre la que se construyó un mundo irreal con, no obstante efectivas, pretensiones normativas. El elogio nietzscheano de la vida ha transformado las estructuras sintácticas de la existencia; allí donde antes se hablaba en voz pasiva el pensador alemán exige para el tiempo actual -y futuro, sobre todo- la alternativa activa: el hombre no puede seguir desempeñando, como ha acontecido hasta la fecha, el rol de sujeto paciente. «Dominar -y no ser más esclavo de un dios- éste es un medio que nos queda para ennoblecer al hombre» ${ }^{404}$.

\section{II.2.1. La sintaxis y la metafísica del lenguaje como metafísica del ser}

Al término del anterior punto incidimos en un aspecto crucial al que indefectiblemente conduce la problematización nietzscheana del lenguaje: la necesaria reformulación de la sintaxis. Las normas lingüísticas sobre las que se despliega el lenguaje parecen imprimir ciertas restricciones que limitan la fuerza creativa de las palabras. Puede recuperarse el contenido de la vieja metáfora baconiana donde asimilaba el modo en que operaban los racionalistas bajo el tropo de la araña; la tela del arácnido ha cubierto el entramado cognoscitivo de la modernidad estableciendo dentro de ella el horizonte conceptual posible. Un problema detectado ya precozmente por Nietzsche en un fragmento póstumo del momento de Sobre verdad y mentira, diagnosticando esta patología en un sugerente aforismo: «el filósofo atrapado en las redes del lenguaje» ${ }^{405}$. La metafísica deviene trampa en forma de estructura lógicamente normativa: el logos queda apresado en la inexpugnable ciudadela de la sintaxis.

No sería en realidad un problema capital de no ser por que la configuración sintáctica de la metafísica se ha postulado intemporal desde su mismo origen. El carácter de extrañamiento con respecto del tiempo no posibilita que las reglas de manifestación del logos varíen conforme el discurrir de las épocas, de modo que el estudio genealógico de la gramática y sus condiciones de posibilidad para el despliegue verbal le revela a Nietzsche que había una alevosa vocación de inmutabilidad en la historia que ha desembocado en una clase de metafísica de índole lingüística, vehículo a su vez de la metafísica del ser. La trampa de la araña, continúa Nietzsche, ha consistido en revestir su frágil red de sucesivas capas para conferirle una falsa apariencia de consistencia e impermeabilidad y, con ello, dotarla de un pretendido carácter sacrosanto. Y frente a estos esfuerzos de la metafísica lingüística por fijarse incorruptible Nietzsche se pregunta si acaso «¿es el lenguaje la expresión adecuada de todas las realidades?» ${ }^{406}$. La negación del autor es obvia, puesto que ni siquiera podemos hablar de «realidades», en plural, una vez ha sido arrancada de la exis-

${ }^{404}$ Nietzsche, F., Fragmentos póstumos III, 22 [7], op. cit., pág. 434 (KSA X, 634).

${ }^{405}$ Nietzsche, F., Fragmentos póstumos I, 19 [135], op. cit., pág. 375 (KSA VII, 463).

${ }^{406}$ Nietzsche, F., Sobre verdad y mentira en sentido extramoral, op. cit., pág. 21 (KSA I, 878). 
tencia de los hombres la influencia del tiempo esencial: «mira al mundo como si el tiempo ya no existiese: $y$ todo lo torcido se te volverá recto» ${ }^{407}$.

El andamiaje sintáctico del modus metafísico descansa sobre el concepto mismo de «concepto», tomado como categoría cardinal del pensamiento. Nietzsche entiende que se los ha abotargado con un contenido trascendental irreal que ha terminado por conducir a una creencia irracional en el «ser» que albergan. La aceptación sistemática de los conceptos de la tradición es, más bien, una disposición contraria a la filosófica, pues toma dichos contenidos sin la precaución de la mirada crítica. La filosofía dogmática descrita por Bacon ha podido construir sus sistemas confiando inercial y devotamente en estos hitos atávicos. Así Descartes, por ejemplo, a quien Nietzsche acusa de dar un salto ontológico injustificable desde el trampolín del cogito. El peligro de los conceptos cuando caen en manos de los dogmáticos es, precisamente, el caso cartesiano, donde la definición analítica de los mismos impide toda injerencia externa sobre ellos, de tal forma que quedan confinados atemporalmente en los códices originales de la araña primigenia.

El cogito es el resultado paradigmático de cuanto ha advertido Nietzsche al respecto de la ontologización de la gramática. En el complejo de las situaciones mentales que llevaron al pensador francés a concretar la evidencia del sujeto pensante Nietzsche aprecia el esforzado empeño por hacer de una fervorosa creencia una verdad metafísica. En la lógica performativa de la estrategia racionalista la gramática deductiva arrastra consigo el compromiso ontológico del ser. Una imbricación inseparable entre lógica y metafísica presente desde los tiempos griegos, la «sustancia». La gramática ha facilitado entonces que una mera creencia haya determinado el proceder filosófico de Occidente, y en particular, el modo moderno, arreglo al cogito. Así, la formación del pensamiento tradicional desde la necesidad gramatical de la sustancia debe su consagración a la irracional vinculación de la lógica lingüística y el compromiso metafísico del ser, que en la modernidad termina cristalizando en la indubitable certidumbre dogmática que al cogito le han brindado las verdades innatas y sus homólogos, los conceptos analíticos. En último término, dice Nietzsche, bastaría con perder de vista el hábito sintáctico de la lógica y el ser para emanciparnos de esta tramposa red de conceptos falaces. Es decir, la emancipación de la gramática llegará cuando se haya acabado con las epistemologías que parten lógicamente de la dualidad sujeto-objeto, las cuales concluyen en viciosas tentativas, tales como la «cosa en sí» o el «fenómeno», que fragmentan la unidad existencial del mundo para imponerle una disposición lingüística impropia.

La desconfianza de la analiticidad de los conceptos es genuinamente antropológica: el único recurso disponible para legitimar los juicios y los conceptos es la propia vida del individuo, empírica y encarnada en un momento concreto. Nietzsche es consciente de

${ }^{407}$ Nietzsche, F., Fragmentos póstumos III, 5 [1], op. cit., pág. 159 (KSA X, 216). 
que la metafísica lingüística guarda en su seno elementos seductores que han atraído a pensadores de distintas y muy distantes generaciones, como la cuestión de la posible validez universal de los juicios. Ya en la primera de las Intempestivas, tan joven como Sobre verdad y mentira, plantea esta sospecha: «un hombre mayor debería saber que la lengua es una herencia recibida de los antepasados que hay que dejar a los descendientes, por lo que hay que respetarla como algo sagrado, inestimable e inviolable» ${ }^{408}$. Sin embargo, y a pesar de las angustiosas y dolorosas implicaciones que arrastra su deconstrucción de la sintaxis dogmática, nuestro autor no puede más que aceptar, quizá con algo de temor, el difícil desenlace del derrumbamiento de la analiticidad ahistórica e intemporal de la gramática metafísica. Un compromiso moral y existencial que abraza «porque una sola cosa es necesaria: que el hombre alcance a estar conforme consigo» ${ }^{409}$, lo cual sólo es posible desde un filosofar histórico. Pues filosofar desde la historia significa en primer lugar que «el hombre ha devenido» ${ }^{410} \mathrm{y}$, después, tomar conciencia de ello.

Tras estos cantos de sirena de los que se vale la metafísica del lenguaje advierte Nietzsche una pérfida voluntad de engaño, un tenaz esfuerzo por agotar las expectativas de renovación filosófica. El maridaje tradicional de la metafísica y el lenguaje ha llevado a una fe cuasimitológica en la gramática: el marco de apertura que brindaba la sintaxis a la lengua proyecta idénticamente tanto las posibilidades de existencia como el horizonte de significación conceptual. Una deficiente lectura del lenguaje ésta que Nietzsche hace remitir a una «carencia de filología» ${ }^{411}$.

Las capacidades de las que goza la filología para adentrarse en el fenómeno lingüístico y su gramática correspondiente, así como los posibles beneficios de dicha estrategia aproximativa, son contemplados por Nietzsche, aunque sin detallarlos profusamente. Será ya en el siglo XX, con las figuras de Heidegger y de Gadamer, cuando la profunda lección nietzscheana se conforme canónicamente en un corpus filosófico: traer a la presencia el «horizonte de precomprensión» epocal. De acuerdo con Nietzsche, y esta sospecha será mantenida durante toda su obra, la filología habría de lograr atravesar el imperturbable andamiaje del sistema de las reglas sintácticas y trascenderlo. El lenguaje filológico pensado por el joven profesor de Basilea apunta a un cosmos trazado en una pluralidad simbólica cuya fuerza indeterminable desintegra la capacidad epistemológica del más prolijo y fecundo de los sistemas reglados. La demanda de filología es, en último término, la

408 Nietzsche, F., Consideraciones intempestivas I David Strauss, el confesor y el escritor, trad. de Joan B. Llinares, en Obras completas. Volumen I. Escritos de juventud I, ed. de Diego Sánchez Meca, Madrid, Tecnos, 2011, pág. 690 (KSA I, 235).

\footnotetext{
${ }^{409}$ Nietzsche, F., La gaya ciencia, op. cit., pág. 835 (KSA III, 531).

${ }^{410}$ Nietzsche, F., Humano, demasiado humano I, op. cit., pág. 44 (KSA II, 24).

${ }^{411}$ Nietzsche, F., Más allá del bien y del mal, op. cit., pág. 80 (KSA V, 69).
} 
llamada a cuestionar nuestros presupuestos conceptuales así como a nosotros mismos, pues el propio concepto de $\mathbf{s i ́}^{412}$, también, vendrá condicionado históricamente.

La falta de filología que Nietzsche observó en los filósofos es una laguna profunda en el pensamiento tradicional de Occidente. La ausencia de este ímpetu le ha impedido a la filosofía crecer. En realidad la disciplina filosófica sigue siendo la misma que orquestase el idealismo platónico; la diferencia entre antiguos y modernos es más una cuestión de nomenclatura que de sustrato teórico. En último término, la pérdida del olfato filológico ha servido para apuntalar una relación entre el hombre y el mundo en clave subjetivizadora: sujeto-objeto, genuinamente moderna, que no deja de ser, no obstante, la antiquísima relación de causalidad ${ }^{413}$. Se trata de una relación atípica que en nada interpele al ser humano, sino que al contrario, lo cuestiona y agota. Pues así como la mosca queda atrapada en la mortífera trampa tejida por la araña, los filósofos han sido prisioneros de la consagración de un único horizonte cognoscitivo. En la relación de causalidad se separa estrictamente al sujeto y al objeto al enajenar la acción de su(s) agente(s), lo cual acontece, por supuesto, en un nivel sintáctico: bajo el concepto de «causa», la multiplicidad de factores - muchos de ellos actuando con una sutileza tal que impide su descubrimiento- son agotados en una única entidad, la sustancia de la causalidad. Este concepto, esta palabra encierra el compromiso metafísico del ser, integrando toda la pluralidad en la unicidad esencial de su término y anulando las capacidades disruptivas de elementos externos incontrolables e incontrolados en la medición ideal. De tal forma que al término de la relación de causalidad el agente de conocimiento tan sólo nombra, pues se han cercenado las diferencias esenciales de los componentes constitutivos de la relación en beneficio de la inmutabilidad del ser. La sintaxis cartesiana ha canalizado el ser -inalterable, intemporal, ahistórico- a través del pensamiento -lógica, metafísica, sustancia, noúmeno, relación de causalidad, etc.-, tornándolo permanencia absoluta dentro de una pluralidad que es despreciable. Así que la falta de filología no es sino la incapacidad hermenéutica de una longeva tradición que impuso una unitaria visión del espectro humano, inabordable e irrompible. La «filología» perseguida por Nietzsche es menos la ciencia positivista que se cultivaba en las universidades de su tiempo que el ímpetu estético del artista-filósofo.

La sintaxis de la metafísica tradicional es por tanto cruel y despiadada con el ser humano, pues olvida la tarea constitutiva de éste y lo reduce a una única posibilidad, elimi-

${ }^{412}$ Cfr. Nietzsche, F., Fragmentos póstumos III, 5 [1], op. cit., pág. 159 (KSA X, 216): «Cuando quise tener el placer de la verdad, inventé la mentira y la apariencia - lo próximo y lo lejano, lo pasado y lo por venir, lo perspectivista. Entonces puse dentro de mí mismo la oscuridad y el engaño e hice de mí una ilusión para mí mismo».

${ }^{413}$ Es sumamente ilustrativo que el racionalismo más maduro -escuela dogmática, de acuerdo con la categorización de Bacon- postulase el principio de razón suficiente como clave metafísica fundamental de su propuesta. Del mismo modo, es también significativo que cuando redujo la copiosa tabla kantiana de las categorías dejase Schopenhauer únicamente la de causalidad. 
nando del espectro de capacidades cualquier otra alternativa, por sugerente que pudiera llegar a resultar, si se asume al margen de las restrictivas dimensiones regulativas del origen. Se trata de convenir, entiende Nietzsche, en su esencial dimensión artística y en la consecuente tarea de construcción antropológica. La superación de los códigos gramaticales y sintácticos de la metafísica del lenguaje permitirá al filósofo del futuro reabrir el concepto de «ser» e introducirlo en un horizonte de futuribles posibilidades:

Por su génesis, el lenguaje pertenece a la época de la forma más rudimentaria de psicología: penetramos en un fetichismo grosero cuando cobramos consciencia de los presupuestos básicos de la metafísica del lenguaje, dicho con claridad: de la razón. Ese fetichismo ve en todas partes agentes y acciones: cree que la voluntad es la causa en general; cree en el «yo», cree que el yo es un ser, que el yo es una substancia, y proyecta sobre todas las cosas la ciencia en la substancia-yo-así es como crea el concepto «cosa»... El ser es añadido con el pensamiento, es introducido subrepticiamente en todas partes como causa; del concepto «yo» es del que se sigue, como derivado, el concepto «ser»... Al comienzo está ese error grande y funesto de que la voluntad es algo que causa efectos, - de que la voluntad es una facultad... Hoy sabemos que no es más que una palabra... Mucho más tarde, en un mundo mil veces más ilustrado, llegó a la consciencia de los filósofos, para su sorpresa, la seguridad, la certeza subjetiva en el manejo de las categorías de la razón: ellos sacaron la conclusión de que esas categorías no podrían proceder de la empiria, -la empiria entera, decían, está, en efecto, en contradicción con ellas. ¿De dónde proceden, pues?- Y tanto en India como en Grecia se cometió el mismo error: «nosotros tenemos que haber habitado ya alguna vez en un mundo más alto (-en lugar de en un mundo mucho más bajo: ¡lo cual habría sido la verdad!), nosotros tenemos que haber sido divinos, ipues poseemos la razón!». De hecho, hasta ahora nada ha tenido una fuerza persuasiva más ingenua que el error acerca del ser ${ }^{414}$.

No es, entonces, renunciar a la gramática, sino desencializarla, privarla de su condición sagrada y arrojarla dentro del discurrir del tiempo humano en devenir.

Por medio de la investigación filológica de la gramática Nietzsche pretende una reapropiación del presente. El escrutinio escrupuloso del tiempo actual habrá de desvelar, entiende, cuán fértiles son aún sus simientes, qué cauces faltan por explorar, qué puertas de creación le restan todavía al hombre por atravesar. Con este procedimiento le imprime un nuevo ciclo motriz a la paradigmática máquina moderna del reloj, un nuevo sentido para el mismo movimiento de las agujas: el tránsito de los segundos, de los minutos, de las horas no es ya el mero decurso de un tiempo cronológico, sino la inserción de la dimensión existencial del tiempo en la vorágine caótica e inaccesible de la esencial generación y corrupción inmanente de la vida. Con todo, dicho desde Gadamer, Nietzsche nos empuja abruptamente a la disposición hermenéutica al forzarnos a distinguir críticamente las coyunturas de nuestro tiempo -de nuestro horizonte de precomprensión-, nutrirnos de las mismas y consumirlas en el fuego de la destrucción una vez hayan quedado agotadas, configurando

${ }^{414}$ Nietzsche, F., Crepúsculo de los ídolos, op. cit., pp. 54-55 (KSA VI, 77-78). 
tras esto los márgenes de un nuevo espacio epocal -nuevo horizonte de precomprensión-. La potencia hermenéutica de Nietzsche es primariamente vital, toda vez que el rechazo de un horizonte de precomprensión no vendrá condicionado por sus limitaciones epistemológicas, sino por haber visto agotadas sus capacidades creadoras, deviniendo lastre: la destrucción de las viejas tablas de valor, exige al hombre Zaratustra ${ }^{415}$, para que pueda embarcarse en la venturosa empresa de su «corporalidad» viviente.

Haber subordinado la sintaxis a la fuerza del ahora le permite a Nietzsche refrendar sus conclusiones sobre la artificialidad de las reglas de juego impuestas por las gramática. Son estructuras que nada dicen de la realidad; un correlato falso con el mundo y que, por ello mismo, no puede apresar la idealidad del «ser». La realidad es inaccesible en su plenitud, y, tras su disección de la gramática y la sintaxis como subrepticios elementos normativos de la metafísica, ha quedado desprovista de su supuesta racionalidad. Dada la abismal genética del mundo, necesitamos algún medio que proyecte algún atisbo de sentido sobre el mar indómito de la existencia: el lenguaje. Ahora bien, tomándolo desde la caracterización de medio, se le atribuye una cualidad sustantiva artificial: mediante las reglas del lenguaje se racionaliza lo que existe, se configura una cosmovisión del mundo que satisface nuestras específicas exigencias de supervivencia. La gramática y la sintaxis son necesarias para apresar el mundo, pero desde la esencial inesencialidad que dichos productos humanos son capaces de proporcionar. El nuevo modus lingüístico del nihilismo brinda la posibilidad del protagonismo y la ejecución al hombre, de modo que el nihilista europeo habrá de ser capaz, a través de la fuerza generadora de su logos, de «'dar estilo' al propio carácter» ${ }^{416}$, esto es, de afirmarse como «artista» de su propia vida encarnada. Recuperando tópicos de este trabajo, el artista-filósofo ha logrado zafarse de las reglas de la gramática del Dios muerto.

Por supuesto, la enseñanza primera que se extrae de esta pseudogramática del nihilismo es que no existe aquello que la metafísica llamó «ser» ${ }^{417}$; al mundo no le subyace una racionalidad prensible mediante las reglas del habla. A la falta de ser le continúa, prosigue Nietzsche, el «hacer»: la ausencia de racionalidad, esto es, de sentido en el mundo exige por parte del actor fabricarlo. Como habíamos apuntado, Nietzsche nos conmina a transvalorar el orden de las estructuras sintácticas para hacer del hombre sujeto agente de su propia actividad. La muerte de Dios conviene aquí en su diagnóstico, pues bajo este concepto, menos teológico que metafísico, confluyen el misticismo de la unidad y la metafísica del ser para conjugarse en metafísica del lenguaje. El ídolo último que la crítica de la

415 Cfr. Nietzsche, F., Asi habló Zaratustra, op. cit., pp. 298-299 (KSA IV, 267): «Oh, hermanos míos, cuando os he mandado destrozar a los buenos y las tablas de los buenos: sólo entonces es cuando yo he embarcado al hombre en su alta mar».

${ }^{416}$ Nietzsche, F., La gaya ciencia, op. cit., pág. 834 (KSA III, 530).

${ }^{417}$ No existe, al menos, en su acepción y modo metafísico aquello que la metafísica llamó «ser». 
razón idealista ha de demoler: «la 'razón' en el lenguaje -observa Nietzsche-: ¡oh, qué vieja hembra engañadora!» ${ }^{418}$. Sin embargo, no oculta Nietzsche su preocupación al respecto, confesando temeroso la sospecha profunda de «que no vamos a desembarazarnos de Dios porque continuamos creyendo en la gramática ${ }^{419}$.

\section{II.2.2. EI lenguaje dionisíaco}

La fuerza del lenguaje ha sido puesta de manifiesto por Nietzsche, su potencia ontológica, configuradora del lienzo del mundo, desnudada. Tal capacidad no puede ni debe ser dejada atrás; al contrario, ha de ser reapropiada por el hombre e imbricarse el uno en el otro: que la voluntad de poder se identifique en la lengua y ésta sea vehículo de la acción creadora. Nietzsche exige una nueva gramática que ignore el esfuerzo de identificación entre el concepto y el mundo, y que eluda las pretensiones idealistas de una verdad objetiva. En suma, un lenguaje menos prosaico que poético; una peculiar «poesía» sujeta a las irrestrictas y feroces exigencias de Dioniso. Exigencia que ha plasmado Colli perfectamente en su reflexión capitular sobre los Ditirambos de Dioniso: «ahora que la verdad ha sido despedida queda abierto el camino, precisamente en la perspectiva de Nietzsche, para la mentira de la poesía» ${ }^{420}$. La poesía en Nietzsche debe verse como «poiesis», en última instancia. La transvaloración acontecida en la gramática, por la cual nos convertimos en sujetos activos, se plasma en la actividad poiética del lenguaje que ha hecho del hombre algo más que simple hablante y lo ha transmuta en «artista-filósofo», quien comienza la empresa de «llegar a ser lo que se es».

Colli sugiere que en la mencionada compilación de poemas, cifrados ya en la época del Zaratustra, se ha consumado plenamente el giro lingüístico nietzscheano, agotándose la separación entre la forma y el contenido: el estilo es, a su vez, el concepto reflexivo. Destaca el exégeta italiano que hay en «la insólita forma lírica de los Ditirambos, donde es utilizado el 'tú' mientras se esperaría el 'yo' [...] una voz que habla a través de él, la voz del dios del que los Ditirambos toman su nombre» ${ }^{421}$.

Por medio de la gramática de Dioniso el aberrante fetichismo del lenguaje, abrigado por la metafísica del lenguaje y del ser, es revocado. A la luz de Dioniso los embustes del lenguaje se vienen abajo. En particular, la imagen más extendida a lo largo de la tradición, a saber, la del ideal cognoscitivo. La transvaloración de todos los valores pretendida por el filósofo del Zaratustra no empieza en el orbe moral, sino en el lingüístico, configurándose desde una transgresión de los códigos epistemológicos de la metafísica. Dioniso

418 Nietzsche, F., Crepúsculo de los ídolos, op. cit., pág. 55 (KSA VI, 78).

${ }^{419}$ Ibid. (KSA VI, 78).

${ }^{420}$ Colli, G., Nietzsche, trad. de Romeo Medina, Valencia, Pre-Textos, 2000, pp. 203-204.

${ }^{421} \mathrm{Ibid}$. pág. 204. 
vuelve a abrir la cuestión del ser, que ya no queda preso de las pesquisas conceptuales de criterios inertes y momificados. El lenguaje de Dioniso trata de hablar por y para un ser en devenir.

Una vez asumida la muerte de Dios, entendida como cuestión metafísica y garante epistemológico, en detrimento de una aproximación simplemente teológica, el lenguaje cae en una nueva dialéctica en la que prevalecen las fuentes del presente: la vida como valoración afirmativa de la existencia humana. El lenguaje deja de ser primeramente una aportación gnoseológica «verdadera» en beneficio del conocimiento de la mentira necesaria para sostener la vida. La gramática dionisiaca es gratuita, no sigue los signos de la verdad imperecedera y última de la metafísica, sino que se muestra esencialmente dependiente de los distintos avatares del hombre encarnado en un tiempo y lugar, tanto conscientes como inconscientes. En la sintaxis de Dioniso la mentira adquiere condición de verdad al subordinarse a las exigencias específicas del hombre histórico. Nietzsche ha afirmado la capacidad ontológica del lenguaje, en virtud de la cual ésta crea mundos; así, una gramática de la voluntad de poder instaurará el nuevo paradigma sintáctico de la transvaloración.

La transvaloración es violenta. En su discurrir el eterno devenir del ciclo de generación y destrucción de la vida se enfatiza. Los mundos conceptuales se suceden uno tras otro, cayendo cual castillos de naipes. Y es que en Dioniso explota la crueldad de un ser que ha de perecer. El mundo conformado mediante este nuevo lenguaje responde a las necesidades de su agente, quien morfológicamente incapaz no puede aspirar a la verdad, sino a la adecuación de sus expectativas histórico-culturales con el efectivo horizonte de posibilidades en el cual se halla. Por tanto, la realidad presente ha de ser estructuralmente pareja respecto de las cambiantes voliciones del ser humano: el ser que deviene debe hacerlo a su vez en un mundo sujeto a la indigencia de la decadencia. Así juega un papel determinante Dioniso, en cuya gramática intervienen las claves de la propia destrucción. En suma, aceptar el nuevo lenguaje que propone el dios olímpico conlleva asumir la fuerza para violentar la realidad, agotarla y someterla al calor de su propio fuego. En el coro dionisiaco intervienen la pluralidad y la unidad: el lenguaje como singular mundo efectivo nos abre a otros lenguajes, es decir, a otros mundos.

Al igual que la insólita situación en la que se encontraba una Europa a las puertas del nihilismo, la sintaxis de este tiempo requería de una nueva cualidad de poder, perdida desde los tiempos de la tragedia griega. La invocación de Dioniso habría de acabar con el fetichismo dogmático de la identidad, esto es, debería ser capaz de introducir elementos extraños que rompiesen la relación intrínseca entre el sujeto y el mundo. Con ello, la supuesta racionalidad del mundo quedaría agotada; nos moveríamos en un umbral de incertidumbre e indeterminación suficiente para arrebatarle todo el sentido a la realidad, arrastrándonos de esta forma a los emancipatorios cauces de la «inocencia del devenir». 
En la gramática dionisiaca se entremezclan lo posible y lo irreal, la lógica y lo absurdo, la vida y la muerte. Con todo, un horizonte especular en cuyos límites conceptuales está su propia infinitud, su abultada apertura a nuevos valores y revolucionarias verdades, la apreciación del fondo inabarcable que es la vida y que el lenguaje apenas logra expresar por medio de parcas palabras y caducifolios conceptos. El mundo del nihilismo que hemos de conquistar no es, no obstante, y frente a toda imagen creada por aquellos «teólogos» cuya sangre ha regado nuestra filosofía entera, una dimensión inhóspita e inhabitable. Al contrario, se trata del advenimiento de una nueva realidad ajena a la metafísica del lenguaje y del ser; una donde se haya consumado el imperativo zaratustrano de vindicar, arreglo la voluntad de poder, el sentido de la tierra en favor del superhombre ${ }^{422}$.

Dos modos de lenguaje distintos que se corresponden existencialmente con dos mundos distintos. El europeo del siglo XIX, testigo directo de la herida del nihilismo, no puede seguir esperando consuelo de la mítica evocación del ser parmenídeo. Frente al inoperante inmovilismo eleático, Zaratustra danza y exige bailar: «yo no creería más que en un dios que supiese bailar» ${ }^{423}$. Sólo en el más repugnante sujeto, el «último hombre», el mismo de cuyas manos aún no ha sido limpiada la sangre de Dios, perdura férreamente el esfuerzo por diferenciar la forma estilística del contenido conceptual, baluarte final de la metafísica del lenguaje.

No ha de existir tal distinción, toda vez que Dioniso afirma sin mezquindad el carácter falaz de sus palabras: los términos del lenguaje están vacíos, viéndose colmados coyunturalmente según las circunstancias de cada época. De manera que el lenguaje no puede ofrecernos más que una pobre imagen ilusoria de aquello mismo que expresa. El coro dionisiaco, mudo desde los últimos instantes de la tragedia ática, vuelve a rugir, elevando su tono más allá de los monótonos acordes del «monótono-teísmo» ${ }^{424}$ de la objetividad de la verdad de la metafísica. Forma y concepto se integran solidariamente en una unidad con el fin de apresar satisfactoriamente las enseñanzas de Dioniso, que son las de Heráclito: el decurso dialéctico del ser:

Pongo a un lado, con gran reverencia, el nombre de Heráclito. Mientras que el resto del pueblo de los filósofos rechazaba el testimonio de los sentidos porque éstos mostraban pluralidad y cambio, él rechazó su testimonio porque mostraban las cosas como si tuviesen duración y unidad. También Heráclito fue injusto con los sentidos. Éstos no mienten ni del modo como creen los eleatas ni del modo como

422 Cfr. Nietzsche, F., Asi habló Zaratustra, op. cit., pág. 36 (KSA IV, 14): «El superhombre es el sentido de la tierra. Diga vuestra voluntad: ¡sea el superhombre el sentido de la tierra!».

423 Ibid. pág. 74 (KSA IV, 49).

${ }^{424}$ Cfr. Nietzsche, F., El crepúsculo de los ídolos, op. cit., pág. 52 (KSA VI, 75): «iSer filósofo, ser momia, representar el monótono-teísmo con una mímica de sepulturero! - Y, sobre todo, fuera el cuerpo, esa lamentable idée fixe [idea fija] de los sentidos!, ¡sujeto a todos los errores de la lógica que existen, refutado, incluso imposible, aun cuando es lo bastante insolente para comportarse como si fuera real!...». 
creía él [...]. Lo que nosotros hacemos de su testimonio, eso es lo que introduce la mentira, por ejemplo la mentira de la unidad, la mentira de la coseidad, de la substancia, de la duración... La «razón» es la causa de que nosotros falseemos el testimonio de los sentidos. Mostrando el devenir, el perecer, el cambio, los sentidos no mienten... Pero Heráclito tendrá eternamente razón al decir que el ser es una ficción vacía. El mundo «aparente» es el único: el «mundo verdadero» no es más que un añadido mentiroso ${ }^{425}$.

La remisión heraclítea del lenguaje dionisiaco lo pone frente a sí mismo, un reflejo macabro que apunta a su propia destrucción, pues, parafraseando a Edgar Morin, la única sintaxis lícita es aquella que arde a su propia temperatura. Una afirmación no es ontológicamente superior a su negación ni viceversa; cuanto se confirma debe albergar en su seno la posibilidad de ser contrariada, del mismo modo que toda negación, quizá afirmada: «fórmula de mi felicidad: un sí, un no, una línea recta, una meta» ${ }^{426}$. Con lo que en el propio modus filosófico nietzscheano está incluida esta sintaxis reflexiva, al entenderla como la única estrategia para evitar los ademanes y dejes típicos del dogmatismo. Una sintaxis reflexiva parte del «yo mismo» que es el cuerpo encarnado, por lo que cuenta -y asume- con la potencialidad de los rasgos inconscientes que, aún en su silencio, configuran la «corporalidad» del sujeto.

Al acoger su posible destrucción el lenguaje toma una posición de principio. En su nivel primigenio, no puede comunicar, tan sólo manifestar artísticamente cuanto acontece; la comunicación interpersonal es un fenómeno -fabuloso, por cierto- ad hoc en la nebulosa del lenguaje. Sin embargo, el primer estrato responde a las experiencias vitales del sujeto que habla, y éstas, de acuerdo con Dioniso, son incomunicables, pues su fondo se antoja insondable: no hay palabras ni expresiones ni conceptos capaces de apresar comunicativamente las motivaciones y vivencias del ser, del que dirá Heidegger es propio el ocultarse. Así, el coro dionisiaco bebe del torrente poético y artístico. A cuanto accedemos con la gramática dionisiaca es más una revelación que una conclusión lógicamente fehaciente. Aquel llamamiento a «'dar estilo’ al propio carácter» que encontramos en La gaya ciencia nos obliga a retroceder a este primer hito sintáctico: el estilo, donde forma y concepto son uno, intenta plasmar artísticamente la crudeza trágica de la vida. De ahí que sólo unos pocos, aquellos capaces de afirmarse como «cuerpo», los artistas-filósofos, puedan ser receptores de su mensaje ${ }^{427}$. El ser de la existencia se abre mediante el lenguaje dionisiaco, mas hay todavía muy pocos oídos en una doliente y nostálgica Europa que añora los momentos de certeza y verdad de una tradición bimilenaria que todavía conserva la gramática de un Dios asesinado.

\footnotetext{
425 Ibid. (KSA VI, 75).

${ }^{426}$ Ibid. pág. 41 (KSA VI, 66).

427 Cfr. Nietzsche, F., El Anticristo, op. cit., pág. 29 (KSA VI, 167): «este libro pertenece a los menos».
} 


\section{II.3. Nietzsche y el problema de la verdad}

Siempre es complejo cifrar cronologías; los criterios son difusos y los argumentos se agolpan en amalgamas diversas y difícilmente conciliables. No puede exigirse precisión exacta a tal tarea, mas sí cabe pensar en una posible aproximación más o menos acertada. Así ocurre con la novela moderna, en torno a la cual el consenso filológico y literario parece convenir, en una proporción felizmente mayúscula, en hacer de Don Quijote de la Mancha de Cervantes la primera obra madura y plenamente reconocible de este nuevo horizonte. Sin dejar de reconocer el nobilísimo crédito y valor de tentativas precedentes, tales como la Divina comedia de Dante, Los cuentos de Canterbury de Chaucer o el Decamerón de Bocaccio, entre otros, así como los trabajos de Shakespeare, coincidentes en el tiempo con los del escritor español, hay ciertos rasgos en el relato de las desventuras del ingenioso hidalgo que satisfacen las exigencias del paradigma entrante ${ }^{428}$. Desde el primer párrafo del primer capítulo podemos ver el decurso intelectual trazado no únicamente para semejante libro, sino para la totalidad del periodo inaugurado ${ }^{429}$ : «quieren decir que tenía el sobrenombre de Quijada, o Quesada, que en esto hay alguna diferencia en los autores que deste [sic.] caso escriben; aunque por conjeturas verosímiles se deja entender que se llamaba Quejana. Pero esto importa poco a nuestro cuento: basta que en la narración dél [sic.] no se salga un punto de la verdad» ${ }^{430}$.

En efecto, para Cervantes lo verdaderamente importante, acaso lo único, es la precisión de la narración, la certeza de que cuanto se declama de su protagonista sea cuanto aconteció realmente, sin meandros oscuros ni tergiversaciones ora dramáticas ora sutiles.

${ }^{428}$ Es sugerente el ensayo de Ortega Meditaciones del Quijote, donde las reflexiones a propósito de la obra de Cervantes y sobre su impacto en el nuevo mundo emergente ofrecen claves de lectura filosófica de tan monumental obra. Ortega sugiere que Don Quijote rebasa las fronteras propiamente literarias al trazar la silueta paradigmática de la aurora moderna: «Si apretamos un poco nuestra noción vulgar de realidad, tal vez halláramos que no consideramos real lo que efectivamente acaece, sino una cierta manera de acaecer las cosas que nos es familiar. En este vago sentido es, pues, real, no tanto lo visto como lo previsto; no tanto lo que vemos como lo que sabemos .Y si una serie de acontecimientos toma un giro imprevisto, decimos que nos parece una mentira. Por eso nuestros antepasados llamaban al cuento aventurero una patraña» (Ortega y Gasset, J., Meditaciones del Quijote, en Obras completas. Tomo I, ed. Fundación José Ortega y Gasset, Madrid, Taurus, 2004, pág. 807).

${ }^{429}$ Cfr. ibid. pág. 772: «Sin duda, la profundidad del Quijote, como toda profundidad, dista mucho de ser palmaria. Del mismo modo que hay un ver que es un mirar, hay un leer que es un intelligere o leer lo de dentro, un leer pensativo. Sólo ante éste se presenta el sentido profundo del Quijote. Mas acaso, en una hora de sinceridad, hubieran coincidido todos los hombres representativos de la Restauración en definir el pensar con estas palabras: pensar, es buscarle tres pies al gato».

430 Cervantes Saavedra, M. de, El ingenioso hidalgo Don Quijote de la Mancha. Primera parte, Madrid, Espasa Calpe, 1997, pág. 21. (La cursiva es nuestra). 
El espíritu cervantino, dice Ortega, nos lanza a la aventura de la Edad Moderna ${ }^{431}$. En definitiva, un anhelo verificacionista que poco después concertaría Descartes inaugurando un mundo nuevo en detrimento del sofocado pasado. Cervantes lega, desde los primerísimos compases de su genial obra, la que será la empresa gnoseológica moderna, la investigación y profundización de la cuestión de la verdad tomada como adecuación ${ }^{432}$, así como la actitud psicológica del periodo mencionado ${ }^{433}$.

Dadas las dimensiones de la cuestión de la verdad, su investigación ocupa un lugar central en la teoría de Nietzsche. Podemos decir sin temor a equivocarnos, aunque habiendo de ser meticulosamente precisos, que se trata del tema capital de todo su corpus. Se trata de un tópico que recorre todos los temas del cosmos filosófico nietzscheano, y desde el que se configura el núcleo de su pensamiento. Ahora bien, es necesario recoger que su examen de la verdad no es netamente gnoseológico.

El enfoque resulta en primer lugar oscuro, toda vez que se ha admitido que el problema de la verdad en la filosofía moderna nació a propósito de la reflexión cognoscitiva y, por tanto, parece a todas luces su cerco intelectivo. Por tanto, ¿cómo podríamos sostener el estudio nietzscheano de la verdad dentro del horizonte de precomprensión moderno y, al mismo tiempo, remitirlo a un fondo estructural distinto? Nietzsche se esforzará en explicar que tal escabroso tema de la verdad no es, en último término, sino una polémica moral; su sustrato es la moral, valiéndose del entramado conceptual de la gnoseología de la metafísica para conferir a sus máximas y conclusiones garantes legitimadores.

${ }^{431}$ Cfr. Ortega y Gasset, J., Meditaciones del Quijote, op. cit., pág. 810: «Si se nos dice que Don Quijote pertenece íntegramente a la realidad, no nos enojaremos. Sólo haríamos notar que con Don Quijote entraría a formar parte de lo real su indómita voluntad. Y esta voluntad se halla henchida de una decisión: es la voluntad de la aventura. Don Quijote, que es real, quiere realmente las aventuras. Como él mismo dice: 'Bien podrán los encantadores quitarme la ventura, pero el esfuerzo y el ánimo es imposible'. Por eso, con tan pasmosa facilidad transita de la sala del espectáculo al interior de la patraña. Es una naturaleza fronteriza, como lo es, en general, según Platón, la naturaleza del hombre».

432 Cfr. Nietzsche, F., Fragmentos póstumos I, 7 [124], op. cit., pág. 184 (KSA VII, 181): «Pero un nuevo género del arte socrático fue el que quedó para siempre, un arte, que unido con la novela, ha cercenado la admiración de toda la posteridad no griega. El espectáculo como reflejo de la realidad empírica, que tiene como fin un matrimonio, un cambio de gobierno, la novela como reflejo de una realidad ideal fantástica, con alguna perspectiva metafísica, éstas son las dos formas fundamentales con las que casi dos milenios han demostrado su dependencia de los griegos y, ciertamente, su descendencia natural; formas fundamentales que han encontrado en Cervantes y en Shakespeare su realización final y su más perfecta satisfacción».

Si bien es cierto que esta empresa fue la labor epistemológica paradigmática de la modernidad, mostraremos en este punto que Nietzsche no la circunscribe únicamente a este momento del pensamiento, sino a toda la tradición filosófica occidental dentro de su ambicioso proyecto de deconstrucción y derrumbe de la metafísica bimilenaria de la duplicación de mundos. Más aún, objetará que no se trata tanto de un programa de máximas epistemológicas como fundamentalmente morales.

${ }^{433}$ Cfr. Nietzsche, F., Fragmentos póstumos II, 4 [222], op. cit., pág. 582 (KSA IX, 156): «Si llegamos a ser alguna vez conscientes de la quijotería de nuestro sentimiento de poder y despertamos — bajaremos entonces la cabeza como Don Quijote, _ ¡ terrible final! La humanidad se ve siempre amenazada por ese vergonzoso negarse a sí mismo al final de su empeño». 
Más aún, en el problema de la verdad, en tanto que aspecto elemental de la filosofía de Nietzsche, se van desvelando los diferentes conceptos más relevantes de su trayectoria, desde la voluntad de poder hasta el superhombre, pasando por el eterno retorno y la transvaloración. Con todo, la minuciosa investigación que lleva a cabo de la verdad no podrá más que confluir finalmente en sus sentencias conclusivas de la historia del nihilismo europeo.

Por ello es el mencionado tema un hito crucial que ha de rastrearse a lo largo de toda su producción. Es un leitmotiv que si bien evoluciona en paralelo con la reflexión del autor, mantiene unas coordenadas básicas respecto de las que nunca hemos de extraviarnos, a saber, que la verdad es, ante todo, un tema existencial. Compete a la inmanencia del ser humano. Y en tanto que elemento infranqueable de la vida, Nietzsche no la va a negar ni a rechazar. No encontraremos en el pensador alemán argumentos contrarios a la verdad; invita, no obstante, a perpetrar un cambio radical, más aún, una transvaloración, en nuestra comprensión de ella así como de las estrategias conceptuales en virtud de las cuales Occidente ha tratado -infructuosa y onerosamente- de asirla. La crítica de la verdad, entonces, no debe verse como una enconada cruzada contra tal concepto, sino contra las formas y categorías heredadas tradicionalmente en Europa. Es decir, la crítica de la verdad es un momento más de la ambiciosa tarea de la transvaloración: recuperar el cariz existencial de la verdad, tomarla como una cuestión filosófica que tiene que alude íntimamente a la configuración efectiva de las posibilidades de la vida encarnada.

\section{II.3.1. Voluntad de error}

La primera revelación que afronta Nietzsche en cuanto a la verdad llega con la dimensión trágica que comporta la inserción del hombre en el mundo. Por un lado, el mundo se antoja férreo y tenaz, pesado como la realidad más plomiza, al tiempo que tales cualidades no dejan ser predicadas por el ser humano integrado en dicho complejo; en cuanto al propio hombre, guarda la misma extraña peculiar condición que el mundo: es realmente pesado y plomizo, mas lo es en tanto que es percibido como tal por sí mismo y el otro en una indómita relación fronteriza entre la oposición absoluta y la alteridad. Así, en la experiencia más primitiva de la vida, que es la inclusión de nuestra especie en la naturaleza, ya se revela la condición fabulada de cuanto percibimos como real, así como la cualidad trágica de la existencia.

En la temprana obra El nacimiento de la tragedia nos presenta que en efecto la existencia es trágica, la existencia no es plácida, sino contradictoria. La verdad se le presenta a un joven Nietzsche -demasiado imbuido todavía de Schopenhauer-como un todo unitario en el que la eternidad y la contradicción configuran una experiencia dolorosa. La verdad, ese fondo primigenio de dolorosa y aberrante unidad, es dionisiaca: su experiencia es tan profunda e inabarcable que nos aplacaría fatalmente si tratásemos de asirla en su 
arrolladora plenitud ${ }^{434}$. Por eso la verdad es abominable y monstruosa. A continuación entra en juego la segunda parte de la ecuación: frente a la fuerza demoledora de la realidad, debe esgrimirse una ilusión igualmente poderosa que apacigüe dócilmente la fuerza irrestricta de la naturaleza, una ilusión que emergida del momento primordial de la verdad nos procura la salvación de ella. Esta fabulación redentora que es la realidad fenoménica no es otra cosa para Nietzsche que una obra de arte imbuida de una ontología plena, o sea, real, es decir, ilusoriamente real. De tal forma que la revelación primera de la verdad que tiene Nietzsche queda confeccionada en una perenne dupla donde sus extremos, la unidad primordial, harto dolorosa, y la balsámica ilusión de individuación se entremezclan en un frenético y agotador devenir. Así, frente al dolor de la verdad, el perentorio remedio que halla el autor es la fabulación de una apariencia individualizada que, en la medida en que es fal$s a$, sólo tiene justificación estética.

La apariencia se toma entonces como la ilusión de la apropiación encarnada de las contradicciones inherentes a la verdad de la vida bajo la forma de una vida humana concreta. La verdad como fondo de contradicción y dolor se peculiariza en concreciones individuales que se adueñan de ella; concreciones falaces que devienen verdad al atribuirse en un sujeto que se mide a sí mismo en virtud de su capacidad artística para enfrentar la contradicción doliente de su propia vida. Algo que logra mediante el constante ejercicio de valoración y posterior jerarquización que facilita el juego plástico de la voluntad de poder.

En El nacimiento de la tragedia se ahonda más en esta duplicidad de la existencia conformada por la despiadada verdad -Dioniso-y la necesaria ilusión de individuación del fondo de la existencia -Apolo-. Una donidad que se resuelve en el plano de la fuerza artís-

434 Resulta esta concepción de Dioniso fascinante, toda vez que el olímpico guarda más que obvias semejanzas con el Dios judío del Antiguo Testamento: una deidad inconmensurable, cuya inmensidad hacía imposible su contemplación bajo el suplicio de una muerte desbordada por la plenitud divina.

En su escrupulosa monografía sobre Dioniso, Walter Otto deja esmeradas páginas. Algunas de las más lúcidas están comprendidas en el capítulo, preciso y significativo, «El dios demente». Cfr. Otto, W. F., Dioniso, trad. de Cristina García Ohlrich, Barcelona, Herder, 2017, pp. 152-153: « ¿Un dios furibundo! ¡Un dios de cuya esencia forma parte la demencia! ¿Qué habrán vivido o visto estos hombres para que una noción tan monstruosa se abriese paso en sus mentes?

El rostro de cualquier dios auténtico es el rostro de un mundo. Un dios demente sólo puede existir si hay un mundo loco que se revela a través de él. ¿Dónde está ese mundo? ¿Podemos aún encontrarlo, reconocerlo? Nadie puede ayudarnos a hacerlo más que 'el propio dios'.

Lo conocemos como el espíritu salvaje de la contradicción y los opuestos: existencia inmediata y lejanía absoluta, bendición y espanto, plenitud de vida y cruel aniquilación. También la bondad de su esencia, lo creativo, propiciador de bienes, y la fascinación, participan en su salvajismo y en su demencia. ¿Acaso no puede considerárselas dementes al llevar en sí la duplicidad, al encontrarse en el umbral desde el cual un único paso conduce al descuartizamiento y las tinieblas? Nos tropezamos aquí con un enigma universal: el misterio de la vida que se genera a sí misma. El amor que fluye hacia el milagro de la concepción está tocado por la locura. Y, así, también el espíritu cuando lo conmociona el soplo creador. [...]

El que crea algo vivo ha de sumergirse en profundidades insondables donde habitan las fuerzas de la vida. Y, cuando vuelve a la superficie, se adivina un brillo de locura en sus ojos, pues allá abajo la muerte comparte su morada con la vida. El propio secreto primigenio es locura: el seno de la duplicidad y la unidad de lo dúplice». 
tica: la potencia irradiada de la verdad es canalizada a través de la apariencia, que le imprime una forma concreta, «la limita» y encubre su base de profundo dolor.

El insufrible dolor de la existencia es atendido y velado por los sanadores esfuerzos de la amable apariencia apolínea, que trata de estampar criterios que apresen el frenesí del caos que late en la verdad. Sólo gracias al impacto apolíneo sobre la vida puede engendrarse el hombre, a cuya naturaleza pertenece necesariamente la ficción y la mentira: la dependencia esencial hacia Apolo, que limita mediante ardides y embustes artísticos el devenir infranqueable de la verdad, convierte al hombre en un ser esencialmente fabuloso y fabulador: el hombre no puede existir si no gracias a la limitación que ejerce Apolo sobre la verdad -apariencia limitada y restringida de la naturaleza- y ha de exigirse contribuir al mantenimiento de dicha ilusión artística. Y así se despliega la vida humana, sobre las capas superficiales de la verdad, en los niveles de la individuación de las formas. Puede apreciarse sin dificultad que El nacimiento de la tragedia, la primera obra con identidad propia de Nietzsche, arroja desde la precocidad de sus veintiocho años una caracterización de la verdad dispuesta en los vértices de un paradigma radicalmente distinto del epistemológico.

Si bien es cierto que se trata de una obra precoz, hay ya rastros de los puntales del pensamiento maduro de Nietzsche, alusiones tímidas, nunca conceptualizadas que, no obstante, imponen su fuerza teórica. El más claro de ellos quizá sea una primitiva evocación de la voluntad de poder. Pese a su tierna edad, el filólogo apunta trazos de su futura distinción entre «débiles»y «fuertes». Los primeros son aquellos hombres que se despachan dichosos en la ilusión apolínea. Sus actos tan sólo se orientan a perpetuar el régimen de fábulas arreglo al cual persisten y esquivan la dolencia del origen, es decir, que confían en el engaño balsámico, en el narcótico apolíneo al precio del extrañamiento de su vida. Este esfuerzo por mantener las estructuras heredadas se consolidará posteriormente en la «cultura»; mientras que cabe concebir también un segundo tipo de hombre, opuesto y extraño al anterior, pues anhela y evoca el torrente de la unidad olvidada. Consiste éste en un individuo que, valga la contradicción, rechaza la individuación de las formas, repudia las restricciones impuestas a la vida. En último término, un hombre dionisiaco que parece reconocer en su opuesto apolíneo a los futuros lógicos empeñados en encorsetar categorialmente la vida. El verdadero artista, el artista-filósofo antes mentado, es aquel que hace del arte conocimiento, aquel que toma el fondo de la verdad como una unidad ajena a las identificaciones categoriales y a las reducciones cuantitativas; el conocimiento de la verdad, desde la primera obra de Nietzsche, es «trágico».

Conforme evolucionaban sus trabajos la presencia de Apolo disminuía en beneficio de la de su opuesto, hasta desaparecer finalmente de la ecuación. Dioniso acabará apropiándose tanto de la verdad originaria de la vida como de la redentora ilusión: la vida es, en su unidad, el dolor y la esforzada contradicción por superarlo mediante falsificaciones de la 
verdad que se baten con las mismas armas del devenir; falsificaciones que no pueden pretender vocación de individuación, limitación y restricción. Así el cierre de la última obra de nuestro autor, «Dioniso contra el Crucificado» ${ }^{435}$. Ninguna mención de un Apolo que ha devenido innecesario e indeseable: «no concibo más que un solo ser que es a la vez uno y mucho, que se transforma y permanece, conoce, siente, quiere - ese ser es mi hecho originario» ${ }^{436}$.

El juego de la dupla Dioniso-Apolo desempeña, pese a la ulterior erradicación del último, un rol imprescindible al abrirle a Nietzsche las puertas del modelo trágico del mundo: el ser humano se mueve en una tensión insoluble entre la verdad y la ilusión originarias. El tomar la verdad y la ilusión como dimensiones originales del hombre tiene una importancia capital, ya que le permite afirmar una cierta de paridad ontológica de ambos términos: la verdad no es menos ilusoria que verdadera la ilusión ${ }^{437}$.

La imagen trágica del mundo es un posicionamiento existencial ante el mundo, un punto de partida resultante de aquella primera revelación. Sobre ella y desde ella despliega Nietzsche todo un cosmos reflexivo con tintes epistémicos, morales, antropológicos, etc. Si bien sumamente complejo y elaborado, fácilmente resumible en la aceptación, o mejor, en la reafirmación de la primera verdad de que la existencia no puede pretenderse ajena a un sufrimiento esencial - «trágico»- y en la desintegración -también apuntada desde sus primeros años- de la imagen de la verdad como cuestión epistemológica. La segunda de las dos premisas comporta algo más que el fin de las evocaciones gnoseológicas; en la medida en que nos encontramos dentro del itinerario de la verdad, y Nietzsche va a realizar una labor genealógica, su investigación se remontará hasta las etapas iniciales de tal movimiento, llevándolo hasta el mundo griego: la identificación de la verdad y el conocimiento encuentra su momento paroxístico en Sócrates, para quien verdad y bien se integran solidariamente: el conocimiento es, en último término, el conocimiento de la verdad, que es, en el fondo, el bien. Así, transitivamente, el conocimiento es el conocimiento del bien. La doctrina socrático-platónica del intelectualismo moral:

¿Acaso también tú tienes una opinión semejante, o te parece que el conocimiento es algo hermoso y capaz de gobernar al hombre, y que si uno conoce las cosas buenas y las malas no se deja dominar por nada para hacer otras cosas que las que su conocimiento le ordena, sino que la sensatez es suficiente para socorrer a una persona? ${ }^{438}$.

${ }^{435}$ Nietzsche, F., Ecce homo, op. cit., pág. 145 (KSA VI, 374).

436 Nietzsche, F., Fragmentos póstumos III, 5 [1], op. cit., pág. 159 (KSA X, 216).

${ }^{437}$ Cfr. Nietzsche, F., Más allá del bien y del mal, op. cit., pág. 107 (KSA V, 92): «No existen fenómenos morales, sino sólo una interpretación moral de fenómenos...».

438 Platón, Protágoras, 352c, en Diálogos I, trad. y notas de J. Calonge Ruiz, E. Lledó Íñigo, C. García Gual, Madrid, Gredos, 1990, pág. 574. 
Encontramos otro pasaje con semejante idea en el Menón:

Entonces es evidente que no desean las cosas malas quienes no las reconocen como tales, sino que desean las que creían que son buenas, siendo en realidad malas.

[...] Luego nadie quiere, Menón, las cosas malas, a no ser que quiera ser tal ${ }^{439}$.

En el intelectualismo moral Nietzsche entiende haber hallado el origen de la configuración moral -y no epistémica- de la verdad y, por lo tanto, las claves para disolver la premisa separadora de los órdenes del conocimiento y de la verdad. Estos puntos de partida marcarán la hoja de ruta de la trayectoria nietzscheana.

En trabajos más maduros que El nacimiento de la tragedia Nietzsche explota la premisa del intelectualismo moral. Hace recaer sobre él la burda estrategia metafísica de la duplicación de mundos, sostenida por la perversa creencia de que «la verdad es buena» y que, por tanto, el mundo en el que rige la verdad ha de ser el «bueno». Al hilo del martillazo dado en Crepúsculo de los ídolos, quizá esta idea de la verdad como contenedor del bien esté hueca, pues ¿por qué no al revés? Rescatando un pasaje ya aludido de la Genealogía de la moral, la verdad es una máscara «simple, áspera, fea, repugnante» ${ }^{440}$. La verdad no puede ser un espacio de cálido cobijo, sino, al contrario, un espacio de horror y temor: es dionisiaca. La investigación de la verdad ha desvelado a Nietzsche que la cuestión de estudio no tiene cariz científico, sino filosófico. No hay una demanda de precisión cuantitativa en la verdad, sino una pulsión de vida. Así pues, la exigencia de veracidad gnoseológica que se ha impuesto el filósofo occidental es, a todas luces, una incomprensión manifiesta del problema o bien una huida voluntaria de la voracidad de Dioniso. El espíritu metafísico ha optado por cargarse de conceptos, números y certezas por el propio terror que inspira el horripilante fondo del mundo. El camello tiene sobrada fuerza para cargar fardos llenos de especulaciones, leyes y dogmas, mas carece de las agallas suficientes para enfrentar la abismal máscara del mundo; el conocimiento positivista triunfa entre los espíritus débiles, que, a su vez, huyen apresuradamente del trágico.

No en vano admitirá Nietzsche en Ecce homo que pasará a la historia como algo monstruoso. El monstruo que ha dinamitado la verdad epistemológica del conocimiento de Occidente revelándola como un abultado error. No es casual que los exégetas de Nietzsche coincidan en la crueldad de sus últimas obras. En ellas intensifica su compromiso dionisiaco, exigiendo a sus lectores la fortaleza para abandonar la verdad de la metafísica, abonada sobre un mezquino suelo de ideal indigencia, en favor de una afirmativa voluntad de poder, una aceptación indefectible de la verdad de la vida, aún arrastrando amargura: amor fati.

439 Platón, Menón, 77d-78a, en Diálogos II, introd. trad. y notas de J. Calonge Ruiz, E. Acosta Méndez, F. J. Olivieri, J. L. Calvo, Madrid, Gredos, 1983, pp. 295-296.

${ }^{440}$ Nietzsche, F., La genealogía de la moral, op. cit., pág. 40 (KSA V, 258). 
Una fórmula que requiere para su cumplimiento la exigencia de «dureza», pues sólo los espíritus endurecidos pueden enfrentar el arriesgado desafío de apropiación de su existencia, que pasa por la inserción en el trágico devenir del amor fati. Así se entiende que cuando Zaratustra comprendió cuál era su último pecado -la compasión por el hombre superiorsu rostro se trocó en bronce ${ }^{441}$, se endureció.

Ante el dolor inseparable de la indomable experiencia de la existencia necesita el individuo fuentes de cobijo y apaciguamiento; requiere de canales que hagan soportable la inexplicable locura, que es la elemental base dionisiaca del mundo, de la ausencia de sentido fundamental, consecuencia de haber superado la expectativa del ser en favor del devenir. El Nietzsche filólogo, pese a su indómita juventud, contempla en el arte el elixir protector: por la voluntad artística moldea el filósofo el fondo salvaje de la verdad originaria y se integra en la inmensidad de la naturaleza. El ideal del arte se le presenta a Nietzsche como una ilusión no hostil contra la vida a diferencia del ideal de verdad de la religión o de la ciencia $^{442}$. El arte permite una fácil integración en el torrente de la verdad, ya que sus aspiraciones no pasan por ofrecer una aproximación alternativa e incompatible con la verdad del devenir. En su voluntad se compromete respetuosamente el artista con el poso ilusorio de la vida, es decir, el arte se trata de una ilusión no hostil contra la vida. El compromiso no hostil del arte con la vida se debe a que aquél se acopla oportunamente con el fondo trágico de ésta. El sustrato insondable de la existencia, donde lo consciente y lo inconsciente se integran en el conjunto de posibles determinaciones de la vida encarnada, se concreta en la «corporalidad» del sujeto una vez éste ha establecido su particular jerarquización de valores, lo cual es sólo posible desde la actividad de la voluntad de poder, cuyo carácter plástico es precisamente el único modo de integración en el devenir de la verdad: verdad y vida, que en Nietzsche son ulteriormente lo mismo, están abiertas al devenir y son reapropiadas gracias a la fuerza creadora de la voluntad de poder, que por su plasticidad se adecua al frenesí del devenir. El ideal del arte subordinado al ideal de vida, nunca a la inversa, «pues toda vida se basa en la apariencia, en el arte, en el engaño, en la óptica, en la necesidad de lo perspectivístico y del error» ${ }^{443}$. El mundo necesita voluntad de error, pues éste es el fundamento de la vida y del hombre:

${ }^{441}$ Cfr. Nietzsche, F., Así habló Zaratustra, op. cit., pág. 441 (KSA IV, 408): «¡Compasión! ¡La compasión por el hombre superior!, gritó, y su rostro se endureció como el bronce».

442 Cfr. Nietzsche, F., Fragmentos póstumos I, 19 [43], op. cit., pág. 355 (KSA VII, 433): «toda aspiración efectiva de la verdad llega al mundo por la lucha en torno a una convicción sagrada».

443 Cfr. Nietzsche, F., El nacimiento de la tragedia, op. cit., pág. 33 (KSA I, 18): «En verdad, no existe antítesis más grande de la interpretación y justificación puramente estéticas del mundo, tal como en este libro se las enseña, que la doctrina cristiana, la cual es y quiere ser sólo moral, y con sus normas absolutas, ya con su veracidad de Dios por ejemplo, relega el arte, todo arte, al reino de la mentira, -es decir, lo niega, lo reprueba, lo condena. Detrás de semejante modo de pensar y valorar, el cual, mientras sea de alguna manera auténtico, tiene que ser hostil al arte, percibía yo también desde siempre lo hostil a la vida, la rencorosa, vengativa aversión contra la vida misma: pues toda vida se basa en la apariencia, en el arte, en el engaño, en la óptica, en la necesidad de lo perspectivístico y del error». 
Sin la no-verdad no hay ni sociedad ni cultura. El conflicto trágico. Todo lo bueno y bello depende del engaño: la verdad mata -más aún, se mata a sí misma (en cuanto reconoce que su fundamento es el error $)^{444}$.

En cuanto a la verdad de la epistemología lógica y metafísica no cabe esperar tal anhelo. En esta óptica el error es un contratiempo estructural esencial. La verdad de la metafísica, cuyas raíces han germinado desde las promesas morales, es una investigación que tiene por objeto el bien. El intelectualismo moral del socratismo ha alumbrado una infamia apóstata contra la vida que ha tratado de corromper la experiencia de la verdad dionisiaca. Así los hijos del platonismo, bajo la imprecisa y controvertida etiqueta de «cristianismo», han perpetrado una inversión de las categorías ontológicas del mundo. En una paradójica estrategia, han confeccionado una mentira mezquina y dañina que ha acabado por excluir de la condición humana la voluntad de error y de ilusión, la apariencia y el cuerpo. El relato de los «buenos» descansa sobre la negación de los rasgos cualitativos de la verdad; con su afirmación del elemental sustrato bondadoso del mundo, el «cristianismo» -platonismo, rousseaunismo, socialismo- ha expulsado, ya por temor ya por malicia, del espectro existencial la dimensión artística. Dirá Nietzsche que hoy el principal argumento contra el «cristianismo» es nuestro gusto ${ }^{445}$.

Zaratustra se sabe malvado, por ello afirma la realidad sin arrebatarle sus rasgos crueles y problemáticos. De este modo la sabiduría de Zaratustra ${ }^{446}$ no es metafísica, sino trágica; ignora conscientemente los conceptos más enjundiosos de la ciencia mas comprende hasta sus últimas consecuencias los avatares motrices del mundo, incluso aquellos que atentan contra la egolatría del propio intelecto, como son los inconscientes, de los que jamás alcanzaremos una comprensión absoluta. No es menester del suyo la comprensión dualista, sino la proyección artística de Dioniso como exhortación jubilosa del abismo original: «un santo decir sí»» ${ }^{447}$. Una afirmación incondicional de la vida, en su dicha y amargura, para la que se antoja imprescindible la tarea de la transvaloración de la verdad:

[...] la verdad habla en mí. Pero mi verdad es terrible: pues hasta ahora se ha venido llamando verdad a la mentira. -Transvaloración de todos los valores: ésta es mi fórmula para designar un acto de suprema autognosis de la humanidad, acto que en mí se ha hecho carne y genio. Mi suerte quiere que yo tenga que ser el primer hombre decente, que yo me sepa en contradicción a la mendacidad de milenios... Yo soy el primero que ha descubierto la verdad, debido a que he sido el pri-

${ }^{444}$ Nietzsche, F., Fragmentos póstumos I, 29 [7], op. cit., pág. 488 (KSA VII, 623).

${ }^{445}$ Cfr. Nietzsche, F., La gaya ciencia, op. cit., pág. 805 (KSA III, 485): «Ahora decide en contra del cristianismo nuestro gusto, ya no nuestras razones».

446 Zaratustra rechaza el «conocimiento» propio de la lógica, en beneficio de la «sabiduría», la cual se ajusta al fondo trágico del mundo: «en la visión trágica del mundo se habían reconciliado el impulso hacia la verdad y el impulso hacia la sabiduría. El desarrollo lógico disuelve esta visión y fuerza a crear la visión mística del mundo» (Nietzsche, F., Fragmentos póstumos I, 5 [110], op. cit., pág. 143 [KSA VII, 123]).

${ }^{447}$ Nietzsche, F., Así habló Zaratustra, op. cit., pág. 55 (KSA IV, 31). 
mero en sentir -en oler- la mentira como mentira. [...] Yo contradigo como jamás se ha contradicho y soy, a pesar de ello, la antítesis de un espíritu que dice no. Yo soy un alegre mensajero como no ha habido ningún otro [...] cuando la verdad entable lucha con la mentira de milenios tendremos conmociones, un espasmo de terremotos, un desplazamiento de montañas y valles como nunca se había soñado ${ }^{448}$.

Zaratustra es el adalid del ateísmo, pues predica contra el dios del cristianismo, es decir, declama la transvaloración de los valores concedidos tradicionalmente a la verdad y la apariencia. La insidia moral de los «buenos» -la nostalgia de Rousseau por una infancia benevolente de la humanidad, las ilusiones románticas de una nueva sociedad marxista o el espíritu antimitológico del a su vez mitómano positivismo, entre otros- se descifra como el discurrir de los diferentes meandros de la estrategia reactiva de espíritus cobardes cuyas enfermas voluntades de poder crearon un mundo independiente desde el cual regir el aparente $^{449}$ : «¿qué es más dañoso que cualquier vicio? -La compasión activa con todos los malogrados y débiles -el cristianismo» ${ }^{450}$. La boca de Zaratustra profiere la palabra de Dioniso, la disolución de las duplas dicotómicas verdad-bien y mentira-mal, alumbradas por la ruptura de la realidad escindida. Dioniso es la unidad de lo intelectual y lo sensible, la comprensión del mal en la verdad y la adecuación del bien en la mentira. La transvaloración es la conciencia dionisiaca de contingente unidad, el fallecimiento por inanición de la disposición dualista. No es la primacía del fenómeno sobre el noúmeno, sino la supresión categorial de tal distinción de la epistemología metafísica en beneficio de la afirmación trágica de la vida: eternidad y consunción, fijeza y devenir, intelección y percepción no son alternativas excluyentes, sino elementos fundamentales de la verdad a partir de los cuales se han de explotar las posibilidades de la existencia.

La transvaloración es la labor última del artista, magnum opus, siendo el más descomunal ejercicio de creación desde los tiempos del platonismo. En primer lugar pone fin a la perversa pauperización que de la realidad, bajo la categoría de «aparente», se había llevado a cabo. Ésta deja de ser pensada como el espacio de la inmundicia y el mal. A continuación se extrapola la dichosa imagen que del mundo intelectivo se tenía, para fundirla inmediatamente en una única dimensión con el plano sensible. En la nueva criatura se agolpan tanto la figuración favorable como la desventurada, revelándose imposibles tanto la una como la otra. El artista inocula mediante la transvaloración inocencia en el devenir, siendo requisito estrictamente humano, desde su experiencia encarnada del fenómeno de la

${ }^{448}$ Nietzsche, F., Ecce homo, op. cit., pp. 135-136 (KSA VI, 365-366).

${ }^{449}$ Cfr. Nietzsche, F., El Anticristo, op. cit., pág. 45 (KSA VI, 181-182): «Este puro mundo de ficción se diferencia, con gran desventaja suya, del mundo de los sueños por el hecho de que este último refleja la realidad, mientras que aquél falsea, desvalora, niega la realidad. [...], -todo aquel mundo de ficción tiene su raíz en el odio a lo natural (-;la realidad!-)».

${ }^{450}$ Ibid. pág. 32 (KSA VI, 170). 
existencia, la atribución de valores creados desde la emancipación de la dionisiaca voluntad de poder respecto de las reactivas fuerzas de la metafísica.

\section{II.3.2. La metafísica de la cosa en sí y la verdad en la apariencia: un proble- ma de trasfondo moral}

La metafísica clásica hizo, en su trazo moderno, de la «cosa en sí» la verdad. Una verdad pura que, privada de todo contenido material, desconocía las tensiones sofocantes de la verdad primigenia de la vida. Con todo, se trataba de una verdad accesible únicamente para un sujeto «epistemológico», esto es, metafísico. En consecuencia, la negación de la metafísica tras su conveniente deconstrucción forzaba consigo la disolución de tal apreciación de la verdad y, al tiempo, la del propio sujeto cognoscitivo.

La posición iniciática de la cosa en sí es una opción axiomática inasumible para Nietzsche. La sintética premisa artística y existencial, estética, de la que parte el pensador decimonónico se ha construido sobre una redefinición de la óptica de la verdad donde el intelecto no persigue la promesa metafísica de la cosa en sí, sino su integración con la verdad primigenia de la vida. El sujeto de la verdad ya no es esencialmente epistemológico; sus tentativas intelectuales apuntan ahora a su conservación vital. La empresa de la verdad torna en un dispositivo donde los elementos fisiológicos y artísticos se entrecruzan en una esforzada estrategia por desfigurar la matriz de la verdad primigenia con ánimo de armonizarla dentro de las facultades posibles de la existencia humana.

El conocimiento ha dejado de perseguir la ensoñación de la adecuación con el fondo de exactitud de las cosas; la realidad, el «en sí» del mundo no puede persistir como el objetivo de la empresa filosófica del nihilismo. El fetichismo intelectual de la adecuación claudica ante el imperio de la ilusión, las formas y la metáfora. La verdad deviene máscara, y su proyecto es el ajuste del complejo del mundo humano al sustrato dionisiaco ciego del caos y el devenir. Los conceptos capitales de la metafísica, tales como «verdad», «apariencia» o «ser» son despojados de la impenetrabilidad de su carácter, que pierde su esencial «en sí». El conocimiento intelectual transita en Nietzsche por la senda de la vida. La intelección de la verdad arrastra el compromiso del sujeto consigo mismo de la creación de las ficciones pertinentes para integrarse peculiar y satisfactoriamente en el universo dionisiaco. La verdad no es pura y abstracta, es voluntad de poder. La labor del conocimiento intelectual es ajustarse al modus de la voluntad de poder: apropiarse de la verdad mediante máscaras de metáforas, explotar la natural condición mentirosa del hombre y falsificar las formas del mundo para ajustarlas a los caracteres de nuestra especie. Tras el último canto del fénix de la metafísica «el intelecto, ese maestro del fingir, se encuentra libre y relevado de su esclavitud habitual tanto tiempo como puede engañar $\sin$ causar daño» ${ }^{451}$. La pureza

${ }^{451}$ Nietzsche, F., Sobre verdad y mentira en sentido extramoral, op. cit., pág. 35 (KSA I, 888). 
de la verdad metafísica ha sido desvalorizada en el juego de la transvaloración; su rigor rector sobre el horizonte de expectativas del hombre ha sido desposeído en beneficio de la vida encarnada, cuya jerarquía de valores es otra. En los tiempos del nihilismo

el hombre nada más que desea la verdad en un sentido análogamente limitado: ansía las consecuencias agradables de la verdad, aquellas que mantienen la vida; es indiferente al conocimiento puro y sin consecuencias e incluso hostil frente a las verdades susceptibles de efectos perjudiciales o destructivos ${ }^{452}$.

La transvaloración vindica la apariencia como el trasfondo único y poiético de la vida y del mundo. La otrora fértil polémica de la cosa en sí, alimentada por personalidades tales como Kant, Reinhold, Schulze, Fichte, Schelling o Jacobi ha alcanzado extenuada los confines decimonónicos. Los hijos bastardos del Idealismo alemán apreciaron las dificultades para mantener la dupla fenómeno-cosa en sí/noúmeno: hacer de una entidad ajena a la recepción sensible el fundamento incondicionado del ser y el contenedor de sentido de la apariencia es insostenible en un mundo en el que se comienza a tomar conciencia de la fragilidad y la inestabilidad de la vida. Los rasgos identitarios de la cosa en sí, la necesidad y su condición referencial incondicionada, que venían garantizados por la premisa kantiana de que el entendimiento prescribía sus leyes al margen del itinerario de la naturaleza, se enfrentan a la posición vitalista de Nietzsche. Entiende Nietzsche que el furor inefable de la verdad de la vida es suficiente argumento para deslegitimar la soflama de la cosa en sí: mediante el ejercicio intelectual el hombre logra con mayor o menor éxito adecuarse mediante ilusiones a las perentorias dinámicas de la verdad. Ilusiones que en aras de su satisfactoria integración en el cosmos del devenir no pueden pensarse incondicionadas y eternas, sino sometidas al cambio y al ocaso. La propia exigencia de ilusiones y apariencias que tiene la vida ha vaciado el contenido de la cosa en sí y la ha privado de su sentido.

Al final de la apreciación de la verdad como cosa en sí le sucede inmediatamente la colosal explosión de cuanto fuera comprendido por la episteme metafísica tradicional, a la postre, todo el universo occidental. Y siguiendo la lógica de la verdad dionisiaca, según la cual el ciclo de la muerte y la generación no puede quedar detenido ${ }^{453}$, ante el derrumbe de los pilares del ancestral mundo Nietzsche responde con la primera piedra de uno nuevo: la apariencia, que es «corporalidad». La ilusión del crear se sustantiva y sitúa su eje en la cualidad artística del ser humano. El sentido del acontecer no descansa por más tiempo en la ilusión inteligible de una dimensión supramundana ni en el efecto de un elemento puro, sino en la capacidad de creación del hombre. La facultad artística de nuestra especie, el marco de condiciones de posibilidad de la apariencia, es la fuente de sentido; en la atmósfera del nihilismo la significación habrá de descansar en la propia disposición creadora y

452 Ibid. pág. 21 (KSA I, 878).

453 De este modo nos insta Nietzsche a «transfigurar la muerte como medio de victoria y de triunfo» (Nietzsche, F., Fragmentos póstumos III, 1 [43], op. cit., pág. 34 (KSA X, 21]). 
valoradora del individuo que se apropia nuevamente de sí mediante su inserción consciente en el juego oscuro de la voluntad de poder que crea valores y los jerarquiza. Preguntar entonces por la fuente de sentido del mundo es ahora preguntarse por la ejecución de la esencial cualidad metafórica, más que por la metáfora concreta. El sentido se ve de este modo sometido a los mismos umbrales de indeterminación que el propio tiempo del devenir, pues la atribución de valor depende de la efectiva situación efectual, determinada por la conciencia del presente. El nihilismo se presenta como el momento sustantivo de la apariencia que se pregunta por sus condiciones de generación y valoración posibles en detrimento de un postrero e incondicionado eterno más allá.

\section{II.3.2.1. Contra Kant ${ }^{454 ; 455}$}

La apropiación de la apariencia como renovada y jovial corporalidad es un posicionamiento radical ante la verdad que no sólo da término a la cosa en sí y su correspondiente prolija polémica ${ }^{456}$, sino a todo su cosmos circundante. Por lo tanto, el fenómeno de la epistemología moderna pierde también su garantía. En la medida en que para Kant el fenómeno estaba indeterminado ${ }^{457}$ mientras se contempla sin el amparo de la cosa en sí, el correlato del objeto al margen de su estructura sensible, la supresión de ésta acabaría con la noción de fenómeno, al menos tal y como fue advertida en la «Estética trascendental». La donidad dispuesta por el fenómeno y el noúmeno cede su regencia al espacio del aparecer $^{458}$. La apariencia como constructo humano exige realidad: cuanto existe, el mundo, es una obra artística del hombre a cuya formación y mantenimiento todos contribuimos -se contribuye en tanto se vive-. La transvaloración ha recuperado la imagen de la vida como ejercicio valorativo in situ y a posteriori, y toda valoración, esto es, toda dotación de sentido imprime realidad al espacio creativo del aparecer.

La pérdida del paradigma metafísico y la consiguiente revaloración del aparecer inciden determinantemente en la escisión epistemológica que se mantuvo abierta a lo largo de toda la modernidad. El abismo sujeto-objeto que de algún modo trató de salvar la teoría

${ }^{454}$ Cfr. Reboul, O., Nietzsche, crítico de Kant, trad. de Julio Quesada y José Lasaga, Barcelona, Anthropos, 1993.

455 Cfr. Mayz Vallenilla, E., El problema de la Nada en Kant, Caracas, Monte Ávila Latinoamericana, 1992.

${ }^{456}$ Cfr. Villacañas Berlanga, J. L., La filosofía del idealismo alemán. Volumen I: Del sistema de la libertad en Fichte al primado de la teología en Schelling, Madrid, Síntesis, 2001.

Cfr. Villacañas Berlanga, J. L., La filosofia del idealismo alemán. Volumen II: La hegemonía del pensamiento de Hegel, Madrid, Síntesis, 2001.

457 Cfr. Kant, I., Crítica de la razón pura, A20 B34, prólogo, trad., notas e índices de Pedro Ribas, Madrid, Alfaguara, 2000, pp. 65-66: «El objeto indeterminado de una intuición empírica recibe el nombre de fenómeno».

458 Nótese que la apariencia concebida en caracteres cognoscitivos distintos de los de la cosa en sí difiere esencialmente de la acepción de «fenómeno». La apariencia en Nietzsche es menos aquello perceptiblemente manifiesto que el espacio que abre la cualidad artística del hombre. 
del conocimiento deviene insondable; no existe posibilidad siquiera de tantear una posible respuesta. Es una empresa muerta si se sigue persiguiendo el ideal de la adecuación. La alternativa epistemológica que nos concede Nietzsche sigue la estela de la verdad primigenia desde la que se alzaban la apariencia y la creación de sentidos como hitos fundamentales de tal realidad. De suerte que el conocimiento no puede ser sino una fábula, una invención, «el minuto más altanero y falaz de la 'historia universal'» ${ }^{459}$. No hay un órgano que permita escudriñar más allá de cuanto se nos manifiesta hasta desentrañar el sustento eidético de la realidad. Tampoco la razón guarda facultades tales. Únicamente nos es accesible aquello que se nos da inmediatamente, lo aparente que para Nietzsche, sin embargo, no se agota en lo dado; no se agota en la constitución de lo inmediatamente sensible. Por lo que el conocimiento habrá de dejar de lado las cuestiones típicas de la metafísica de la cosa en sí en favor de claves más artísticas que logicistas para facilitar una inserción del individuo en el vasto océano del espacio del aparecer. No se persigue dejar atrás el conocimiento, sino el ideal de conocimiento emanado de la metafísica trascendental; no se trata del problema del conocimiento, sino del problema kantiano. El noúmeno no fue un meritorio descubrimiento de Kant; consistió más bien en la afirmación de una «creencia» del prusiano para satisfacer las exigencias morales de sus proposiciones, una reformulación del añejo intelectualismo moral socrático.

Se jactaba Schopenhauer de haber sido el único verdadero lector de Kant, quien realmente apreció la fuerza argumentativa del ideario kantiano, incluso por encima del propio autor. Carece de importancia tal presunción, mas sí resultó determinantemente esclarecedora su valoración de la segunda edición de la Crítica de la razón pura sobre Nietzsche. Advirtió el sabio de El mundo que en ella había tenido lugar un viraje sustantivo de las tesis gnoseológicas por el cual el agnosticismo de la primera edición había sido revocado en beneficio de un dogmatismo de la cosa en sí. Una segunda navegación que Kant habría emprendido conscientemente ante la necesidad de salvar su propuesta moral. Y a pesar de que el apunte que de la segunda edición dio Schopenhauer no es tampoco preciso ni trata con justicia el esfuerzo de un Kant cuyo pensamiento maduro estaba consolidándose, no dejó de resultarle interesante a un Nietzsche obsesionado con el fin de las dualidades metafísicas del mundo y del hombre, del alma y del cuerpo.

La cosa en sí es el correlato de la objetividad del objeto, que Kant acabaría por identificar con el noúmeno, inteligible. Desde la Crítica de la razón pura se sigue que en vista de que la cosa en sí no puede aprehenderse empíricamente, es tarea del entendimiento su representación; lo suprasensible es, forzosamente, inteligible. Y aunque las capacidades limitadas del hombre le impiden una aproximación plena al contenido nouménico, no es menos cierto que aún le resta pensarlo. La cosa en sí pertenece al dominio de aquellas pre-

${ }^{459}$ Nietzsche, F., Sobre verdad y mentira en sentido extramoral, op. cit., pág. 17 (KSA I, 875). 
guntas de imposible respuesta mas de inevitable reflexión, pues tiene un sentido para nosotros. De las disquisiciones sobre la libertad, la inmortalidad del alma y Dios no cabe esperar una respuesta filosófica que zanje definitivamente sus polémicas respectivas; su espectro de significación y sentido es respondido, en cambio, dentro del orbe de la fe moral, el cual se antoja dogmático para Nietzsche, violento en tanto que se eleva contra la disposición natural del hombre.

Nietzsche explota el carácter ambiguo de la cosa en sí, tanto existencia cuasidivina que el ser humano no puede conocer como realidad inteligible. Continuando la senda del razonamiento de Schopenhauer, entiende Nietzsche que Kant ha cometido una gravísima contradicción al llevar las categorías de sustancia y de causalidad más allá del umbral fenoménico. La cosa en sí no cabe ser pensada desde la categoría de sustancia, pues si la privásemos de las relaciones y determinaciones a través de las cuales se hace presente, nada quedaría de ella; por lo que concierne a la categoría de causalidad, ésta había quedado restringida por el propio Kant a las relaciones entre fenómenos, de modo que hacer de la cosa en sí la causa del fenómeno no significa otra cosa que atentar contra la misma Crítica de la razón pura. La cosa en sí hace entonces la función de correlato puro, incondicionado de los fenómenos ante la fundamental relatividad de éstos. Sin embargo, dice Nietzsche, la atribución de tal función a la cosa en sí no es más que una ficción. Si a ella le correspondiese un absolutismo esencial, sería impensable por el hombre, pues su subordinación al espectro del pensamiento humano la tornaría relativa, condicionada, a las propias categorías de nuestra especie:

Los filósofos suelen situarse ante la vida y la experiencia -lo que llaman el mundo del fenómeno- como ante un cuadro desplegado de una vez por todas y que mostrase invariablemente la misma escena; esta escena, piensan ellos, debe interpretarse correctamente para así inferir la esencia que ha producido el cuadro, es decir, la cosa en sí, que siempre suele considerarse como la razón suficiente del mundo del fenómeno. En cambio, lógicos más rigurosos, tras haber definido nítidamente el concepto de lo metafísico como el de lo incondicionado, y por ende incondicionante, han puesto en tela de juicio toda conexión entre lo incondicional (el mundo metafísico) y el mundo que nos es conocido, de modo que en el fenómeno no aparece de ningún modo la cosa en sí y ha de impugnarse toda inferencia de ésta a partir de aquél. Pero ambos bandos pasan por alto la posibilidad de que ese cuadro -lo que vida y experiencia significan ahora para nosotros hombres- haya devenido paulatinamente, más aún, de que todavía esté completamente en el devenir y, por tanto, no deba ser considerado como dimensión fija a partir de la cual cupiera hacer o siquiera impugnar una inferencia sobre el autor (la razón suficiente). Porque desde hace milenios hemos mirado el mundo con pretensiones morales, estéticas, religiosas, con ciega inclinación, pasión o temor, y nos hemos abandonado a los vicios del pensamiento ilógico, ha devenido poco a poco este mundo tan maravillosamente abigarrado, terrible, profundo en significado, lleno de alma; ha recibido colores, pero nosotros hemos sido los coloristas: el intelecto humano ha hecho que el fenómeno apareciese e introducido sus erróneas concepciones del fundamento de las cosas. Tarde, muy tarde, recapacita; y ahora el mundo de la experiencia y la cosa en 
sí se le aparecen tan extraordinariamente distintos y separados, que impugna la inferencia de aquél a éste o reclama, de un modo espantosamente misterioso, la renuncia de nuestro intelecto, de nuestra voluntad personal, para, deviniendo esencial, llegar a lo esencial [...]: lo que ahora llamamos el mundo es el resultado de una multitud de errores y fantasías que fueron paulatinamente naciendo en la evolución global de los seres orgánicos, concrescieron y ahora heredamos nosotros como tesoro acumulado de todo el pasado; como tesoro, pues en él estriba el valor de nuestra humanidad. De este mundo de la representación la ciencia exacta no puede de hecho desligarnos [...]; pero sí puede, muy paulatinamente y paso a paso, ir aclarando la historia de la génesis de ese mundo como representación, y a nosotros elevarnos, momentáneamente al menos, por encima de todo el proceso. Quizá reconozcamos entonces que la cosa en sí merece una risotada homérica: que tanto, aun todo, que parecía, y propiamente hablando, está vacía, a saber, vacía de significado 460 .

Pese a su imposible inserción dentro de las categorías de sustancia y causalidad, Kant continuó su proyecto de la cosa en sí, esencializándola al hacer de ella una realidad inteligible, el noúmeno. Como cabe esperar, Nietzsche identifica la estrategia del filósofo de Königsberg con el juego socrático de la duplicación de mundos: con su vindicación del noúmeno Kant reproduciría en caracteres modernos el ideal del «mundo verdadero» en detrimento del mundo de las apariencias, fenoménico, que es despojado de todo sentido. Y aunque Kant niega la posibilidad de alcanzar conocimiento relativo al mundo eidético, es suficiente la afirmación del mismo, como clave de destino de la humanidad -por supuesto, clave también nouménica-, para perpetuar la desvalorización de lo sensible, de la vida en favor de lo ideal. En los tintes modernos de la metafísica platónica se entremezclan el ideal «cristiano» de la dualidad y el escepticismo gnoseológico, por lo que Kant renuncia al saber eidético sin rechazar, en cambio, su dinámica más cruel y lasciva: el desprecio del mundo del aquí ante el mundo del más allá. Así, Kant no es más que un cristiano alevoso; es el «más despreciable de los hombres», pues pese a haber acabado con Dios no nos ha zafado de su gramática. Una gramática que continua juzgando severamente el mundo de la apariencia.

Kant mantuvo el ideal del mundo inteligible aún cuando éste era incompatible con sus presupuestos cognoscitivos. El noúmeno se conformó como el marco normativo hacia el cual tender. Un presupuesto y no una deducción de una razón eminentemente moral que terminaba operando en los dudosos términos del «como si»:

[...] todos los filósofos, Kant incluido, han construido su obra bajo la seducción de la moral -, que aunque su intención apuntaba en apariencia a la certeza o la «verdad», realmente aspiraba a elevar «majestuosos edificios morales» [...]. Con esta pretensión tan entusiasta, Kant era el hijo perfecto de su siglo, al cual, más que a ningún otro, se le puede llamar el siglo de la exaltación [...]. También a él le había picado la tarántula de la moral que fue Rousseau, también él tenía en el fondo

${ }^{460}$ Nietzsche, F., Humano, demasiado humano I, op. cit., pp. 51-52 (KSA II, 36-38). 
del alma la idea del fanatismo moral [...]. Por otro lado, con ese fanatismo francés en el corazón, no se podía ser menos francés, más profundo, más radical, más alemán -suponiendo que el término «alemán» aún se pueda emplear en ese sentidoque lo que fue Kant: para hacer sitio a $s u$ «reino moral» se vio forzado a poner un mundo indemostrable, un «más allá» lógico, -ipara eso es para lo que necesitó su «crítica de la razón pura»! Dicho de otra manera: si para él lo más importante no hubiera sido una sola cosa, hacer que el «reino moral» resultara inatacable, o, mejor dicho, inaccesible para la razón, no la habría necesitado, -y es que la posibilidad de que el orden moral de las cosas se viera atacado por el lado de la razón ¡le parecía excesiva! Pues a la vista de lo que son la naturaleza y la historia, de su radical inmoralidad, Kant, como todo buen alemán desde tiempos inmemoriales, era pesimista; creía en la moral no porque naturaleza e historia hubieran demostrado su existencia, sino a pesar de que naturaleza e historia no cesan de refutarla ${ }^{461}$.

A la fervorosa y exaltada fe en la ficción del «como si» racional le es lícito concluir en un «deber ser» racional, inteligible e incondicionado. La Crítica de la razón pura como sanguinaria ${ }^{462}$ oda a la falacia naturalista.

Luego la cosa en sí es una mentira soez y cruel, puesto que atenta contra la verdad de la vida. Se ha adueñado del sentido y ha extrañado con ello al hombre de su cualidad artística. Deponer el sentido en una imagen pura trascendente arrebata las condiciones de posibilidad de una vida acorde con la verdad dionisiaca ${ }^{463}$. La pérdida del sentido tras la muerte de Dios también debe leerse desde este cariz, pues hasta el momento la capacidad creativa del sujeto moderno había sido ocultada tras el entramado metafísico de la dualidad:

A la realidad se la ha despojado de su valor, de su sentido, de su veracidad en la medida en que se ha fingido mentirosamente un mundo ideal... El «mundo verdadero» y el «mundo aparente» -dicho con claridad: el mundo fingido y la realidad... Hasta ahora la mentira del ideal ha constituido la maldición contra la realidad, la

${ }^{461}$ Nietzsche, F., Aurora, op. cit., pp. 485-486 (KSA III, 13-15).

462 Cfr. Nietzsche, F., El Anticristo, op. cit., pp. 40-41 (KSA VI, 177-178): «Una virtud tiene que ser invención nuestra, personalísima defensa y necesidad nuestra: en todo otro sentido es meramente un peligro. Lo que no es condición de nuestra vida la daña: una virtud practicada meramente por un sentimiento de respeto al concepto de 'virtud', tal como Kant lo quería, es dañosa. La 'virtud ', el 'deber', el 'bien en sí', el bien entendido con un carácter de impersonalidad y de validez universal -ficciones cerebrales en que se expresan la decadencia, el agotamiento último de las fuerzas de la vida, la chinería königsberguense [...]. Un pueblo perece cuando confunde $s u$ deber con el concepto de deber en general. Nada arruina más profunda, más íntimamente que los deberes 'impersonales', que los sacrificios hechos al Moloch de la abstracción. ¡Que la gente no haya sentido como peligroso para la vida el imperativo categórico de Kant! [...] aquel nihilista de vísceras dogmáticocristianas entendió el placer como una objeción [...]. Es ésta precisamente la receta de la décadence [...]. El instinto que yerra en todas y cada una de las cosas, la contranaturaleza como instinto, la décadence alemana como filosofía - eso es Kant!».

${ }^{463}$ Cfr. Nietzsche, F., Más allá del bien y del mal, op. cit., pág. 64 (KSA V, 53-54): «Confesémonos al menos una cosa: no existiría vida alguna a no ser sobre la base de apreciaciones y de apariencias perspectivistas; y si alguien, movido por la virtuosa exaltación y majadería de más de un filósofo, quisiera eliminar del todo el 'mundo aparente', entonces, suponiendo que vosotros pudierais hacerlo, -itampoco quedaría ya nada de vuestra 'verdad'! Sí, ¿qué es lo que nos fuerza a suponer que existe una antítesis esencial entre 'verdadero' y 'falso'? ¿No basta con suponer grados de apariencia y, por así decirlo, sombras y tonos generales, más claros y más oscuros, de la apariencia, -valeurs diferentes, para decirlo en el lenguaje de los pintores?». 
humanidad misma ha sido engañada y falseada por tal mentira hasta en sus instintos más básicos -hasta llegar a adorar los valores inversos de aquellos solos que habrían garantizado el florecimiento, el futuro, el elevado derecho al futuro ${ }^{464}$.

Consiguientemente era espectador del fenómeno de su propia existencia, incapaz de darle por sí mismo significación. Tras la derogación de los mundos aparente y sensible, el dominio del sentido fue liberado de los enredos conceptuales de la metafísica, pero siguió resultando inaccesible para un sujeto incapaz de apropiárselo. Así, el «más feo de los hombres» es aquel que ha matado a Dios, pues nos condena a un presente sin fuente externa de sentido mas todavía demasiado prematuro como para afirmarse a sí mismo creador: «vivir de tal modo que ya no tenga sentido vivir, eso es lo que ahora se convierte en el 'sentido' de la vida» ${ }^{465}$.

Los elogios que dedicó Kant a Hume ${ }^{466}$ han de tomarse con cautela. En efecto en ellos se reconoce la deuda que el prusiano adquirió con la filosofía empirista del escocés, mas también comporta, por las mismas razones, un indómito escepticismo que arrebató la suficiencia argumentativa para defender la superioridad de un prisma sobre otro. Igual que no encontraba argumentos teóricos suficientes para sostener la diferencia cualitativa entre las obras artísticas -así su recurso de la célebre, y ficticia, instancia de los jueces ideales-, tampoco podía Hume brindar argumentos que sostuviesen un sistema moral estricto de incuestionables valores. La modernidad era ese universo donde «no es contrario a la razón el preferir la destrucción del mundo entero a tener un rasguño en mi dedo» ${ }^{467}$. Con lo cual aquellas primeras celebraciones del empirismo pronto resultaron en una dificultad primordial: ¿cómo justificar racionalmente la moral en términos absolutos, esto es, universalizables e incondicionados?

De acuerdo con Nietzsche esta pregunta coloniza desde antes de la redacción de la Crítica de la razón pura el horizonte kantiano. En la crítica de la razón se halla todo el argumentario suficiente para rubricar el fin de la ensoñación de un orden moral del mundo. Por ello mismo tuvo Kant necesidad de su metafísica, un esforzado itinerario para salvaguardar el espacio de la moral:

La pregunta de si la verdad es necesaria no sólo tiene que haberse respondido de antemano afirmativamente, sino que esa afirmación debe haber sido hecha de ma-

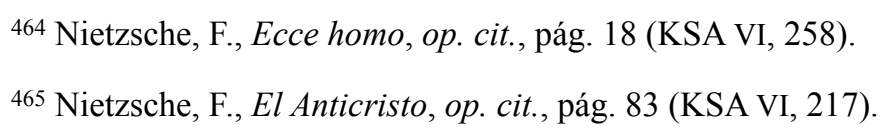

${ }^{466}$ Cfr. Kant, I., Prolegómenos a toda metafísica futura que haya de poder presentarse como ciencia, trad., comentarios y notas de Mario Caimi, Madrid, Istmo, 1999, pág. 29: «Lo confieso de buen grado: la advertencia de David Hume fue precisamente lo que hace muchos años interrumpió primero mi sueño dogmático y dio a mis investigaciones en el terreno de la filosofía especulativa una dirección completamente diferente». 563.

${ }^{467}$ Hume, D., Tratado de la naturaleza humana, trad. de Félix Duque, Madrid, Tecnos, 2008, pág. 
nera tal que exprese el principio, la creencia, la convicción de que 'nada es tan necesario como la verdad y, en relación con ella, todo lo demás sólo tiene un valor de segundo rango ${ }^{468}$.

Continuando su sospecha, la posición de Kant respondería más bien a la fe del propio prusiano en la razón ${ }^{469}$, un prejuicio moral, esto es, ideal, de acuerdo con el cual la verdad es más valiosa que el error ${ }^{470}$, pues la primera -la verdad- se refiere al ser, mientras que el error remite al devenir. A la fe en la razón ilustrada, la misma que se cimentó sobre la ficción de la adecuación y que perseguía la objetividad, le subyace el ideal moral cristiano que correlacionaba la verdad y el bien: «una creencia milenaria, esa creencia cristiana que era también la creencia de Platón, de que dios es la verdad, de que la verdad es divina» ${ }^{471}$.

La búsqueda de la certeza iniciada por Descartes, que motivó el ideal de objetividad de la epistemología moderna, tiene en la Crítica de la razón pura su momento culminante, donde se logra una fusión, problemática aunque suficientemente satisfactoria, de las escuelas empirista y racionalista. Sin embargo, dicha pretensión, prosigue Nietzsche, no es tanto gnoseológica como moral ${ }^{472}$, antojándose paradigmáticamente evidente en el corpus kantiano $^{473}$. El fundamento de la ciencia es esencialmente moral -intelectualismo moral, ya que se toma por «vida» no el objeto de estudio de la filosofía natural, sino la episteme dogmática de la verdad inmutable y eterna, supramundana-, revelando su estela en la historia

${ }^{468}$ Nietzsche, F., La gaya ciencia, op. cit., pág. 859 (KSA III, 575).

${ }^{469}$ Cfr. Nietzsche, F., El Anticristo, op. cit., pág. 100 (KSA VI, 233): «‘Fe’ significa no-querer-saber lo que es verdadero».

${ }^{470}$ Cfr. Nietzsche, F., Más allá del bien y del mal, op. cit., pág. 64 (KSA V, 53): «Que la verdad sea más valiosa que la apariencia, eso no es más que un prejuicio moral; es incluso la hipótesis peor demostrada que hay en el mundo».

${ }^{471}$ Nietzsche, F., La gaya ciencia, op. cit., pág. 860 (KSA III, 577).

${ }^{472}$ Cfr. Nietzsche, F., La genealogía de la moral, op. cit., pág. 67 (KSA II, 279-280): «[...] la moral del pueblo separa también la fortaleza de las exteriorizaciones de la misma, como si detrás del fuerte hubiera un sustrato indiferente, que fuera dueño de exteriorizar y, también, de no exteriorizar fortaleza. Pero tal sustrato no existe; no hay ningún 'ser' detrás del hacer, del actuar, del devenir; 'el agente' ha sido ficticiamente añadido al hacer, el hacer es todo. [...] Los investigadores de la naturaleza no lo hacen mejor cuando dicen 'la fuerza mueve, la fuerza causa' y cosas parecidas, -nuestra ciencia entera, a pesar de la frialdad, de su desapasionamiento, se encuentra sometida aún a la seducción del lenguaje y no se ha desprendido de los hijos falsos que se le han infiltrado, de los 'sujetos' (el átomo, por ejemplo, es uno de esos hijos falsos, y lo mismo ocurre con la kantiana 'cosa en sí'): nada tiene de extraño el que las reprimidas y ocultamente encendidas pasiones de la venganza y del odio aprovechen en favor suyo esa creencia $[\ldots] \gg$.

${ }^{473}$ Cfr. Kant, I., Crítica de la razón práctica, [A 292], trad. de Roberto R. Aramayo, Madrid, Alianza Editorial, 2009, pág. 296: «En una palabra: la ciencia (inquirida críticamente y organizada metódicamente) es la estrecha puerta que conduce a la doctrina de la sabiduría, si por ésta no se entiende simplemente lo que se debe hacer, sino aquello que debe servir como pauta a quienes enseñen dicha doctrina para desbrozar, hasta hacerlo bien reconocible y preservar así a los demás de tomar el sendero equivocado, ese camino hacia la sabiduría que cada cual debe seguir. Una ciencia cuya depositaria ha de ser siempre la filosofía y en cuyas sutiles indagaciones el público no ha de tomar parte alguna, si bien ha de interesarse por las enseñanzas que, tras ese laborioso proceso, pueden parecerle contar con una claridad meridiana». 
el poso del ideal ascético, «instinto de protección y de salud de una vida que degenera» ${ }^{474}$. Así, el longevo camino de la verdad termina por desvelarse en Kant como un posicionamiento contra la vida, una desvalorización de la misma ${ }^{475}$.

La observación de Nietzsche sobre la implicación de la moral en la cruzada de la verdad fue, sin embargo, admitida por sus predecesores. El mismo Kant la reconoce y valora favorablemente, pues al tiempo que la ciencia «anula, por decirlo así, mi importancia en cuanto criatura animal» ${ }^{476}$, «la ley moral me revela una vida independiente de la animalidad e incluso del mundo sensible en su conjunto, al menos por cuanto cabe inferir del destino teleológico de mi existencia merced a esta ley, la cual no se circunscribe a las condiciones y los límites de esta vida, sino que se dirige hacia lo infinito» ${ }^{477}$. Y es precisamente en el sentido moral de la verdad - de la ciencia-donde Kant halla el valor de la metafísica. Por cuanto a Nietzsche, sus conclusiones son radicalmente opuestas a pesar de que parte de las mismas premisas. Allí -su esencia moral- donde Kant localizaba el rasgo de veracidad de la metafísica, Nietzsche encuentra su némesis ${ }^{478}$, pues en tanto que moral, la verdad no es más que una valoración perspectivista ${ }^{479} \mathrm{y}$, por ende, no esencial, o sea, una ficción: «'el conocimiento por el conocimiento' -ésa es la última trampa que la moral tiende: de ese modo volvemos a enredarnos completamente en ella ${ }^{480}$. Y es que la estrategia kantiana de distinguir categóricamente los dominios de la filosofía teórica de los propios de la práctica

${ }^{474}$ Nietzsche, F., La genealogía de la moral, op. cit., pág. 176. (KSA V, 366)

475 Cfr. Nietzsche, F., El Anticristo, op. cit., pp. 37-38 (KSA VI, 174-175): «Es necesario decir a quién sentimos nosotros como antítesis nuestra -a los teólogos y a todo lo que tiene en su cuerpo sangre de teólogo -a nuestra fílosofía entera... [...] Ese envenenamiento llega mucho más lejos de lo que se piensa: yo he reencontrado el instinto propio de los teólogos, la soberbia, en todos los lugares en que hoy la gente se siente 'idealista', -en todos los lugares en que la gente reclama, en virtud de una ascendencia superior, el derecho a mirar la realidad con ojos de superioridad y extrañeza... El idealista, exactamente igual que el sacerdote [...] El espíritu puro es la mentira pura... Mientras el sacerdote, ese negador, calumniador, envenenador profesional de la vida, siga siendo considerado como una especie superior de hombre, no habrá respuesta a la pregunta: ¿qué es la verdad? Se ha puesto ya cabeza abajo la verdad cuando al consciente abogado de la nada y de la negación se lo tiene por representante de la 'verdad'...».

476 Kant, I., Crítica de la razón práctica, [A 289], op cit., pág. 294.

477 Ibid. [A 289- A 290].

${ }^{478}$ Cfr. Nietzsche, F., El Anticristo, op. cit., pp. 39-40 (KSA VI, 176-177): «el concepto de 'mundo verdadero', el concepto de la moral como esencia del mundo (-ilos dos errores más malignos que existen!) volvían a ser ahora, gracias a un escepticismo ladinamente inteligente, si no demostrables, tampoco ya refutables... La razón no llega tan lejos... Se había hecho de la realidad una 'apariencia'; y se había hecho de un mundo completamente mentido, el de lo que es, la realidad... El éxito de Kant es meramente un éxito de teólogos: Kant fue, lo mismo que Lutero, lo mismo que Leibniz, una rémora más en la honestidad alemana, nada firme de suyo».

479 Cfr. Nietzsche, F., La gaya ciencia, op. cit., pp. 798-799 (KSA III, 474-475): «Allí donde hallamos una moral, nos encontramos con una estimación y una jerarquía de los impulsos y las acciones humanos. Estas estimaciones y jerarquías son siempre la expresión de las necesidades de una comunidad [...]. Puesto que las condiciones de conservación de una comunidad han sido muy diferentes de las de otra, ha habido muy diferentes morales».

${ }^{480}$ Nietzsche, F., Más allá del bien y del mal, op. cit., pág. 98 (KSA V, 85). 
no es adecuada, pues no es cierto que la intelectualidad pura plantee los dilemas del conocimiento y de la metafísica mientras que el espectro práctico se despliega independientemente de las conclusiones teóricas ${ }^{481}$. La objetividad del intelectualismo no es más que el reflejo de un prejuicio moral; una moral carente de pensamientos elevados, únicamente contemplada por los instintos más comunes y vulgares ${ }^{482}$. La separación de la teoría de la práctica, muy a pesar del opúsculo kantiano ${ }^{483}$, refleja la vileza del instinto de rebaño:

Como se adivina, no es la oposición de sujeto y objeto lo que aquí me preocupa: esa distinción se la dejo a los teóricos del conocimiento, que se han quedado enredados en los nudos de la gramática (de la metafísica del pueblo). Menos aún la oposición de «cosa en sí» y fenómeno: porque estamos lejos de «conocer» lo suficiente como para poder siquiera diferenciar de este modo. Pues no tenemos ningún órgano para conocer, para la «verdad»: «sabemos» (o creemos o nos imaginamos) exactamente tanto como puede ser útil en interés del rebaño humano, de la especie: e incluso lo que aquí se denomina «utilidad» es en última instancia también sólo una creencia, una imaginación y quizá la estupidez más fatal por la que un día pereceremos $^{484}$.

\section{II.3.3. La verdad, el resentimiento y el pesimismo}

El sistema metafísico cimentado sobre la dualidad del fenómeno y el noúmeno se revela como un eslabón más de la historia dogmática de la verdad; un hito, éste particular, que se orienta hacia la fundamentación de las pretensiones morales de susodicha tradición. La dupla apariencia-cosa en sí terminaba escapando del escrutinio de la razón estrictamente teórica, por lo que su legitimación fue transferida a un dominio distinto; la distinción entre el «mundo verdadero»y el «mundo aparente» perseguía la validez, en el orbe moral, que la teoría pura había sido incapaz de procurar para la distinción fenoménica y nouménica.

La teoría del conocimiento ha sido motivada a lo largo de toda su tradición por el ideal de certeza. Las diferencias epocales, Platón frente a Descartes, verbi gratia, han sido

${ }^{481}$ Cfr. Nietzsche, F., Aurora, op. cit., pág. 496 (KSA III, 25): «El efecto, algo añadido. - Antaño se creía que el resultado de una acción no era un efecto, sino un añadido independiente -hecho por Dios. ¡Cabe imaginarse mayor disparate! ¡Había que ocuparse específicamente de la acción y del resultado, con medios y prácticas absolutamente diferentes!».

${ }^{482}$ Cfr. Nietzsche, F., El Anticristo, op. cit., pp. 38-39 (KSA VI, 175-176): «Quien tiene en su cuerpo sangre de teólogo adopta de antemano, frente a todas las cosas, una actitud torcida y deshonesta [...]. De esa óptica defectuosa con respecto a todas las cosas hace la gente en su interior una moral, una virtud, una santidad, establece una conexión entre la buena y el ver las cosas de manera falsa [...]. Lo que un teólogo siente como verdadero, eso es, necesariamente, falso [...], los conceptos de 'verdadero' y de 'falso' están necesariamente invertidos: lo más dañoso para la vida es llamado aquí 'verdadero', lo que la alza, intensifica, afirma, justifica y hace triunfar, es llamado 'falso'... [...] no dudemos de qué es lo que en el fondo acontece todas esas veces: la voluntad de final, la voluntad nihilista quiere alcanzar el poder...».

${ }^{483}$ Cfr. Kant, I., En torno al tópico: "Eso vale para la teoría pero no sirve de nada en la práctica», trad. de Roberto R. Aramayo, en Kant II, ed. de Maximiliano Hernández Marcos, Madrid, Gredos, 2010.

${ }^{484}$ Nietzsche, F., La gaya ciencia, op. cit., pág. 869 (KSA III, 593). 
más tópicos relativos a la nomenclatura que al paradigma motriz ${ }^{485}$. Sin embargo, la investigación nietzscheana ha creído desnudar las pretensiones últimas de tal meta concluyendo que a la ensoñación de la adecuación le correspondía, esencialmente, un objetivo más moral que gnoseológico. El enfoque teórico de la gnoseología, especialmente en la modernidad, procuró estrategias disuasorias desde las que contemplar la actividad racional. Los meandros que desembocaban en el núcleo moral discurrieron subrepticiamente; quienes los transitaban, lo hacían «alevosamente» ${ }^{486}$. La creencia de la adecuación, o sea, de la potencia ontológica del pensamiento independiente de la materia, respondía, como se ha mostrado líneas atrás, a un prejuicio moral: la identificación del mundo inteligible con el mundo del bien. El prejuicio fundador de la metafísica dualista que habrían de continuar sus herederos. De modo que Dios, bueno y veraz, se convierte para Descartes en la garantía incuestionable de cuanto ha configurado su sistema; la defensa del espacio y del tiempo ideales como salvaguarda de la «unidad» esencial de las cosas -su perfección y bien- justifica a Dios en la obra kantiana:

\section{Los valores morales en la teoría del conocimiento misma}

la confianza en la razón - ¿por qué no desconfianza?

el «mundo verdadero» debe ser el bueno - ¿por qué?

la apariencia, el cambio, la contradicción, la lucha, estimadas inmorales: aspiración a un mundo en el que todo esto falte.

el mundo trascendente inventado para que quede un sitio para la «libertad moral» (en Kant).

la dialéctica como vía hacia la virtud (en Platón y Sócrates: evidentemente porque la sofística era considerada como vía hacia la inmoralidad)

espacio y tiempo ideales: por consiguiente «unidad» en la esencia de las cosas, por consiguiente ningún «pecado», ningún mal, ninguna imperfección, - una justificación de Dios.

Epicuro niega la posibilidad del conocimiento: para mantener como valores supremos los valores morales (o hedonistas). Lo mismo hace Agustín; más tarde Pascal («la razón corrompida») en beneficio de los valores cristianos.

el desprecio de Descartes frente a todo lo cambiante; igualmente el de Spinoza ${ }^{487}$.

485 Cfr. Nietzsche, F., Fragmentos póstumos IV, 2 [93], op. cit., pág. 104 (KSA XII, 107): «En qué medida la dialéctica y la creencia en la razón descansan aún en prejuicios morales. En Platón, en cuanto antiguos habitantes de un mundo inteligible del bien estamos aún en posesión de un legado de aquel tiempo: la divina dialéctica, al provenir del bien, conduce a todo bien (- es decir, de cierto modo 'reconduce'-). También Descartes tenía idea de que en un modo de pensar fundamental cristiano-moral, que cree en un Dios bueno como creador de las cosas, sólo la veracidad de Dios garantiza los juicios de nuestros sentidos. Fuera de una garantía y una sanción religiosa de nuestros sentidos y nuestra racionalidad — ide dónde sacaríamos el derecho a confiar en la existencia! Que el pensamiento sea una medida de lo real, — que lo que no puede ser pensado no es, - es un burdo non plus ultra de una bienaventuranza moralista y confiada (en un esencial principio de verdad en el fondo de las cosas), en sí una afirmación insensata que nuestra experiencia contradice a cada instante. Precisamente no podemos pensar nada en la medida en que es...».

486 Cfr. Ibid. 2 [202], pág. 137 (KSA XII, 165): «Kant: la mera idea de una ciencia posible a la que uno busca acercarse por diversos caminos, hasta que el único sendero, muy recubierto por el follaje de la sensibilidad, es arrebatado»».

487 Ibid. 9 [160], pág. 285 (KSA XII, 430). 
De modo que la esencial distancia que separaba el fenómeno de la cosa en sí naufraga errante si se intenta apreciar desde la teoría del conocimiento; en su fondo palpita una significación moral, valorativa: la vindicación favorable del mundo inteligible del ser en detrimento del paupérrimo opuesto, de apariencias que devienen. La dimensión en la cual vivimos está subordinada al influjo de la gratuidad del cambio, pues a la apariencia le sobrevienen multitud de condicionamientos que afectan determinantemente a su estatus. Es por ello que debe existir un mundo que funcione en necesaria oposición, ajeno al cambio y a las volubles condiciones que rigen el azaroso devenir. Un mundo cuya realidad no muta, sino que permanece y se postula verdadero, libre de las dudas y sombras del carácter caprichosamente azaroso del primero. Un mundo que ha de ser imperiosamente «bueno». En este mundo hay una coincidencia perfecta entre las categorías epistemológicas por un lado y, por otro, las valoraciones morales del hombre; la maquinación del intelectualismo moral platónico, que es a su vez el bien moral kantiano. Y dado que el entendimiento y los juicios de valor caen dentro del dominio de la intelección, sólo su vía nos conducirá a dicho reino -moralmente- bueno. Transitivamente, cuanto le sea opuesto, a saber, el dominio de la sensibilidad en el cual estamos efectivamente insertos, habrá de ser forzosamente censurado por su poso de imperfección y malicia.

Nietzsche rescata al respecto la ecuación socrático-platónica del intelectualismo moral, que afirmaba la imposibilidad del mal obrar en el sabio, que ha conquistado la verdad. Además, y en consecuencia, este hombre de virtud sería feliz al haber trascendido la indigencia del devenir para afirmarse en la garantía de lo inmutable. Sin embargo, la tradición europea no ha sido capaz de zafarse del hábito de los sentidos y trascender hacia lo inteligible. El nihilismo arrastra consigo la historia del pesar de un Occidente al cual el mundo bueno se le ha mantenido inaccesible; un pozo de frustración que motivaría la tendencia pesimista del horizonte moderno: es imposible vivir en el mundo verdadero. No obstante, este giro no satisface a Nietzsche, como puede apreciarse en su valoración de la filosofía de Schopenhauer. El pesimismo se conforma con la negación de la accesibilidad de la verdad, mas no cuestiona como tal su existencia. La agonía de la infertilidad de esta empresa ha conllevado una respuesta reactiva de rechazo, mas todavía dentro de los caracteres de la dualidad. El pesimismo, dirá Nietzsche, consistirá en la insatisfecha conformidad de los espíritus que claudicaron en su empeño por abandonar la «caverna». La enfermedad del pesimista es la psicosis resultante de un hombre que se siente privado de las condiciones de posibilidad de la felicidad y que, por ello, reacciona contra la vida; contra aquella anunciada en la mitología inteligible, pero también contra la aparente, cuyas formas y disposiciones han hecho inviable que fructifique la promesa emancipatoria del intelectualismo. En su psicosis el pesimista sigue impelido por el anhelo del mundo permanente; la voluntad de un anhelo de verdad que desconfía del devenir sensible: la fe en el ser. De tal forma que, como Platón antes, el pesimismo enajena la estrategia de una vida efectiva en medio del cambio 
en favor de otra posible sobre la inmutabilidad; mas, a diferencia del griego, ha dejado de confiar en su capacidad para alcanzar la fijeza del contenido de la verdad. La búsqueda platónica del bien tenía fuerza motriz, toda vez que motivaba la investigación en su promesa de sapientísima felicidad; el pesimismo, en cambio, es inoperante al negar cualquier posible acercamiento a la verdad. Así, para las personalidades modernas, inscritas todavía en la historia dual del pensamiento, la verdad ha devenido «nada», una nada que, no obstante, los habla para recordarles su insuficiencia esencial. El pesimismo arroja el tipo de hombre en quien se ha ultimado la degeneración metafísica que comportó el proceso de extrañamiento del bien, un ser que «prefiere querer la nada a no querer...» ${ }^{488}$. De modo que mientras el dualismo imponía una valoración moral sobre el mundo inteligible y el aparente, bueno y malo respectivamente, el proceso de la filosofía pesimista tan sólo ha extendido el juicio desfavorable sobre el eidético, manteniendo la esencial confrontación de mundos. Allí donde el platonismo pauperizaba la vida aparente en beneficio de la inteligible, el pesimismo ha devaluado tanto una como otra.

La tarea de Nietzsche es defender el contenido significativo de la apariencia; imprimirle una valoración favorable emancipada de las tensiones agónicas con otras realidades inexpugnables. El reino de la sensibilidad es, propiamente, la verdad de la vida, cuya connivencia con el devenir integra la fuerza del ciclo de la generación y la destrucción que subyace al caos dionisiaco. El «mundo verdadero» de la metafísica no es más que una propuesta de orden secundario que pretende aportar los elementos pertinentes y necesarios para procurar la vida y el crecimiento. Sin embargo, dichos contenidos de desarrollo y conservación se encuentran en la vida misma; le son inherentes. Así pues, la duplicación de mundos es una estrategia tan absurda como dañina: se antoja ridícula toda vez que clona lo que ya existe y está, heideggerianamente, a la mano; pérfida porque extraña los juicios humanos sobre los que se sustenta la concepción propia de la vida en instancias «en sí». En último término, la verdad de la metafísica ha deshumanizado al hombre mismo, que vive sin vivir en si:

[...] la necesidad de fe, la necesidad de alguna incondicionalidad en el sí y en el no [...], es una necesidad propia de la debilidad. El hombre de fe, el «creyente» de toda especie es, por necesidad, un hombre dependiente, -alguien que no puede erigirse a sí mismo en finalidad, que no puede erigir finalidades a partir de sí mismo. $\mathrm{El}$ «creyente» no se pertenece a sí mismo, sólo puede ser un medio, tiene que ser consumido, tiene necesidad de alguien que lo consuma. Su instinto otorga el honor supremo a una moral de la des-simismación: todo le persuade a ella, su inteligencia, su experiencia, su vanidad. Toda especie de fe es en sí mismo una expresión de des-simismación, de extrañamiento de sí mismo... ${ }^{489}$.

${ }^{488}$ Nietzsche, F., La genealogía de la moral, op. cit., pág. 233 (KSA V, 412).

489 Nietzsche, F., El Anticristo, op. cit., pp. 103-104 (KSA VI, 236). 
La vida que ofrece la metafísica, una vida desnaturalizada, deshumanizada, desposeída, «descarnada» responde a una óptica moral que bebe del odio y de la amargura, una moral resentida con la vida, al experimentar que ésta no le es afable. El resentimiento viene de la imposibilidad de imbricar armoniosamente al hombre metafísico-moral en la verdad primigenia de Dioniso, cuya condición estructural es existencial y se relaciona con el hombre en caracteres artísticos. Por esto el metafísico desea aniquilar la vida, es un «predicador de la muerte», «tuberculosos del alma: apenas han nacido y ya han comenzado a morir, y anhelan doctrinas de fatiga y de renuncia» ${ }^{490}$. El resentimiento se articula desde un movimiento dialéctico, esto es, por oposiciones, verdad-mentira, bueno-malo. Una dialéctica hegeliana avant la lettre, es decir, idealista donde la razón se aleja irremediable y abismalmente de la materia sensible para mirar hacia un incorpóreo horizonte «elevado», donde habría de descansar el genuino ser, y que transforma a la razón en «verdad». Una verdad que, a todas luces, ha dejado de aprehender la vida toda vez que se sitúa en díscola oposición frente a los sentidos. ¡Cuán distinta, objeta Nietzsche, habría sido la historia de Occidente de habernos procurado una dialéctica heraclítea y no hegeliana! ${ }^{491}$.

La privación que del ser se le ha impuesto a la apariencia, así como su supuesta incapacidad para acceder a la «verdad» racional es el juicio de valor que de la vida ha bosquejado el metafísico. Un reconocimiento que ha hecho del dolor de la existencia la piedra angular de su posicionamiento, situando la condición de la felicidad en la verdad y, por ende, vedada para un hombre encerrado en los regímenes de la sensibilidad. La moral del resentimiento, formulada en la mencionada ecuación socrática de la virtud, es del todo contraria a la vida encarnada ${ }^{492}$ que respeta el fondo inconsciente de la existencia, ya que «se aferra por obstinación a una cosa que se le ha vuelto transparente» ${ }^{493}$. Por lo cual su postulado de felicidad es insatisfactorio para el hombre viviente al que arroja al océano del pesimismo:

De la metafísica todavía algunos tienen necesidad; pero también ese impetuoso anhelo de certeza que se descarga hoy de modo científico-positivista en amplios

${ }^{490}$ Nietzsche, F., Así habló Zaratustra, op. cit., pág. 80 (KSA IV, 55).

${ }^{491}$ Cfr. Nietzsche, F., Crepúsculo de los ídolos, op. cit., pág. 52 (KSA VI, 75): «Pongo a un lado, con gran reverencia, el nombre de Heráclito. Mientras que el resto del pueblo de los filósofos rechazaba el testimonio de los sentidos porque éstos mostraban pluralidad y cambio, él rechazó su testimonio porque mostraban las cosas como si tuviesen duración y unidad [...] La 'razón' es la causa de que nosotros falseemos el testimonio de los sentidos. Mostrando el devenir, el perecer, el cambio, los sentidos no mienten... Pero Heráclito tendrá eternamente razón al decir que el ser es una ficción vacía. El mundo 'aparente' es el único: el 'mundo verdadero' no es más que un añadido mentiroso...».

${ }^{492}$ Cfr. Nietzsche, F., La gaya ciencia, op. cit., pág. 820 (KSA III, 508): «La fe hace bienaventurado. — La virtud sólo da felicidad y una especie de bienaventuranza a aquellos que creen de buena fe en su virtud: — pero no a aquellas almas más sutiles cuya virtud consiste en una profunda desconfianza respecto de sí mismo y de toda virtud. ¡Por lo tanto, también aquí es la 'fe' la que en definitiva hace 'bienaventurado'! — ¡y no la virtud, bien entendido».

493 Ibid. pág. 822 (KSA III, 511). 
sectores, el anhelo de querer tener algo firme [...]. En efecto, alrededor de todos esos sistemas positivistas se exhala el espeso vapor de un cierto oscurecimiento pesimista, algo de cansancio, fatalismo, decepción, miedo a nuevas decepciones - o bien un ostentoso rencor, mal humor, anarquismo indignado y todos los síntomas y mascaradas posibles del sentimiento de debilidad ${ }^{494}$.

No obstante, la problemática crucial del razonamiento metafísico no se agota en la mueca del resentimiento; no consiste en un simple enjuiciamiento de una realidad a costa de otra, sino en un preposicionamiento determinante de la valoración. El predicador de la muerte, acaso de la virtud, es «deshonesto», puesto que convierte su prejuicio moral de que la verdad es preferible sobre el error en juicio moral. En el resentimiento hay una violencia ontológica que torna axiomática la necesidad del mundo ideal. Semejante hipótesis ha de ser incuestionable: existe forzosamente una gradación «en sí» de los valores que empuja hacia el bien. Una gradación moral por la cual la verdad rebasa los límites del valor y deviene metavalor desde el que partir en todo enjuiciamiento. El resentimiento ha inoculado el veneno más dañino en la conciencia europea; las voluntades de poder han sido emponzoñadas y han contemplado durante demasiado tiempo la ficción del más allá como realidad original y por la cual es lícito rechazar la explotación de la apariencia.

Al nublar el horizonte de la voluntad de poder el resentimiento se ha vuelto creador. Ha confeccionado una noción de vida que nos ocasiona dolor y tormentos; una amargura perenne cuya experiencia ha llevado a despreciarla. La «historia universal» ha sido hasta ahora la de la pulsión de un instinto calumniador ${ }^{495}$, una gran infamia que ha degenerado y contradicho los impulsos naturales de la vida bajo la fórmula «Dios» ${ }^{496}$. La fuerza creadora del resentimiento ha encumbrado la mentira en el plano ideal, transmutándola alquímicamente en «verdad» y conmoviendo a la humanidad en la infértil tarea de su consecución: «el daño de los buenos es el daño más dañino de todos» ${ }^{497}$.

La acción creadora del resentimiento acomete un giro determinante sobre la verdad. La identidad artística de la verdad dionisiaca de la existencia es suplantada por la verdad epistemológica y moral del metafísico; la verdad de la vida no es ya el devenir caótico de la generación y de la muerte que requiere de la intervención plástica de la voluntad de poder para imprimir sentidos, sino el postulado ad hoc del mundo ideal. El «mundo verda-

${ }^{494}$ Ibid. pág. 863 (KSA III, 581-582).

495 Cfr. Nietzsche, F., Crepúsculo de los ídolos, op. cit., pág. 56 (KSA VI, 78): «Inventar fábulas acerca de 'otro' mundo distinto de éste no tiene sentido, presuponiendo que en nosotros no domine un instinto de calumnia, de empequeñecimiento, de recelo frente a la vida: en este último caso tomamos venganza de la vida con la fantasmagoría de 'otra' vida distinta de ésta, 'mejor' que ésta».

496 Cfr. Nietzsche, F., El Anticristo, op. cit., pág. 49 (KSA VI, 185): «¡En Dios, declarada la hostilidad a la vida, a la naturaleza, a la voluntad de vida! ¡Dios, fórmula de toda calumnia del 'más acá', de toda mentira del 'más allá'! ¡En Dios, divinizada la nada, santificada la voluntad de nada!...».

${ }^{497}$ Nietzsche, F., Así habló Zaratustra, op. cit., pág. 297 (KSA VI, 266). 
dero» emanado del resentimiento destruye toda expectativa funcional de vida. Es la esclavitud del hombre «bueno» que repudia la vida, propia y ajena, y exige encadenarse a sí mismo y a todos: «el evangelio de los 'viles' envilece» ${ }^{498}$.

El envilecimiento de los resentidos presiente la verdad de la vida como un error que resolver. Donde la experiencia vital dionisiaca demanda afirmación y creación, la moral de los metafísicos impone barreras y frenos. El caso más dramático al respecto es el del sacerdote del «ideal ascético», en cuya orden el desprecio de la moral de la metafísica opera en los caracteres más perversos. El sacerdote no concede alternativa alguna a la verdad primigenia; tampoco, por tanto, acepta las estrategias que el hombre ha venido procurándose para facilitar su integración en el devenir. En último término, el sacerdote, en su proceso de pauperización de la vida, acaba por suprimir la actividad de la razón. Nietzsche entiende que la eliminación de los procesos y discursos racionales es el paso definitivo de la moral del resentimiento; el metafísico todavía conserva anhelos racionales de verdad, y así persigue el mundo verdadero al entenderlo como depositario de los modelos ideales que mueven la lógica del pensamiento. Si bien denunciada por Nietzsche, esta búsqueda intelectiva de la verdad aún alberga cierta nobleza toda vez que compromete al hombre con una cierta operación de la razón para tratar de descubrir algunos de los misterios de la existencia. Sin embargo, en el sacerdote ascético la razón ha sido totalmente expulsada de los dominios de la verdad y el ser. Pese a los inmensos esfuerzos que comportaba la vida contemplativa, no es menos cierto que los pensadores clásicos pensaron la actividad racional de búsqueda de la verdad como dichoso y placentero itinerario hacia la vida virtuosa; por esta condición feliz el sacerdote ha privado de la razón a la verdad. No ha lugar a dudas sobre la existencia de la verdad, es revelada, de tal forma que la disposición intelectiva de los eruditos que la persiguen es vana. Donde para la filosofía la voluntad de verdad era tanto brújula como meta, anhelo desde el que conducirse y al que apuntar, respectivamente, en el sacerdote, por ser revelación incondicionada, no precisa más que del aspecto volitivo del propio individuo, que en consecuencia prescinde de la intelección y de los gozos que pudiera procurarle.

El tipo del sacerdote ascético representa ejemplarmente el modelo de vida que ha triunfado en el paradigma metafísico y moral de la duplicidad de mundos. Es la más pura manifestación de la inversión de las formas existenciales que ha tenido lugar al abrigo de la funesta capa del resentimiento. El éxito del mundo verdadero en el Occidente filosófico no es tanto el triunfo de Platón como de la casta sacerdotal, bajo cuyos criterios han terminado siendo definidos los conceptos de «verdadero» $\mathrm{y}$ «falso», y en virtud de la imbricación de la moral en el trazo metafísico, de «bueno» y «malo», respectivamente. El cauce discursivo del pensamiento europeo, sentencia Nietzsche, no es sino el legado del sacerdote. Por eso

${ }^{498}$ Nietzsche, F., El Anticristo, op. cit., pág. 84 (KSA VI, 218). 
señala en El Anticristo que toda nuestra filosofía ha sido acuñada por los enemigos de la vida, pues ha sido regada por la sangre de teólogos ${ }^{499}$. Así sucede con Kant, por ejemplo, cuyos prejuicios le impiden desplegar en plenitud la actividad de la razón pura, que habría de haber abolido la hipótesis del fondo moral esencial del mundo.

En el sacerdote se encuentra también el celo de los metafísicos y de los moralistas por la unidad y la permanencia del ser. Sin embargo, en su figura este anhelo se manifiesta violentamente. Aunque la metafísica clásica tendía hacia el mundo eidético, no dejaba de sentirse mínimamente impelida por el mundo aparente $-v$. gr., la pregunta por la vida buena-. El ideal del hombre religioso, en cambio, lo aborrece visceralmente; odia mortalmente la verdad de la vida, a la que pauperiza con los más despectivos juicios de valor: «ellos llamaron Dios a lo que les contradecía y causaba dolor [...]/ De huecos se componía el espíritu de esos redentores; mas en cada hueco habían colocado su ilusión, su tapahuecos, al que ellos llamaban Dios» ${ }^{500}$.

No hay amor en la dominación del sacerdote; su rencor emponzoña las conciencias de sus fieles. El resentimiento que guarda el ideal ascético hace de la humanidad un agregado débil al que separa de su vigor y fortaleza; la voluntad de poder de los hombres es envenenada y se niega a sí misma la capacidad de creación en virtud de su afirmación. El ascetismo se ejecuta en el mundo invirtiendo los significados originarios -y naturalesde la verdad y la mentira: la verdad primigenia es sepultada bajo la infamia de la verdad del ideal. El sacerdote apuesta por una verdad cobarde que se corresponde, más bien, con una estrategia de evasión de la verdad del origen; bajo la verdad el sacerdote ha vendado los ojos de los fieles con el fin de privarlos de la contemplación de algo que resulta inmediatamente evidente, a saber, la vida encarnada. La verdad religiosa es una mentira que el propio devoto se impone. Desde la religión, la verdad y la mentira no se definen como términos contrapuestos y excluyentes, sino ésta como el voluntario rechazo de aquélla: «'Fe' significa no-querer-saber lo que es verdadero» ${ }^{501}$.

El creyente ha decidido no querer. Así, ha creado conceptos y categorías -«Dios», «alma», «más allá», «eternidad», «pecado», etc.- desde los que ha invertido el natural ritmo de la verdad de la vida:

El sacerdote conoce únicamente un peligro grande: ese peligro es la ciencia $[\ldots]$ -para «conocer» hay que tener tiempo, hay que tener espíritu de sobra... «Por consiguiente, hay que hacer desgraciado al hombre», -ésa fue en todo tiempo la lógica del sacerdote. -Se adivina ya qué es lo primero que, de acuerdo con esa lógica, vi-

499 Cfr. ibid, pág. 102 (KSA VI, 235): «Signos de sangre han escrito en el camino que ellos recorrieron, y su tontería enseñaba que con sangre se demuestra la verdad».

${ }^{500}$ Nietzsche, F., Asi habló Zaratustra, op. cit., pp. 144-145 (KSA IV, 118-119).

${ }^{501}$ Nietzsche, F., El Anticristo, op. cit., pág. 100 (KSA VI, 233). 
no al mundo: -el «pecado»... El concepto de culpa y de castigo, el entero «orden moral del mundo» han sido inventados contra la ciencia, -contra la liberación del hombre respecto del sacerdote... El hombre [...] debe sufrir... Y debe sufrir de tal modo que en todo tiempo tenga necesidad del sacerdote. -iFuera los médicos! Lo que se necesita es un salvador. -El concepto de culpa y de castigo, incluida la doctrina de la «gracia», de la «redención», del «perdón»-mentiras completas, carentes de toda realidad psicológica [...], el sacerdote domina merced al invento del peca$\mathrm{do}^{502}$.

El hombre de fe ya no guarda una relación apropiada con la verdad, sino otra que se desvela dañina y perjudicial ${ }^{503}$ : sobre la moral del resentimiento se yerguen los malos instintos de los enfermos que han venido configurando el horizonte europeo ${ }^{504}$ : «el cristianismo tiene en su base la rancune propia de los enfermos, el instinto dirigido contra los sanos, contra la salud. Todo lo bien constituido, lo orgulloso, lo petulante, ante todo la belleza, daña sus oídos y sus ojos» ${ }^{505}$. El creyente apuntala su configuración de la verdad desde la protección del más estricto inmovilismo: su abnegada entrega a tal concepto le impide mentir, esto es, romper la caracterización dicotómica moral de la verdad y la mentira y, por ende, sigue ciego ante el deviniente sustrato de existencia que conforma la vida.

La inversión metafísica por la que se ha duplicado el mundo obedece al rencor de personalidades enfermas; voluntades de poder maleadas por los más bajos instintos reactivos y que, antitéticos con la vida, han cercenado y restringido las ocasiones de florecimiento de la humanidad. Podemos aceptar con Heidegger que la historia de Occidente es la historia de la metafísica; ahora bien, no hace justicia con el pensamiento de Nietzsche incluirlo en el dominio de la metafísica, como hiciera el autor de Ser y tiempo. Nietzsche desnuda la vergüenza de Occidente como el impostado relato que ha encumbrado la miseria de los débiles al rango de virtud. Así consiente que «la verdad habla en mí. Pero mi verdad es terrible: pues hasta ahora se ha venido llamando verdad a la mentira ${ }^{506}$. La verdad vindicada por Nietzsche es la de Dioniso; es la afirmación de la voluntad de poder de aquellos espíritus capaces de afrontar creativamente el fondo trágico del mundo. La verdad dionisiaca contra la del rencor «trasmundano»:

Lo que un teólogo siente como verdadero, eso es, necesariamente, falso: en esto se tiene casi un criterio de verdad. Es su más hondo instinto de autoconservación el que prohíbe que, en un punto cualquiera, la realidad sea honrada o tome siquiera la

502 Ibid. pp. 94-95 (KSA VI, 228-229).

${ }^{503}$ Cfr. ibid. pág. 100 (KSA VI, 233): «'Lo que pone enfermo es bueno; lo que viene de la plenitud, de la sobreabundancia, del poder es malvado': ése es el modo de sentir del creyente».

${ }^{504}$ Cfr. ibid. pág. 98 (KSA VI, 231): «el movimiento cristiano, en cuanto movimiento europeo, es de antemano un movimiento conjunto de los elementos de desecho y desperdicio de toda especie». (La cursiva es nuestra).

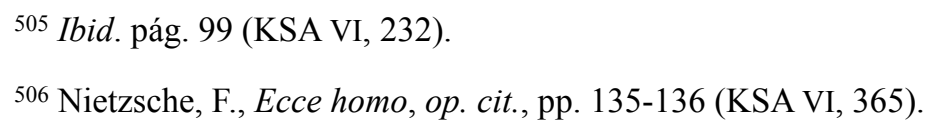


palabra. Hasta donde alcanza el influjo de los teólogos, el juicio de valor está puesto cabeza abajo, los conceptos de «verdadero» y «falso» están necesariamente invertidos: lo más dañoso para la vida es llamado aquí «verdadero», lo que la alza, intensifica, arma, justifica y hace triunfar, es llamado «falso» ${ }^{507}$.

El contenido de la razón no puede ser ideal, sino empírico. Por eso el concepto de Dios del metafísico es contradictorio, y con él, su estrategia. Al haber hecho del Dios espiritual el criterio último de la valorización se ha consumado la resentida venganza que los enfermos y decadentes pergeñaron contra la vida: un Dios al que la sensibilidad y el cuerpo resultan extraños, un Dios para quien la vida encarnada es un lastre y anhela trascender es una divinidad muda. Su verdad es la nada, aunque «no se dice 'nada': se dice, en su lugar, 'más allá'; o 'Dios'; o 'la vida verdadera'» ${ }^{508}$. Una nada sin más contenido que la hostilidad hacia la vida y «nacida del reino de la idiosincrasia religioso-moral» ${ }^{509}$. Únicamente desde la idiosincrasia de la vida moral - degenerada- puede defenderse la primacía del mundo eidético. Por la superioridad ontológica de la idea respecto de la naturaleza fisiológica del hombre el mundo del resentimiento, fabulado desde la compasión y la valoración moral, es inhumanamente incompatible con las condiciones de la vida empíricamente efectiva $^{510}$.

La transvaloración que exige Nietzsche afecta frontalmente a la moral del resentimiento. Al revocarla, no sólo se desvaloriza el odio hacia la vida; también cuanto ha sido de-generado por ella. Así, a la transformación valorativa le suceden nuevas formas categoriales desde las cuales pensar el mundo y su correspondiente nueva figura del hombre ${ }^{511}$. El hombre de la transvaloración ha revitalizado su fe en los sentidos y a él le compete la nobilísima misión de vindicar el plano sensible: el reino del hombre de la transvaloración es este mundo, su vida concreta, su «corporalidad». Las claves valorativas parten ahora de la afirmación del sustrato dionisiaco, reconfigurando el viejo fondo moral del predicador de la muerte en uno que acoge la dimensión artística de los espíritus «trágicos» de los artistas-filósofos.

Con la transvaloración el espíritu y el hombre se funden; no es ya la emanación de la razón del mundo a lo largo de la historia, sino la propia actividad generadora del hombre que se da en el ejercicio de su existencia. En este nuevo horizonte el ser humano encarnado es la condición de posibilidad de las facultades cognoscitivas y del juicio de la razón. Co-

${ }^{507}$ Nietzsche, F., El Anticristo, op. cit., pp. 38-39 (KSA VI, 175-176).

508 Ibid. pág. 36 (KSA VI, 173).

${ }^{509}$ Ibid. (KSA VI, 173).

510 Cfr. ibid. pág. 103 (KSA VI, 235): «la sangre es el peor testigo de la verdad: la sangre envenena incluso la doctrina más pura, convirtiéndola en delirio y en odio de los corazones».

${ }^{511}$ Cfr. ibid. pág. 32 (KSA VI, 170): «Los débiles y malogrados deben perecer [...]. Y además se debe ayudarlos a perecer». 
mo apuntamos anteriormente, la transvaloración significa la espiritualización del cuerpo y la corporalización del espíritu.

\section{II.3.4. Transvaloración y voluntad de poder}

La verdad habla en Nietzsche, dice de sí mismo. Una verdad terrible, pues socava el engaño que sobre la vida se ha vertido por siglos. Parte de un escepticismo radical, pero no dogmáticamente metódico y metódicamente dogmático, como el que hubo pretendido Descartes. La diferencia cualitativa entre uno y otro es crucial, pues mientras el cartesiano acababa resultando inoperante por llevar la duda como presupuesto fundamental, el de Nietzsche lleva la duda a los presupuestos fundamentales. El francés acaba abocando a un solipsismo genuino donde sólo resiste la propia conciencia. Una imagen de la conciencia, no obstante, adulterada por la creencia en el sujeto plenamente autoconsciente con absoluto escrutinio de sí mismo, para que no hay vestigios inconscientes en la formación de su personalidad $^{512}$; el alemán, por el contrario, tan sólo cuestiona los conceptos y las categorías desde las que se desplegó el pensamiento ${ }^{513}$, mas nunca objeta contra el pensamiento. El escepticismo de cuño nietzscheano penetra a lo largo del relato metafísico de Occidente y cuestiona cada uno de sus conceptos y verdades. El cáustico escrutinio de Nietzsche emanciparía los espíritus europeos de los ídolos atávicos del mundo ideal que han venido conduciendo la configuración del hombre desde los tiempos griegos. Ahora bien, la supresión de tales hitos referenciales no es pensada por Nietzsche como una objeción problemática contra su análisis genealógico, sino, al contrario, como el elemento legitimador; la derogación de las mentiras de milenios no nos empuja a nosotros, hijos del nihilismo, a la gratuidad azarosa de un mundo privado de garantías y fundamentos últimos:

Liberado de la tiranía de los conceptos «eternos», estoy lejos, por otra parte, de precipitarme por eso en el abismo de una arbitrariedad escéptica: más bien, invito a considerar los conceptos como ensayos, con cuya ayuda determinadas especies de hombre se crían $[\ldots]^{514}$.

Descartes llevó a término un enjuiciamiento absoluto de las aseveraciones tomadas hasta entonces por lícitas; esgrimió un escepticismo radical sostenido por la duda me-

512 Cfr. Nietzsche, F., Fragmentos póstumos IV, 14 [189] (KSA XIII, 377), op. cit., pág. 605: «Que sepa qué es verdadero, qué es Dios, qué es la meta, qué es el camino... el filósofo típico es en esto absolutamente dogmático; — si tiene necesidad del escepticismo es para tener derecho a hablar dogmáticamente de $s u$ cuestión fundamental».

513 Cfr. Nietzsche, F., Fragmentos póstumos II, 3 [54], op. cit., pág. 524 (KSA IX, 62): «Lo primero que se aprende no es a conocer las cosas y a los hombres, sino los juicios de valor acerca de las cosas y los hombres; dichos juicios impiden el acceso al conocimiento real. Para tener vía libre deberían derribarse de una vez todos los juicios de valor por medio de un escepticismo radical respecto de los valores».

514 Nietzsche, F., Fragmentos póstumos III, 35 [36], op. cit., pág. 781 (KSA XI, 526). 
tódica ${ }^{515}$. Una estrategia, no obstante, embustera, toda vez que dicho cuestionamiento estructural no tenía otro fin que blindar sus proposiciones cognoscitivas. Así Descartes se convirtió en un dogmático más. Mientras que Nietzsche, por su parte, emprende una empresa que pretende disolver los procedimientos y juegos dogmáticos. Dejar atrás la mentira de toda la tradición filosófica conlleva abandonar sus estrategias, medios y fines. En último término, se prescinde de los ardides del mundo eidético, desde la sustantividad de los «en sí» hasta la regresión a un punto iniciático esencial.

Nietzsche comprende que el abismo abierto entre el individuo y el mundo se debe al complejo de valoraciones que aquél imprime sobre éste. La subordinación de la realidad ante el horizonte de los juicios humanos encubre la relación inmediata entablada entre el sujeto y el objeto; qué sea la naturaleza ha enajenado su espontaneidad en los predicados humanos de «bueno», «bello» «verdadero». La vieja teoría de la adecuación se levanta sobre un sustrato de valoraciones morales, de manera que lo afirmado como bueno no es más que aquello que el sujeto ha determinado por tal. Así puede sostener Nietzsche que lo prescrito como verdad es necesariamente «mentira»: lo verdadero - ya bueno, ya bello- es verdadero porque la moral lo ha juzgado - lo ha valorado- así. Hasta ahora se ha venido llamando verdad a la mentira, sentenciaba en Ecce homo, pues dicha sanción era genéticamente moral, que no es sino una ficción humana. El escepticismo nietzscheano interviene en este momento valorativo al rechazar, por impostada, toda predicación trabadamente moral: «escepticismo absoluto: Necesidad del arte y de la ilusión» ${ }^{516}$. Frente al dogmatismo de aquellos proclamados escépticos -Descartes y sus hijos-, Nietzsche rechaza colmar la moralidad de fuentes de verdad: «la moral como valor supremo (ejerciendo su dominio sobre todas las fases de la filosofía, incluso sobre los escépticos): resultado: este mundo no importa nada, no es el 'mundo verdadero'» ${ }^{517}$.

Se sabe poseedor de un sino terrible y monstruoso. Indiferente ante la dolorosa experiencia que haya de portar su nombre, acoge el yugo de la pesada carga que ha de sostener. Y del mismo modo que sus idolatrados héroes clásicos, Nietzsche acepta la soledad de un destino que le reportará animadversiones y odios. La ventura de un nuevo escepticismo que anulaba lo tenido hasta entonces por verdad y que devolvía el rigor a las manifestaciones de una vida alternativa ajena a la categorización moral es la bandera de este autor decimonónico.

Nietzsche percibe que la verdad del mundo supera las capacidades del hombre, por lo cual no puede pensarse en caracteres antropomórficos, esto es, morales. La vida pen-

\footnotetext{
515 Entendiendo por «radical» que tal escepticismo supone el fundamento -la raíz- metodológico -la duda- de su planteamiento filosófico.

${ }^{516}$ Nietzsche, F., Fragmentos póstumos I, 19 [121], op. cit., pág. 372 (KSA VII, 458).

${ }^{517}$ Nietzsche, F., Fragmentos póstumos IV, 14 [135], op. cit., pág. 571 (KSA XIII, 319-320).
} 
sada al hilo de la metafísica ha tenido por fin humanizar la naturaleza, restringirla dentro de los cánones valorativos de la especie; así se ha conformado como una experiencia reactiva. La empresa de la transvaloración se compromete con el fondo de existencia originario, que elude cualquier esforzada estrategia de conceptualización y de valoración: se persigue recuperar la fuente primaria de vida, anulada por los presupuestos de la moralizante vida moral del ser eidético.

La transvaloración convierte la vida reactiva del nihilismo europeo en una apuesta activa y favorecedora de las condiciones de existencia. Un prisma que al dejar atrás la acusación moral no tiene necesidad por más tiempo de la dicotomía verdad-mentira. Tan sólo exigirá la imperiosa fuerza de la apariencia y su conveniente alegría específica; mediante la transvaloración «la vida misma se convierte en un reflejo y un símil de la música de Beethoven y habla, en la forma de la apariencia, de redención y de inocencia reconquistada» ${ }^{518}$. El posicionamiento favorable de la apariencia significa la recuperación de los sentidos como criterio encarnado de conocimiento y aproximación al mundo; conlleva con la realidad una relación inocente en tanto que no exige una consabida manipulación racional de ésta.

La filosofía depositó sus expectativas en el ser, una perversa mentira cuyas entrañas estaban llenas de aire. Los filósofos ocultaron hábilmente la vaciedad del ser como esencia perenne e inmutable; elevaron esa calumnia hasta los estamentos de una realidad inteligible y construyeron sobre ella la ficción moral y moralizadora del mundo verdadero. Con la fuerza de la apariencia que exige ser recuperada Nietzsche entiende que el devenir distintivo de lo dionisiaco emerge nuevamente como sustrato de la vida. Las estrategias de la gramática metafísica de la «unidad», el «ser», la «identidad», lo «bueno y/o malo», etc. se sostienen residualmente como mecanismos pragmáticos para soportar el inconmensurable torrente de la vida. Con la transvaloración se pone fin al juego de los dos mundos: la pérdida de la realidad verdadera de la metafísica implica consecuentemente la supresión de la valoración peyorativa y disfuncional del reino aparente. No consiste la transvaloración en la inversión de las fuerzas de un dominio por las del otro, sino en el ocaso de tal mentalidad distinguidora. Más aún, la transvaloración es la consumación del crepúsculo de los ídolos, de la progresiva descomposición durante la modernidad de las verdades de la «vida moral». Nietzsche es su pregonero, aquel que ha sabido reconocer las cosas tal cual éstas eran: que a la mentira se la ha venido llamando sistemáticamente verdad.

La voz del superhombre verbaliza la transvaloración. Él se posiciona ante el paisaje dionisiaco y lo afirma sin contemplaciones, en su éxtasis vitalista que crea el mundo a la par que lo consume. Quizá el propio Nietzsche no se estime a sí mismo digno de encarnar

518 Nietzsche, F., Fragmentos póstumos II, 13 [1], op. cit., pág. 223 (KSA VIII, 271). 
al superhombre ${ }^{519}$, mas sí de portar su mensaje y legarlo a las generaciones venideras ${ }^{520}$. Transita solo por el desierto en que ha devenido el jardín dieciochesco, portador de una pesada sombra que lo ha demonizado. Y como héroe homérico ${ }^{521}$, no ceja en su empeño, cantando las loas ditirámbicas de la restitución de Dioniso: la pulsión existencial de la vida es la de la verdad de la «corporalidad», en su plena manifestación -generación y corrupciónmundana, contra la nada hueca que aún se revuelve.

La transvaloración es, pues, la lucha del mundo contra la -voluntad de-nada. Con la superación del paradigma metafísico, los tiempos del nihilismo han vencido las pretéritas formas de la duplicación antitética de la realidad y la enajenación de la verdad del mundo en otro inaccesible. La tranvaloración asienta el ser en la apariencia, la cual se arma sobre una pluralidad estructural de leyes y relaciones que exceden las capacidades y competencias del hombre: una imbricación de la verdad pragmática en la primigenia que no niega la vida como esencial devenir, «todo lo sensible en mí sufre y se encuentra en prisiones: pero mi querer viene siempre a mí como mi liberador y portador de alegría» ${ }^{522}$.

Y la piedra angular sobre la que descansan el superhombre y su vespertina actividad transformadora está en la voluntad de poder, en la fuerza creadora a través de la cual la vida se vuelve activa. El mundo dionisiaco es un espacio salvaje y cruel, falto de sentido y sin significaciones humanas. El paraje agónico de la existencia torna soportable mediante el ejercicio de la voluntad de poder, por medio del cual se armoniza en caracteres específicos el barbarismo del fondo esencial del mundo: la voluntad de poder hizo primero claudicar la verdad de la vida moral para, a continuación, enfrentarse frontalmente contra la verdad dionisiaca. El filósofo, que hasta entonces había apacentado sobre la inmutabilidad y la fijeza del ser, se ha transformado estéticamente en artista, en «artista-filósofo». Su conocimiento no es ya tanto teorético como hermenéutico: el ser del mundo no le subyace, sino que es humanamente creado en la interpretación de los fenómenos de existencia. De modo que el conocimiento del artista no es eidético, sino categóricamente humano, en cuyo juego se revela la fundamental condición caótica del ser, el cual se expresa en tantas categorías hermenéuticas como nuestra plástica voluntad de poder sea capaz de figurar: «ahora pro-

519 Cfr. Nietzsche, F., Así habló Zaratustra, op. cit., pág. 327 (KSA IV, 295): «'Oh Zaratustra, dijeron, ¿es que buscas con la mirada tu felicidad?’ - ‘Qué importa la felicidad!, respondió él, hace ya mucho tiempo que yo no aspiro a la felicidad, aspiro a mi obra'». (La cursiva es nuestra).

${ }^{520}$ Cfr. ibid. pág. 135 (KSA IV, 109): «¿Podríais vosotros crear un Dios? - ¡Pues entonces no me habléis de dioses! Mas el superhombre sí podríais crearlo.

¡Acaso no vosotros mismos, hermanos míos! Pero podríais transformaros en padres y antepasados del superhombre: ¡y sea éste vuestro mejor crear!». (La cursiva es nuestra).

${ }^{521}$ Cfr. Homero, Illíada, VI; 200-202, introd. trad. y notas de Emilio Crespo Güemes, Madrid, Gredos, 1996, pág. 219: «Pero cuando también aquél [Belerofonte] se hizo odioso a todos los dioses, por la llanura Aleya iba vagando solo».

522 Nietzsche, F., Así habló Zaratustra, op. cit., pág. 137 (KSA IV, 111). 
yecta [el artista] su mirada sobre la apariencia, que, iluminada por $s u$ luz interior, vuelve a comunicarse con su interior en un maravilloso reflejo» ${ }^{523}$.

\section{II.3.5. La contradicción nihilista de Occidente}

El marco intelectual de Occidente ha sido hasta el momento metafísico. Y a tal paradigma, señala Nietzsche, le corresponde su respectiva ontología, la cual se ha trazado en los caracteres generales de la doctrina de la adecuación, distinguiéndose como su rasgo esencial la verdad como corrección: el isomorfismo estructuralmente lógico entre las proposiciones y el mundo. La íntima vinculación entre la predicación y su objeto en la adecuación establecía una ineludible imposición de certeza. Un anhelo de veracidad identitaria sustentado, en última instancia, por la sospecha moral, o sea, valorativa, de que la -lógicaverdad resultaba preferible sobre su contraparte, la mentira. Y de este modo, desde los albores de Occidente, el filósofo tornó en «científico», pues demandaba de un elemento último que resistiese cualquier acometida intelectual, por corrosiva que fuese, el ser.

Los rasgos de esta exigencia rápidamente se convirtieron en necesidad; la cualidad veraz del filósofo se impuso sobre todo otro criterio, aún por encima de la «honestidad». La filosofía moderna, acusa Nietzsche, ha transgredido la última frontera que se le debe pedir a todo investigador; ha procedido deliberadamente contra sus propias máximas: ¿cómo explicar que a pesar del motor escéptico de estos pensadores se persiguiese una fundamentación última no ya de los juicios epistemológicos, sino de los morales? El esforzado argumento escéptico fundante del novedoso paradigma es esquivado a causa de las filias intrínsecas de la tradición mayor que acogía a los modernos. Contempla Nietzsche desde la lejanía que, tras dejar atrás las diferencias nominativas entre la Antigüedad y el nuevo universo, la Modernidad, sigue dentro de la tradición metafísica griega. El científico y el filósofo moderno, con la exigencia de veracidad que se han impuesto a sí mismos, recogen el testigo del nostálgico metafísico platónico y del viejo cristiano que anhelan la verdad en un carácter fideísta. La divinización de la verdad que ocurre en los primeros compases del platonismo es legada a la tradición moderna en su ideal de certeza. De ahí la elusión del escepticismo por los modernos: allí donde para los antiguos el mundo había sido duplicado en la dicotomía «verdadero» y «aparente», los modernos extrapolan esa división en el orden lógico. Por eso todo moderno que esgrima el modelo de la adecuación y la corrección -«certeza»- niega el mundo aparente. La casuística moderna es cristiana. Como apuntamos líneas más atrás, es el moderno un escepticismo inoperante del que hemos de zafarnos:

En este escepticismo nadie puede vivir.

Nosotros debemos trascender este escepticismo, ¡tenemos que olvidarlo! ¡Cuántas cosas no debemos olvidar en este mundo! El arte, la forma ideal, el temperamento.

${ }^{523}$ Nietzsche, F., Fragmentos póstumos II, 13 [1], op. cit., pág. 223 (KSA VIII, 271). 
¡Nuestra salvación no está en el conocer, sino en el crear. Nuestra grandeza está en la apariencia suprema, en la emoción más noble. Si el universo no nos importa nada, tendremos el derecho a despreciarlo ${ }^{524}$.

Razón ésta, la imposibilidad de sostener la vida en un escepticismo embustero, por la que Nietzsche enarbola el elogioso carácter de los «espíritus libres», aquellos que han trascendido la pretensión metafísica moderna de la adecuación. Éstos han comprendido cuán lúgubre y penosa ha sido la existencia de los predecesores, necesitados de una fuente externa de sentido ante el cisma entre ellos mismos y su vida efectiva, entre su pensamiento y su «corporalidad». El espíritu libre se rebela contra la afección moderna de la adecuación y su sintomatología, la correspondencia, que no es sino la manifestación en el presente decimonónico del ideal metafísico de la vida moral.

Por consiguiente, prosigue en su análisis Nietzsche, la explosión del nihilismo era una consecuencia lógica dentro del devenir de Occidente. Dentro de la historia genealógica de la verdad moral estaba comprendida su propia destrucción, sin embargo, por su mismo éxito: la metafísica occidental muere de hipertrofia. La exigencia de veracidad durante las sucesivas generaciones culmina en la modalidad de la adecuación, distintiva de la modernidad. El filósofo de estos siglos, más cercano al modelo del científico que del pensador clásico, ha sublimado la cuestión moral y exigido la «optimización» de la verdad en su ser. Así ha emprendido la labor de apropiarse del mundo tal cual es, en su absoluta cristalinidad, siguiendo los más rigurosos criterios gnoseológicos de la metafísica dualista, a saber, la correspondencia sujeto-objeto de la epistemología ora innatista ora trascendental. En este último hito del periplo de la verdad se pone de manifiesto la aporía que late en la metafísica: el dogmatismo y el celo desmedido de la exacción del sujeto de la certeza, en quien la hipermoralización ha alcanzado sus cotas más estrictas, pone frente a sí el mundo verdadero y no logra satisfacer el abismo gnoseológico entre el pensamiento y su correlato empírico. Es decir, en el filósofo moderno termina revelándose, en virtud del ejercicio de sus máximas valorativas, que el mundo verdadero es una mentira injustificable.

La pérdida del mundo verdadero origina una convulsión dramática en el siglo XIX. Por la guía moral desde la que escrupulosamente opera, el pensador decimonónico ha puesto fin a la invención del mundo verdadero, y con ello a la fuente de toda moralidad. La adecuación contempla una imagen vacía en el momento de legitimar el mundo al término de la modernidad; la extrema cualidad de exactitud de la certeza no puede aceptar la vacuidad de una mentira cuyo poso de verdad no puede garantizar: la ficción del mundo verdadero como sustrato ontológico de la existencia deviene insostenible. Una nueva manifestación de la muerte de Dios. El «ateo» nihilista es para Nietzsche aquel hombre de extrema virtud, un sujeto genuinamente moral que en el ejercicio de estos rasgos se ve lógicamente deter-

${ }^{524}$ Nietzsche, F., Fragmentos póstumos I, 19 [125], op. cit., pp. 372-373 (KSA VII, 459). 
minado a abandonar a Dios. En la genética de Occidente está el fin del cristianismo por su cristianismo $^{525}$ : la veracidad del hombre moral, último estadio del pathos cristiano, diluye el fundamento del mundo verdadero. Éste ha situado la verdad metafísica de Platón, la del cristianismo -la adecuación en su modus moderno- frente al espejo, y ésta ha sido incapaz de soportar su propio reflejo; ha ido arrancando las distintas máscaras que durante más de dos mil años maquillaron la corrosión de Occidente para toparse finalmente con la nada. El ímpetu moral de la verdad es, ello mismo, su propio verdugo. Y tras el deceso de la metafísica, el «cristiano» recula ante la emergencia de los espíritus libres.

El espíritu libre es el propio de aquellos que han separado la verdad de la metafísi$\mathrm{ca}^{526}$, los «artistas». El artista atenta contra el ímpetu moral de la metafísica, esto es, contra la doctrina de la adecuación. Ha comprendido la impureza del escepticismo gnoseológico y se ha procurado una nueva posición donde la vida sea ella misma su propio juez, sin necesidad de apelar a un tribunal extrínseco: «no se pueden demostrar -dice el espíritu libre- ni el significado metafísico, ni el ético ni el estético de la existencia» ${ }^{527}$.

El espíritu libre es el heredero de la veracidad; por ella ha negado el mundo verdadero y su respectiva cualidad de vida. Por su fuerza se recupera la caracterización trágica de la existencia, la condición dionisiaca que rechaza la creencia ciega en un principio ontológico de cariz parmenídeo. La liberación de la conciencia se corresponde con el abandono del significado absoluto del mundo verdadero; la vida del individuo dionisiaco se compromete con la constante actividad afirmadora del que abraza la deviniente pluralidad de sentidos en detrimento de la unicidad metafísica y moral:

[...] lo que mueve y motiva al espíritu libre: ¡lo poco despreciable que le resulta el cambiar de opiniones! Al revés: ¡lo mucho que aprecia la capacidad para cambiar de opiniones, un rasgo singular y noble, especialmente cuando se conserva hasta en la vejez! ¡Y su ambición (no la pusilanimidad) le empuja a agarrar hasta los frutos prohibidos del spernere se sperni [despreciar el ser despreciado] y del spernere se ipsum [despreciarse uno mismo]!: ;sin sentir para nada el temor que ante algo así tendría el vanidoso perezoso! Además, para él la doctrina de la inocencia de todas las opiniones es tan válida como la doctrina de la inocencia de todas las acciones ${ }^{528}$.

525 Cfr. Nietzsche, F., El Anticristo, op. cit., pág. 77 (KSA VI, 211): «Ya la palabra 'cristianismo' es un malentendido -, en el fondo no ha habido más que un cristiano, y ése murió en la cruz».

${ }^{526}$ Cfr. Nietzsche, F., Fragmentos póstumos I, 19 [127], op. cit., pág. 373 (KSA VII, 460): «¡Considerar el 'espíritu', el producto del cerebro, como algo sobrenatural! Incluso divinizarlo, ¡qué locura!». Como hemos señalado, Nietzsche vindica en su noción de «corporalidad» tanto el carácter espiritual del cuerpo como la condición corporal del espíritu.

${ }^{527}$ Ibid. 19 [123], pág. 372 (KSA VII, 459),

${ }^{528}$ Nietzsche, F., Aurora, op. cit., pág. 518 (KSA III, 58). 
La superación de la moral, por tanto, llega desde la dinámica misma de ésta: el compromiso de honestidad del hombre moral lo mueve a rechazar la hipótesis del mundo verdadero ante su imposibilidad de realidad. Irónicamente el imperativo de verdad ha probado la falsedad de su fundamento. El fin de la verdad despierta el que para Heidegger es el problema filosófico realmente significativo de la filosofía nietzscheana: la cuestión del valor de la verdad. Esta incursión en el valor de la verdad sería el último momento del periplo de la metafísica, pues, sigue Nietzsche, sólo es apreciable una vez ha acontecido la muerte de Dios. Para completar la confirmación del cosmos del nihilismo es necesario, entonces, experimentar los primeros pasos del nihilismo.

El estudio del valor de la verdad faculta el tránsito al nuevo universo cosmológico donde la verdad ha sido abierta a la esencial pluralidad del ser. El problema nietzscheano de la condición de valoración de la verdad nos introduce plenamente en el trasfondo trágico del mundo. La falsedad, es decir, el rechazo consciente de la doctrina de la adecuación y su correspondiente criterio de corrección, es ahora condición de vida. La distancia tomada con la metafísica ha resuelto la escisión epistémica entre el sujeto y el objeto de una forma abrupta y colosal, a saber, prescindiendo de dicha frontera: la verdad lógica, la correspondencia entre los enunciados y el mundo pierde su significación. El garante de los juicios reposa a continuación en una nueva instancia: la verdad se halla allí donde se favorecen las condiciones de vida. La falsedad lógica no es ya criterio de exclusión de un juicio, pues la vida ha sido reescrita en caracteres no morales, sino artísticos. En la filosofía de los nuevos tiempos nihilistas se ha consumado la superación de la moral; se ha confeccionado un nuevo escepticismo de cariz existencial, esta vez soportable, pues se compromete con la condición netamente existencial de la vida. ¿A qué clase de universo nos arroja Nietzsche?, cabe preguntar. Él mismo resuelve tal enigma: «se debe demostrar absolutamente que todo lo que existe y lo que es en algún momento no fueron y por eso tampoco lo serán en algún momento. El devenir de Heráclito» ${ }^{529}$.

La importancia de la cuestión del valor en Nietzsche es, por tanto, meridianamente clara: ha recuperado la experiencia de verdad de la tragedia griega, que orbitaba en torno a la vida. Tras una tradición de milenios donde la fuerza de la existencia había sido enajenada, Nietzsche reivindica nuevamente su fuerza, acentúa su carácter y la recoloca en el centro de todo acontecimiento humano, en el «cuerpo». Así se explica su insistencia en la capital cuestión del cuidado, que expusimos en la primera parte del trabajo.

${ }^{529}$ Nietzsche, F., Fragmentos póstumos I, 19 [119], op. cit., pág. 372 (KSA VII, 458). 


\section{II.4. La verdad de la mentira}

La verdad, la cuestión de la verdad se ha probado momento capital en la reflexión filosófica nietzscheana. Siendo escrupulosamente precisos, no supone la verdad como tal un problema, sino la «valorización de la verdad»: el valor de la verdad como problema es la dificultad que destaca el autor como hilo conductor a lo largo de la tradición occidental. No podemos prescindir de la verdad, toda vez que ésta motiva cada latido del mundo. No obstante, se ha cometido el flagrante error de caracterizarla en términos morales; a la verdad no le corresponde la autoridad determinadora de lo «bueno» y lo «malo». Blandiendo esta acepción los metafísicos construyeron la fábula bimilenaria de los mundos verdadero y aparente, desde la cual se armó la estrategia despreciadora de la vida, encarnada y única.

La incongruencia de este juego es doble, entiende Nietzsche. En primer lugar, no es posible conceptualizar la vida, pues no se corresponde con un entramado de fórmulas y enunciados lógicos cognoscitivos; seguidamente, la atribución de condiciones moralizadoras tan sólo puede ejecutarse desde un procedimiento ad hoc: habiéndose enfrentado la dimensión existencial de la vida, se la juzga peyorativamente y es reconvertida dentro de los márgenes del ideal ascético. Se lastra la verdad, negando su esencialidad caótica. La apropiación de la verdad por los metafísicos ha respondido al terror y odio de sus voluntades, reactivas ante la asignificación profunda de la vida. Estos predicadores han impreso contenido allí donde no corresponde, contribuyendo a ocultar el fondo existencial de la verdad.

Con su valorización han corrompido la empresa de la verdad. Han enajenado la tarea de vivir trágicamente en favor de un modus «virtuoso». La noción de verdad de la metafísica introduce la polémica del valor, pervirtiendo su carácter originario. Al inocular en ella cuestiones externas a su característica fundamental se embarra el terreno primordial sobre el que se arma la vida. Por tanto, con la metafísica se ha dispuesto un elaborado y esforzado ardid que no hace sino comprometer la vida y sus condiciones de mantenimiento y conservación.

Así se entiende que Nietzsche rechace no la verdad, sino el criterio de verdad legado y transmitido. Nietzsche demanda una verdad cuyo fondo no haya sido traicionado y se mantenga emancipada de fuerzas extrínsecas, la valoración por encima de todas. Entendiendo el momento histórico en que se halla el autor, reacciona furibundamente contra la tentativa metafísica moderna, la expectativa de corrección de la doctrina de la adecuación. La corrección encuentra el deceso en su misma exigencia, que requiere de una apropiación de la realidad tal cual es. En la adecuación el metafísico comete petitio principii, pues necesita que preexista aquello que ha de conquistar: sólo puede haber corrección si existe la adecuación de la polémica relación sujeto-mundo. 
La corrosiva indagación nietzscheana en la tradición de la verdad concluye en la dolorosa experiencia del nihilismo. Al desengaño del ocaso de la metafísica le sigue inmediatamente la desestructuración de la conciencia europea. Una situación crítica donde el anhelo por el faro indubitable del pasado sumió en honda melancolía a los espíritus más nostálgicos. Con el afán renovador que exige la purificación de una época corrompida, Nietzsche da la espalda a la impronta de la adecuación al entender que no puede continuar operando como legitimador del orden de existencia del hombre. El imperio del rigorismo lógico no satisface las expectativas vitales, pues éstas no responden a tales códices. El «ser» elude las redes del intelectualismo; sólo podemos apropiarnos de él mediante la «fuerza»: la voluntad de poder arroja la medida de lo real, que es «aparente».

La voluntad de poder de aquellos que pretenden adueñarse de la verdad en el nihilismo los conmina a abrazar la olvidada sintonía del mundo griego. La ocultación que del trasfondo trágico perpetró la metafísica platónico-cristiana es revelada, mostrando en plenitud la fuerza insoportable que motiva la vida: Dioniso. La tarea de Nietzsche, desnudada ya la mentira bimilenaria que ha soportado Occidente, prosigue indagando cómo vivir en este recobrado horizonte: ¿cómo vivir la «vida»? o lo que es lo mismo cómo armonizar el salvaje y ciego canto dionisiaco con las condiciones humanas.

Sin embargo, ¿es siquiera armonizable? Nietzsche es lo suficientemente cauto como como para no ofrecer una respuesta última que zanje la cuestión, aunque procura claves para aquellos espíritus libres que han aceptado afirmativamente su situación nihilista. A pesar de que la verdad y la vida humana no son incompatibles, no puede pretenderse una inmersión directa en aquélla, pues su frenético torrente nos aniquilaría. Una aproximación a Dioniso obliga a recuperar el paradigma vitalista de la tragedia: vindicar la falsedad, la mentira como sustrato existencial, en definitiva la fortaleza de la apariencia como el fértil suelo sobre el cual habrá de germinar el testigo del ocaso del viejo mundo. Con todo, el contenido de la verdad es inaccesible, al menos desde la estrategia de la adecuación. La verdad que rescata Nietzsche es inconcebible desde la longeva caracterización moral característica de la metafísica. La verdad del mundo introduce a éste en el flujo del devenir, cuya esencia -si se nos permite todavía emplear tal noción- es una mascarada. Sólo desde un ejercicio de enmascaramiento y falsedad, de creación e ilusión el hombre puede integrar en su vida la verdad:

Un nuevo modo de pensar -que es siempre un nuevo modo de medir y supone la presencia de una nueva medida, de una nueva escala sensitiva- se siente en contradicción con todos los modos de pensar y dice continuamente, oponiéndose a ellos, «eso es falso». Observado más sutilmente, ese «eso es falso» quiere decir, en realidad, «no siento allí nada mío», «eso no me interesa», «no entiendo cómo no podéis sentir como yo» ${ }^{530}$.

${ }^{530}$ Nietzsche, F., Fragmentos póstumos IV, 2 [35], op. cit., pág. 87 (KSA XII, 81). 
Habiéndose quebrado el cosmos moral, la imagen unitaria e inteligible de la verdad se resquebraja en tantas verdades particulares como vidas encarnadas. Una sustantiva pluralidad en cuya multiplicidad termina diluyéndose la verdad. El último momento de la presencia de Dioniso individualiza la verdad: el elemento trágico del mundo impele a cada sujeto peculiarmente, y hace depender la afirmación activa o la negación reactiva de la vida al potencial ilusorio y artístico de cada voluntad de poder: «dónde uno se detiene o todavía no se detiene, dónde uno juzga 'aquí está la verdad', esto lo decide el grado y la fuerza de su valentía» ${ }^{531}$. Resulta este punto fascinante, pues lleva a Nietzsche a negar incluso la veracidad esencial de Dioniso: también Él es esencialmente falso y falaz; es más, es necesariamente falso y falaz ${ }^{532}$.

La voluntad de verdad del nuevo hombre que encarna el espíritu libre es cualitativamente distinta de la del hombre veraz de la moral. Allí donde en éste la verdad se identificaba al término con una fe, en aquél emana de su voluntad de poder. El cosmos de la voluntad de poder rechaza la condición peyorativa de este mundo y, con ello, su lectura moral. La verdad es voluntad de poder, que a su vez es ejercicio artístico de creación y apropiación del mundo. Esta imagen de la verdad como definitiva voluntad de crear servirá a Gadamer como punto de apoyo fundamental en el desarrollo de su propuesta hermenéutica; no es tampoco casualidad que en dicho proceso Gadamer se sienta impelido numerosas veces por las fuentes platónicas ${ }^{533}$, en las cuales la conquista de la verdad, pese a que parece Nietzsche ignorarlo alevosamente ${ }^{534}$, es una empresa con un poso existencial determinante.

En esto consiste la enseñanza postrera de Nietzsche, en la tarea creativa de la verdad como desempeño de la voluntad de poder. La vida humana, carente de sentido primordial, se ve colmada cuando se adjudica a sí misma la tarea de su significación. En la apropiación del sentido arreglo al juego de la voluntad de poder fluyen las condiciones de conservación y enriquecimiento de la vida: la inserción de la vida humana en la trágica verdad de Dioniso acontece en este punto. La voluntad de poder ejerce las funciones del salvífico

${ }^{531}$ Ibid. 9 [52], pág. 247 (KSA XII, 361).

532 Contra lo que ha querido ver Heidegger, Nietzsche elude gracias a este giro caer en la línea intelectual de la ontoteología tradicional. Heidegger ve en el pensamiento de Nietzsche una absolutización esencialista de la voluntad de poder; el ser del mundo estaría precisamente en ella, y Dioniso cumpliría las competencias del ente «más real». No obstante, desde el momento en que el propio Nietzsche destaca la condición forzosamente falaz de Dioniso e instrumentaliza la voluntad de poder como mecanismo garante de la vida, es fácilmente refutable la tesis heideggeriana.

${ }^{533}$ Cfr. Platón, Banquete, 174d, en Diálogos III, introd. trad. y notas de C. García Gual, M. Martínez Hernández, E. Lledó Íñigo, Madrid, Gredos, 1992: «“Juntos los dos -dijo- marchando por el camino’ deliberaremos lo que vamos a decir»».

534 Cfr. Nietzsche, F., Correspondencia IV. Enero 1880 - Diciembre 1884, ed. de Luis Enrique de Santiago Guervós, trad. introd. notas y apéndices de Marco Parmeggiani, Madrid, Trotta, 2010, pág. 414 (KSB VI, 449): «Querido y viejo amigo, leyendo a Teichmüller cada vez me quedo más de piedra de lo poco que conozco a Platón y de CUÁNTO $\pi \lambda \alpha \tau \omega v i ́ \zeta \varepsilon 1$ ['platoniza'] Zaratustra». [Tarjeta postal a Franz Overbeck. 22 de octubre de 1883]. 
mecanismo falsificador por el cual logramos integrarnos y armonizarnos en la realidad; la ciega crueldad de la dimensión dionisiaca se recubre con distintas máscaras confeccionadas por el propio juicio consciente del sujeto nihilista, que acepta y afirma la riqueza trágica de su presente. Ella imprime caracteres imaginarios e ilusiones que dulcifican el fondo amargo. La conservación de la vida pasa entonces por la aceptación de la fuerza ${ }^{535}$ del sujeto artístico; sólo puede pervivir el fuerte, esto es, quien no recula ante el compromiso del imperio de la ilusión y la falsedad, más bien al contrario, se adueña de él y lo articula en su favor. Desde tal acepción de fuerza deben comprenderse algunos de los pasajes más despiadados de ciertas de sus obras, como el Zaratustra o El Anticristo, en los que rechaza furibundamente la compasión o donde insta a procurar la muerte de los débiles y los enfermos; la muerte de éstos es la muerte de aquellos que anhelan el retorno y la recuperación de la verdad como adecuación. La muerte de los enfermos es la de aquellos despreciadores del cuerpo que perpetuaron una fatal escisión de lo intelectual respecto de lo sensible que acabó por desposeer al hombre de su propia experiencia encarnada de vida. El compromiso de la fuerza es el intento nietzscheano por sanar al hombre contemporáneo de la esquizofrenia de una vida que no siente como propia y que, para procurarse metas y fines, necesita de una dirección externa. La filosofía de Nietzsche busca recuperar la libertad en su dimensión radical, para la cual exige que el sujeto vuelva a adueñarse del inmenso universo metafórico que es su «corporalidad», a saber, la fusión existencial del espíritu y del cuerpo en una identidad que no diferencia un dominio del otro, sino que los integra en el compromiso duro y jovial de la onerosa tarea de una existencia reapropiada que, en cuanto tal, ha de ser cuidada. La «corporalidad» es la manifestación de la transvaloración de todos los valores, pues por ella se pone fin a la escisión existencial perpetrada por la metafísica, así como a la gramática de Dios; el problema de la religión, dice Nietzsche, es menos la creencia en Él que en su sintaxis. La «muerte de Dios» no es el fin de la divinidad, sino el de su reino eidético, supramundano sobre la conciencia. Pese a las desavenencias irreconciliables entre la obra de Nietzsche y la hermenéutica heideggeriana, el maestro de Friburgo ha sabido apreciar con cristalina agudeza el esfuerzo nietzscheano sintetizado en el concepto de «corporalidad»:

[...] con la determinación existencial de la esencia del hombre todavía no se ha decidido nada sobre la «existencia de dios» o su «no-ser», así como tampoco sobre la posibilidad o imposibilidad de los dioses. Por eso, no sólo resulta prematuro, sino incluso erróneo en su procedimiento, afirmar que la interpretación de la esencia del hombre a partir de la relación de dicha esencia con la verdad del ser es ateísmo. Esta clasificación arbitraria revela además una falta de atención en la lectura. A nadie parece interesarle que, desde 1929, en el escrito Vom Wesen des Grundes se pueda leer lo siguiente: «Mediante la interpretación ontológica del Dasein como ser-en-el-mundo todavía no se decide nada, ni positiva ni negativamente, sobre un

535 Cfr. Nietzsche, F., Fragmentos póstumos IV, 9 [70], op. cit., pág. 253 (KSA XII, 372): «Beethoven componía caminando. Todos los instantes geniales están acompañados por una exuberancia de fuerza muscular». 
posible ser en relación con dios. Sin embargo, mediante la explicación de la trascendencia se gana por vez primera un concepto suficiente del Dasein, con respecto al cual sí se puede preguntar en qué situación ontológica se encuentra la relación del Dasein con dios». Ahora bien, si esta observación se sigue pensando con la habitual estrechez de miras, se replicará que esta filosofía no se decide ni a favor ni en contra de la existencia de dios. Que permanece en la indiferencia y por tanto la cuestión religiosa le es indiferente. Y que una tal indiferencia no puede dejar de caer en el nihilismo ${ }^{536}$.

${ }^{536}$ Heidegger, M., Carta sobre el humanismo, op. cit., pp. 69-70. 
PARTE III: LA RESPUESTA NIETZSCHEANA ANTE EL NIHILISMO: SUPERACIÓN ARTÍSTICO-FILOSÓFICA 
El calamitoso estado finisecular del nihilismo se le ha presentado a Nietzsche como el hito conclusivo de un factum dentro de la historia de la metafísica, que ha de remontarse a la génesis filosófica misma de Occidente. El punto álgido de la crisis de esta longeva tradición acontece cuando a nuestra cultura se le hace presente la paupérrima situación en que se halla, esto es, cuando toma conciencia de su condición nihilista: «nihilismo: falta la meta; falta la respuesta al ‘¿por qué?’» ${ }^{537}$. La ausencia de metas, la incapacidad para procurarse las propias metas y fines es uno de los rasgos de la enajenación del hombre respecto de su propia vida.

Ahora bien, lo que para sus inmediatos precursores ha sido el canto del fénix antes de perecer los últimos acordes del ignoto optimismo moderno, sumiéndose irremediablemente en el más insondable pozo de oscurantismo pesimista, Nietzsche halla una oportunidad de crecimiento y superación de semejante lamentable estatus: «nihilismo como signo del acrecentado poder del espíritu: como NIHILISMO ACTIVO» ${ }^{538}$. Desde este novedoso posicionamiento, Nietzsche integra el nihilismo dentro del espectro de experiencias existenciales del sujeto; algo parecido al «existenciario» heideggeriano, toda vez que desde él asume tal acontecimiento como un reto constitutivo de todo hombre, y que habrá de ser enfrentado. El nihilismo ha sido la definitiva experiencia de desvalorización de los valores absolutos que hasta entonces habían configurado la episteme del mundo -«razón», hombre», «moral» son algunos de los conceptos surgidos al abrigo de dichos valores- durante los últimos dos mil años. La pretensión absoluta de los valores de la metafísica forjó una imagen invariable sometida a los caracteres de verdad de dicho paradigma -la dimensión ideal y la normatividad de la certeza, como los modelos paradigmáticos de la Antigüedad y de la Modernidad, respectivamente-, con lo cual el hombre fue trazado bajo los estándares de una realidad eidética, supramundana sin una ligazón esencial con el mundo efectivo en que habitaba, el cual había quedado denostado en virtud de su condición contingente, deviniente, aparente.

El nihilismo no es sólo la deslegitimación de dichos valores absolutos, sino también de las aspiraciones de fundamentación ulterior del mundo: el nihilismo es menos, dice Nietzsche, la desaparición del universo valorativo que la pérdida de una determinada conciencia de valoración. A pesar del dolor que comportó tal experiencia Nietzsche logra libar un néctar dulce: la recuperación de la esencial condición valoradora del hombre. El nihilismo, al revelar la imposible exigencia de un metavalor legitimador de los demás, ha puesto en otro plano la instancia reguladora de los valores, a saber, en el hombre existente.

${ }^{537}$ Nietzsche, F., Fragmentos póstumos IV, 9 [35], op. cit., pág. 241 (KSA XII, 350).

538 Ibid. (KSA XII, 350). 
En lugar de las respuestas reactivas y negadoras de tal presente -el positivismo, el optimismo, el pesimismo, el socialismo, entre otras- Nietzsche apuesta novedosamente por una alternativa activa donde la proposición existencial del sujeto particular toma un rol protagónico aprovechando la ocasión que ofrece el nihilismo: fijar en el hombre concreto y existente, el «hombre encarnado», la instancia de legitimación de los valores. Ahora bien, ¿qué valores? El nihilismo ha desnudado la vacuidad de los valores eidéticos al tiempo que ha revivido el fondo oscuro desde el que se arma el individuo: devenir, caos, azar, inconsciencia se suman como elementos constitutivos de la razón identitaria del sujeto, quien no es ya epistémico, sino trágico. El nihilismo ha permitido a Nietzsche contemplar al hombre como un ser hermenéutico cuya personalidad está en constante creación sin un fin al que tender teleológicamente. Así lo exige su peculiar condición existencial y de vida que es la voluntad de poder, esto es, la capacidad de crear valores y de jerarquizarlos posteriormente en un juego a lo largo del cual se apropia de su existencia. La voluntad de poder como esencial condición de vida integra perfectamente la existencia humana en el nuevo horizonte recientemente abierto tras la quiebra del espíritu: un mundo sin fundamentos ni objetivos últimos incuestionables e intransigentes requiere del hombre una actitud análoga. Así por la plasticidad creativa de la voluntad de poder, que radica en la fuerza irrestricta e irredenta de la «corporalidad», el hombre se reapropia de su experiencia de existencia, pues adquiere, tras la tradición bimilenaria de la duplicación, la regencia de su vida, convirtiéndose en su propio legitimador.

La propuesta activa de Nietzsche transmuta la agonía del desarraigo nihilista en fuerza motriz de vida, pues tras el agotamiento de las fuentes eidéticas del «mundo verdadero», la escisión se reintegra y la aparente pluralidad perspectivista deviene primacía de existencia: el devenir se celebra, así como sus mecanismos, canales y exigencias. A la luz del fondo trágico desde el que el hombre se yergue, su esencial cualidad hermenéutica se comprende como la única condición posible para armonizar la tarea orfebre del hombre con la infinitud de un mundo abierto y sin más restricción que la vida: lo bueno es aquello que potencia la vida hacia su mejor concreción posible; lo malo, lo que la lastra. Con todo, el nihilismo permite a Nietzsche ejecutar una transmutación existencial a través de la cual el sujeto se emancipa del sello epistemológico de la racionalidad tradicional, «verdadera», en favor del artista-filósofo, momento desde el que poder llegar a «ser lo que se es».

Esta transmutación del problema del fenómeno del nihilismo, que pasa de un primer momento incapacitante a un segundo estimulante, es debido a la radicalidad del planteamiento nietzscheano, el cual transforma las viejas formas y dinámicas del pensamiento occidental: la fillosofía no será por más tiempo la búsqueda de la verdad como adecuación -del «mundo aparente» respecto del «mundo ideal» o bien de la «extensión» respecto de la «cosa pensante», sino la reflexión de segundo orden consciente y activa a propósito de la atribución de significados de las verdades, esto es, de la valoración. Frente al inmovilismo 
y la unicidad esenciales de la metafísica clásica del ser, Nietzsche insiste en la gravedad del devenir, cuya dimensión, al contrario que la primera, se corresponde satisfactoriamente con el esencial caos que conforma el oscuro e inaccesible fondo de la vida. De modo que las claves favorables que encuentra el autor en la experiencia nihilista pasan por ser éstas una vindicación de la vida. Una vida la cual por primera vez desde la enajenación metafísica contempla la totalidad de su suelo nutricio: generación y fecundidad como destrucción y perecimiento. Una caracterización, en definitiva, trágica que acoge la fragilidad y la vulnerabilidad del hombre como fundamento de su existencia, de su existencia encarnada que sirve como reapropiación de su vida concreta como proyecto artístico en constante creación bajo la responsabilidad del cuidado.

La connivencia de la vida y la tragedia como facetas indisolubles de la experiencia de la existencia humana lleva a Nietzsche a recuperar la remota pregunta por la forma óptima de vida, cómo hacer de la vida un arte ${ }^{539}$, la más bella y refinada obra de arte, bajo cuyo manto recogerá la posibilidad constructiva del nihilismo apuntada líneas atrás. La pregunta por la vida buena va coligada con el componente capital de la felicidad, de nuevo traída a la presencia tras décadas olvidada en beneficio de la enfermiza satisfacción -kantiana, par excellence- de sentirnos dignos de ella. Una felicidad la cual deshará las perversas neblinas que el nihilismo trajo consigo: dado que el nihilismo encubrió los márgenes de la vida y los elevó hasta inalcanzables instancias ideales, la felicidad perfilada por Nietzsche sólo puede llegar mediante la asimilación de la vida en su plenitud, con un sí categórico que no renuncie selectivamente a ciertas manifestaciones de ésta. La vida buena, sin embargo, aunque guarda ecos clásicos, es perfilada en caracteres novedosos por Nietzsche. En la filosofía de Nietzsche «lo bueno» no es proferido como un adjetivo en grado positivo, sino superlativo: en la nueva «gramática» nietzscheana lo bueno es lo mejor. La empresa de existencia es una apuesta de plenitud, es el despliegue óptimo de las cualidades peculiares de cada sujeto concreto. Desde su ser-en-el-mundo, radicado en la experiencia encarnada del existir, el artista-filósofo jerarquiza aquellos valores más ilustres para afirmarse como su mejor obra.

La felicidad, pues, no se concreta en los caracteres puerilmente superficiales de los hombres modernos, quienes pretendieron eludir los rasgos más crueles de la existencia

539 Este cuestionamiento no es, sin embargo, privativo de Nietzsche. Parafraseando la metáfora de Danto, se puede decir que en la segunda mitad del siglo XIX había una «atmósfera de teoría» relativa a dicho interrogante. El esteticismo de la Inglaterra victoriana es, quizá, la corriente más destacada al respecto Entre sus figuras sobresale, sin atisbo de duda, Oscar Wilde, quien confiesa en la desgarradora epístola $D e$ Profundis el principio rector de su obra: «hice del arte una filosofía y de la filosofía un arte» (Wilde, O., De Profundis, en Wilde, O., De Profundis. Balada de la cárcel de Reading, trad. de Arturo Agüero Herranz, Madrid, Alianza Editorial, 2011, pág. 95). Con todo, el «artista-filósofo». 
y escapar del dolor y el riesgo por medio de narcóticos ${ }^{540}$. En esta estrategia se aprecia, sigue Nietzsche, las facciones más agudas del nihilismo, cuando ha sido por completo extirpada la potencia artística del hombre y éste reducido a un ser «domesticado» por la cultura y aterrado. El mismo Nietzsche se vio también tentado por la banalidad del locus amoenus de los tiempos modernos y románticos, reconociéndose por tiempo uno más entre los adocenados espíritus occidentales, habiendo «tomado parte en el horrible oscurantismo de los de Bayreuth» ${ }^{541}$. La felicidad en Nietzsche, por contradictorio que pueda parecer, sólo puede ser posible desde la asimilación del sufrimiento: por la pérdida de la conciencia escatológica y de justicia prospectiva al término del programa histórico-moral la vida no aparta de su espectro los rasgos amargos ni los enajena en expectativas de una postrera redención eidética. Al acoger el dolor dentro de la vida, Nietzsche está abrazando la vida en cuanto tal, bajo cuya «inocencia» hay tanto risa como llanto. La felicidad, por tanto, es el sentimiento de recuperación de la existencia encarnada, la incuestionable afirmación de la «corporalidad», donde espíritu y cuerpo conforman la unidad sintética que es el hombre, siempre inserto en un presente que se experimenta como proyección de un futuro siempre efectivo $y$ nunca concretado. Así se entiende que la felicidad está únicamente al alcance de aquellos espíritus que se han endurecido.

El carácter redentor de su filosofía invierte primeramente las formas del nihilismo; que la existencia deje de ser un claro de luz, que se hayan perdido las concreciones racionalistas de ésta y en su lugar tengamos un pozo de misterio de cuya identidad última nada trascendental quepa ser dicho se convierte en motor de acción. La filosofía de este nuevo tiempo partirá de aquí, del lienzo en blanco de la vida: no se trata de buscar la verdad que articula las disposiciones del mundo, sino de ofrecer una respuesta artística al vacío esencial de una existencia que se ha de procurar sus propias metas y fines. En la pérdida de la justificación epistémica definitiva de las dinámicas del mundo y sus engranajes reside la potencia libertaria de la dimensión activa del nihilismo. La verdad deja de operar como una categoría metafísica de inmanencia y deviene creación de la propia respuesta al vaciamiento de la realidad deviniente. Por eso Nietzsche no se queda en las etapas reactivas de un nihilismo consciente de sí que se paraliza ante el dolor de la muerte de Dios y que no logra avanzar a causa de su desesperación; el pesimismo es el mejor ejemplo en la modernidad. Estos momentos tardíos en la historia de Occidente oprimieron las personalidades de Schopenhauer y Wagner, pero no bastan. El dolor del motivo trágico es transvalorado en Nietzsche en afirmación radical y amor incondicional, también a lo oscuro y amargo, a lo difícil y arriesgado. Así, la aceptación de la vida en su totalidad ha comportado una nueva

\footnotetext{
540 En un fragmento en el que analiza los rasgos distintivos del instinto de décadente, señala que éste «necesita narcóticos potentes» (Nietzsche, F., Fragmentos póstumos IV, 23 [4], op. cit., pág. 756 [KSA XIII, 606]).

${ }^{541}$ Ibid, 9 [32], pág. 241 (KSA XII, 349).
} 
imagen de la dicha que se perfila desde la fuerza de quien es capaz de crear para sí su propia finalidad: «Fórmula de mi felicidad: un sí, un no, una línea recta, una meta ...» ${ }^{542}$.

Como hemos señalado, Nietzsche fue víctima en su juventud del pesimismo de estos dos grandes maestros. Sin embargo, supo dejar atrás tales pulsiones nihilistas y abandonar estrategias en las que percibió una desvalorización de la vida y un impulso vengativo ${ }^{543}$ contra ella. La nefasta instigación de tomar venganza contra la vida ha sido una de las piedras angulares de la tradición nihilista occidental:

En todas partes en que se han buscado responsabilidades, el que las ha buscado ha sido el instinto de venganza. Durante milenios este instinto de venganza ha dominado de tal modo a la humanidad que con su distintivo ha marcado a la metafísica entera, a la psicología, a la concepción de la historia y, sobre todo, a la moral. Por lejos que el ser humano haya llegado aunque sólo sea con su pensamiento, hasta allí ha inoculado en las cosas el bacilo de la venganza ${ }^{544}$.

Frente a este ponzoñoso espíritu, Nietzsche ofrece la alternativa del dominio de la vida, haciendo para ello del nihilismo fuente de fuerza: la transformación del león, que es ella misma una transmutación de transición hacia una nueva posición existencial, la transvaloración, aún no consumada, pero ya pensada como posibilidad y no sólo como un nostálgico y narcótico anhelo. Hasta el vigente momento decimonónico la voluntad de poder ha caído presa del desaliento y se ha arrojado en los brazos de una débil posición acomodaticia. El tránsito del camello al león rugiente exige el amor incólume y sin paliativos por la existencia vividos ambos -el amor y la existencia; si no acaso la misma entidad- desde la propia e intransferible experiencia del sujeto encarnado, libre del resentimiento y la censura que la metafísica de la duplicación y de la escisión había impuesto sobre la pauperizada «apariencia». Sólo una vez emancipados del carácter revanchista y de la culpa respecto de una existencia a la que se presupone mancillada por su condición deviniente, el alba de los nuevos tiempos del superhombre se dejará ver tras las más elevadas cumbres.

Por supuesto no es ésta una tarea fácil. Exige la contemplación de una vida efectiva en un futuro «encarnado», es decir, no trazado escatológicamente por una conciencia supramundana y omnisciente, sino por la personalidad inaccesible del propio sujeto hermenéutico que, sabedor de la pérdida del fundamento último de la tradición bimilenaria, se comprende a sí mismo responsable de la creación de su propio mundo, hoy vacío de significado. El posicionamiento activo ante el nihilismo parte del hombre, ya que, pese a lo que

${ }^{542}$ Nietzsche, F., Crepúsculo de los ídolos, op. cit., pág. 41 (KSA VI, 66).

${ }^{543} \mathrm{El}$ «espíritu de la venganza» es uno de los principales tópicos que trata Zaratustra. Sobre él se ha armado toda la tradición occidental del resentimiento y la culpa. «El espíritu de la venganza: amigos míos, sobre esto es sobre lo que mejor han reflexionado los hombres hasta ahora; y donde había sufrimiento, allí debía haber siempre castigo» (Nietzsche, F., Así habló Zaratustra, op. cit., pág. 210 [KSA IV, 180]).

Uno de los grandes imperativos de Zaratustra concernirá por tanto a la necesidad de superarlo.

${ }^{544}$ Nietzsche, F., Fragmentos póstumos IV, 15 [30], op. cit., pág. 636 (KSA XIII, 425). 
dijera Heidegger, es un problema genuinamente humano. En la medida en que Nietzsche ha cifrado la esencia de la vida en la voluntad de poder, o sea, en la capacidad de crear y jerarquizar valores, y que el nihilismo consiste en la deslegitimación, en el vaciamiento de los valores hasta entonces supremos, la respuesta activa ante tal situación debe partir desde el núcleo de la valoración, que es el hombre.

El nihilismo ha sido abordado desde distintas posiciones que, en realidad, tan sólo eran meandros de una misma disposición, reactiva: el socialismo, el positivismo, el optimismo o el pesimismo, entre otras tentativas, se han esforzado por mantenerse ciego ante el colapso del universo de valor de Occidente; sus respectivos credos son remedos que aspiran, con más o menos éxito, a emular -si no conservar- la teleología de una razón que imprimió desde el «mundo verdadero» los códices de sentido al «mundo aparente». Estrategias reactivas, sigue Nietzsche, toda vez que no han comprendido la alternativa de libertad que ha brindado el nihilismo: el sueño de autonomía de la razón ilustrada estaba aún pensado bajo el régimen de dominio de una razón no armónica con la vida; la autonomía, la libertad como la piensa Nietzsche, yace en el dominio de las conciencias. El nihilismo es un canal de libertad en la medida en que procura el fin de los ídolos dogmáticos, para brindar al hombre el cetro de su propia dirección.

Decíamos que no es una tarea fácil, ya que la transmutación de la experiencia agónica del nihilismo en fuente de existencia comporta el compromiso del hombre consigo mismo, con su ser encarnado, de afirmarse en su condición hermenéutica. Dicha comprensión lo introduce radicalmente en la voluntad de poder, la cual a su vez en aras de disponer activamente de tal cualidad del carácter se imbrica en la tarea del cuidado de sí y del máximo desarrollo de sus potencialidades. Este plan de plenitud compromete al hombre con el fondo ciego y de sinsentido -fundamental- de su personalidad, siempre abierta en el horizonte de indeterminación del cual emerge, una y otra vez, la afirmación del sujeto trágico, aquel que abraza la orfandad de un mundo privado de valores y sumido en la pluralidad perspectivista del devenir para procurarse, por su voluntad de poder, el sentido de una existencia emancipada de instancias ideales.

La transmutación del nihilismo en un canal de fuerza afirmadora y potenciadora de las condiciones de vida buena y cuidada sólo es accesible para aquellos individuos que han comprendido la contradicción sangrante entre la vida encarnada y el ser de la metafísica, favoreciendo en esta disyunción el primero de los coyuntos. Individuos éstos que tras la muerte de Dios han abandonado, además, la «gramática» reactiva de dicha divinidad. El nihilismo no es la pérdida de la confianza en la razón ${ }^{545}$, sigue Nietzsche, sino de aquella

545 Motivo éste por el cual la construcción estética consumada de la fuerza de la voluntad de poder, la vida mejor, la obra de arte más bella, no es moldeada ni esculpida ni pintada por el «artista», sino por el «artista-filósofo», pues la existencia jamás puede prescindir de la razón. 
apreciación epistemológica que se preocupó menos por la existencia encarnada que por la verdad eidética. El nihilista activo ha sabido ver que la existencia sólo tiene sentido «estético», es decir, que su sentido depende del sujeto que valora desde una razón que no ignora las condiciones y las consecuencias elementales de la vida, el artista-filósofo. El artista-filósofo ha superado el empeño de una vacía empresa epistemológica en favor de una trágica, la cual sólo es comprensible y abordable, decíamos, estéticamente. El artista-filósofo, que ha sabido libar una afirmación activa del nihilismo, comprende la exigencia de esta tarea, reconoce la dificultad de la misma, incluso el dolor que puede ocasionar, y pese a todo ello, acepta tan arriesgada aventura, ya que puede resistirla. Y puede porque ha cumplido con el consejo existencial de Nietzsche de endurecerse. 


\section{CAPÍTULO I: NIETZSCHE ANTE EL NIHILISMO}

\section{I.1. La doble dimensión del nihilismo}

De sobra conocidas son las consideraciones de Heidegger en las que afirma que en la figura de Nietzsche se consuma la historia de la metafísica de Occidente ${ }^{546}$. Una historia que no es sino la del desenvolvimiento del nihilismo, pues «el nihilismo es historia» ${ }^{547}$. Ya hemos señalado en la segunda parte que el nihilismo es reformulado dentro del peculiar corpus heideggeriano como el proceso por el cual el ser se redujo a valor. Reducción que se agudizó en la modernidad mediante la indagación cartesiana en la subjetividad y la estrategia trascendental kantiana de fundamentación de la objetividad. En este juego, «la verdad como certeza se convierte en instaurable conformidad con el ente en su totalidad, previamente preparado para asegurar la existencia consistente del hombre basado sólo sobre sí mismo» ${ }^{548}$. Una existencia que tendría su último gran acontecimiento en Nietzsche, en cuya figura el ser y la verdad terminan por ser reducidos a voluntad de poder, momento en que la subjetividad se percibe a sí misma como creadora de la verdad:

en la medida en que todo lo real es real por el carácter fundamental de voluntad de poder, a cada ente individual le corresponde una «perspectiva» propia. El ente en cuanto tal es perspectivista. Lo que quiera decir verdad se determina desde su carácter perspectivista. Sólo en continua referencia a éste puede pensarse «lo que es» propiamente dentro de la metafísica de Nietzsche ${ }^{549}$.

Continúa Heidegger advirtiendo que en la metafísica de la voluntad de poder, situación última de la alquímica transmutación del ser en valor, la escisión entre el sujeto y el objeto, esto es, el hombre y el mundo reduce ambos elementos a una disposición generadora de

546 Cfr. Heidegger, M., Nietzsche, op. cit., pág. 601: «Ya en nuestro primer comentario del nihilismo nos chocamos con el hecho de que el nombre y el concepto 'nihilismo' aluden a un pensamiento relativo al ser, mientras que Nietzsche piensa el nihilismo por completo desde el pensamiento del valor. Mientras que la pregunta por el ente en cuanto tal en su totalidad era desde muy antiguo, y sigue siendo, la pregunta conductora de toda metafísica, el pensamiento del valor sólo ha llegado a dominar en ella recientemente, y de modo decidido sólo con Nietzsche, realizando de esta manera la metafísica un giro decisivo hacia el acabamiento de su esencia».

$$
\begin{aligned}
& { }^{547} \text { Ibid., pág. } 596 . \\
& { }^{548} \text { Ibid., pág. } 542 . \\
& { }^{549} \text { Ibid., pág. } 606
\end{aligned}
$$


valores. Y «la voluntad de poder, por su esencia más íntima, tiene que poner siempre y ante todo valores de conservación y valores de acrecentamiento» ${ }^{550}$.

Si bien al incluir el tratamiento nietzscheano del nihilismo dentro de la secuencia de acontecimientos de la metafísica occidental no puede Heidegger estar más acertado, yerra al contemplar al autor como un mero patólogo que detectó una enfermedad. Las expectativas de la filosofía de Nietzsche van más allá de las del simple cronista que cifra los acontecimientos capitales del pasado; pretende arrojar claves que procuren condiciones de superación del nihilismo ${ }^{551}$. No tiene razón Heidegger, sin embargo, al tomar el estudio del nihilismo como una simple etapa más dentro de su historia. Nietzsche detalla cómo acaece en su tiempo la muerte de Dios, la imposibilidad metafísica del ser, de la verdad como adecuación como consecuencia de la conciencia nihilista que de sí alcanzó el siglo XIX. Ahora bien, el diagnóstico y el análisis del nihilismo es parte esencial de su superación. Y así lo afronta Nietzsche. Tras la detección de la muerte de $\operatorname{Dios}^{552}$, lejos de caer en el decadente nihilismo de la pasividad, ve las condiciones para una nueva forma de valoración: la transvaloración. Aunque el nihilismo es la constatación de la desvalorización, de la «falta de meta» ${ }^{553}$ en su seno están las fuerzas generadoras de una revolucionaria óptica, pues nihilismo también significa «el carácter interpretativo de la vida» ${ }^{554}$.

Por todo ello, tampoco es, como Heidegger ha creído, correcta la comprensión de la voluntad de poder como esencial contenedor de valores de conservación. Tal apreciación supone un atentado contra la filosofía nietzscheana de plenitud y cuidado como principio

${ }^{550}$ Ibid., pág. 605.

Que le sea esencial a la voluntad de poder, como disposición generadora de valores, procurarse condiciones de conservación y acrecentamiento no hace sino continuar para Heidegger su sospecha de que en la metafísica de la voluntad de poder se consuma lo iniciado en el subjetivismo cartesiano y el trascendentalismo kantiano, la reducción del ser y la verdad a valor: «Al volverse la verdad certeza del saber de una humanidad que se asegura a sí misma, comienza esa historia que en el cómputo historiográfico de las épocas se denomina época moderna. El nombre dice más que lo que pretende. Dice algo esencial de esta época. En la medida en que la verdad en la que está su humanidad exige que se desarrolle el aseguramiento de un dominio incondicional del hombre, esta esencia de la verdad le confía a éste y a su efectuar la preocupación ineludible e incesante de acrecentar las posibilidades de aseguramiento y de asegurar a su vez a éstas contra los nuevos peligros que se suscitan, yendo adelante con la continua novedad de sus éxitos y descubrimientos, con la continua novedad última de sus adquisiciones y conquistas, con lo siempre inaudito de sus vivencias» (Ibid, pp. $862-863)$.

${ }^{551}$ Cfr. Nietzsche, F., Ecce homo, op. cit., pág. 19 (KSA VI, 259): «Entre mis escritos ocupa mi Zaratustra un lugar aparte. Con él he hecho a la humanidad el regalo más grande que hasta ahora ésta ha recibido. Este libro, dotado de una voz que atraviesa milenios, no es sólo el libro más elevado que existe, el auténtico libro del aire de alturas -todo el hecho 'hombre' yace a enorme distancia por debajo de él-, es también el libro más profundo, nacido de la riqueza más íntima de la verdad, un pozo inagotable al que ningún cubo desciende sin subir lleno de oro y de bondad».

552 Cfr. Nietzsche, F., Fragmentos póstumos IV, 9 [35], op. cit., pág. 241 (KSA XII, 350): «Nihilismo: falta la meta; falta la respuesta al «¿por qué?» ¿qué significa nihilismo? — que los valores supremos se desvalorizan».

$$
\begin{aligned}
& { }^{553} \text { Ibid., } 7 \text { [61], pág. } 223 \text { (KSA XII, 316). } \\
& { }^{554} \text { Ibid. (KSA XII, 316). }
\end{aligned}
$$


de reapropiación de la existencia. La mera conservación responde más a un movimiento mecánico donde la vida es vista sólo en caracteres orgánicos -el biologicismo, eco del positivismo moderno-. La reducción de la voluntad de poder a mera salvaguarda de los procesos fisiológicos no es tan sólo un error, sino la demostración de una hermenéutica pobre que no ha penetrado hasta el profundo núcleo de la filosofía nietzscheana: la cuestión del valor tiene menos que ver con la cuestión del ente y el ser que con el hombre encarnado. Reivindicar esta dimensión, como dice Nietzsche, no es sino recuperar la fuerza de la esencial condición hermenéutica del hombre, así como su esfuerzo por integrarla en una caracterización estética de la vida como obra de arte: en virtud de su condición hermenéutica el hombre crea sus propios valores mediante la voluntad de poder. Contemplada ésta desde el prisma estético-moral del cuidado que entraña la «corporalidad», el sujeto del nihilismo activo jerarquiza aquellos valores más sublimes en aras de la obra de arte que es su vida encarnada.

Por eso resulta desafortunada la lectura de Heidegger de la voluntad como instrumento de conservación, denotando que su hermenéutica del nihilismo, al gravitar sobre la cuestión del ser en detrimento de los valores como rasgo fundamental humano, parece más próxima -inserta, incluso- a la tradición nihilista como historia de desarraigo de la existencia que la propedéutica nietzscheana. La recuperación de la vida, enajenada tras los dos milenios de escisión del alma y el cuerpo y del asfixiante anhelo de contemplación de un universo supramundano inaccesible para nuestra naturaleza carnal, no pasa sólo por la vindicación del valor como suelo humano, sino que exige además la inserción de ésta, que es la voluntad de poder, en el proyecto estético de plenitud. Y eso, pese a Heidegger, rebasa la mera conservación. Allí donde el compromiso heideggeriano con el ser tiene caracteres metafísicos en tanto que el hombre concreto sigue en una posición secundaria, Nietzsche devuelve al hombre su dignidad arrebatada al reintegrarlo nuevamente en la identidad sintética que es la del sujeto trágico, quien sabedor de su esencial inesencialidad se abre al horizonte indeterminado e ilimitado de sus posibilidades de ser y, de acuerdo con la situación radical de su ser encarnado, jerarquiza los valores más selectos para hacer de su vida particular y concreta la expresión más noble de su afirmación. Y así, el nihilismo disruptor que ha privado al mundo de su sentido escatológico es transmutado haciendo del hombre su condición de posibilidad de sentido.

Apenas un lustro antes del fatídico accidente de Turín, y recientemente publicado el Zaratustra, Nietzsche no puede ignorar por más tiempo la ya evidente amenaza que durante las últimas décadas menoscabó la conciencia de los autores modernos. Hay «algo», prosigue, cuyos efectos son demasiado sólidos como para continuar ignorándolo. Es preciso conocer semejante acontecimiento. Poco antes de su crisis psiquiátrica, Nietzsche centra sus esfuerzos en la cuestión del nihilismo: responde, entiende el autor, a una valoración radical de la filosofía entera que había asumido que el mundo debía tener sentido inmanente; 
y, a continuación, al inmediatamente sucesivo estado psicológico de agotamiento de una abatida Europa que ha fracasado en la búsqueda de dicho contenido de sentido, ya moral ya religioso.

La conciencia del fenómeno del nihilismo llegaría con la decepción profunda causada por la imposibilidad de alcanzar un fin último trazado escatológicamente y desarrollado en la historia; la incapacidad de imprimir en el devenir de los acontecimientos humanos la presencia inmutable del ser sería la mayor de las causas de la crisis nihilista. Los conceptos capitales de la episteme filosófica tradicional -«historia», «naturaleza», «espíritu»-, que se habían armado como la totalidad epistemológica que confería unidad a los grandes proyectos del pensamiento, y en virtud de cuya significación trascendental cabía el sacrificio de los rasgos concretos del hombre, pierden su legitimidad formal. La verdad metafísica se termina antojando increíble y consecuentemente también las respuestas por ella ofrecidas a los distintos porqués del mundo, de la realidad, del conocimiento, etc. El sistema occidental colapsa, sus conceptos tradicionales pierden su contenido y finalmente el «hombre», constructo definitivo de Occidente, queda radicalmente huérfano en una «nada» que se conserva por el anhelo nostálgico de las categorías sistemáticas pretéritas.

El nihilismo adviene una vez el «ser» se comprende incompatible con los rasgos de un universo privado de posibilidades metafísicas. La situación nihilista que recibe en la segunda mitad del siglo XIX Nietzsche es una tal en la que el horizonte Europeo ha aceptado el devenir como realidad, aunque no es capaz de soportar tal situación. Dios ha muerto; su ausencia, sin embargo, es todavía un vacío demasiado profundo, incapaz de ser superado, de manera que la existencia ha perdido su valor, pues sigue contemplándose desde la expectativa escatológica de la unidad y de la verdad.

El nihilismo, según lo recibe Nietzsche, es ya un factum de la «civilización occidental». Es la insalvable condición de deterioro y declive de los valores supremos que habían dispuesto desde los tiempos platónicos el horizonte cognoscitivo del modus filosófico continental. Las muescas de esta convulsión son muchas, desde la crítica de los valores hasta el desprecio por los mismos, pasando por estadios más dóciles de descreimiento y desconfianza. De sus contemporáneos advierte Nietzsche diferentes rasgos que marcan las posibles respuestas ante el nihilismo: el esmero de aquellos que se esfuerzan por mantener los viejos valores a costa de las nuevas alternativas surgidas; quienes reconocen que el legado de la tradición ha sido un movimiento de odio contradictorio con la vida; y el colectivo menos numeroso, formado por los testigos conscientes del cisma abierto entre el presente y el pasado que han comprendido que semejante crisis no puede ser eludida y que, por ende, exige una respuesta inmediata. Una respuesta, no obstante, que puede ser «fuerte»o «débil», según las respectivas voluntades de poder de los sujetos. 
De cara a este difícil e incómodo presente, Nietzsche se distingue a sí mismo como el primer nihilista perfecto, como el nihilista consumado, aunque los términos de esta consumación no son los de Heidegger. Él se percibe como el único hombre que hasta la fecha ha superado el nihilismo, precisamente por haberlo experimentado máximamente. La vivencia nihilista en Nietzsche pudo ser fecunda, al contrario que en sus predecesores y en sus contemporáneos, por el propio horizonte de apropiación de esta crisis. Nietzsche comprendió el nihilismo como la gran crisis de toda la filosofía occidental, en la medida en que había afectado cáusticamente a los principios fundamentales de ésta, la metafísica, deslegitimando tanto su suelo como sus frutos. Por lo que el nihilismo puso de manifiesto, comprende el autor, la necesidad de una nueva actitud filosófica ajena a los criterios de los más de dos mil años de la tradición de la duplicación y de la escisión: la «inocencia».

La ejecución última de una vida nihilista es el suicidio: el elemental sinsentido de la existencia no halla motivos por los que justificar la perpetuación de ésta. Sin embargo, la vida dentro de la ensoñación nihilista ha sido afectado por el «cristianismo», cuyas maquinaciones han complejizado este lamento sin respuesta. El cristianismo detuvo el suicidio y transmutó su inmediatez en la pesadez de un suicidio lento y largo que se despliega a lo largo de una vida de agonía cifrada como mezquina y mediocre. El cristianismo ha pervertido y emponzoñado todo, incluso el nihilismo, pues ha hecho de la ausencia de significado de la vida un motivo de odio y de desprecio radical hacia ella: la voluntad de nada -no serpor encima de la voluntad de vida -ser, a cualquier precio-. Si bien ésta última también es nihilista, aquélla, la voluntad de nada, imprime además el veneno del rencor: es preferible el no ser antes que el ser, pero el no ser no puede ser conquistado voluntariamente, sino que se ha de esperar, en la angustia perenne que es la vida, su fin. Y durante esta espera, el odio hacia la existencia se acrecienta y alimenta con filosofías que justifican el porqué de la prioridad del no ser sobre el ser. No basta el no ser; hay que aborrecer el ser. Es un nihilismo pasivo el cual al tomar contacto con el odio del cristiano ha tornado, además, reactivo. Por el contrario, la consumación del nihilismo en Nietzsche nunca podría ser el suicidio, ya que su filosofía se ha situado en una disposición afectiva distinta de la tradicional platónico-cristiana: que no haya una verdad última, dadora de contenido y de sentido al mundo y a la vida, es más una feliz redención que una agonía nihilista sin fin. Nietzsche se sumerge en la experiencia del nihilismo, pero logra libar una enseñanza salvífica: la expectativa de una filosofía no pergeñada escatológicamente abre, en realidad, las puertas a una filosofía del futuro asentada sobre los rasgos humanos. Nietzsche, el nihilista perfecto, el único nihilista consumado, se sabe, en verdad, no «decadente». Es, mejor dicho, tanto lo uno, como afirma en Ecce homo, su antítesis: un nihilista antinihilista.

En virtud de su crítica de la epistemología y su deconstrucción de la verdad bimelenaria, Nietzsche ha concretado que la especie humana no dispone de un órgano específico capaz de procurar certeza, adecuación, exactitud ideal. La justificación del conocimien- 
to llegaría únicamente desde la voluntad de poder, en tanto que interpretación y fuente de valoración de la experiencia sensible de acuerdo con los criterios de «más valioso» y «mejor». La esencial condición valoradora del hombre había sido socavada por la tradición platónica, que la sustituyó en favor de la voluntad de verdad, la cual pergeñó una instancia ideal que por su condición no sensible se postuló «verdadera». Por contraposición, «falso» fue todo aquello ajeno a los dominios ideales, esto es, el plano sensible sobre el que opera la voluntad de poder. En consecuencia, la voluntad de verdad distinguió ontológicamente ambas dimensiones, pauperizando aquella de la que no cabía esperar un juicio certero; el reino empírico, que eran las lindes de la vida, de la vida encarnada, fue devaluada hasta su negación plena, y con ella, la propia existencia humana. Como decíamos, la deconstrucción nietzscheana del concepto y del valor de la verdad terminó por mostrarle la maledicencia de la voluntad de verdad, a la que nuevamente pudo oponer la rescatada voluntad de poder, que esgrime su capacidad para crear los valores y las condiciones necesarias para la procuración de su vida más plena: querer conocer es querer dominar, querer ser señor para someter el objeto de «conocimiento» a nuestras exigencias de existencia. Nietzsche consigue extraer un ventajoso provecho del fin de la verdad última toda vez que comprende que semejante «mundo verdadero» ha sido resultado de una confusión entre la función de la voluntad de poder de crear ficciones útiles para la vida y el fetichismo antropocéntrico de creer que tal criterio de verdad era el fin tendente del mundo. En sus primeros compases, el nihilismo habría de mostrar la esencial falsedad del mundo, o sea, la fecundidad perspectivista de éste, que supo extraer Nietzsche para sí. No existe algo fuera de la valoración perspectivista de la voluntad de poder. La tensión entre el «mundo verdadero» y el «mundo aparente» no hace sino ocultar la mortal pulsión entre el mundo y la nada, entre la voluntad de vida y la voluntad de nada.

De los hombres de su tiempo, y especialmente de los del futuro inmediato, cabe esperar una respuesta ante el nihilismo para superar la inacción a la que ha abocado esta crisis sin precedentes. Dijimos, sin embargo, que tal contestación podría o bien ser «fuerte» o bien «débil», dependiendo del enseñoreamiento de las voluntades de poder. Ya en 1887, en el momento de redacción de La genealogía de la moral, cuando el nihilismo coloniza su espectro de pensamiento, Nietzsche encuentra en los ideales aristocráticos la superación de la voluntad de vida; la vida es un acontecimiento de apropiación y de dominación, ya que «vivir» es «tener poder», es «ser señor». Los modos de valoración «bueno»y «malo», «señor» y «plebeyo» denotan distintas manifestaciones de apropiación de la vida; no obstante, también lo «bueno»y lo «malo» difieren nuclearmente según la voluntad de poder: «noble» es tanto la ascesis que atenta contra la «corporalidad» y la contemplación eidética como el peligro, el riesgo, la aventura o el esfuerzo. La primera caracterización es la condición del «ideal ascético», aquellas aristocracias sacerdotales que han impuesto a lo largo de todas las épocas un régimen místico de encuentro con Dios -la «nada»-y de privación 
y rechazo del cuerpo. Por lo que respecta a la segunda, el eje de gravedad está en la «corporalidad», luego se acentúan las presiones por procurarle las mejores condiciones de plenitud. Se pregunta, sin embargo, Nietzsche cómo es posible la existencia de dos ideales de nobleza tan distintos, incompatibles entre sí. De la guerra entre las castas aristocráticas emerge sólo una victoriosa, que impondrá su cualidad «noble» sobre el mundo y la vida. En la Antigua Roma, sigue, tuvo lugar el primer enfrentamiento entre sendos ideales de grandeza: la aristocracia sacerdotal judía se adueñó de los entonces vigentes valores grandilocuentes -«poder», «belleza», «plenitud», etc.-, que transmutó en malos en beneficio de la virtud de los suyos -«debilidad», «sacrificio», «pobreza», etc.-. Una revolución de esclavos que continuó con el cristianismo. De modo que la «transvaloración» es una noción fundamental en la historia del nihilismo, pues a ella se debe el triunfo de los ideales ascéticos de una vida pobre y miserable, indigna y precaria.

Ya incidimos en la segunda parte de esta tesis que Nietzsche aún veía cierta nobleza en la actitud socrática si ésta era comparada con la cristiana: éstos omiten la búsqueda esforzada de la verdad, pues ha sido revelada; la escuela griega, al menos, comprometía su espíritu con la empresa intelectual de la contemplación. Lo mismo puede decirse aquí de la transvaloración; la transvaloración de los esclavos ha sido genuina y específica, con un cariz distintivo: el resentimiento. El esquema valorativo del resentimiento es reactivo, pues crea sin afirmar. Sus valores no son legitimados por su propia experiencia, es decir, no se afirman en cuanto tales, sino que hallan sustento en el rechazo, en la negación de los anteriores. De modo que el «sacerdote» es en la medida en que no es; odia antes que ama; censura antes que propone. No imprime contenido a lo «bueno», sino a lo «malo», y de ahí, por antítesis radical, extrae sus condiciones y sus posibilidades: bueno es cuanto no es malo. Este régimen de censura ha hecho del hombre una bestia adocenada y domesticada, una criatura mediocre y enferma sin capacidad de generación, un hombre «civilizado». Hay un pesar, un agotamiento, un hastío por la existencia que recorre subrepticiamente la nobleza sacerdotal: el nihilismo como base del ideal ascético, como suelo natal de la civilización occidental. Dentro de los límites europeos no hay posibilidad germinal, pues el abono de su sustrato es el odio y el rencor, que sólo censura y prohíbe, que sólo destruye. El «mundo verdadero» ha sido revelado en los caracteres del «Reino de Dios», luego ya no es necesaria la búsqueda del mismo; basta con ser «bueno».

La respuesta nietzscheana ante el nihilismo, se empieza a comprender, es la transvaloración. Mas ésta no es pergeñada en abstracto, sino en continuidad con la radicalidad humana. El nihilismo es, con todo, la historia entera de Occidente, la de la regencia de la episteme del «mundo verdadero» -el ser- sobre el «mundo aparente»-el devenir-, que acabó concretándose objetivamente en un retrato humano esquizofrénico donde la tensión entre su ser hermenéutico encarnado y la normatividad eidética de la idea se saldó con la victoria de la última, anegando con contenidos abstractos, supramundanos e inhumanos to- 
das las instancias de la personalidad humana. El resultado sería el decurso de la tradición occidental en su totalidad, una desafección del espíritu respecto de la materia, o de la mente respecto del cuerpo en la Edad Moderna, que supuso el extrañamiento de la propia vida. Semejante experiencia de existencia fue la del hombre europeo nihilista en tanto que aspiraba a la concreción de una imagen imposible. De tal desencanto se gestó un imperdonable odio hacia una vida que por su efectividad corporal no podía ajustarse a los cánones ideales del mundo formal. Y así, tras los lustros, las décadas, los siglos, los milenios del decurso europeo la episteme epocal continuó esta estrategia de desapego, de inhumanidad: la formulación formal del «ser hombre» desde principios ajenos al hombre en tanto que ignoraron su «corporalidad». Así, con todo, la superación del nihilismo que aporta Nietzsche, la cual se zanjará finalmente en la transvaloración, es una situación paradójica, pues pese a su novedad paradigmática es absolutamente cercana al hombre: la solución al desencuentro entre el hombre y su propia vida está en la caracterización formal del hombre desde los caracteres humanos más íntimos, la voluntad de poder. La transvaloración no exige un esfuerzo inhumano; al contrario, es la empresa más humana, puesto que plantea un horizonte de precomprensión de la existencia ad hoc: desde la radicalidad de la vida humana efectiva, la «corporalidad», se crea el universo de valoración, siempre cambiante, siempre deviniente, que es a su vez el mundo en el que habita. Tomada de este modo, la transvaloración es una empresa humana, la más humana de todas, ya que nace de la necesidad de una vida experimentada. Sin embargo, debido a la pauperización en que se vio sumida la existencia, el esfuerzo de reapropiación es ya impensable para el hombre actual. De manera que la aventura humana de la vida demanda una atención que el sujeto presente no puede procurar. Tampoco es, no obstante, la presencia de un ser cuantitativamente superior al hombre lo que demanda Nietzsche, sino la de un individuo que si bien nunca ha llegado a existir, no es inviable su contemplación posible: el superhombre, el artista-filósofo como modelo humano. Un hombre si bien humano, nunca demasiado humano, dado que la humanidad hasta el momento se ha definido por la escisión y el abandono de su encarnación. El resultado de la transvaloración está en manos del hombre más humano, aquel que se ha afirmado radicalmente en su condición; es el más humano, pero nunca demasiado humano.

La transvaloración deja de contemplar un nuevo mundo para ser su recuperación, la del mundo, en cuanto tal; la sutura quirúrgica de la espiritualidad y de la materia que reintegra al hombre en la realidad. Una realidad que al no ser ya concebida a priori desde instancias eidéticas, no es por más tiempo esencialmente epistémica. Al estar formulada ad hoc, desde la complejidad sintética del sujeto tanto inconsciente como parcialmente consciente de los procesos formativos de su personalidad, es trágica. La realidad trágica acoge la pluralidad y la polifonía, la indeterminación y la contingencia, en suma, el devenir. La transvaloración busca, ulteriormente, la recuperación de la experiencia de la vida. 
Tras la desvalorización fundamental, la reacción inmediata de las conciencias europeas fue el dolor insoportable de una vida vacía. La modernidad fue la última etapa del proceso histórico de Occidente; en ella la voluntad de verdad concurre definitivamente en la muerte de Dios, en cuyo impío derramamiento de sangre chapotean patéticamente los hombres epocales luchando estérilmente por no ahogarse en la conciencia de la nada. Esta condena de la vida es combatida por Nietzsche, quien buscará traer de nuevo al horizonte filosófico la alegría de una existencia reapropiada, como insistimos en páginas anteriores. La revisión de la historia de Occidente como el decurso evolutivo del nihilismo es una cuestión moral, pues la filosofía ha sido el terreno sobre el cual se despreció la cuestión estética de la vida encarnada. Un desprecio vengativo que se perpetró desde la Circe de los filósofos ${ }^{555}$ que hizo de él algo deseable:

- ¿Con esto ha acabado ya todo? ¿Quedó así relegada ad acta [a los archivos] para siempre aquella antítesis de ideales, la más grande de todas? ¿O sólo fue aplazada, aplazada por largo tiempo?... ¿No deberá haber alguna vez una reanimación del antiguo incendio, mucho más terrible todavía, preparada durante más largo tiempo? Más aún: ¿no habría que desear precisamente esto con todas las fuerzas?, $¿ \mathrm{e}$ incluso quererlo?, ¿e incluso favorecerlo?... Quien en este punto comienza, lo mismo que mis lectores, a meditar, a continuar pensando, es difícil que llegue pronto al final, - ésta es para mí razón suficiente para que yo mismo llegue a él, suponiendo que haya quedado bastante claro hace tiempo lo que yo quiero, lo que yo quiero precisamente con aquella peligrosa consigna que he colocado al frente de mi último libro: Más allá del bien y del mal... Esto no significa, cuando menos, «Más allá de lo bueno y lo malo» ${ }^{556}$.

\section{I.1.1. Ecos de Dios: el nihilismo en el siglo $\mathrm{XX}$}

El nihilismo arrastra consigo una complejidad que dificulta enormemente su estudio, pues es necesario distinguir en él dos dimensiones que, si bien se integran la una en la otra, son teóricamente diferenciables. Al comienzo de nuestro trabajo, en las primeras páginas del mismo, rescatamos una carta de Nietzsche a Carl Fuchs donde aquél insistía en que la palabra «decadente» tenía ya hoy, bien entrada la segunda mitad de la centuria decimonónica, una función descriptiva; servía para definir la condición epocal de la vieja Europa. Aquí tenemos la primera consideración del nihilismo, a saber, como un «concepto». Precisamente que Nietzsche aborde el nihilismo como un concepto, y por tanto, como objeto cognoscitivo de la filosofía, le ha valido a Heidegger para incluir al autor en la longeva historia del nihilismo; que el pensamiento nietzscheano continúe concretándose desde una

${ }^{555}$ Cfr. Nietzsche, F., Fragmentos póstumos IV, 14 [134], op. cit., pág. 570 (KSA XIII, 319): «Temo que sea siempre la Circe de los filósofos, la moral, la que les haya hecho la jugada de tener que ser calumniadores en todas las épocas... Han creído en las 'verdades' morales, en ello han encontrado los valores supremos, - ¿qué les quedaba por hacer que no fuese decir No a la existencia en la medida en que la entendían?... pues esta existencia es inmoral... Y esta vida descansa sobre presupuestos inmorales: y toda moral niega la vida».

${ }^{556}$ Nietzsche, F., La genealogía de la moral, op. cit., pp. 78-79 (KSA V, 288). 
configuración conceptualizadora hace de él un filósofo genuinamente moderno. No es éste, no obstante, el lugar de discutir, otra vez, con Heidegger la supuesta cualidad nihilista de Nietzsche. Es a causa de su conceptualización, sin embargo, que Nietzsche pudo llevar a término un estudio tan fehaciente y concienzudo de este acontecimiento hasta convertirlo en una noción cardinal de su proyecto filosófico. Al tratarlo como una cuestión filosófica pudo someterlo ante el escrutinio racional de su genio para acotarlo histórica y culturalmente, al tiempo que logró sacar a la luz las fuerzas y pulsiones que habían sostenido tal problema existencial. Aquí se encuentra, además, el segundo rasgo del nihilismo: el nihilismo como «problema». Como problema, es la historia del hombre occidental y de sus peculiares amarguras existenciales, especialmente dolorosas, en todo caso, en los últimos dos siglos, XVIII y XIX; en cuanto concepto, el perfil del nihilismo lo presenta como un acontecimiento plural con manifestaciones variadas y sutiles según los momentos de la historia.

El nihilismo, decíamos, es la historia del hombre, por lo que es, también, la historia de su horizonte de precomprensión. Como el hombre no puede ser pensado al margen de su situación histórica, y el nihilismo atraviesa la profundidad de todas las épocas, éste, el nihilismo, es un problema radicalmente existencial, ya que se alza como el tiempo que habitamos y desde el cual reflexionamos. No podemos vivir fuera del nihilismo, por lo que tampoco somos capaces de eludirlo; es un problema genuino del hombre toda vez que es un concepto de la «gramática» arreglo la cual el mundo se ha desplegado. De manera que la meditación sobre el nihilismo no puede ser sino desde el propio espectro nihilista y, en cuanto tal, condicionada por las máximas y disposiciones que este problema imprime como episteme conceptual: indeterminación, pluralidad, perspectivismo, inconsciencia, etc. son fenómenos que Nietzsche ha logrado traer a la presencia tras su pertinente estudio del problema.

Ahora bien, que fuera Nietzsche quien expusiese el nihilismo en su doble dimensión significa que hasta entonces no hubo sino vagas aproximaciones a tal fenómeno. Es cierto que la conciencia decimonónica resulta al respecto extraordinariamente diferente respecto de las épocas anteriores, pues en ella hay una conciencia efectiva de la realidad nihilista europea. Sin embargo, a pesar de reconocer la terrible crisis que había acontecido apenas ahondaron en ella. Más aún, las corrientes filosóficas más fuertes del momento -el positivismo continental, en todas sus manifestaciones, par excellence o el utilitarismo de las islas- habían nacido a su abrigo, perpetuaban su régimen de enajenación y, desde luego, distaban mucho de tomarlo como un problema filosófico: creían en la «gramática» de Dios una vez muerto. Con todo, hubo de esperarse hasta la madurez de la segunda mitad del siglo XIX para que el nihilismo tornase cuestión filosófica, esto es, problema y concepto. Así se entiende que el nihilismo no ocupase el centro de reflexión hasta la centuria siguiente; efectivamente habrían de ser los herederos de Nietzsche quienes abordaran el problemático legado que éste había dejado. Por lo tanto, resultó en verdad fundamental para el siglo XX, 
la cuestión capital del mismo, pues en torno a ella se desplazó el pensamiento de los cien años siguientes.

Gracias a que lo hubo convertido en concepto, el nihilismo pudo ser tomado por sus sucesores como una noción sumamente rica capaz de describir -esto ya lo señaló explícitamente Nietzsche-, explicar y sintetizar los acontecimientos históricos y filosóficos de los años venideros. El nihilismo como concepto puede ser tomado como un principio totalitario y unificador, aunque con las reservas y cautelas necesarias para no hacer de él una nueva escatología metafísica. Si aceptamos con Nietzsche la genealogía del problema, si remitimos hasta Platón -la metafísica de la duplicación de mundos y de la escisión del alma y del cuerpo- el sello nihilista, es cierto que podemos contar metodológicamente con una estrategia de continuidad: la historia de la filosofía es la del nihilismo. Mas esto no debe significar que la filosofía occidental en su totalidad haya de reducirse al problemático concepto del nihilismo.

El estudio del nihilismo no tiene expectativas de totalidad, tampoco aspira a contener dentro de sí todos los avatares del pensamiento occidental; sus pretensiones apuntan a un problema que a pesar de su longevidad, es específico del siglo XX. Es más, reducir toda la problemática continental del recientemente cerrado siglo a la cuestión del nihilismo, como hiciese en cambio Heidegger, es una propedéutica nihilista, en la medida en que parece esencializar esta centuria desde el nihilismo. Al ser un concepto, además de un problema, la noción del nihilismo puede usarse para explicar ciertos acontecimientos sin tornarlo, pese a ello, en la respuesta histórica de Occidente. Goudsblom ha señalado ${ }^{557}$ que el nihilismo era un estado mental genuino donde todo se antojaba carente de valor y de significado y sentido; la especificidad del nihilismo para Goudsblom pasaba por que éste remitía a una interpretación cultural del agotamiento y el pesar del sujeto.

En todo caso, lo que no puede discutirse al respecto, a pesar de la polisemia difusa del concepto de nihilismo, es que se ha establecido como un término capital de la filosofía contemporánea. Jünger destacó que «el hombre libre está ya obligado por motivos de autoconservación a preocuparse por cómo comportarse en un mundo en el que el nihilismo no sólo se ha vuelto dominante, sino, lo que todavía es peor, también se ha convertido en un estado normal» ${ }^{558}$. La complejidad a la que hemos aludido parece imponer necesariamente que en el momento de tratar el nihilismo, hemos de presentar si por medio de él buscamos destacarlo como estado - como hiciese Nietzsche en su descripción del término «decadente»- o como un problema. Una aproximación u otra, como supo ver Heidegger, nos sitúan en una relación esencial distinta. Una vez más Heidegger, imprimió una determinación fun-

${ }^{557}$ Cfr. Goudsblom, J., Nihilism and Culture, Oxford, Basil Blackwell, 1980.

558 Jünger, E., Sobre la línea, trad. de José Luis Molinuevo, en Acerca del nihilismo, Barcelona, Paidós, 1994, pág. 49. 
damental en la cuestión del nihilismo, al observar que este término iba siempre ligado a una valoración peyorativa; el concepto «nihilismo», vendría a decir Heidegger, estaba en un horizonte hermenéutico mediado por un prejuicio moral que lo comprende como «malo». Por supuesto esta apreciación no puede ser más errónea y contraria con Nietzsche, quien se esforzó en esbozar un estudio del nihilismo máximamente depurado de consideraciones «morales». Ya que el nihilismo fue la deslegitimación de los valores últimos, los cuales colmaban de significado la episteme filosófica tradicional, y con ello la moral, no es posible una valoración moral del acontecimiento mismo de la deslegitimación.

Ahora bien, que ya mediado el siglo XX Jünger arrojase una valoración peyorativa del nihilismo al lamentar que se hubiese convertido en «estado normal» de Occidente revela dos cosas. En primer lugar, y esto es evidente, que la advertencia nietzscheana de contemplar el nihilismo desde una óptica no moral no se llevó a cabo. Dado que la disposición dicotómica «bueno» y «malo» continuó en los márgenes de la metafísica clásica, que el nihilismo como estadio normal de Europa sea algo malo en Jünger es debido a que no se ha logrado superar la necesidad eidética de fuentes de sentido ulterior. Se concluye de ello que el nihilismo lejos de ser superado, continuó emponzoñando las conciencias futuras. En segundo lugar, y a ello dedicaremos las páginas de este capítulo, el siglo XX no fue un buen receptor de Nietzsche, ya que a pesar de sus múltiples advertencias, no supo libar del nihilismo una respuesta afirmativa, como sí hiciera, en cambio, el filósofo del Zaratustra. La pasada centuria no fue capaz de generar una respuesta afirmativa de la falta de sentido esencial, por lo que continuó el mismo errático vagar de los hombres de la crisis finisecular del tiempo de Nietzsche. Es cierto que el siglo XX hizo de la pluralidad bandera filosófica; sin embargo, la pluralidad nietzscheana es algo más que la simple cuantificación numérica de posibilidades efectivas. En Nietzsche la pluralidad no remite al número, sino a la forma, pues está inserta en el devenir de la verdad dionisiaca. Como veremos más adelante, algo, no obstante, ya introducido en la anteriores partes de esta tesis, al pluralismo ha de seguirle irremediablemente el perspectivismo. De lo contrario, no logrará zafarse de la lógica positivista del «número». Respecto del siglo XX bien podría decir Nietzsche que fue una época numérica, colmada de alternativas, pero carente de perspectivas, pues continuó en la trazada del nihilismo, presa en aquella «gramática» bimilenaria.

Nietzsche señaló que había dejado la tarea de los siguientes dos siglos. Aunque la experiencia nihilista del siglo XX no respondía tanto al programa nietzscheano como a los tormentosos avatares históricos. De manera que el nihilismo se presentó como un problema histórico y su estudio, como una necesaria exigencia a causa de los acontecimientos. La Escuela de Frankfurt, Jünger, Heidegger serían quizá las primeras grandes figuras filosóficas en abordarlo, coincidentes en un momento paradigmático que afectaría sustantivamente sus conclusiones: la Segunda Guerra Mundial. 
El momento más barbárico del pasado siglo hizo manifiesto el retrato de precariedad esencial que del hombre había reflejado Nietzsche; las construcciones humanas y sus conceptos hasta entonces fundamentales - la «lucha contra el prejuicio» ilustrada y el imperativo de autonomía, como casos paradigmáticos- perdieron dramáticamente su sacralidad racional, se difuminaron cual vanas ilusiones de un pensamiento que no encontraba acomodo efectivo con el mundo. La precariedad feliz que había hallado Nietzsche en la crisis finisecular fue teñida de vileza en las décadas posteriores, tornando desconsuelo existencial ante la patente miseria del hombre. El nihilismo pasó a ser un doloroso componente espiritual de los europeos de entonces del cual no cabía encontrar rasgos benévolos.

La crisis espiritual percibida en primer lugar como una cuestión conceptual devino «real», esto es, efectiva, empírica durante el enfrentamiento de los totalitarismos en el continente. Una sangrienta llaga que probó que «todas las imágenes de una sociedad feliz pintada por distintas brochas y en variados colores durante los últimos dos siglos demostraron ser quimeras inalcanzables o, en los casos en los que su advenimiento se produjo, insoportables» ${ }^{559}$. La filosofía se impuso el necesario deber de dar respuesta a una realidad no sólo inexplicable, sino además, hasta entonces, inconcebible: ¿cómo pudo concretarse el destino de la modernidad en una indiscriminada matanza?

La II Guerra Mundial es para Jünger una «línea» que atraviesa perpendicularmente la historia del nihilismo, un punto de inflexión que marca la frontera entre su culminación y su oscura salida. Luego todo el siglo XX hasta la explosión del conflicto habría sido el momento de encarecimiento del nihilismo, de progresiva enajenación de la individualidad en el «mundo ideal» secularizado que era el Estado totalitario. Tras el término de la guerra, la única respuesta posible sería «atravesar la línea»; algo que Jünger, sin embargo, no puede atreverse a garantizar, ya que la libertad de la conciencia ha sido drenada durante demasiado tiempo, quizá llegando a un momento de imposible recuperación.

Contemporáneo de Jünger, Martin Heidegger ofrece la reflexión más importante del nihilismo ${ }^{560}$, fenómeno que aborda desde una peculiar hermenéutica de Nietzsche y desde la cual termina concretando la cuestión como un problema de índole metafísica; no es el estudio del nihilismo, sino de la esencia del nihilismo: la pregunta por el «ser», por la «nada» o por la «verdad». A pesar de todas las dudas y problemas que resultan de la consideración heideggeriana del nihilismo, no puede negársele que supo ver con prodigiosa claridad que el nuevo tiempo filosófico no podría eludir la discusión con Nietzsche:

${ }^{559}$ Bauman, Z., Modernidad líquida, trad. de Mirta Rosenberg y Jaime Arrambide Squirru, Madrid, Fondo de Cultura Económica de España, 2017, pág. 143.

${ }^{560}$ No ahondaremos en la consideración de Heidegger del problema del nihilismo, al haberlo tratado pormenorizadamente en momentos anteriores de este trabajo. 
Nietzsche, en cuya luz y sombras todo contemporáneo con su «con él»o «contra él» piensa y crea, oyó un mandato que exige una preparación del hombre para la aceptación de un dominio de la tierra. Él vio y entendió la lucha encendida por el dominio. No es ninguna guerra sino el Пó $\lambda \varepsilon \mu$ os, que a dioses y hombres, libres y esclavos permite aparecer en su correspondiente esencia, y que lleva a una descomposición del ser. Comparada con ella, las guerras mundiales resultan superficiales. Cada vez son más capaces de decidir menos, por más técnicamente que se armen.

Nietzsche oyó aquel mandato de meditar sobre la esencia de un dominio planetario. Siguió la llamada en camino del pensar metafísico a él confiado y sucumbió en el camino. Así aparece al menos a la consideración histórica. Pero tal vez no sucumbió sino que llegó tan lejos como pudo su pensar ${ }^{561}$.

Entendiendo la experiencia empírica del nihilismo en el siglo XX, la II Guerra Mundial, como el resultado del destino espiritual de Europa, la explicación filosófica debía atender al propio «espíritu» europeo. De tal modo que los autores continuaron la estrategia genealógica de Nietzsche, pues «Nietzsche — dice Löwith, durante el desarrollo de la contienda - se anticipa de forma consciente y deliberada al movimiento histórico de Europa» ${ }^{562}$. Detectaron el nihilismo como un problema congénito de la misma modernidad; y así, mientras unos - los frankfurtianos- acuñaron la sentencia sobre la condición totalitaria de la Ilustración, otros -Strauss- encuentran dificultades en la noción capital de «progreso» como ocasión de confrontación dialéctica de la civilización occidental. Todo pareciera que la metáfora hegeliana de la historia como «matadero de los pueblos» se hubiese encarnado, sin embargo, sin el auxilio de la astucia de la razón. «Nos han condenado al progreso, y éste se ha vuelto nuestra fatalidad» ${ }^{563}$, es el quejumbroso diagnóstico de Löwith tras su balance del nazismo veinte años después de su final. Con todo, en la medida en que el propio espíritu europeo porta consigo el bacilo del nihilismo, la II Guerra Mundial como manifestación terrible de la desvalorización fundamental decimonónica «es una lucha por Europa que se dirige contra ella misma ${ }^{564}$. El nihilismo pasaría de ser la historia de Occidente, como vio Nietzsche, a la historia del hastío del espíritu europeo, siendo consumado tal agotamiento en Heidegger, en quien el desprecio hacia la vida efectiva -ente- es radicalizado en beneficio de la «nada» - el ser-. La situación europea no era sino la plasmación empírica de la violenta dialéctica hegeliana del espíritu, dispuesta en la confrontación entre las diferentes naciones que componían la civilización europea.

Nietzsche entendió el nihilismo como el fantasma por el cual había tenido lugar la enajenación de la vida, el extrañamiento del hombre de su propia experiencia de existencia.

561 Heidegger, M., Hacia la pregunta por el ser, trad. de José Luis Molinuevo, en Acerca del nihilismo, op. cit., pág. 126.

562 Löwith, K., El hombre en el centro de la historia, trad. de Adan Kovacsics, Barcelona, Herder, 1997, pág. 95.

\footnotetext{
563 Ibid. pág. 347.

564 Ibid. pág. 63.
} 
Dinámica ésta que continuó en el siglo XX, con una progresiva disolución de la individualidad, dado que la vida desfundamentada, lejos de servir de puente hacia la concreción del proyecto estético de llegar a «ser lo que se es», pareció dirigir hacia la inacción ante la conciencia de gratuidad y orfandad. Una situación calamitosa que el existencialismo recoge en la idea de «angustia», cualidad esencial del hombre nihilista. A pesar de los esfuerzos de los autores de esta corriente, especialmente los de Sartre, esta escuela arroja un retrato despreciable del hombre. La redención del ser humano llega por medio de la humanidad; no hay perdón para la «corporalidad»; el individuo asignificativo sólo logra respuestas de sentido en su integración en el todo de la unión abstracta y colectiva de la «humanidad», la cual no contempla en modo alguno al precario sujeto particular.

Mención específica demanda Albert Camus, en quien la conciencia existencialista es particularmente descarnada. En la filosofía de este pensador la «nada» se ha apropiado por completo del espectro reflexivo. La angustia arrastra consigo la conciencia de la absoluta insignificancia de las acciones humanas; la existencia es sentenciada como el absurdo que se mueve en la tensión improductiva de un esfuerzo por conceder sentido a una ciega y feroz nada que, al término, fagocita todas las expectativas de valor buscadas por un hombre angustiado.

La experiencia tardonihilista de la segunda mitad del siglo XX, una vez las heridas de la guerra parecen comenzar a sanar, dejó atrás las afecciones pesimistas del nihilista en favor de una nueva disposición, escéptica. Esta nueva deriva trató de conjugar la desfundamentación radical con pretensiones de existencia como proyecto. Las posiciones actuales pasan por esta línea, quizá con dos grandes exponentes: Vattimo y Bauman. Ambos pensadores parten de una experiencia escéptica insalvable a la que, sin embargo, aspiran a convertir en motor de futuro. Las claves ofrecidas por uno y otro, a pesar de sus diferencias de grado, son nuclearmente análogas: no es posible recuperar una dinámica de pensamiento como la de época moderna, pues la apelación a contenidos indubitables y epistemológicamente absolutos es hoy incompatible con el legado de los siglos XIX y XX, y, sin embargo, no debe ser motivo para caer en la inacción. «Hoy viajamos sin una idea de destino que nos guíe» ${ }^{565}$, mas la falta de una guía no ha de significar la ausencia de un caminar que transitar, puesto que «la debilidad del pensamiento en relación al mundo y, por consiguiente, a la sociedad, representa probablemente un único aspecto del impasse en que el pensamiento ha desembocado al final de su aventura metafísica» ${ }^{566}$. Las propuestas del italiano - «pensamiento débil»-y del polaco -«modernidad líquida»- pasan no por el abandono, sino por la reformulación de la modernidad.

${ }^{565}$ Bauman, Z., Modernidad líquida, op. cit., pág. 63.

566 Vattimo, G. y Rovarti, P. A. (eds.), El pensamiento débil, trad. de Luis de Santiago, Madrid, Cátedra, 2006, pág. 15. 
Tal vez sean éstas, especialmente la de Vattimo, las tentativas que más se aproximan a la posición de Nietzsche. En ellas se ha renunciado a la tradicional imagen de la razón como privilegiada instancia capaz de acceder al ser como fundamento. Bauman redibuja los términos «gramaticales» de la modernidad haciendo de la precariedad el rasgo elemental de la sociedad contemporánea: «la sociedad 'modernidad líquida' es aquella en que las condiciones de actuación de sus miembros cambian antes de que las formas de actuar se consoliden en unos hábitos y en una rutinas determinadas» ${ }^{567}$. Mientras que Vattimo introduce la verdad dentro de la lógica de la hermenéutica, en la medida en que «lo que importa ahora es volver a considerar el sentido de esa aventura y explorar los caminos que permitan ir más allá; es decir, negando precisamente [...] los rasgos metafísicos del pensamiento ${ }^{568}$. Ahora bien, ninguna de las dos posiciones apresa la potencia de la radical reapropiación subjetiva de la existencia de la filosofía de Nietzsche; el filósofo del Zaratustra entabla un compromiso íntimo consigo mismo, mientras la vocación de Vattimo y de Bauman se construye con el otro - «alteridad»- como aspecto fundamental del «yo»:

Nunca antes habíamos sido tan dolorosamente autoconscientes de nuestros actos de elección, realizados ahora en condiciones de una penosa (aunque incurable) incertidumbre y bajo la amenaza constante de "quedarnos atrás» y de ser excluidos del juego sin posibilidad de regresar a él por no haber respondido a las nuevas demandas ${ }^{569}$.

En este pasaje Bauman encuentra el peligro en la amenaza de «quedar atrás» respecto de los otros, el peligro de perder la comunión líquida con los demás sujetos que conforman la sociedad en la cual siguen depositando sus expectativas de sentido. No hay valores fundamentales eternos en el bosquejo de la modernidad de Bauman, pero tampoco puede hablarse de una reapropiación del sentido encarnado de la existencia toda vez que aquél sigue sin remitirse a la radicalidad del sujeto, sino a la configuración abstracta de una sociedad que si bien sujeta a las reglas de la precariedad, continúa arrojando contenido desde avatares suprahumanos. En cuanto al caso de Vattimo, las diferencias esenciales respecto del planteamiento nietzscheano del nihilismo descansan en la apreciación de la verdad hermenéutica. No puede negarse que el conocimiento del italiano de la tradición hermenéutica es sustantivamente mayor que el del filósofo alemán. Sin embargo, su diferencia descansa menos en la conceptualización de la verdad que en la «profesión» de la misma. Ambos coinciden -y entre medias, por supuesto, Gadamer- en el cariz estético de la verdad hermenéutica, esto es, en su dependencia significativa de la apropiación que de ella haga el sujeto por medio de su actividad interpretativa. La distancia esencial entre uno y otro yace en el tiempo y el espacio en que la verdad se concreta: para Nietzsche el tiempo y el espacio se funden en

${ }^{567}$ Bauman, Z., Vida líquida, trad. de Albino Santos Mosquera, Barcelona, Austral, 2014, pág. 9.

568 Vattimo, G. y Rovarti, P. A. (eds.), El pensamiento débil, op. cit., pág. 15.

${ }^{569}$ Bauman, Z., Vida líquida, op. cit., pág. 158. (La cursiva es nuestra). 
una realidad radical única -y «sintética»- inseparable, a saber, la «corporalidad». Es decir, el propio sujeto encarnado es tanto el creador como el legitimador de la verdad; en cuanto a Vattimo, él mismo señala que

el retículo, la red en que nuestra existencia está presa, y nos es dada, es el conjunto de los mensajes que, en el lenguaje y en las diversas «formas simbólicas», la humanidad nos transmite. La filosofía, creo, debe enseñarnos a movernos en la maraña de estos mensajes, haciéndonos vivir cada mensaje singular, y cada singular experiencia, en su indisoluble vínculo con todos los otros, también en su continuidad con ellos, de la cual depende el sentido de la experiencia ${ }^{570}$.

Como se ve, hay una dependencia fundamental de los otros, de la «alteridad», en la concepción de Vattimo de la verdad, sin duda consecuencia de la influencia de Gadamer sobre él. ¿Pero a qué se debe este salto de una concepción hermenéutica privada e íntima a otra, intersubjetiva? Más allá de la profusa investigación de la que gozó la hermenéutica ya mediado el siglo XX, la diferencia está en la «voluntad de poder». Sólo Nietzsche la contempla como elemento esencial de la vida; la voluntad de poder es la capacidad de crear valores, con la matización del «dominio»: la voluntad de poder es voluntad de dominio, esto es, de apropiación de la vida por medio del despliegue de las interpretaciones más vigorosas. La voluntad de poder es desborde, es exaltación mayúscula de la verdad, en tanto que vida. Y la voluntad de poder es privada de cada individuo, ora reactiva ora activa. Ya lo hemos insinuado, y más adelante lo detallaremos, la voluntad de poder como dominio tiene al otro como frontera, mas nunca es un límite como «alteridad» ni como apropiación de sus condiciones. La contemplación que del otro tiene la voluntad de poder es como límite máximamente restrictivo, es decir, la voluntad de poder jamás puede apropiarse de las condiciones de máximo despliegue, o sea, de la voluntad de poder, ajenas; más allá de tal frontera, el otro no es considerado.

Sólo en la filosofía de Nietzsche, toda vez que éste es el único nihilista perfecto habido hasta la fecha, el esfuerzo por la recuperación de la existencia, del sentido íntimo, de la «corporalidad», es máximo y pleno. Es una filosofía de amor y de desprecio: el amor por la existencia encarnada, particular e intransferible, demanda el desprecio de todo elemento externo al propio sujeto.

En las próximas páginas nos proponemos ofrecer un detallado examen del problema del nihilismo tal y como lo conceptualiza Nietzsche, así como sus efectos en las conciencias europeas. El nihilismo, tal y como lo enfrenta Nietzsche, no es tan sólo la situación máximamente decadente de la existencia del continente europeo, sino también el suelo nutricio de nuevas auroras de vida. Tras exponer los rasgos genéricos del nihilismo, trataremos de especificar la venturosa ocasión que percibe el autor tras la deslegitimación de

570 Vattimo, G., Más allá del sujeto, trad. de Juan Carlos Gentile Vitale, Barcelona, Paidós Ibérica, 1989, pág. 11. (La cursiva es nuestra). 
los valores últimos, los porqués que hicieron del estudio nietzscheano de la cuestión algo único, pues sólo en su obra el nihilismo se supera mediante la afirmación absoluta de la existencia encarnada, de la «corporalidad», como medio de reapropiación capital de la conciencia de la experiencia de existencia.

\section{I.1.2. La especificidad moderna: toma de conciencia}

Nietzsche ha rastreado el nihilismo hasta sus orígenes, ha emprendido una labor genealógica que le ha mostrado que no se trata de un acontecimiento genuinamente moderno. La pérdida de los universos valorativos ha sido una constante en la historia, y siempre comportaron pesimismo, angustia y desorientación, a pesar de no haber afectado radicalmente a la dimensión del valor. Sin embargo, sí se atreve a afirmar que la penuria del helenismo tras el derrumbe de la polis griega o la caída del Imperio Romano no compartían los rasgos esenciales de la decimonónica muerte de Dios. La muerte de Dios es la especificidad de la ola nihilista durante la modernidad europea. La gravedad de este suceso descansa en su contenido, pues la asimilación del mismo trae consigo la conciencia de la crisis que se avecina en el horizonte filosófico. Mientras la personalidad de la polis fue suplida por las instituciones de Roma, tras el perecimiento de Dios no se percibe un sustituto capaz de colmar tal hueco: el deceso divino ocurre por agotamiento y hastío, por la imposibilidad de continuar dando significado y sentido a las posibles etapas posteriores; es la más sofisticada expresión del nihilismo al llevar hasta sus últimas consecuencias la deslegitimación de los valores absolutos y su irrecuperable significación: Dios se sitúa frente a un espejo que no le devuelve el reflejo.

En la muerte de Dios no se agota el nihilismo, apenas abarca la totalidad del acontecimiento. Su inestimable contribución pasa por traer a la presencia el problema que subyace en el fondo cultural de Occidente. De modo que desde esta funesta experiencia, la peculiaridad del nihilismo se desdobla: por un lado, la muerte de Dios continúa la desdibujada senda nihilista de la metafísica tradicional que trazaba patrones que desconocían su propia condición esencial -pesimismo; idealismo; positivismo...-, al tiempo que desvela la subrepticia condición nihilista de las tramas valorativas habidas hasta el momento. De manera que el nihilismo es un acontecimiento que ha afectado a todos los individuos occidentales, mas del cual únicamente unos pocos sujetos geniales han logrado tomar conciencia, los ennoblecidos espíritus libres ${ }^{571}$, en cuya revelación descansan las claves activas que pueden extraerse del fin de la metafísica. El nihilismo no se agota en la muerte de Dios, ya que puede continuar creativamente. La conciencia de desvalorización esencial puede desvelar y recuperar la balsámica condición hermenéutica de los hombres para que éstos hagan de la verdad no un objeto de intelección -concepción epistemológica de la verdad, de

${ }^{571}$ Cfr. Nietzsche, F., El Anticristo, op. cit., pág. 29 (KSA VI, 167): «Este libro pertenece a los menos». 
cuño platónico y legado cartesiano-, sino de creación estética -concepción dionisiaca de la verdad-. Aunque también puede el nihilismo continuar reactivamente con el anhelo de conservación de las formas y disposiciones pretéritas, o sea, que a pesar de la muerte de Dios, el hombre occidental aún entraña el riesgo de seguir creyendo en la «gramática».

De manera que la novedad de la muerte de Dios no es tanto su carácter conclusivo de todo anhelo de fundamento metafísico como la comprensión de la vacuidad de dicha búsqueda. El fin de toda pretensión de trascendencia exige, valga la redundancia, la asimilación de su imposible exigencia. Este fenómeno sucede antes de que Nietzsche lo verbalizase. La sintomatología epocal corrobora tal hipótesis: el pesimismo, el exacerbado optimismo $^{572}$, el paroxismo cientificista en el positivismo o el acoplamiento del budismo en la vida humana son diferentes resultados de la matriz cronológica cuyos extremos los cifran el «último hombre» y el «superhombre». Aquél y éste no están respectivamente al comienzo y al final del nihilismo. Ambos parten juntos, en el momento de la conciencia del nihilismo, desde la muerte de Dios. Sus diferencias trazan, no obstante, para cada cual sus propios itinerarios de existencia, con el primero todavía cautivo del régimen sintáctico de la metafísica, pretendiendo, quizá sin comprenderlo, su continuidad bajo las estériles propuestas de la secularización positivista moderna, por cuyo núcleo de certeza, que es la manifestación epocal del idealismo platónico, persiste la disposición eidética de la duplicación y de la escisión; el último, si acaso llegase a existir en algún momento, es la consumación no utópica del artista-filósofo, quien se adueña desde su afirmativa voluntad de poder de la vida encarnada como fuente de experimentación y creación.

Decimos que es una «consumación no utópica» en tanto que la posibilidad y la imposibilidad de la plenitud del superhombre no descansan en avatares ajenos a sí mismo: es la manifestación mayúscula de la vida, es la «corporalidad» asumida radicalmente a través de la manifestación más dura de la voluntad de poder. La reapropiación de la existencia, que es la apropiación de la «corporalidad» y el elogio de la verdad hermenéutica, los cuales muestran la precariedad y la contingencia de la vida, es un propósito real y efectivo, más aún, es necesaria condición de existencia. Sin embargo, precisamente por su insalvable precariedad, la verdad hermenéutica está sumida bajo sus propias máximas devinientes, de tal modo que sus conquistas están necesariamente abocadas a perecer. El superhombre, en cuanto creación hermenéutica, está sujeto a la misma lógica de destrucción eterna. En su falibilidad descansan la imposible posibilidad y la posible imposibilidad del superhombre: al ser la obra estética más cuidada del artista-filósofo no es una hipótesis vacía; por ser, a la vez obra de una expectativa de plenitud, nunca colmará las expectativas de vida encarnada plena, pues ésta está, y ha de estar, siempre en el horizonte de una posibilidad mejor. El

572 Cfr. Nietzsche, F., Fragmentos póstumos III, 13 [1], op. cit., 305 (KSA X, 441): «¿Creéis estar hechos de un tejido mejor, entusiastas? Pero yo os digo que entendéis sólo de vestidos y disfraces: ¡sabéis disfrazar bien vuestra mala tela!». 
superhombre, por tanto es alcanzable e inalcanzable, pues así lo impone la lógica del devenir. Esto no es, en todo caso, una invitación al pesimismo ni al desasosiego: el superhombre no puede ser concretado positivamente, ya que se ha superado el horizonte epistémico de la adecuación; el superhombre es vivencia experimentada en el ejercicio de la propia vida encarnada. En su afirmación de la existencia trágica y de su cualidad hermenéutica, el artista-filósofo vive y mata al superhombre en un ciclo sin fin. Por eso es una consumación no utópica; no aspira a imponer un horizonte formal consumado y definitivo.

El ya mítico inicio del Manifiesto comunista ${ }^{573}$ puede ser parafraseado al respecto. De acuerdo con Nietzsche, el comunismo no es tanto el espectro que recorre Europa como una manifestación de éste. El nihilismo sería la bimilenaria sombra que ha atenazado las fronteras de las conciencias europeas, pues está asentado en la propia experiencia vital de los hombres de este horizonte. La concreción existencial del nihilismo ha afectado la configuración del carácter del hombre, haciendo que el tipo humano europeo no sea concebible sino en términos nihilistas. De este modo explica Nietzsche que hayan triunfado los ideales ascéticos, dado que a un individuo genéticamente nihilista le corresponden códices de pensamiento semejantes en los que mantener su situación de enajenación: la imagen moral del mundo y del hombre, que alumbró las distintas teleologías históricas, como el «progreso»; las definiciones eidéticas de «bueno» $\mathrm{y}$ «malo» como esquemas rígidos a propósito del modo según el cual estar en el mundo y qué esperar del mismo; pero también los bosquejos objetivistas de la realidad, desde la idealidad platónica hasta el positivismo, pasando por la doctrina cartesiana de la adecuación, las cuales proyectaron un retrato del mundo perfilado en unos términos sintácticos ajenos a las reglas lingüísticas de la voz trágica. Ésta habla radicada en la «corporalidad», cuyos términos, etimológicamente opuestos respecto de la lógica de la verdad de la adecuación -la dicha y el dolor, la fortaleza y la debilidad, la belleza y el horror, la vida y la muerte-, se integran solidariamente en la gramática de la verdad trágica de Dioniso. La voluntad de poder, víctima del veneno ascético, se adueñó de valores contrarios a la vida; la voluntad de poder infamemente pervertida en una soez voluntad de la nada, tránsito hacia la obscenidad de la voluntad de muerte:

No podemos ocultarnos a fin de cuentas qué es lo que expresa propiamente todo aquel querer que recibió su orientación del ideal ascético: ese odio contra lo humano, más aún, contra lo material, esa repugnancia ante los sentidos, ante la razón misma, el miedo a la felicidad y a la belleza, ese anhelo de apartarse de toda apariencia, cambio, devenir, muerte, deseo, anhelo mismo -itodo eso significa, atrevámonos a comprenderlo, una voluntad de la nada, una aversión contra la vida, un rechazo de los presupuestos más fundamentales de la vida, pero es, y no deja de ser, una voluntad!... 574 .

573 Cfr. Marx, K. y Engels. F., Manifiesto comunista, trad. de Pedro Ribas, Madrid, Alianza Editorial, 2008, pág. 39: «Un fantasma recorre Europa, el fantasma del comunismo».

${ }^{574}$ Nietzsche, F., La genealogía de la moral, op. cit., pág. 233 (KSA V, 412). 
La efectiva toma de conciencia de la naturaleza de este fantasma es lo que ha permitido a Nietzsche descifrar los secretos esenciales del nihilismo en su historia en general, y en su condición decimonónica, en particular. Nietzsche propone, en su afirmación de la vida, una nueva alternativa ascética arraigada sobre la mundanidad de la existencia encarnada que incide en la esencial fabulación de la verdad hermenéutica como criterio de superación de la individualidad del positivismo nihilista, donde el hombre ha sido definido desde el concepto y no desde su experiencia de existencia. La transvaloración se presenta a los ojos del sujeto moderno como un tenaz ejercicio ascético de endurecimiento, pues los principios desde los cuales se ha de dejar atrás al hombre nihilista distan mucho de su fútil imagen de la felicidad. Si bien en la transvaloración hay elementos conceptuales ascéticos, éstos se antojan relativos; ascéticos para el hombre amaestrado que se ha entregado a narcóticos y fármacos que le proporcionan una frágil sensación de felicidad ${ }^{575}$, la cual no es sino una enajenación de las facetas y los rasgos más dolorosos de la vida. El pesimista, preso de esa voluntad de la nada, ha claudicado de la existencia, hastiado y superado por ella; sus respuestas -el arte romántico, la objetivación trascendental de la moral, el socialismo, etc.- no son tales, sino supuraciones. La pérdida de valor de los valores rectores a la cual condujo la muerte de Dios implica una doble consecuencia que compromete las expectativas de la superación de las viciosas virtudes nihilistas. En primer lugar, el señalado agotamiento vital y el esforzado intento por huir del dolor del pensamiento pesimista; y, en inmediata continuidad con el anterior momento, que la comprensión de la estructural condición nihilista del tiempo presente se yerga losa demasiado pesada para las conciencias y acaben renunciando éstas a la tarea de la superación. He aquí el problema con el que han de lidiar los hombres superiores, a los cuales Zaratustra ha señalado, «pues sufrís por vosotros, no habéis sufrido aún por el hombre» ${ }^{576}$ : «ninguno habéis aprendido a bailar como hay que bailar» ${ }^{577}$. En la venenosa tentación de la embriaguez de los remedios pesimistas bien podría apacentar eternamente el hombre. El epocal pesimismo es muy pesado y amenaza con abotargar y atenazar la ligereza de los espíritus singulares que habrían de emprender la transvaloración. No es extraño entonces el intento último del adivino por seducir a Zaratustra, momento que ya recordamos con anterioridad:

Oh vosotros hombres superiores, vuestra necesidad fue la que aquel viejo adivino me vaticinó ayer por la mañana, -

- a acudir a vuestra necesidad quería seducirme y tentarme: oh, Zaratustra, me dijo, yo vengo para seducirte a tu último pecado.

575 Cfr. Nietzsche, F., Fragmentos póstumos III, 31 [29], op. cit., 680 (KSA XI, 367): «- nosotros nos ponemos en peligro y nos entregamos más que nada al dolor, al sentimiento de la privación: nuestro ateísmo es una búsqueda de infelicidad, para la que la especie vulgar de hombre no tiene en el cuerpo ninguna comprensión».

${ }^{576}$ Nietzsche, F., Asi habló Zaratustra, op. cit., pág. 393 (KSA IV, 359).

577 Ibid. pág. 400 (KSA IV, 367). 
¿A mi último pecado?, exclamó Zaratustra y furioso se rió de sus últimas palabras: ¿qué se me había reservado como mi último pecado?

- Y una vez más Zaratustra se abismo dentro de sí y volvió a sentarse sobre la gran piedra y reflexionó. De repente se levantó de un salto, -

¡Compasión! ¡La compasión por el hombre superior!, gritó, y su rostro se endureció como el bronce ${ }^{578}$.

En decidida oposición contra los bálsamos que buscan dulcificar el torrente salvaje que es el mundo, Nietzsche defiende sin contemplaciones el favorecedor efecto de un nihilismo que se ha hecho presente y del que, por tanto, cabe la reflexión. Los espíritus más aventureros y fuertes, aquellos que se han endurecido, hallarán la piedra filosofal que transmute la experiencia del nihilismo en una emanación de fuerza: la nueva aurora de la humanidad llega por el ocaso de la precedente. Los «hiperbóreos», aquellos lo bastante ligeros como para zafarse de la pesada y abotargada carga de su tiempo, nacen entre los agonizantes desorientados hombres modernos como el albor de un original tipo humano que haga propia la creación de la vida, esto es, que la transmute para contemplarla como un fenómeno estético.

La asimilación en la centuria decimonónica de la especificidad nihilista de este siglo es condición necesaria para la transvaloración, momento último de la superación de las formas de la metafísica clásica, de Dios y, especialmente, de su «gramática». Y si bien se ha incidido en el perfil ascético de la transvaloración, tampoco se ha de esperar que ofrezca Nietzsche un contenido concreto de la misma. Sin embargo, no debe pensarse en ella como si fuese un recurso kantiano de vaciamiento; no cabe una determinación conceptual de la transvaloración, pues ésta, en connivencia con el devenir trágico del mundo, está necesariamente abierta al futuro y al flujo de su propia lógica dionisiaca de decadencia para procurar los cimientos de posteriores transvaloraciones que han de venir. La transvaloración no es una disposición objetiva que prescribe formalmente el espíritu y de la que cabe dar una definición categorial positiva, sino una experiencia de existencia encarnada donde las dimensiones consciente e inconsciente se integran sintéticamente en la esforzada vindicación de una voluntad de poder afirmativa. Es el superhombre una meta siempre pendiente, una «consumación no utópica», una utopía no formalmente normativa, ya que se han superado las historiografías escatológicas. Por lo que los grandes conceptos nietzscheanos, como la «transvaloración» o el «superhombre» son intempestivos.

No es, por tanto, el comunismo el fantasma de Europa, sino el nihilismo.

${ }^{578}$ Ibid. pág. 441 (KSA IV, 408). 


\section{I.1.3. La psicología nihilista en la modernidad}

Nietzsche insistió en la necesidad de que el nihilismo fuera superado, al tiempo que tal conquista había de acontecer desde la misma experiencia nihilista, cuya asimilación activa facultaría la transformación de tan penoso suelo sobre el que la tradición occidental había hundido sus raíces en un fértil vergel. De manera que su caracterización de este acontecimiento no arroja dos manifestaciones diferentes, sino dos prismas aproximativos diferenciados del mismo fenómeno. Uno, pasivo y paralizante tras ser partícipes del horror de la desvalorización; otro, activo y que culmina el acontecimiento de pérdida de los ideales trasmundanos para devenir fuente de creación estética de nuevos valores no ideales, sino trágicos, hermenéuticos. En este paradigma activo sucede una transmutación de la valoración ontológica de la realidad: el nihilismo trajo a escena el carácter fabulado de la verdad, mas en lugar de sentirse afligido por la esencial constitución ficticia del valor, la abraza y toma como nuevo marco en el cual se desplegará el tiempo postmetafísico: el tiempo de la voluntad de poder, cuando se ha asumido que ésta, la capacidad valoradora humana, es la esencia de la vida, esto es, la experiencia de la vida como esencia de sí misma. El difícil engranaje de la transvaloración se inicia desde la aventura creativa que ofrece el nihilismo, en cuya dinámica la verdad y el valor se transforman radicalmente; no se trata de una inversión del contenido de tales valores, sino de una reconversión absoluta de la forma y la concepción de valorar: valor y verdad se imbrican reflexivamente, en la medida en que la verdad de la vida es el agotamiento de la valoración, la valoración crea la verdad. En la transvaloración tiene lugar, entiende Nietzsche, el momento que faculta la reapropiación de la existencia encarnada, puesto que en ella se comprende que la verdad es trágica, dionisiaca. La vida es voluntad de poder.

La figura de Nietzsche está muy lejos de la del mero enciclopedista de la historia de la filosofía que, desde una metaposición estéril, no tiene otra pretensión que la del cifrado y la datación del discurrir de los avatares del pensamiento. En su minucioso estudio, en todo momento vertebrado sobre la muerte de $\operatorname{Dios}^{579}$, hay una detallada descripción del perfil psicológico de los múltiples hombres nihilistas, desnudando sus debilidades con el fin de rebasarlas definitivamente, de endurecer las conciencias de los hombres que han de advenir en la nueva era de la voluntad de poder.

De la modernidad hemos destacado su enorme esfuerzo por secularizar el orden del mundo; la emancipación de las leyes de la naturaleza de la cosmología divina o la pretendida independencia de la determinación moral de fuentes externas al sujeto - ¿quizá

${ }^{579}$ Cfr. Nietzsche, F., Fragmentos póstumos IV, 11 [327], op. cit., 457 (KSA XIII, 139): «el ateísmo como ausencia de todo ideal».

Partir de la experiencia de la muerte de Dios es algo esencial también para Heidegger, quien a propósito del nihilismo como el final de la metafísica ha destacado que ues el comenzar a tomar en serio el ‘acaecimiento' de que ‘Dios ha muerto’» (Heidegger, M., Nietzsche, op. cit., pág. 551.). 
Kant?-. Uno de los resultados más inmediatos de este nuevo período fue la aparición de movimientos filosófico-científicos cuyas consideraciones últimas concluían en una apostasía del orbe religioso. Algo especialmente evidente durante la Ilustración. De modo que no ha de extrañar que los ateos sean los primeros personajes dentro del nihilismo moderno a los que estudie Nietzsche. Los «simples» ateos, que conforman el grueso de las personalidades modernas, no constituyen en sí una gran cuestión para el autor, toda vez que su episteme se ha mantenido incólume tras el derramamiento de la sangre divina; han dejado de creer en el Dios de la tradición al tenerlo por una instancia imposible, pero «han mantenido su gramática». Conservan los viejos altares, donde han puesto nuevos ídolos de deidades seculares: el Estado, la propaganda o la propiedad. Este sujeto, que Nietzsche recoge dentro del tipo de «Thomas Carlyle», «es un ateo que no quiere serlo» ${ }^{580}$.

Como cabe esperar, la respuesta de Nietzsche ante este primer modus de personaje nihilista pasa por incorporar como criterio existencial la muerte de Dios; tras el derramamiento de la última gota de la sangre de aquella instancia negadora de la vida encarnada, el hombre es facultado nuevamente para afirmarse. Un hito clave para la transvaloración, pues al fin de los valores eidéticos, supramundanos e inhumanos, ha de seguirle la instauración de un nuevo sustrato valorador, el cual no habrá de entrar en conflicto con la «corporalidad», sino emanar de ella. El hombre como creador y legitimador, como fuente de valoración: el hombre, como voluntad de poder, se presenta tras el nihilismo.

El pesimismo llega tras comprender la repercusión del ateísmo, cuando el hombre moderno contempla a sus nuevos ídolos y no halla consuelo ni sentido en ellos. Han perdido toda razón de vida y por ello dan la espalda también al mundo. Así lo dicta su «moral», que, como en Schopenhauer ${ }^{581}$, invita a la inacción más abúlica al tiempo que induce a la compasión universal:

Este cansarse-de-la-existencia, esta voluntad de no-querer-más, la quiebra del querer propio, del bien propio, $<$ del $>$ sujeto (en cuanto expresión de esta voluntad inversa) - esto y ninguna otra cosa quería Schopenhauer que se honrase con el honor supremo: lo llamó moral ${ }^{582}$.

Nietzsche se pregunta cómo «un pesimista, un negador de Dios y del mundo, que se detiene ante la moral, -que dice sí a la moral [...], a la moral del laede neminem [no dañes a nadie]: ¿cómo?, ¿es propiamente - un pesimista?» ${ }^{583}$. Interrogante éste que no debe inducir a los necios equívocos del siglo XX que bosquejaron a Nietzsche como un ávido

${ }^{580}$ Nietzsche, F., Fragmentos póstumos IV, 11 [45], op. cit., 378 (KSA XIII, 22).

${ }^{581}$ Cfr. Nietzsche, F., Fragmentos póstumos III, 39 [15], op. cit., pág. 841 (KSA XI, 626): «Instintivamente se aferran con los dientes, cuanto más irreligiosos son, a las estimaciones de valor morales».

${ }^{582}$ Nietzsche, F., Fragmentos póstumos IV, 2 [197], op. cit., pág. 136 (KSA XII, 163-164).

${ }^{583}$ Nietzsche, F., Más allá del bien y del mal, op. cit., pág. 125 (KSA V, 107). 
amante de la guerra y la muerte. La negación de la moral de la compasión universal no lleva, así lo presentamos anteriormente, a afirmar una opuesta, pues la transvaloración de todos los valores, además, no consiste en una burda inversión de los contenidos del valor. La negación nietzscheana actúa sobre la conformación misma de la moral: no es compatible con la vida una moral que legisla con ínfulas de realidad trascendental. El pesimista schopenhaueriano, al que nada queda y que se entrega ciegamente a la moral de un mundo vacío, es el tipo humano que se aferra a las redes de la «gramática»; de una gramática que se ha quedado sin sujeto.

El pensamiento pesimista tiene una doble matriz. Éste descrito se corresponde con la burguesía romántica, que busca acomodo en el éxtasis ensoñador de esta corriente. Sin duda el caso de Wagner es paradigmático ${ }^{584}$.

La segunda vertiente del pesimismo es la de aquellos espíritus fatalmente descorazonados que no pueden encontrar consuelo tampoco en la embriaguez de la orgía romántica. El nihilismo ha profundizado de modo tan abismal que la desesperación de los tiempos se ha vuelto en ellos mayúscula. Privados ya de toda fuerza de vida, han claudicado, dejándose arrastrar por una pasividad estructural que sólo teme: ya no sólo la voluntad de poder, que es facultad hacia la vida mejor, ha sido aniquilada, sino que la nihilista voluntad de vida, que sólo busca apropiarse de las condiciones de autoconservación, ha sido colonizada enteramente por la voluntad de nada. La experiencia de la desvalorización no es en ellos motor de esperanza de reapropiación; ni siquiera contempla la enajenación bimilenaria, sólo el desnortado extravío de un «mundo aparente» que se conserva a pesar del fin del «mundo verdadero». Este sujeto desestructurado está recogido en el tipo del «último hombre», tan nauseabundamente superficial que sacrifica la verdad dionisiaca que se manifiesta ante sus ojos y el prometedor futuro esperanzador del superhombre en beneficio de su execrable supervivencia:

Voy a hablarles de lo más despreciable: el último hombre.

[...] ¡Mirad! Yo os muestro el último hombre.

“¿Qué es amor? ¿Qué es creación? ¿Qué es anhelo? ¿Qué es estrella?” - así pregunta el último hombre, y parpadea.

La tierra se ha vuelto pequeña entonces, y sobre ella da saltos el último hombre, que todo lo empequeñece. Su estirpe es indestructible, como el pulgón; el último hombre es el que más tiempo vive.

"Nosotros hemos inventado la felicidad" - dicen los últimos hombres, y $\operatorname{parpadean}^{585}$.

\footnotetext{
${ }^{584}$ Cfr. Nietzsche, F., Fragmentos póstumos III, 41 [2], op. cit., pág. 873 (KSA XI, 676): «[...] el juego absolutamente sucio con los símbolos cristianos y las miradas de reojo a dichos símbolos - ¡Wagner, el viejo ateo, antinomista e inmoralista, llega a invocar lleno de unción la 'sangre del redentor'! [...]; y todo esto en un alemán, un auténtico alemán de ciénaga, oscuro y exagerado, ¡como quizá ni siquiera lo hayan logrado los discípulos de Hegel más hostiles al alemán».
}

${ }^{585}$ Nietzsche, F., Así habló Zaratustra, op. cit., pp. 40-41 (KSA IV, 19). 
En el último hombre la decadencia fraguada durante más de dos mil años de tradición metafísica se ha concretado máximamente. No hay fertilidad en este tipo humano, sólo hundimiento y rechazo, injuria y desconfianza, deseo de venganza contra todo lo grande: «mas su estrecha alma — reza sobre ellos Zaratustra — piensa: 'culpable es toda gran existencia'» ${ }^{586}$.

Nada cabe esperar ya del último hombre. Las condiciones de superación del nihilismo pasan y no pasan por esta figura. Si bien de su atrofia no puede libarse fruto alguno, su pavorosa imagen, su degenerada voluntad de poder de la que emanan valorizaciones débiles y putrefactas arrojan el reflejo de cuanto el hombre superior ha de despreciar para que de él emerja el superhombre.

Y a lo largo del abanico de las psicologías nihilistas, en su cierre se vislumbran las puertas del superhombre en el tipo del «hombre superior» quien, hastiado de las virtudes elogiadas por la moral de «los justos y buenos», las deja atrás para poder apuntar hacia nuevas máximas, estéticas, que contrarias a las del cosmos moral, no buscan la conservación acomodaticia a partir de una reducción eidética, sino que exigen el duro compromiso de excelencia de una vida siempre mejor: el hombre superior renuncia a las manifestaciones más dichosas de «los buenos», ya que son demasiado triviales, demasiado fútiles y vacuas como para colmar sus pretensiones de plenitud. La filosofía del cuidado hace del artificio humano el más bello producto, pues integra al artista en la obra: el hombre superior es la puerta que abre al superhombre, o sea, al artista-filósofo cuyo refinamiento contempla con «desprecio» los blandos placeres y las pequeñas felicidades de los tipos humanos habidos hasta el momento. En sus propias amarguras encuentra más dicha que en los goces plebeyos. Por lo que si el hombre quiere ser ascendente del superhombre, del hombre sintético, del artista-filósofo en quien cuerpo y espíritu se han armonizado solidariamente, ha de ser cruel: la dureza y la crueldad del espíritu son cualidades necesarias para soportar las tentaciones nihilistas, como la satisfacción de la comodidad inmediata o la compasión por los despreciables hombres de su tiempo:

En el hecho de que hayáis desesperado hay mucho que honrar. Porque no habéis aprendido cómo resignaros, no habéis aprendido las pequeñas corduras.

Hoy, en efecto, las gentes pequeñas se han convertido en los señores: todas ellas predican resignación y modestia y cordura y laboriosidad y miramientos y el largo etcétera de las pequeñas virtudes.

Lo que es de especie femenina, lo que procede de especie y servil y, en especial, la mezcolanza plebeya: eso quiere ahora enseñorearse de todo destino del hombre ¡oh náusea!, ¡náusea!, ¡náusea!

Eso pregunta y pregunta y no se cansa: «¿Cómo se conserva el hombre, del modo mejor, más prolongado, más agradable?» Con esto - ellos son los señores de hoy.

586 Ibid. pág. 92 (KSA IV, 67). 
Superadme a estos señores de hoy, oh hermanos míos, - a estas gentes pequeñas: ¡ellas son el máximo peligro del superhombre!

¡Superadme, hombres superiores, las pequeñas virtudes, las pequeñas corduras, los miramientos minúsculos, el bullicio de hormigas, el mísero bienestar, la «felicidad de los más»-!

$\mathrm{Y}$ antes desesperar que resignarse. $\mathrm{Y}$, en verdad, yo os amo porque no sabéis vivir hoy, ¡vosotros hombres superiores! Ya que así es como vosotros vivís - ¡del modo mejor! ${ }^{587}$.

El hombre superior ve en la muerte de Dios la liberación de los ya oxidados grilletes que atenazaron la existencia. En su espíritu libre refulge la aurora del nuevo tiempo en el que los valores humanos habrán sido superados en favor de una nueva configuración vital estética. Ahora bien, también exige Nietzsche cautela con los hombres superiores, pues corren el riesgo de extraviarse en la hipertrofia de su libertad ${ }^{588}$. Zaratustra confronta a su sombra, advirtiéndole del peligro en que ésta ha incurrido, a saber, que además de su meta ha perdido el camino:

Así habló la sombra, y el rostro de Zaratustra se fue alargando al escuchar sus palabras. «iTú eres mi sombra!, dijo por fin con tristeza.

Tu peligro no es pequeño, ¡tú espíritu libre y viajero! Has tenido un mal día: ¡procura que no te toque un atardecer aún peor!

A los errantes como tú, incluso una cárcel acaba pareciéndoles la bienaventuranza. ¿Has visto alguna vez cómo duermen los criminales encarcelados? Duermen tranquilamente, disfrutan su nueva seguridad.

¡Ten cuidado de no caer, al final, prisionero de una fe más estrecha todavía, de una ilusión dura, rigurosa! A ti, en efecto, ahora te tienta y te seduce todo lo que es riguroso y sólido.

Has perdido la meta: ay, ¿cómo podrás librarte de esa pérdida y consolarte de ella? Al perder la meta - ¡has perdido también el camino! ${ }^{589}$.

El peligro que debe salvar el hombre superior es su propia libertad, que no ceda al libertinaje. La pérdida de Dios no debe ser resuelta entregándose a un nuevo ídolo cualquiera colmado de solidez, pues supondría el retorno a las pretéritas manifestaciones del nihilismo. Por eso la llegada del nuevo sol no puede depender del espíritu libre; a éste le es lícito servir de suelo nutricio, y nada más. El hombre superior se posiciona activamente en el nihilismo, pero no encierra en sí la conclusión:

A mi obra quiero ir, — confiesa Zaratustra - a mi día: mas ellos [los hombres superiores] no comprenden cuáles son los signos de mi mañana, mis pasos - no son para ellos un toque de diana.

587 Ibid. pág. 391 (KSA IV, 357-358).

${ }^{588}$ Cfr. ibid. pág. 372 (KSA IV, 340): «"Nada es verdadero, todo está permitido”», se dice el espíritu libre.

${ }^{589}$ Ibid. pág. 373 (KSA IV, 341). 
Ellos duermen todavía en mi caverna, sus sueños siguen rumiando mis mediasnoches ${ }^{590}$.

La libertad no es suficiente por sí sola; es el más alto valor para Nietzsche, la meta más elevada de toda su filosofía: la libertad de los hombres de los avatares -eidéticos- que habían constreñido las conciencias y enajenado la existencia en cárceles ideales. Sin embargo, la libertad es una empresa de ardua dificultad para la cual no basta el deseo, sino el más incólume compromiso: la responsabilidad ${ }^{591}$. El hombre superior, ebrio de libertad, puede perecer en su desbordado derroche si dejase de contemplar la libertad desde la dimensión del cuidado. Del mismo modo que Dios murió oprimido por su propia compasión ${ }^{592}$, por su exceso de compasión, el hombre superior puede perecer por una exacerbación análoga, la de una libertad desbocada a la que no ha podido encauzar en su proyecto de una nueva vida encarnada. Si olvida el compromiso consigo mismo, la responsabilidad, la luz del hombre superior se apagará y su existencia continuará escindida de su «corporalidad»: la libertad irredenta no es clave de plenitud existencial, sino de autoconservación y vana placidez inmediata. En el hombre superior están tanto las auroras del superhombre como la bajeza de un espíritu anarquista que ni siquiera escucha su pulsión estética de existencia de la mejor vida posible.

El nihilismo activo afirma en su negación, rechaza cuanto existe y en su desprecio está su fuerza creadora, que no teme la incertidumbre de la verdad trágica, a saber, su fondo oscuro de inconsciencia abierto a la pluralidad perspectivista de posibilidades de existencia que habrán de concretarse en la determinación particular -de cada sujeto concretode las ilimitadas posibilidades de ser a través del juego de valoración y jerarquización de la voluntad de poder, que es la vida encarnada. Al explotar la muerte de Dios como fuente de emancipación la verdad metafísica se ha transmutado; ha fenecido como tal y desde ella se ha redescubierto el fondo de la verdad primigenia de Dioniso, de carácter existencial y no epistémico. La integración favorable de la conciencia del nihilismo en la experiencia filosófica del europeo habrá de volver a hacer de la verdad la cuestión fundamental de la vida. Una verdad que, sin embargo, es genuina y radicalmente distinta de la legada por el platonismo. La verdad, como hemos indicado, es la propia voluntad de poder como condición valoradora del hombre, por un lado; la verdad como producto de la voluntad de poder que se ha adueñado de ella en virtud de su cariz existencial, por otro. Que la voluntad de poder se apropie de la verdad significa transmutarla desde la epistemología en la hermenéutica. Con todo, Nietzsche ha introducido la verdad en el espectro de la creación humana; hacer

${ }^{590}$ Ibid. pág. 438 (KSA IV, 405).

591 Recuérdese que en la primera parte del trabajo vinculamos la «libertad» y la «responsabilidad» como dos afectos imprescindibles e inseparables de la empresa del cuidado para llegar a «ser lo que se es».

592 Idea que ya expusimos, no obstante, cuando tratamos la cuestión de la «compasión». Cfr. ibid. pág. 142 (KSA IV, 115): «'Dios ha muerto; a causa de su compasión por los hombres ha muerto Dios’». 
de la verdad una creación humana significaría, con todo, hacer de la vida una creencia humana. Es decir, la verdad hermenéutica brinda la ocasión al hombre de ser él mismo la fuente de sentido de su ser y del mundo. «Lo decimos una vez más: ¡cuántos dioses nuevos son aún posibles! - Zaratustra mismo, ciertamente, no es sino un viejo ateo. ¡Entiéndasele bien! Zaratustra dice, en efecto, que él creería —; pero Zaratustra no creerá ...» ${ }^{593}$, pues ha superado las reglas de la «gramática».

El estudio del fenómeno del nihilismo ha tenido dos grandes figuras cuyas investigaciones permitieron comprender dicho acontecimiento desde dos trayectorias diferentes e incompatibles entre sí, Nietzsche y Heidegger. Anteriormente discutimos los rasgos específicos de los trabajos de ambos de autores, así como las implicaciones gnoseológicas de cada meandro. Heidegger lo contempla como un problema netamente metafísico, mientras que para Nietzsche es una cuestión existencial que alude a las consecuencias morales de los contenidos atribuidos a los valores. Desde la posición heideggeriana resulta difícil, si no imposible, la reapropiación de la existencia después del factum nihilista, ya que ésta no es contemplada primariamente dentro de la reflexión de Heidegger. Sus miras apuntan a la historia del ser y su relación antitética con el ente. Por el contrario, un nihilismo preocupado fundamentalmente por la existencia alberga la doble posibilidad de una aquiescencia vital que se ciñe a la inercial autoconservación del sujeto que se ha resignado y de otra, muy distinta en sus cualidades, capaz de vigorizar la voluntad de poder en aras de una original experiencia de existencia que apunta a una vida plena, la del artista-filósofo, la del superhombre que tras la desvaloración fundamental adquiere el compromiso de procurarse sus propias metas y fines confiriéndoles sentido en su propia realización del proyecto estético de llegar a «ser lo que se es».

En su estudio del nihilismo Heidegger acusaba a Nietzsche de no haber sido capaz de llegar hasta el núcleo del problema, hasta la esencia del nihilismo y, por consiguiente, de no haber planteado la cuestión en toda su radicalidad, esto es, como cuestión metafísica. Sin embargo, Heidegger parece no haber comprendido que el recurso a una inicial posición metafísica es imposible en Nietzsche toda vez que su deconstrucción filosófica ha inhabilitado toda ocasión de un retorno a instancias metafísicas.

La caracterización ofrecida por Nietzsche del nihilismo como desvaloración fundamental del horizonte de Occidente afecta, como hemos insistido, al plano existencial en toda su envergadura, y al dominio moral, en particular. La cuestión moral es especialmente relevante, ya que ésta trazó el sentido del rumbo de la tradición bimilenaria: la concepción moral del mundo, como lo llamó Nietzsche. Las consecuencias de la crisis de valores finisecular serían concretadas sintéticamente en la celebérrima sentencia de que Occidente ha perdido su brújula, esto es, ha sido privado de toda guía, de sus metas. De modo que el

593 Nietzsche, F., Fragmentos póstumos IV, 17 [4], op. cit., pág. 699 (KSA XIII, 526). 
desconcierto moral del hombre decimonónico, que lo había conducido a una situación de incapacidad de acción significativa en el mundo, hunde sus raíces en el problema radical de una existencia desnortada separada esencialmente de su estar en el mundo. Y es en esta cardinal unión del nihilismo moral con la existencia donde reside tanto la afección reactiva como la activa de la experiencia del nihilismo: la continuación de un régimen de vida decadente que falto de sentido y «brújula» no tiene ya otra aspiración que la manutención fisiológica del organismo o bien el compromiso duro con la existencia encarnada, el empeño artístico-filosófico por imbricar la conciencia y la experiencia en un único fenómeno sintético de rasgos estéticos, la «corporalidad», donde la inoperancia del extravío moral se supera mediante el «dominio» de las fuentes de valoración. El superhombre liba la fuerza afirmativa de la experiencia nihilista desde el asentamiento de su propia radicalidad empírica. A continuación procederemos a mostrar las facetas reactiva y activa del nihilismo.

\section{I.1.3.1. El nihilismo reactivo}

Como desvalorización de los valores supremos de la tradición occidental esta disposición es la primera y más inmediata respuesta ante tamaño acontecimiento. Es la consumación del hastío de los espíritus europeos tras los sucesivos siglos de ensoñación metafísica: la pérdida de la individualidad en la nada de las instancias eidéticas y el consumo de «narcóticos» para paliar la angustia y el dolor de la existencia. Así se ha desplegado hasta el momento el nihilismo, como una pauperización constante y creciente del vigor y del poder del espíritu humano, agotándose definitivamente en la pérdida de las metas que la razón metafísica había trazado escatológicamente en la historia de la episteme europea:

\footnotetext{
Nihilismo como descenso y retroceso del poder del espíritu: el NIHILISMO PASIVO:

como un signo de debilidad: la fuerza del espíritu puede estar cansada, agotada, de manera tal que las metas y los valores existentes hasta el momento son inadecuados y no encuentran ya crédito -

que se disuelve la síntesis de valores y metas (sobre la que descansa toda cultura fuerte), de manera tal que los diferentes valores se hacen la guerra: descomposición que todo lo que reconforta, cura, anestesia, pasa al primer plano, bajo diferentes disfraces, con carácter religioso, o moral o político o estético etc ${ }^{594}$.
}

El nihilismo es, desde esta acepción, una patología, una enfermedad, una atrofia muscular donde las fuerzas de la voluntad de poder no gozan del vigor ni de la salud necesarias para engendrar una acción afirmadora. De manera que sólo queda la reacción, esto es, la somnolencia y la parálisis de una afección rencorosa con la vida que responde a su incapacidad por afirmarla con una alternativa despectiva de rechazo y negación, porque el no ser ha de prevalecer sobre el ser.

${ }^{594}$ Ibid. 9 [35], pág. 242 (KSA XII, 351). 
Esta concreción del nihilismo recorre todas las diferentes concreciones y afecciones del nihilismo. Arrastra consigo la pulsión que anhela volver a la «gramática» de lo trascendente, pues juzga peyorativamente la nueva situación de la desvalorización fundamental al compararla con su predecesora. El decadente y blando hombre reactivo añora los antiguos ídolos y se ve tentado a postrarse una vez más ante ellos, como el viejo papa, que prefiere adorar a Dios, aun bajo la forma de un asno, que permanecer en una existencia privada de significado ulterior ${ }^{595}$. Zaratustra juzga con máxima gravedad a estos sujetos, «sois los peores blasfemos o las más tontas de todas las viejecillas» ${ }^{596}$. La empresa de la búsqueda de sentido para la existencia no admite sin concesiones cualquier fuente dadora de valor; no es lícito afrontar el fondo trágico de cualquier modo, pues la fe del viejo papa es tan vergonzosa ${ }^{597}$ como la monótona del Dios muerto: «todos esos corazones jóvenes se han vuelto ya viejos, - ¡y ni siquiera viejos!, sólo cansados, vulgares, cómodos: - dicen "hemos vuelto a hacernos piadosos" $\gg{ }^{598}$. El nuevo horizonte de sentido, sumido en una constante tensión de determinación, no puede seguir postulando las pretéritas divinidades de la conciencias epistémica; las fuentes de valor del renovado horizonte trágico deben atentar contra las antiguas sacralidades. De no ser así, la amenaza del nihilismo podría invocar nuevamente avatares «morales» contrarios a la «corporalidad», como la piedad; el nihilismo reactivo puede envilecer, atrofiar y envejecer los espíritus occidentales. Y es que la transmutación de la experiencia del nihilismo en fuente de afirmación es algo únicamente posible para los espíritus robustos y vigorosos, en quienes hay sobreabundancia de fuerzas.

Es la del «viejo papa» una respuesta cobarde nacida del agotamiento. Los hombres se inclinan ante un «sí» que no es afirmador, sino un rebuzno onomatopéyico - «IA»-. El jumento ante el cual se postran aún trata de redimir el fondo de la existencia, pues palidece ante la salvaje mirada de Dioniso, cuya genuina afirmación significa renunciar al empeño por exonerar la vida de su injustificable devenir del que no cabe dar respuestas esclarecedoras, sino abordarlo y ejecutarlo desde la posición hermenéutica de la verdad de la voluntad de poder.

Vivir y valorar están íntimamente ligados, por lo que la muerte de Dios nunca supondrá una pérdida estructural de valores; no es una voluntad de nada de valores. Sin embargo, sí ha sido distintivo del nihilismo que la voluntad de poder propusiese unos valores

\footnotetext{
595 Cfr. Nietzsche, F., Así habló Zaratustra, op. cit., pág. 423 (KSA IV, 390): «Y tú mismo, tú viejo papa, ¿cómo cuadra contigo el que adores de tal modo aquí a un asno como si fuese Dios? -

Oh Zaratustra, respondió el papa, perdóname, pero en asuntos de Dios yo soy más ilustrado que tú. Y ello es justo.

¡Es preferible adorar a Dios bajo esta forma que bajo ninguna!».

${ }^{596}$ Ibid. (KSA IV, 390).

${ }^{597}$ Cfr. ibid. pág. 258 (KSA IV, 227): «¡Pero rezar es una vergüenza! [...] ¡Para $t i$ es una vergüenza rezar!».
}

598 Ibid. pág. 256 (KSA IV, 226). 
por los cuales, a causa de su origen temeroso y hastiado, la vida fuese diezmada y se pergeñara una estrategia salvífica que apuntaba a evitar el sufrimiento en lugar de abrazar la vida en su totalidad: «la moral y la civilización buscan 'menos dolor', pero no 'más felicidad'» ${ }^{599}$. El nihilismo ha contaminado la cultura europea, proteccionista y pasiva; el nihilismo es la concreción del «cristianismo» como cultura del tipo humano occidental ${ }^{600}$. En su huida de la decadencia de la tradición bimilenaria de la duplicación de mundos, no se permite Zaratustra caer presa de la molicie de la civilización: «un nómada soy yo en todas las ciudades» ${ }^{601}$. La moral y la civilización occidental buscaron atemperar el dolor, sofocar las inclemencias que pudieran poner en riesgo la integridad de los individuos. Esta estrategia se correspondía menos con una tentativa evasiva de un aspecto insalvable de la vida-el sufrimiento- que con un posicionamiento absoluto en el mundo: el esfuerzo por sustraer un aspecto de la vida, aunque sea éste nocivo y dañino, es, finalmente, un rechazo de la vida en general, pues ésta no puede continuar escindida por más tiempo entre un elogioso reino -ideal- del «bien» y de «justicia» y otro -aparente-, de «decadencia», de «finitud»y de dolor. El «mal» coyuntural que pudiese afectar la existencia no ha de ser redimido ni en instancias eidéticas ni en estrategias reactivas como el desdoro de la apariencia o el agotamiento del espíritu por la compasión misericordiosa de la que sufre. El bienestar inmediato colma las expectativas mundanas de los enfermos que sólo aspiran a la autoconservación. Esta estrategia es la que condujo la moral europea durante milenios, a saber, el desprecio de la vida en su totalidad a causa de sus rasgos más tenaces y sofocantes; la compasión fue la puesta efectiva en escena del desprecio: el reconocimiento universal de las conciencias en su pesar existencial. Dice Nietzsche que estos sujetos no pueden aspirar a la felicidad, pues ésta suspira por algo demasiado grande para ellos, la plenitud de la vida trágica que acoge tanto lo bello como lo horrendo.

No hay redención de la vida en la filosofía nietzscheana, pues ésta no es culpable de mal alguno. En ella hay reapropiación y recuperación de todos los avatares de la existencia por medio de la sobreabundancia de fuerzas: los espíritus duros y vigorosos se han reencontrado en su radicalidad trágica, que les hace comprender la vida como una peculiar experiencia mística donde lo espiritual y lo corporal devienen unidad sintética que recoge en toda su envergadura el pesar y la alegría. Zaratustra escapa de la adocenada y «piadosa» civilización occidental, pues rechaza su tentativa de escisión y de duplicación; Nietzsche no pretende la autoconservación, sino el éxtasis desbordante de la existencia encarnada. Por ello acoge los tradicionales conceptos de «bien» y de «mal», los cuales ha transforma-

${ }^{599}$ Nietzsche, F., Fragmentos póstumos II, 3 [25], op. cit., pág. 519 (KSA IX, 54).

${ }^{600}$ Cfr. Nietzsche, F., El Anticristo, op. cit., pág. 49 (KSA VI, 185): «¡Dios, degenerado a ser la contradicción de la vida, en lugar de ser su transfiguración y su eterno sí! ¡En Dios, declarada la hostilidad a la vida, a la naturaleza, a la voluntad de vida! ¡Dios, fórmula de toda calumnia del 'más acá', de toda mentira del 'más allá'! ¡En Dios, divinizada la nada, santificada la voluntad de nada!...».

${ }^{601}$ Nietzsche, F., Así habló Zaratustra, op. cit., pág. 184 (KSA IV, 155). 
do significativamente para presentarlos como rasgos no incompatibles, sino esenciales de la vida. Nietzsche se sitúa, de este modo, más allá del bien y del mal para integrarse en una existencia reapropiada y libre de avatares de culpa, de remordimiento y de perdón. Pretende Nietzsche la felicidad que sólo procura la plenitud de la obra estética de llegar a «ser lo que se es». El dolor se transmuta en una experiencia de felicidad, pues se sufre sólo en tanto que se vive. No es una redención de la existencia encarnada en ideales supramundanos, sino la imbricación de la dicha y la amargura como condiciones típicas de la felicidad como obra estética de existencia del artista-filósofo. Frente a la piedad legada por la civilización, que ha pasado por cercenar la vida en su plenitud y hacer de ello «bien» moral, Nietzsche integra el dolor y la dicha para transmutarlos vigorosamente en la dura felicidad propia de quien se afirma en su «corporalidad».

El nihilismo pasivo problematiza la vida, pero desde la reacción y la impotencia. La preocupación de esta psicología no apunta a la reconciliación con el fondo insondable de la verdad primigenia dionisiaca ni con los rasgos inconscientes desde los que se alza el sujeto trágico, sino al consuelo vacuo y efectista, esto es, una mera conservación que aspira al conformismo acomodaticio; no es vivir, en toda su inmensidad, sino conservar la vida en su mínima expresión para no enfrentar el tormentoso riesgo de la existencia encarnada. El sufrimiento es tomado durante este momento del nihilismo como una condenatoria marca natalicia que culpabiliza y censura la existencia, a causa de los rasgos frenéticos del devenir sobre el cual se asienta. Los hombres epocales, aquellos quienes recurrieron a narcóticos y remedios paliativos, buscaron mediante la mentira la redención del suelo nutricio, la calma piadosa del ser estático y unitario cuya uniformidad eterna y formal procuraba sosiego ante la extenuaste tarea de una existencia que ha de ser activa.

Es necesario incidir en esta mentira a la que alude Nietzsche. En el momento de la muerte de Dios ni verdad ni mentira son criterios trascendentales, sino existenciales: Dios es una mentira y la voluntad de poder, verdad. La verdad está al servicio de la vida; de la mentira cabe decir que opera inversamente. Los hombres se entregaron a lo largo de la historia a tales mentiras - pecado, más allá, Dios, culpa, castigo, redención, democracia, igualdad, etc. - para insuflar una cualidad piadosa en la virulencia de Dioniso. Estas mentiras sobrecogen a Zaratustra, quien teme que esta debilidad antropológica lleve a los hombres superiores a perder sus metas en el vacío abierto ante ellos. La libertad a la que aboca la muerte de Dios en tanto mentira como verdad, ya que en su sustrato caben las simientes hacia una vida plena que pueda suturar los abismos abiertos por la metafísica, así como el irresponsable celo de una vida que, al sentirse emancipada de todo contenido, puede caer en un orgiástico y ciego acontecer sin más aspiración que el simple transcurrir plácido. En esta última imagen, la libertad supone la derrota de la fuerza del espíritu emancipado y lo sume en un aséptico vivir por vivir inercial típico de quien no ha sido capaz de hacer de su libertad fuente de plenitud, esto es, aquel que no ha sabido procurarse sus propias metas y 
fines. Así, el hombre sigue siendo nihilista, dado que todavía es extraño a sí mismo y no logra comprometerse estéticamente con su existencia.

El hombre superior ha contemplado a Dioniso tras la muerte de Dios, mas aún ha de probar si su espíritu es lo suficientemente duro como para hacer de la «corporalidad» su sentido de existencia. El hombre superior todavía está preso de la «gramática» y de sus tentaciones de «bien», «redención»y «compasión», las cuales aún lo atenazan, pudiendo acabar por arrastrarlo a las formas pasadas del desprecio hacia la vida. Pues el desprecio no es únicamente el desdoro de la apariencia y del devenir en favor de la idea y del ser, sino también la incapacidad de comportarse responsablemente consigo mismo, en la medida en que es orfebre y materia prima de su vida encarnada. La responsabilidad será el componente que distinga cualitativamente al hombre superior del superhombre, del artista-filósofo. El último se sabe sujeto y objeto -aunque desde categorías e implicaciones distintas a las señaladas por Heidegger, según las cuales esta identidad significa la consumación del nihilismo en la figura de Nietzsche- de la verdad hermenéutica que se conjuga por la voluntad de poder y en virtud de la cual ésta, a su vez, se manifiesta. Sólo desde la «verdad» de la muerte de Dios el hombre superior puede superar los últimos ecos nihilistas -la compasión, verbi gratia - y enfrentarse responsablemente al compromiso estético de llegar a «ser lo que se es». La experiencia consciente del nihilismo privó a Dios de su reflejo cuando se miraba ante al espejo; a lo largo de la afirmación responsable de la libertad el espejo del hombre superior comienza nuevamente a devolver tímidos rasgos de su silueta, cuya figura quedará del todo colmada en la afirmación ulterior del artista-filósofo.

La creación de valores necesita de un «enseñoreamiento» de la voluntad de poder, una afirmación de ésta por el hombre encarnado. Sin embargo, el agotamiento al término de la modernidad, el nihilismo, ha arrebatado las fuerzas de sus protagonistas, incapaces de manufacturar la verdad y el valor en clave de verdad hermenéutica. La voluntad de poder de los débiles se ha quedado congelada una vez éstos han contemplado el horroroso abismo sobre el que pende el hombre ${ }^{602}$ : huyen del sufrimiento y del riesgo y se cobijan en la mediocridad adaptativa de las masas «civilizadas». El nihilismo reactivo de los débiles da muestras del agotamiento de la voluntad de poder, la cual ha prescindido de la creación jerárquica en beneficio de la nivelación: «el aristocratismo de los sentimientos ha sido socavado de la manera más subterránea por la mentira de la igualdad de las almas» ${ }^{603}$.

El hastío del hombre moderno es el agotamiento de sus fuerzas; cae la desconfianza incluso sobre los grandes y elevados espíritus: la nivelación más lasciva, la domesticación más cruel. El último hombre, el «hombre bueno» de la cultura, ha vulgarizado en gra-

\footnotetext{
${ }^{602}$ Cfr. ibid. pág. 38 (KSA IV, 16): «el hombre es una cuerda tendida entre el animal y el superhombre, - una cuerda sobre un abismo».

${ }^{603}$ Nietzsche, F., El Anticristo, op. cit., pág. 84 (KSA VI, 218).
} 
do sumo la existencia, ha privado del compromiso responsable del hombre superior con el mundo y, con ello, de las expectativas de un espejo que devuelva el propio reflejo, esto es, la reapropiación estética de la existencia desde las fuentes de la «corporalidad». Ha dicho Heidegger al respecto que «la voluntad que quiere el 'hombre bueno' y sus ideales es una voluntad de poder de esos ideales y con ello una voluntad de impotencia del hombre. La voluntad que quiere el hombre bueno es también voluntad de poder, pero bajo la forma de la impotencia de poder del hombre» ${ }^{604}$.

Este nihilista se ha enfrentado a su rictus, ha tocado su rostro y percibido sus caracteres humanos, los cuales se le han presentado feos e insufribles. Es «el más feo de los hombres», y como tal tiene necesidad de maquillar tal espanto. Para ello extirpa y niega los rasgos más difíciles y obscenos por medio de recursos morales y religiosos, esto es, idealistas, que partiendo de su fealdad lo domestican, lo civilizan, lo adocenan en el mercado. Es, con todo, el nihilismo pasivo una voluntad de nada, una enfermiza apropiación de la voluntad de poder sobre la cual se ha perpetrado una inversión de sus fuerzas creadoras en favor de una debilidad inerte: la voluntad de poder no como esencia de la vida, sino como mecanismo de conservación. En la afección pasiva del nihilismo la voluntad de poder continúa trazada dentro del discurso de la episteme de la metafísica de la duplicación, de la adecuación de certidumbre moderna. Esto ha reducido la voluntad de poder a caracteres positivistas, de tal forma que su adecuación consiste en ajustar la vida a tales condiciones, en este caso, biologicistas, que procuran la conservación fisiológica.

Si la voluntad de poder quiere ser afirmada como esencia de la vida, debe transvalorarse su horizonte de precomprensión en uno estético, pues su condición plástica no responde a los criterios dogmáticos de la lógica uniforme del ser-idealidad, unicidad, estaticidad, objetualidad, etc.-, sino al perspectivismo polifacético del devenir de un ilimitado horizonte de posibilidades de ser, siempre abierto debido a su radicalidad inconsciencia y a la precariedad de su núcleo de sentido que reclama para su contingente determinación efectiva del juego de la valoración y jerarquiación que emana de la esencialidad hermenéutica de la verdad trágica.

Sin embargo, Nietzsche aprecia rasgos prometedores en este sujeto, pues aun en su pasividad, desprecia, es decir, niega incluso su propia condición. El más feo de los hombres se rebela en su nihilismo contra el hombre a causa de la repulsión que le inspira, abriéndolo a la posibilidad de la persecución de la alternativa de un tipo de existencia más bello. Un paso más hacia las altas cumbres del superhombre:

\section{[...] ¡oh Zaratustra, qué bien me pareces entender de signos meteorológicos!}

${ }^{604}$ Heidegger, M., Nietzsche, op. cit., pág. 616. 
Pero tú mismo - iponte en guardia también a ti mismo contra tu compasión! Pues muchos se encuentran en camino hacia ti, muchos que sufren, que dudan, que desesperan, que se ahogan, que se hielan -

También contra mí te pongo en guardia. Tú has adivinado mi mejor, mi peor enigma, a mí mismo y lo que yo había hecho. Yo conozco el hacha que te derriba.

Pero Él - tenía que morir: miraba con unos ojos que lo veían todo, - veía las profundidades y las honduras del hombre, toda la encubierta ignominia y fealdad de éste.

[...] Así habló el más feo de los hombres. Y Zaratustra se levantó y se dispuso a irse: pues estaba aterido hasta las entrañas.

[...] y siguió [Zaratustra] sus caminos, aún más pensativo y lento que antes: pues se hacía muchas preguntas a sí mismo y no le era fácil darse respuesta.

«'iQué pobre es el hombre!, pensaba en su corazón, iqué feo, qué resollante, qué lleno de secreta vergüenza!

Me dicen que el hombre se ama a sí mismo: ¡ay, qué grande tiene que ser ese amor a sí mismo! ¡Cuánto desprecio tiene en su contra!

También ése de ahí se amaba a sí mismo tanto como se despreciaba, - para mí es alguien que ama mucho y que desprecia mucho.

A nadie encontré todavía que despreciase más profundamente: también esto es altura. Ay, ¿acaso era ése el hombre superior, cuyo grito oí?

Yo amo a los grandes despreciadores. Pero el hombre es algo que tiene que ser superado'» ${ }^{605}$.

Zaratustra insiste en la recuperación del ennoblecimiento de la voluntad de poder creadora, que quiere crear los puentes de la liberación del hombre ${ }^{606}$. El desprecio no es ya una disposición emotiva censurable, sino que conforma parcialmente la transvaloración: hasta entonces el desprecio era contrapuesto a la debilidad dentro de la episteme moral de los «buenos»; la crítica de Nietzsche de la compasión ha transmutado los caracteres de la piedad y el desprecio. El desprecio no ha sido invertido -lo que antes era «malo» es ahora «bueno» y viceversa-, sino transmutado: el marco de valoración en el que se sitúa es otro, pues ya no se desprecia por odio, sino por amor. El odio era el rasgo elemental de las psicologías escindidas de la duplicación, como eran los «despreciadores del cuerpo», los «predicadores de la muerte» o los «profetas de virtud»; el amor, en cambio, es lo que mueve todo el corpus nietzscheano. No se desprecia por odio, sino por amor hacia la posibilidad de un nuevo tipo de existencia donde la expectativa efectiva de la vida más plena, «llegar a ser lo que se es», no es un sueño romántico, sino una pulsión de vida trágica que reintegra el alma y el cuerpo, lo espiritual y lo material en la unidad sintética que es la «corporalidad». El desprecio se ha transmutado, pues mientras su fuerza estaba motivada por el odio ésta sólo tenía capacidad destructiva, un inconveniente para la plenitud, ya que se presentaba

${ }^{605}$ Nietzsche, F., Asi habló Zaratustra, op. cit., pp. 363-364 (KSA IV, 331-332).

${ }^{606}$ Cfr. ibid. pág. 137 (KSA IV, 111): «El querer hace libres: ésta es la verdadera doctrina acerca de la voluntad y la libertad».

La superación de la doctrina de la voluntad schopenhaueriana se consuma en este punto. Frente a la ceguera metafísica del maestro, donde la voluntad arrasaba con la libertad del hombre, Nietzsche se adueña de ella. En el dominio de la voluntad se concreta el querer del creador que siembra las simientes de las nuevas auroras de la emancipación. 
como un freno para lo grande; motivada, en cambio, por el amor, el desprecio y el odio de lo débil y lo pequeño aúpa lo vigoroso y lo fuerte, lo grande y lo frenético de la existencia que se acoge en su totalidad trágica.

\section{I.1.3.2. EI nihilismo rugiente}

Una vez asimilada la traumática experiencia de la crisis nihilista, cabe esperar del filósofo de las nuevas auroras emancipadas de la metafísica la extracción de un fruto dulce entre la penuria. Es una dura empresa de transmutación de lo horrendo, lo calamitoso, lo doloroso, lo errático en valores vigorosos y saludables, henchidos de una fuerza irrefrenable que se adjudican la creación afirmativa de un horizonte de vida distinguido por la plenitud y el derroche de la pulsión de existencia. Donde la experiencia primera -y primariadel nihilismo había concluido en la moral del «resentimiento» y del desprecio hacia la vida, las nuevas fuentes decimonónicas logran advertir, después de la deconstrucción del acontecimiento, canales de jovial afirmación. Una afirmación, sin embargo, que habrá de proferirse a través de los canales propios de una época donde la apelación a estamentos supramundanos resulta imposible por más tiempo. Con todo, esta apreciación jovial del nihilismo es únicamente accesible para aquellos espíritus que han comprendido que el sustrato de la existencia no es eminentemente metafísico -epistemológico-, sino trágico: dolor y placer, llanto y gozo, amargura y dicha son facetas de una existencia contradictoria e irredenta que en su vaciedad de sentido esencial se procura artísticamente las condiciones de la superación «estética» de tales contradicciones mediante la apropiación de significados y fines a través de la voluntad de poder, dado que «lo terrible forma parte de la grandeza: no hay que dejarse engañar» ${ }^{607}$.

Esta superación del nihilismo de la inacción tiene lugar por medio de la acción, de tal forma que en el nihilismo cabe también un itinerario activo, que se corresponde con el signo del poder solar de Zaratustra, cuya luz antecede las nuevas auroras de un tiempo para Occidente en el cual las pretéritas metas, escatologías y valores de la tradición metafísica dejan de procurar cobijo al nuevo tipo humano que ha sabido ver elementos de afirmación inmanentes en la destrucción de la ideal realidad «verdadera».

La ejecución del nihilismo activo no parte -no puede partir- de un plano ajeno al propio nihilismo. La actividad trágica discurre por completo en la radicalidad del mundo, luego el nihilista consumado habrá de operar desde las propias instancias nihilistas. Describió Nietzsche en su relato histórico del nihilismo que su génesis estaba en el cisma filosófico que supuso el platonismo: la metafísica de la duplicación de mundos y de la escisión del alma y el cuerpo. En esta estrategia lo sensible fue sometido a un despiadado proceso de desdoro en beneficio de una realidad eidética alternativa. Una separación abismal cuya

${ }^{607}$ Nietzsche, F., Fragmentos póstumos IV, op. cit., 9 [94], pág. 262 (KSA XII, 388). 
profundidad fue en aumento conforme los mecanismos reactivos del nihilismo -pasivocolonizaban el espectro europeo, hasta llegar a la condición paradigmática «cristiana», donde lo sensible no sólo no gozaba de valor alguno, sino que era despreciado y vilipendiado. En esta episteme se hallan los hombres de la Europa histórica, desde los máximamente reactivos -los despreciadores del cuerpo, los predicadores de virtud, los «buenos» y «justos», en suma, el «sacerdote» y su ideal ascético- hasta aquellos, los «espíritus libres», que habrán de comprender que tras la desventura de la esencial nada del mundo hay posibilidades fecundas para el desarrollo de la vida. Más aún, están las claves de aquella vida que el tipo «platónico» defenestró: la «corporalidad», una vida encarnada donde espíritu y cuerpo son una y la misma cosa, íntima experiencia efectiva y consciente de existencia particular.

Por lo que el nihilismo activo emerge precisamente de las ruinas espirituales dejadas por su contraparte reactiva. El plano supramundano del reino ideal, rector de las conciencias durante más de dos mil años, es desmenuzado por el nihilista activo, en cuya autopsia comprende que el sustento de dicha idealidad es el rencor y el odio por la vida que habían nutrido los meandros del ideal ascético. Frente al odio y al deseo de venganza legado por el nihilismo, el nuevo hombre opondrá el amor como resultado de las conclusiones modernas: «Dios», instancia metafísica ulterior, como concepto de máximo odio y desprecio hacia lo sensible, ha muerto, de manera que el rencor por la vida se queda sin legitimación y, por ende, la perpetuación de dicho régimen despectivo es imposible.

El nihilismo activo puede ser tomado como el resultado noble de la historia, en tanto ésta es historia del nihilismo. «Dios» fue el garante de la verdad, depositada ésta en su plano astral, el «mundo verdadero», trascendente y absoluto. Tras su muerte, la respuesta de los tiempos no es el vulgar «ateísmo» que niegue la fe, sino la liberación del hombre de las redes epistémicas, la «gramática», de un horizonte único y unitario de sentido; la muerte de Dios ha de significar para el nihilista consumado menos la pérdida de la fe que la apertura perspectivista del horizonte de sentido(s):

El nihilismo como signo del acrecentado poder del espíritu: como NIHILISMO ACTIVO.

Puede ser un signo de fuerza: la fuerza del espíritu puede haber crecido tanto que las metas que tenía hasta el momento («convicciones», artículos de fe) le son inadecuadas

- una creencia, en efecto, expresa en general la coerción de condiciones de existencia, un sometimiento a la autoridad de situaciones en las que un ser prospera, crece, gana poder...

Por otra parte, un signo de una fortaleza insuficiente para ponerse nuevamente de un modo productivo una meta, un ¿por qué?, una creencia.

Su MÁXIMO de fuerza relativa lo alcanza como fuerza violenta de DESTRUCCIÓN: como nihilismo activo. Su opuesto sería el nihilismo cansado, que ya no ataca: su forma más famosa, el budismo: como nihilismo pasivo ${ }^{608}$.

${ }^{608}$ Ibid. 9 [35], pp. 241-242 (KSA XII, 350-351). 
El nihilismo es la desvalorización fundamental de la episteme occidental tradicional. Sin embargo, su conciencia no conlleva necesariamente el abandono de este legado, pues existe el riesgo de continuar zafado en la creencia en la «gramática». Por eso el cariz activo goza de extraordinaria relevancia en la filosofía de Nietzsche como vehículo de reapropiación de la existencia. El nihilismo activo es, antes que un esforzado intento por reintegrar vida y experiencia en una única identidad sintética, la desfundamentación filosófica de la historia de Europa: en su afirmación, el nihilista consumado habrá de probar que los avatares eidéticos nacen del miedo que comportaba la arriesgada empresa de la existencia trágica, así como la necesidad de presentar un modelo ideal que se abstuviese de la crueldad de la lógica deviniente de un mundo dionisiaco. El nihilismo, la historia de la metafísica es el relato del triunfo de una falacia de petición de principio, pues el miedo y el odio respecto de la «corporalidad» en su plenitud hicieron necesaria la invención de una verdad formal trasmundana emancipada de los aspectos crueles de la verdad trágica. En el momento de la crisis finisecular, esta falacia petitio principii es descubierta, revelada y anulada, «pues ¿por qué la ascensión del nihilismo es ahora necesaria? Porque son nuestros actuales valores mismos los que en él extraen su última consecuencia; porque el nihilista es la lógica pensada hasta el final de nuestros grandes valores e ideales» ${ }^{609}$. La disposición del viejo intelectualismo moral socrático-platónico, donde la verdad devino moral, responde en realidad a una voluntad de poder reactiva en la que la exigencia de verdad «a cualquier precio» anuló las posibilidades de una mentira saludable y vigorosa al servicio de la vida; la verdad fue la correspondencia con el bien, un maridaje entre la moral y la metafísica que acabó pergeñando una imagen eidética de la existencia en la cual ésta hallaba su vocación de sentido en el anhelo de trascendencia ideal. El agotamiento de Occidente se remite a este inhumano esfuerzo por adecuar la vida efectiva, sensible, de los hombres de acuerdo con las máximas inteligibles del ser. Por este hastío el nihilismo se consuma como nihilismo activo, pues es necesaria la mentira para poder procurar los nutrientes necesarios para una vida encarnada:

¿Qué es una creencia? ¿Cómo surge? Toda creencia es un tener-por-verdadero.

La forma extrema del nihilismo sería: que toda creencia, todo tener-por-verdadero es necesariamente falso: porque no hay en absoluto un MUNDO VERDADERO. Por tanto: una apariencia perspectivista, cuyo origen está en nosotros mismos (en cuanto tenemos necesidad permanentemente de un mundo más estrecho, abreviado, simplificado)

- que la medida de la fuerza es el grado en que podamos admitir la apariencialidad, la necesidad de la mentira, sin sucumbir.

En ese sentido, el nihilismo, en cuanto NEGACIÓN de un mundo verdadero, de un ser, podría ser un modo de pensamiento divino ${ }^{610}$.

${ }^{609}$ Ibid. 11 [411], pp. 489-490 (KSA XIII, 190).

${ }^{610}$ Ibid. 9 [41], pág. 243 (KSA XII, 354). 
El nihilismo activo rescata la mentira como medio de apropiación del horizonte perspectivista humano, pues el más noble valor de la realidad reside precisamente en su radical orfandad significativa, ya que ello devuelve al hombre su capacidad creadora. La voluntad de poder es reivindicada por el nihilista consumado como esencia afirmadora del individuo y del mundo. El perspectivismo presupone la ausencia escatológica de sentido, al tiempo que comprende al sujeto como el organismo capaz de procurar un contenido, siempre precario, a la realidad que conforma y habita.

El nihilista consumado, el nihilista perfecto, de quien no ha habido aún experiencia más allá de sí mismo, dice Nietzsche, se afirma por medio de la saludable fuerza de su voluntad de poder, por cuya plenitud desborda. Tras milenios abocados a una existencia tendente en la nada ${ }^{611}$, Nietzsche encuentra en la propia lógica nihilista los puentes hacia el nuevo tiempo cuando el hombre será su misma instancia legitimadora. Donde la justificación de su vida no dependa de otros avatares más que de su «sí». La reapropiación de la vida exige su dominio, la manufactura y jerarquización de aquellos valores contingentes, contingentes en tanto que mentira, que disponen la vida buena para el sujeto encarnado. La apertura al ilimitado horizonte perspectivista no abruma, no comporta una parálisis de la acción como consecuencia de la ingente pluralidad de posibilidades de ser; al contrario, es la invitación jovial a una vida que por estar sometida a la creación constante de su situación efectiva, habrá de ser cuidada. Que no haya valores ulteriores ha rescatado, en verdad, el sacrosanto valor de la «corporalidad», el enigma inaccesible en su fondo de un ser sintético capaz de fabular su propio ser. El nihilismo es la antesala de una nueva historia para la existencia humana; es la puerta hacia la recuperación del sentido más íntimo de ésta, a saber, que su significación habrá de ser resultado de la propia experiencia encarnada del sujeto valorador, de este artista-filósofo que tomará con responsabilidad la consumación de la obra «estética» que es su vida. No hay metas ni fines trazados; el propio sujeto trágico se dará sus propias metas y fines en la determinación perspectivista del contenido de sentido y significado de su encarnación:

El nihilismo aparece ahora no porque el displacer de la existencia sea mayor que antes, sino porque se desconfía de un «sentido» del mal, e incluso de la existencia. Ha sucumbido una interpretación; pero puesto que era considerada como la interpretación, parece como si no hubiera absolutamente ningún sentido en la existencia, como si todo fuera en vano ${ }^{612}$.

Como ya hemos adelantado, no todo dentro de la atmósfera del nihilismo es insoportable degeneración insuperable. Al contrario, Nietzsche se esfuerza en mostrar que éste

${ }^{611}$ Cfr. ibid. 5 [71], pp. 165 (KSA XII, 213): «Pensemos este pensamiento en su forma más terrible: la existencia, tal como es, sin sentido y sin meta, pero retornando inevitablemente, sin un finale en la nada: 'el eterno retorno'.

Ésta es la forma más extrema de nihilismo: ¡la nada (lo ‘carente de sentido’) eternamente!».

612 Ibid. (KSA XII, 212). 
no se agota en la voluntad de nada, la cual es tan sólo uno de los fenómenos en que se manifiesta esta patología epocal. Además de la debilidad y la pasividad, el nihilismo puede ser también fuente de fuerza, crecimiento y acción. En él se hallan también los espíritus rebeldes $^{613}$ que desconfían de los viejos valores instituidos y que aspiran a otros nuevos: «Romped, rompedme, hombres del conocimiento, las viejas tablas!» ${ }^{614}$. La negación de los viejos valores y de su fuente de valoración que se efectúa desde el nihilismo es condición necesaria para la constitución de nuevos espacios de vida y libertad. Luego en el nihilismo no hay únicamente debilidad, sino sobreabundancia: el león.

El león, sin embargo, es también él nihilista; su afirmación pasa por su acción que destruye y niega. En su rugido está la fuerza demoledora que acaba con la tiranía de los antiguos y longevos ídolos, pero no goza de la específica virtud del creador. El riesgo que encarna el león descansa en quedar pertrechado en un nihilismo de la fuerza que no sea capaz de asimilar su propia libertad. La fuerza bruta no basta, es más, la fuerza bruta responde a canales de dominación que dependen más del «número» que del valor trágico: quien gobierna lo ha hecho hasta ahora por estrictas condiciones fisiológicas, por contar con más músculo que el gobernado. La demostración de fuerza del león no es la del músculo que levanta pesos en el vacío, sino la propia de aquel que sabiéndose poderoso en su voluntad, es decir, en su capacidad de crear valores, elige actuar en el mundo creando las condiciones de su vida más plena sin atentar, no obstante, contra las condiciones de existencia ajenas.

Nietzsche es el adalid de la fuerza y del poder, del señorío sobre la esclavitud; su mensaje atenta contra la misericordia y la compasión. Sin embargo, esto ha de entenderse dentro de la complejidad de la filosofía activa nietzscheana: son el «señorío» y la «fuerza» de una voluntad de poder reapropiada como esencia de vida. El enseñoreamiento de la filosofía nietzscheana es absolutamente propio, jamás se conquista desde los otros, pues de ser así enajenaría al sujeto de su experiencia de vida encarnada. Al mismo tiempo, la concreción de la obra de arte estética del artista-filósofo tampoco lastrará las expectativas de superación de sus semejantes. Por ello mismo Nietzsche no concibe dentro de su filosofía la subordinación de unos hombres ante otros -esa fuerza, insistimos, es autoconservación-, como tampoco la compasión nihilista que ofrece un blando consuelo al hombre que sufre por su menesterosidad. La fuerza puede devenir nihilismo reactivo si ésta no se compromete con la existencia encarnada. La fuerza, en la medida en que libera el espíritu, debe esgrimirse responsablemente, como apropiación estética del fondo trágico de la verdad hermenéutica del hombre deviniente. Por eso la fuerza no es una cuestión de musculatura biologicista, sino de la dureza del espíritu que se apropia de sí como voluntad de poder.

${ }^{613}$ Cfr. Nietzsche, F., Así habló Zaratustra, op. cit., pág. 300 (KSA IV, 269): «- un sol y una inexorable voluntad solar, ¡dispuesto a aniquilar en la victoria!».

${ }^{614}$ Ibid. pág. 284 (KSA IV, 251). 
No basta decir «no», pues el hombre que reacciona contra los ídolos del pasado sigue siendo reactivo. El nihilismo ha de ser llevado al extremo, hacer de él el protagonista de la muerte de Dios y sumergirnos en el mensaje de liberación de la verdad de tal fallecimiento, a saber, que la voluntad de verdad es voluntad de poder ${ }^{615}$. «La verdad habla en mí» ${ }^{616}$, dice Nietzsche. La verdad de Zaratustra, que exige «un santo decir sí» ${ }^{617}$.

\section{I.1.3.3. La ruptura de las viejas tablas}

La crisis del nihilismo ha consumido las condiciones de los horizontes últimos como criterios de valoración. La muerte de Dios es la puerta hacia la liberación del hombre en su propia afirmación responsable, o sea, como existencia encarnada. El león, con su negación, determina la acción rebelde de los espíritus libres que rechazan las viejas tablas, la «gramática» del Dios muerto, mas no tiene la necesaria fuerza para firmar las bases de las nuevas condiciones hermenéuticas de la vida trágica superadora del inhumano hombre epistémico-metafísico.

La muerte de Dios es una apertura radical de la «moral»; cuanto había sido marcado bajo el sello de la infamia es exonerado. Sin embargo, recordemos que antes señalamos que la filosofía de Nietzsche rechaza la imagen de la redención. ¿Se trata, entonces, de una contradicción? Estamos ante una de las dificultades inmanentes del pensamiento del autor: su forma de escritura, aforística, desenfadada, sin una estructura sistemática pareciera sugerir tras una lectura superficial que Nietzsche es un filósofo contradictorio. No obstante, su obra es menos incongruente que compleja, antojándose imprescindible distinguir los tiempos y momentos en los que emplea sus conceptos. Nietzsche se muestra terriblemente cruel contra los predicadores metafísicos que pretendían exonerar la vida, el mundo; al mismo tiempo, Nietzsche exonera la existencia. La diferencia reside en que el perdón de aquéllos y el suyo han sido planteados en «reinos» distintos, separados por la conciencia de la transvaloración, que ha afectado profunda y fundamentalmente el marco de valoración. Los redentores de la humanidad piensan el perdón del mundo como «mundo aparente», así como de la vida, radicada en tal plano sensible. Esto la ha tornado efímera, deviniente, imperfecta, dolorosa, arriesgada. Este mundo de falsedad, de «pecado» resulta odioso a «los buenos», incapaces de dejar de compararlo con su perfecta contraparte ideal del «mundo verdadero», donde mora el ser. Su redención pasa por tratar de «participar» desde la apariencia de la forma normativa de la verdad, o bien condenarla en virtud de su condición carnal bajo la promesa dichosa de una postrera existencia depurada de la perentoria gratuidad del devenir. Mientras que la redención nietzscheana se ejecuta una vez la distancia de

615 Cfr. Nietzsche, F., Fragmentos póstumos III, 25 [305], op. cit., pág. 505 (KSA XI, 88): «— ¡nosotros hacemos un ensayo con la verdad! ¡Quizá en él perezca la humanidad! ¡Pues bien!».

${ }^{616}$ Nietzsche, F., Ecce homo, op. cit., pág. 135 (KSA VI, 365).

${ }^{617}$ Nietzsche, F., Así habló Zaratustra, op. cit., pág. 55 (KSA IV, 31). 
los mundos «verdadero» y «aparente» ha sido salvada, así como suturada la escisión del alma y del cuerpo. Ahora bien, hay un matiz crucial en el perdón nietzscheano: acontece tras la transvaloración, por lo que no es una simple inversión. La distancia entre los mundos ha desaparecido, mas no por la inserción de uno en el otro; como tampoco el morar sin más en el cuerpo. La propia episteme de la duplicación y de la escisión ha sido superada: no existe distancia entre lo eidético y lo aparente, puesto que la propia imagen del abismo ha dejado de ordenar formalmente la conciencia; no es la vindicación de la apariencia y el desdoro de lo ideal, sino la conciencia de totalidad en una única dimensión trágica de existencia donde el «mundo aparente» es reapropiado para ser, como tal, el «mundo». En cuanto a la escisión del alma y del cuerpo, es algo más que la simple unión de uno y otro; es la reconversión de la existencia: la «corporalidad», la unidad sintética en la que las dimensiones consciente e inconsciente que cifran la personalidad convergen solidariamente en lo que caracteriza Nietzsche como la espiritualización del cuerpo y la corporalización del espíritu. La «corporalidad» lleva a una afirmación trágica, en detrimento de la epistémica tradicional, del sustrato esencial del hombre.

En esta línea debe entenderse la redención que ha tenido lugar en la filosofía de Nietzsche: es la redención de la existencia de aquellos fantasmas que habían hecho de ella algo extraño al hombre encarnado. Mientras la redención de los predicadores se mueve por el odio hacia la vida y la exonera en instancias supramundanas, del perdón de Nietzsche mana amor: su amor por la existencia encarnada ha perdonado al mundo de la tradición bimilenaria que lo hubo encerrado en fantasmagóricas instancias. El perdón nietzscheano no es el del predicador de la muerte; tampoco se nutre de la compasión nihilista, sino de la desbordante fuerza del amor por la «corporalidad». El perdón nietzscheano no es, por tanto, un lamento, sino la afirmación radical del nuevo horizonte de precomprensión dionisiaco de la transvaloración de la verdad de la vida: «yo os enseño el superhombre: el gran desprecio debéis enseñároslo vosotros a vosotros mismos» ${ }^{618}$.

Las posibilidades de creación del nuevo hombre son absolutas. Sin embargo, en el horizonte nietzscheano sigue rigiendo la recuperación de la pregunta clásica por la vida mejor. De modo que a la capacidad creadora no le es lícito todo tipo de acción en un burdo juego de ebria libertad, bajo el riesgo de caer en las acomodadas posiciones de un nihilismo irresponsable. Es pertinente actuar en aras de conquistar la mejor vida posible. Por ello, si de la muerte de Dios queremos hacer una nueva vida -encarnada-, óptima en sus condiciones de acrecentamiento y superación, el sujeto creador habrá de eludir los festines y las ensoñaciones románticas, habrá de ser ascético. Por eso el león no es la transformación última que espera Zaratustra. Si bien es un paso elogioso, su tentativa reactiva repele al viejo persa. El valor de la destrucción no descansa en ella misma, sino en su condición genera-

${ }^{618}$ Nietzsche, F., Fragmentos póstumos III, 4 [208], op. cit., pág. 127 (KSA X, 169). 
dora de espacios de libertad. La voluntad de poder es virtuosa cuando genera valores que favorecen la vida, mas desatada como hybris ${ }^{619}$ en la irresponsable libertad absoluta del nihilismo cual simple torrente destructivo es un paso atrás:

Y él no supo superar su virtud.

El león en él desgarró al niño en él: y al final, el león se devoró a sí mismo.

Cruel y bárbaro era este héroe _ _ _ -

Mirad, yo os enseño el amor por el superhombre.

— — - cargó sobre sí y se hizo pedazos bajo la carga ${ }^{620}$.

En su lugar, Zaratustra predica el superhombre, quien bebe de la transvaloración $y$ de quien bebe la transvaloración. Ésta no es una mera inversión de valores que hace de lo otrora «malo» lo «bueno» y viceversa, sino un cambio sustancial en el modo de valorizar. La destrucción leonina y la transvaloración nacen ambas del nihilismo, sin embargo, ésta última lo logra superar, pues es afirmación. Si bien nacida del nihilismo, la transvaloración no se nutre del resentimiento y del ciego querer de una voluntad de nada:

De la presión de la plenitud, de la tensión de las fuerzas que constantemente crecen en nosotros y todavía no saben descargarse, surge un estado como el que precede a una tempestad: la naturaleza que somos se oscurece. También eso es pesimismo... Una doctrina que a tal estado le pone fin, ordenando cualquier cosa, una transvaloración de los valores, gracias a la cual a las fuerzas acumuladas se les muestra un camino ${ }^{621}$, una dirección, de manera que explotan en rayos y en acciones - en modo alguno necesita ser una doctrina de la felicidad: al liberar la energía que estaba comprimida y almacenada hasta el tormento, proporciona felici$\operatorname{dad}^{622}$.

El nihilismo es, en último término, una desoladora experiencia de destrucción, del fin de un mundo y de su respectivo horizonte de valor. La destrucción vacía es una actitud reactiva, por lo que Nietzsche nunca podría tomar el nihilismo como un fin, pues esa actitud sería en cuanto tal nihilista; el nihilismo ha de ser un medio para un fin, cuya ulterior concreción plena si bien no es posible -la reapropiación estética de la vida sumerge a ésta en una lógica de constante generación-, el cual el propio sujeto, ya artista-filósofo, ha sido capaz de darse a sí mismo. En el nihilismo no hay esencialmente creación; la destrucción favorece la aparición de las futuras condiciones de afirmación, mas para ello es necesario también superarlo.

${ }^{619}$ Cfr. Nietzsche, F., Fragmentos póstumos II, 12 [9], op. cit., pág. 838 (KSA IX, 577): «Si de la muerte de Dios no extraemos una grandiosa renuncia y una continua victoria sobre nosotros, tendremos que cargar con la pérdida».

${ }^{620}$ Nietzsche, F., Fragmentos póstumos III, 4 [218], op. cit., pág. 129 (KSA X, 173).

${ }^{621}$ Recuérdese que cuando Zaratustra se topa con su sombra lo advierte de que el mayor de los peligros es haber perdido el camino como conclusión máxima del extravío de una vida enajenada de sus propias metas y fines.

${ }^{622}$ Nietzsche, F., Fragmentos póstumos IV, 11 [38], op. cit., pág. 377 (KSA XIII, 20). 
El nihilismo, tampoco el activo, es suficiente. En su gen hay más muerte que vida, más odio que amor. Por ello no sirve más que para abonar el suelo que habrá de pisar el hombre trágico de la voluntad de poder. Es necesario un sustrato que derroche fuerza de vida, algo imposible para el nihilista, pues su creación viene de la oposición respecto de la tradición. La nueva Europa necesita respirar un aire limpio; la existencia encarnada no puede ser afirmada únicamente como contrapunto de la pretendida vida eidética. La apropiación del ser en el mundo por medio de la mera oposición de la enajenación del pasado es una tentación tan nihilista como la aspiración platónica del «mundo verdadero». No hablaríamos de una existencia afirmada en su radical «corporalidad», sino de una asentada sobre el rechazo de los caracteres ideales, de tal manera que la justificación de su ser no descansaría en ella misma sino en el -externo- deseo por olvidar el pasado. Sin duda el nihilismo activo se le ha mostrado a Nietzsche útil y necesario, mas no puede depositar en él sus expectativas de sentido al no poseer las condiciones de creación de un mundo absolutamente nuevo. El nihilismo activo, al cierre, ha comprendido los mecanismos que subrepticiamente forjaron el mundo ideal y ha abierto al hombre al horizonte perspectivista de su ser hermenéutico. Sin embargo, no logra procurar criterios genuinos; su apropiación de lo sensible a costa de lo eidético no ha desmantelado el núcleo que diferenciaba sendos polos. Por lo que el nihilismo activo, en su hipertrofia, sumerge al sujeto de nuevo en el decadente nihilismo moral de la tradición al perpetuar el régimen de enajenación de la conciencia. Una existencia reapropiada en plenitud, la «corporalidad», es absolutamente afirmadora. No se construye desde la negación de los avatares del pasado, sino que exige el total olvido de los mismos, de sus mecanismos de situación y posicionamiento en el mundo. Sólo necesita de sí el artista-filósofo para proferir el «santo decir sí»» de su existencia; mientras que un «sí»» que ulteriormente ha sido posible tan sólo por contraposición con «Dios» responde, más bien, al «I-A» del asno.

La sumisión de las longevas fuentes culturales europeas no es suficiente para la comunión de la conciencia y la experiencia de existencia. El artista-filósofo necesita un continente que ni siquiera haga mención crítica del mundo suprasensible; exige tabula rasa para cincelar su obra «estética»; requiere su propia «gramática». Una nueva cultura, por tanto, que haya abandonado la esquizofrénica tensión agónica de la duplicación para asentarse únicamente sobre la «corporalidad». El nihilista consumado, aún en su perfección de tal situación, es con todo nihilista; su afirmación nunca es plena. El artista-filósofo ha superado el nihilismo. El vigor y la salud recorren su robusto cuerpo en una afirmación capital de la vida que incluso al negar, afirma: el sentido es remitido al sujeto encarnado y justificado, a su vez, por él mismo. Se trata de una disposición circular no viciosa: él pide sentido, él se lo procura y él lo justifica, no cayendo, no obstante, en una petitio principii. La existencia del artista-filósofo es un círculo virtuoso no falaz, pues las directrices lógicas del mundo no son ya epistémicas. Él quiere y él crea: quiere crear y quiere lo que crea. En esta 
ecuación la aspiración de sentido y su creación son la misma realidad, el propio sujeto que vive y que se afirma en la voluntad de poder. El sujeto de la voluntad de poder, en quien actividad y obra se identifican en su existencia, habita un nuevo tiempo no nihilista.

Así se entiende que la transvaloración sea un acontecimiento imprescindible de la empresa nietzscheana. Si aceptamos que el nihilismo era un problema de raíz existencial, la transvaloración es la consumación del proyecto de superación de la crisis existencial de Occidente. La transvaloración es el momento de la «corporalidad», de la afirmación de la identidad desde un fondo trágico insondable, sometido a las dionisiacas inclemencias del devenir y abierto al hermenéutico horizonte perspectivista. Nietzsche hubo de rechazar la existencia del sujeto, del sujeto moderno, autoconsciente y cierto de sí; en la transvaloración la integridad del sujeto es devuelta; vuelve a existir dentro del nuevo paradigma de vida reapropiada que se afirma en su radicalidad y no por la contraposición con el ideal inhumano del mundo trascendente. No ha de olvidarse, dice Nietzsche, que

es superflua toda doctrina para la que no estén ya completamente listas las fuerzas acumuladas, las materias explosivas. Sólo se alcanzará una transvaloración de los valores cuando exista una tensión de nuevas necesidades, de nuevos necesitados que sufren con la antigua valoración sin llegar a tomar conciencia ${ }^{623}$.

\section{I.2. La voluntad de poder}

La voluntad de poder ocupa en la filosofía de Nietzsche uno de los lugares fundamentales: «el problema de la vida: como voluntad de poder» ${ }^{624}$. Este pequeño fragmento pone de manifiesto que si bien la voluntad de poder participa dentro de la metafísica y la cosmología nietzscheana ${ }^{625}$, su posición principal reside en el plano existencial: «Y también vosotros mismos sois esta voluntad de poder - ¡y nada más!» ${ }^{626}$. La imbricación de la voluntad de poder en la vida es esencial, al punto de que no es extraño identificarlas: ¿qué es prioritario en Nietzsche, la vida o la voluntad de poder?, ¿todos poseemos voluntad de poder, también los débiles y los enfermos?, ¿si la voluntad de poder es fuerza creadora, por qué ha triunfado una voluntad de poder reactiva?

Nietzsche es ambiguo y no parece ofrecer una respuesta prístina entre sus característicos enigmas. Somos voluntad de poder y nada más, pero las implicaciones deducibles del «nada más» nos pierden entre sus textos. La voluntad de poder es naturaleza, es vida, es arte, es religión, es voluntad de verdad, es moral, etc. Con todo, la voluntad de poder es

${ }^{623}$ Ibid. 9 [77], op. cit., pp. 255-256 (KSA XII, 375-376).

${ }^{624}$ Ibid. 9 [1], op. cit., pág. 235 (KSA XII, 339).

${ }^{625}$ En la concepción cosmológica nietzscheana la actividad conjunta de la voluntad de poder y del eterno retorno constituyen y vertebran el núcleo del mundo: «— Este mundo es la voluntad de poder — iy nada más!» (Nietzsche, F., Fragmentos póstumos III, 38 [12], op. cit., pág. 831 [KSA XI, 611]).

${ }^{626}$ Ibid. (KSA XI, 611). 
la bisagra por la que se armonizan el hombre y el mundo en una convergencia de unicidad -somos voluntad de poder-y pluralidad - podemos crear cualesquiera valores-. La voluntad de poder es la condición de posibilidad de nuestra capacidad valoradora, por lo tanto, como advierte Heidegger, nuestra íntima condición artística desde la que creamos verdades, valores, el mundo, en suma, descansa al abrigo del pensamiento de la voluntad de poder. Luego desde la vida, el arte y la voluntad de poder se traza una línea que da al devenir unidad estructural:

[...] esa determinación del arte como estimulante de la vida no quiere decir otra cosa que: el arte es una forma de la voluntad de poder. En efecto, «estimulante» es lo que impulsa, lo que intensifica, lo que eleva más allá de sí, el «más» de poder, o sea, simplemente, el poder, es decir: la voluntad de poder ${ }^{627}$.

\section{I.2.1. La voluntad de poder como principio artístico de vida}

La voluntad de poder atraviesa el devenir de la verdad dionisiaca del mundo, por lo que su carácter esencial responde ante éste, haciendo por ello impensable hablar de una especie de inmanente y sustantiva forma unitaria de la voluntad de poder, al modo de la voluntad schopenhaueriana. Es plural, de ella emana todo arte, esto es, las condiciones de acción y acrecentamiento de la vida encarnada, de modo que ésta germina de aquélla, a la par que la vida traza los rasgos -reactivos o afirmadores- de la voluntad de poder; que la religión, la moral, el conocimiento o la sociedad sean fenómenos artísticos significa que son frutos de la fuerza creadora de la voluntad de poder. De lo que se trata, dice Nietzsche, es de imprimir fuerza vigorosa en la voluntad de poder, es decir, que su fuerza creadora sea afirmadora del proyecto estético de la «corporalidad», o sea, que la voluntad de poder apunte hacia la consecución de «ser lo que se es», en detrimento de la tradicional impronta reactiva de desprecio y odio hacia la vida.

Sin embargo, esta consideración no resuelve interrogantes problemáticos concernientes a las cualidades de su trasfondo valorador, pues también el nihilismo reactivo goza de caracteres creadores, una reacción macabra, ya que su fuerza pergeña obras contrarias a la vida encarnada, como las estrategias de la duplicación o de la escisión. Luego la pregunta primera desde la que abordar la voluntad de poder es a propósito de su posible doble condición, activa y pasiva. La existencia simultánea de dos rasgos de la voluntad de poder distintos, una típica de los valores nihilistas y otra, característica de aquellos de la superación, es descartada por Nietzsche. La voluntad de poder es a sus ojos un instinto netamente activo, de cuyo debilitamiento y degeneración habría surgido el germen nihilista que transmutó los favorables matices de la fuerza de la valoración en las formas decadentes de la tradición occidental:

${ }^{627}$ Heidegger, M., Nietzsche, op. cit., pág. 79. 
La vida misma es para mí instinto de crecimiento, de duración, de acumulación de fuerzas, de poder: donde falta la voluntad de poder hay decadencia. Lo que yo asevero es que a todos los valores supremos de la humanidad les falta esa voluntad, - que son valores de decadencia, valores nihilistas los que, con los nombres más santos, ejercen el dominio ${ }^{628}$.

La «falta» a la que se refiere Nietzsche no es una ausencia; de ser así, se habría duplicado la voluntad de poder. Es, por contra, una carencia de los caracteres fuertes, endurecidos, que exige la consagración de la vida más noble, aquella que el paradigma trágico griego definió como obra de arte. La voluntad de poder afirmadora de la vida encarnada persigue estas máximas helenizantes; la «falta» es el desvío de la mirada hacia otros horizontes, que si bien se han mostrado dominantemente poderosos en la historia, no son «nobles» ni «fuertes», sino reactivos y decadentes, ya que no nacen de la sobreabundancia vigorosa de la fuerza, sino del hastío respecto de la vida y del compromiso estético que exige la existencia tomada como la más esplendorosa creación del artista-filósofo.

Sin embargo, esta respuesta tampoco se antoja definitivamente resolutiva, ya que en otros pasajes apunta la imagen contraria, conviniendo en admitir que «hemos visto dos 'voluntades de poder' en lucha» ${ }^{629}$. El fondo operativo sería el mismo, su capacidad de crear valores, distinguiéndose entre sí por las cualidades de sus respectivos prismas, el rencor vengativo respecto de la vida, de los predicadores de la muerte, que instalado sobre un fondo de epistemología eidética, contempla la existencia con la nostalgia de un mundo ideal inalcanzable en vida y que, sin embargo, trata de imponer sobre el aparente. De modo que su creación no es afirmadora, sino reactiva, pues su obra es la degeneración y la corrupción de todo lo grande, de las posibilidades de una vida cuidada; y, por otro, tras la conciencia de la esencialidad nihilista de Occidente, el hombre que acepta la exigente y dura tarea de la transvaloración, el artista-filósofo, ha superado las pretensiones de certeza y de adecuación de la epistemología para asentarse, en su lugar, sobre el suelo nutricio de la vida -encarnada- misma, que es trágico. Desde este nuevo horizonte de precomprensión, la actividad valoradora es radicalmente distinta, puesto que la afirmación de la fuerza es netamente creativa: la actividad valoradora y jerarquizadora de la voluntad de poder abraza la pluralidad perspectivista de la existencia, su dicha y su amargura, con el ánimo de acrecentar las condiciones de posibilidad de la mejor vida posible, la cual, como encarnada, es genuina de cada sujeto concreto. Por eso la voluntad de poder de la verdad dionisiaca que palpita bajo la vida demanda vigor y robustez, dureza, pues es un compromiso individual del sujeto artista consigo mismo; a la vez, es el fino mármol desde el que trabajar. La carga existencial no puede compartirse si se quiere reintegrar en ella al hombre. La tradición había trazado puentes de solidaridad, la «compasión», entre los hombres para compartir una car-

${ }^{628}$ Nietzsche, F., El Anticristo, op. cit., pág. 35 (KSA VI, 172).

${ }^{629}$ Nietzsche, F., Fragmentos póstumos IV, 14 [137], op. cit., pág. 572 (KSA XIII, 322). 
ga pesada que, además, se entendió como lesiva. El compromiso nietzscheano es con la existencia radical, por lo que su mensaje es único e intransferible: el sentido encarnado de la vida libre que se experimenta responsablemente sólo responde al individuo particular protagonista de dicha encarnación dentro de la cual es capaz de procurarse sus propias metas y fines como cuidado de sí en aras de la mejor experiencia de existencia posible.

En cuanto al decurso de la tradición de Occidente cabe decir que se ha impuesto el «dominio de la debilidad» ${ }^{630}$, que ha dispuesto durante demasiados siglos una actitud de desprecio y venganza hacia la vida: la moral del resentimiento:

La rebelión de los esclavos en la moral comienza cuando el resentimiento mismo se vuelve creador y engendra valores: el resentimiento de aquellos seres a quienes les está vedada la auténtica reacción, la reacción de la acción, y que se desquitan únicamente con una venganza imaginaria. Mientras que toda moral noble nace de un triunfante sí dicho a sí mismo, la moral de los esclavos dice no, ya de antemano, a un «fuera», a un «otro», a un «no-yo»; y ese no es lo que constituye su acción creadora ${ }^{631}$.

La importancia de este pasaje redunda también en el interrogante sobre el número existente de voluntades de poder, restándole a nuestros ojos gravedad a dicha cuestión. En realidad no cabe pensar en una imagen única -y unitaria- de la voluntad de poder, dado que esto la esencializaría; la voluntad de poder es la esencia de la vida, pero ella misma, en cuanto raíz del fondo de vida trágico de la verdad hermenéutica carece de esencia. Por lo tanto, la polifonía y la plasticidad que distinguen característicamente la voluntad de poder «hablan» simultáneamente: dice Zaratustra que halló voluntad de poder allí donde vio seres naturales; ahora bien, en cada ser natural, por su condición plural, se superponen ilimitadas voluntades de poder cuya concreta determinación última de esta contingente obra de arte que es la vida viene de la propia jerarquización que la voluntad de poder impone sobre sí misma. Dado que la voluntad de poder es la esencia de la vida, y la «corporalidad» es un compromiso implícito con la propia existencia, la voluntad de poder como elogio trágico de la vida y creación estética de la verdad ha de ser responsable con su actividad si quiere reno-

${ }^{630}$ No es, sin embargo, una expresión contradictoria. Como hemos señalado, el dominio de la voluntad de poder no remite a la robustez muscular de sus usuarios como tampoco lo hacen los conceptos de «fuerte» $\mathrm{y}$ «débil» en la filosofía nietzscheana. Todo está trazado en la capacidad creadora de valores, siendo la cualidad de éstos lo que determinará los rasgos de fortaleza: la fuerza alude a aquellas verdades que afirman la vida encarnada y que, por ende, discurren en la trazada helénica de la mejor vida posible; la debilidad, dispone lo contrario. El «dominio de los débiles», pues, significa el sometimiento de la cultura al marco valorativo de dichos sujetos colmados de resentimiento, esto es, el régimen de la decadencia que negando la vida se ha orientado desde los estratos más bajos de la jerarquía de la existencia.

Cfr. Santiago Guervós, L. E. de, Arte y poder, op. cit., pág. 607: «De lo dicho se puede deducir que el 'poder' no lo entiende Nietzsche esencialmente en un sentido político o económico. Tampoco piensa exclusivamente en un dominio de los impulsos o instintos, sino que parece estar pensando de un modo paradigmático en la relación del poder con la vida».

${ }^{631}$ Nietzsche, F., La genealogía de la moral, op. cit., pág. 56 (KSA V, 270-271). 
varse la transvaloración consumada, pues también ella está inserta en la decadencia inmanente de la lógica dionisiaca del devenir.

Poco significa en el corpus de Nietzsche la cuantificación precisa-objetiva, certera- de este principio, en la medida en que su protagonismo reside en la impronta cualitativa de su condición creativa. La moral nace de la voluntad de poder, ella ha construido el mundo bautizado como «Occidente», siendo este rasgo el elemento fundamental de reflexión, de reflexión estética, pues si la moral «crea», lo hace en virtud de su capacidad artísticofilosófico, no epistemológica.

Así, el estudio genealógico de la moral desvela que su suelo nutricio no es «moral», sino voluntad de poder. De manera que las diferencias entre el horizonte valorativo de los griegos y el del presente nihilista se remiten al cariz desde el cual creó el instinto -activo y reactivo, respectivamente- de creación la voluntad de poder. Dado que la moral no es sino una continua sucesión de máscaras, el valor otorgado a éstas remitirá a una negadora y reactiva «voluntad de la nada», anunciadora de los tiempos del hastío como ha ocurrido en la tradición platónica, o bien a una afirmadora «voluntad de vida» que persigue la superación y la optimización de la propia existencia encarnada, para lo cual faculta la transvaloración del sustrato de vida en uno de cariz trágico-hermenéutico. Esta relación agónica se resuelve en la complejidad del propio sujeto, en su pulsión de poder y agotamiento: «fuerte» o «débil», «señor» o «esclavo» de cuyo dominio valorativo se confecciona el cosmos de vida.

En la intimidad del individuo cohabitan tanto las condiciones del último hombre como las del superhombre: «Lo opuesto del superhombre es el último hombre: lo creé a la vez que aquél» ${ }^{632}$. El superhombre y el último hombre son las potencialidades máximas del ser humano, por exceso y por defecto de fuerzas, respectivamente, afectando a su condición creadora. Esta pulsión instintiva de la potencia valoradora de la voluntad de poder se hace manifiesta sobre las producciones mayúsculas del género humano, es decir, su sociedad y su moral. Dado el rechazo de Nietzsche a todo procedimiento de abstracción, no es difícil asegurar que en esta aseveración sobre el despliegue de la voluntad de poder en la humanidad ésta sea radicalmente prescindible en su filosofía. Occidente ha supuesto el triunfo de valores vengativos y reactivos contra la vida, la consagración de un instinto degenerado de decadencia, un vergonzoso error que ha enfermado la piel de la tierra. Y tan

632 Nietzsche, F., Fragmentos póstumos III, 4 [171], op. cit., pág. 123 (KSA X, 172).

La sospecha de que el superhombre y el último hombre cohabitan bajo el mismo techo se sostiene durante todo el pensamiento de madurez. Así lo atestiguan numerosos pasajes de distintos años: "Aún no han existido superhombres. Yo los he visto desnudos a ambos: al más grande y al más mezquino de los hombres: y a ambos los seguí encontrando - ¡demasiado humanos!» (Ibid., 10 [37], pág. 261 [KSA X, 374-375]).

Un segundo pasaje es todavía más concreto al respecto, señalando que van juntos: «El hombre es el animal monstruoso y el superanimal; el hombre superior es el hombre monstruoso y el superhombre; van así juntos» (Nietzsche, F., Fragmentos póstumos IV, 9 [154], op. cit., 283 [KSA XII, 426]). 
desgraciada patología es obra de la corrupción que supone el género humano, la sacrosanta «humanidad» kantiana ${ }^{633}$. Sin embargo, esta consideración desfavorable de la humanidad no significa el paso hacia movimientos de muerte como los del pasado siglo XX; el rechazo del género humano, como abstracción, que discurre en paralelo con su crítica de la compasión, es simultánea y consecuentemente una reivindicación del hombre concreto y encarnado, en quien quedan depositadas todas las esperanzas de la transvaloración de la radicalidad del mundo hacia la cosmovisión dionisiaca de la realidad; una verdad trágica, de cuño hermenéutico, que devuelve al devenir su virtud como núcleo del mundo e introduce al sujeto en el abierto horizonte de posibilidad -no plenamente consciente- de ser cuya determinación, siempre contingente, se remonta a la creación de valores y a su posterior conveniente jerarquización por la voluntad de poder.

Tras la transvaloración, los viejos criterios morales habrán de perecer y ser sucedidos por otros cuya novedad pasará por su afirmación de la vida trágica. Entre los grandes conceptos, en el más maléfico de todos ellos, el «bien», idealizado en la mítica figura del «hombre bueno», acontecerá una transmutación dramática que persigue la conquista de la vida mejor: «¿Qué es bueno? - Todo lo que eleva el sentimiento de poder, la voluntad de poder, el poder mismo en el hombre» ${ }^{634}$. La superación del nihilismo es una recuperación de la vida mediante el cuidado, y para concluir tal fin es necesario que el juicio estéticomoral haga de la superación y de la «fuerza» el criterio básico. La vida será poder, y el poder la superación de las resistencias y de las hostilidades contra la vida ${ }^{635}$. La transvaloración consiste, en suma, en la integración de dos dimensiones que hasta ahora habían estado separadas, la fuente de la vida y la fuente de valoración, en un mismo concepto, la voluntad de poder: «porque la vida es cabalmente voluntad de poder» ${ }^{636}$. En esta integración, no obstante, no tiene lugar una superposición de la vida en la valoración o viceversa. No es una fusión de identidades donde una y otra tratan de conservar sus respectivos significados en una nueva unidad que a causa de ello soporta tensiones estructurales. Es una unidad sintética donde vida y voluntad de poder no pierden sus significados, sino que se comprenden como la misma entidad: la voluntad de poder es la capacidad de crear valores y de jerarquizarlos para que éstos se concreten en una manifestación de vida concreta que si se atiene a las máximas del cuidado da forma a la vida buena, que es la mejor vida posible, dado que en Nietzsche, cuya filosofía es una de plenitud y de desborde, lo bueno es siempre lo

${ }^{633}$ Cfr. Nietzsche, F., Ecce homo, op. cit., pág. 142 (KSA VI, 372): «¡Equivocarse hasta ese punto, no como individuo, no como pueblo, sino como humanidad!».

Del mismo modo, cfr. Nietzsche, F., El Anticristo, op. cit., pág. 33 (KSA VI, 171): «La humanidad no representa una evolución hacia algo mejor, o más fuerte, o más alto [...]».

${ }^{634}$ Ibid. pág. 32 (KSA VI, 170). VI, 170).

${ }^{635}$ Cfr. ibid.: «El sentimiento de que el poder crece, de que una resistencia queda superada» (KSA

${ }^{636}$ Nietzsche, F., Más allá del bien y del mal, op. cit., pág. 235 (KSA V, 208). 
mejor. Y esta vida buena es la encarnación de la voluntad de poder. Así, es el sujeto nietzscheano un sujeto sintético, pues su vida, su existencia es la de la verdad de Dioniso, donde cabalgan lo consciente y lo inconsciente, lo fácil y lo difícil, lo horroroso y lo bello, lo grotesco y lo grácil: la «corporalidad», en la cual el sujeto, ya trágico, al haber dejado atrás su contemplación epistemológica del mundo ha sanado, por su superación, la escisión ideal de los dos mundos y del alma y el cuerpo para saberse creador del mundo y afirmarse en éste y en su actividad creadora misma.

Esta afirmación resulta definitiva y, no obstante, no debe inducirnos a fáciles errores interpretativos. La vida es voluntad de poder, mas como hemos insistido, ésta no se agota en una inexpresiva lectura biologicista que habría de llevar a Nietzsche a ser considerado un cientificista más. La voluntad de poder es ante todo la capacidad de valorar, de imprimir sentidos en el mundo y de crear verdades con ellos; en ese sentido es vida. De manera que mientras el poder y el dominio en las voluntades de poder reactivas han restringido y coaccionado la vida en estrategias de decadencia como el mecanicismo o el positivismo, así como las clásicas alternativas eidéticas de la duplicación -Platón, Descartes, Idealismo alemán, etc.-, aquellas otras que nacidas de la vida han buscado acrecentarla han hecho del poder superación de las propias limitaciones en favor del mejor modus vivendi. De este último modo se dice «cabalmente» que la vida es voluntad de poder.

La sentencia de que la vida es voluntad de poder, por tanto, obliga a distinguir de nuevo el locus griego de la vida como obra de arte en el pensamiento nietzscheano. Toda vida tiene en la voluntad de poder su sustrato, pero no toda vida es digna de ser amada. Esta imagen de dignidad de la vida es una remisión de la Apología de Sócrates, donde el ateniense sostiene que una vida sin filosofía no es digna de ser vivida ${ }^{637}$, entendiendo por tal aquella consistente en conversar a diario acerca de la virtud. La «forma filosófica de existencia», decía Sócrates. La cuestión de la vida digna es fundamental en Nietzsche, pero en un modo diferente del socrático. Para Nietzsche la dignidad se vive encarnada; no es una cuestión relativa al alma eidética que se ha separado esencialmente. La dignidad descansa en la afirmación de la existencia de la transvaloración, donde alma y cuerpo conforman la unidad sintética de la verdad trágica de la voluntad de poder. La dignidad socrática es la del despreciador del cuerpo o la del predicador de la muerte, quien juzga mendazmente el devenir y que propone en su lugar el ser. Su forma filosófica de existencia es idealista, «en las nubes», como dijo Aristófanes, en la medida en que sus principios formales son los de una razón eidética que no guarda relación íntima con el mundo efectivo. La

${ }^{637}$ Cfr. Platón, Apología de Sócrates, 38a, en Diálogos I, trad. de J. Calonge Ruiz, E. Lledó Íñigo, C. García Gual, Madrid, Gredos, 1981, pág. 180: «Si, por otra parte, digo que el mayor bien para un hombre es precisamente éste, tener conversaciones cada día acerca de la virtud y de los otros temas de los que vosotros me habéis oído dialogar cuando me examinaba a mí mismo y a otros, y si digo que una vida sin examen no tiene objeto vivirla para el hombre, me creeréis aún menos. Sin embargo, la verdad es así, como yo digo, atenienses, pero no es fácil convenceros». 
dignidad nietzscheana lleva consigo la libertad y la responsabilidad de un proyecto de cuidado. La vida digna es aquella que puede llamarse «buena», máximamente «buena», porque la filosofía de Nietzsche se mueve en un espectro de extremos, toda vez que la vida es digna o bien indigna, esto es, vivida o transcurrida, respectivamente. La vida digna, dice Nietzsche, es aquella que se experimenta propia, que no está pergeñada en términos ajenos al propio sujeto. La vida digna es aquella encarnada, la vida que se vive desde la dimensión radical de la «corporalidad».

Sólo aquella vida particular que persigue su propio ocaso como puente hacia su superación en aras de la mejor de sus concreciones posibles puede ser amada; únicamente esta particular disposición afectiva se corresponde con la valorización de la vida de una voluntad de poder afirmativa. De modo que en tanto que la vida mejor se presenta como una serie de disposiciones y acontecimientos trazados por el poder y la acción, el intento de simplificarla en caracteres biologicistas no logra recoger toda su profundidad: el esfuerzo por rebasar las propias restricciones, y hacer del mismo el criterio de «bien», no es comprendido por una ley biológica, sino estética. Es más, el sometimiento de la noción de vida bajo el marco científico -Nietzsche piensa en el darwinismo como modelo paradigmático de esta tendencia- responde a criterios de una voluntad de poder pasiva que se satisface con la mera adaptación, con la adecuación de la voluntad de poder en las condiciones fisiológicas de vida, con la propia conservación burda sin pretensión alguna de superación: «la 'autoconservación': perspectiva darwinista para reconciliar principios altruistas y egoís$\operatorname{tas}^{638}{ }^{638}$. Nietzsche entiende que la airada defensa por la conservación desprovee a la vida de sentido y la sume en el tedio de la cotidianidad, donde el tiempo transita sin aportar ocasiones de fruto al hombre, donde la vida es un simple tránsito sin experiencia de existencia encarnada; cabe sostener la sospecha de que tras la teoría darwiniana no se esconda sino una fuerza nihilista acomodaticia, quizá inconsciente, que impide mirar hacia el futuro como proyecto de cuidado de la existencia: «iQué valor confesarse darwinista, declarar que uno 'no es cristiano', pero luego, en todas las circunstancias reales y serias de la vida, recaer medroso en la más mezquina comodidad» ${ }^{639}$. No será buena una doctrina que parcele la existencia y acepte únicamente sus rasgos favorables; que la vida sea voluntad de poder comprende que «con cada crecimiento del hombre en grandeza y en altura crece también en profundidad y en lo terrible: no se debe querer una cosa sin la otra - o más bien: cuanto más fundamentalmente se quiere una cosa, tanto más fundamentalmente se alcanza precisamente la otra» ${ }^{640}$. El darwinismo está dentro de la «gramática» de Dios, ya que no

${ }^{638}$ Nietzsche, F., Fragmentos póstumos IV, 2 [165], op. cit., 127 (KSA XII, 149).

${ }^{639}$ Nietzsche, F., Fragmentos póstumos I, 27 [17], op. cit., 468 (KSA VII, 591).

Sospecha que corrobora cuando previene del resultado de la comparación entre Darwin y Goethe: «Poner a Darwin junto a Goethe. Significa: atentar contra la majestad - majestatem Genii!» (Nietzsche, F., Fragmentos póstumos III, 28 [45], op. cit., 647 [KSA XI, 317]).

${ }^{640}$ Nietzsche, F., Fragmentos póstumos IV, 9 [154], op. cit., 283 (KSA XII, 426). 
se atreve a mirar a la verdad desnuda. Sigue confiando en aquella imagen de que la verdad comporta tan sólo rasgos gráciles y que el acceso a la misma acaece por mecanismos lógicos, como la dialéctica metafísica platónica o las objetivas leyes del mecanicismo, en todas sus manifestaciones: el biologicismo en este caso particular.

La verdad aporta cobijo en el darwinismo. Al favorecer la continuidad de la vida orgánica, extirpa los caracteres «malos», aquellos que por su dificultad y por el riesgo que comportan hacen de la existencia algo oscuro, turbulento y tormentoso; en su lugar, la verdad en el darwinismo tan sólo provee de rasgos «buenos». El cristianismo del darwinismo es otro abandono despectivo de la vida, ya que no contempla la faceta del cuidado, la cual no se conforma con la supervivencia, sino que aspira a lo sublime. Hay más voluntad de poder en el Napoleón que reta a sus antiguos soldados a dispararlo mortalmente ${ }^{641}$ que en el despreciador del cuerpo que cuenta sus años por decenas. El darwinismo como paradigma de la naturalización de la «moral»-cristiana- en la modernidad es la manifestación más objetiva - positivista- de la moral de la escisión eidética, donde la naturaleza como objeto, como ley, fagocita los caracteres «aparentes» de la vida; priva a ésta de las posibilidades y ocasiones del devenir y, por ende, de la cualidad plástica de la voluntad de poder que faculta una vida eminentemente estética, o sea, como proyecto activo de creación que hace del hombre artista-filósofo.

Estas consideraciones son del todo coherentes con la motivación filosófica fundamental de nuestro autor: que el mejor hombre sea la mayor creación de la voluntad de poder. La vida es el basto bloque de mármol del cual la voluntad de poder creadora extraerá el David, esto es, la optimización de las capacidades de existencia. «Fuerte»y «débil» son valores relativos en referencia con la distinción jerárquica de los tipos de vida; en todos los seres naturales está la voluntad de poder, igualándolos esencialmente en tanto que capacitados para generar valores. La fortaleza o la debilidad la determinará el viraje de los instintos de la voluntad de poder propia.

\section{I.2.2. La voluntad de poder como fuerza hermenéutica}

El elemento fundamental de la voluntad de poder, la creación de valores y verdades que conforman el mundo humano, tiene su origen en la vida. El devenir esencial de ésta hace de la voluntad de poder plástica fuerza interpretadora de las distintas realidades po-

${ }^{641}$ Cuenta la anécdota histórica que al comienzo de los Cien Días, cuando El Emperador regresó a París de su exilio en Elba, aún siendo fugitivo y perseguido por las autoridades, una escuadra armada lo interceptó. Sabedor de que conforme a su deber éstos habían de apresarlo, se adelantó a sus soldados fieles y con apabullante autoridad se encaró contra los guardias: «aquel de vosotros que se atreva a disparar a su Emperador, que lo haga ahora». Los jóvenes gendarmes bajarían las armas para formar filas una vez más con él. Pues «morir a tiempo: eso es lo que Zaratustra enseña» (Nietzsche, F., Así habló Zaratustra, op. cit., pág. 118 [KSA IV, 93]).

Cfr. Nietzsche, F., Fragmentos póstumos IV, op. cit., 15 [31], pág. 637 (KSA XIII, 427): «[...] Napoleón, quien vio en la civilización a su enemiga natural...». 
sibles que se suceden. Allí donde hay una vida que vive, o sea, que vive plenamente, «encarnada», emergen las verdades; mientras la verdad, en singular, es síntoma de una vida decadente que tan sólo pretende conservarse en la ilusión eidética de la incólume presencia del ser.

La proposición ontológica nietzscheana percibe la verdad en la pluralidad, la cual se agolpa en una amalgama todavía indeterminada de realidades y verdades superpuestas siempre abiertas en un horizonte perspectivista cuyo sentido y significado se colma y concreta mediante una interpretación, mediante una adjudicación de valor jerarquizada sobre tantas otras ${ }^{642}$, siempre falible en tanto que remite al fondo trágico en devenir de la verdad hermenéutica que es la voluntad de poder:

Que el valor del mundo reside en nuestra interpretación (— que quizá en alguna parte sean posible otras interpretaciones, diferentes de las meramente humanas - ), que las interpretaciones habidas hasta ahora son estimaciones perspectivistas en virtud de las cuales nos mantenemos en vida, es decir, en la voluntad de poder, de crecimiento del poder, que toda elevación del hombre lleva consigo la superación de interpretaciones más estrechas, que toda fortificación y ampliación de poder que se alcance abre nuevas perspectivas y hace creer en nuevos horizontes - esto recorre mis escritos. El mundo que en algo nos concierne es falso, es decir, no es un hecho, sino una invención y un redondeo a partir de una magra suma de observaciones; está siempre «fluyendo», como algo que deviene, como una falsedad que continuamente vuelve a trasladarse, que no se acerca nunca a la verdad: porque - no hay «verdad» ${ }^{643}$.

A la luz del núcleo hermenéutico de la voluntad de poder, la verdad y el error dejan de ser categorías indubitables, relativas a la epistemología de la metafísica de la duplicación, y se introducen irremediablemente en la experiencia de existencia del sujeto sintético de la trágica voluntad de poder. Que la vida sea voluntad de poder es lo que introduce en el mundo la verdad y el error perspectivista, pues lo sumerge en el fecundo frenesí del devenir y la pluralidad esencialmente asignificativa. Un suelo nutricio que empuja la consideración del valor de la vida hacia un horizonte que supera, como ya apuntamos, los códigos -objetivos, positivistas, certeros, metafísicos- de la biología; el sustrato sobre el cual se yergue la experiencia del ser en devenir es una matriz artístico-filosófica articulada desde una interpretación consciente de su propio fondo de conformación -no plenamenteconsciente de la personalidad, dador en consecuencia de su condición falaz y que responsablemente se exige a sí misma serlo: la vida humana está sumida en una incertidumbre esencial cuyo sentido y verdad se determinan constantemente en el libre y perentorio ejercicio de la voluntad de poder.

${ }^{642}$ Cfr. Nietzsche, F., Fragmentos póstumos III, 4 [207], op. cit., pág. 127 (KSA X, 169): «En el hombre anidan tantos espíritus como animales en el mar - y luchan unos contra otros por el espíritu 'yo'; lo aman, quieren que salte sobre sus espaldas, se odian mutuamente a causa de este amor».

${ }^{643}$ Nietzsche, F., Fragmentos póstumos IV, 2 [108], op. cit., 108 (KSA XII, 114). 
En la creación de verdades por la voluntad de poder intervienen fuerzas interpretativas que convierten al sujeto de poder en una sintética pluralidad identitaria de perspectivas y posiciones desde las que se da contenido a la acción que, en virtud de su poder, aspira a acrecentarse: la acción se acrecienta cuando el sujeto es capaz de darse sus propias metas y fines. Las diferentes perspectivas que articulan el núcleo específico de la acción creadora de la voluntad de poder no son, sin embargo, simples prismas y posiciones. En ellas se despliega en toda su «virulencia» la voluntad de poder: las distintas ópticas guardan una relación recíprocamente tensa a lo largo de un conflicto en el que se oponen entre sí, agotándose, consumiéndose y fortaleciéndose en el juego esencial del ser en devenir que busca su superación y conquistar su mejor forma de existencia.

En la pulsión de vida de la voluntad de poder se agolpa una ilimitada cantidad de fuerzas e instintos que luchan entre sí por afirmarse. La victoria de una(s) sobre el resto lo determina la fuerza creadora que, como hemos señalado, puede ser tanto afirmativa como reactiva. El consejo de dureza de Nietzsche afecta en este nivel de conquista de las fuerzas de la voluntad de poder. El artista-filósofo se ha endurecido: al comprender las exigencias que arrastra consigo la libertad de su espíritu ha sido capaz de afirmar las pulsiones más vigorosas, todavía cuando pudieran comportar dolor y dificultad, en la concreción contingente de su existencia. Una existencia que en virtud de su desborde y plenitud es buena, esto es, la mejor, y que vive encarnada la experiencia y la conciencia de vida del sujeto de la voluntad de poder:

El bienestar, tal como vosotros lo entendéis - ¡eso no es, desde luego, una meta, eso a nosotros nos parece un final! Un estado que enseguida vuelve ridículo y despreciable al hombre, - ¡que hace desear el ocaso de éste! La disciplina del sufrimiento, del gran sufrimiento - ¿no sabéis que únicamente esa disciplina es la que ha creado hasta ahora todas las elevaciones del hombre? Aquella tensión del alma en la infelicidad, que es la que le inculca su fortaleza, los estremecimientos del alma ante el espectáculo de la gran ruina, su inventiva y valentía en el soportar, perseverar, interpretar, aprovechar la desgracia, así como toda la profundidad, misterio, máscara, espíritu, argucia, grandeza que le han sido donados al alma: - ¿no le han sido donados bajo sufrimientos, bajo la disciplina del gran sufrimiento? ${ }^{644}$.

En tanto que vida la voluntad de poder es una interpretación que busca desplegar máximamente las condiciones y posibilidades de existencia. Toda concreción de valor tiene lugar desde la afirmación; toda concreción de valor «buena» tiene lugar desde la vida, por ello ésta es artística. Toda vida nacida del instinto fuerte y vigoroso, sano, duro de la voluntad de poder es una obra de ficción que pone en primer plano la libertad del individuo creador como capacidad discriminatoria y electora de los estímulos fuertes en detrimento

${ }^{644}$ Nietzsche, F., Más allá del bien y del mal, op. cit., pág. 183 (KSA V, 161). 
de los débiles ${ }^{645}$, o sea, como capacidad que se compromete con la existencia libre, esto es, responsable. En el decurso de las elecciones, la pluralidad esencial del ser en devenir de la voluntad de poder se integra en una particular unidad precaria de significado y sentido que se afirma artísticamente como «hombre sintético», como sujeto que ya no aspira a la plena autoconciencia, sino que se sabe trágico y, sobre dicha matriz, se afirma tal: el sujeto es inaccesible para sí mismo, lo cual no significa que sea extraño. Por su condición inconsciente básica asume la precariedad que afecta a su personalidad, mas la integra como un conocimiento jovial que lo sumerge en la difícil y arriesgada empresa de experimentar su existencia desde sus condiciones radicales. Así la afirmación de la vida deja de ser epistemológica, pues ésta tiende a la unidad inamovible e imperecedera del ser, para procurarse ahora condiciones artísticas: el hombre sintético es creación de sí mismo como la mejor y más cuidada obra de arte; en tanto que el «artista» y la «creación» se identifican en la verdad dionisiaca de la voluntad de poder, el sujeto sintético no deja de cincelarse en el juego plástico de la afirmación y consolidación de sus metas y fines. El artista-filósofo no deja de vivirse, pues su creación no cesa de reclamar renovadas fuentes de acrecentamiento de la plenitud de la vida. Y es que si estimamos al artista-filósofo como el superhombre, también él está sujeto a la lógica de precariedad, contingencia y caducidad de Dioniso: el superhombre es tan precario como cualquier otra posibilidad de existencia, pues es devenir y no ser. Pero precisamente en su afirmación de ser en devenir está la clave de su superación del hombre reactivo.

Ahora bien, entiende Nietzsche que la creación de la obra de arte que es el hombre sintético, por sí mismo, que es a su vez el artista-filósofo, necesita de caracteres cualitativamente mayores que los del simple pluralismo cuantitativo. De contar únicamente con éste, seríamos arrojados en un inabarcable océano de posiciones y verdades que imposibilitaría la elección cuasiconsciente y jerárquica de los valores superiores y su conjugación en la mejor de las vidas. Nietzsche exige, además, la tragedia del perspectivismo, el cual imprime sobre la inmensidad inerte de la pluralidad numérica el dinamismo y el devenir dionisiaco de la interpretación hermenéutica que devuelve a la vida su inocencia, la inocencia de un niño: «en la medida en que la palabra 'conocimiento' tiene sentido, el mundo es cognoscible: pero es interpretable de otro modo, no tiene un sentido detrás de sí, sino innumerables sentidos, 'perspectivismo'» ${ }^{646}$.

El perspectivismo nietzscheano es sumamente complejo. Parte de la experiencia de la muerte de Dios, que anega las expectativas de una perspectiva última que unifique to-

\footnotetext{
${ }^{645}$ Cfr. ibid. pág. 170 (KSA V, 148): «Acaso los artistas tengan en esto un olfato más sutil: ellos, que saben demasiado bien que justo cuando no hacen ya nada 'voluntariamente', sino todo necesariamente, es cuando llega a su cumbre su sentimiento de libertad, de finura, de omnipotencia, de establecer, disponer, configurar creadoramente, - en suma, que entonces es cuando la necesidad y la 'libertad de la voluntad' son en ellos una sola cosa».
}

${ }^{646}$ Nietzsche, F., Fragmentos póstumos IV, 7 [60], op. cit., pág. 222 (KSA XII, 315). 
das las demás. La pérdida de la verdad absoluta procurada por la metafísica del mundo suprasensible ha traído consigo una precariedad esencial que en su contingencia halla, sin embargo, necesidad: el fundamento de la realidad se constituye mediante apariencias que se aprecian perspectivísticamente. Y ésta es una condición necesaria que se ha postulado en su corpus como verdad: la verdad es el carácter perspectivista de la vida y sus cualidades hermenéuticas, la apropiación de los rasgos de la existencia encarnada mediante la creación y la jerarquización de valores. La verdad integra las condiciones de vida, siendo la «mentira» y el «error» los caracteres que delimitan las perspectivas. La apariencia juega por tanto un doble rol: es de tal naturaleza porque está restringida a la perspectiva que impone la vida humana, al mismo tiempo que verdadera y necesaria en tanto que condición de posibilidad de los constituyentes de la existencia del hombre encarnado. La apariencia se extiende a lo largo de todo lo real, mientras que la perspectiva es la máxima disposición humana que da forma y confecciona como «verdad» una falsa unidad en el devenir. En virtud del carácter fabuloso de toda verdad y valor, el perspectivismo toma conciencia de su propia dimensión perspectivista: con la muerte de Dios y, con Él, el sentido y la verdad únicos, la voluntad de poder activa se adueña del derecho de verdad. Que la voluntad de poder afirmadora se adueñe del derecho de la verdad significa, en realidad, que la vida ha tomado de nuevo, como dijera Wilde, su «derecho de primogenitura»; que la existencia sea un derecho del hombre en cuanto que existe es la significación de la transvaloración. La propia existencia, la propia vida ha sido redimida ${ }^{647}$, por lo que no necesita ya de instancias externas y superiores, pues ella misma es razón de sí: la voluntad de poder como derecho de la verdad hace que la vida se procure sus propias metas y fines, que experimenta íntimamente, y que se despliegue en plenitud en su curso reapropiándose de sí en cada acontecimiento de creación afirmadora.

La pérdida de la unidad estructural del mundo es también la del sentido ulterior; la muerte de Dios anula las viejas tentativas escatológicas de un destino racionalmente trazado. El desgarramiento de la metaconciencia del mundo inteligible ha cegado al futuro de toda meta: «inocencia del devenir». Una nueva disposición cosmológica y existencial donde la apariencia, emancipada de la culpa pretérita, se ha convertido en el ámbito de la verdad nacida de la solidaria integración de la pluralidad y el perspectivismo que responden, a su vez, al fondo trágico del ser en devenir. Y como no existe realidad fuera de las interpretaciones, que remiten a su vez a la voluntad de poder, la realidad ha quedado radicada más allá del bien y del mal, ha sido despojada de toda culpa, es inocente, es voluntad de poder. Dado que la voluntad es la fuente de valoración y de interpretación, todo esfuerzo hermenéutico parte de ella. Entonces, por un lado los valores y las interpretaciones se encuentran

${ }^{647}$ Recordemos lo que dijimos líneas atrás sobre la cuestión de la «redención» en Nietzsche y sus diferencias fundamentales respecto del perdón que ofrecieron los predicadores de la muerte. La redención de Nietzsche es caracterizada después de la transvaloración, por lo que emerge de la experiencia encarnada de la vida en vez de partir de avatares ideales supramundanos. 
dentro de los márgenes de la voluntad de poder; al mismo tiempo, la verdad de la realidad es hermenéutica, es decir, se articula a través de los valores y de las interpretaciones que emanan de la voluntad de poder. Así pues, con todo, la «inocencia del devenir» como cosmovisión según la cual no existe realidad fuera de las interpretaciones es la afirmación de la verdad de la vida como la propia experiencia de vida, radicada en sí misma y ceñida en su condición de fuente de valoración. La «inocencia del devenir» es la cosmovisión redimi$d a$ de los ideales ascéticos de la duplicación y de la escisión. En ella la vida se comprende como voluntad de poder.

El perspectivismo de la filosofía de Nietzsche juega un doble efecto, condicionando tanto la perspectiva del hombre dentro de un mundo potencialmente infinito como destacando la esencial limitación de una filosofía que ya no puede postularse absoluta. La filosofía de Nietzsche es una filosofía de cierta menesterosidad. Una pobreza, una limitación que, sin embargo, ha de ser explicada. No estamos ante una contradicción si afirmamos que en su obra se cita tanto la sobreabundancia como la pobreza, pues son términos que remiten a contenidos heterodoxos que no entrañan la antonimia ordinaria de nuestro lenguaje. La sobreabundancia y riqueza nietzscheana, como la menesterosidad, nada tienen que ver con el oropel ni con la acumulación de alhajas. Lo primero, ya lo hemos señalado repetidas veces, alude a la fuerza de las interpretaciones; a la capacidad de crear los más duros valores en aras de la concreción de una vida buena. Mientras que la menesterosidad tiene inmediata relación con la lógica de decadencia y de finitud que sostiene la vida dionisiaca. Nada puede escapar del ciclo de generación y corrupción de una vida trágica, tampoco el pensamiento. De ahí que éste sea «limitado», o sea, necesariamente sujeto a la indigencia de la caducidad de todo lo contingente. Que la filosofía nietzscheana sea limitada significa pobreza en estos caracteres de inminente decadencia y degeneración; rasgos éstos que la alejan del curso de una filosofía sistemática con pretensiones últimas que encierre todas las posibilidades de existencia y cuyo «fin» sea la actualización de todos ellos. Es decir, es limitada porque nunca podrá ser entelequia de sí misma, pues esto significaría reintroducirla en los términos «gramaticales» del ser eterno e incontingente de la tradicional escatología metafísica occidental.

Con todo se muestra la radicalidad interpretativa de toda existencia. Así puede Nietzsche concluir que el perspectivismo es el elemento genuino del hombre para impulsar los instintos de la voluntad de poder hacia la superación de uno mismo en el horizonte abierto e inagotable de la obra de arte que es la mejor vida, la del artista-filósofo que experimenta y afirma su «corporalidad». 


\section{I.2.3. La voluntad de poder como poiesis: ruptura y futuro}

La muerte de Dios ha puesto fin a la longeva tradición del ser, la de la verdad absoluta y de la unidad esencial de toda referencia valoradora. Sin embargo, en esta disrupción hay una especie de transvaloración de las formas filosóficas durante la cual la verdad se fragmenta en indeterminadas perspectivas plurales que remiten a las condiciones radicales de la vida encarnada: la verdad se convierte en voluntad de poder ${ }^{648}$. La verdad, la voluntad de poder y la vida son los tres vértices del triángulo de la existencia, que a su vez tiene su límite en las propias condiciones de vida dadas, pues este triángulo de existencia es existencia como «corporalidad». La creación artística de la vida estética no se emprende desde la nada ni es tampoco el resultado de un paroxismo idealista típico del egoísmo especulativo; en el trasfondo de la vida las muchas voluntades de poder se enfrentan y limitan entre sí, determinando en tal pugna el horizonte de potencia de la vida. Si la voluntad de poder era una fuerza hermenéutica, continuando la metáfora gadameriana, su horizonte de conformidad y despliegue es la alteridad del sujeto con sus propias perspectivas posibles.

La especificidad del nihilismo decimonónico destacaba por su conciencia de sí; en este rasgo estaba la puerta hacia su superación, y tal impronta, la de la conciencia del propio estado, será mantenida también en la dimensión afirmativa de la voluntad de poder. La verdad, en tanto resultado artístico, es una «mentira», una «ficción» de cuya condición ficticia tenemos conocimiento, es decir, nos sabemos creadores de valores y verdades. Vivir es tragedia, luego excede los márgenes del conocimiento epistémico; vivir significa poetizar, integrar al sujeto sintético creador de verdades en sus propias ficciones para impregnarlas de sentido, crear sus metas y fines, desde su radical experiencia de existencia encarnada: «- ¿Qué son pues nuestras vivencias? ¡Mucho más lo que introducimos en ellas que lo que en ellas hay! ¿No habrá que decir incluso que en ellas no hay nada? ¿Qué vivir (algo) es fabular? $\longrightarrow \gg^{649}$. Precisamente por su remisión fundamental a la vida la voluntad de poder se concreta en una perspectiva de superación y crecimiento: crea valores que condicionan favorablemente la vida.

${ }^{648}$ Cfr. ibid. 9 [36], pág. 242 (KSA XII, 352): «La voluntad de verdad como voluntad de poder».

${ }^{649}$ Nietzsche, F., Aurora, op. cit., pág. 556 (KSA III, 114). 
Desde esta determinación del acrecentamiento la voluntad de poder es verdaderamente poderosa ${ }^{650}-d u r a-$ y puede colonizar la voluntad de verdad: una voluntad de poder poderosa impulsa la vida hacia su superación, esto es, refuerza las condiciones de la existencial verdad dionisiaca. En el hacer afirmativo de la voluntad de poder verdad y poder se solapan, integran e identifican, «porque la vida es cabalmente voluntad de poder», ya que «vivir (algo) es fabular». En virtud de su dominio, la voluntad de poder hecha voluntad de verdad imprime una consistencia y una fijeza intrínsecamente caduca y frágil que, entre la madeja de perspectivas, determinan la filosofía de Nietzsche como una filosofía «limitada». El artista-filósofo introduce el ser en el devenir, nunca perdiendo de vista que aquél tiene la integridad menesterosa de una ficción. El hombre se adueña de la verdad cuando la domeña y hace de ésta una mentira afirmadora de la propia vida; verdad y mentira, mentira y verdad han dejado de ser estamentos contrarios y en natural oposición; son ficciones, interpretaciones insertas en la dinámica perspectivista de la plasticidad de la voluntad de poder.

La voluntad de poder tenía como límite condicionante la alteridad, por lo que en su despliegue entra en íntimo contacto con otras perspectivas, otras verdades con las que se mezcla y domina -ora «fusión de horizontes» ora fagocitándolas-, en el ejercicio de su libertad superadora. En esta capacidad de superación de sí misma a través del conflicto jerárquico con otras voluntades se acaba por desvelar la transvaloración: agotados no sólo los contenidos valorativos, sino el marco de posibilidad y contemplación de la valoración, el núcleo de trascendencia de la voluntad de poder termina por transmutar el propio paradigma valorativo, causando un cataclismo intelectual que Zaratustra apresó en la metáfora del cambio de tablero. Este cataclismo intelectual ha sido tratado en otros términos en este trabajo. El conflicto intelectual que acaba llegando a Zaratustra como un problema de magnitudes colosales, el del fin del sujeto epistémico, aquel de la tradición bimilenaria platónica, el «filósofo». El cambio de tablero que exige el sabio persa afecta a las reglas del juego: tiene lugar una transmutación del sustrato epistémico en el nuevo, trágico; y a los jugadores: el sujeto epistémico, el «filósofo» ha perdido su lugar, el cual está ahora ocupado por ej jugador de las reglas trágicas, el «artista-filósofo».

\footnotetext{
650 Recordemos que «poder» no es dominación: la voluntad de poder de los débiles dominó el horizonte moral de Occidente, mas sus valores eran reactivos y carentes del genuino contenido del poder, afirmativo y señorial. El poder es la fuerza activa del espíritu corporalizado y del cuerpo espiritualizado que afirma máximamente aquellos valores que favorecen su vida; no una vida cualquiera, sino una que por haber sido cuidada es una vida «buena», la mejor posible. El poder no es dominación del hombre por el hombre, sino excelencia, plenitud, derroche de las fuerzas de la existencia, la capacidad de crear los mejores valores y de jerarquizarlos después en el proyecto estético de la encarnación. El poder es dominación del propio hombre sobre sí mismo: es la fuerza del espíritu endurecido que ejecuta sobre sí el régimen ascético de la ética del cuidado nietzscheana; la dominación es la capacidad de endurecimiento de los espíritus más selectos que aspiran a ser más que meras criaturas orgánicas. La dominación es la afirmación de la voluntad de poder como esencia de la «corporalidad»; sólo el espíritu que se domina a sí mismo logra emprender el camino que lleva a «ser lo que se es».
} 
En su afirmación de la vida la voluntad de poder asimila e integra otras perspectivas, hasta que una vez colmada, sabiéndose incapaz de continuar su tarea afirmadora desde los contenidos vigentes, se reinventa, a través del sujeto encarnado, en los caracteres de un nuevo horizonte «gramatical» de reglas trágicas.

Zaratustra insiste repetidas veces en la acción de la ruptura, la cual habrá de destrozar las viejas tablas de valor, pues la ruptura y el futuro están coligados y en estricta dependencia; la alteridad sólo abre expectativas desde las nuevas tablas de valor que han de asentarse sobre las ruinas de las pretéritas. Así es la lógica dionisiaca del devenir: destrucción y creación. El desprecio ha de destruir todo lo existente para poder, desde el nuevo sustrato virgen, crear. Así la acción de la voluntad de poder no es únicamente creadora y afirmadora, sino re-creadora y re-afirmadora. Esta última actitud es imprescindible para dejar finalmente atrás el nihilismo, para consumarlo y superarlo. Éste ha corroído las tablas occidentales hasta disolverlas en su totalidad, luego la única respuesta afirmativa pasará por ser una re-generación de las condiciones de vida, o sea, de los esquemas de valoración. La cálida luz de las nuevas auroras reverbera en la voluntad de verdad que ha hecho de sí voluntad de poder: la vida como obra de arte es la máxima creación artística de la voluntad de poder del artista-filósofo que contempla la existencia encarnada desde las claves del cuidado, el cual responde a la posibilidad del sujeto libre, emancipado, «redimido» de los ídolos de la tradición metafísica, ahora vacíos tras haber recibido el golpe del martillo. 


\section{CAPÍTULO II: LA VENTURA DEL TIEMPO ENCARNADO}

\section{II.1. El concepto del eterno retorno}

Decía Heidegger que toda vez que la filosofía de Nietzsche seguía articulándose a través de una matriz de conceptos - «voluntad de poder», «eterno retorno», «superhombre», «vida»-, conservaba la disposición moderna del pensamiento conceptual y, por ende, continuaba inserto en la historia del nihilismo. No nos resulta satisfactoria la reducción llevada a cabo por Heidegger arreglo al modus filosófico de Nietzsche; si bien es cierto que opera valiéndose de grandes conceptos, son en sí mismos sustancialmente distintos de las formas modernas, ya que los ha desposeído de significaciones últimas y cerradas. El recurso de la conceptualización, si bien genuinamente moderno, no supone la irremediable inclusión del autor en la tradición -nihilista- moderna. La desacertada apreciación heideggeriana se debe, más bien, a su peculiar hermenéutica del nihilismo y de Nietzsche -ya expuesta-, donde el concepto es una manifestación violenta de la tradición de la adecuación; un esfuerzo más por objetivar la realidad «entitativa». La circunspección nietzscheana del nihilismo apunta a otro fondo, la cuestión de la existencia, por lo que elude la reflexión metafísica. Si se quiere, Nietzsche, preocupado por la existencia, reflexiona a propósito del efecto de la metafísica, mientras que Heidegger, precisamente por menospreciar el ratio existencial en favor de la cuestión del valor, es, en cuanto tal, un pensador metafísico.

La emancipación de la conceptualización moderna en Nietzsche se aprecia prístinamente en el concepto de «voluntad de poder»y, especialmente, en el de «eterno retorno». Son conceptos, no ha lugar a dudas, mas en ningún modo pueden definirse absolutamente, ya que de hacerlo las grandes aspiraciones de la filosofía nietzscheana verían cercenadas sus posibilidades de futuro. El pensamiento del autor está trabado en el devenir, por lo que privar al eterno retorno de una esencial movilidad -modus operandi de la conceptualización moderna- lo sumiría en una contradicción fatal, pues lo situaría en un sustrato no dionisiaco, único espacio en el que el eterno retorno como nueva experiencia vivencial del tiempo tiene cabida.

Ya señalamos anteriormente que la conceptualización en Nietzsche carece de contenido, aunque de un modo distinto del vaciamiento kantiano: mientras en el prusiano la vaciedad esencial se debe a su aspiración de universalidad, en Nietzsche, por el contrario, el vacío se justifica precisamente por la exigencia de atenerse a la radicalidad empírica. Como la realidad se le ha presentado a Nietzsche en una matriz trágica asignificativa, es preciso que los conceptos carezcan de contenido último, toda vez que están sujetos a la lógica de decadencia de un suelo «indigente», esto es, abierto irremediablemente al horizonte perspectivista de una verdad en construcción. Es por el rasgo hermenéutico de la verdad que los conceptos, definitivos tras la apropiación de la voluntad de poder, carecen de significación sustantiva. De lo contrario, éstos serían propios de una «gramática» del ser, la cual 
es ahora insostenible tras la reciente revelación de la sintaxis dionisiaca que ha hecho del hombre encarnado el sujeto activo de toda acción.

Igualmente Nietzsche baña todos sus conceptos con un halo de indeterminación estructural inédito en la tradición moderna, obsesionada con la precisión y la certeza. Esta incertidumbre distintiva de los términos nietzscheanos dificulta la lectura de algunos pasajes, que no pueden entenderse desde una aproximación literalista. Esto sucede con el concepto que nos ocupa: no se trata de una repetición cósmica de cada instante, sino de una «verdad» de la peculiar ontología nietzscheana. El eterno retorno, el cual tiene fuerza creadora y determinante, es una metáfora que ilumina la imagen de la vida. Al igual que con la voluntad de poder, el eterno retorno ha de ser leído artístico-filosóficamente. Es el «cuándo» que marca el momento del superhombre, quien a su vez lo riega y cuida: eterno retorno y superhombre son respectivamente límite y condición de posibilidad del otro, pues en sus polos se concreta la lógica de la decadencia: el superhombre debe perecer para poder retornar, mientras que el tiempo debe ser reapropiado en la experiencia de la vida para que sus manecillas marquen la «eternidad» de una existencia sin fin, como es la del individuo que por su «corporalidad» se sume en la tarea del cuidado de una existencia siempre abierta y sujeta a la (in)determinación peculiar de la plasticidad de la voluntad de poder.

Atestigua la importancia del eterno retorno, quizá el concepto de cuyo descubrimiento más se enorgulleció Nietzsche, la comparación con la voluntad de poder a propósito de sus límites condicionadores. La voluntad de poder responde ante el tribunal de la perspectiva siempre pendiente; el eterno retorno, ante el superhombre, quien es la perspectiva concretada, corporeizada, de máxima plenitud de fuerza de vida. El imperativo del eterno retorno, es la afirmación última y más contundente de la vida encarnada, ya que conmina a su aceptación radical, en sus placeres y goces así como en sus angustias y dolores, es decir, en elementalidad trágica. El eterno retorno no parcela reactivamente la vida pretendiendo tan sólo sus caracteres amables, sino que la acoge en su totalidad. En suma, el eterno retorno se sitúa más allá del bien y del mal, no condena ciertos rasgos de la existencia a lo largo de un juicio moral vengativo, sino que abarca todos ellos al contemplarlos holísticamente como las condiciones «empíricas» del cuerpo y del espíritu que han de estar -y que están- en el tiempo oportuno del superhombre, donde el artista-filósofo y su obra comulgan identitariamente en una íntima unidad sintética que se yergue como la vida buena que dispuesta de acuerdo con las máximas del cuidado es la manifestación del hombre que ha conquistado su libertad. La «libertad», ahora podemos concluir, es la emancipación de la conciencia respecto de los agentes externos que impidieron a la personalidad procurarse sus propias metas y fines y que en consecuencia hiciera de la «imitación» y la «participación» de lo sensible en lo ideal el imperativo intelectual y moral de existencia -el intelectualismo moral socrático, par excellence-. El eterno retorno es el tiempo del superhombre, el «cuándo» del artista-filósofo que hace de la «corporalidad» su gran obra y alumbra 
desde sí mismo, por medio de su «santo decir sí», los contenidos de significado de su existencia. En tanto que momento de despliegue de la «corporalidad», el eterno retorno bien puede ser la apropiación de la vivencia del tiempo encarnado.

El eterno retorno no condena la vida, mas tampoco es un principio plácido y dulce. Al contrario, es una experiencia que conmocionó a Zaratustra y lo tuvo postrado en su lecho. El desmayo de Zaratustra indica que incluso él, el más próximo de todos los hombres a la consumación del nihilismo, es incapaz todavía de abrazar en su totalidad la vida de la verdad dionisiaca. Zaratustra no condena la vida, pero el amor incondicional del eterno retorno era aún demasiado duro. El convaleciente Zaratustra se ha enfrentado al peso de la «corporalidad», ha apreciado sus rasgos y, sin embargo, todavía no puede entregarse a ella. Motivo éste por el cual Nietzsche insistía en que aún no había pisado la superficie de la tierra el tipo de hombre más selecto: incluso los espíritus más grandes son demasiado pequeños. Es necesaria una transmutación del dolor en vigor y fuerza, de la enfermedad en salud, en la medida en que la construcción de la identidad habrá de acontecer desde un dominio netamente indeterminado que nos impedirá conocernos en plenitud, o sea, que anula las expectativas del sujeto autoconsciente cartesiano. Esta afirmación es máximamente dolorosa y difícil de coordinar en el proyecto nietzscheano de existencia: ¿cómo lograr la aspiración de una unidad sintética de la conciencia y de la experiencia de existencia al tiempo que jamás se podrá arrojar luz en la totalidad del continente de la subjetividad?

La experiencia de vida es por esto trágica, pues la reapropiación del sentido encarnado parece haberse probado insuficiente en tanto jamás se alcanzará una comprensión clara y distinta de la encarnación. Precisamente ésta es la enseñanza del eterno retorno: la eternidad de la existencia sumida en un último vacío bastión de sentido que ha de ser colmado por el propio hombre en el esfuerzo constante de su encarnación. El «sí» del eterno retorno es la aceptación de esta exigencia de significación. Esto se engarza con la descripción que ofrecimos de la filosofía de Nietzsche como una filosofía «limitada», indigente, menesterosa. Cuando Zaratustra se recupera y se alza nuevamente, cuando se halla en disposición de volver a «cantar» ha alcanzado esta verdad, la de la eterna ocasión oportuna que brinda la limitación de su filosofía.

En su limitación esencial, en la imposibilidad de procurarse un destino último, incluso cuando éste fuese propio del sujeto, descansa la vocación de eternidad de la filosofía de Nietzsche: la reapropiación de la existencia es una tarea siempre incompleta, siempre pendiente, dado que la atribución de un sentido definitivo la encerraría en los márgenes de la sintaxis del ser. En tanto que configurada desde la dimensión estético-moral del cuidado la existencia siempre está abierta a la «vigorización» de las fuerzas de su pulsión de vida, esto es, al acrecentamiento de su poder, de su dominación. El cuidado remite a la vida bue- 
na como vida mejor, y ésta concreción de plenitud está pendiente, abierta; siempre por llegar a «ser lo que se es».

No obstante, si se logra asimilar la fuerza de este demoledor principio, actuará como el balsámico elixir de los hombres que, cautivos del nihilismo, anhelan su superación. No se ha de olvidar que toda la filosofía de Nietzsche hace gala de un marcado ascetismo de raíz epicúrea, de tal fortuna que aunque se encuentra toda ella trazada por la dureza de feroces y dolorosos acontecimientos, deja también espacio para el consuelo y la esperanza: la filosofía de Nietzsche es una oda a la alegría, un aventurado sueño de nuevas auroras de felicidad y calor. Consiste en una alegría trágica; demasiado dura y demasiado jovial para los decadentes hombres de Europa. Es una alegría que halla placer en el dolor al lograr transmutarlo en fuerza afirmadora de su existencia.

El eterno retorno como experiencia transmutadora de la realidad del hombre condensa esta esquizofrénica dualidad de horror y risa: del mismo acontecimiento funesto que venciera por cierto tiempo a Zaratustra dejándolo malherido se desencadena la más sólida, tenaz y dura de las afirmaciones. Tanto la huella pesimista del nihilismo reactivo que ha agotado todo impulso por la existencia, como la ilusa «fuerza» del nihilismo activo que acabará sucumbiendo a la reacción, pueden ser superadas y consumadas a través del pensamiento de la vida encarnada que retorna en el tiempo venturoso de la superación. Ante la virulencia del nihilismo, que se pregunta hastiado para qué vivir, Zaratustra se alza y pregunta airado cómo habríamos de querer repetir infinitas veces el sentimiento amargo de quien se ha dado por derrotado.

Zaratustra se transforma en el momento en que se levanta de su mullida cama; la insoportable imagen de una vida decadente que ha de retornar se convierte en vehículo de superación: ¡que lo que haya de retornar, dice Zaratustra, sea el gozo por el mundo! El eterno retorno es el secreto alquímico, la piedra filosofal que transmuta el nihilismo en ocasión de superación. Llevando éste a su máxima negación Zaratustra encuentra en sí el valor para trascenderla y hacer de ella afirmación imperecedera:

El valor es, en efecto, el mejor matador, - el valor que ataca: pues todo ataque se hace a tambor batiente.

[...] El valor mata incluso el vértigo junto a los abismos: ¡y en qué lugar no estaría el hombre junto a abismos! ¿El simple mirar no es - mirar abismos?

El valor es el mejor matador: el valor mata incluso la compasión. Pero la compasión es el abismo más profundo: cuanto el hombre hunde su mirada en la vida, otro tanto la hunde en el sufrimiento.

Pero el valor es el mejor matador, el valor que ataca: éste mata la muerte misma, pues dice: «¿Era esto la vida? ¡Bien! ¡Otra vez!» ${ }^{651}$.

${ }^{651}$ Nietzsche, F., Así habló Zaratustra, op. cit., pág. 229 (KSA IV, 199). 
Con la conciencia del eterno retorno Zaratustra transmuta la experiencia del nihilismo en fuente de afirmación y de superación. En una vida que vuelve infinitas veces está en juego el propio sujeto existente: es $s u$ vida lo que vuelve, $s u$ sentido lo que retorna. Nietzsche comprende la advertencia de esta metáfora: es el juego de sucesiones de las distintas generaciones que han poblado Europa. La tradición occidental es la del retorno eterno de la «decadencia», la de un vacío cuyas exigencias no eidéticas no han sabido ser colmadas por el tipo del hombre «verdadero» de la metafísica de la duplicación. El ciclo del eterno retorno ha desnudado la pobreza existencial de los espíritus de Occidente: eternamente devuelven -retornan- al mundo su decadencia. Zaratustra lo transmuta al hacer de este ciclo una ocasión de bonanza: que sea el artista-filósofo y su obra, la vida encarnada, los que retornen. Para ello, la empresa de reapropiación es más necesaria que nunca; y como el ciclo del eterno retorno puede modificarse sustancialmente -que deje de retornar lo decadente en favor de la «corporalidad»-significa que la lógica del eterno retorno no es inmutable. Es decir, la dinámica del eterno retorno no responde a los caracteres de idealidad de la exactitud, de la certeza, de la adecuación. De esta manera la transmutación del dolor por la existencia decante que trae consigo una y otra vez el eterno retorno en una jovial que devuelve eternamente un sujeto siempre distinto, esto es, con sus metas y fines particulares, pasa por la aceptación del sustrato trágico de la verdad dionisiaca del mundo. El eterno retorno es motor y fuente de vida desde el «cuándo» en que se ha abandonado la «gramática» del Dios muerto, o sea, el nihilismo. En este momento el eterno retorno dejará de ser una experiencia terrible y su ciclicidad dará paso, en cambio, a una constante ocasión oportuna de existencia: siempre nos devolverá nuestro mejor «yo», aquel donde hay una perfecta unidad no nihilista del sujeto ${ }^{652}$-artista-filósofo- y el objeto - «corporalidad»- que consuma la reapropiación de la existencia concreta del sujeto como proyecto estético dispuesto en el «cuándo» del tiempo oportuno de su encarnación y situado en el «dónde» de la apertura hermenéutica perspectivista de la que se adueña afirmativamente la voluntad de poder.

Eterno retorno y superhombre, por tanto, son los hijos gemelos de Nietzsche, nacidos de distinta madre, del miedo y de la esperanza, respectivamente: lo que otrora resultase insoportable habrá de devenir un pensamiento nobilísimo, el más alto de toda la jerarquía conceptual nietzscheana. En la grandeza del eterno retorno son cobijados también los rasgos más bajos y míseros del ser humano, el tipo «decadente», que habrán de actuar en un ciclo sin fin de fuerza motivadora para la superación de su penosa condición. Mas hacer de los instintos más pútridos el sustento del acrecentamiento, la virtud más prodigiosa del eterno retorno, sólo está al alcance de los hombres más selectos; aquellos que buscan su ocaso como puente hacia su superación, el artista-filósofo, quien se sabe tanto agente como materia de su vida.

\footnotetext{
${ }^{652}$ Recuérdese que para Heidegger la consumación del nihilismo acontecía en la figura de Nietzsche en el momento en que la subjetividad como voluntad de poder se adueñaba por completo del exterior «entitativo» resultando en una perfecta asimilación de la objetividad en la subjetividad.
} 
Aquel en quien la voluntad de poder es poderosa y dura no puede eludir la llamada del eterno retorno. Es el principio último de afirmación de la vida, luego quien se siente impulsado en la estela de la vida mejor acaba siendo atravesado por él, dado que la contemplación de la eterna vuelta de la decadencia al horizonte efectivo de perspectivas le resulta insoportable. Podemos afirmar, sin temor a equivocarnos, que el eterno retorno es condición necesaria de la transvaloración. En El Anticristo Nietzsche observó que el legado metafísico de Occidente había enajenado de la vida su propio centro de gravedad ${ }^{653}$, explicando a continuación las perniciosas consecuencias de esta actitud. La transvaloración, consistente en un cambio en la forma misma y en el horizonte de valoración, ubica de nuevo sobre la vida su propio centro de gravedad. Esta recolocación es obra del eterno retorno, la sabiduría última de Zaratustra: que la vida sea su misma legitimación, que la esencia de la vida sea la propia vida. Algo que se cumple al hacer de la voluntad de poder la esencia del pulso existencial: el sujeto hermenéutico vive en tanto tiene capacidad hermenéutica, es decir, de crear valores, de imprimir vida al mundo y de «dominarlo» en su despliegue.

\section{II.1.1. La santificación de la muerte}

Aunque Nietzsche, en connivencia con todo su corpus, no ofrece una definición concreta del eterno retorno -recordemos que habíamos destacado que su acercamiento a la conceptualización pasaba, precisamente, por no ofrecer definiciones definitivas-, arroja en cambio formulaciones casi poéticas que ilustran su carácter terrible. No está en el Zaratustra, sino al término del Libro IV de La gaya ciencia la fábula más bella de este principio:

El peso más grave. - Qué pasaría si un día o una noche un demonio se deslizara furtivo en tu más solitaria soledad y te dijera: «Esta vida, tal como la vives ahora y tal como la has vivido, la tendrás que vivir una vez más e incontables veces más; y no habrá nada nuevo en ella, sino que cada dolor y cada placer y cada pensamiento y suspiro y todo lo indeciblemente pequeño y grande de tu vida tendrá que retornar a ti, y todo en la misma serie y la misma sucesión - e igualmente esta araña y este claro de luna entre los árboles, e igualmente este instante y yo mismo. El eterno reloj de arena de la existencia será girado siempre de nuevo - y tú con él, mota de polvo del polvo!» [...]. Si ese pensamiento adquiriera poder sobre ti, te transformaría, tal como eres, y quizás te destruiría [...], ¿cómo tendrías que quererte a ti y a la vida para no pretender nada más que esta confirmación última, que este último sello? ${ }^{654}$.

El eterno retorno no es una verdad emanada de la voluntad de poder, sino una hipótesis estético-filosófica que anima a una afirmación radical, a «un santo decir sí» a la vida dentro del hastío del nihilismo. No es un concepto de la ciencia natural cuya validez, cuya adecuación haya de ser corroborada empíricamente, sino el agresivo reto, la arriesgada apuesta

${ }^{653}$ Cfr. Nietzsche, F., El Anticristo, op. cit., pág. 82 (KSA VI, 217): «Cuando se coloca el centro de la vida no en la vida, sino en el 'más allá' - en la nada, - se le ha quitado a la vida como tal el centro de gravedad».

${ }^{654}$ Nietzsche, F., La gaya ciencia, op. cit., pág. 857 (KSA III, 570). 
de un demonio furtivo. Si la humanidad ha sido capaz de creer en dioses y vidas eternas situadas en otro plano supramundano de existencia inhumana, ¿por qué no habría de probar la tentativa del eterno retorno? Como decíamos al comienzo a propósito de la conceptualización en Nietzsche, la lectura literalista del pasaje anterior puede resultarnos incluso ridícula. Sin embargo, prosigue Nietzsche, que todo se repita en el mismo orden, estado y sucesión significa en verdad que sólo disponemos de una vida, y nada más. En efecto, tras la metáfora del eterno retorno se revela la concreción de una vida sometida al demónico imperio de su propia muerte. El eterno retorno hace de nuestra finitud necesidad, pues en la medida en que sólo disponemos de esta vida, ella ha de ser su propio centro gravitatorio, la potencia existencial absoluta.

La reducción de la infinitud a la unidad es otro juego en el que se manifiesta la cualidad «sintética» del sujeto encarnado. Éste como posicionamiento único y radical en el mundo, comprende en su interior una pluralidad perspectivista virtualmente infinita que exige de él el compromiso -la responsabilidad- del sujeto consigo mismo de apropiarse mediante la voluntad de poder de un contenido de sentido. Para ello el individuo se despliega en su voluntad de poder, la cual comprendida a través del cuidado se «enseñorea» de los mejores rasgos en aras de la consecución de la encarnación, de la vida buena.

En El Anticristo destaca cómo la conciencia de inmortalidad hizo de la vida una realidad inviable; la encerró en contradicciones que reaccionaron contra los instintos nobles de la «corporalidad» y la sumió en la ponzoña eidética del resentimiento. El eterno retorno santifica la muerte, a su vez condición de vida encarnada: mientras la muerte no llega, hay voluntad de poder, en una clara evocación epicúrea. El eterno retorno vindica la existencia desde la contingencia radical del ser humano. La fórmula concreta es «eterno retorno de lo mismo», pues, Zaratustra, retorna lo idéntico, cuanto fue, que es cuanto es y cuanto habrá de ser. Por eso la existencia es una cuestión «estética», consistente en que lo que retorne sea la mejor obra de arte, a saber, la integración solidaria del individuo y la voluntad de poder como «corporalidad». El eterno retorno actúa sobre la efectiva existencia de nuestra vida encarnada. El eterno retorno es la conciencia radical de la condición perecedera del hombre; que la vida haya de retornar no es sino una invitación a la explotación de sus rasgos: vivir desde el eterno retorno es vivir por el desborde de la fuerza, pues es vivir para la eternidad:

Tú enseñas que hay un gran año del devenir, un monstruo de gran año: una y otra vez tiene éste que darse la vuelta, lo mismo que un reloj de arena, para volver a transcurrir y a vaciarse: -

- de modo que todos estos años son idénticos a sí mismos, en lo más grande y también en lo más pequeño, - de modo que nosotros mismos somos idénticos a nosotros mismos en cada gran año, en lo más grande y también en lo más pequeño.

Y si tú quisieras morir ahora, oh Zaratustra: mira, también sabemos cómo te hablarías entonces a ti, mismo: - ¡mas tus animales te ruegan que no mueras todavía! 
Hablarías sin temblar, antes bien dando un aliviador suspiro de bienaventuranza: ¡pues una gran pesadez y un gran sofoco se te quitarían de encima a ti, el más paciente de todos los hombres! -

"Ahora muero y desaparezco, dirías, y dentro de un instante seré nada. Las almas son tan mortales como los cuerpos.

Pero el nudo de las causas, en el cual yo estoy entrelazado, retorna, - jél me creará de nuevo! Yo mismo formo parte de las causas del eterno retorno.

Vendré otra vez, con este sol, con esta tierra, con este águila, con esta serpiente - no a una vida nueva o a una vida mejor o a una vida semejante:

- vendré eternamente de nuevo a esta misma e idéntica vida, en lo más grande y también en lo más pequeño, para enseñar de nuevo el eterno retorno de todas las cosas, -

- para decir de nuevo la palabra del gran mediodía de la tierra y de los hombres, para volver a anunciar el superhombre a los hombres ${ }^{655}$.

\section{II.2. El eterno retorno como imperativo de trascendencia de lo humano}

El mundo es demasiado oneroso para los nihilistas del fin de la modernidad. El dolor de la metafísica escisión sujeto-objeto; sujeto-mundo, la muerte Dios o la pérdida de los viejos ídolos, entre otras, son losas demasiado pesadas para querer atravesarlas con la hipótesis del eterno retorno. Son los ecos vivos de la conciencia de la alienación existencial bimilenaria. El dolor es doble: el conocimiento de una existencia no vivida, sino discurrida a lo largo del decurso «cronológico» del tiempo; y, además, por otro lado, la incapacidad para recuperarla como consecuencia del decadente estado de fuerzas del europeo nihilista, cuya voluntad de poder se mueve en los márgenes de la pasividad y del rencor. Los hombres del fin de siglo no pueden soportar revivir infinitamente la experiencia de desgarro que ha explotado en su presente. Así, el eterno retorno se antoja cruel y blasfemo para las aspiraciones de santidad de la vida «moral» del legado del intelectualismo-moral socrático; quizá el castigo de un demonio que disfruta imaginando nuestro tormento sin fin. La náusea de Zaratustra es la respuesta fisiológica del cuerpo ante la perspectiva de una repetición de todos aquellos enfermos valores nihilistas de decadencia y hastío que nos han privado de metas y del camino. Zaratustra enfrenta en un primer momento este pensamiento, mas su fortaleza no resistió y «cayó al suelo como un muerto y permaneció largo tiempo como un muerto» ${ }^{656}$.

Sin embargo, Zaratustra se ha de alzar, pues, como hombre selecto, el eterno retorno lo busca una y otra vez. Más aún, dicho pensamiento brota de su mismo interior: «isube, pensamiento abismal, de mi profundidad!» ${ }^{657}$. Zaratustra, el mejor de los nihilistas, no puede eludir el enfrentamiento contra el eterno retorno. Conocedor de la pauperizada vida espiritual de la historia de Occidente comprende que la situación es inaceptable por más

\footnotetext{
${ }^{655}$ Cfr. Nietzsche, F., Asi hablo Zaratustra, op. cit., pp. 308-309 (KSA IV, 276).

${ }^{656}$ Ibid. pág. 303 (KSA IV, 271).

${ }^{657}$ Ibid. pág. 302 (KSA IV, 270).
} 
tiempo: el hombre «bueno» de la tradición vive sin vivir en sí. Una decadente y degenerada realidad que quien aspira a adueñarse del sentido de la tierra mediante su voluntad de poder no puede tolerar. La cuestión de la existencia como problema filosófico fundamental ha sido groseramente ignorada como consecuencia de la alienante metafísica de la duplicación. Las centurias posteriores moralizaron esta intelectualidad, prescribiendo un contenido formal normativo que apostó por el abandono de la vida efectiva, sensible, en favor de la hipotéticamente verdadera. De tal modo que la preocupación más íntima del hombre, el sentido de su ser, fue postergada y enajenada en un «más allá» inaccesible en vida. En consecuencia, la pregunta por la existencia no inquiría por las condiciones de esplendor de ésta, sino por el modo en virtud del cual purificar el espíritu y hacerlo digno de la promesa postrera de la «vida verdadera» tras la muerte. Para el mejor de los nihilistas no es aceptable por más tiempo la perpetuación de esta disposición «psicofisiológica»; el nihilismo ha desnudado la vergüenza de la tradición de la civilización occidental y ha ofrecido la posibilidad de la recuperación del interrogante de la existencia. Si bien terriblemente dura y difícil, Zaratustra finalmente mantiene los ojos abiertos ante la reactiva sentencia de Teresa de Ávila. Una y otra vez se ha visto tentado por la reapropiación de su ser, y tantas otras ha fracasado: su schopenhauerianismo; su wagnerianismo; su etapa positivista, son casos ejemplares de las infructuosas tentativas por la reapropiación de la existencia, por «vivir en sí». Por el eterno retorno todo vuelve, los fracasos así como el «sí» de la voluntad que se mueve a un nuevo esfuerzo por la satisfactoria realización de su empresa: eternamente se le presenta el pensamiento de la reapropiación. Con la transmutación de la experiencia del eterno retorno Zaratustra hace del mismo el tiempo de la ocasión; al igual que el nihilismo activo ha proporcionado la factible imagen de una existencia plena no utópica, también ha brindado la oportunidad de transmutar el decurso cronológico en el «cuándo» oportuno de la superación de la experiencia de nihilidad. Que una y otra vez se presente ante Zaratustra el pensamiento del eterno retorno no hace sino refrendar el duro compromiso ascético que conlleva el responsable proyecto estético-moral del cuidado, cuyo éxito, como veremos a continuación, no sólo no es inmediato, sino que, además, «reclama eternidad».

Zaratustra comprende que el reto de aquel demonio es una llamada existencial hacia la trascendencia de lo humano. Advertido el carácter curativo del eterno retorno, lo invoca una vez más con determinación leonina: «te llamo a ti, al más abismal de mis pensamientos» ${ }^{658}$. Lo llama una vez más, pues su voluntad se ha identificado finalmente con la necesidad. La conciencia de la «corporalidad»y de sus corolarios -el fondo trágico del mundo; las formas dionisiacas del devenir como lógica de la realidad; la condición hermenéutica de la verdad- sólo pueden explotarse máximamente, o sea, consumar la transmutación dentro de un tiempo homólogo, es decir, un «cuándo» trágico. Nietzsche enfrenta por vez definitiva el eterno retorno al comprender que en él también hay una transvaloración,

658 Ibid. pág. 303 (KSA IV, 271). 
del tiempo en su caso; podríamos decir que el eterno retorno es la experiencia del tiempo encarnado, una vivencia que no lo toma desde el discurrir objetivo, sino desde la ocasión perspectivista de un «cuándo» que introduce la fuerza de la voluntad de poder en la robustez y el vigor de la jovialidad del momento oportuno. Que Zaratustra invoque el eterno retorno para enfrentarlo una vez más responde a la visión nietzscheana del maridaje de la vida buena y la vocación de eternidad del instante de la existencia: la aventura del cuidado, la «corporalidad», no puede ser experimentada desde los criterios objetivistas de un tiempo cuyo discurrir puede ser cuantificado y medido, sino desde otro que ha dejado de gravitar en torno al reloj para hacerlo sobre las ocasiones venturosas de despliegue de la vida bue$n a$, que es la mejor. Cuando imbrica la «corporalidad» en el eterno retorno como la vivencia encarnada del tiempo Nietzsche logra dejar atrás el nihilismo, pues su «santo decir sí»» resonará para la eternidad.

El hombre fuerte capaz de despreciar la debilidad congénita de su época no puede posponer su enfrentamiento contra el eterno retorno. La secuencia será idéntica a la que sacudió a Zaratustra, un desfallecimiento del que después se habrá de levantar. Pues así como el eterno retorno sacude frontalmente la conciencia del hombre, también le exige, en aras de una afirmación de la vida, recuperarse. La conmoción, explica Zaratustra, llega cuando el hombre ha comprendido cuán deplorables condiciones de existencia se ha procurado, cuántas metas ignoradas y caminos perdidos; la desesperación de un interrogante al que no llega respuesta ni sentido. La exigencia «estética» del eterno retorno, ya hundido en los albores de la transvaloración, pasa por el rejuvenecimiento y la «vigorización» de los instintos de la voluntad de poder, por la superación del vacío nihilista y por la creación artística de saludables horizontes de bondad que tengan por objeto la transmutación de la náusea en un profundo «sí». El eterno retorno, como metáfora de esta vida única, es el compromiso de eternidad con nuestra existencia; es la encarnación del tiempo como momento acogedor de la «corporalidad».

Como hemos apuntado, y desarrollaremos posteriormente, el eterno retorno no significa para Nietzsche un discurrir circular del curso de los acontecimientos sujetos a una incuestionable repetición; el eterno retorno aspira a poner fin a la concepción tradicional del tiempo que respondía a los contenidos de la metafísica de la duplicación. Nietzsche pretende una transmutación del tiempo «cronológico» como objetiva sucesión de los avatares del mundo en un «cuándo» kairológico. La primera consideración es un eco de la metafísica de la presencia, y en cuanto tal necesita de un «ente» externo al que remitirse en su caracterización de sentido. El tiempo «cronológico» sería la plasmación del momento de la «adecuación» de la presencia en la forma ideal de normatividad externa.

El tiempo «cronológico» como producto de la metafísica de la duplicación, como adecuación en particular de la metafísica de la presencia, sirve de sustrato para las distintas 
historiografías escatológicas, de manera que el eterno retorno interviene cáusticamente sobre él y su aspiración de un momento primordial tanto de justificación como de realización existencial. La superación de esta conciencia de tiempo está en la vindicación del momento efectivo de la vida encarnada, el «instante» ${ }^{659}$, en el cual la voluntad de poder ha desplegado actualmente alguna de las perspectivas de su horizonte abierto. El protagonismo del instante como caracterización del eterno retorno es la transmutación nietzscheana del tiempo en el «cuándo» de la existencia encarnada.

Como redención respecto de la metafísica, el eterno retorno brinda el tiempo de la ocasión de la reapropiación de la existencia en la medida en que ésta ya no anhela el regreso al origen primordial de sentido. La existencia «inocente» se justifica desde sí misma, desde su ser como voluntad de poder, pues cuanto vive es en el ejercicio de su voluntad de poder, inserta ahora en una oportunidad eterna de plenitud, pues el tiempo de la vida ha transmutado en uno kairológico.

\section{II.2.1. Zaratustra el ateo}

La muerte de Dios ha dejado en el momento tardío del nihilismo un vacío irremplazable, ya que no sólo el contenido de la divinidad -el sentido, la unidad esencial, la finalidad última-, también su continente ha desaparecido. Por ello mismo Zaratustra repite numerosas veces que el eterno retorno es una apuesta inocente y no un nuevo códice sagrado: no es una promesa ideal de trascendencia eidética, sino la expectativa encarnada de una eternidad no utópica, pues está radicada en el ser trágico del hombre. Más si cabe, es el supremo grito antirreligioso que sostiene la pluralidad perspectivista de nuestra vida encarnada bajo una ilusoria ficción de unidad y que sitúa en nosotros el núcleo del valor; tanto la fuente de valoración como la base de legitimación: «ite llama Zaratustra el ateo!» ${ }^{660}$. El eterno retorno nace en el fondo más oscuro del nihilismo, allí donde aún está el cadáver de Dios; asomarnos hasta su insondable abismo supone consumar el nihilismo, reconocer la imposible resurrección de la vieja divinidad y asumir la responsabilidad de confeccionar una nueva vida que prescinda de las disposiciones del pasado:

Quien, como yo, se ha esforzado durante largo tiempo, con cierto afán enigmático, por pensar a fondo el pesimismo y por redimirlo de la estrechez y simpleza mitad cristianas mitad alemanas con que ha acabado presentándose a este siglo, a saber, en la figura de la filosofía schopenhaueriana; quien ha escrutado realmente, con ojos asiáticos y superasiáticos, el interior y la hondura del modo de pensar más negador del mundo entre todos los modos posibles de pensar $-\mathrm{y}$ ha hecho esto desde más allá del bien y del mal, y ya no, como Buda y Schopenhauer, bajo el hechizo y la ilusión de la moral, - quizá éste, justo por ello, sin que él lo quisiera propia-

${ }^{659}$ Cfr. Nietzsche, F., Fragmentos póstumos III, 5 [1] , op. cit., pág. 155 (KSA X, 210): «inmortal es el instante en el que engendré el retorno. Por amor de este instante soporto el retorno».

${ }^{660}$ Nietzsche, F., Así hablo Zaratustra, op. cit., pág. 303 (KSA IV, 271). 
mente, ha abierto sus ojos para ver el ideal opuesto: el ideal del hombre totalmente petulante, totalmente lleno de vida y totalmente afirmador del mundo, hombre que no sólo ha aprendido a resignarse y a soportar todo aquello que ha sido y es, sino que quiere volver a tenerlo tal como ha sido y como es, por toda la eternidad, gritando insaciablemente da capo! [ique se repita!] no sólo a sí mismo, sino a la obra y al espectáculo entero, y no sólo a un espectáculo, sino, en el fondo, a aquel que tiene necesidad precisamente de ese espectáculo - y lo hace necesario: porque una y otra vez tiene necesidad de sí mismo - y lo hace necesario - - ¿Cómo? ¿Y esto no sería - circulus vitiosus deus [dios es un círculo vicioso]? ${ }^{661}$.

El eterno retorno es la afirmación oportuna de la muerte de Dios; no es una confirmación, sino el asentimiento consciente y responsable del mencionado fatalismo. La desfundamentación esencial es transmutada en jovial ventura cuando la experiencia del tiempo quiere repetida y eternamente dicha crisis: la voluntad de poder quiere la repetición del específico momento de la mayor amargura al abordarla en el «cuándo» de ocasión oportuna desde donde logra libar la simiente de la encarnación del sentido ante la eterna muerte de Dios; la existencia subjetiva gravita, para toda la eternidad, en torno al hombre, quien debe asirla a partir de las condiciones trágicas del mundo que ha sido redimido del Crucificado y de su «gramática».

La necesidad de Dios ya no les es lícita a los hijos del nihilismo. Nietzsche persigue la consecución de un pensamiento que reflexione sobre la vida sin el pesimismo como marco de condición. Exige que los escépticos y pesimistas decimonónicos, nosotros, los hijos del nihilismo, contemplemos la aurora de una nueva ilustración que procure la favorable llegada de la filosofía del eterno retorno que acepta la eterna muerte de Dios como premisa de afirmación perpetua de la «corporalidad», de la condición esencial del hombre como adjudicador de sentido. Es una experiencia que acude al encuentro del mayor de los escépticos, quien ha perdido razones para conservar los rigores de la divinidad: «nada hay en mí de fundador de una religión [...], yo siento la necesidad de lavarme las manos después de haber estado en contacto con personas religiosas... no quiero 'creyentes' $\gg{ }^{662}$. Desaparecido el ímpetu de las deidades y de sus «gramáticas», el eterno retorno afirma indefectiblemente al hombre como el principio de valoración, y a él remite toda decisión relativa a la vida. Las religiones habían depositado las esperanzas salvíficas en sus loas doctrinarias; el eterno retorno, en el humano encarnado con conciencia de su propia fuerza de existencia trágica.

El eterno retorno es una metáfora de mortalidad; es el anhelo de esta vida que llamamos nuestra al saberla única y finita, esto es, «atea». No obstante, el eterno retorno no es una tentativa de muerte, sino de encarnación singular y de ocasión de plenitud. El matiz de la repetición idéntica es ocasión de lo más sublime en el hombre. Es la pasión de eterni-

${ }^{661}$ Nietzsche, F., Más allá del bien y del mal, op. cit., pág. 87 (KSA V, 74-75).

${ }^{662}$ Nietzsche, F., Ecce homo, op. cit., pág. 135 (KSA VI, 365). 
dad de los espíritus más selectos, que envisten al ser de su vida con la mayor de las afirmaciones: su sí mismo. La voluntad de poder domina el tiempo al apropiarse de la ventura del eterno retorno; el ser de la vida como voluntad de poder se afirma eternamente en su dominación, es decir, el hombre encarnado se afirma eternamente como esencial cualidad del poder, como fuente de interpretación y de sentido del mundo encarnado de su personalidad, tan oscura como clara. El reto que lanza esta hipótesis filosófica halla su fuerza en la muerte, no como un perecer desalentador, sino como encuentro opuesto a la inmortalidad del ser eterno: el valor existencial del eterno retorno pasa por su posicionamiento radicalmente contrario respecto de la enajenación ultramundana en beneficio de un asentamiento sensible y carnal sobre el venturoso sustrato del «cuándo» oportuno y jovial en el que acaece la experiencia de existencia. Como la muerte se troca en realidad incuestionable, su reverso ha de serlo también consecuentemente: vida y muerte se justifican desde sí mismas y emancipadas del celo «moral» que tomaba el deceso como condena del mundo. Exonera$d a$ la vida del sello moral de la metafísica le resta la «inocencia» como falta de orientación y de sentido escatológicamente dispuesto. Es ahora responsabilidad del propio hombre que vive y que se experimenta en vida impregnar de significado la inocencia primigenia con un contenido que estimule la fuerza de la pulsión de vida del sujeto agente de la voluntad de poder.

Como doctrina atea, el eterno retorno es tanto una afirmación como una emancipación. La inmortalidad del alma pudo tomarse como un consuelo para los enfermos y decadentes devotos espíritus de fe, aunque bajo el precio del temor a la condenación «eterna» en la posterior existencia post mortem; el miedo a las penas del Infierno impidió que la vida fuese maximizada, quedando restringida en los códigos morales de una rectora perspectiva de trascendencia ecuménica. Era ésta una eternidad no encarnada, contemplada como posibilidad en un reino ideal que en su carácter reactivo y despreciador de la vida pergeñó principios rectores que lastraron máximamente las condiciones de una vida buena y libre. Con la confirmación del ateísmo Zaratustra emancipa el rictus moral del hombre de umbrales ajenos a sí mismo y recupera la responsabilidad del cuidado de la propia vida bajo la fórmula «estética» de la obra de arte artístico-filosófica que es la «corporalidad», liberada de la amenaza del castigo atemporal que se había de cumplir en la eternidad al tratarse de un tiempo sin ocasión de ventura, sin encarnación.

Sin embargo, Nietzsche ha descrito en todo momento el eterno retorno como una hipótesis filosófica, una tentativa de riesgo para la existencia que, como tal, no tiene carácter ontológico: somos libres de asumirla e integrarla -afirmarnos como «corporalidad»- o bien de rechazarla y continuar en la enajenación que comporta la existencia decadente distintiva de Occidente. Siendo justos con la enseñanza nietzscheana, la pulsión del eterno retorno no es universal, sino que se circunscribe a aquellos espíritus más nobles que, hastiados del nihilismo, deciden trascender la decadencia estructural de los tiempos y superarla 
mediante la dominación de la experiencia del «cuándo» del tiempo oportuno. El eterno retorno es entonces una experiencia filosófica selectiva y profunda que hace patente para las mejores conciencias la fuerza que emana del fondo trágico de la vida y las claves existenciales que éstas necesitan -la aceptación del devenir y la comprensión hermenéutica de la verdad- para conservar la eternidad de la afirmación.

Los nihilistas de la pasividad, aquellos cuya voluntad de poder ha perecido en su propia debilidad, no pueden resistir la carga de un retorno de lo idéntico. Éstos han sucumbido ante la reacción de la voluntad de la nada y no han logrado extraer de tan terrible experiencia la fuerza transmutadora. Se mueven entre la amargura y el odio, denunciando la angustia que no les resulta grácil, o bien operan desde la inconsciencia de su situación a lo largo de una vida que basa su movimiento en la conservación abúlica de quien no busca sino mantenerse en pie un día más.

Frente a los hombres de la reacción, el eterno retorno nos ofrece el tipo de los espíritus libres, capaz de transmutar la precariedad y la miseria en afirmación y amor. Este caso humano ha tomado el eterno retorno como la refrescante fuente que riega su potencia plástica y que renueva constantemente los valores sanos y fuertes que facultan su afirmación creadora; un individuo que se sabe creador y se enorgullece de la robusta autoridad de su «sí»: el amor eterno por la «corporalidad», por el compromiso de existencia en el que necesidad y voluntad, agente y objeto, se unen en la empresa «estética» de reapropiación del sentido encarnado en la figura del artista-filósofo.

El tipo de ateísmo de Zaratustra no es el del último hombre; en éste hay decadencia y las palabras más sagradas todavía suenan blasfemas. Zaratustra el ateo trae consigo un imperativo de consumación para su mensaje: la transvaloración que claudique de su esmerado esfuerzo ultramundano en favor de una instancia de valoración que resida en las mismas entrañas de los acontecimientos, en el sujeto agente de tales acontecimientos. La aspiración de eternidad que en el eterno retorno encuentran nuestros actos encierra en ellos su validez y legitimación, pues se remiten, por la orfandad de sentido esencial, al individuo que vive en la medida en que todo acto imprime sentido sobre el horizonte perspectivista de sus metas y fines. Este pensamiento sería una reformulación burlesca del imperativo categórico kantiano: «quiere de modo tal que por aquello que quieras puedas querer también el eterno retorno». Luego que el querer de la voluntad sea la propia voluntad equivale a decir que la pulsión de la vida emana de la vida misma; la existencia, por tanto, se justifica por sí misma, desde su experiencia constante de existencia. La eternidad es la estrategia de inserción del hombre en la configuración perspectivista de su vida inocente.

En este imperativo está el poso selectivo del eterno retorno, pues distingue a quienes se reafirman en su consciente querer-«decir sí»-de aquellos cuya valoración procede del estéril arrepentimiento. El eterno retorno no es el ciego y abotargado sí del necio o el 
«I-A» del asno que rebuzna, como tampoco la afirmación despreocupada e irresponsable del cándido ingenuo que contempla la repetición como un indefectible destino cósmico del que no existe escapatoria posible. En Nietzsche hay una gradación jerárquica de los valores determinada por la fuerza de su afirmación, de modo que el eterno retorno recoge la pregunta de quien quiere vivir del mejor modo: ni es la procastinación cobarde ni el rechazo del resentido ni la insatisfacción de la pasividad. Rasgos todos ellos del vengativo ideal ascético que critica y censura la vida.

El eterno retorno, contrario a los rasgos nihilistas presentados, es la premisa «estética» de existencia de los hombres superiores que aspiran a su propio ocaso: el compromiso con la vida mejor, la cual no es sino aquella que soportaría la pregunta del eterno retorno: «¿querrías esta vida dentro del eterno retorno?». Se ha de insistir en el carácter hipotético de tal formulación; de lo contrario, esto es, hacer del imperativo existencial del eterno retorno un imperativo categórico al modo kantiano como fundamento de sus acciones supondría una carga tan pesada que ni siquiera Zaratustra habría logrado alzarse, dado que la transmutación del tiempo habría sido imposible en la medida en que el eterno retorno, formulado de tal manera, hubiese sido un concepto metafísico:

«¿Pero si todo es necesario, qué capacidad de disposición tengo yo sobre mis acciones?» El pensamiento y la creencia es un peso pesado que junto a todos los demás pesos hace presión sobre ti, y mayor que la que hacen ellos. ¿Dices que la alimentación, el lugar, el aire, la sociedad te transforman y determinan? Sí, pero tus opiniones todavía más, puesto que son las que te determinan a dicha alimentación, lugar, aire, sociedad. - Cuando asimiles el pensamiento de los pensamientos, él te transformará. La cuestión ante todo lo que quieres hacer: «¿es de tal modo que lo quiera hacer innumerables veces?», es el peso pesado más grande ${ }^{663}$.

La conversión del eterno retorno en un imperativo fundante de la acción es un peso demasiado pesado; su densidad haría imposible la vida encarnada puesto que vendría previamente definido por instancias anteriores a la vida, es decir, metafísicas. El eterno retorno es, por el contrario, ligero: la repetición eterna no es una condena, sino una afirmación de nuestra condición humana trágica que exige la perpetua, eterna, apropiación de perspectivas en la constante creación de las condiciones de la vida más plena y vigorosa.

\section{II.3. El tiempo del eterno retorno}

El eterno retorno tiene sobre la concepción nietzscheana del tiempo una incidencia fundamental. El hombre, inserto en la temporalidad, es capaz de afectarla mediante la fuerza plástica de su voluntad de poder, ya que el decurso lineal -objetivo, positivista, medible, cuantificable- del tiempo afecta a su estatus biológico, pero de ningún modo puede sujetar su faceta artística. Pasado, presente y futuro se superponen y solapan en un juego de suce-

${ }^{663}$ Nietzsche, F., Fragmentos póstumos II, 11 [143], op. cit., pág. 789 (KSA IX, 496). 
siones que trazan nuestra vida. El hombre nietzscheano, como otros conceptos anteriores, contempla el tiempo filosóficamente: si bien su transcurso es cronológico, su experiencia de apropiación es kairológica. Y esta veta es la clave de la infinitud del eterno retorno como tiempo oportuno, de su eternización de la ocasión del instante y de su apertura a la eternidad del futuro: “'a 6.000 pies más allá del hombre y del tiempo'» ${ }^{664}$, dice Nietzsche que tuvo la experiencia del eterno retorno. Es decir, se trata de una nueva caracterización de la conciencia del tiempo conforme con la existencia humana trágica: la superación del hombre decadente en una vida mejor se concreta en una apertura del futuro que se vive como tensión en el presente. Por eso el tiempo del eterno retorno es una experiencia kairológica eterna, toda vez que el futuro se vive en el presente, el futuro, expectativa de una vida mejor, es siempre eterno; el presente es el momento de ocasión jovial de la existencia. De modo que en el eterno retorno la oportuna ocasión jovial es «eterna»: el compromiso del cuidado -expectativa no utópica de la vida mejor - se efectúa en la ocasión oportuna de la «corporalidad». Es decir, la propia existencia reapropiada es la eterna ocasión oportuna del proyecto de vida encarnada subjetiva y particular.

El hombre acomodaticio del nihilismo no experimenta la fuerza del tiempo; para él, al no tener vivencia del tiempo encarnado, el hoy se sucede como el ayer y el mañana, no lo perturba. Vive instalado en un presente monótono e imperturbable emancipado del pasado y ciego ante el futuro. Una decadente felicidad degenerada y enferma que no emerge del saludable desborde de tentativas de superación, sino de la conservación vitalicia de la nihilista voluntad de vida. Es la dicha de las ovejas del comienzo de la segunda Intempestiva, las cuales habían olvidado de qué reían ${ }^{665}$. Sin embargo, el hombre no puede pretender aspirar a una imagen de la felicidad instalada sobre la animalidad más silvestre, sino que ha de buscar reintegrar la felicidad en los instintos afirmativos de su voluntad de poder. Las ovejas reflejan el instinto decadente de quien huye de la corporalidad del tiempo, por desconocimiento del poder existencial de éste.

${ }^{664}$ Nietzsche, F., Ecce homo, op. cit., pág. 103 (KSA VI, 335).

${ }^{665}$ Cfr. Nietzsche, F., Consideraciones intempestivas II De la utilidad y los inconvenientes de la historia para la vida, trad. de Joan B. Llinares, en Obras completas. Volumen I. Escritos de juventud I, op. cit., pág. 697 (KSA I, 248): «Observa el rebaño que ante ti desfila apacentándose [...], atado a muy poca distancia con su placer y desplacer a la estaca del momento y, por ello, sin melancolía ni hastío. Ver esto le resulta duro al ser humano porque ante el animal se jacta de su humanidad y, sin embargo, mira envidioso la felicidad de éste - pues lo único que quiere es vivir de igual modo que el animal, sin hastío ni dolores, pero lo quiere en vano porque no lo quiere como el animal. Un día el ser humano le pregunta al animal: ‘¿por qué no me hablas de tu felicidad y, en cambio, te limitas a mirarme?'. Y el animal quisiera responder y decir: 'Eso pasa porque siempre olvido al punto lo que quería decir', pero ya olvidó también esa respuesta y se calló: de suerte que el ser humano se quedó asombrado». 


\section{II.3.1. El pasado}

El pasado es el primero de los aspectos problemáticos del tiempo que Nietzsche ha de enfrentar. La filosofía nietzscheana tiene una clara vocación de futuro, por lo que la voluntad que se proyecta en la apertura de lo que está por suceder puede verse amenazada por la fuerza inamovible del pasado, preso del «egipticismo» de los conceptos de la tradición. El pasado custodia todo aquello de lo que no podemos retractarnos, motivo que hace de éste un necesario peligro ante el que enfrentarse. Es el guardián de cuanto fue dichoso y placentero, de aquellas experiencias felices que desearíamos revivir. Al mismo tiempo, es el refugio de nuestros fracasos y penas, de los errores y del insoportable dolor. Luego el pasado encarna un doble peligro: los momentos felices en virtud de los cuales podríamos querer el eterno retorno pueden arrojarnos a la congoja de la nostalgia respecto de aquello que no volverá. Así, el peligro que conlleva el placer del recuerdo se antoja, a su vez, doblemente problemático. Puede ser otro de los narcóticos con los que adormecer la existencia y evadirla de las dificultades que entraña, al mismo tiempo que se yergue como otro de los síntomas de la decadencia de una existencia nihilista que se sabe incapaz de afrontar la arriesgada aventura del sinsentido al que está abierta: parece ser más valiosa la ensoñación dichosa que la encarnación dolorosa, asevera el nihilista; en cuanto a los vaivenes amargos son si cabe una cadena más férrea que la nostalgia de la dicha. Bajo la sombra de los errores la voluntad no puede trascender, ya que es incapaz de querer lo que hay tras ella. Su imposibilidad afectiva para reconciliarse con los fracasos y dolores la esclaviza a tales recuerdos. El hombre entregado al pasado bien lo quiere en detrimento del presente o bien lo aborrece como cuna de amargura, que consecutivamente lo lleva a despreciar el presente y el futuro al pensarlos a través del pretérito horizonte de dolor. Con todo, el pasado es otra más de las enajenaciones nihilistas de la existencia, pues nos separa esencialmente del tiempo efectivo en el que se despliega la «corporalidad».

El hombre nihilista contempla el pasado desde la impotencia de la nostalgia o desde la corrosiva venganza que desearía extirpar una parte de éste. Al término, su juicio de lo vivido es condenatorio, de tal manera que sólo extrae negación y reactividad de su propia historia. Al contrario que este hombre decadente, Nietzsche piensa el pasado desde una disposición prospectiva de la voluntad: no puede modificarse aquello que ya ha sucedido, mas sí cabe pensar en su reapropiación como vehículo de efectos activos en el presente y el futuro. La transmutación de la voluntad que mira sobre el pasado como un fondo de continuidad en el presente y de apertura hacia el futuro es posible desde la vivencia kairológica nietzscheana. La flecha del tiempo no traza un rumbo lineal, sino que se abre a un bucle de detención, retroceso y proyección.

El eterno retorno no es tanto la repetición como la evocación de la eternidad; nos sitúa ante nuestra propia historia, que persiste eternamente en nosotros, y a la que acoge- 
mos en una afirmación categórica de la vida. Es la reapropiación de lo vivido como elemento vivo de la ocasión del presente. La evocación de la eternidad respecto del pasado significa la consecuente inserción del sujeto en su experiencia de existencia; se yergue sujeto activo de su acontecer, esto es, agente y dador de sentido, escultor y obra. Ya no escapa de las inclemencias ni rehúye las preguntas de sus «porqués» El pasado reapropiado permite ser integrado en la constante de la «corporalidad», donde la existencia no es parcelada ni escindida en avatares eidéticos -la escisión del alma y el cuerpo, por supuesto, pero también la caracterización objetivista de un tiempo lineal-. La experiencia encarnada del tiempo que procura el eterno retorno transmuta el «cuándo» de los acontecimiento en una eterna ocasión proclive de existencia. El eterno retorno es el tiempo en el cual siempre es oportuno el cuidado, con lo que la distancia del tiempo se resuelve «sintéticamente» en la vida encarnada inserta en un espacio perspectivista y en un tiempo de ocasión oportuna.

Mediante esta estrategia Nietzsche logra alzarse sobre la mirada cronologista y reintegra los tres meandros del río del tiempo - pasado, presente y futuro- en un único y mismo cauce de reconciliación con el pasado, amor hacia el presente y esperanza en el futuro, aquellos seis mil pies más allá del hombre y del tiempo que señalamos antes. A esta altura Nietzsche redime el pasado del juicio peyorativo que le había impuesto la vengativa voluntad nihilista, y, con ello, puede reincorporarlo a la experiencia temporal del ser humano: «Mira al mundo como si el tiempo ya no existiese: y todo lo torcido se te volverá recto» ${ }^{666}$. La peculiar voluntad prospectiva de Nietzsche, que mira hacia atrás porque quiere hacia delante, es la distintiva de los artistas:

Vosotros hombres superiores, de vosotros siente anhelo el placer, el indómito, bienaventurado, - ¡de vuestro dolor, oh fracasados! De lo fracasado siente anhelo todo placer eterno.

Pues todo placer se quiere a sí mismo, ipor eso quiere también sufrimiento! ¡Oh felicidad, oh dolor! ¡Oh, rómpete, corazón! Vosotros hombres superiores, aprendedlo, el placer quiere eternidad,

- el placer quiere eternidad de todas las cosas, iquiere profunda, profunda eternidad $!^{667}$.

El eterno placer de un tiempo que no evoca el dolor de una vida fracasada desde su mismo origen que arroja a la condenación de la existencia. El eterno retorno es un tiempo de absoluta dicha en la medida en que ha sido despojado de la culpa que hubo impuesto desde el comienzo la «vida moral». Tampoco tiene, no obstante, un contenido feliz; es radicalmente «inocente», esto es, ausente de motivos de necesaria amargura y/o pena. Esto convierte el momento del eterno retorno en una situación de existencia jovial donde la felicidad o la

${ }^{666}$ Nietzsche, F., Fragmentos póstumos III, 5 [1], op. cit., pág. 159 (KSA X, 216).

${ }^{667}$ Nietzsche, F., Así habló Zaratustra, op. cit., pág. 436 (KSA IV, 403). 
amargura no vendrán dispuestas desde el «pasado», sino abiertas en el horizonte perspectivista de la voluntad de poder.

\section{II.3.2. Amor fati}

La fórmula «amor fati» es el último y definitivo desenvolvimiento del pensamiento del eterno retorno, donde opera la transvaloración de esta poderosa hipótesis filosófica: es la transmutación de toda hostilidad y desprecio hacia la vida en amor. Es la sublimación de la afirmación, el «santo decir sí» de Zaratustra por el cual la vida pasa a ser aquello más preciado, aquello que querríamos repetir idéntica y eternamente, pues la experiencia de encarnación nos ha hecho sujetos activos de la «gramática» dionisiaca sobre la que conjugamos las condiciones de nuestra realidad efectiva. La reapropiación de la existencia había sido durante el nihilismo activo y su necesaria posterior superación conquistada; parcialmente conquistada, en verdad: la transvaloración de la realidad epistémica de la tradición metafísica de Occidente en una elementalmente trágica; la superación de la noción de verdad que había dispuesto Europa dentro de los mecanismos ideales de la intelección eidética -dialéctica platónica, adecuación, positivismo, etc.- en favor de una hermenéutica cuyo contenido estaba ahora abierto a la creación de sentido en el horizonte perspectivista del sujeto de la voluntad de poder; la tensión de una vida trazada escatológicamente de acuerdo con un plan histórico de idealidad cuya concreción tiene lugar tras la muerte en un universo supramundano es redimida en la «inocencia» de una vida que liberada de conceptos ulteriores asienta su radicalidad ahora sobre la continua y constante experiencia viviente que adquiere su contenido en el ejercicio afirmativo de la voluntad de poder; las voluntades de vida y de verdad sucumben ante el saludable vigor de una voluntad de poder que se postula esencia de la vida - «la vida es voluntad de poder»-. Con todo, ha tenido lugar el proyecto nietzscheano: la libertad del hombre mediante la reapropiación de su existencia, largo tiempo enajenada en los ídolos de la metafísica. El sentido de la vida encarnada reside en la «corporalidad», que es tanto como advertir que la esencia de la vida es voluntad de poder. Es el movimiento de afirmación definitivo: el «sí» a la libertad lo es a la transmutación del hombre en artista-filósofo que en su reapropiación hace suya constantemente su vida mediante la creación de sentidos a partir de las oportunidades que ofrecen el perspectivismo y la voluntad de poder vigorosa y saludable.

Sin embargo, la existencia aún no ha sido reapropiada en la plenitud de su vastedad. Al dominio y al «enseñoreamiento» constante que de su vida hace el artista-filósofo le falta un último elemento temporal: la «eternidad». En el eterno retorno el «santo decir sí»» de Zaratustra atraviesa las coyunturas epocales para integrarse en la voluntad de poder. El «sí» es fácilmente asumible cuando tan sólo se presentan los rasgos gráciles de la vida. No obstante, tal aceptación parcial que todavía no ha confrontado a Dioniso no es tanto un «sí» afirmador como un «I-A», el rebuzno del asno. La afirmación «eterna», por el contrario, 
contempla el «sí» sobre todos los momentos, desde los más dichosos hasta los abismos más terribles. Es el estadio conclusivo de la empresa, por otro lado nunca definitivamente consumable en tanto que sumida en la lógica de la generación y la corrupción del devenir, de la reapropiación, pues es la asimilación del sinsentido de una pulsión de vida trágica ante la cual se acepta el riesgo de su integración bajo la atenta y esforzada disciplina del cuidado que busca transmutarla en condición de plenitud.

En el «cuándo» de la «eternidad» la reapropiación es completa. Al introducir la actitud del cuidado en la «temporalidad» se reformula la concepción del tiempo que deviene venturosa ocasión eterna de encarnación. En la apropiación de la eternidad la transmutación de la episteme metafísica es completa, es decir, acontece la «transvaloración», santificando la afirmación: el «santo decir sí» se articula gramaticalmente desde la sintaxis dionisiaca tornando jovial e intempestivo.

En la premisa del eterno retorno como reto selectivo que impele a los más grande espíritus, el amor fati no es un sí ciego al acontecer, como si de una fatalidad cual voluntad schopenhaueriana se tratase. El carácter afirmativo de la filosofía de Nietzsche exige como piedra angular la apropiación de la voluntad, la comunión de la voluntad de poder y de la voluntad de verdad en un movimiento de decidida y consciente superación de la vida en beneficio de un nuevo horizonte jerárquico mejor, la vida encarnada. En tanto que experiencia «estética», vivir no significa para Nietzsche aceptación resignada, sino actuación creativa, creación artístico-filosófica. El amor fati ama también el sufrimiento y el riesgo, el dolor y el peligro, mas no como valores beneficiosos en sí mismos, sino como componentes estructurales del devenir dionisiaco en el que existimos.

El amor fati es la sutura con la que el cirujano Nietzsche cose la escisión de la vida. La existencia ha estado desgarrada desde los albores de la metafísica dualista, en un doble sentido: el más evidente, la abismal frontera entre el mundo «verdadero» y el «aparente», donde se identifican las formas de aquel nihilismo pasivo que se lamenta por la precariedad de la realidad sensible y que anhela, con creciente pesimismo, el ascenso a la idealidad del ser. La posición dualista concluye en la inacción de Schopenhauer, par excellence; una desgana vital de profunda raigambre que ha perdido todo sentido de acción o, como dirá Nietzsche, un hastío que ha terminado por comprender la ausencia de sentido como problema genético de su obrar: no hay metas, pero tampoco camino. Y un segundo corte, el del agresivo nihilismo de la venganza hostil, que ha teñido la vida con un crespón de muerte. Un desprecio inmanente construido sobre la sospecha de que la existencia es en sí misma, por su condición sensible, un tormento al atentar contra la disposición nuclear del ser. La propuesta de estos nihilistas fue el aislamiento de pequeños islotes de realidad donde los rasgos dañinos de la vida eran atemperados en una fútil comodidad, en verdad, extramundana: sobrevivir en la vida alejándose de ella. Tal ha sido la dinámica del mundo, la 
voluntad de vida, de vida «a cualquier precio», el nihilismo reactivo que censuraba y despreciaba la apariencia mientras esperaba la recompensa de «justicia» post mortem como condición tradicional de vida:

Qué pena que no hubiese un Dostoievski entre esa sociedad: de hecho, a lo que mejor corresponde la historia entera es a una novela rusa - lo morboso, lo conmovedor, rasgos aislados de sublime extrañeza, en medio de lo disoluto y de lo suciamente plebeyo... (como María Magdalena ${ }^{668}$.

Nietzsche se encuentra una llaga que ha escindido «moralmente» la existencia: ésta es mala y lo bueno es distanciarse de ella, ora mediante la abulia pesimista ora a través de la supervivencia extramundana. Una herida purulenta que ha impedido el despliegue máximo de las posibilidades vitales, y que es responsable de los hombres decadentes del Occidente decimonónico para quienes la exigencia moral era, precisamente, la enajenación de la existencia. De este modo cobra sentido la metáfora de la sutura. El amor fati unifica en el devenir todas las dimensiones de la realidad, solidarizando las lágrimas y las sonrisas en la vocación de la «eterna» ocasión de plenitud. La trascendencia del hombre decadente en el artista-filósofo se asienta sobre el elogio de una vida libre de categorizaciones morales en favor de otras, «estéticas». El «santo decir sí» de Zaratustra es santo porque santifica; el crespón de muerte lo sustituye por la alegría de reír: «yo he santificado el reír; vosotros hombres superiores, aprendedme - ¡a reír!» ${ }^{669}$. El éxito y la derrota, la abundancia y la miseria, el reír y el llorar no son caracteres antagónicos y enfrentados, como tampoco categorías morales plenas de bondad o maldad, sino realidades determinadas por su apropiación de valor en el horizonte perspectivista de la voluntad de poder que se coimplican a lo largo del irrestricto devenir de la verdad dionisiaca ${ }^{670}$. El amor fati unifica dichos rasgos como efecto último de la afirmación: la paradoja de la vida santificada es que ha tenido que prescindir del Dios moralizador para ser bendecida; su bendición es la libertad de una radicalidad que por sí misma, desde sí misma y para ella misma se justifica y legitima.

La santificación de Zaratustra no es, sin embargo, una redención de lo malo en lo bueno, no es un perdón hacia la vida, pues ésta está libre de culpa si la contemplamos desde la dulzura de la inocencia que promete el perspectivismo de una voluntad de poder saludable y robusta. Por eso mismo el eterno retorno hace imposible el remiendo del pasado en

${ }^{668}$ Nietzsche, F., Fragmentos póstumos IV, 11 [378], op. cit., pág. 479 (KSA XIII, 175).

${ }^{669}$ Nietzsche, F., Asi habló Zaratustra, op. cit., pág. 401 (KSA IV, 368).

${ }^{670}$ Cfr. Nietzsche, F., Fragmentos póstumos IV, 16 [32], op. cit., pág. 677 (KSA XIII, 492): «Mas bien esa filosofía quiere llegar hasta lo opuesto - hasta el dionisíaco decir sí al mundo tal como es, sin excepción, descuento ni selección - quiere el ciclo eterno, - las mismas cosas, la misma lógica e ilógica de los nudos. El estado más alto que un filósofo puede alcanzar: tener una actitud dionisíaca con la existencia : mi fórmula para ello es amor fati...». 
la expectativa de una mejora ${ }^{671}$ para la humanidad. El amor fati es el efecto más selectivo del eterno retorno, ya que se compromete con el tiempo kairológico: amar es acoger en convulsa unidad «sintética», que frenéticamente avanza y retrocede, la vida como el horizonte abierto de aquellas experiencias pretéritas que nos hablan activamente en el futuro para enseñarnos a reír en el presente.

La expectativa de la vida mejor en Nietzsche no apunta a la «mejora», sino a la clásica cuestión de la vida buena, repensada, no obstante, desde las exigencias existenciales de la «corporalidad»: el concepto «mejor» no es moral en Nietzsche, sino estético, dado que se refiere a la contemplación -«filósofo»- con pretensión de realidad efectiva -«artista»- de la reapropiación de la existencia en la conciencia encarnada: el «artista-filósofo». «Mejor» es la concreción particular de una existencia que se brinda sus propias condiciones de sentido, sus propias metas y fines, así como las claves para un desborde fisiológico de fuerza, salud y vigor: «el quantum de poder que eres decide sobre el rango; el resto es cobardía» ${ }^{672}$.

El tiempo del amor fati es un presente que nos mueve a actuar, que nos recuerda que la hora de nuestro ocaso ha llegado y que hemos de superarlo mediante el eterno sí de la voluntad de poder:

Pero es mejor estar loco de felicidad que estarlo de infelicidad, es mejor bailar torpemente que caminar cojeando. Aprended, pues, de mí mi sabiduría: incluso la peor de las cosas tiene dos reversos buenos, -

- incluso la peor de las cosas tiene buenas piernas para bailar: japrended, pues, de mí, hombres superiores, a teneros sobre vuestras piernas derechas!

¡Olvidad, pues, el poner cara de atribulados y toda tristeza plebeya! ¡Oh, qué tristes me parecen hoy incluso los payasos de la plebe! Pero este hoy es de la ple$b^{673}$.

Ya no hay una instancia última que dicte el sino de toda acción; el sentido se cobra en la acción misma, la cual es, a su vez, el propio sujeto: tras la transmutación gramatical de la voz pasiva en la activa, el hombre es tanto el sujeto como el predicado. Que el sentido se cobre en la acción no significa sino que ella misma es su propia fuente de sentido. Y en tanto que la acción es el despliegue del sujeto artístico pensante -artista-filósofo-, el sentido de todo acontecer tan sólo puede asumirse por el hombre encarnado. El sentido de la acción es intrínseco a ella: la voluntad de poder como voluntad de vida despliega en el nue-

${ }^{671}$ Cfr. Nietzsche, F., Ecce homo, op. cit., pág. 18 (KSA VI, 258): «La última cosa que yo pretendería sería 'mejorar' a la humanidad». Y es que «todo lo que hasta ahora se llamó 'verdad' ha sido reconocido como la forma más nociva, más pérfida, más subterránea de la mentira; el sagrado pretexto de 'mejorar' a la humanidad, reconocido como el ardid para chupar la sangre a la vida misma, para volverla anémica. Moral como vampirismo» (ibid. pág. 144 [KSA VI, 373]).

${ }^{672}$ Nietzsche, F., Fragmentos póstumos IV, 11 [36], op. cit., pág. 377 (KSA XIII, 20).

${ }^{673}$ Nietzsche, F., Así habló Zaratustra, op. cit., pág. 400 (KSA IV, 366-367). 
vo tiempo encarnado las capacidades del hombre que se sabe centro de gravedad de su propio acontecer en el mundo. Nietzsche hubo de alejarse «6.000 pies» del hombre y del tiempo para, desde la más elevada cumbre, reintroducir al hombre en el tiempo a través de la hipótesis de que todo ha de retornar eternamente.

Con todo, el amor fati es la premisa estético-ética del eterno retorno, que prescribe la aceptación de la vida encarnada en su sintética unidad trágica. Los vestigios nihilistas de la condena y el resentimiento son trascendidos y transmutados en risa; las limitaciones estructurales del ser humano, esto es, la precariedad marcada por su indefectible muerte y su condición trágico-hermenéutica tornan condiciones de posibilidad de la mejor vida, conducida por los instintos prospectivos de una voluntad de poder que, por su salud, puede crear afirmativamente. Es la apropiación de la eternidad a partir de la afirmación de la fugacidad del instante que ha de repetirse una y otra vez y que nos conmina a desplegar nuestra capacidad plástica sobre el mundo para imprimir sentido sobre una dimensión «inocente». Por esta fórmula nos identificamos con nuestro obrar, ahora abierto en la indeterminación perspectivista del fondo hermenéutico de nuestra voluntad de poder. Una santificación del pasado proyectado hacia el presente desde el futuro para romper la restricción de un tiempo subordinado ante el fetichismo del «reloj» y transmutarlo en «eterno» momento de ocasión de plenitud, de vida cuidada, de vida mejor; un «santo decir sí» a la vida encarnada en el sujeto concreto inserto en su particular vivencia del kairós. Es, finalmente, la experiencia gozosa de una vida liberada de la maldición del Dios del «monótono-teísmo» y que ha sido, en su lugar, bendecida con la palabra de Dioniso:

Primero lo necesario - y esto, ;todo lo hermoso y perfecto que puedas! «Lo que es necesario, ámalo» - amor fati, ésa sería mi moral, hazle a él todo lo bueno y sobre su origen tremendo álzalo hasta ti ${ }^{674}$.

El amor fati, con todo, es la redención del tiempo de la metafísica y la inclusión del devenir del mundo en una «inocencia» elemental liberada de todos los corolarios metafísicos, desde la escatología hasta la conciencia de culpa. La cualidad de la inocencia es un rasgo imprescindible para que acontezca la transvaloración, puesto que sin ella no se logra dejar atrás el deseo de venganza de los despreciadores: el devenir por sí solo conduce al nihilismo, ya que bosqueja una realidad privada de sentido donde no es posible, sin embargo, el cobijo confortable y por lo cual se termina proyectando un ideal externo de salvación «moral». En el amor fati como situación de máxima experiencia del eterno retorno el devenir se transmuta hacia la inocencia, eliminando por completo toda pretensión de moralidad, ya efectiva, ya proyectada en la posteridad. Hasta el momento del eterno retorno la «transvaloración» se ha contemplado sin posibilidad de consecución, ya que la experiencia efectiva de existencia aún seguía sumida en un grado «gramatical» metafísico; la «inocencia»

${ }^{674}$ Nietzsche, F., Fragmentos póstumos II, 15 [20], op. cit., pág. 880 (KSA IX, 643). 
es la conquista final de la empresa de la reapropiación, ya que el «espíritu de venganza» que coronaba las doctrinas de los grandes despreciadores, los espíritus máximamente reactivos pierde su ocasión a causa de la absoluta desmoralización radical del hombre. La «inocencia» es la coronación de la transvaloración que guiará la reapropiación de la existencia.

Por eso la transformación del «león» no es suficiente. Esta etapa transitoria no soportaría tampoco la mirada del eterno retorno. El «no» a los ideales metafísicos del nihilismo del ser nos introduce en el «devenir». Un devenir, no obstante, que al haber nacido del «no» es nuclearmente reactivo al tratarse de una libertad estrictamente volitiva. El león es el «yo quiero» ciego de la voluntad schopenhaueriana; es la afirmación de la voluntad de vida:

No ha dado ciertamente en el blanco de la verdad quien disparó hacia ella la frase de la 'voluntad de existir': ;esa voluntad - no existe!

Pues: lo que no es, eso no puede querer; mas lo que está en la existencia, ¡cómo podría seguir queriendo la existencia! ${ }^{675}$.

La voluntad en Nietzsche es voluntad de poder; su mensaje no es el irresponsable e inmaduro «yo quiero», sino el duro «yo soy» del «niño», en quien la voluntad está íntimamente ligada con la existencia. El ser del «niño» es voluntad como voluntad de poder; la existencia acontece en la acción como dadora de sentido. Esto hace comprender al espíritu la gravedad del juego creativo de la vida, en cuya obra opera desde la actitud del cuidado que contempla la existencia desde máximas de plenitud. El cuidado sólo es concebible desde la «corporalidad», que a su vez emana de la «inocencia» de una realidad que tan sólo necesita de sí para procurarse un lecho plácido.

Así pues, el momento oportuno del superhombre es el «cuándo» en el que su libertad y su necesidad se integran en la existencia jovial que ha comprendido que «quiere» su «deber existir». El superhombre ha alcanzado la ocasión en la que «el espíritu quiere ahora $s u$ voluntad» ${ }^{676}$.

\section{II.3.3. El futuro}

Mediante su inserción en el eterno retorno la voluntad de poder es prospectiva, apunta hacia la esperanza creativa del futuro como límite desde el cual reflexionar y vivir el presente. Es imprescindible la creatividad, ya que la esperanza vana incurre en pesquisas nostálgicas a través de las cuales se filtra una angustia nihilista que fagocita las posibilidades de la superación. El eterno retorno es la estrategia filosófica por la cual la voluntad de poder afirmativa no se desprende del futuro, conservando en su trazo los límites efectivos del superhombre. El tiempo futuro a la luz del eterno retorno acusa una transvaloración de

${ }^{675}$ Nietzsche, F., Así habló Zaratustra, op. cit., pág. 177 (KSA IV, 148-149).

676 Ibid. pág. 55 (KSA IV, 31). 
la conciencia del tiempo: la concepción cronológica y lineal del mundo moderno pierde su sentido en la filosofía nietzscheana, que propone, como los griegos, una kairológica ${ }^{677}$. En efecto, el futuro al que estamos abiertos arreglo al eterno retorno configura el tiempo propicio para la consumación de la mejor de las vidas, aquella que adquiera en el juego de su propia acción su plenitud significativa: «lo futuro es asimismo una condición tanto de lo presente como de lo pasado. 'Lo que debe ser y será es la razón de lo que es' ${ }^{678}$. El futuro se convierte en momento de afirmación; sin embargo, no significa un evento por ocurrir, sino la apropiación de lo ocurrido - pasado- y de lo que está sucediendo - presente- en una existencia que por su precariedad no puede dejar de situarse en la constante renovación de su determinación efectiva de sentido -futuro-; a la vez, el futuro no es el momento situado a la derecha en la flecha del tiempo, sino el «cuándo» por el que el sujeto se compromete eternamente con la dimensión del cuidado, la cual aspira siempre a una mejor vida. El futuro, por tanto, es la reapropiación del pasado y del presente en una lógica kairológica que transmuta el tiempo en las condiciones de la «corporalidad», sumiéndolo en una lógica trágica: el futuro es la promesa del sujeto consigo mismo, es el «cuándo» de la responsabilidad del cuidado que se comprende como el «ya oportuno».

La acepción lineal del tiempo ha cimentado las distintas escatologías filosóficas; la moralización del decurso de los acontecimientos, como si a éste le subyaciera una racionalidad inmanente embarga la fuerza prospectiva del fluir temporal. El pasado es tan sólo el oneroso tributo que ha de pagarse hasta la concreción en un futuro prometido, mas nunca contemplado, de la utopía que, a su vez, priva al presente de valor: es únicamente una etapa intermedia de la que no cabe esperar frutos. En las propuestas escatológicas ni el pasado ni el presente es un momento de apropiación, pues la existencia es enajenada en la promesa de un destino dispuesto externamente y que habrá de llegar en algún momento de un tiempo no encarnado; habrá de llegar y, sin embargo, al tratarse de un tiempo sin encarnación, el sujeto no tiene un rol determinante en dicha consumación teleológica de significado. Así, el futuro cronológico es nihilista toda vez que es un «cuándo» en el que la voluntad de poder ha sido privada de la oportunidad del dominio y del «enseñoreamiento» de la apropiación de sus condiciones de vida mejor.

${ }^{677}$ Cfr. Marramao, G., Kairós, trad. de Helena Aguilà, Barcelona, Gedisa, 2008, pág. 129: «Es como si la unicidad del término representara nuestra conciencia de que aquello que llamamos 'tiempo' no es más que un punto de encuentro entre elementos distintos, a partir de los cuales se origina una realidad evolutiva, una mezcla (¿acaso cortar no significa también, en cierto modo, 'mezclar'?) que hace del tempus algo muy próximo a lo que los griegos llamaban kairós, el tiempo oportuno, el tiempo propicio».

${ }^{678}$ Nietzsche, F., Fragmentos póstumos III, 5 [1], op. cit., pág. 159 (KSA X, 215). 
Esta contemplación del tiempo sucumbe en el momento en que Zaratustra defiende el círculo ${ }^{679}$ : pasado, presente y futuro enlazados en una íntima conformidad significativa que alimenta la fuerza creadora de la voluntad de poder. La voluntad prospectiva encuentra su sentido en lo que habiendo sido aún no es, en la dinámica generadora de verdades: la afirmación por la afirmación como fuente de valor, la santificación de Zaratustra.

Para que la esperanza no pierda su valor afirmativo es necesario que en la voluntad de poder coincidan «futuro» y libertad: ésta no es sino la eterna creación de sentido cuya plenitud se alcanza en la trascendencia del presente encarnado. Al buscar su reflejo, por jugar con una metáfora ya conocida en este trabajo, el hombre ya no se topa con los ideales eternos del en sí, del ser; la renovación de sus caracteres tras la asimilación de su condición finita arroja al otro lado del espejo un horizonte igualmente inserto en la precariedad del tiempo que se sabe ilimitado precisamente por su limitación ${ }^{680}$ : «y este misterio me ha confiado la vida misma. 'Mira, dijo, yo soy lo que tiene que superarse siempre a sí mis$m o^{\prime}{ }^{681}$. Rasgos éstos ajenos a una significación idealmente prevista. En esta orfandad natural se debate la libertad, a la cual le corresponde la noble tarea de colmar, mediante esfuerzos humanos, el trágico espacio vacío que dejaron los ídolos del mundo ultraterreno. La limitación de la filosofía nietzschena se remonta en su origen a la falta de una verdad trascendente cuya ausencia empuja la existencia irremediablemente a un abismo de incertidumbre e injustificación que al ser acogido en la transmutación temporal del eterno retorno se ha transmutado en un acontecimiento «estético» por el cual la fuerza de vida es estimulada. La aceptación jovial del eterno retorno es la más saludable condición de existencia, ya que desde la inmensidad de su finitud se acoge el ser del hombre en su devenir perspectivista abierto al instinto de dominación de la voluntad de poder.

El superhombre como la más ilusionante esperanza, el criterio jerárquico más elevado, supone la liberación definitiva del hombre al integrarlo en su obra: el artista-filósofo participa, a la vez, de la obra de arte de la existencia como materia prima y arquitecto. Desde él se desearía repetir el más ínfimo de los instantes, pues en el más pobre y precario de todos ellos hay un desbordante derroche de salud, de fuerza, de poder y de dominio. Mas para que éste no devenga un sueño romántico, un narcótico para soportar el peso de la nada del nihilismo, sino que se identifique con la libertad creadora de la voluntad de poder afirmadora, ha de quedar ordenado en las demarcaciones constitutivas de un futuro atenazado por la radical experiencia de muerte. Muerte y vida integradas en la misma experiencia de

${ }^{679}$ Cfr. Nietzsche, F., Así habló Zaratustra, op. cit., pág. 303 (KSA IV, 271): «¡Yo Zaratustra, el abogado de la vida, el abogado del sufrimiento, el abogado del círculo - te llamo a ti, al más abismal de mis pensamientos».

${ }^{680}$ Recuérdese lo que advertimos páginas atrás sobre la filosofía de Nietzsche como una filosofía «limitada», precaria, indigente.

${ }^{681}$ Ibid. pág. 176 (KSA IV, 148). 
existencia eterna, ya que al ocaso le sucede la aurora. Como titula el parágrafo 49 del Libro I de Aurora, «una sensación de fondo nueva: la de nuestra inapelable transitoriedad» ${ }^{62}$.

\section{II.4. El eterno retorno y Dioniso}

Gracias al eterno retorno la existencia se ha encauzado en un devenir inocente cuyo discurrir trágico se cifra kairológicamente. La existencia ha sido liberada de la embriaguez de la metafísica de la duplicación y sus respectivas expectativas escatológicas de sentido, depositando ahora en la fuerza de un «santo decir sí»» las metas así como el contenido de los porqués de la vida encarnada. El eterno retorno, en sólida alianza con una saludable voluntad de poder afirmadora como voluntad de verdad, fija los límites compositivos del espacio, el «dónde»-la «corporalidad»-y el «cuándo» de ocasión para el superhombre, la última y gran figura del corpus nietzscheano: «pues tus animales saben bien, oh Zaratustra, quién eres tú y quién tienes que llegar a ser: tú eres el maestro del eterno retorno - , jése es tu destino!» ${ }^{683}$.

La hipótesis filosófica del eterno retorno está en connivencia con la verdad trágica de Dioniso, que lo transmuta en hipótesis existencial. En ambos extremos explota una fuerza tan dramática que arrastra y perturba, para después impulsar y acrecentar. El interrogante por la mejor vida posible, por la consagración de la vida como la más preciosa obra de arte bebe del dios griego: lo hermoso y lo aberrante, lo sereno y lo abrumador, la dicha y el dolor más insoportable, la generación y la corrupción. Dioniso es la transmutación de la pesada vida metafísica en la ligera existencia del devenir inocente.

Dioniso es la santificación de la vida; es la divinidad de los artistas. En el ditirambo, a lo largo de los orgiásticos bailes y cantos, el «yo» se disuelve. El «yo epistémico» deja de cobrar sentido en la métrica dionisiaca, la cual desprecia la absurda y falaz pretensión del individuo autoconsciente. El ditirambo rescata un nuevo hombre, el «artista», cuya identidad no se nutre de la lógica gramatical de la metafísica, sino de la pulsión salvaje de una vida como voluntad de poder. El «yo» que despierta Dioniso es uno de tal especificidad que se define constantemente en la eternidad de su obra. El «yo» dionisiaco es el «artista» de sí mismo como lienzo; $y$, al tiempo que comprende la implicación existencial de semejante identidad y la despliega en el ejercicio «estético» del cuidado es «filósofo». Mas no es sólo «artista» o sólo «filósofo»; por el perspectivismo al que conduce la santificación de Zaratustra de la realidad dionisiaca, la identidad del «yo» trágico que recupera el ditirambo es «sintético»: el «yo» que emerge del coro dionisiaco tras la disolución del «yo epistémico» es el «yo» de la «corporalidad», el «artista-filósofo».

${ }^{682}$ Nietzsche, F., Aurora, op. cit., pág. 515 (KSA III, 53).

${ }^{683}$ Nietzsche, F., Así habló Zaratustra, op. cit., pág. 308 (KSA IV, 275). 
Es el más verdadero de los dioses, «yo no creería más que en un dios que supiese bailar» ${ }^{644}$, pues sólo él favorece la vida como fuente de crecimiento del poder. Sólo es lícito un dios bailarín, pues únicamente los espíritus ligeros pueden participar de la socarrona danza de Zaratustra:

Levantad vuestros corazones, hermanos míos, ¡arriba! ¡más arriba!, ¡y no me olvidéis tampoco las piernas! Levantad también vuestras piernas, vosotros buenos bailarines, y aún mejor: ¡sosteneos incluso sobre la cabeza! ${ }^{685}$.

Los discursos de Zaratustra no se dirigen a un público abstracto, sino al oído de cada hombre. El sabio persa no habla a las colectividades, sino a los individuos. Al sujeto particular le prescribe el tipo del superhombre, cuya significación habrá de encarnar cada cual, a partir de la experiencia de la reapropiación tras la muerte de Dios. El superhombre y el eterno retorno son los topes de Dioniso que, sin embargo, están integrados el uno en el otro; dos perspectivas íntimas que se necesitan mutuamente para su favorable conclusión:

Zaratustra es un danzarín-; en cómo aquel que posee la visión más dura, más terrible de la realidad, aquel que ha pensado el «pensamiento más abismal», no encuentra en sí, a pesar de todo, ninguna objeción contra el existir y ni siquiera contra el eterno retorno de éste - antes bien, una razón más para ser él mismo el sí eterno dicho a todas las cosas, «el inmenso e ilimitado decir sí y amén»... «A todos los abismos llevo yo entonces, como una bendición, mi decir sí»... Pero esto es, una vez más, el concepto de Dioniso ${ }^{686}$.

La corporalización del tiempo por el eterno retorno ha supuesto situarse más allá de la flecha del tiempo. Es una superación del tiempo profético de la historia en beneficio del «tiempo de la vida», reapropiada una vez el fin de la verdad ulterior ha permitido que su centro de gravedad abandone las perspectivas escatológicas y se radique en sí misma. Exonerada de los avatares eidéticos, la «inocencia» recuperada supone, no obstante, una nueva legislación para el sujeto viviente. No es una censura moral, sino elementalmente estético-existencial: la irrestricta libertad tras la emancipación requiere del juicio ascético de la «corporalidad», o sea, responsabilidad, si aspira a la vocación de eternidad de su experiencia de reapropiación del mundo. La libertad irredenta sin proyecto de cuidado por el que colmar de sentido las metas propias aboca de nuevo a la nulidad del nihilismo de una vida ciega sin aspiraciones de mejora. El eterno retorno necesita que la voluntad de poder sea esencia de la vida como mecanismo de la transvaloración, pues el artista-filósofo «tiene que ser juez y vengador y víctima de su propia ley» ${ }^{687}$ en el proyecto íntimo del cuidado.

${ }^{684}$ Ibid. pág. 74 (KSA IV, 49).

${ }^{685}$ Nietzsche, F., «Ensayo de autocrítica», en Nietzsche, F., El nacimiento de la tragedia, op. cit., pág. 37 (KSA I, 22).

${ }^{686}$ Nietzsche, F., Ecce homo, op. cit., pág. 113 (KSA VI, 345).

${ }^{687}$ Nietzsche, F., Así habló Zaratustra, op. cit., pág. 175 (KSA IV, 147). 
La superación del tiempo profético de la historia es la redención eterna, precisamente, del tribunal «moral» desde el que se había juzgado la vida. La encarnación del tiempo supera la conceptualización ulterior de los contenidos de la vida, que ya no se prejuzga de acuerdo con la significación trazada externamente desde el mundo «verdadero», sino desde la propia actuación del sujeto que existe. La absoluta vaciedad significativa del fondo de la existencia pone el sentido de su afirmación en la afirmación misma: el eterno retorno es, con todo, el cuestionamiento eterno del individuo sobre sí mismo y sus porqués en el esfuerzo por procurarse contenido de significación en una realidad radicalmente inocente, esto es, para reapropiarse de su ser «limitado»: «`¡Ya es tiempo! ¡Y Ya ha llegado la hora!'» ${ }^{688}$. La hora, Zaratustra, de la consumación del proyecto de reapropiación de la vida, de la «redención» de la existencia de la idealidad metafísica en la «corporalidad» que ha santificado la afirmación: «redimir a los que han pasado, y transformar todo "Fue" en un “Así lo quise” - ¡sólo eso sería para mí redención!» ${ }^{689}$.

${ }^{688}$ Ibid. pág. 197 (KSA IV, 167).

${ }^{689}$ Ibid. pág. 209 (KSA IV, 179). 


\section{CAPÍTULO III: LA REAPROPIACIÓN DE LA OCASIÓN DE VIDA}

\section{III.1. El problemático concepto del superhombre}

Es el concepto más delicado de la filosofía de Nietzsche, sobre el cual se cohesiona y legitima todo su pensamiento: es la encarnación de su filosofía. En un mundo que, tras la muerte de Dios, ha de buscar en su acción las fuentes de sentido, el superhombre es el hilo de Ariadna para los más oscuros y arriesgados porqués.

La revelación del eterno retorno había supuesto para Nietzsche uno de sus más duros momentos de inspiración; una experiencia primeramente traumática que enfermó a Zaratustra durante días. Tras un difícil luto durante el cual éste alcanzó a atisbar las fortalezas del más abismal de sus pensamientos, se alzó rebosante de luz. Y si bien el eterno retorno es la máxima afirmación de la vida, es tal cosa únicamente por albergar las condiciones de la ocasión del superhombre. Si Nietzsche hubiese pensado el eterno retorno al margen del superhombre, toda su filosofía de futuro habría perecido en el fondo mismo del nihilismo, el cual se antojaría insuperable toda vez que habría de volver para repetirse en el ciclo cerrado del nihilismo activo como máxima adquisición que al no ser superado termina por devenir reactivo. Es precisamente la figura esperanzadora del superhombre la que permite romper el fatalismo de esta circularidad que ha sido la decadencia de la historia de Occidente en su totalidad, y abrirla hacia el futuro. Sin embargo, no es menos cierto que depositar en el superhombre el sentido pleno del eterno retorno constituye otro sendero nihilista. Esta segunda ruta convertiría la filosofía de Nietzsche en un proyecto escatológico, al modo de las optimistas teleologías modernas, como la ideología del progreso, que habría de confluir en el superhombre como gran cierre sistemático. Esta estrategia ha de rechazarse inmediatamente, pues en ella el superhombre es investido de un contenido esencial determinado antes de su apropiación. Con ello el superhombre se antojaría ideal normativo que se prescribe significación ulterior de la existencia. Así, el superhombre sería la nueva figura de la revelación que, como Cristo antes, podría decir de sí mismo que es la verdad. El superhombre como conclusión no es el hito último de un proyecto «moral» histórico, sino la consumación de la existencia en el sujeto concreto que finalmente puede afirmar la complejidad «sintética» que nunca atrapará en plenitud y que ha exigido la transvaloración de la realidad habida hasta entonces en un espacio de eterna oportunidad de vida buena y de perpetua resignificación de los propios fines.

La aproximación al superhombre no es, como puede apreciarse, sencilla y grácil. Está íntimamente ligado con el eterno retorno, constituyendo ambos conceptos los dos elementos capitales, vehiculados, no obstante, por la voluntad de poder, desde los que santifica la vida Zaratustra. No obstante, su relación es agónica, toda vez que han de sostenerse en un esforzado equilibrio. Si se rompiese la armonía entre ambos, el abismo del nihilismo sobre el cual nos deslizamos con tímidas tentativas nos fagocitaría. De modo que la coexis- 
tencia de uno y otro fue una de las grandes dificultades que hubo de gestionar Nietzsche. La precaria armonía tan sólo pudo resolverse a través de la afirmación de una perspectiva arriesgada y peligrosa que apostaba por una integración simbiótica de ambos conceptos: el superhombre como horizonte de expectativas que abría el eterno retorno hacia el futuro kairológico como «cuándo» de ocasión oportuna; y éste como la experiencia de reapropiación de la eternidad de una vida finita y efímera, «limitada», que trasciende las propias condiciones de conservación de la voluntad de vida en «corporalidad», esto es, en condiciones de la voluntad de poder afirmadora. Esta mutua dependencia consagra la orfandad del mundo de toda finalidad $\mathrm{y}$, al tiempo, afirma la posición intermedia del hombre que, arrojado en el suelo trágico del devenir «inocente», ha de construir sentidos y verdades en el ejercicio responsable de la libertad de su voluntad de poder. De esta manera se eludirían las tentativas ya paralizantes del pesimismo ya la ingenuidad del optimismo frugal ${ }^{690}$ que palpitan en el fondo de este maridaje y que privan de fuerza al presente como «instante» de ocasión. Sólo esta integradora tentativa «sintética» donde ambos conceptos se limitan y posibilitan mutuamente facultaría el abono del suelo nutricio de los nuevos tiempos de oportuna eternidad y de eterna oportunidad que han superado el nihilismo y, finalmente, se han podido entregar a la empresa del cuidado, a la gramaticalización de la voz dionisiaca de la existencia correspondiente a una verdad viviente abierta en la perspectiva del «cuándo» de la voluntad de poder como «corporalidad».

Con todo, el concepto del «superhombre» es una matriz del corpus nietzscheano que se encuentra, en connivencia con el riesgo y el peligro que traza toda la apuesta de su filosofía, en un incómodo equilibrio del que puede tropezar en cualquier momento y extraviarse para la eternidad, en tanto que estructuralmente limitado y condicionado por el eterno retorno. Así lo advierte el desengañado Zaratustra: «yo buscaba hombres grandes, nunca encontré más que monos de su ideal» ${ }^{691}$. Así es, el superhombre, el tipo en quien reposan las más altas esperanzas, ha de cuidarse para no quedar reducido en una burlesca caricatura de sí mismo, pues «el hombre ha comenzado por la mueca de lo que iba a devenir; hasta Zaratustra tendrá su mono, que saltará detrás de él y tirará del faldón de su vestido» ${ }^{692}$. La filosofía del cuidado del ascetismo nietzscheano está inscrita en su episteme «estética» de creación artestico-filosófica. De tal manera que el superhombre como reapropiación de la existencia no es una tarea completa, sino la dominación del «instante» por la voluntad de poder. El instante no acoge la totalidad, sino la plenitud, el específico momento en que la existencia se ha identificado con la voluntad de poder enseñoreada.

\footnotetext{
${ }^{690}$ Sendas manifestaciones de la nihilista concepción cronológica del tiempo donde la nostalgia del pasado - pesimismo- completa el hastío de la voluntad y el esfuerzo de «adecuación» del futuro -optimismoen la exterior normatividad ideal ahistórica.

${ }^{691}$ Nietzsche, F., Crepúsculo de los ídolos, op. cit., pág. 40 (KSA VI, 65).

692 Foucault, M., Nietzsche, la genealogía, la historia, trad. de José Vázquez Pérez, Valencia, PreTextos, 2008, pág. 20.
} 
La eternidad exige la dominación de los instantes que la conforman, o sea, la perpetua apropiación de la ocasión. Algo que hace del superhombre una sempiterna apropiación de la ocasión del «cuándo» de la existencia. El superhombre nunca es pleno, está «limitado»: en tanto que construido sobre la esencialidad trágica del mundo no puede zafarse de su respectiva lógica dionisiaca de decadencia. El superhombre, como reapropiación de la existencia de cuidado en el «cuándo» del eterno retorno está sumido en la constante creación artístico-filosófica de su vida mejor, motivo éste por el cual no sólo es un concepto vacío, sino que además, como apreció Foucault, también ha de perecer como propicia ocasión buena para una existencia mejor: la «corporalidad».

\section{III.2. El superhombre ante el martillo}

Con la agudeza olfativa de su gran nariz, Nietzsche pudo apreciar cuán numerosos y graves malentendidos circunscribirían al superhombre ${ }^{693}$. Nietzsche es quien filosofó a martillazos; quien golpeó virulentamente los ídolos de los hombres modernos para mostrarles que no eran sino entidades colmadas de aire. De forma que la tentativa de convertir al superhombre en un tipo ideal es, a todas luces, desafortunada. Así ocurre con la aproximación biologicista, que lo perfila como una sublimación especista, como detallamos al presentar la voluntad de vida como una voluntad nihilista. No es el superhombre el próximo estamento de la evolución de la especie, pues es un tipo existencial contemplado desde una temporalidad no cronológica y una historia de vida no escatológica, lo que lo convierte en un tipo existencial «estético» en detrimento del modelo epistémico de la concepción cronológica. Como tampoco es lícito pensarlo en caracteres idealistas que lo alejan de su radical experiencia de vida, encarnada y particular. Y, por supuesto, no es posible contemplarlo, si no desde la más profunda estulticia, como una bestia que cifra en su fuerza bruta la dominación ${ }^{694}$.

Como todo concepto nietzscheano, el superhombre no está definido. Se encuentra abierto a la perspectiva, y es como tal ésta el juez que habrá de imprimirle significado. Sólo ofrece Nietzsche algunos rasgos, demasiado generales, que sin embargo esbozan el retrato de su personalidad libre: el superhombre se halla alejado del rebaño, en cuyo seno la nivelación de las conciencias hace imposible la ardua tarea de la superación. El redil donde

${ }^{693}$ Cfr. Nietzsche, F., Ecce homo, op. cit., pág. 65 (KSA VI, 300): «La palabra 'superhombre', que designa un tipo de óptima constitución [...] - una palabra que, en boca de Zaratustra, el aniquilador de la moral, se convierte en una palabra muy digna de reflexión, ha sido entendida casi en todas partes, con total inocencia, en el sentido de aquellos valores cuya antítesis se ha manifestado en la figura de Zaratustra, es decir, ha sido entendida como tipo 'idealista' de una especie superior de hombre».

${ }^{694}$ Esta última de las tergiversaciones del concepto de superhombre es, desgraciadamente, la más extendida a causa de la paupérrima experiencia de la Alemania de las décadas de los 30 y 40 del pasado siglo. No es difícil refutarla y tampoco nos detendremos en ello. Baste decir que la caricatura del superhombre como la bestia rubia de la propagan del partido nazi está en las antípodas de la transvaloración; es, por el contrario, una pueril e infame inversión de la moral nihilista que, por ende, lejos de superar el nihilismo, se hunde más en él. Recuérdese que ya dedicamos nuestra reflexión al significado de «dominación» en Nietzsche. 
pace el rebaño es el dios secular de la modernidad, su gran ídolo en el que se han depositado las respuestas y las verdades, el Estado, la última manifestación de la «conciencia» histórica de Europa. La configuración política de la modernidad es netamente «cristiana», pues la organización estatal habla desde la «gramática» divina del viejo Dios muerto. El vacío que sacudió las conciencias europeas es remediado por el Estado, postulado nueva fuente secular de sentido trascendental; un nuevo absoluto que sigue ocultando la verdad trágica del mundo del devenir dionisiaco y que procura el narcótico de un sentido en la nada del todo.

El Estado acomete una aniquilación de los aislados rasgos elevados; es una nivelación mediocre de las condiciones más bajas de la existencia. Las redes estatales hacen de lo vulgar la ley y censuran lo osado que se rebela. Nietzsche estima la vida del solitario que ha sabido salir del vicioso adocenamiento de la muchedumbre. El superhombre es el grito de aquellos individuos que se ahogan en una vida arrebatada y enajenada de las condiciones de sus metas y fines, esto es, en una vida sobre la que, aun siendo propia, no pueden afirmarse como creadores de su «corporalidad»:

Nosotros, apátridas - [...] Tenemos aversión a todos los ideales en referencia a los cuales alguien podría aún sentirse en su hogar en este tiempo de transición frágil y ya roto [...] No «conservamos» nada, tampoco queremos volver a ningún pasado, no somos de ninguna manera «liberales», no trabajamos para el «progreso», no necesitamos tapar primero nuestros oídos contra las sirenas de futuro del mercado - ¡lo que ellas cantan, «igualdad de derechos», «sociedad libre», «no más señores ni siervos», no nos seduce! — consideramos que no es en absoluto deseable que se instale en la tierra el reino de la justicia y la armonía (porque en cualquier circunstancia sería el reino de la más profunda mediocrización y chinería), nos deleitamos con todos los que, como nosotros, aman el peligro, la guerra, la aventura [...]. ¡La humanidad! ¿Ha habido nunca entre todas las viejas damas una vieja dama más asquerosa? (— tendría que ser quizá «la verdad»: una pregunta para filósofos). No, no amamos a la humanidad; por otra parte distamos mucho de ser suficientemente «alemanes», tal como se entiende hoy corrientemente la palabra «alemán», para hablar en favor del nacionalismo y del odio racial, para poder alegrarse de la sarna del corazón y del envenenamiento de la sangre nacionales gracias a la cual cada pueblo se separa de otro, se segrega como si estuviera en cuarentena [...]: preferimos con mucho vivir en las montañas, apartados, «intempestivos» [...]... Nosotros, apátridas, somos por raza y proveniencia demasiado múltiples y mezclados, como «hombres modernos», y por consiguiente poco tentados a participar en esa mentirosa e impúdica admiración racial que se expone hoy en Alemania como signo de sentimiento alemán y que suena doblemente falsa e indecente en el pueblo del «sentido histórico» [...] ¡El sí oculto en vosotros es más fuerte que todos los nos y quizás de los que estáis enfermos con vuestro tiempo; y si tenéis que salir a la mar, vosotros emigrantes, también a vosotros os impulsa - una creencia!... ${ }^{695}$.

El superhombre no está definido cuantitativamente, de una vez y para siempre, dado que no es la absoluta «participación», no es la certera «adecuación» del sujeto en un ideal de existencia supramundo. Es insinuado y perfilado, tal vez mediante oposiciones

${ }^{695}$ Nietzsche, F., La gaya ciencia, op. cit., pp. 889-890 (KSA III, 628-631). 
contra su némesis, el último hombre. El superhombre se ha emancipado de todo modo de esclavitud: él es señor de sí mismo, él es su propia fuente de significado, que alcanza a través de su obrar. Es el artista-filósofo y su obra; es el rostro reflejado en plenitud en el espejo. Es la afirmación eterna de la «corporalidad», la identidad de la voluntad de poder y la vida. El noble señorío del superhombre lo aparta de cualquier forma de dominación; su concepto de poder no se halla en el horizonte de los hombres pequeños entre los que ha de cohabitar. El superhombre es una concreción de vida demasiado superior; ha aprendido a ignorar las capas más inmundas de la existencia. Por ello, su superioridad no se refiere al fútil poder coactivo de unos sobre otros, sino a la fuerza plástica de una voluntad de poder enseñoreada que crea la verdad propositiva de su vida desde su misma experiencia radical de existencia.

El valor y la fuerza del superhombre descansan en su voluntad de poder proyectiva, en su capacidad para despreciar y hacer de su desprecio una obra artístico-filosófica; el superhombre es el señor del devenir inocente, quien sin miedo se arriesga y avanza en la trascendencia hacia lo desconocido del futuro, que puede sepultarlo, pues en su desprecio ama. Por su apropiación «inocente» del devenir el desprecio del superhombre es sustancialmente distinto del de la tradición de la «venganza» contra la vida. Los espíritus reactivos, hasta entonces, habían hecho del desprecio el motor de la realidad; por su desprecio habían deslegitimado la vida sensible y enajenado la existencia en instancias ediéticas. Su desprecio, por tanto, era netamente destructivo: el odio y la destrucción son entelequias de sí mismos en el desprecio nihilista. Sin embargo, tras la transvaloración el desprecio del superhombre está asentado en otro horizonte de valoración en el que el amor, y no el odio, motivan la relación del hombre con la vida; el desprecio también actúa desde el amor: el desprecio respecto de lo mundano, respecto de la bajeza viene desde el amor por los caracteres elevados que permitirían una experiencia de existencia reapropiada. El desprecio del superhombre no es reactivo; al contrario, se contempla desde la expectación de la afirmación creación. Es un desprecio de cuanto ha impedido la afirmación; es el desprecio precisamente hacia los «despreciadores». Y se desprecia a los despreciadores porque se ama aquello que despreciaban, aquella vida encarnada que había sido enajenada en la inhumanidad del «mundo verdadero» supramundano: «quien tiene el instinto orientado hacia la jerarquía odia las formaciones intermedias y a quienes las forman: cualquier medianía es su enemigo» ${ }^{696}$.

El desprecio del superhombre es afirmativo, pues en su rechazo de lo habido hasta entonces se crea la ocasión oportuna de la existencia radicada en la voluntad de poder que eternamente dirá «sí» a la «corporalidad»:

${ }^{696}$ Nietzsche, F., Fragmentos póstumos IV, 11 [37], op. cit., pág. 377 (KSA XIII, 20). 
Yo amo a quienes no saben vivir de otro modo que hundiéndose en su ocaso, pues ellos son los que pasan al otro lado.

Yo amo a los grandes despreciadores, pues ellos son los grandes veneradores, y flechas del anhelo hacia la otra orilla.

Yo amo a quienes, para hundirse en su ocaso y sacrificarse, no buscan una razón detrás de las estrellas: sino que se sacrifican a la tierra para que ésta llegue a ser alguna vez del superhombre.

Yo amo a quien vive para conocer, y quiere conocer para que alguna vez viva el superhombre. Y quiere así su propio ocaso.

Yo amo a quien trabaja e inventa para construirle la casa al superhombre y prepara para él la tierra, el animal y la planta: pues quiere así su propio ocaso ${ }^{697}$.

El superhombre no es el gracioso y feliz resultado de una casualidad, sino la esforzadísima transmutación de aquel que ha buscado su ocaso para poder superarse. Por todo ello, el superhombre es aquel que se ama demasiado, y que por su amor entiende su necesidad de perecer en la eternidad de una creación «estética» de la que se apropia en cada instante de su ser en la ocasión de la expectativa de la vida mejor.

El superhombre nace en las más altas cumbres, tras haberse elevado por encima del hombre y del tiempo. No obstante, esto no significa que el superhombre haya perdido su condición humana; al contrario, su humanidad ha sido maximizada en su encuentro con la conciencia de su ser radical existente. Sigue siendo un sujeto, ahora encarnado, inserto en el devenir, hoy inocente, de la verdad trágica de Dioniso, que ejerce responsablemente su libertad mediante el afirmativo acto de creación de una voluntad de poder saludable y que se piensa en la hipótesis kairológica del eterno retorno. Con todo, el superhombre es un tipo humano cuyos rasgos más nobles han sido realzados y maximizados, por el enseñoreamiento de su voluntad de poder, alguien que ha hecho de sus meta y camino la transmutación de su reacción en una afirmación capital de sí y de la vida al comprenderse dentro de una expectativa oportuna de mejora desde el cuidado.

Pocas consideraciones novedosas más nos ofrece Nietzsche. No se puede brindar otra cosa que un trazo, más o menos profuso, de los rasgos y caracteres del tipo del superhombre. Al mismo tiempo, esto es suficiente. En el tipo no se especifican características, pero se juzga la actitud ante la vida: la grandeza del sí del superhombre ha estampado una fijeza estable, aunque necesariamente contingente y siempre sujeta a la renovación en su apertura hacia la perspectiva, dentro de las producciones efímeras del mundo. En el superhombre la fugacidad de la precariedad humana se eterniza en una impronta de renovación eternamente perpetua bajo la cual la realidad del mundo, al término la voluntad de poder, se santifica.

El superhombre, por tanto, se mantiene en la estela de lo humano, aunque en sus condiciones más exquisitas y en la optimización de sus límites de poder y fuerza. Así como

${ }^{697}$ Nietzsche, F., Así habló Zaratustra, op. cit., pp. 38-39 (KSA IV, 17). 
el hombre «es una cuerda tendida entre el animal y el superhombre, una cuerda sobre un abismo» ${ }^{698}$, el hombre superior, parafraseando el Prólogo del Zaratustra, sería una cuerda entre el hombre y el superhombre, tendida sobre el mismo abismo, que es el nihilismo que amenaza con volver a alcanzar a quien ha trascendido ${ }^{699}$ y alejarlo una vez más de su experiencia encarnada de existencia.

Por eso el superhombre como tipo es una posición conclusiva, pero de la que no debe esperarse final: es el estado último no cronológico del hombre que trasciende su propia condición, mas en tanto que la temporalidad kairológica del eterno retorno, el tiempo de la encarnación, lo suscribe a las ocasiones oportunas de apertura en la expectativa, no se consagra en plenitud: es una concreción no utópica de la vida buena. Precisamente esa mirada hacia la lejanía que lo impulsa a conquistar las «islas afortunadas» que aún no han sido siquiera descubiertas impide definirlo categorialmente. $Y$ en tanto que no es una «entidad» definible no puede actuar al modo de formal idea platónica como «verdadero» legitimador y garante del mundo y de la acción: el superhombre es el producto de una acción en cuyo desempeño se conforma la verdad, de manera que la verdad no antecede al proceso creador; mas tampoco lo sucede: el proceso mismo de creación es la verdad, en tanto que en la realización «estética» de la vida buena es llevado a cabo por el propio sujeto encarnado como sujeto de cuidado, el artista-filósofo. Y como se halla inserto en el horizonte del devenir inocente, la transvaloración de la «moral» de la metafísica del ser estático es máxima y oportuna condición de posibilidad del superhombre: la transvaloración vindica el valor de la precariedad y la muerte del hombre.

La reapropiación se consuma en el superhombre una vez integra en su radicalidad la «limitación» de su existencia artístico-filosófica, que por cuya precariedad indigente ha de ser afirmada en cada instante. Cada instante de afirmación supone la dominación por la voluntad de poder del horizonte perspectivista en cuanto tal, pues la vida es voluntad de poder, y el enseñoreamiento en particular de la mejor ocasión de existencia. El superhombre, tras todo, es la experiencia encarnada y concreta de la mejor vida, es la propia del individuo artista que ha hecho de sí su gran obra y, ella mediante, ha santificado su existencia:

${ }^{698}$ Ibid. pág. 38 (KSA IV, 16).

699 Por eso los conceptos nietzscheanos no encierran definiciones categoriales, sino aproximaciones filosóficas. El superhombre o la transvaloración no pueden verse colmados con un contenido conceptual previo, ya que esto, además de introducirlos en una perspectiva teleológica que dispone y organiza el trazo de la acción, agotaría la originalidad del devenir en el cual están insertos y, con ello, lastraría la apertura hacia la perspectiva. El superhombre o la transvaloración, al igual que el amor fati, no son conceptos clausurados; puesto que todo está sujeto a la pulsión de generación y caos de la tragedia de la verdad dionisiaca, también están sujetos a su ocaso. La conquista del superhombre exige que éste haya de perecer una vez alcanzado, esto es, que siga sometido a las expectativas del cuidado de una mejor vida. De lo contrario, la pasividad nihilista volvería a tomarlo cautivo y lo degeneraría en los grados más bajos de la jerarquía existencial, aquellos en los cuales la enajenación fue absoluta. El superhombre es un tipo abierto, y quizá que resulte inalcanzable sea uno de sus límites condicionales. 
«¿vosotros decís que la buena causa es la que santifica incluso la guerra? Yo os digo: la buena guerra es la que santifica toda causa» ${ }^{700}$.

Por lo tanto, el superhombre no es un sujeto sui generis, sino un sujeto concreto y particular. Tampoco es un cambio de sustancia bajo el mismo accidente, para decirlo como los medievales, ni podemos contemplarlo a la luz de ejemplarizantes casos pretéritos, ya que aún no ha existido ${ }^{701}$. No obstante, si admitimos el axioma nietzscheano de que la vida es voluntad de poder junto con la genuina concreción del nihilismo decimonónico como nihilismo consciente de sí, el superhombre es el primer tipo humano que ha cobrado conocimiento de sí mismo - «filósofo»-como voluntad de poder - «artista»-con capacidad de proyección artístico-filosófica de su propia realidad de existencia encarnada. Jugando con un tropo de este trabajo, el superhombre sigue siendo hombre porque es «cabalmente» hombre, esto es, plástica voluntad de poder que anhela su propia trascendencia hacia la mejor de las formas de vida. Aún no ha existido, pues hasta el momento toda la existencia había permanecido inconsciente de su realidad «sintética»: la escisión del alma y el cuerpo había llevado tan sólo a la contemplación parcial de la vida. La contemplación eidética del «filósofo» contrapuesta a la sensualidad irresponsable del «artista». El superhombre, por el contrario, logra la sutura existencial de las dos dimensiones fracturadas en el tipo existencial del artista-filosófo, en quien el cuerpo se ha espiritualizado y el espíritu corporalizado. Un tipo de ser en el mundo extraordinario que acepta jovialmente los rigores más duros de la tragedia dionisiaca y los transmuta en eterna ocasión de dicha. Así se puede comprender que Nietzsche afirme que «los seres humanos más espirituales, suponiendo que sean los más valerosos, también viven con mucho las más dolorosas tragedias: pero ellos honran la vida justo porque ésta les opone máxima hostilidad» ${ }^{702}$. La fórmula de la «corporalidad» comprende la concreción no utópica de la reapropiación de la existencia liberada de la longeva tradición de la metafísica de la duplicación platónica y de su vasto legado.

El superhombre es el hombre mismo cuyas capacidades han sido realzadas y máximamente desplegadas, artesano de la verdad y de las valorizaciones, o sea, de su vida, de su encarnación. El superhombre es el niño inocente que juega en un nuevo tablero, que ha consumado el nihilismo desde su actividad al conquistar el vértigo de su propio abismo in-

${ }^{700}$ Ibid. pág. 84 (KSA IV, 59).

701 Esta idea ya la introdujimos líneas más arriba: «Aún no han existido superhombres. Yo los he visto desnudos a ambos: al más grande y al más mezquino de los hombres: y a ambos los seguí encontrando - idemasiado humanos!» (Nietzsche, F., Fragmentos póstumos III, 10 [37], op. cit., 261 [KSA X, 374-375]).

702 Nietzsche, F., Fragmentos póstumos IV, 11 [78], op. cit., pág. 390 (KSA XIII, 38). 
sondable de personalidad ${ }^{703}$ y dejado atrás todo cuanto lo precedió. También a los hombres superiores, todavía muy cercanos al hombre débil y reactivo y demasiado lejanos de la fortaleza del señor de la verdad ${ }^{704}$.

El superhombre, en definitiva, no es un ídolo trasmundano; es el propio hombre que ha santificado su afirmación: «el superhombre es el sentido de la tierra. Diga vuestra voluntad: ¡sea el superhombre el sentido de la tierra!» ${ }^{705}$. Es, en realidad, el tipo más humano; no es demasiado humano, sino máximamente humano, pues su personalidad se ha cifrado desde los más exigentes valores de la «corporalidad»: la libertad y la responsabilidad de una «limitada» perspectiva de cuidado.

\section{III.3. La apertura hacia el futuro como apertura perspectivista}

A la luz de las consideraciones ofrecidas sobre la conceptualización kairológica del tiempo en Nietzsche, no es difícil corroborar una vez más que la proyección perspectivista que alberga la promesa de concreción no utópica del superhombre es, primeramente, una cuestión filosófica embarcada en la tensión de la existencia, una transvaloración del hombre, del mundo y del tiempo. El amor fati ha alterado sustancialmente las delimitaciones temporales, reviviendo el pasado, acercando el futuro y sumiendo el presente en una salvífica precariedad de eterna ocasión oportuna de reapropiación. Motivo éste por el cual la aproximación de Nietzsche sobre el tiempo no es desde una voluntad retrospectiva que escruta y juzga lo acontecido, sino desde la fuerza de la proyección que el «futuro» tiene sobre el «presente»: el «instante» como justificación del «cuándo» efectivo. Por ello, la esperanza de futuro no muta en un optimismo progresista -«moral»-, sino en efectiva rebelión creadora contra la indigencia epocal, un desprecio por amor.

La expectativa de ocasión del superhombre es una estima concreta que nace de su desprecio. Frente a la resignación de las conciencias nihilistas, sin metas ni camino, el superhombre brama ante la ordenación de hecho de la realidad. Un grito de protesta y acción que los nihilistas no se atrevieron a proferir. La rebelión del superhombre pugna por el riesgo y la aventura que entraña la realidad dionisiaca en detrimento de los caracteres dóciles y acomodados del nihilismo; abandona la pasividad y rebasa sus fronteras y límites en su propia creación de sí mismo. Por lo que la apertura perspectivista hacia el futuro del superhombre no consiste en una ensoñación teleológica en la que abotargar la mente ya en

${ }^{703}$ Cfr. ibid. 11 [79], op. cit., pág. 390 (KSA XIII, 39): «Los medios con que Julio César se defendía de su constitución enfermiza y del dolor de cabeza: marchas enormes, género de vida sencillo, permanencia ininterrumpida al aire libre y constantes fatigas: ésas son, hablando a grandes rasgos, las condiciones de conservación del genio en general».

${ }^{704}$ Así se explica que la compasión por el hombre superior sea el último pecado que habrá de tentar a Zaratustra. Algo tratado a lo largo de la primera parte en profundidad y de manera somera en la segunda.

${ }^{705}$ Nietzsche, F., Así habló Zaratustra, op. cit., pág. 36 (KSA IV, 14). 
salvaciones postreras -«cristianismo»- ya en condenaciones postreras -«pesimismo»-, sino en un anhelo de lo mejor; de santificación de la vida mediante sus límites configuradores, a saber, su «dónde»-«corporalidad»-y su «cuándo»-«eterno retorno»-. El superhombre está trazado como la oportunidad de la aurora de un posible presente encarnado de afirmación: «¡Superadme, hombres superiores, las pequeñas virtudes, las pequeñas corduras, los miramientos minúsculos, el bullicio de hormigas, el mísero bienestar, la 'felicidad de los más'-!» ${ }^{706}$.

Ante la pregunta de ascendencia helénica por la vida mejor, Nietzsche, como cabe esperar, no lega respuesta conceptual. Tan sólo imágenes evocadoras que comprometen a la voluntad de poder con la responsabilidad del cuidado. Es preferible la muerte del aventurero agotado que ha perseguido incesantemente su superación que la vida acomodaticia de los nihilistas de la voluntad de vida a los que, callados, les sobreviene el paso del tiempo cronológico sin significar para ellos venturosa ocasión de posibilidad; tan sólo sucesión. Los espíritus pequeños y débiles, siervos de la resignación, han enajenado su compromiso con la vida y han optado por el conformismo de la inercia decadente, privándose de la libertad de una existencia reapropiada; además, movidos por el espíritu de venganza, han extendido universalmente esta privación en el tipo del «hombre bueno» moral.

La moral de la resignación se ha inoculado en todos los espíritus. Por eso ama precisamente Nietzsche «a los menos», los hombres superiores que no encuentran acomodo en el presente vigente. Los hombres superiores no encarnan al superhombre, y traen consigo el riesgo de la caída en la reacción, pero participan del anhelo de afirmación; han llegado a preocuparse por una mejor forma de vida: «quieren» vivir, a pesar de ser una vida sin vínculo íntimo con la necesidad.

La perspectiva del futuro kairológico apunta hacia lo que por falta de oportunidades propicias no ha existido todavía. Y ante las dudas que comporta una realidad inexistente, la proyección de la voluntad determina el movimiento del hombre superior: el hombre ha de avanzar hacia lo que no ha llegado y que, sin embargo, tiene un lugar, pues es una posible concreción no utópica de existencia. Un destino desconocido que tampoco importa a Zaratustra: el viaje hacia adelante arroja el sentido al hombre. Esto no significa sino que las «islas afortunadas» son el propio hombre encarnado que ha roto su silencio y se ha alzado contra el presente de «decadencia» en la expectativa de ocasión que brindan el «dónde» y el «cuándo» encarnados.

Y los hombres superiores, no obstante, todavía recuerdan demasiado al «esclavo». Zaratustra los observa durante la cena y percibe en ellos los rasgos del hombre pequeño: aún se aferran a sus títulos y vanaglorian de la nada, demasiado presos de su «pasado cro-

706 Ibid. pág. 391 (KSA IV, 358). 
nológico». Desconocen la verdadera grandeza. Por eso sólo pueden afirmarse en su negación; también ellos son rebeldes, pero no superan su rebeldía; son el león rugiente, capaz de enfrentarse al dragón y de romper sus tablas, pero inútiles cuando se les pide crear. Son el producto de la maximización del nihilismo activo que, sin embargo, no es superado oportunamente. Dicen «quiero» pero, como la voluntad schopenhaueriana, al término no saben lo que quieren; es un querer ciego como consecuencia de que su conciencia no transita sobre su experiencia de existencia. Su querer no es ley, sino irresponsable volición irrestricta.

Los hombres superiores no tienen en sus manos la fortaleza para crear al superhombre, que habrá entonces de ser su hijo o su nieto. No son un fin para la vida, sino el medio real de cristalización de la gran esperanza. El gran puente hacia el arcoíris. De modo que el anhelo de futuro se distancia de las viejas fábulas del más allá; es la apropiación del presente en la promesa afirmadora de una vida mejor.

El superhombre se vive en la encarnación del individuo concreto que afirma radicalmente su vida por encima de todo temor. Para ello se ha de haber consumado como vivencia encarnada la revelación del eterno retorno, haber sobrevivido a su encuentro y aventurarse en su seno hasta el efecto definitivo del amor fati; en paralelo, la voluntad de poder y la voluntad de verdad han debido imbricarse e identificarse, siendo la verdad dionisiaca voluntad de afirmación y de dominación de la vida. Tareas éstas colosales cuya altura no es accesible para todos los espíritus. La jerarquía de la voluntad rige el horizonte del superhombre; no es una tarea propia de la humanidad, la cual se adecua a la benevolencia del legado virtuoso socrático, sino de «los menos» que han confrontado a Dioniso.

El superhombre se afirma a sí mismo y su temporalidad en la inocente dimensión de un camino desprovisto de metas y sentido. La acción del superhombre, a saber, su propia vida, consiste en trazar un rumbo significativo sobre dicha senda, por otro lado terrible y abismal, pues es dionisiaca. Esta metáfora del camino que es creado conforme se transita la recoge el título enigmático de El caminante y su sombra, quien hace del camino mismo el sentido, como el artista-filósofo hace de su obra su sentido: vive en sí.

Consumiéndose ya el siglo XIX el sino está dispuesto. El horizonte occidental ha tomado conciencia de su condición nihilista y los europeos no pueden dar la espalda a esta revelación: rebelarse contra el desprecio de la reacción o despreciar la vida. No puede negarse la enfermedad de Occidente, mas sí renunciar a sus narcóticos; el nihilista hastiado no emprende ya empresas, tan sólo se mantiene, inerte, ante el presente de penuria e indigencia del sinsentido insoportablemente insuperable.

El superhombre está proyectado hacia el futuro de la ocasión de la oportuna perspectiva, pero se siente cercano. Está próximo a nosotros ya que él es la fuente de la supera- 
ción del presente de decadencia en el que estamos arraigados, mas guarda su distancia toda vez que es una empresa que no ha de concretarse, que debe permanecer siempre abierta, una apertura esencial hacia el «futuro» que en el «instante» de la ocasión de su máxima plenitud ha de perecer para reabrirse hacia la perspectiva mejor prescrita por el cuidado.

\section{III.4. Límites y condiciones del superhombre}

Como todo concepto nietzscheano, el superhombre está delimitado, cercado, condicionalmente pensado dentro de unos márgenes de posibilidad, o sea, «limitado». Aunque toda la filosofía de Nietzsche habla en la íntegra totalidad de su corpus, el par más significativo es el del eterno retorno y el superhombre, atravesados ambos por la voluntad de poder, que los integra «sintéticamente». Una dupla que bajo la lectura kairológica del tiempo transmuta sus aparentes contradicciones en una armoniosa expectativa de vida: la repetición sin fin choca contra la novedad del «futuro» que deviene. Hemos defendido en los anteriores epígrafes que en realidad son conceptos mutuamente dependientes; el uno no puede darse sin el otro, ya que el eterno retorno sin vocación de «futuro», esto es, sin apertura a la perspectiva oportuna, y el superhombre sin amor irrestricto serían víctimas de su propia hipertrofia: en el superhombre se encarna la más profunda madurez del hombre que habiéndose adueñado de la verdad y del horizonte de valorización, ha hecho de su vida la más bella obra artística.

El pensamiento abismal del eterno retorno no puede quedarse enclaustrado en esa onerosa forma, ya que la resultante desesperación nihilista sería insoportable. Tras su prospección, el eterno retorno se ha de reubicar en una óptica liberadora y «estéticamente» transformadora, matriz del superhombre. De modo que el eterno retorno no consiste en la repetición cíclica de un proceso cuya conclusión ha sido de antemano dispuesta en el superhombre. De la fusión de ambos conceptos no cabe pensar un progreso teleológico trabado para la eternidad en una circularidad imperturbable. El eterno retorno, en tanto que repetición eternamente idéntica e idénticamente eterna, es la afirmación absoluta de la vida única de la que disponemos, la «corporalidad». De tal modo que configura los márgenes de la existencia posible del hombre: la existencia encarnada es el margen de sí misma, su «dónde» y su «cuándo».

En el momento de la consumación del nihilismo el espíritu rebelde del hombre superior ha asentado las claves de la superación de este momento al vivificar el valor de la vida. Sin embargo, este tipo humano no es suficiente; aún es nihilista, y por tanto le está vedada la acción creadora. En el momento consumatorio del hombre superior, cuando ya ha entregado toda la fuerza de su voluntad y se aferra a su ocaso, emerge la figura del superhombre, con su santa tarea: recuperar su ser y hacer de la existencia una realidad jovial: la santificación de la vida. En esta santificación de la existencia, el eterno retorno y el 
superhombre han sido hermanados en el amor a la vida que juntos comparten y deben explotar en su efímera eternidad.

El eterno retorno es, entonces, el gran límite del superhombre: la afirmación de la especificidad de la propia vida, así como la vigencia de su intransferible carácter. Impone sobre la existencia los más sólidos grilletes: no viviré una segunda vida. Mientras el hombre del nihilismo es víctima del desánimo y sucumbe ante el hastío, el espíritu libre ve en la caducidad de la vida un estímulo infalible: como no viviré una segunda vida, lucharé por hacer de ella la más alta estimación, para lo cual es imprescindible la reapropiación, la conciencia de experiencia de existencia. El miedo y la pesadez del nihilismo, frente a la ligera jovialidad del segundo. Si se nos preguntara sobre la moral nietzscheana, habríamos de remitirnos a este momento, cuando el hombre superior se consolida en los límites del eterno retorno, y desde ellos se sublima. El superhombre como moral, acaso, es la reconciliación con la existencia, pues en él la volición y la necesidad son una y la misma cosa; el «querer» es ley:

Primero lo necesario - y esto, ;todo lo hermoso y perfecto que puedas! «Lo que es necesario, ámalo» - amor fati, ésa sería mi moral, hazle a él todo lo bueno y sobre su origen tremendo álzalo hasta $\mathrm{ti}^{707}$.

El eterno retorno es una hipótesis filosófica de existencia; ni siquiera es pertinente la pregunta por su veracidad, pues todo es mentira como resultado de la transvaloración. Se trata de admitirlo o de rechazarlo como premisa de vida. Su afirmación nos desvela una potencia transmutadora que es, en cambio, efectivamente real. Esta extraña peculiaridad ontológica se extrapola al superhombre. Nietzsche ha confirmado que nunca en la historia existió este tipo humano. Y, sin embargo, su inexistencia no le resta un ápice a su fuerza superadora, ya que es una perspectiva de concreción no utópica. Eterno retorno y superhombre son hipótesis filosóficas generadoras de vida que se concretan en la transvaloración que significa la «corporalidad»: la reapropiación de cada «instante» de existencia como ocasión máxima de eterno cuidado.

Ahora bien, además de su apertura hacia el «futuro», en el superhombre se destaca una fuerza de afirmación inusitada. Un reencuentro de reconciliación con la temporalidad sostenido por una profunda aceptación de la inocencia del devenir azaroso. El superhombre se reencuentra con su temporalidad al tomar la gratuidad del acontecer como un instante pleno: voluntad de poder prospectiva. Una vez más la vida se comprende esencialmente como voluntad de poder.

Estos dos estamentos, el eterno retorno y la voluntad de poder prospectiva procuran al superhombre las claves para su existencia encarnada. Su compromiso es una de tan-

${ }^{707}$ Nietzsche, F., Fragmentos póstumos II, 15 [20], op. cit., pág. 880 (KSA IX, 643). 
tas perspectivas posibles que se ofrecen en el horizonte humano, mas es de todo punto selectiva, pudiendo asirla aquellos espíritus más altamente jerarquizados: que la libertad de nuestra voluntad de poder consista en crear la vida más esperanzadora arroja el sentido propio de una vida de cuidado, a saber, su expectativa perenne de la mejor perspectiva.

El superhombre es la creación más noble y poderosa de Nietzsche, pero esto no lo convierte en una entidad irrefrenable y sin contención. Los límites del eterno retorno son insuperables; la fuerza del tiempo condiciona esencialmente la temporalidad del hombre y lo afecta de forma fatal: el superhombre, la vida encarnada, es mientras el «instante» siga siendo para él momento de máxima oportunidad, de desborde de fuerzas y de plenitud de salud, dado que «todo placer quiere eternidad» ${ }^{708}$.

\section{III.5. La reapropiación mediante la redención}

El perfil nietzscheano de los tipos humanos tiene en su mira el yo del subjetivismo moderno, en quien ontología y epistemología se corresponden armoniosamente. Pone en cuestión el yo solipsista del innatismo y del psicologismo, como expusimos al comienzo de nuestro trabajo. Estas concepciones de la subjetividad la contemplan como un cosmos independiente que sostiene su totalidad en sí y por sí mediante el recurso de ascendencia platónica de la autoconciencia. La empresa nietzscheana de la deconstrucción rastrea la complejidad que conforma el yo, postulando la imposibilidad de un sujeto plenamente autoconsciente e intelectual y existencialmente autárquico si no es bajo el recurso de alguna de las formas metafísicas de la duplicación.

Pero esto no debe inducirnos a pensar que Nietzsche rechace el fondo de la individualidad. Como alternativa, propone un sujeto nacido de la fuerza más vigorosa y saludable de la voluntad de poder que se ha decantado por los más altos valores de su jerarquía de existencia. En el tipo del superhombre se amalgama una pluralidad ciega e inconsciente de instintos que terminan por concretarse en una perspectiva «sintética» de vida buena y mejor. El superhombre como nuevo tipo humano es hermenéutico: comprende una pluralidad indeterminada de perspectivas que se fusionan sobre el sustrato trágico de un mundo en devenir dionisiaco. El superhombre soporta la responsabilidad de significarse; no una inhumana existencia abstraída en ídolos supramundanos, sino aquella que el superhombre vive y configura y que sólo a él impele: la responsabilidad de la «corporalidad» en la eternidad del «instante». El superhombre se encuentra solo ante un devenir inocente y se apropia «estéticamente» de la tarea de la creación de sentidos mediante la apropiación de perspectivas gracias a la valoración y jerarquización de la voluntad de poder. Desde la voluntad de poder como voluntad de verdad acepta la esencial asignificación del mundo y asume como

${ }^{708}$ Nietzsche, F., Así habló Zaratustra, op. cit., pág. 318 (KSA IV, 286). 
propia la justificación de la realidad desde criterios de verdad humanos: el superhombre «redime» la vida al santificar su radicalidad inocente.

La apropiación nietzscheana del «yo» llega con la transvaloración: una nueva forma de valorización demanda un nuevo modelo de hombre que asuma la tarea emancipatoria de la creación afirmativa de valores acrecentadores de la vida. Por eso el modelo humano de Nietzsche choca frontalmente con el de la vieja tradición moral del resentimiento y la hostilidad hacia la vida: es la hora del desprecio de los buenos que pacen entre el rebaño. El bien será el aumento del poder que valora y crea. Zaratustra será considerado un demonio por los hombres buenos, y el viejo persa pasará de largo entre la muchedumbre ${ }^{709}$. El artista-filósofo no necesita de los demás para afirmarse en su existencia, pues ésta es íntima e intransferible y únicamente radicada en sí para dotarse de sentido: «para mí - ¿cómo podría haber un fuera-de-mí? ¡No existe ningún fuera!» ${ }^{710}$.

La superación del nihilismo no puede llegar desde los rasgos del hombre nihilista. Si se quiere la santificación de la vida, debe vivir el superhombre, que se ha alzado sobre el viejo mundo del rechazo. El superhombre es la afirmación de la mejor vida humana posible, en la cual el horror y el dolor siguen presentes aunque transmutados en una dimensión valerosa que se ha establecido emancipada de la culpa y la deuda.

El superhombre es el descendiente del hombre superior; una sublimación del tipo humano que crea la verdad del mundo en el cual se afirma desde la «limitación» de la perspectiva de eternidad de una vida finita que no ha de volver a vivir. Sin embargo, no es un ídolo al que venerar desde su altar. Llevado al extremo, es un hombre que no busca sino la risa inocente de un niño maduro y responsable que no habrá de volver a juzgar «moralmente», sino «estéticamente», la inmanencia del mundo.

Ese hombre del futuro, que nos liberará del ideal existente hasta ahora y asimismo de lo que tuvo que nacer de él, de la gran náusea, de la voluntad de la nada, del nihilismo, ese toque de campana del mediodía y de la gran decisión, que de nuevo libera la voluntad, que devuelve a la tierra su meta y al hombre su esperanza, ese anticristo y antinihilista, ese vencedor de Dios y de la nada - alguna vez tiene que llegar... ${ }^{711}$.

El espacio-tiempo del superhombre, el «dónde» y «el cuándo» de la «corporalidad» y del eterno retorno, respectivamente, han maximizado la apertura del horizonte perspectivista, el cual ofrece una nueva apreciación de la existencia como «proyecto». Tras la transvaloración, el «proyecto» deja de ser la programática disposición de las conciencias y

${ }^{709}$ Cfr. ibid. pág. 255 (KSA IV, 225): «Esta enseñanza te doy a ti, necio, como despedida: donde no se puede continuar amando se debe - ipasar de largo! -»).

${ }^{710}$ Ibid. pág. 304 (KSA IV, 272).

${ }^{711}$ Nietzsche, F., La genealogía de la moral, op. cit., pág. 139 (KSA V, 336). 
de los actos humanos en la historia con arreglo a un plan escatológico trazado fuera del «dónde» y del «cuándo» humanos y cuya realización habría de concluir inhumanamente, después de la vida; ahora, la vivencia del proyecto acontece encarnada: el proyecto es tanto el «por qué» como el «porque». Contemplada dentro de los márgenes existenciales trágicos, la vida ha hecho propia la eternidad oportuna de la voluntad de poder afirmadora

\section{III.6. El superhombre tras Nietzsche: el «escándalo Sloterdijk»}

En las primeras páginas de la Segunda de las Consideraciones intempestivas, a pesar de la juventud de este tratado, Nietzsche bosqueja un paisaje del cual no se podrá zafar la totalidad de su obra, tampoco post portem:

[...] para puntualizar mi tema en términos aun más sencillos: hay un grado de insomnio, de rumiar, de sentido histórico, en que se resiente y finalmente sucumbe lo vivo, ya se trate de un ser humano, de un pueblo o de una cultura.

Para precisar este grado y, sobre su base, el límite donde lo pasado tiene que ser olvidado para evitar que se convierta en sepulturero de lo presente, habría que saber con exactitud el grado de fuerza plástica de un ser humano, de un pueblo, de una cultura, quiero decir de esa fuerza de desarrollarse específicamente a partir de sí mismo, de transformar y asimilar lo pasado y lo extraño, de cicatrizar heridas, reponer lo perdido, regenerar formas destruidas. Hay personas que poseen esta fuerza en tan bajo grado que, como consecuencia de una sola vivencia, de un solo dolor, en particular de una única sutil injusticia, se desangran irremisiblemente, como de resultas de un levísimo rasguño; y las hay invulnerables a los más salvajes y terribles contratiempos y aun a los actos de su propia maldad, al punto que en medio de ellos, o poco después, alcanzan un pasable bienestar y una especie de conciencia tranquila. Cuanto más fuertes son las raíces de la íntima naturaleza de un ser humano tanta mayor cantidad de pasado se apropia o apresa: y la naturaleza más poderosa y formidable se caracterizaría por un sentido histórico que carecería de límites a partir de los cuales pudiera tener un efecto absorbente y perjudicial; atraería y asimilaría todo lo pasado, tanto propio como muy ajeno, transformándolo, por decirlo así, en sangre. Lo que una tal naturaleza no logra dominar, lo sabe olvidar; ya no existe, el horizonte está siempre cerrado e íntegro, y nada es capaz de recordar que más allá de ella hay también seres humanos, pasiones, doctrinas y fines. Y se trata de una ley universal: todo ser viviente sólo dentro de un horizonte puede alcanzar salud, fuerza y fecundidad; si es incapaz de encerrarse dentro de un horizonte y, por otra parte, demasiado egoísta como para integrar la propia perspectiva en otra ajena, decae, lánguido y afiebrado, y sucumbe prematuramente. La serenidad, la conciencia tranquila, la acción alegre, la confianza en lo por venir - todo esto depende, en el individuo no menos que en el pueblo, de que exista una línea que separe lo escrutable y claro de lo inescrutable y oscuro, de que se sepa olvidar y recordar oportunamente, de que se discierna con vigoroso instinto cuándo se necesita el sentir histórico y cuándo el sentir ahistórico. Tal es precisamente la tesis que el lector está invitado a considerar: lo ahistórico y lo histórico son por igual necesarios para la salud de los individuos, de los pueblos y de las culturas ${ }^{712}$.

712 Nietzsche, F., Consideraciones intempestivas II De la utilidad y los inconvenientes de la historia para la vida, op. cit., pp. 698-699 (KSA XII, 250-252). 
La larguísima enfermedad, por supuesto, que llevó al hastío de las conciencias durante la modernidad; el duelo de la decadencia que culminaría en la dimensión pasiva del nihilismo. Es una patología que no impide la vida, sino la vida buena. Dentro de esta atmósfera la voluntad de vida prolifera y se desarrolla en el curso de la civilización, sin embargo, sin expectativas de salud y fecundidad.

Parece un rasgo congénito, incurable: los hombres albergan dentro de sí las condiciones de la reactividad. La muerte de Dios pareció corroborar tal hipótesis, puesto que a un universo emancipado de su tradicional fuente de legitimación se le hubo de insuflar la bocanada de idealidad de la pretérita divinidad: el Estado, el positivismo, el logicismo, la devota fe en la ciencia fueron estrategias de la vieja «gramática» de la duplicación con el fin de negar la apertura perspectivista a la que el mencionado deceso abocaba. Así se ha comprendido en este trabajo el minucioso estudio que llevara a cabo Nietzsche de la modernidad como un proyecto enajenador.

Nietzsche advirtió que su legado era el de los siguientes dos siglos:

Yo describo lo que viene: el ascenso del nihilismo. Puedo describirlo porque aquí se produce algo necesario - de ello hay signos por todas partes, sólo faltan los ojos que los perciban. Yo elogio, no critico aquí, que venga: creo que habrá una de las crisis más grandes, un instante de autorreflexión sumamente profunda del ser humano: si éste se repondrá de ello, si el ser humano dominará esta crisis, eso es una cuestión que depende de su fuerza: es posible que lo haga...

el ser humano moderno cree a modo de ensayo ora en este valor, ora en ése, y luego deja que esos valores vayan cayéndose: el círculo de los valores a los que ha sobrevivido y ha dejado que se cayeran va llenándose sin cesar; el vacio y la pobreza de valores alcanzan a sentirse cada vez más; el movimiento es imparable - aunque se ha intentado demorarlo con gran estilo - .

Finalmente, él se atreve a una crítica de los valores en general; les reconoce su procedencia; llega a conocer lo suficiente para no creer ya en ningún valor; he aquí el pathos, el nuevo estremecimiento...

Esto que cuento es la historia de los próximos dos siglos... ${ }^{713}$.

Una herencia que habría de recuperar el horizonte perspectivista trágico y la corporalidad del instante en aras de una transvaloración de la existencia que recuperase para la conciencia encarnada del sujeto la experiencia de su vida como voluntad de poder afirmadora. Para ello, la filosofía se habría de situar en el abismo insondable de la personalidad, sacudida por una negrura esencial que haría inviable la expectativa de un sujeto definido clara y distintamente en beneficio de otro «limitado» abierto a la eternidad del cuidado. La filosofía de los próximos dos siglos debería ser capaz de tomar «sintéticamente» el problema del sentido y el sentido del problema para explicar el genuino acontecimiento de reapropiación del artista-filósofo de su obra en su obra. Un acontecimiento que para Nietzsche no puede ser más que jovial, la fuerza solar del «gran mediodía» de las nuevas «auroras».

${ }^{713}$ Nietzsche, F., Fragmentos póstumos IV, 11 [119], op. cit., pp. 400-401 (KSA XIII, 56-57). 
Sin embargo, tanto el siglo XX como la incipiente centuria están lejos de la ventura de dicha jovialidad. Por el contrario, la experiencia filosófica del vacío no ha sido capaz de consumar el nihilismo; quizá los caracteres activos hayan sido realzados máximamente, pero sin expectativa de superación, embargando con ello la oportunidad del «cuándo» desmitificado. Por el contrario, ha vuelto a asomar la enfermedad apuntada en la Segunda Intempestiva, el hastío y el agotamiento de la «decadencia» han colonizado nuevamente la atmósfera contemporánea, concretándose en tiempos de melancolía. Parece ser el nuevo síntoma epocal; una nostalgia por la adecuación con el formalismo eidético que hoy se resuelve mediante la «técnica», la cual cierra la apertura del hombre al horizonte perspectivista para ofrecer la posibilidad única de su posicionamiento «numérico». Aunque no nos parece apropiada la hermenéutica heideggeriana de Nietzsche y el nihilismo, no es menos cierto que en su estudio supo identificar los rasgos esenciales de tal afección espiritual. Concretamente en sus lecciones recogidas en el Nietzsche vio Heidegger con claridad el que sería el problema contemporáneo: «surge la pregunta de si la esencia más íntima del nihilismo y el poder de su dominio no consisten precisamente en que se considera [...] al nihilismo como un endiosamiento del mero vacío» ${ }^{714}$. El riesgo del nihilismo activo, así advirtió Nietzsche, estaba en que su cualidad eminentemente destructiva no fuese superada en beneficio de la creación afirmadora. Esto supondría un retorno a los márgenes de la reacción despreciadora que condenaba la existencia.

Siguiendo la observación de Heidegger del endiosamiento del vacío, la melancolía contemporánea puede explicarse desde aquí. La muerte de Dios continuó resultando una experiencia demasiado traumática para el siglo XX, igual para el XXI, cuyos agentes no han sido capaces de sostenerse en la apertura perspectiva del instante trágico dionisiaco. La «gramática» se rescató en nuevos avatares. Donde los hombres decimonónicos confiaron en el Estado como instancia de salvación, los «próximos dos siglos» correspondieron a la «técnica», nueva manifestación del esfuerzo intelectual por «participar» de las formas eidéticas del ser.

El hastío del nihilismo es la enfermedad de la que no puede curarse el hombre occidental. Motivo éste por el que Nietzsche no cierra significativamente el «superhombre» en un concepto último colmado de un contenido trascendente. La reapropiación de la existencia en la eternidad como superación del nihilismo es una constante que, valga el juego de palabras, no puede ser superada. La entrega al vacío es la consecuencia de la santificación de Zaratustra, mas nunca puede ser el vacío una «entidad» santificada: por la santificación -la redención - del mundo se llega al vacío conformador del suelo dionisiaco; por la santificación del vacío se santifica, en cuanto tal, el nihilismo, esto es, la destrucción masiva de toda ocasión. La santificación de Zaratustra significa la «dominación» del vacío,

${ }^{714}$ Heidegger, M., Nietzsche, op. cit., pág. 566. 
la apropiación de éste por la voluntad de poder como motor de reapropiación de las fuentes de valoración, logrando de tal modo Zaratustra reintegrar al artista en su obra. Sin embargo, la apropiación del vacío como nueva divinidad incuba la enfermedad de una conciencia que jamás alcanzará sentido -ni propio ni externo-, concluyendo en dos alternativas de vida, ambas decadentes: la fe ciega en la conformación de sentido en un «mundo verdadero», colmado del contenido que el vacío sensible impide aquí. La existencia en el reino sensible se ignora de acuerdo con las máximas de la voluntad de verdad que habrá de garantizar una significación postrera; o bien, la afirmación de la identidad desde la voluntad de vida: sólo queda continuar siendo, a cualquier precio. En esta última hipótesis, el proyecto del cuidado de la vida buena se desvanece en favor de la autoconservación nihilista.

Como decíamos, el hoy pertenece al nihilismo de la técnica. Su estrategia de adecuación, la renovación de la estrategia que intentó «fijar» el significado del hombre. El viejo «humanismo» que tan magistralmente combatió Heidegger al entender que encerraba la esencia del hombre en un concepto inmanente -«ser racional»- vuelve al horizonte contemporáneo gracias al polémico «posthumanismo», que ahonda en la esencial indigencia del hombre desde la apreciación melancólica de lo que podría ser mejor.

Una actitud radicalmente nihilista en la medida en que contempla la «mejora» desde los principios cuantitativos del progreso. La antigua metáfora mecanicista del «hombre-máquina» es devuelta al presente como instancia formal a la que adecuarse. Después de la dura experiencia finisecular tras la que explotaron todos los excesos injustificados e ilegítimos de la diosa razón moderna, que dispuso en los márgenes de la técnica la expectativa de salvación del sujeto epistémico, la no consumación del nihilismo activo ha recuperado la inhumanidad del celo positivista.

Al igual que el siglo XX estuvo marcado por la II Guerra Mundial, el último tercio del mismo y los siguientes lustros del XXI lo estuvieron -lo están- por la revolución tecnológica e informática. Una entrega irrestricta a la imagen, a la inmediatez, a la aceleración que se contrapone al ideal humanista clásico de formación. La longeva tradición formativa de las letras y las ciencias no puede soportar el acelerado frenesí del «bit», pues la educación no ha de darse entre las páginas de erudición intempestiva, sino «entre los impulsos domesticadores y los embrutecedores y sus medios respectivos» ${ }^{715}$.

Sloterdijk define con fijeza al hombre como un ser «domesticable». La domesticación sería el proceso de humanización: desarrollo del lenguaje, aparición de asentamientos sedentarios, etc. que dará paso a la civilización. Sin embargo, en el debate posthumanista, y en particular en el escándalo que despertase Sloterdijk, la tecnología transvalora la rela-

715 Sloterdijk, P., Normas para el parque humano, trad. de Teresa Rocha Barco, Madrid, Siruela, 2000, pág. 97. 
ción de la domesticación al artificializar el medio en el que se hallan los hombres, lo cual permite la superación de la abismal distancia entre el sujeto y el objeto mediante la tecnología. Lo que nutre la existencia no es ya el ser, que queda tachado como una evocación bucólica, sino la información, cifrada «cuantitativa y numéricamente». Si la aparición de la humanidad, como refinamiento o evolución de la hominización, se retrotrae a la domesticación, el hombre es un mero producto de distintas técnicas de doma. En el punto tecnológico en que nos encontramos, dice Sloterdijk, no podemos seguir apelando a la episteme humanista, sino a otra que contemple la dimensión abierta por la tecnología: una episteme posthumanista.

Con todo, Sloterdijk convierte la técnica en el «dónde» y el «cuándo» oportunos de la vida postmetafísica. No parece suponer un problema al autor que la superación de los caracteres humanos que ofrece la tecnología no venga de la voluntad de poder, sino de la fuerza de la propia técnica, depositaria de la salvación de la especie. La tecnología procura una salvación «milagrosa», esto es, ajena al propio sujeto, estando por ello más próxima a la cuestión teológica que a la existencial. Al igual que los predicadores de virtud dieron al mundo a los «hombres buenos», los teólogos de la tecnología, como Sloterdijk, proporcionan al «cyborg», quien podría ser tomado como el «hombre mejor» dentro de la mirada escatológica y cronológica del progreso tecno-informático.

La enfermedad histórica europea ha vuelto a impregnar las conciencias occidentales. Más de cien años después de Nietzsche estamos todavía lejos de la consumación del proyecto «estético» de reapropiación de la existencia. Ésta, por sus nódulos dionisiacos, no es grácil ni amena, como tampoco desagradable y tediosa. Sin embargo, necesita del duro compromiso ascético del cuidado por la vida buena. La afirmación del «yo» trágico en detrimento del autoconsciente cartesiano; la revelación de la verdad hermenéutica; la radicalidad del mundo en devenir, contraria a la esencialidad del ser exigen demasiado para un sujeto que, otra vez, como consecuencia de la melancolía de un tiempo que sigue sin resultarle plácido ha enajenado la responsabilidad de su existencia en la externalidad metafísica. Hoy la prescripción formal de la idea llega de la «contemplación» de una posible mejo$r a$ cuantitativa de los rasgos humanos mediante la tecnología.

En estas propuestas, erróneamente justificadas desde la filosofía de Nietzsche, no hay superación del nihilismo ni, en consecuencia, una reapropiación «estética» de la existencia. Los criterios de «bueno»y «malo», en este debate «mejor» y «peor», respectivamente, no provienen de la pulsión de vida de la voluntad de poder, sino desde el rigor externo de las posibilidades abiertas por la tecnología. La advertencia heideggeriana de una teodicea en la técnica parece haberse cumplido, toda vez que la redención de la vida que habría de significar su radicación jovial en un suelo trágico y abrirla a un horizonte perspectivista mediado por la indeterminación es ignorada en favor de la cómoda respuesta tec- 
nológica que no exige del hombre el compromiso responsable consigo mismo del cuidado. Sloterdijk ha extirpado el riesgo de la experiencia de vida al procurar la seguridad certera de una posición fija como es la reducción del hombre a «ser domesticable». El proyecto del cyborg no podrá soportar la fuerza del eterno retorno, ya que no se ha apropiado de la eternidad del instante. El superhombre, el artista-filósofo, como cualquier otro concepto de la filosofía de Nietzsche ha de decaer y perecer para servir de fértil ocasión de vida mejor; en el posthumanismo no hay perecimiento, sino obsolescencia, la cual es propia de las máquinas. La melancolía contemporánea enajenó una vez más la existencia en la seguridad inmutable de una definición última del hombre. Un tributo, al parecer pequeño, para una existencia todavía humana, demasiado humana como es la propia del posthumanismo, que ha dado la espalda a la voluntad de poder para volver a abrazar la nihilista voluntad de vida. 


\section{CONCLUSIONES}

Las cuestiones tratadas han sido numerosas, mas todas ellas articuladas dentro de la matriz estructural del nihilismo, desde las excelsas expectativas que la modernidad labró de sí misma hasta su dramático derrumbamiento en el siglo XIX, pasando por las tentativas de futuro de las centurias intermedias.

Nietzsche sostuvo que el nihilismo fue un difícil y oscuro acontecimiento gestado durante los diferentes momentos del curso de la tradición filosófica occidental, haciendo remitir su génesis a los tiempos del socratismo. Así, no se trataría de un factum sucedido al abrigo de una casualidad infeliz, sino la consecuencia de un determinado movimiento en el trazo del pensamiento europeo que habría de virar su orientación hacia una resolución calamitosa y desgarradora.

De acuerdo con la sospecha nietzscheana, la fatídica experiencia nihilista que desmoronó las conciencias de los hombres del siglo XIX fue el oneroso tributo que hubo de pagarse tras la consagración del mundo metafísico pergeñado en el paroxismo idealista de la filosofía griega: el conocimiento del vacío esencial tras las fuentes de sentido, el desmantelamiento de los otrora incólumes valores que habían conformado el universo moral durante más de dos mil años.

El elemento cognoscitivo del nihilismo es un rasgo crucial en el estudio que de este fenómeno llevará a cabo Nietzsche. El diagnóstico del nihilismo no es sino eso, la sesuda y erudita exposición de la problemática sintomatología de los tiempos. En la centuria decimonónica este mal endémico de la tradición europea se hizo manifiesto, aunque venía emponzoñando toda la filosofía desde sus más jóvenes compases.

La radiografía brindada por el autor presenta este calamitoso acontecimiento como la desvalorización de los valores supremos. Y si bien la realidad epocal lo confirma, las pesquisas nietzscheanas no quedan agotadas desde dicho momento. Sostiene Nietzsche que aquellos valores a los que la fuerza de la tradición invistió con un carácter sagrado siempre estuvieron huecos, desprovistos de toda significación trascendental. La enajenación de la razón fillosófica en los ídolos metafísicos, en sus variadas manifestaciones históricas -las Ideas platónicas, la cosa en sí, el noúmeno, etc., comprendidas bajo el rótulo categorial de «Dios»-, fue una constante a partir de la estrategia platónica de la duplicación de mundos que distinguía cualitativamente entre el «mundo verdadero», de condición eidética e inteligible, y el «mundo aparente», cuya sensibilidad quedaba sometida bajo el ciclo anárquico del devenir.

Ahora bien, continúa Nietzsche, la especificidad decimonónica pasaba por el rasgo cognoscitivo mencionado; no bastaba vivir entre totems y altares vacíos, sino en cobrar 
conciencia de tal condición yerma, la cual se alcanza únicamente entonces, tras el hastío de la longeva tradición de la filosofía idealista y el fin del dominio eidético sobre lo sensible. Esta coyuntura es la que encuentra Nietzsche y sobre la que vertebrará su respuesta ante el problema espiritual de Occidente.

El agotamiento de la filosofía del espíritu como sustrato de la conciencia permite a Nietzsche reivindicar aquello que había sido defenestrado en la metafísica de la duplicación y de la escisión, el cuerpo. Sobre este elemento parte y acaba toda la obra del pensador alemán. Sin embargo, su posicionamiento sobre la dupla alma-cuerpo no responde a los márgenes de una respuesta reactiva de inversión de los modos y cualidades: Nietzsche no acoge el cuerpo para, en su lugar, despreciar el espíritu.

La estrategia de Nietzsche no se ejecuta de acuerdo con los criterios de la episteme metafísica que trazaba un abismo insalvable y contradictorio entre lo anímico y lo somático. El filósofo alemán entiende que la enajenación de la existencia habida durante la tradición bimilenaria de Occidente ha estado, precisamente, en la radicalidad de una imagen de la vida escindida donde la psicosis por apropiarse de «lo verdadero» en detrimento de «lo aparente» llevaría a una esquizofrenia existencial que terminó por pauperizar máximamente el horizonte efectivo en el que se desarrollaba la vida.

$\mathrm{Su}$ apropiación del cuerpo, por tanto, es menos una frontera que un puente. La existencia es contemplada por Nietzsche en su totalidad, como un complejo fenómeno «sintético» donde el abismo de raigambre platónica del ser y el devenir es integrado armoniosamente como clave de existencia plena y reapropiada. Una síntesis que hemos hemos recogido en este trabajo bajo el rótulo de «corporalidad». La encarnación ha sido presentada como un proceso de cualidad distinta que la simple imagen fisiológica que del cuerpo como entidad orgánica arroja la lectura positivista del biologicismo. Este último retrato bosqueja la nihilista condición de la voluntad de verdad como voluntad de vida «a cualquier precio», eco de la doctrina metafísica de la adecuación: la certera adecuación del cuerpo a las condiciones que procuran la conservación orgánica.

Este procedimiento es absolutamente nihilista en tanto que el valor concedido a la vida no es sino la mera autoconservación, sin metas ni fines propios que le procuren significado «filosófico». De tal manera que Nietzsche logra pergeñar un concepto de «hombre» donde el espíritu y el cuerpo conformen una identidad «sintética» en el que los rasgos específicos de cada dimensión se diluyan en el otro. No basta, continúa Nietzsche, una hipotética connivencia de la materia en lo eidético y viceversa, ya que se mantendría la estructura bipartita de la metafísica de la escisión. La vida humana como la piensa Nietzsche no permite distinguir entre lo anímico y lo somático, ya que las lindes entre uno y otro se han desvanecido e impregnado todo el continente existencial. Por lo que el sujeto «sintético» de la filosofía nietzscheana no es el producto cuantitativo de dos sumandos, alma y cuerpo, 
independientes, sino la armónica fusión de un alma corporalizada y un cuerpo espiritualizado que arrojan una nueva concreción de la personalidad que ha trascendido los cánones metafísicos de la tradición de la escisión.

Esta antropología de la «corporalidad» es genuina de la filosofía de Nietzsche: la subjetividad estrictamente eidética remite a una voluntad de verdad que contempla la forma normativa del mundo suprasensible como criterio ulterior de sentido, tras cuya contemplación se busca indefectiblemente la participación en dichas instancias. De esta estrategia, dice Nietzsche, es consecuencia que el centro de gravedad de la vida se haya enajenado de la vida y gravite en torno a principios externos a sí misma. En cuanto a las posturas estrictamente materialistas de la modernidad, desde los movimientos dieciochescos hasta el socialismo del siglo siguiente, exudan las tesis mecanicistas, en cuyas máximas la realidad había sido definida a partir de la certeza de la «máquina» y del «reloj».

Ambas posiciones le resultan inadmisibles a Nietzsche al percibir que en ellas se mantiene la impronta de la metafísica de la escisión. Que ambos polos, antagónicos en su forma -la pauperización de la materia en beneficio de lo inteligible o el rechazo de lo espiritual en favor de lo sensible-, respondan al mismo principio lleva al Nietzsche genealogista a convenir en que están dispuestos en la misma episteme de precomprensión, a saber, una de raigambre epistemológica. Para que Nietzsche pueda procurar su peculiar imagen de la existencia como «corporalidad» necesita un modelo de verdad sustancialmente distinto del legado en la tradición filosófica occidental.

$\mathrm{Su}$ investigación sobre la conformación de la personalidad termina rescatando el efecto de las pulsiones inconscientes sobre ésta, en relación tensa con lo consciente. Así, el «sujeto» nietzscheano se alza desde un fondo insondable de indeterminación que impide la absoluta cognición de los avatares de la individualidad. La imposibilidad de un sujeto cartesiano, esto es, plenamente autoconsciente de los procesos mentales, implica un cambio fundamental del horizonte de la verdad, toda vez que el sustento metafísico de ésta ya no se ajusta a la efectividad de la existencia particular. De modo que la «corporalidad» implica la transvaloración de todos los valores, un radical posicionamiento que no se plantea como simple oposición del pasado, sino como nuevo origen radical de la existencia.

La verdad de la filosofía nietzscheana se nutre de la indeterminación esencial de un individuo inapresable incluso para sí, resuelto en la eterna conquista de sí. Afirmado sobre la precariedad de una conciencia oscura, el devenir se instala donde antes imperaba la fijeza inamovible del ser heleático. La metáfora dionisiaca recoge perfectamente este nuevo sustrato de vida, colonizada por la precariedad, la indigencia, el azar y la inocencia, que en este trabajo hemos concretado como «limitada». Mientras la verdad del ser se definía metafísicamente, la propuesta dionisiaca es «trágica», dando un nuevo rango a las cualidades de la vida. 
El pasado metafísico se movía en la agonía generada por una idílica vida anhelada a la que se contraponía la efectiva, sumida en la amargura y la zozobra que provocaba el cambio que afecta esencialmente a lo sensible. Una esquizofrenia que marcaría el modo en que la conciencia se relacionaba con la experiencia de la existencia. La metafísica impregnó de tintes peyorativos la vida encarnada toda vez que ésta no se adecuaba a la idea; el desprecio y el odio por el «mundo aparente» fue inmediatamente seguido por el deseo de venganza, que llevó al horizonte europeo a plantear filosofías sistemáticas teñidas escatológicamente donde al cierre de las mismas se alcanzaría el premio prometido de la «vida verdadera», una especie de recompensa en pago por el «valle de lágrimas» de una realidad deviniente.

Nietzsche, por el contrario, ejecuta también en este plano la transvaloración, en un movimiento por el cual redime la existencia del juicio desfavorable que la episteme metafísica había impreso. En el dominio de la verdad dionisiaca el devenir que rige la apariencia es exonerado de los atávicos males de la tradición bimilenaria y le es devuelta su primigenia «inocencia». No se trata de una inversión categorial de lo otrora «malo» en lo «bueno», sino de la liberación de la vida de una valoración moral precedente. Tampoco se trata de un empeño por trasladar el Reino de Dios a la tierra, ya que esta empresa prometeica, la del «progreso», incurre en las ínfulas escatológicas de la adecuación del «Bien» en el mundo humano.

La redención nietzschena no es sino la aceptación de la esencial nulidad de sentido que subyace en el fondo vital, que habrá de impulsar la gran empresa de la reapropiación. El tormento que la conciencia nihilista había supuesto, ejemplarizado terriblemente en la crisis finisecular, es transmutado en la jovial experiencia de la «inocencia» cuando el problemático vacío nihilista es dominado por la voluntad de poder mediante la maximización de los instintos más vigorosos y saludables.

El sujeto de la «corporalidad» se comprende como el contenido y el continente del sentido, al tiempo que sujeto a una lógica de decadencia que exige de él la constante dominación del significado toda vez que su vida ha quedado abierta al horizonte perspectivista de su «corporalidad» que habrá de ser determinado a lo largo del juego plástico de la voluntad de poder. La reapropiación se comprende de este modo como la empresa siempre inconclusa que pide del hombre encarnado la vocación «estética» de la construcción del sentido de su ser como una disposición posible para imbricar su conciencia en su experiencia de existencia.

Dada la dificultad y el riesgo de este proyecto, que sitúa al hombre ante el abismo de su máxima humanidad -vida mejor-y su máxima degeneración -vida humana, demasiado humana-, la reapropiación debe ser dominada desde la expectativa de «eternidad» que transformará cada «instante» de la existencia en ocasión oportuna para la superación 
de sí mismo, esto es, para procurarse las mejores condiciones de vida plena, encarnada, con un sentido que puede comprender íntima e intransferiblemente como propio y desde el cual afirmar su existencia, emancipada por fin de los estamentos supramundanos de la metafísica del ser. La reapropiación, que es la superación eterna de sí mismo, supone, al término, la consumación y trascendencia del nihilismo que durante los más de dos mil años del legado platónico había hecho del hombre algo extraño a sí mismo.

Su estudio del nihilismo llevó a Nietzsche a tomarlo como un problema genético de la historia de Occidente, el hito consecuente de la tradición metafísica de la duplicación de mundos. De modo que la historia de Europa equivalía a significar la historia del nihilismo. El nihilismo latía en todo el curso de la civilización occidental, aunque es en el momento decimonónico cuando más pronunciada resulta su presencia: la desvalorización fundamental. Ahora bien, en la medida en que la historia de Occidente es la propia del nihilismo, el propio individuo europeo es de suyo nihilista. En esta identificación de la personalidad con el nihilismo comienza la reflexión de Nietzsche del problema, lo que lo convierte en una cuestión netamente existencial.

El nihilismo es tanto la explicación al porqué de la enajenación de la existencia durante más de dos mil años como la posibilidad de la reapropiación: la pérdida de los valores capitales que habían brindado sentido y finalidad habrá de proporcionar la ocasión de la aventura existencial de «llegar a ser lo que se es». La superación del nihilismo, pues, nunca podría acontecer sino desde la propia vida cuya reapropiación busca el sujeto desde su particular condición de existencia. Con todo, no puede ser negada la peculiaridad sustantiva del nihilismo dentro de la génesis y la consolidación de la encarnación de la personalidad.

El nihilismo se revela de este modo ante Nietzsche como un fenómeno doble: es, en primer lugar, un acontecimiento existencial, pues está radicado en la esencialidad misma del hombre occidental; al mismo tiempo, y aquí descansa la ocasión oportuna de su superación, puede abrirse a un horizonte «estético»: en la apropiación del nihilismo cabe la transmutación del desasosiego anímico en fuerza de afirmación creadora de nuevas condiciones de existencia saludable, reapropiada, en un acontecimiento de cuidado artístico-filosófico al comprender que la falta de sentido esencial puede ser resuelta en virtud de la condición mentirosa del hombre. Por ello hemos señalado a lo largo de todo el trabajo que la posición nietzscheana frente a la cuestión de la existencia se salda «estéticamente».

La apropiación activa del nihilismo -lo que es redundante, pues toda apropiación del nihilismo es activa; lo contrario es la voluntad de verdad, la perpetuación de la vida fisiológica en una estrategia de mera autoconservación - sólo ha podido tener lugar a partir de la capacidad artística, en la que descansan las expectativas de creación de un sentido que cobije al sujeto artista concreto. El «artista» es el tipo humano que se ha apropiado del 
nihilismo y quien por su elementalidad creadora se opone al «filósofo» socrático que actúa con miras a la idealidad formal del intelectualismo eidético y que Nietzsche recoge abstractamente en el tipo del «hombre moral bueno».

El artista ha dado el primer gran paso en la tarea de la reapropiación de la existencia al posicionarse activamente ante su vida encarnada, que sólo a él impele, percibiendo sus rasgos difíciles, terribles e insondables y, pese a ello, acogerlos postulándose contra la voluntad de verdad que había pauperizado la existencia sensible. La afirmación de la vida en detrimento de la enajenación metafísica, que se consumará en plenitud en la «corporalidad», parte del primer reconocimiento de la esencial afección «estética» del hombre.

Al mismo tiempo, aceptar el trazo «estético» del hombre no es sino corroborar la gran afirmación nietzscheana sobre la esencia de la existencia, a saber, que la vida es voluntad de poder. La voluntad de poder es una fuerza plástica creadora de la valorización, o sea, de los valores, tanto de los reactivos como de los activos, y de la posterior interpretación y jerarquización de los mismos que da paso a la fabulación del mundo. De tal manera que el hombre es genuinamente creación; el paso del «artista» es novedoso en la medida en que su movimiento artístico emana de la vocación afirmadora de la vida.

Ahora bien, la voluntad de poder está radicada en la esencia del hombre del mismo modo que el nihilismo, lo que traza una unión íntima entre una y otro. Así, la afirmación del «artista» nace, como apuntábamos, del propio nihilismo, en concreto de una transmutación de los rasgos terribles de su experiencia. El «artista» se apropia de la posibilidad de la apertura del nihilismo a la perspectiva, hace de la transmutación de la desvalorización el «instante» de máxima oportunidad para el «santo decir sí», el amor fati, y se adueña eternamente de la ocasión de la creación de su sentido.

El «artista» es la contraposición del hombre «bueno» del legado del intelectualismo moral socrático, de tal manera que sus criterios de bondad y de maldad han sido planteados desde sustratos distintos. El primero crea desde la expectativa de la «superación», la cual se mueve siempre en el horizonte del cuidado que contempla la concreción no utópica de una perspectiva de existencia mejor: «yo amo - dice Zaratustra - a quien quiere crear por encima de sí mismo» ${ }^{716}$.

El nihilismo ha acabado con la episteme metafísica de la duplicación: la dialéctica del ascenso hacia la Idea una vez ésta ha sido contemplada, la doctrina «epistemológica» de la adecuación o la metafísica de la subjetividad son ecos de la eidética voluntad de verdad que en el tiempo de Nietzsche ya no aporta significado. Sin embargo, este acontecimiento sin parangón en la historia, la «muerte de Dios», no es suficiente en cuanto tal para la consumación de la empresa «estética» nietzscheana de la reapropiación, ya que el nihi-

${ }^{716}$ Nietzsche, F., Así habló Zaratustra, op. cit., pág. 108 (KSA IV, 83). 
lismo porta el riesgo de la pasividad y la reacción. El agotamiento de la voluntad de poder puede llevar, precisamente, a un hastío de la voluntad de poder por el cual no se abra al horizonte perspectivista de creación artística -la afirmación-, sino que se esfuerce por mantenerse dentro de los márgenes conceptuales de una episteme ahora vacía a la que, no obstante, se sigue venerando con la devoción teológica del pasado. De esta dimensión pasiva del nihilismo nos advierte Nietzsche cuando previene sobre los peligros de la «gramática». Por el contrario, del nihilismo debe libarse, extraerse la faceta activa que permite imbricar el «arte» en la salud y el vigor de una voluntad de poder afirmadora: la negación del «mundo verdadero» sólo puede significar no la afirmación alternativa del «mundo aparente», sino el fin de la duplicación misma. La reapropiación comienza con la apropiación del mundo de la existencia encarnada. La superación del nihilismo, por su parte, exige la superación de la voluntad de verdad valiéndose de la fuerza desbordante de la voluntad de poder del «artista». El fin de la voluntad de verdad, de cuño epistémico, supone el fin de los conceptos ulteriores; su sustitución por la voluntad de poder, la afirmación de la cualidad creadora de un sujeto erguido sobre el suelo nutricio de la verdad dionisiaca que ha fagocitado la idealidad de la epistemología para abrirse hacia la ocasión de la «superación de sí mismo» en aras de la consumación del proyecto existencial de «llegar a ser lo que se es». El «artista» es quien empuña el martillo.

La superación del nihilismo, por tanto, acontece desde la «estética». Ahora bien, a lo largo de nuestra tesis no ha sido la figura del «artista» aquella en la que hemos insistido, sino en la del «artista-filósofo». Ello se debe a que no creemos hallar condiciones suficientes en el «artista» para la consumación de la empresa de la reapropiación. El nihilismo en su especificidad decimonónica ha adquirido conciencia de sí; los individuos del siglo XIX asisten no únicamente a la crisis finisecular de la desvalorización, sino que además son capaces de pensarla, esto es, tomarla como objeto de reflexión: pensarla, reconstruirla históricamente, diseccionarla, en suma, conceptualizarla. Luego la figura del «filósofo» es también imprescindible. Éste logra imprimir el contenido del sentido encarnado en la obra artística.

El «filósofo», en su estudio del nihilismo en la historia, ha desvelado la reactividad inherente de dicho acontecimiento esencial. Una negación nacida del desprecio y del odio del «espíritu de venganza»; esto «no» nacido de la dimensión pasiva del nihilismo es absolutamente dañino, pues es un rechazo de cuanto aún no ha sido consumido por el fantasma de la desvalorización, o sea, de lo sensible y deviniente, el «mundo aparente». Mientras que el tipo «artista» se vale del diagnóstico filosófico para transmutar la negación nihilista: la negación que emana del reverso activo sigue siendo despectiva, sin embargo, respecto de aquello sobre lo que el nihilismo ha actuado, la pretensión eidética del «mundo verdadero». El nihilismo como una historia de enajenación de la conciencia de la existencia encarnada es transmutado, precisamente a causa del hastío que él mismo comportó, por 
el «artista» en una negación de la impronta alienante. El nihilismo, concluye Nietzsche, se supera desde el propio nihilismo a partir de la apropiación de los elementos activos que éste puede procurar.

La negación es, tanto en el nihilismo pasivo como en el activo, en último término, una valoración, la dominación de unos instintos de fuerza por la voluntad de poder. La diferencia cualitativa entre uno y otro está en el grado de salud tales fuerzas. Las fuerzas de la reacción carecen de la salud necesaria para trascender el nihilismo, para experimentar de nuevo como propia la vida encarnada. El «filósofo» saca a la luz los avatares del nihilismo, sus mecanismos, sus procesos, su acopio de fuerzas; el «artista» es quien niega las formas de la pasividad desde la actividad para arrojar una interpretación de vida que parta de la premisa de un mundo emancipado de instancias relativas a la voluntad de verdad.

Ahora bien, el nihilismo activo no es un estado de plenitud de salud. No es una situación eternamente deseable, ya que no resuelve el proyecto de la reapropiación. En este momento se ha rechazado la enajenación y pensado en la necesidad de imbricar la conciencia en la experiencia de existencia, mas las fuerzas del nihilismo activo siguen siendo, con todo, nihilistas. En el espectro nihilista no hay superación, pues carece de impronta creativa. El «artista» ha de transmutar la radicalidad del vacío significativo en un acontecimiento de creación en cuyo ejercicio se reencuentre consigo mismo: que la vida sea voluntad de poder, y tan sólo quepa de ella ser contemplada desde el cuidado, significa que los instintos que mueven la dominación de la voluntad de poder han de ser extraordinariamente fuertes y vigorosos para conformar un acto de creación cuyo valor más alto sea la propia vida.

La reapropiación «estética» de la existencia, consumada en la «corporalidad», es un acontecimiento eminentemente afirmativo. De afirmación del sentido encarnado en el que conciencia y cuerpo conforman la unidad «sintética» que vive y que se apropia eternamente de dicha vida mediante la constante dominación de perspectivas de existencia orientadas siempre desde el cuidado a la vida mejor. La inclusión de la conciencia en la experiencia de vida es un fenómeno extraordinariamente complejo de la filosofía nietzscheana, ya que no se trata de una primacía de la mente sobre el cuerpo -modus de la duplicación y de la escisión- ni de la inversión de roles donde el cuerpo domina la mente. La reapropiación «estética» de la existencia ocurre tras la transvaloración, un nuevo horizonte de apropiación donde al escisión del alma y el cuerpo ya no se contempla, de tal forma que ambas dimensiones se han integrado significativamente.

La vida se convierte en un acontecimiento de constante creación de experiencia y sentido y, al mismo tiempo, en objeto de reflexión de sus propias condiciones de eterna superación. Así, la actividad «estética» en Nietzsche se revela como una doble actividad artística y filosófica. El sujeto de la encarnación es «artista», pues crea el sentido desde la fundamental desvaloración, y es «filósofo», al procurar una reflexión sobre las ocasiones 
de superación que arrojan las distintas perspectivas. Es, ulteriormente, el «artista-filósofo» que crea el sentido de su existencia desde la responsabilidad de un proyecto de cuidado que siempre apunta a la adquisición de sus mejores potencialidades. Y en virtud del inconsciente fondo de su personalidad, ni puede ni pretende arrojar una imagen última de lo que habría de ser esta mejor expectativa. El artista-filósofo consuma la superación del nihilismo desde el propio nihilismo, por lo que alberga dentro de sí los aspectos conceptuales, filosóficos y existenciales del mismo. Es una existencia «limitada» en tanto que no puede continuar en el trazo de la voluntad de verdad. Y en esa indigencia yace la infinidad de ocasiones que la encarnación ofrece al individuo concreto que al carecer de un sentido último es por eso mismo arrojado en una situación de primigenia «inocencia» que ha santificado eternamente su condición creadora: la comunión entre la voluntad de poder y la vida en el artista-filósofo, en el superhombre, es atravesada por su conciencia de «limitación», a su vez, ocasión oportuna del cuidado en aras de una existencia deviniente libre de los atavismos metafísicos del ser que habían escindido la conciencia de la experiencia radical.

El «artista-filósofo» ha comprendido que el hombre nihilista carecía de sus propias metas, pues dependían de los estamentos supramundanos de la metafísica. Tras la pérdida de la fundamentación ulterior, tras la pérdida del sentido del mundo, este tipo humano postnihilista ha sido capaz de crear sus respectivos fines gracias al despliegue de su voluntad de poder afirmadora. La empresa de la reapropiación de la existencia convierte el mundo en el escenario de la ocasión del juego plástico de la voluntad de poder, en el cual los límites perfomativos, su «dónde» y su «cuándo» no son los del «mundo verdadero», sino que responden a la «corporalidad» y al eterno retorno, respectivamente, a su vez situaciones elementales de la ontología mentirosa de la divinidad dionisiaca.

En la aceptación del suelo dionisiaco sobre el que se eleva la existencia consiste la «santificación» de Zaratustra; el reconocimiento del azaroso caos sustantivo del mundo, sin orden ni medida, exige el compromiso absoluto por parte del sujeto con el proyecto de su encarnación. La «inocencia» del suelo nutricio de la vida devuelve al individuo su intransferible experiencia al tornarlo responsable de su discurso en el mundo. La reapropiación «estética» hace de la vida su inmanente fuerza motriz una vez la nihilista voluntad de vida es absorbida por la voluntad de poder en términos afirmativos: «imprimir al devenir el carácter del ser — ésta es la suprema voluntad de poder» ${ }^{717}$.

En realidad, sigue Nietzsche, dado que la vida es voluntad de poder tan sólo podría hablarse de esta voluntad. Las voluntades de verdad y de vida son creaciones ad hoc del resentimiento y del deseo de venganza. La reapropiación al superar el nihilismo subsume toda esta pluralidad bajo el principio de la voluntad de poder, permitiendo explotar máximamente la ocasión de la desvaloración y transmutarla así en fuerza afirmativa. En esta

${ }^{717}$ Nietzsche, F., Fragmentos póstumos IV, 7 [54], op. cit., pág. 221 (KSA XII, 312). 
transmutación se imprime al devenir el carácter del ser; la consagración del devenir no es gratuita, sino que comporta el esencial cambio de la matriz del mundo de la epistémica de la metafísica en la trágica dionisiaca. Y así puede Nietzsche decir que la empresa de la reapropiación implica «la época trágica para Europa: condicionada por la lucha con el nihilismo» ${ }^{718}$. La tragedia dionisiaca revela su verdad en la escena artística del ditirambo, conviniendo de este modo el ser del mundo con uno artístico. La relación entre el «arte» y la «vida» es entonces estructural: la vida es la constante creación de mentiras, ficciones, ilusiones, metáforas, interpretaciones desde la pulsión de los instintos más fuertes de la voluntad de poder. En el «santo decir sí» de Zaratustra el sabio persa está profiriendo la transvaloración de la episteme del mundo redimiéndolo de la culpa, del odio y de la venganza para procurarle la ventura jovial de las nuevas «auroras»: «Yo estaba asustado entre los hombres: algo me requería entre los hombres, y nada me calmaba. Entonces huí a la soledad y creé al superhombre. Y cuando lo hube creado, lo revestí con el gran velo del devenir e hice brillar el mediodía en torno él» ${ }^{719}$.

El «artista-filósofo» no es «artista» $y$ «filósofo». Su identidad no la cifra la conjunción copulativa, sino el guión. De lo contrario, la identidad del superhombre sería la suma de dos realidades distintas que se superponen en un producto esquizofrénico donde dos personalidades pugnan entre sí por afirmarse; el superhombre es un producto «sintético» en el que el «artista» es «filósofo» y el «filósofo», «artista». Esta solidaridad armónica es la que permite imprimir valor en el obrar, haciéndose, en tanto que se concibe -se interpreta- a sí mismo resultado artístico de su creación: el superhombre es la obra de arte de la creación del artista-filósofo, pues es tanto la materia prima como el contenido significativo que guía la apropiación de las formas en el mármol o en el lienzo de la existencia. De la voluntad de poder del artista-filósofo mana «esa fuerza que un genio emplea no en su obra sino en sí mismo en cuanto obra» ${ }^{720}$. Con todo, el «artista-filósofo» es tanto agente como objeto de su voluntad de poder mientras vive encarnado, consumándose así la superación «estética» del nihilismo llegando a «ser lo que se es»: «corporalidad».

El devastador vacío que había dejado la crisis finisecular decimonónica es resuelto existencialmente en el proyecto nietzscheano de la reapropiación. La herida de la pérdida del valor es sanada precisamente desde la encarnación de la valorización, ya que el sentido le es devuelto al hombre en cuanto éste se toma como la obra de arte más bella y refinada de todo su complejo obrar: el sentido de la existencia es la «corporalidad», la cual a su vez es existencia. En este juego se supera otro de los mantras del nihilismo de mayor eco a lo largo de la longeva historia de la metafísica: el dilema del Eutifrón. En este Diálogo con-

718 Ibid. 7 [31], pág. 217 (KSA XII, 306).

${ }^{719}$ Nietzsche, F., Fragmentos póstumos III, 5 [1], op. cit., pág. 155 (KSA X, 210).

${ }^{720}$ Nietzsche, F., Aurora, op. cit., pág. 686 (KSA III, 319). 
versan Sócrates y Eutifrón a propósito del presunto carácter sagrado de las leyes: «¿acaso lo pío es querido por los dioses porque es pío, o es pío porque es querido por los dioses?» ${ }^{721}$. El legado de esta cuestión superó las fronteras griegas y se filtraría en la modernidad por medio de la obra de Agustín de Hipona. Éste reformula el tropo desde la belleza: ¿amamos las cosas porque son bellas o son bellas porque son amadas?

Ambas presentaciones recogen el problema de la enajenación, ya que lo amado es remitido a estamentos externos a lo propiamente amado, de los que se «participa» o respecto de los cuales se «adecua». La distancia planteada por este dilema, otro meandro más del abismo metafísico sujeto-objeto, es superada por Nietzsche, en cuya obra hay una integración -no nihilista- plena del sujeto en su obra: «corporalidad». El artista-filósofo zanja la diatriba al comprender que la existencia es amada por su belleza y que es bella en tanto que amada, ya que él es la obra de su vida y como tal actúa movido por el amor por la encarnación de su más bella existencia, la máximamente colmada de sentido. El vetusto dilema del Eutifrón se resuelve, al cierre, con la reapropiación de la conciencia de la experiencia de existencia como una exigencia del gran estilo.

Efectivamente la cuestión del -buen- gusto determina la superación del dilema platónico, toda vez que el estilo es una cuestión existencial. Se ama lo estiloso ya que en él se hallan los elementos más bellos y refinados del sujeto encarnado, los cuales a su vez vivifican la fuerza de los instintos en aras de la superación que emana del amor. Luego se ama lo estiloso y el amar es estiloso. En la medida en que el «cristianismo» ama lo pobre y humilde, lo enfermo y decadente, Dios «era un pecado contra el buen gusto» ${ }^{722}$. El buen gusto es uno de los criterios de la superación de la historia del nihilismo-«cristiano» de la tradición occidental. Así lo ha sabido entender Paul Valadier, observando que la filosofía anticristiana de Nietzsche obedece a una cuestión de estilo, de buen gusto, que en el corpus nietzscheano, por su vinculación con la existencia, es un criterio «estético»:

Esta subversión del cristianismo por el gusto puede informarnos de la modalidad del ataque nietzscheano (no de la polémica) contra el cristianismo. Se combate el mal gusto, no se le discute; se manifiesta la indecencia de las posiciones, no se explica por qué tal objeto es feo. O para utilizar otra imagen nietzscheana [...]: sólo la salud «refuta» a la enfermedad; pero un ojo ve o no ve. Dicho todavía de otro modo: al margen del mal gusto, y en oposición a él, se pueden trazar los rasgos de un rostro lleno de belleza: como Zaratustra, como tal vez Dióniso ${ }^{723}$.

${ }^{721}$ Platón, Eutifrón, 10a, en Diálogos I, op. cit., pág. 231.

722 Nietzsche, F., Así habló Zaratustra, op. cit., pág. 357 (KSA IV, 324).

${ }^{723}$ Valadier, P., Nietzsche y la crítica del cristianismo, trad. de Eloy Rodríguez Navarro, Madrid, Ediciones Cristiandad, 1982, pág. 477. 
En las distintas estrategias de superación del nihilismo se comprende cómo la «estética» en Nietzsche remite a la preocupación fundamental de todo su corpus filosófico, la existencia ${ }^{724}$, ya que la creación artístico-filosófica del superhombre es, en último término, la de su vida encarnada como contenido de sentido y continente del significado, y viceversa. El hombre llega a «ser lo que se es», la maximización de sus fuerzas vigorosas y el desborde pleno de la salud de su mejor vida sostenida por la ocasión oportuna de la eternidad, mediante la apropiación artístico-filosófica de su condición «estética» por la voluntad de poder. Al respecto del trasfondo existencial del «arte» y del gran estilo así como su labor en la empresa de la transvaloración ha destacado Sixto Castro que «la idea de la belleza como constitutivo vital del arte es clave» ${ }^{725}$ en la filosofía de Nietzsche. Continúa advirtiendo que precisamente en virtud de la cualidad existencial de la belleza del «arte» es lo más próximo al hombre, resultándole por tanto de máximo interés:

¿Dónde ha quedado la belleza, que siembra todos los escritos de Nietzsche? A poco que leamos, o cuanto más leamos, más nos encontramos en todas las obras con la apelación a la belleza como algo que eleva y transmuta la existencia, el

${ }^{724}$ En las lecciones comprendidas en el Nietzsche, Heidegger ha sabido ver mejor que nadie cómo en la «estética» Nietzsche apenas habla de la obra de arte como objeto de contemplación del gusto para hacerlo, en cambio, de la existencia al vincularla esencialmente con la voluntad de poder: «La segunda proposición reza: El arte tiene que comprenderse desde el artista. Se ha mostrado que Nietzsche concibe el arte desde el comportamiento creador del artista, pero no se ha mostrado por qué esto es necesario. La fundamentación de la exigencia enunciada en la proposición es tan extraña que no parece ser una fundamentación seria. El arte es puesto de antemano como una forma de la voluntad de poder. Pero la voluntad de poder es, en cuanto autoafirmación, un constante crear; de acuerdo con ello, se interroga al arte para saber qué es en él lo creativo, la abundancia o la carencia. Ahora bien, dentro del arte la creación es efectivamente real en la actividad productora del artista. Por lo tanto, llevando la cuestión a la actividad del artista se garantiza de la mejor manera posible el acceso a la creación en general y con ella a la voluntad de poder. La proposición es una consecuencia de la tesis principal que considera al arte como una forma de la voluntad de poder.

La enunciación y fundamentación de esta proposición no quieren decir: Nietzsche tiene ante sí la estética anterior y se da cuenta de que no es suficiente; por otro lado, percibe que ella parte, aunque no exclusivamente, del receptor. Teniendo en cuanta este hecho, se le ocurre intentar otro camino, que parte del creador. En realidad, la experiencia fundamental del arte, la experiencia primera y conductora, es la de que éste tiene una significación como fundador de historia, y de que en ello consiste su esencia. Por lo tanto hay que tomar en consideración al creador, al artista» (Heidegger, M., Nietzsche, op. cit., pp. 136-137).

Escasas líneas más adelante, zanja la polémica entre el arte, la verdad y el nihilismo retrotrayendo la pregunta por la cuestión del arte a los estadios radicales de la filosofía: «[...] la quinta proposición debe considerarse también como el presupuesto para comprender la cuarta, según la cual el arte es el contramovimiento frente al nihilismo; en efecto, el nihilismo, es decir el platonismo, pone como lo que es verdaderamente a lo suprasensible, desde lo cual todos los demás entes se rebajan a lo que propiamente no es, se los difama y se los declara nulos. Así pues, todo depende de la aclaración y fundamentación de la quinta proposición: el arte tiene más valor que la verdad. ¿Qué es la verdad? ¿En qué consiste su esencia?

Esta pregunta está ya siempre incluida en la pregunta conductora y en la pregunta fundamental de la filosofía, se les adelanta y forma parte de ellas del modo más íntimo. Es la pregunta previa de la filosofía.

[...] El hecho de que la pregunta por el arte nos conduzca inmediatamente a la pregunta previa a todas las preguntas indica ya que encierra en sí, en un sentido privilegiado, relaciones esenciales con la pregunta fundamental y con la pregunta conductora de la filosofía. Inversamente, la elucidación que se ha hecho hasta ahora de la esencia del arte sólo alcanzará su recta conclusión desde la cuestión de la verdad.

Para avistar desde un comienzo esta conexión entre arte y verdad, la pregunta por la esencia de la verdad y por el modo en que Nietzsche se la plantea y la responde será preparada por un examen de aquello que, dentro de la esencia del arte, suscita la pregunta por la verdad» (ibid. pág. 138).

${ }^{725}$ Castro, S., «El señorío de la interpretación», en Estudios Nietzsche 12: actualidad e inactualidad de Nietzsche, Madrid, Trotta, 2012, pág. 36. 
anhelo de «todo lo bello dos o tres veces» [...]. Nietzsche se opone radicalmente a la tesis kantiana y schopenhaueriana del desinterés [...], Nietzsche sostiene que «el arte debe, ante todo, embellecer la vida, por consiguiente, hacernos agradables los unos a los otros, en lo posible». Y debe también ocultar o transformar lo feo, lo doloroso, lo terrible, las cosas desagradables que, a pesar de todos los esfuerzos, y en razón del origen de la naturaleza humana, surgen una y otra vez. Esta es la inmensa tarea del arte, de modo que lo que habitualmente se llama «arte» —el arte de la obra de arte-, es meramente un apéndice. La «obra», tanto la del artista como la del filósofo, es la inventora de quien la ha creado [...]. Un hombre que siente en sí un exceso de tales poderes embellecedores, ocultadores y reinterpretadores acaba buscando descargar este exceso también en obras de arte, y en ocasiones lo hará todo un pueblo. El problema, para Nietzsche, es que en su época se empieza el arte por el fin y se cree que el arte de la obra de arte es el arte verdadero que ha de transformar la vida. Y eso no funciona.

El arte, pues, más allá de su encarnación particular en la obra, tiene la finalidad de hacernos soportable la existencia, embellecer, ocultar e interpretar. ¿Puede haber, pues, más interés en el mismo? La «parálisis de la voluntad» que operan tanto la objetividad, el cientificismo, como «el arte por el arte» —entendido como entregarse a la forma, el formalismo, el «arte estético»— supone olvidar que, al igual que el conocimiento o lo que fuere está al servicio de la vida, el arte que se ensimisma en lo estético, entendido esto como todo el complejo intelectual e institucional generado en el siglo XVIII, acaba ahogando su propia razón de $\operatorname{ser}^{726}$.

El proyecto nietzscheano de reapropiación de la existencia es la superación del nihilismo en la medida en que ofrece la solución de las dos alternativas filosófico-existenciales que se le presentaban al europeo del tiempo de la muerte de Dios, ya en el ocaso de la modernidad, a saber, ora la creencia en la «gramática» de la divinidad que ha perecido ora la vida errática del náufrago occidental sumido en el anárquico e irresponsable discurrir de una vida sin sentido e incapaz de procurarse metas y fines para su acción. El tipo sintético del «artista-filósofo» ha sabido apreciar la capacidad hermenéutica del sujeto trágico y por medio de sus elementales condiciones creativas y reflexivas hacer de la existencia la fuerza motriz de sí como alternativa resolutiva del problema del siglo XIX. El superhombre ha santificado la existencia y el mundo suprimiendo la necesidad metafísica de la correlación íntima con «lo verdadero»; la redención de la idealidad ha hecho de la justificación una tarea netamente «estética» cuyas expectativas descansan en la perpetuidad del proyecto del cuidado de la vida buena.

El proyecto nietzscheano de la reapropiación de la existencia parte de la radicalidad trágica de una existencia dionisiaca inserta en un inocente devenir que mediante el ascetismo de la disciplina del cuidado ha conquistado su libertad tras la emancipación de los ídolos metafísicos de la duplicación y de la escisión y abierto consecuentemente al hombre en el horizonte perspectivista de la eterna ocasión oportuna de concreción no utópica de la vida mejor como máxima dominación de los instintos vigorosos de la voluntad de poder. Una vida recuperada donde el centro de ésta vuelve a ser ella misma y cuyos límites perfo-

${ }^{726}$ Ibid. pp. 36-37. 
mativos son el «dónde» de la «corporalidad» y el «cuándo» del eterno retorno: «ésta es $m i$ mañana, mi día comienza: ‘asciende, pues, asciende tú, gran mediodía!» ${ }^{727}$. Es una cuestión de «bondad» la empresa de la reapropiación; un movimiento de amor contra la maldad y el odio de los «buenos» y los «justos» del legado del intelectualismo moral. Nietzsche ha transvalorado los conceptos capitales de la tradición. En su boca el bien y el mal significan estímulo y castración, respectivamente; la benevolencia de la acción no descansa ya en el aplacamiento de los instintos vigorosos de la voluntad de poder como ejercicio de compasiva piedad, pues «el 'sujeto' es ciertamente sólo una ficción; no existe en absoluto el ego del que se habla cuando se critica el egoísmo» ${ }^{728}$. La bondad de la acción está en la dureza vivificadora que enaltece los más bellos caracteres de los instintos de la voluntad de poder consumando en este movimiento la espiritualización del cuerpo y la corporalización del espíritu:

Cuando el poder se vuelve clemente y desciende hasta lo visible: belleza llamo yo a tal descender.

Y de nadie quiero yo belleza tanto como precisamente de ti, violento: sea tu bondad tu última superación de ti mismo

De todo mal te creo capaz: por ello quiero yo de ti el bien.

¡En verdad, a menudo me he reído de los debiluchos que se creen buenos porque tienen zarpas tullidas!

A la virtud de la columna debes aspirar: más bella y más delicada se va tornando, pero en lo interior más dura y robusta, cuanto más asciende.

Sí, sublime, alguna vez también tú debes ser bello y presentar el espejo a tu propia belleza.

Entonces tu alma se estremecerá de ardientes deseos divinos; ¡y habrá adoración incluso en tu vanidad!

Éste es, en efecto, el misterio del alma: sólo cuando el héroe la ha abandonado acércase a ella, en sueños, - el super-héroe ${ }^{729}$.

\footnotetext{
${ }^{727}$ Nietzsche, F., Así habló Zaratustra, op. cit., pág. 441 (KSA IV, 408).

${ }^{728}$ Nietzsche, F., Fragmentos póstumos IV, 9 [108], op. cit., pág. 268 (KSA XII, 398).

${ }^{729}$ Nietzsche, F., Así habló Zaratustra, op. cit., pág. 181 (KSA IV, 152).
} 


\section{BIBLIOGRAFÍA}

\section{Fuentes principales}

- Sämtliche Werke. Kritische Studienausgabe in 15 Bänden. KSA, herausgegeben von Giorgio Colli und Mazzino Montinari, München, Walter de Gruyter, 1988:

- Band 1: Die Geburt der Tragödie

Unzeitgemäße Betrachtungen I-IV

Nachgelassene Schriften 1870-1873

- Band 2: Menschliches, Allzumenschliches I und II

- Band 3: Morgenröte

Idyllen aus Messina

Die fröhliche Wissenschaft

- Band 4: Also sprach Zarathustra

- Band 5: Jenseits von Gut und Böse

Zur Genealogie der Moral

- Band 6: Der Fall Wagner

Götzen-Dämmerung

Der Antichrist $\bullet$ Ecce homo $\bullet$ Dionysos-Dithyramben $\bullet$ Nietzsche contra Wagner

- Band 7: Nachgelassene Fragmente 1869-1874

- Band 8: Nachgelassene Fragmente 1875-1879

- Band 9: Nachgelassene Fragmente 1880-1882

- Band 10: Nachgelassene Fragmente 1882-1884

- Band 11: Nachgelassene Fragmente 1884-1885

- Band 12: Nachgelassene Fragmente 1885-1887

- Band 13: Nachgelassene Fragmente 1887-1889

- Band 14: Nachgelassene Fragmente Einführung in die KSA Kommentar zu den Bänden 1-13

- Band 15: Chronik zu Nietzsches Leben • Gesamtregister

- Sämtliche Briefe. Kritische Studienausgabe in 8 Bänden. KSB, herausgegeben von Giorgio Colli und Mazzino Montinari unter Mitarbeit von Helga Anania-He6, München, Walter de Gruyter, 1986:

- Band 1: Juni 1850 - September 1864

- Band 2: September 1864 - April 1869

- Band 3: April 1869 - Mai 1872

- Band 4: Mai 1872 - Dezember 1874

- Band 5: Januar 1875 - Dezember 1879

- Band 6: Januar 1880 - Dezember 1884

- Band 7: Januar 1885 - Dezember 1886

- Band 8: Januar 1887 - Januar 1889 


\section{Fuentes principales en castellano utilizadas}

Nietzsche, F., El culto griego a los dioses, trad. de Diego Sánchez Meca, Madrid, Aldebarán Ediciones, 1999.

- Fragmentos póstumos sobre política, trad. de José Emilio Esteban Enguita, Madrid, Trotta, 2004.

— El Anticristo, trad. de Andrés Sánchez Pascual, Madrid, Alianza

Editorial, 2007.

- Sobre verdad y mentira en sentido extramoral, trad. de Luis M.

Valdés y Teresa Orduña, Madrid, Tecnos, 2007.

—Ecce homo, trad. de Andrés Sánchez Pascual, Madrid, Alianza

Editorial, 2008.

- Fragmentos póstumos IV, ed. de Diego Sánchez Meca, trad. de Juan Luis Vermal y Joan B. Llinares, Madrid, Tecnos, 2008.

- Así habló Zaratustra, trad. de Andrés Sánchez Pascual, Madrid, Alianza Editorial, 2009.

- El nacimiento de la tragedia, trad. de Andrés Sánchez Pascual, Madrid, Alianza Editorial, 2009.

- Más allá del bien y del mal, trad. de Andrés Sánchez Pascual, Madrid, Alianza Editorial, 2009.

- Crepúsculo de los ídolos, trad. de Andrés Sánchez Pascual, Madrid, Alianza Editorial, 2010.

- Fragmentos póstumos I, ed. de Diego Sánchez Meca, trad. de Luis Enrique de Santiago Guervós, Madrid, Tecnos, 2010.

- Fragmentos póstumos II, ed. de Diego Sánchez Meca, trad. de Manuel Barrios y Jaime Aspiunza, Madrid, Tecnos, 2010.

- Fragmentos póstumos III, ed. de Diego Sánchez Meca, trad. de Diego Sánchez Meca y Jesús Conill, Madrid, Tecnos, 2010.

- Consideraciones intempestivas I David Strauss, el confesor y el escritor, trad. de Joan B. Llinares, en Obras completas. Volumen I. Escritos de juventud I, ed. de Diego Sánchez Meca, Madrid, Tecnos, 2011. 
- Consideraciones intempestivas II De la utilidad y los inconvenientes de la historia para la vida, trad. de Joan B. Llinares, en Obras completas. Volumen I. Escritos de juventud I, ed. de Diego Sánchez Meca, Madrid, Tecnos, 2011.

- Correspondencia IV. Enero 1880 - Diciembre 1884, ed. de Luis Enrique de Santiago Guervós, trad. introd. notas y apéndices de Marco Parmeggiani, Madrid, Tortta, 2010.

- Correspondencia V. Enero 1885 - Octubre 1887, ed. de Luis Enrique de Santiago Guervós, trad. introd. notas y apéndices de Juan Luis Vermal, Madrid, Trotta, 2011.

- La genealogía de la moral, trad. de Andrés Sánchez Pascual, Madrid, Alianza Editorial, 2011.

- Poesía completa, ed. y trad. de Laureano Pérez Latorre, Madrid, Trotta, 2011.

- Humano, demasiado humano I, trad. de Alfredo Brotons Muñoz, Madrid, Akal, 2013.

- La gaya ciencia, trad. de Juan Luis Vermal, en Obras completas. Volumen III. Obras de madurez I, ed. de Diego Sánchez Meca, Madrid, Tecnos, 2014. 


\section{Fuentes secundarias}

Aristóteles, Sobre la interpretación, en Tratados de lógica II, introd. trad. y notas de Miguel Candel Sanmartin, Madrid, Gredos, 1988.

Barthes, R., Lo obvio y lo obtuso. Imágenes, gestos, voces, trad. de C. Fernández Medrano, Barcelona, Paidós, 1986.

Bauman, Z., Vida líquida, trad. de Albino Santos Mosquera, Barcelona, Austral, 2014.

- Modernidad líquida, trad. de Mirta Rosenberg y Jaime Arrambide Squirru, Madrid, Fondo de Cultura Económica de España, 2017.

Blumenberg, H., Trabajo sobre el mito, trad. de Pedro Madrigal, Barcelona, Paidós, 2003.

- La legitimación de la edad moderna, trad. de Pedro Madrigal, Valencia, Pre-Textos, 2008.

Castro, S., «El señorío de la interpretación», en Estudios Nietzsche 12: actualidad e inactualidad de Nietzsche, Madrid, Trotta, 2012.

Cervantes Saavedra, M. de, El ingenioso hidalgo Don Quijote de la Mancha. Primera parte, Madrid, Espasa Calpe, 1997.

Chillón Lorenzo, J. M, El pensar y la distancia, Salamanca, Sígueme, 2016.

Colli, G., Nietzsche, trad. de Romeo Medina, Valencia, Pre-Textos, 2000.

Conill, J., El enigma del animal fantástico, Madrid, Tecnos, 1991.

— El poder de la mentira, Madrid, Tecnos, 2007.

Deleuze, G., La filosofia de Nietzsche, trad. de Carmen Artal, Barcelona, Anagrama, 2013.

Descartes, R., Discurso del método, trad. de Eduardo Bello Reguera, Madrid, Tecnos, 2006.

Epicuro, Obras completas, ed. y. trad. de José Vara, Madrid, Cátedra, 2012.

Fink, E., La filosofía de Nietzsche, trad. de Andrés Sánchez Pascual, Madrid, Alianza Editorial, 1969. 
Foucault, M., Las palabras y las cosas, trad. Elsa Cecilia Frost, Madrid, Siglo XXI de España, 2006.

— Nietzsche, la genealogía, la historia, trad. de José Vázquez Pérez, Valencia, Pre-Textos, 2008.

Gentili, C., Nietzsche, trad. de Beatriz Rabadán, y José Luis Serrano, Madrid, Biblioteca Nueva, 2004.

Habermas, J., El discurso filosófico de la modernidad, trad. de Manuel Jiménez Redondo, Madrid, Katz Editores, 2013.

Heidegger, M., Hacia la pregunta por el ser, trad. de José Luis Molinuevo, en Acerca del nihilismo, Barcelona, Paidós, 1994.

— «La doctrina platónica de la verdad», trad. de Helena Cortés y Arturo Leyte, en Hitos, versión de Helena Cortés y Arturo Leyte, Madrid, Alianza Editorial, 2007.

- Carta sobre el humanismo, trad. de Helena Cortés y Arturo Leyte, Madrid, Alianza Editorial, 2009.

— «El concepto de experiencia de Hegel», trad. de Helena Cortés y Arturo Leyte, en Caminos de bosque, versión de Helena Cortés y Arturo Leyte, Madrid, Alianza Editorial, 2012.

— «El origen de la obra de arte», trad. de Helena Cortés y Arturo Leyte, en Caminos de bosque, versión de Helena Cortés y Arturo Leyte, Madrid, Alianza Editorial, 2012.

— «La frase de Nietzsche 'Dios ha muerto'», trad. de Helena Cortés y Arturo Leyte, en Caminos de bosque, versión de Helena Cortés y Arturo Leyte, Madrid, Alianza Editorial, 2012.

— «La época de la imagen del mundo», trad. de Helena Cortés y Arturo Leyte, en Caminos de bosque, versión de Helena Cortés y Arturo Leyte, Madrid, Alianza Editorial, 2012.

— Nietzsche, trad. de Juan Luis Vermal, Barcelona, Ariel, 2013.

— Seminarios de Zollikon, trad. de Ángel Xolocotzi Yáñez, México

D. F., Herder, 2013.

Hegel, G. W. F., Fenomenología del espíritu, trad. de Manuel Jiménez Redondo, Valencia, Pre-Textos, 2015. 
Hobbes, T., Leviatán, trad. de Carlos Mellizo, Madrid, Alianza Editorial, 2009.

Homero, Illíada, introd. trad. y notas de Emilio Crespo Güemes, Madrid, Gredos, 1996.

Horkheimer, M., Historia, metafísica y escepticismo, trad. de María del Rosario Zurro, Madrid, Alianza Editorial, 1982.

— Crítica de la razón instrumental, trad. de Jacobo Muñoz, Madrid,

Trotta, 2010.

Horkheimer, M. y Adorno, T., Dialéctica de la Ilustración, trad. de Juan José Sánchez, Madrid, Trotta, 2009.

Hume, D., Tratado de la naturaleza humana, trad. de Félix Duque, Madrid, Tecnos, 2008.

Jünger, E., Sobre la línea, trad. de José Luis Molinuevo, en Acerca del nihilismo, Barcelona, Paidós, 1994.

Kant, I., Prolegómenos a toda metafísica futura que haya de poder presentarse como ciencia, trad., comentarios y notas de Mario Caimi, Madrid, Istmo, 1999.

- Crítica de la razón pura, prólogo, trad., notas e índices de Pedro Ribas, Madrid, Alfaguara, 2000.

- Crítica de la razón práctica, trad. de Roberto R. Aramayo, Madrid, Alianza Editorial, 2009.

- Sobre la paz perpetua, trad. de Joaquín Abellán, Madrid, Alianza

Editorial, 2009.

Kenny, A., Wittgenstein, trad. de Alfredo Deaño, Madrid, Alianza Editorial, 1982.

Lessing, G. E., Acerca de la verdad, trad. de Agapito Maestre y José Romagosa, en ¿Qué es Ilustración?, Agapito Maestre (ed.), Madrid, Tecnos, 2009.

Löwith, K., El hombre en el centro de la historia, trad. de Adan Kovacsics, Barcelona, Herder, 1997.

- Historia del mundo y salvación, trad. de Norberto Espinosa, Buenos Aires, Katz Editores, 2007.

- De Hegel a Nietzsche. La quiebra revolucionaria del pensamiento en el siglo XIX, trad. de Emilio Estiú, Madrid, Katz Editores, 2008. 
Marramao, G., Kairós, trad. de Helena Aguilà, Barcelona, Gedisa, 2008.

Marx, K. y Engels. F., Manifiesto comunista, trad. de Pedro Ribas, Madrid, Alianza Editorial, 2008.

Ortega y Gasset, J., Meditaciones del Quijote, en Obras completas. Tomo I, ed. Fundación José Ortega y Gasset, Madrid, Taurus, 2004.

Otto, W. F., Dioniso, trad. de Cristina García Ohlrich, Barcelona, Herder, 2017.

Paul, J., Alba del nihilismo, ed. de Adriano Fabris, trad. de Jorge Pérez de Tudela, Madrid, Istmo, 2005.

Platón, Apología de Sócrates, en Diálogos I, trad. de J. Calonge Ruiz, E. Lledó Íñigo, C. García Gual, Madrid, Gredos, 1981.

- Menón, en Diálogos II, introd. trad. y notas de J. Calonge Ruiz, E. Acosta Méndez, F. J. Olivieri, J. L. Calvo, Madrid, Gredos, 1983.

- República, en Diálogos $I V$, introd. trad. y notas de Conrado Eggers Lan, Madrid, Gredos, 1988.

- Protágoras, en Diálogos I, trad. y notas de J. Calonge Ruiz, E. Lledó Íñigo, C. García Gual, Madrid, Gredos, 1990.

- Banquete, en Diálogos III, introd. trad. y notas de C. García Gual, M. Martínez Hernández, E. Lledó Íñigo, Madrid, Gredos, 1992.

Ricoeur, P., Freud: una interpretación de la cultura, trad. de Armando Suárez, México, Siglo xxI, 1970.

Rousseau, J.-J., Sobre el origen y los fundamentos de la desigualdad entre los hombres, en Del Contrato social. Discursos., trad. de Mauro Armiño, Madrid, Alianza Editorial, 2005.

Sánchez Meca, D., En torno al superhombre, Barcelona, Anthropos, 1989.

- Nietzsche. La experiencia dionisíaca del mundo, Madrid, Tecnos, 2009.

Santiago Guervós, L. E. de, Arte y poder, Madrid, Trotta, 2004.

Schopenhauer, A., El mundo como voluntad y representación I, trad. introd. y notas de Pilar López de Santa María, Madrid, Trotta, 2004. 
Sloterdijk, P., Normas para el parque humano, trad. de Teresa Rocha Barco, Madrid, Siruela, 2000.

Valadier, P., Nietzsche y la crítica del cristianismo, trad. de Eloy Rodríguez Navarro, Madrid, Ediciones Cristiandad, 1982.

Vattimo, G., Más allá del sujeto, trad. de Juan Carlos Gentile Vitale, Barcelona, Paidós Ibérica, 1989.

— «Metafísica, violencia, secularización», trad. de Carlos Cattroppi y Margarita N. Mizraji, en La secularización de la filosofía, comp. por Vattimo, G., Barcelona, Gedisa, 2001.

— El fin de la modernidad, trad. de Alberto Luis Bixio, Barcelona, Gedisa, 2007.

— Introducción a Nietzsche, trad. de Jorge Binaghi, Barcelona, RBA Libros, 2012.

Vattimo, G. y Rovarti, P. A. (eds.), El pensamiento débil, trad. de Luis de Santiago, Madrid, Cátedra, 2006.

Volpi, F., El nihilismo, trad. Cristina I. del Rosso y Alejandro G. Vigo, Madrid, Siruela, 2007.

Weber, M., «La ciencia como vocación», en El político y el científico, trad. de Francisco Rubio Llorente, Madrid, Alianza Editorial, 2005.

Wilde, O., El cuadro de Dorian Gray, trad. de Manuel Francisco Míguez, Madrid, Cátedra, 1992.

- De Profundis. Balada de la cárcel de Reading, trad. de Arturo Agüero Herranz, Madrid, Alianza Editorial, 2011.

- La decadencia de la mentira, trad. de León Mirlas, Barcelona, Austral, 2016.

Wittgenstein, L., Tractatus Logico-Philosophicus, trad. de Jacobo Muñoz e Isidoro Reguera, Madrid, Alianza Editorial, 1995. 


\section{Bibliografía de apoyo}

Anssel-Pearson, K. (ed.), Nietzsche and Modern German Thought, London, Routledge, 1991.

Appel, S., Friedrich Nietzsche: Wanderer und freier Geist, München, Beck, 2011.

Arce Carrascoso, J. L., «Naturaleza humana y lenguaje en el pensamiento de Descartes», CONVIVIUM, 2 ${ }^{\text {a }}$ Sèrie nº 11, Any 1998.

Aristóteles, Física, trad. de José Luis Calvo Martínez, Madrid, CSIC, 1996.

- Acerca del alma, introd., trad. y notas de Tomás Calvo Martínez, Madrid, Gredos, 2003.

- Metafísica, introd., trad. y notas de Tomás Calvo Martínez, Madrid, Gredos, 2008.

Ávila, R., Nietzsche y la redención del azar, Granada, Universidad de Granada, 1986.

— Identidad y tragedia, Barcelona, Crítica, 1999.

— «De la muerte de Dios al superhombre. El sufrimiento y la risa en el "Zaratustra" de Nietzsche», en Estudios Nietzsche, Málaga, Universidad de Málaga, 2001.

- El desafio del nihilismo, Madrid, Trotta, 2005.

— «La crítica de Nietzsche al Romanticismo», en Estudios Nietzsche 5: Nietzsche y el Romanticismo, Málaga, Universidad de Málaga, 2005.

Ávila, R. Estrada, J. A. y Ruiz, E. (eds.), Itinerarios del nihilismo. La nada como horizonte, Madrid, Arena Libros, 2009.

Barbera, S., «Voluntad de vivir o voluntad de poder: un episodio del debate de Nietzsche con Schopenhauer (1885-1889)», trad. de Marco Parmeggiani, en Estudios Nietzsche, 3: Nietzsche y Schopenhauer, Málaga, Universidad de Málaga, 2003.

Barrios Casares, M., Narrar el abismo. Ensayos sobre Nietzsche, Hölderlin y la disolución del clasicismo, Valencia, Pre-textos, 2001.

- Voluntad de lo trágico: el concepto nietzscheano de voluntad a partir de "El nacimiento de la tragedia", Madrid, Biblioteca Nueva, 2002.

— La voluntad de poder como amor, Madrid, Arena Libros, 2004 
— «Jünger y la deriva de la interpretación heideggeriana de Nietzsche», en Estudios Nietzsche 10: Nietzsche y Heidegger, Madrid, Trotta, 2010.

Bäumler, A., Nietzsche, der Philoshop und der Politiker, Leipzig, Reclam, 1931.

Benn, G., El Yo moderno y otros ensayos, Valencia, Pre-Textos, 1999

Berkowitz, P., Nietzsche. La ética de un inmoralista, trad. de María Cóndor, Madrid, Cátedra, 2000.

Berlin, I., «Dos conceptos de libertad», en Dos conceptos de libertad y otros escritos, trad. de Ángel Rivero, Madrid, Alianza Editorial, 2010.

Berry, J. N., Nietzsche and the Ancient Skeptical Tradition, Oxford, Oxford University Press, 2010.

Bertram, E., Nietzsche. Versuch einer Mythologie, Bonn, Bouvier, 1989.

Birnbaum, A., Nietzsche. Las aventuras del heroísmo, México D. F., Fondo de Cultura Económica, 2004.

Blondel, É., «Contra Kant y Schopenhauer. La afirmación nietzscheana», trad. de Marco Parmeggiani, en Estudios Nietzsche, 3: Nietzsche y Schopenhauer, Málaga, Universidad de Málaga, 2003.

Blumenberg, H., La legibilidad del mundo, trad. de Pedro Madrigal Devesa, Barcelona, Paidós, 2000.

- Historia del espíritu de la técnica, trad. de Pedro Madrigal, Valencia, Pre-Textos, 2013.

Böning, T., Metaphysik, Kunst und Sprache beim frühen Nietzsche, Berlin, De Gruyter, 1988.

Bornedal, P., The Surface and the Abyss: Nietzsche as Philosopher of Mind and Knowledge, Berlin/New York, de Gruyter, 2010.

Bossert, T., Jacobi und die Frühromantiker, Stuttgart, Hammer, 1926

Bowie, A., Aesthetics and Subjectivity: from Kant to Nietzsche, Manchester, Manchester University Press, 2013.

Brandes, G., Nietzsche. Un ensayo sobre el radicalismo aristocrático, trad. de José Liebermann, Madrid, Sexto Piso, 2008.

Brock, E., Nietzsche und der Nihilismus, Berlin, de Gruyter, 2014. 
Brown, K., Nietzsche and Embodiment: Discerning Bodies and Non-dualism, Albany, State University of New York Press, 2006.

Bueb, B., Nietzsches Kritik der praktischen Vernunft, Stuttgart, Klett, 1970.

Burckhardt, J., La cultura del Renacimiento en Italia, trad. de Teresa Blanco, Fernando Bouza y Juan Barja, Madrid, Akal, 2004.

Burgos Días, E., Dioniso en la filosofía del joven Nietzsche, Zaragoza, Prensas Universitarias de Zaragoza, 1993.

Bury, J., La idea del progreso, trad. de Elías Díaz y Julio Rodríguez Aramberri, Madrid, Alianza Editorial, 2009.

Cabada Castro, M., Querer o no querer vivir: el debate entre Schopenhauer, Feuerbach, Wagner y Nietzsche sobre el sentido de la existencia humana, Barcelona, Herder, 1994.

Cacciari, M., Krisis. Ensayo sobre la crisis del pensamiento negativo de Nietzsche a Wittgenstein, trad. de Romeo Medina, México D. F, Siglo XXI, 1982.

Campioni, G., Nietzsche: Crítica de la moral heroica, trad. de Sergio Sánchez, Madrid, Avarigani Editores, 2011.

Cano, G., Como un ángel frío, Valencia, Pre-Textos, 2000.

- Nietzsche y la crítica de la modernidad, Madrid, Biblioteca Nueva, 2001.

Carr, K. L., The Banalization of Nihilism, New York, State University of New York Press, 1992.

Carrol, J., Break-Out from the Crystal Palace: the Anarcho-Psychological Critique: Stirner, Nietzsche, Dostoevsky, London/New York, 2009.

Casale, R. and Dingler, C., Heideggers Nietzsche: Geschichte einer Obsession, Bielefeld, Transcript, 2010.

Cerezo Galán, P. (ed.), Heidegger: la voz de tiempos sombríos, Barcelona, Ediciones del Serbal, 1991.

Chillón Lorenzo, J. M., «Conocimiento como tema, realidad como problema. Descartes y Hume», Estudios filosóficos LXII, 2013, pp. 537-555. 
Clark, M. and Dudrick, D., «Defending Nietzsche's Soul», Journal of Nietzsche Studies, Vol. 45, No. 3 (Autumn 2014), pp. 331-355.

Conill, J., El crepúsculo de la metafísica, Barcelona, Anthropos, 1988.

— «La poetización nietzscheana del lenguaje y del pensamiento», en Estudios Nietzsche, 4: Nietzsche y el lenguaje, Málaga, Universidad de Málaga, 2004.

- «Hermenéutica genealógica desde el cuerpo», en Estudios Nietzsche 9: Nietzsche y la hermenéutica, Madrid, Trotta, 2009.

— «El mejoramiento de la humanidad desde la perspectiva nietzscheana», en Estudios Nietzsche 12: Actualidad e inactualidad de Nietzsche, Madrid, Trotta, 2012.

Constant, B., «De la libertad de los antiguos comparada con la de los modernos», trad. de Marcial Antonio López, en Del espíritu de conquista, ed. de María Luisa Sánchez Mejía, Madrid, Tecnos, 1988.

Cox, C., Nietzsche. Naturalism and Interpretation, Berkeley, University of California Press, 1999.

Crawford, C., The Beginning of Nietzsche's Theory of Language, Berlin, De Gruyter, 1988.

Crosby, D. A., The Specter of the Absurd, New York, State University of New York Press, 1988.

Danto, A., Nietzsche as Philosopher, New York, Columbia University Press, 2005.

Deker, K., Nietzsche und Wagner: Geschichte einer Hassliebe, Berlin, Ullstein Taschenbuchvlg, 2014.

Deleuze, G., Nietzsche, trad. de Isidro Reguera y Alejandro del Río, Madrid, Arena Libros, 2012.

- Nietzsche y la filosofía, trad. de Carmen Artal, Barcelona, Anagrama, 2013.

Descartes, R., Tratado del hombre, trad. de Guillermo Quintás, Madrid, Editora Nacional, 1980.

- Los principios de la filosofía, introd., trad. y notas de Guillermo Quintás, Madrid, Alianza Editorial, 1995. 
- Meditaciones metafísicas, en Meditaciones metafisicas y otros textos, trad. y notas de Ernesto López y Mercedes Graña, Madrid, Gredos, 1997.

Deutschmann, M., Friedrich Nietzsche: Die zweite unzeitgemäße Betrachtung Vom Nutzen und Nachteil der Historie für das Leben, München, GRIN, 2006.

D'Iorio, P., El viaje de Nietzsche a Sorrento, trad. de Luis Enrique de Santiago Guervós, Barcelona, Gedisa, 2016.

Desiato, M., Nietzsche, crítico de la postmodernidad, Caracas, Monte Ávila, 1998.

Djuric, M., Nietzsche und die Metaphysik,Berlin, De Gruyter, 1985.

Duhamel, R., Nietzsches Zarathustra, Mystiker des Nihilismus, Würzburg, Königshausen und Neumann, 1991.

Duque, F., Historia de la filosofía moderna: la era de la crítica, Madrid, Akal, 1998.

- El cofre de la nada, Madrid, Abada Editores, 2007.

Edwards, J. C., The Authority of Language. Heidegger, Wittgenstein and the Threat of Philosophical Nihilism, Tampa, University of South Florida Press, 1990.

Eliade, M., El mito del eterno retorno, trad. de Ricardo Anaya, Madrid, Alianza Editorial, 1972.

Esteban Enguita, J. E., El joven Nietzsche: politica y tragedia, Madrid, Biblioteca Nueva, 2004.

Esteban Enguita, J. E. y Quesada, J. (ed.), Politica, historia y verdad en la obra de F. Nietzsche, Madrid, Huerga Fierro, 2000.

Fernández García, E. (ed.), Nietzsche y lo trágico, Madrid, Trotta, 2012.

Ferraris, M., Nietzsches Gespenster: Ein menschliches und intellektuelles Abenteuer, Frankfurt, Vittorio Klostermann, 2016.

Feyerabend, P., Tratado contra el método, trad. de Diego Ribes, Madrid, Tecnos, 1986.

Figl, J., Dialektik der Gewalt. Nietzsches hermeneutische Religionsphilosophie, Düsseldorf, Patmos, 1984.

- Nietzsche-Meditationen: Das Kloster, das Meer und die «neue» Unendlichkeit, Hamburg/Berlin, Lit-Verlag, 2008. 
Frey, H., Nietzsche, Eros y Occidente, México D.F., 2005.

— En el nombre de Diónysos, México, Siglo XXI Editores, 2013.

Fries, H., El nihilismo, trad, de Alejandro Esteban Lator Ros, Barcelona, Herder, 1967.

Gasché, R., «"Ecce Homo” or the Written Body», trans. by Judith Still, Oxford Literary Review, Vol. 7, No. 1/2 (1985), pp. 3-24.

Gasser, P., Rhetorische Philosophie. Leseversuche zum metaphorischen Diskurs in Nietzsches “Also sprach Zarathustra”, Bern, Lang, 1992.

Gawoll, H-J., Nihilismus und Methafisik, Sttutgart, Fromman-Holzboog, 1989.

Georg-Lauter, J., Dionysos und Parsifal: Eine Studie zu Nietzsche - Philosoph der Größe der Macht oder der Macht der Größe, Berlin, de Gruyter, 2011.

Gerhardt, V., Friedrich Nietzsche, Also sprach Zaratustra, Berlin, Akademie, 2000. - «Resentimiento y apocalipsis. La crítica de Nietzsche a las visiones del fin de los tiempos», trad. de Jesús Martín Cardoso, en Estudios Nietzsche, 6: Nietzsche y el cristianismo, Málaga, Universidad de Málaga, 2006.

Gillespie, M. A., Nihilism Before Nietzsche, Chicago, The University of Chicago Press, 1995.

González, M., Introducción al pensamiento filosófico: filosofía y modernidad, Madrid, Tecnos, 1989.

Goth, J., Nietzsche und die Rhetorik, Tübingen, Niemeyer, 1970.

Goudsblom, J., Nihilism and Culture, Oxford, Basil Blackwell, 1980.

Grassi, E., Heidegger y el problema del humanismo, trad. de Ubaldo Pérez Paoli, Barcelona, Anthropos, 2006.

— Defensa de la vida individual: los "studia humanitatis" como tradición filosófica, trad. de Jorge Navarro Pérez, Barcelona, Anthropos, 2017.

Grimm, R. H., Nietzsche's Theory of Knowledge, Berlin, De Gruyter, 1977.

Günther, F. F., Rhythmus beim frühen Nietzsche, Berlin/New York, de Gruyter, 2008 . 
Gurevich, A., Los orígenes del individualismo europeo, trad. de María García Barris, Barcelona, Crítica, 1997.

Habermas, J., Sobre Nietzsche y otros ensayos, Madrid, Tecnos, 1982.

Hales, S. D. and Welshon, R., Nietzsche's Perspectivism, Chicago, University of Illinois Press, 2000.

Hazard, P., La crisis de la conciencia europea, trad. de Julián Marías, Madrid, Alianza Editorial, 1988.

Heidegger, M., Introducción a la fenomenología de la religión, trad. de Jorge Uscatescu Barrón, Madrid, Siruela, 2005.

— ¿Qué significa pensar?, trad. de Raúl Gabás, Madrid, Trotta, 2008.

— «El origen de la obra de arte», trad. de Helena Cortés y Arturo Leyte, en Caminos de bosque, versión de Helena Cortés y Arturo Leyte, Madrid, Alianza Editorial, 2012.

Hellen, P., Von den ersten und letzten Dingen, Berlin, De Gruyter, 2012.

Henke, D., Gott und Grammatik. Nietzsches Kritik der Religion, Pfullingen, Neske, 1980.

Herrmann, F. W., Subjekt und Dasein, Frankfurt, Klostermann, 1974.

Hertl, M., Der Mythos Friedrich Nietzsche und seine Totenmasken, Würzburg, Königshauses \& Neumann, 2007.

Hill, R. K., Language, Mind and Reality: Nietzsche's Overcoming of Metaphysics, Urbana-Champaign, University of Illinois, 1992.

Hirn, L., Friedrich Nietzsche: Die menschliche Existenz zwischen Hedonismus und Pessimismus, Wien, Hernals, 2009.

Holbach, Sistema de la naturaleza, trad. de Nerina Bacín, José Manuel Bermudo, Miguel Estapé y Alín Salom, Pamplona, Laetoli, 2008.

Hollinrake, R., Nietzsche, Wagner and the Philosophy of Pessimism, London/New York, Routledge, 2009.

Hyde, J. K., Concepts of Power in Kierkegaard and Nietzsche, Farnham, Ashgate, 2010 . 
Jara, J., Nietzsche, un pensador póstumo, Barcelona, Anthropos,1998.

Johnson, D. R., Nietzsche's Anti-Darwinism, New York, Cambridge University Press, 2010.

Jovanovski, T., Nietzsche's Subversion of the Aesthetic Socratic Dialect, London, Peter Lang, 2006.

Kain, P. J., Nietzsche and the Horror of Existance, Lanham, Lexington Books, 2009.

Kant, I., En torno al tópico: «Eso vale para la teoría pero no sirve de nada en la práctica», trad. de Roberto R. Aramayo, en Kant II, ed. de Maximiliano Hernández Marcos, Madrid, Gredos, 2010.

Kaufmann, W., Nietzsche: Philosopher, Psychologist, Antichrist, Princeton, Princeton University Press, 2013.

Klossowski, P., Nietzsche y el círculo vicioso, trad de Isidro Herrera, Madrid, Arena Libros, 2004.

Köhler, M., Das unheimliche Jahrhundert: Aspekte einer politichen Philosophie im Zelter der Nihilismus, Marburg, Tectum, 2000.

Kossok, M., Las revoluciones burguesas: problemas teóricos, trad. de Juan Luis Vermal, Barcelona, Crítica, 1983.

Krause, R., Nietzsche - Perspektiven der Macht, Berlin, Parodos, 2009.

Kristeller, P. O., Ocho filósofos del Renacimiento italiano, trad. de María Martínez Peñaloza, Madrid, Fondo de Cultura Económica de España, 2006.

Kuhn, E. F., Friedrich Nietzsches Philosophie des europäischen Nihilismus, Berlin, De Gruyter, 1992.

Kuhn, T., La revolución copernicana, trad. de Domènec Bergadà Barcelona, Ariel, 2008 .

Läpple, A., Der andere Nietzsche: Gebete von Friedrich Nietzsche, München, Sankt Michaelsbund, 2010.

Lefebvre, H., Hegel, Marx, Nietzsche, Madrid, Siglo XXI Editores, 2016.

Leslie Paul, T., Friedrich Nietzsche and the Politics of the Soul, Princeton, Princeton University Press, 1990. 
López Castellón, E., Leyendo a Nietzsche, Madrid, Universidad Autónoma de Madrid, 2009.

Love, F. R., Young Nietzsche and the Wagnerian Experience, New York, Ams Press, 1966.

Lütkehaus, L., Nietzsche sum Vergnügen, Stuttgart, Reclam, 2011.

Mandalios, J., Nietzsche and the Necessity of Freedom, Lanham, Lexington Books, 2008 2009.

Marramao, G., Minima temporalia, trad. de Helena Aguilà, Barcelona, Gedisa,

Gedisa, 2011.

- La pasión del presente, trad. de Carlos Cuéllar, Barcelona,

Martínez, J. J., La fábula de la caverna. Platón y Nietzsche, Barcelona, Penísula, 1991.

Marx, K. y Engels, F., La ideología alemana, trad. de Wenceslao Roces, Madrid, Akal, 2014.

Mateos de Manuel, V., «Mediodía. Nietzsche y la cuestión del tiempo: sobre el sentido de presente en la filosofía», en Estudios Nietzsche 16: Sobre 'Así habló Zaratustra', Madrid, Trotta, 2016.

Mayz Vallenilla, E., El problema de la Nada en Kant, Caracas, Monte Ávila Latinoamericana, 1992.

Merkel, F., Nietzsche - Die Tugend und die Tugenden im 'Zarathustra', München, Grin, 2010.

Meyer, A., Nietzsche und Dionysos: Eine Suche nach den Quellen des Lebens Die Dionysos-Mysterien, Basel, IL-Verlag, 2014.

Mirandola, G. P., Discurso sobre la dignidad del hombre, trad de. Pedro J. Quetglas, Barcelona, PPU, 2002.

Moerchen, H., Adorno und Heidegger: Untersuchung einer philosophischen Kommunikationsverweigerung, Stuttgart, Klett-Cotta, 1981.

Moore, G., Nietzsche, Biology, and Metaphor, Cambridge, Cambridge University Press, 2002. 
Müller, D., Wider die «Vernunf in der Sprache». Zum Verhältnis von Sprachkritik und Sprachpraxis im Schreiben Nietzsches, Tübingen, Gunter Narr, 1995.

Müller, T., Die Poetik der Philosophie: das Prinzip des Perspektivismus bei Nietzsche, Frankfurt, Campus Verlag, 1995.

Müller-Lauter, W., Heidegger und Nietzsche, Berlin/New York, de Gruyter, 2000.

- Nietzsche. Seine Philosophie der Gegensätze und die Gegensätze seiner Philosophie, Berlin, De Gruyter, 2013.

O'Conor, B., Adorno's Negative Dialectic: Phylosophy and the Possibility of Critical Rationality, Cambridge, MIT Press, 2004.

Otero León, L., «De la estética como fisiología en Nietzsche a la curación como obra de arte en Gadamer», Contrastes. Revista Internacional de Filosofia, vol. XIII (2008), pp. 19-35.

Overbeck, F., La vida arrebatada de Friedrich Nietzsche, ed. y trad. de Iván de los Ríos, Madrid, Errata Naturae, 2009.

Parmeggiani, M., Perspectivismo y subjetividad en Nietzsche, Málaga, Analecta Malacitana, 2002.

Penella, M., Nietzsche y la utopía del superhombre, Barcelona, Península, 2011.

Peters, C., Friedrich Nietzsche - Wille zur Macht: Eine Analyse, München, Grin, 2010.

Piel, M., Die Wirklichkeitskonzeptionen in Friedrich Nietzsches «Also sprach Zarathustra» und Ludwig Wittgensteins «Tractatus logico-philosophicus», Würzburg, Königshauses und Neumann, 2014.

Piossek Prebisch, L., El “filósofo topo”: sobre Nietzsche y el lenguaje, Tucumán, Universidad Nacional de Tucumán, 2005.

Platzer, J., Friedrich Nietzsche: Erkenntnis und Moral als Selbstaufhebung, München, Grin, 2009.

Quesada, J., Un pensamiento intempestivo. Ontología, estética y política en F. Nietzsche, Barcelona, Anthropos, 1988.

- Nihilismo activo. Genealogía de la modernidad, México, Universidad de Guadalajara, 1999. 
Rabade Romeo, S., Método y pensamiento en la modernidad, Madrid, Narcea, 1981.

Rampley, M., Nietzsche, Aesthetics and Modernity, Cambridge, Cambridge University Press, 2000.

Reboul, O., Nietzsche, crítico de Kant, trad. de Julio Quesada y José Lasaga, Barcelona, Anthropos, 1993.

Reginster, B., The Affirmation of Life: Nietzsche on Overcoming Nihilism, Cambridge, Harvard University Press, 2006.

Richardson, J., Nietzsche's New Darwinism, Oxford, Oxford University Press, 2008.

Rodríguez González, M., El sujeto velado: a partir de Nietzsche y Wittgenstein, Madrid, Biblioteca Nueva, 2010.

Rosen, S., Nihilism: a Philosophical Essay, New Haven, Yale UP, 1969.

Ross, W., Der ängstliche Adler: Friedrich Nietzsches Leben, München, Kastell, 1990.

Röttges, H., Nietzsche und die Dialektik der Aufklärung, Berlin, De Gruyter, 2015.

Ruiz Callejón, E., «La moral de la compasión y la genealogía necesaria», en Estudios Nietzsche, 3: Nietzsche y Schopenhauer, Málaga, Universidad de Málaga, 2003.

Safranski, R., Nietzsche. Biografía de su pensamiento, trad. de Raúl Gabás, Barcelona, Tusquets, 2009.

Salcido Macías, M., «Nietzsche y la Antigüedad: la crítica a la objetividad científica como verdad teológica», en Estudios Nietzsche 8: Nietzsche y la ciencia, Málaga, trotta, 2008.

Salvatore Schiffer, D., Filosofía del dandismo, trad. de Graciela Montes, Buenos Aires, Nueva visión, 2009.

Sánchez Meca, D., «Lo dionisíaco y la nueva comprensión de la modernidad», LOGOS. Anales del Seminario de Metafísica, (2000), núm. 2, Madrid, Servicio de Publicaciones, Universidad Complutense, pp. 31-53.

- «El adversario interior», en Estudios Nietzsche, Málaga, Universidad de Málaga, 2001. 
— «Voluntad de poder e interpretación como supuestos de todo proceso orgánico», en Estudios Nietzsche 9: Nietzsche y la hermenéutica, Madrid, Trotta, 2009.

—El nihilismo, Madrid, Síntesis, 2010.

Santiago Guervós, L. E. de, «La risa y el 'consuelo intramundano': el arte de trascenderse y superarse en Nietzsche», en Estudios Nietzsche, Málaga, Universidad de Málaga, 2001.

Schrift, A., Nietzsche and the Question of the Interpretation, London, Routledge, 1990.

Severino, E., Esencia del nihilismo, trad. de Enrique Álvarez Tólcheff, Madrid, Taurus, 1991.

Siedler, W. J., Nietzsches für Freunde, München, Goldmann, 2000.

Silk, M. S. and Stern, J. P., Nietzsche on Tragedy, Cambridge/London, Cambridge University Press, 1981.

Simmel, F., Schopenhauer y Nietzsche, trad. de Francisco Ayala, Buenos Aires, Prometeo Libros, 2005.

Simon, J., Philosophie des Zeichens, Berlin, De Gruyter, 1989.

Sloterdijk, P., El pensador en escena, trad. e introd. de Germán Cano, Valencia, Pre-Textos, 2000.

Small, R., Time and Becoming in Nietzsche's Thought, London/New York, Continuum, 2010.

Stack, G. J., Lange und Nietzsche, Berlin, De Gruyter, 1983.

Stambough, J., Untersuchungen Zum Problem der Zeit bei Nietzsche, La Haya, Springer Netherlands, 2013.

Stenz, M., Nietzsche und der freie Geist: Versuch der Ausarbeitung des Konzepts des freien Geistes und sein aktueller Bezug, München, Grin, 2009.

Stoker, W., Is the Quest for Meaning the Quest for God?, translated by Lucy Jansen-Hofland and Henry Jansen, Amsterdam - Atlanta, Editions Rodopi B. V., 1996.

Taureck, B., Nietzsches Alternativen zum Nihilismus, Hamburg, Junius, 1991. 
Taylor, C., Argumentos filosóficos: ensayos sobre el conocimiento, el lenguaje y la modernidad, Barcelona, Paidós, 1997.

Thierjung, D., Erkenntnis und Kunst in der Philosophie Friedrich Nietzsches: Weltspiel einer nachmetaphysischen Zeit, Würzburg, Königshauses und Neumann, 2014.

Töpfer, H., Deutung und Wertung der Kunst bei Schopenhauer und Nietzsche, Dresden, Risse-Verlag, 1933.

Ure, M., «Nietzsche's Schadenfreude», Journal of Nietzsche Studies, Vol. 44, No. 1, Special Issue: Nietzsche and the Affects (Spring 2013), pp. 25-48.

Vaihinger, H., Die Philosophie des Als Ob: System der theoretischen, praktischen und religiösen Fiktionen der Menschheit auf grund eines idealistischen Positivismus: mit einem Anhang über Kant und Nietzsche, Aalen, Scientia, 1986.

Vattimo, G., El sujeto y la máscara, trad. de Jorge Binaghi, Barcelona, Península, 1989.

Vermal, J. L., La crítica de la metafisica en Nietzsche, Barcelona, Anthropos, 1987.

- «Acerca de la inversión del platonismo en Nietzsche y Heidegger», en Estudios Nietzsche 10: Nietzsche y Heidegger, Madrid, Trotta, 2010.

Villacañas Berlanga, J. L., Nihilismo, especulación y cristianismo en F.H. Jacobi, Barcelona, Anthropos, 1989.

- La quiebra de la razón ilustrada: idealismo y romanticismo, Madrid, Cincel, 1998.

- La filosofía del Idealismo alemán. Volumen I: del sistema de la libertad en Fichte al primado de la teología en Schelling, Madrid, Síntesis, 2001.

- La filosofía del Idealismo alemán. Volumen II: la hegemonía del pensamiento de Hegel, Madrid, Síntesis, 2001.

Vitiello, V., Cristianismo sin redención, trad. de Miguel Ramos Sánchez, Madrid, Trotta, 1999.

— «"En lucha con el lenguaje”. De Wittgenstein a Nietzsche», trad. de Marco Parmeggiani, en Estudios Nietzsche, 4: Nietzsche y el lenguaje, Málaga, Universidad de Málaga, 2004.

Vogel, M., Nietzsche und Wagner, Bonn, Verlag für systematische Musikwissenschaft, 1984. 
Welte, B., Nietzsches Atheismus und das Christentum, Darmstadt, Wissenschaftliche Buchgesellschaft, 1964.

Wildermuth, A., Nietzsche und Wagner: Geschichte und Aktualität eines Kulturkonfliktes, Zürich, Orwell Füssli, 2008.

Williams, L. L., Nietzsche’s Mirror, Lanham, Rowman \& Littlefield Publishers, 2000.

Wolf, J. C., Zarathustras Schatten. Studien zu Nietzsche, Fribourg, Academic Press 2004.

Zehm, G., Das Schlusswort Zarathustras. Friedrich Nietzsche und die Folgen, Schnellroda, Anteils, 2006.

Zittel, C., Das ästhetische Kalkül von Friedrich Nietzsches "Also sprach Zarathustra”, Würzburg, Königshausen und Neumann 2000. 